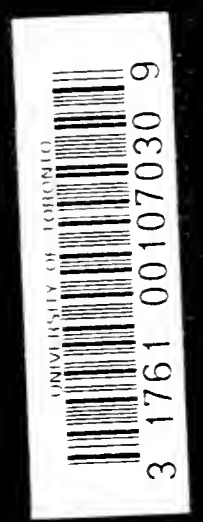



. 
THE

\section{TELL EL-AIIARIA TABLETS}

IN THE

B RITISH MUSEUM. 



\section{.}




\section{Digitized by the Internet Archive in 2007 with funding from Microsoft Corporation}





\title{
TELL EL-AMARNA TABLETS
}

IN THE

\section{BRITISH MUSEUM}

WITH

\section{AUTOTYPE FAOSIMILES}

\author{
PRINTED BY ORDER OF THE TRUSTEES
}

$$
\frac{2510^{4}}{9 ! 119^{2}}
$$

SOLD AT THE BRITISH MUSEUM;

$$
\text { AND BE }
$$

LONGMANS \& Co., 39, Paternoster Row; B. QUARITCh, 15, Piccadilly;

ASHeR \& Co., 13, Bedford Street, Covent Garden;

kegan PaUl, trench, Trübser, \& Co., Paterxoster House, Charing Cross Road; AND OXFORD UNIVERSITY PRESS, AMEN CORNER, LONDON.

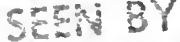
Preperantion Survices SEP $\rightarrow 1993$ 
HARRISON AND SONS,

Printers in Ordinary to Her Majestr,

St. Martin's Lane, London. 
This edition of the Tell el-Amarna Cuneiform Tablets in the Department of Egyptian and Assyrian Antiquities of the British Museum is the work of Dr. C. Bezold. The Introduction and Summary have been written jointly by Dr. Bezold and Dr. E. A. Waldrs Budge, Acting Assistant-Keeper of the Department.

\section{E. MAUNDE THOMPSON,}

Principal Librarian and Secretary.

British Museum, 16th February, 1892. 



\section{CONTENTS.}

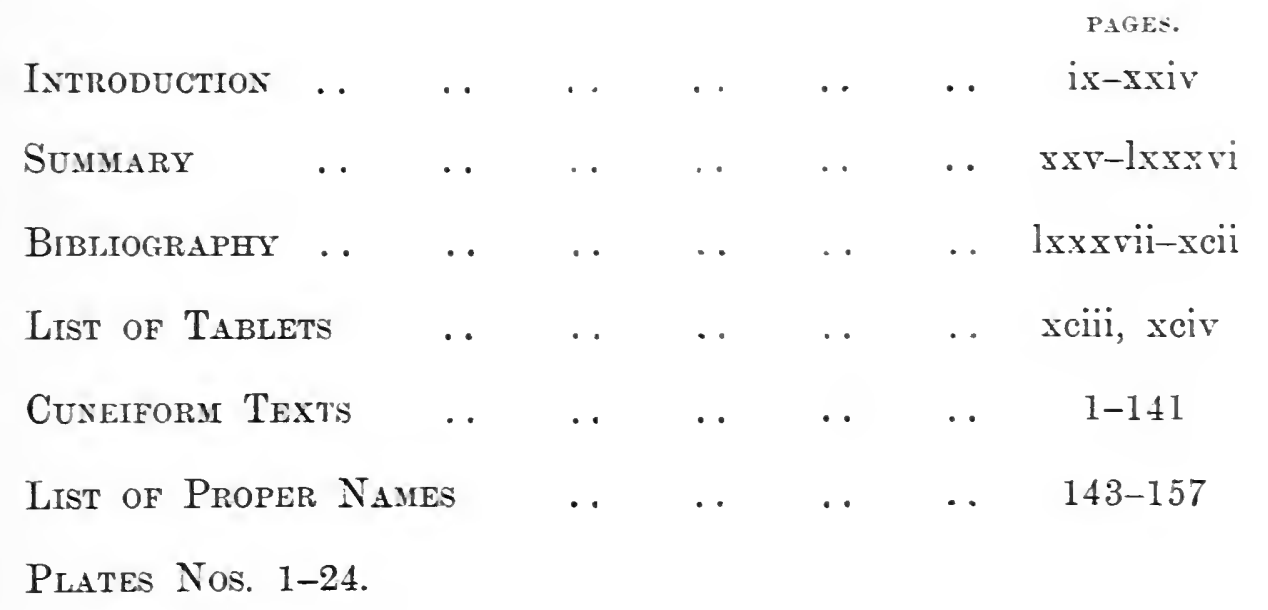





\section{INTRODUCTION.}

The collection of Cuneiform Tablets recently found at Tell Finding of the el-Amarna in Upper Egypt, consisted of about three hundred Tell el-Amarna and twenty documents, or portions of documents. The British Museum possesses eighty-two, which were purchased for the 'Irustees by Mr. E. A. Wallis Budge in 1888; the Berlin Museum has one hundred and sixty, a large number being fragments; the Gizeh Museum has sixty; and a few are in the hands of private persons.

The discovery is said to have been accidentally made by a peasant woman when searching for antiquities in the loose sand and broken stones at the foot of the mountains behind the village, in which there are several interesting rock hewn tombs.

Tell el-Amarna, to the village near the ruins of the town, temple and palace Tell el-Amarna. which were built on the right or east bank of the Nile, about $1 S 0$ miles south of Memphis, by Khu-en-aten or Amenophis IV., King of Egypt, about B.c. 1500. The town was called Khu-aten,

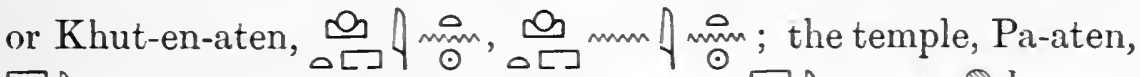

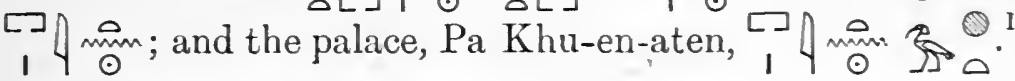

With the tablets were found :-

1. A clay seal having two impressions of the prenomen objects found

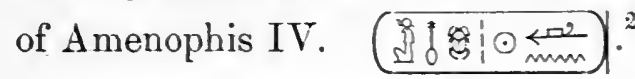
with the tablets.

1 Lepsius, Denkmäler, Abth. III, Bl. 97 ; Brugsch, Dict. Géog., pp. 82, 83. On Jacotin's Carte Topographique de l'Égypte [1821], Sheet 13, between Hâaggi

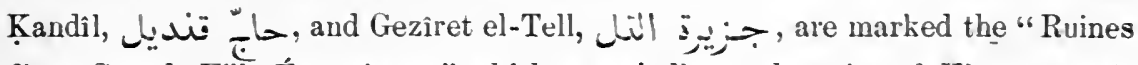
d'une Grande Ville Égyptienue," which must indicate the ruius of Khu-en-aten's palace.

2 Now in the Royal Museum at Berlin. 
2. Five square alabaster plaques, inlaid with the prenomen and name of Amenophis III. in dark-blue glazed faïence. ${ }^{1}$
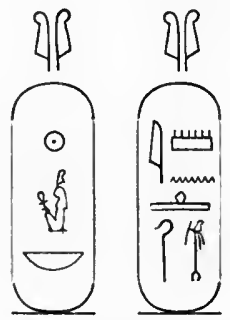

3. A light-blue glazed faience plaque, rounded at the top and inlaid with the names and titles of Amenophis III. and his wife Thi in hieroglyphics of dark-blue faience. ${ }^{2}$

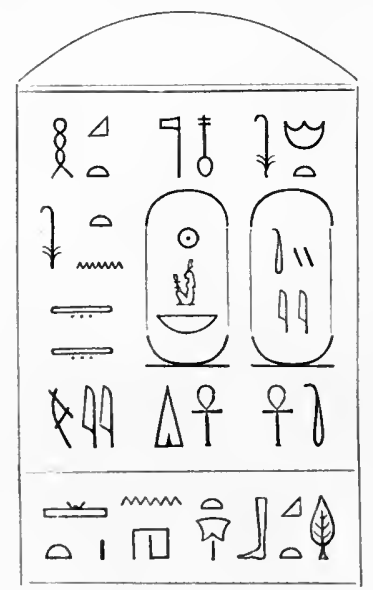

This plaque was originally inlaid in an alabaster tablet which is now lost.

4. Cover of a vase or jar made of stone resembling rosso antico, and carved to represent a lion and a bull fighting, the style of which seems to indicate Mesopotamian workmanship. ${ }^{2}$

Size of the tablets.
The size of the tablets in the British Museum varies from $8 \frac{3}{4}$ in. $\times 4 \frac{7}{8}$ in. to $2 \frac{1}{8}$ in. $\times 1 \frac{11}{16}$ in. ; the longest text contains 98 lines, the shortest 10 .

1 Now in the Royal Nuseum at Berlin.

${ }^{2}$ Now in the British Museum, Nos. 22,878 and 22,866. 
The greater number are rectangular, and a few are oval ; Shape. and they differ in shape from any other cuneiform documents known to us. Some are flat on both sides ( $c f$. Nos. 6, 25, 26, 44); some are convex on both sides ( $c f$. Nos. $3,41,57)$; and some are pillow-shaped ${ }^{1}$ ( $c f$. Nos. $28-31,36,37,61$ ).

In colour the tablets vary from a light to a dark dust tint, Colour and and from a flesh-colour to durk brick-red. The nature of the material. clay of which they are made sometimes indicates the countries from which they come.

No. 1, a draft of a letter from Amenophis III. to KallimmaSin, is made of finely kueaded Nile mud; Nos. 8-11, 36, 37, and 41 are of the dark-red clay which is met with in the north of Syria; five of Rib-Adda's letters are written upon the yellow clay which is common near the Syrian coast; ${ }^{2}$ the tablets from Shubandi, Widya, and Shuardata contain fragments of flint. ${ }^{3}$

Nos. 10 and 11, letters from Tushratta, King of Mitani, have Dockets; dockets which record the date of their arrival in Egypt; No. 4 , ${ }_{\text {impressions. }}^{\text {scarab }}$ a letter from Burraburiyash, bears on the Reverse an impression of an Egyptian steatite scarab, which probably formed the bezel of a ring; and No. 58 has on the Reverse an impression of a Babylonian cylinder seal.

The writing on the Tell el-Amarna tablets resembles to a Writing. certain extent the Neo-Babyloniau, i.e., the simplification of the writing of the first Babylonian Empire used commonly in Babylonia and Assyria for about seven centuries B.c. It possesses, however, characteristics different from those of any other style of cuneiform writing of any period now known to exist; and nearly every tablet contains forms of characters which have hitherto been thought peculiar to the Ninevite or Assyrian style of writing.

But, compared with the neat, careful hand employed in the official documents drawn up for the kings of Assyria,

"Compare the name given to such tablets by the Arabs : ئني "pillows."

2 Judging from the colour of the clay alone, No. 44 must belong to a letter of Rib-Adda.

${ }^{3}$ See plates 12 and 1 . 
it is somewhat coarse and careless, and suggests the work of unskilled scribes. One and the same hand, however, appears in tablets which come from the same person and the same place. On some of the large tablets the writing is bold and free; on some of the small ones the characters are confused and cramped, and are groups rather of strokes than of wedges. ${ }^{1}$

Paragraphs and margins.

Division of words.

Punctuation.

Syllabic spelling.
The letters of Tushratta ${ }^{2}$ (Nos. 8-11), Ammunira (Nos. 26,27), Akizzi (Nos. 36, 37), the inhabitants of Tunip (No. 41), Widya (No. 52), Pu-Adda (No. 56) and Labawi (No.61) are divided into paragraphs by straight lines drawn across the tablet. Some paragraphs begin with the word shanitu, "moreover." On certain of the tablets the left-hand edge is inscribed with one or more lines of writing which form the end of the document and which read from the top of the tablet to the bottom; in letters found at Kouyunjik such lines read from the bottom to the top. A wide margin was sometimes allowed for such lines (see Nos. $30,36,37)$.

In ordinary Babylonian and Assyrian documents the scribe usually ended a line with a complete word; in the Tell elAmarna tablets a break in a word at the end of a line is more frequent. Sometimes the concluding portion of the word is carried over to the beginning of the following line $;^{3}$ but more generally it is written immediately beneath the first part of the word, and is then distinguished by a diagonal wedge, $\uparrow$ or $\$$, placed before it.

An attempt at punctuation seems to be indicated by the red dots on No. 82 (see p. lxxxv).

The spelling is, with few exceptions, syllabic, and comparatively few ideographs occur. It is often careless, and in some instances syllables have been omitted. At present it is not possible to say whether the irregular spelling is due to the

1 Nos. 26 and 27 are examples of a very remarkable hand; for the peculiarities of that on No. 82, see below, p. Ixxxv.

${ }^{2}$ In this Introduction, and in the Summary which follows, the common forms of proper names have bcen adopted; for exact transcriptions see the List of Proper Names on pp. 143 ff.

${ }^{3}$ No. 4.j, 1. 80 f.; No. $47,1.5$ f.; No. $79,1.11$ f. 
ignorance of the scribe, or to dialectic peculiarities; in either case much useful knowledge concerning the grammatical structure of the language is to be gained therefrom.

The Semitic dialect in which these letters are written is Language. Assyrian, and is, in some important details, closely related to the Hebrew of the Old Testament. The forms of pronouns are particularly noteworthy.

A peculiar feature in these tablets is the numerous glosses Glosses. which occur. They are of three kinds, and consist of :-

1. Explanations of Sumero-Accadian ideographs by Assyrian words spelt in syllables; the ideograph coming first, and the Assyrian word second, but separated from the ideograph by a diagonal wedge, e.g. :-

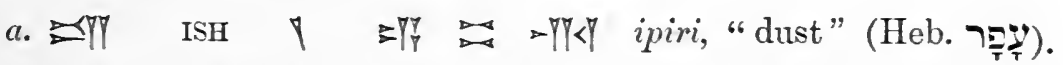

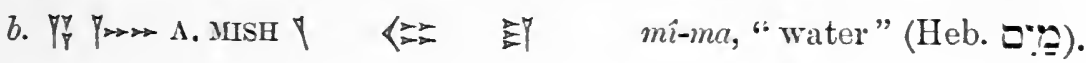

2. Explanations of Sumero-Accadian ideographs by Canaanite ${ }^{1}$ words spelt in syllables; the ideograph coming first, and the Canaanite word second, but separated from the ideograph by a diagonal wedge, e.g.:-

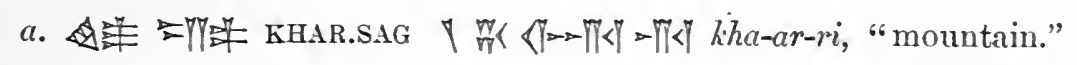

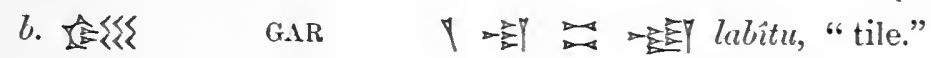

(Heb. הַ)

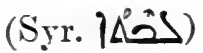

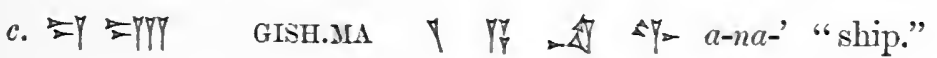

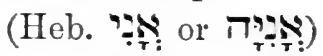

3. Explanations of Assyrian words in syllables by Canaanite words in syllables, e.g.:-

$$
\begin{aligned}
& \text { a. } \\
& r a-b i-z i \quad z u-k i-n i \text { "prefect." (Heb. סע) }
\end{aligned}
$$

1 "Canaanite" is the name which has been giren to the native dialects spoken by the rassals of Amenophis in Syria and Palestine. They closely resemble the Hcbrew of the Old Testament. The Canaanite forms found cn these tablets arc new. 
Lax use of determinatives.

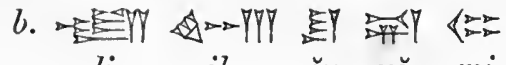 $l i-\quad i h ̧-\breve{s} u-u \breve{s}-m i$
c. $5 Y \overline{D F}$ DPR $n i-r i$

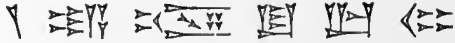 "let him meditate." (Heb. ריְְ")

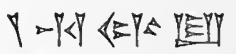 lihu - ul - lu "yoke." (Heb. 'ע) ya - $a z-k u-u r-m i$

An instance of three words in Assyrian translated by three in Canaanite is-

$$
\begin{aligned}
& i \text { - na kat - ti-shu } \\
& \text { "in hands his" }
\end{aligned}
$$

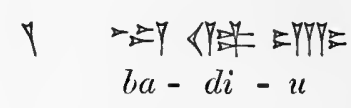

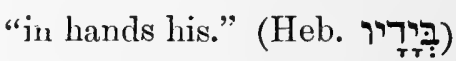

As compared with the practice observed in other cuneiform documents, determinatives and phonetic complements are carelessly used. For example, the plural of nouns is usually expressed by $7 \rightarrow \gg, \quad P Y$ or $\gg$, or by a doubling of the ideograph; but in these tablets we find $P \leftrightarrow r$ pro doubled ideograph plus P $\rightarrow$, or $\rightarrow p_{Y}$. Usually, pronouns are placed after the sign for the plural; but in these tablets they sometimes come before it.

Dual.

The two wedges, the sign of the dual, which are usually placed after the noun, e.g., $\langle Y-p Y$ "eyes," these tablets before the noun.

Ideographs. In compound ideographs the order of the signs is sometimes

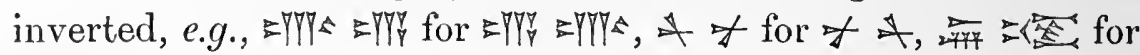
二 etc.

Proper Names. Besides the Semitic names, a few are Egyptian, e.g., Amanappa, Manî, Manakhbirya; a few are Mitalian, e.g., 'Tushratta, Gilu-khîpa, Tâtum-khîpa; and a few are Kassite, e.g., Burra-buriyash, Kuri-galzu, Kara-duniyash, Kara-indash, Shindi-shugab (?). The origin of many names, e.g., Ti'uwatti, Itagamapairi," Widya, and Wyashdata, is not yet definitely ascertained.

Age of the tablets, and contents.
The documents were most probably written between the years B.c. 1500-1450. They consist of: A letter from Amenophis III. to Kallimma-Sin; three letters from Burraburiyash King of Karaduniyash, to Amenophis IV.; three letters from the

1 'The reading of many of the proper names must be considered as tentative. For the complete list sce Ip. 143 ff. 
King of Alashiya to the King of Egypt; three letters from Tushratta, King of Mitani, to Amenophis III.; a letter from Tushratta, probably to Thi, wife of Amenophis III.; fourteen letters from Rib-Adda, governor of Byblos, eleven of which are addressed to the King of Egypt, and three to Amanappa, an Egyptian official; two letter's from Ammunira of Beyrut; four letters from Abi-milki of Tyre; fifteen letters from governors of towns in Phœnicia and Syria; twenty-seven letters from governors of towns in Palestine; eight letters fiom governors of towns the positions of which are unknown; and a part of a mythological text referring to the goddess Irishkigal.

They give an insight into the nature of the political relations Historical which existed between the kings of Western Asia and the kings value. of Egypt, and prove that an important trade between the two countries existed from very early times. They also supply information concerning offensive and defensive alliances between the kings of Egypt and other countries, commercial treaties, marriage customs, religious ceremonies, and intrigues, which has been derived from no other source.

They offer a new field for the researches of the geographical student, and promise important results. The identification of many towns and countries mentioned in the Bible and in Egyptian inscriptions has already been obtained.

In addition to facts which they record concerning the general condition of Western Asia and Egypt, they give us for the first time the names of Artatama, Artashumara, and Tushratta, Kings of Mitani, and of Kallim(?)ma-Sin, King of Karaduniyash.

The dialect in which these letters are written is of special Philological interest for Semitic philology, as it affords a new proof that the value. age of a Semitic dialect cannot be altogether judged from the state of the development of its grammatical forms. It also supplies a number of new words and forms, and exhibits peculiar grammatical constructions, the existence of which has been hitherto unsuspected, and which have a close affinity to the language of the Old Testament. On this account they will be regarded as of the highest value in the study of Hebrew. 
The conquest of Western Asia by the

Egyptians.

Amenophis I., B.c. 1666 .

Thothmes I., B.c. 1633.

Thothmes II., Hâtshepset.

The Egyptians appear to have gained their first foothold in Syria under Ảhmes or Amasis I., the first king of the XVIIIth dynasty, about B.c. 1700 .

He brought to a successful close the war of independence against the Hyksos rule which had been commenced by the Theban kings of the XVIIth dynasty, and captured Avaris, a the chief stronghold of the Hyksos in the east of the Delta, and drove them from the country. He followed up his victory by marching upon Sharhan, to the south of Gaza, and mentioned in Joshua xix. 6), in the fifth year of his reign; but he was not strong enough to advance further into Syria.

Amenophis I. made war upon the Aamu-Kehak, or Asiatics, but he undertook no campaign in Syria or Mesopotamia.

Thothmes I., the first great warrior and conqueror of the XVIIIth dynasty, after subduing the Nubians and other natiuns to the south of Egypt, advanced to the conquest of Palestine, Syria and Mesopotamia. ${ }^{3}$ In northern Syria or Ruthen he set up a tablet to record his victories and to mark the limit of the frontier of Egypt.

During the reign of Thothmes II. no expedition to Mesopotamia is recorded; but it is probable that the people conquered by his father continued to pay tribute. The princes of Ruthen appear to have remained the vassals of Egypt during the reign of Queen Hâtshepset. Upon the wall of a room in the temple of Dêr el-Bahari is painted a scene in which she receives the tribute of Ruthen.2 Her famous expedition to Punt could never have been sent out had any powerful enemy of Egypt been actively hostile.

Thothmes III., Shortly after 'I'bothmes III. ascended the throne, a rebellion B.c. 1600 . broke out which extended from Sharhan to the Euphrates. He

${ }^{1}$ In Egyptian

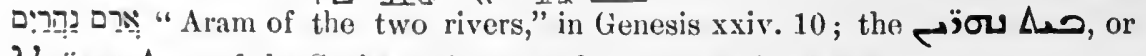
ILojou صئ of the Arals.

2 Dimirhen, IIstorische Inschriften, II, pl. 14. 
at once set out to crush the rebels, and marching by the way of the Peninsula of Sinai reached the loyal city of Gaza in a few days. He there learned that Megiddo was in the hands of the Prince of Kadesh; sixteen days later the two armies joined battle; the rebels were defeated and Megiddo was captured. In the $23 \mathrm{rd}$ year of his reign the princes of Ruthen and Mesopotamia paid tribute to him, and he received as his wife the daughter of the prince of Ruthen. This seems to have been the beginning of the custom of Egyptian kings to take wives from the royal houses of the nations whom they conquered. His example was followed by Amenophis III., who married several princesses from Mesopotamia; by Rameses II., who married a princess of the Cheta; and by Rameses XII., who married a princess of Bechten.

During the 24-30th years of his reign Thothmes captured Tunip, where he established the worship of the gods Amen and Harmachis; Aradus, Tyre, Kadesh on the Orontes, and Carchemish.

In the $33 \mathrm{rd}$ year of his reign he set up a tablet at Ruthen, near that of Thothmes I., mentioned above, and another at Nî, a town on the Euphrates. He also received tribute from the Cheta and other powerful nations.

His last great campaign, against the porverful league of the kings of Kadesh, Tunip, Arantu, etc., took place in the 41st year of his reign.

In the Tell el-Amarna tablets Thothmes III. ${ }^{1}$ is named

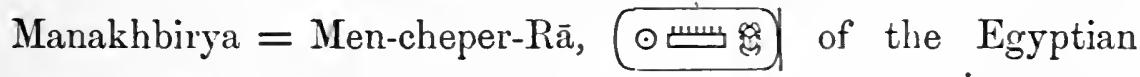
inscriptions, and his institution of the worship of Amen and Harmachis at 'Tunip seems to be referred to in a letter from the people of this city, ${ }^{2}$ probably to Amenophis IV., in which they claim his protection as Thothmes III. had protected them, and because the gods of the two countries are the same.

The lists of countries and cities subdued by this king in Palestine, Syria, and Mesopotamia, which are engraved on the walls of the temple of Karnak, together with the Tell el-Amarna

$$
{ }^{1} \text { See p. lxx. } \quad \text { "No. } 41 \text {; see below, p. lxxi. }
$$


tablets, afford the means of identifying a considerable number of cities in Western Asia.

Amenophis II., In Ruthen Amenophis II. slew seven kings, and took their B.C. 1566 . bodies to Egypt; six were hung up at Thebes, and one in Napata in Nubia. He marched as far as Nî on the Euphrates, where he was well received.

Thothmes IV., Thothmes IV. is said to have conquered all his foes from the B.C. 1533. far south of Nubia to Mesopotamia on the north, but no details of his expeditions are forthcoming.

Amenophis IlI., Amenophis III., the son of Thothmes IV., was not a great B.c. 1500 . conqueror like his grandfather; but the Egyptian monuments state that he subdued Kadesh, Tunip, Sankar, Carchemish, and north-western Mesopotamia. His expeditions, however, to these countries partook more of the nature of triumphal progresses than of wars: lion-hunting in those parts being apparently one of the chief attractions. Several large steatite scarabs state that he slew one hundred and two lions with his own hand during the first ten years of his reign.

Wives of Amenophis.
From the Tell el-Amarna tablets we learn that besides Thi, the Mesopotamian princess whose arrival in Egypt in the 10th year of his reign is mentioned on a scarab, ${ }^{1}$ Amenophis III. married at least five other ladies from various parts of Western Asia. From the first tablet in our series it appears that he had already married a sister and a daughter of KallimmaSin, King of Karaduniyash, a country probably lying to the north-east of Syria, and that he was renewing a proposal for another daughter named Sukharti (i.e., "little one"). He had originally made the proposal when Șukharti was a child, and negotiations had consequently to be delayed until she had grown up, when Kallimma-Sin himself informed him of the fact.

The tablets numbered 8,9 and 10 prove that from the house of Shutarna, son of Artatama, King of Mitani, Amenophis married two ladies, viz., Gilukhîpa, the sister of Tushratta, ${ }^{2}$ son

1 The text is published by Brugsch in Eg. Zeits., 1880, p. 82.

${ }^{2}$ Me succeeded to the throne of Mitani after the death of his brother, Artashumara, who had been murdered by rebels. 
of Shutarna, and Tâtumkhîpa, Tushratta's daughter. Of the latter no mention is made in the Egyptian inscriptions; but it is stated on the scarab mentioned above that Gilukhîpa,

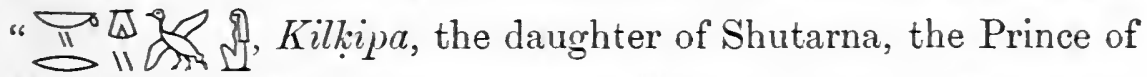
Mesopotamia, was brought to His Majesty together with three hundred and seventeen of the first ladies of her train." 1 The Tell el-Amarna tablets show that Tushratta frequently sent gifts to his sister and daughter with the letters which he sent to his son-in-law Amenophis.

Neither Gilukhîpa nor Tâtumkhîpa was acknowledged "Queen of Egypt," this honour being reserved solely for the lady Thi, or Tii, (4911 It , who, as already stated, had become. the wife of Amenophis in the 10th year of his reign. Her father's name was Iuaa, 44 in 4 , and her mother's $\Longrightarrow 4$ II, Thua. It is not stated that she was the daughter of royal parents, but the frequent occurrence of her name on scarabs, rings, vases, amulets and other objects bears testimony to the unusual position and influence of this queen. The tomb of a Queen Thi, who is described as "royal daughter, Thi, Queen of royal sister, royal mother, royal wife, great lady, lady of the Egypt. North and South," 2 was opened early in this century at Thebes. There is little doubt that it was the tomb of the chief wife of Amenophis. The portrait of this lady ${ }^{3}$ represents her with a fair complexion and blue eyes; the colour of her skin is that of natives of north-eastern Syria: Thi was the mother of Amenophis IV. She also gave birth to a daughter, Set-Ämen,

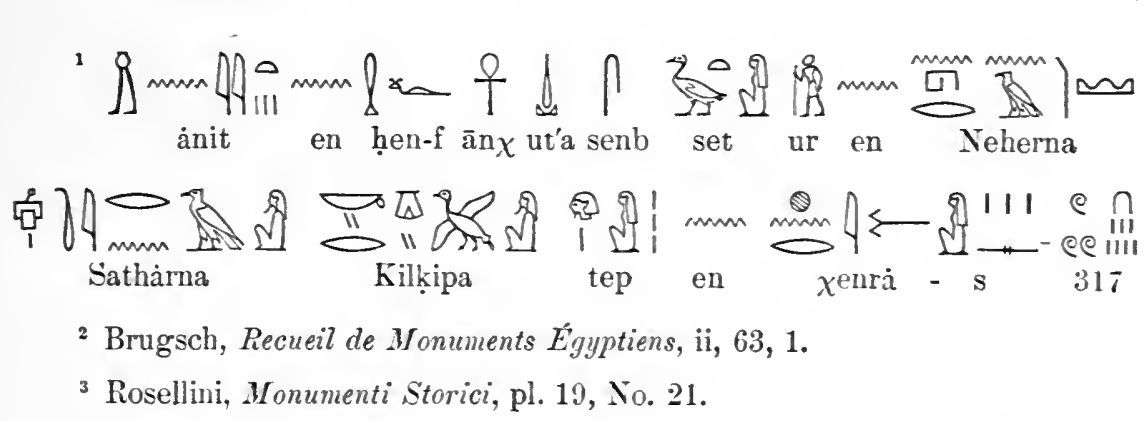


4 mu $20 .{ }^{\circ}$. The British Museum possesses a blue-glazed faience stibium tube ${ }^{2}$ and a double wooden stibinm tube ${ }^{3}$ inscribed with the names of Amenophis and Thi. They probably formed part of the toilet service deposited in the tomb for the Queen's use.

Babylonian forms of names of Amenophis and Thi.

Queen Thi's name appears in the Tell el-Amarna tablets ${ }^{4}$ in the form of Mimmuriya, Nimmuriya, and Immuriya, each form representing

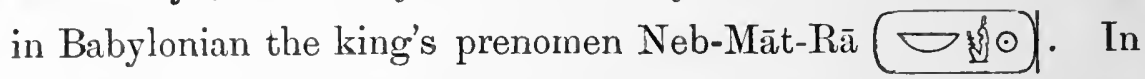
the forms Mimmuriya and Nimmuriya we have the interchange of the letters $\mathrm{M}$ and $\mathrm{N}$, which is common in the Semitic languages. ${ }^{5}$ It has been assumed that the name Mimmuriya is that of Thothmes IV., because in a tablet in Berlin (No. 23), from which the name of the person addressed is broken off, and which is supposed to have been written to Amenophis III., mention is made of "Mimmuriya, thy father." There is, however, no reason for the assumption that the tablet was addressed to Amenophis III.; on the contrary, the following extract ${ }^{6}$ from it proves that it was written to Amenophis IV. :The writer, Tushratta, says: "Khâmashshi, the envoy of my brother [the King of Egypt], hath informed me of the contents

1 As recorded in an inscription on a fragment of wood, used for inlaying, now in the British Museum, No. 5899a. Amenophis had two other daughters, Auset and Hentmerheb.

${ }^{2}$ No. 25726, Fourth Egyptian Room, Northern Gallery, Case E.

${ }^{3}$ No. 2598a, Fourth Egyptian Room, Northern Gallery, Case E.

4 Berlin Collection, No. 23, rev. line 54; No. 24, obv. lines 3, 8, 9, 45, 46, $61,63,66$; rev. lines $13,30,49^{\text {bis }}, 93$.

See Wright, Comparative Grammar of the Semitic Languages, p. 67; Bondi, Dem Hebräisch-Phönizischen Sprachzweige angehörige Lelnwörter, p. 42; Barth, Zeits. f. Assyr., Vol. II, pp. 111 ff.; Vol. IV, pp. 374 ff.

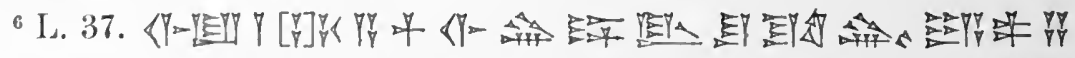

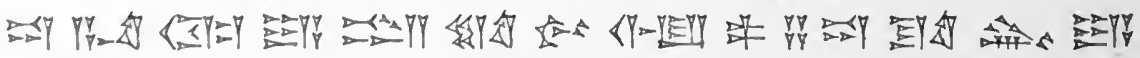

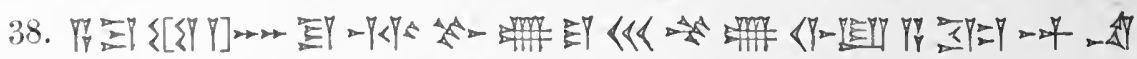

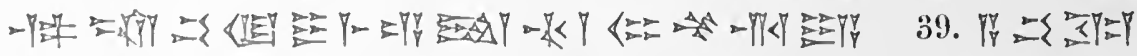

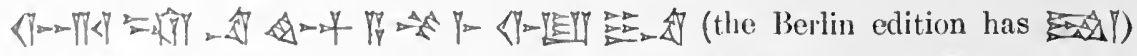

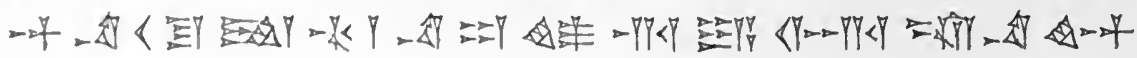


of my brother's despatch, and I have understood them. And now, I say that just as I was in friendship with Mimmuriya thy father, so also will I be more than ten times more so with Napkhurriya. Thus did I speak to Khâmashshi, thy messenger:" It is certain that Napkhuriya is the Babylonian form of the prenomen of Amenophis IV., Nefer-cheperu-Rā, $(\odot)$, and it is equally certain that by Mimmuriya is meant his father, and not his grandfather. Moreover, the occurrence in the Berlin Tablet No. 24, which, it is admitted, is addressed to Amenophis IV., of a reference to the messenger Khâmashshi, is a proof that both it and Tablet No. 23 are contemporaneous. It is quite evident from paragraphs II and III of Tablet No. 9 of our series, as will be seen on referring to the Summary at the end of this Introduction, that Tushratta only asceuded the throne of Mitani after Amenophis had begun to reign in Egypt, and on this account he specially asks him to continue to himself the friendship which he bore to his predecessor Shutarna. In this tablet the King of Egypt is named Ni-ib-mu-a-ri-ya, and in No. 10, Ni-im-mu-ri-ya; both of which forms represent the Egyptian Neb-Māt-Rā, i.e., Amenophis III. Moreover, No. 10 bears a hieratic docket stating that the tablet was brought to Egypt in the 36th year of the king, who must have been Amenophis III.; for Thothmes IV., according to the testimony of all the authorities, including the monuments, reigned less than ten years. In Tablet No. 8 the king's name appears as Mimmuriya (or Inmuriya), and internal evidence shors that it was addressed to the same person as Nos. 9 and 10. Finally, in Tablet No. 11 the Queen of Egypt is quoted as styling her husband Mimınuriya, and apparently as referring to Napkhurriya (Amenophis IV.) as his son.

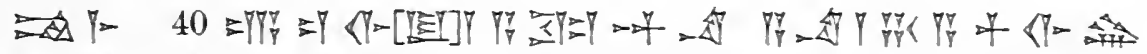

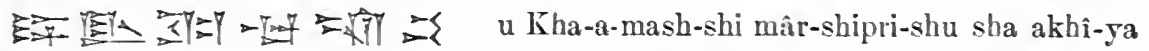
pa-za-du a-ua mukhi-ya il-li-gu u pa-za-du sha akbî-ya a-ma-ti-shu ik-bu-u-ma ish-mu-u u a-ka-an-na ał̣-ta-bi ki-i-mi-i it-ti Mi-mu-ri-ya a-bi-ka ar-ta-na-'. a-mu-mi u i-na-an-na $x$-suc it-ti Na-ap-khur-ri-ya ar-ta-na-'-am-mi dannis(is) u a-ka-an-ua a-na Kha-a-mash-shi mâr-shipri-ka aǩ-ta-bi. 
Amenophis IV. or Khu-en-A ten, B.c. 1466 .
Amenophis III. was succeeded by his sun Amenophis IV., or Khu-en-aten, who is commonly known as the "heretic king." His reign was comparatively short, extending to about twelve years. Although the peoples of Syria and Ethiopia paid him tribute, his hold upon those countries cannot have been firm. Soon after the beginning of his reign he publicly seceded from the worship of Amen, the great god of Fgypt, and endeavoured to supersede the old religion of the country by the worship of Aten or the disk of the Sun. His hatred of Amen was so excessive that he changed his name from Amen-hetep (Amenophis) to Khu-en-Aten (i.e., " the splendour of Aten"), and erased the name of the god from the walls of temples and other public buildings. His attempts to alter the worship of the country were vigorously opposed by the priesthood, and in the end he was compelled to withdraw from Thebes. He retired to a spot about 180 miles above Memphis on the Nile and built there an entirely new town, temple, and palace (see above, p. ix), in which he lived with his mother, his wife, and his seven daughters. After his death the town seems to have been forsaken and shunned, and no buildings were erected on or near its site. The plan of the streets can be distinctly traced to this day. The portraits of Amenophis on the monuments are frequently caricatures; he is represented with receding forehead, thick lips, protruding chin, round shoulders, and pendulous belly. They afford proof, if any is required, that Khu-en-Aten and Amenophis IV. are one and the same person. Some scholars have suggested that he was a eunuch, and some that he was a woman.

In the Tell el-Amarna tablets Amenophis IV. is called Napkhurriya $=$ Nefer-cheperu-R $\bar{a}$; the first portion of his pre-

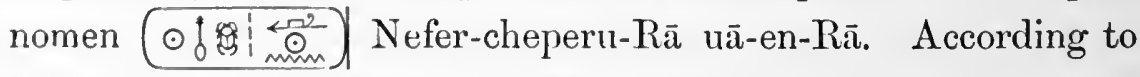
Tablet No. 3 he gave one of his daughters in marriage to the son of Burraburiyash, King of Karaduniyash. His father Amenophis III. refused to entertain the proposal of KallimmaSin, King of Karaduniyash, to marry an Egyptian princess, haughtily replying that "the daughter of the King of the land 
of Egypt hath never been given to a "nobody." It is probable that Burraburiyash was a more powerful king than his predecessor, and had grown strong as the Egyptian power waned in Western Asia, and could therefore better claim such an alliance.

A large number of the present tablets are addressed to Decline of "the King of Egspt," either Amenophis III. or Amenophis IV Egyptian power Nearly all of them consist of reports of disasters to the Egyptian power and of successful intrigues against it, coupled with urgent entreaties for help, pointing to a condition of distraction and weakness in Egypt. That some may have been addressed to Amenophis III., probably in his declining years, may be inferred from the fact that the despatches of the governor of Katna (Nos. 36, 37) to that king are couched in a similar strain; but it is probable that most of them belong to the next reign, and reflect the troubles which we know resulted from the struggle between Amenophis IV. and the old priesthood.

The most graphic details of the disorganized condition, and of the rival factions, of the Egyptian dependencies lying on the coast-line of Phœnicia and northern Palestine, are to be gathered from a perusal of the despatches of the governors of the cities of Byblos, Beyrut, and Tyre.

Rib-Adda, of Byblos, reports the revolt of almost the whole district under his command; the successes of his rivals AbdAshirta and his active son Aziru; the loss of the ships of Șumuru, Beyrut, and Sidon, and the capture of his own ship; above all, the siege and capture of the important northern city of Sumuru, or Simyra, which commanded the road to Aradus. Beyrut has fallen (No. 17) and the enemy are closing in upon Byblos. Appeal follows appeal for help; but the King of Egypt is indifferent and unmoved. Rib-Adda's enemies include members of his own household, but he still protests his unswerving loyalty, and only in his despair does he threaten to abandon the city and renounce his fealty to the Egyptian king.

Ammunira, of Beyrut (Nos. 26, 27), takes the other side. He had repulsed Rib-Adda's appeals for help (No. 16), and perhaps it was on this account that the latter had reported 
Beyrut as lost, meaning that it was in the hands of one of the adverse faction. Now Ammunira denounces Rib-Adda as the oppressor of the King of Egypt's officials (apparently referring to Abd-Ashirta and Aziru and others of his faction); and he is watching the men of Byblos until he shall learn the king's pleasure. Abd-Ashirta himself appear's in the correspondence with a letter (No. 33) protesting his loyalty.

Abi-milki, governor of Tyre, belongs to the party of RibAdda (Nos. 28-31). His appointment to his government had been the signal for his enemies to attack him; and Zimrida, governor of Sidon, through whose agency (whether by force or guile) Șumuru had fallen, now, with the assistance of Aziru and the men of Arvad, or Aradus, lays siege to the island-fortress of Tyre, first capturing Sazu on the mainland and thus cutting off Abi-milki's supply of wood and water. The last that we hear of the unhappy governor is his withdrawal from Tyre, apparently in disgust at being superseded; and we may infer that, in the end, the whole of the littoral between Sidon and Aradus passed into the power of the faction led by Abd-Ashirta and Aziru.

Origin of Sun-worship in Egypt.
The details of the worship of the Disk which Amenophis IV. tried to establish are unknown, and the Tell el-Amarna tablets give us no information. A point of interest, however, concerning the religion of Egypt is brought out in No. 36, in which Akizzi, governor of Kaṭa, when applying to Amenophis III. for means to ransom the "Sun-god of Egypt," which had been carried off by the people of Khatti, declares that Shamash, the Sun-god, the god of his fathers, became also the god of the ancestor's of Amenophis, and that they called themselves after his name. This evidently has reference to the title "son of the Sun" which was adopted by nearly every king of Egypt, and indicates that Akizzi believed that the worship of the Sun was introduced into Egypt from Asia.

In the following Summary translations of passages have been made as literal as possible, but some of the renderings are necessarily free. 


\section{SUMMARY OF THE CONTENTS OF THE TABLETS.}

1.-Letter from Amenophis III., King of Egypt, to Kallimma(?)- Sin, King of Karaduniyash. ${ }^{1}$

This document is of more than ordinary interest, being the only known letter of Amenophis III. in the Babylonian language and writing, ${ }^{2}$ and being addressed to a king who has become first known to us by the Tell el-Amarna tablets. Kallimma-Sin ${ }^{3}$ is probably to be placed in the gap which occurs in the list of Babylonian kings immediately preceding Kara-indash, especially as his name is clearly Babylonian and not Kassite. He probably belongs to the fourth dynasty of Berosus, who describes it as "Chaldean."

The letter begins:-" To Kallimma-Sin, King of Karaduniyash, my brother, thus saith Amenophis, the Great King, the King of Egypt, thy brother: 'I am well, may it be well with thee, with thy government, with thy wives, with thy children, with thy nobles, with thy horses, and with thy chariots, and may there be great peace in thy land; with me may it be well, with my government, with my wives, with my children, with my nobles, with my horses, with my chariots, and with my troops, and may there be great peace in my land." "

1 Northern Babylonia, conterminous with Assyria.

2 A tablet at Gîzeh (B., No. 10), written in the cuneiform character, in an unknown language, appears to be a despatch from Amenophis III. to Tarkhundaradush, Kiug of Arșapi; but some scholars maintain that Amenophis III. is the person addressed, and not the writer.

3 A letter of Kallimma(?)-Sin to Amenophis III. is preserved at Gizeb(B., No. 1), another is at Berlin (B., No. 2), and a third seems to be that which forms No. 3 of the Berlin Collection.

'See Gutschmid, Beiträge zur Geschichte des alten Orients, 1858, p. 2 ก. 
Amenophis then states that he has understood the words of the despatch concerning Șukharti, ${ }^{1}$ daughter of Kallimma-Sin, which her father has sent to him. He appears to have asked the hand of this lady in marriage, and Kallimma-Sin had replied, "Thou wishest for my daughter to wife; but from the time when my father gave thee my sister to wife, no man hath seen her, and none knoweth whether she be alive or dead," implying that he was not prepared to send his daughter Sukharti to Egypt until he was well assured that her aunt, his own sister, was alive and was being treated in a manner befitting the wife of the King of Egypt. With the despatch containing the extract here quoted by Amenophis, Kallimma-Sin had sent messengers, viz, Rîka, son of Zaḳara, and other high officials, to bring back news of his sister. Referring to this embassy, Amenophis now replies that none of its members was personally acquainted with Kallimma-Sin's sister, as they were not old enough to remember her marriage, which had taken place during the lifetime of KallimmaSin's father ; and he recommends him to send a wise man ${ }^{2}$ who was personally acquainted with his sister and had conversed with her, and who would thus be able to recognize and speak with her.

Then follows a break in the text ( 7 lines).

Kallimma-Sin had also referred to the conversation which the Egyptian king had held with his messengers, and to the orders which he had given to his wives that they should assemble and appear before them, and he had informed Amenophis that his messengers had failed to recognize his sister, the queen, from among the other ladies who stood before them. In reply to this, Amenophis now writes, "Since thou sayest, "My messengers cannot identify her,' I answer, 'Then who can identify her?' and I ask further, 'Why dost thou not send a wise man who might give thee a trustworthy account, and describe to thee the comfort and good health of thy sister here?' Command, then, one of thy wise men to come and examine her household, and let him see for himself the honour in

1 I.e., "Little one."

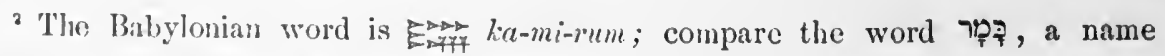
given by the Hebrews to a licathen piest. 
which she is held by the king," -in fact, repeating what he had already said in the earlier part of the letter.

Kallimma-Sin also had written to the effect that, although his messengers had seen the wives of the king assembled before them, and although a certain woman had been pointed out to them as his sister, it was impossible for them to be sure that she was not a native of the land of Gagaya, or of Khanigalbi, ${ }^{1}$ or of Ugarit; and he had asked: who was there that could truthfully assure them that the woman was his sister? or who was there upon whom they could rely to tell them truthfully if she were dead or alive? Most unfortunately the lines of text which gave the comments of Amenophis upon this extract are broken, but the few words which remain here and there seem to indicate that he appealed to Amen, the great god of Egypt, to bear witness to the truth of his words, and that he assured Kallimma-Sin that "kings of the land of Egypt" were not wont to act deceitfully.

Referring to the matter of the bestowal of his daughter's hand, Kallimma-Sin had stated that it was his custom to give his daughters in marriage to the "kings of Karaduniyash," and that the messengers who took them to their future homes were treated with generous hospitality, and that handsome gifts were sent back to him in their hands by the husbands' relatives. Amenophis replies that whatever the great kings and nobles of Karaduniyash may possess and are willing to give to Kallimma-Sin as dowries for his daughters, he not only possesses, but is willing to give, far more than they all; nay! he is even prepared to send Kallimma-Sin a gift in honour of his sister who is now living in Egypt with him. He also says that he will not discuss the words spoken by his father (Thothmes IV.), which Kallimma-Sin had quoted, and he asks that they may be forgotten, especially as he wishes for "brotherhood" to be maintained between the houses of Egypt and Karaduniyash. 'This last observation is a reply to Kallimma-Sin's words: "Now let us two be brethren," and following this up, the Eyyptian king announces that he has sent his messenger to make a commercial treaty, the chief points

- Usually read Klanirabi. This country was situated near Lake Van. See Norris, Assyrian Dict., Vol. II, p. 435. 
of which seem to be as follows:-Any Mesopotamian travelling in Egypt with merchandize shall pay certain duties to the King of Egypt, and should the traveller, whether a trader or otherwise, refuse, the duty shall be exacted by force. Among the articles upon which duty shall be levied are mentioned gold, silver, oil, clothing, and other objects of value.

The mutilated condition of the text of lines 71-77 makes it impossible to give a connected rendering of them, but it appears that Amenophis complains that the first and second company of messengers who came to Egypt from Mesopotamia made false reports on their return home.

When Amenophis applied for the hand of Kallimma-Sin's daughter Șukharti, he appears to have demanded a contingent of Mesopotamian soldiers also. Kallimma-Sin had replied that "he had no soldiers," and that "his daughter Șukharti was not beautiful." To this Amenophis now answers that he knew that "these words were not the words of Kallimma-Sin," and that he believed that "the Mesopotamian messengers had spoken falsely"; there is no one of whom to make enquiries whether Kallimma-Sin has soldiers, or not, or whether the chariots and horses which bring the messengers are his, or not; but in any case he advises Kallimma-Sin not to believe the reports of his returning messengers, as they are afraid of him, and they lie concerning the King of Egypt. Kallimma-Sin must have previously asked that certain chariots, and horses, and officers, whom he sent to Egypt should be returned, for, referring to them, Amenophis says that "they had been seen by no man"; KallimmaSin may have sent them to the frontier of his own territory, but in Egypt they had certainly not been seen. The chariots and horses which are in Egypt belong to himself. The chariots which have recently arrived he intends to load with oil, and to send them back to Mesopotamia under the charge of Rîka.

The concluding lines of the letter repeat the request that Kallimma-Sin will send his daughter Șukharti to Egypt.

[In a tablet preserved at Berlin (No. 3, 1. 27) it appears that Kallimma-Sin had stated that Amenophis had had no children by his daughter whom he had already given to the Egyptian king, and 
hence it would appear that Amenophis had not only married KallimmaSin's sister, but also one of his daughters, before he asked for the younger daughter Șukharti. In the same letter he refers to a former request to Amenophis that he would give him an Egyptian princess to wife, and quoting the Egyptian king's answer: "The daughter of the King of the land of Egypt hath never been given to a "nobody," he asks, "Why not? Thou art king and canst act as thou pleasest; and if thou wilt give [her to me], who shall say a word [against it]? When these words were reported to me I wrote again, saying, 'Surely there be daughters of nobles (?) who are beautiful women [in Egypt]. Now, if thou knowest a beautiful lady, I beseech thee to send her unto me; for who here could say that she is not a princess?' But if thou wilt not send such an one, then dost thou not act as a friend and brother should. Now even as thou, because we are connected with each other, hast written unto me concerning a marriage [with my daughter], so because of our brotherhood and friendship, and because we are connected, have I also written unto thee concerning a marriage [with thy daughter]. Why has not my brother sent me a wife? Inasmuch as thou hast not sent me a wife, in like manner will I do unto thee, aud will hinder any [Mesopotamian] lady from going into Fgypt."

Notwithstanding his indignation, Kallimma-Sin proceeds forthwith to discuss the matter of a loan of a quaritity of gold, which, however, he really intends should be a dower for his daughter; and he asks that it may reach him during the months of Tammuz and $\mathrm{Ab}$ (i.e., the latter half of June, the month of July, and the first half of August), during the period of harvest, for he wishes to pay to the temple the completing part of an offering which he has vowed. If Amenophis cannot send him the gold, to reach him by the time stated, what good is there in his sending it at all? For what use can he find for gold when the work for which it is intended is all over and done? If Amenophis should send even three thousand talents of gold when the work is done, he will not accept it, but will return it, and will conclude that henceforth all question of the marriage of the King of Egypt with his daughter is at an end. What answer Amenophis made to this letter, or whether he sent the 
gold or not, is unknown; but some satisfactory arrangement must have been arrived at, for, from a tablet preserved at Gîzeh (B., No. 1), we learn that Kallimma-Sin afterwards wrote to Amenophis saying: "With reference to thy request that my daughter Șukharti be given to thee to wife, my daughter Șukharti hath now come to the age of puberty and may be married; if thou wilt write unto me, she shall be brought unto thee." Thus it appears that Amenophis "contracted affinity" with several of the kings of Mesopotamia by marrying their daughter's and sisters.]

The present tablet is probably a copy of the despatch which was actually sent to Mesopotamia; written by a native of Mesopotamia, maintained at the court of Amenophis as the official scribe for such correspondence. If it be not a copy, it must be the original which; for some reason or other, was never sent.

2.-Letter from Burraburiyash, ${ }^{1}$ King of Karaduniyash, to Amenophis IV., probably soon after he became King of Egypt.

This letter, which is one of the most important of the British Museum series, begins by stating that Burraburiyash is himself in good health, and he hopes that Amenophis, and his wives and children are also in good health, and that his country and army and government are in a prosperous cundition. In days gone by their fathers were agreed in friendship, and used to accept and return each other's gifts, without any definite feeling of obligation. Amenophis had recently sent him a gift of two manehs of gold, but this is a much smaller quantity than his father Amenophis III. was wont to send. Burraburiyash entreats him to send at least the half of what his father used to send, and asks why so little as two manehs has been sent. To account for his urgency, he explains that he has promised to contribute largely to the support of the temple of the god of his native land, a promise which he is bound to carry out; he begs that Amenophis will send "much gold," and in return he promises to send him anything that he wishes for of the productions of his land. He next reminds Amenophis that in the days of his

3 Four letters of this king are preserved at Berlin (Nos. 4, 6-8). 
father Kurigalzu the Canaanites sent a messenger inviting him to join them in an invasion of Kannishat, a district under the suzerainty of Egypt; but that Kurigalzu declined to make any league with them, and sent their messenger away with an answer that, if they induced any other king to join them in an attack upon the possessions of the King of Egypt " his brother," he would go forth against them in battle. Kurigalzu formed this resolution after consultation with Burraburiyash his son. Burraburiyash continues that he had sent to Amenophis accounts of the recent proceedings of the Canaanites by the hands of a trusty Assyrian messenger, and claims that it is not his fault that the Canaanites had actually invaded Egyptian territory in Mesopotamia. He begs Amenophis to remember that, as long as there is an offensive and defensive alliance between them, the Canaanites are powerless to do much harm and may be easily driven off. To disarm the wrath of the Egyptian king, he sends hin three manehs of lapis-lazuli and five pairs of horses for five wooden chariots. ${ }^{1} \quad$ The invasion here referred to appears to have been one of the periodic migrations usual among all nomad tribes in Mesopotamia, when seeking pasturage and water for their cattle.

3.-Letter from Burraburiyash, King of Karaduniyash, to Amenophis IV., King of Egypt.

After the usual salutations, Burraburiyash refers to the amicable relations which existed between Karaindash, a former King of Karaduniyash, and the father of Amenophis in days of old, and he hopes that these relations may be continued. He complains, however, that the messengers of the King of Egypt have come to him three times in succession without bringing any gift with them, and he will therefore send vo gift to Amenophis. $\mathrm{He}$ adds, "If thou hast nothing of value for me, then have I nothing of value for thee." $\mathrm{H} \epsilon$ next complains that the messenger who was sent to him from Egypt with twenty manehs of gold did not deliver them; five appear to have been offered, but these Burraburiyash refused to accept. Re-

\footnotetext{
I It is probable that these chariots were made of a special kind of wood.
} 
peating the hope that peace may exist ${ }^{1}$ and wax old between Egypt and Karaduniyash, Burraburiyash seems to propose to send certain gifts to Egypt, in return for which he expects to receive chariots, which his messenger Shindishugab will bring back. In conclusion he hopes that their messengers may travel together as in days of old, and he sends two manehs of lapis-lazuli as a gift for Amenophis, and various presents for "thy daughter, the wife of my son." The fact that a daughter of Amenophis IV. was married to a Mesopotamian prince is new, and is of considerable interest; whether this prince was Karakhardash, who succeeded his father on the throne of Karaduniyash in the time of Ashur-uballit, ${ }^{2}$ King of Assyria, cannot at present be decided. As appears above (p. xxix), Kallimma-Sin was refused by Amenophis III. the hand of one of his daughters, as "The daughter of the King of the land of Egypt hath never been given to a "nobody." It would seem then that Burraburiyash must have been an independent king, while Kallimma-Sin was a "shêkh" of comparatively little importance.

4.-Letter from Burraburiyash, King of Karaduniyash, to Amenophis IV.

This tablet is much mutilated; three of its four corners are wanting, and several of the signs which remain are nearly effaced. Line 17 of the Obverse is continued across the Reverse, which is almost blank. At the bottom left-hand corner of the Reverse is the impression of a scarab, or the bezel of a ring, which was inscribed with the hawk of Horus wearing the crowns of the North and South, the disk of the sun, $\odot$, a winged uræus, and other signs the impressions of which are wanting.

After the usual salutations, Burraburiyash states that he has heard that the King of Egypt possesses fair palaces, and that he is preparing to send back with Shutti, ${ }^{3}$ an officer of Amenophis, fair gifts for his fair palaces, consisting of an ivory and gold throne, wood and

1 With line 21 a break in the text begins, and it is uncertain how many lines are wanting at the end of the Obverse and the beginning of the Reverse.

${ }^{2}$ A letter of this king to Amenophis IV. is preserved at Gîzeh (B., No. 9).

- This pame is probably Egyptian. 
gold thrones, and a number of golden objects, the weights of which are specified in manehs and zâzu. These gifts probably formed part of the dowry of the daughter of the Egyptian king who was about to "contract affinity" with the royal house of Karaduniyash.

\section{5.-Letter from the King ${ }^{1}$ of Alashiya to the King of Egypt. ${ }^{8}$}

The name of the country of Alashiya has not hitherto been found in any cuneiform document except the Tell el-Amarna tablets; in which, however, it is spelt Alasiya. In the Egyptian inscriptions a city A通 Alesa is mentioned pretty often; and it is most probable that the Egyptian Alesa and the Assyrian Alasiya are one and the same

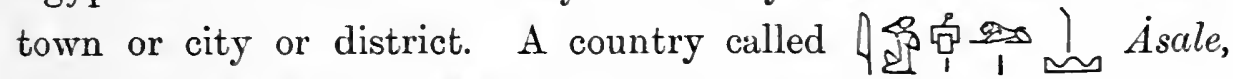
mentioned in British Museum Papyrus No. 10,247, p. 23, 1. 6 (Select Papyri, pl. 57), was thought by Chabas (Voyage, p. 225) to be another form of 4 通 t. x, p. 210) is of the same opinion. In 1.49 of the present tablet, the King of Alashiya seems to refer to the countries of Khatti and Shankhar as if they were neighbouring tributary states. If this be the case, Alashiya was probably situated to the west or south-west of Tunip and Aleppo, and sufficiently near them to be able to supply a contingent of men to the great league of cities of Northern Syria, which lost no opportunity of rebelling against the kings of Egypt. In the Egyptian inscriptions the general position of Alesa and the cities mentioned in connexion with it is sufficiently indicated, and it may without much hesitation be assumed that by the names Alesa and Alashiya, the Egyptian and Babylonian writers indicated the same country. In the annals of Thothmes III. and Amenophis III. no mention appears to be made of Alesa, but during the reign of Rameses II. it is certain that the people of Alesa included among their allies the inbabitants of a number of cities to the south-east and south-west and west of Aleppo; for in the list of the conquered peoples of Northern Syria drawn up for that king

1 The name of this king is unknown.

2 Probably Amenophis III. or his sou Amenophis IV. 
(see Denkmüler, Abth. iii, Bl. 131) the names of Neherni (Mesopotamia) (Denkmäler, Abth. iii, Bl. 145a) are grouped together. The King of Alashiya states in his letters that he sends as gifts to the King of Egypt bronze, wood, oil, and horses; and British Museum Papyrus No. 10,249 (Anastasi IV.), pp. 16, 1l. 2-4; 18, 1l. 8-10 (Select Papyiri, pll. 96 and 98) mentions as products of Alesa and the neighbouring countries horses, unguents, cows, etc. There appears to be little doubt as to the identity of the countries. That the Egyptians believed Alesi to be the same country as that called Alashiya by the Babylonians we know from the hieratic docket written upon one of the Tell el-Amarna tablets preserved at Gîzeh (B., No. 12) and inscribed with a letter of the King of Alashiya, the

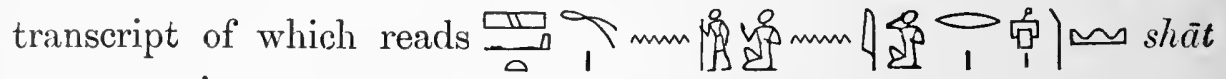
en ser en Alesa, "Letter of the prince of Alesa."

The present letter begins: "To the King of Egypt, his brother, thus saith the King of Alashiya, his brother: ' $I$ am well, and it is well with my government, with my wife, with my children, with my nobles, with my horses, and with my chariots, and in my territories is great peace. And with thee, $\mathrm{O}$ my brother, and with thy government, with thy wives, with thy children, with thy nobles, with thy horses, with thy chariots and with thy territories may it also be well.'" The King of Alashiya next announces that he sends his own messenger to accompany the messenger of the King of Egypt, and also that he sends 500 pieces of bronze as a gift to "his brother" the King of Egypt, praying him not to be offended because of the small quantity, as the "hand of Nergal," i.e., the pestilence, had killed all the people of his land and it was not possible to continue the manufacture; therefore let him not "take it to heart." $\mathrm{He}$ then begs the King of Egypt to send the two messengers back to him as soon as possible, and promises to send him in the future as much bronze as he may wish; in return he asks for a large amount of silver of which he is in need to make a contribution to the temple of his grods, and he offers to send to Egypt whatever Amenophis may wish for. He also sends by the hand of his messenger an ox, and 
two measures of choice oil, for which Amenophis had asked, and accompanying them, also, as a gift, runners "swifter than eagles."

The meaning of the next paragragh is not clear, but it appears to refer to some horses and chariots which had become the property of the King of Egypt.

In the following paragraph the king states that one of his subjects died in Egypt, where he left property, and, as his wife and son live in Alashiya, he asks Amenophis to have the property collected and to send it back to the relatives of the deceased by the hands of the Alashiyan messenger. About three years before an Egyptian messenger had arrived in Alashiya, and having remained there some time was unable, through the pestilence, to leave the country. The King of Alashiya now begs the Egyptian king not to take this amiss, and, making the severity of the epidemic an excuse for the Egyptian official's delay, points out that his own palace had been attacked, and that the child to which the queen had recently given birth had fallen a victim to the disease. Repeating his request that Amenophis will send the money and the property of the dead Alashiyan, the king begs him not to make any treaty or league with the Kings of Khatti ${ }^{1}$ and Shankhar, ${ }^{2}$ and promises that whatever gifts they may send to him he will pass on to the Egyptian king, together with the addition of a like amount from himself. The idea of the King of Alashiya ${ }^{3}$ is, apparently, to

1 This country has often been identified with the Egyptian Cheta.

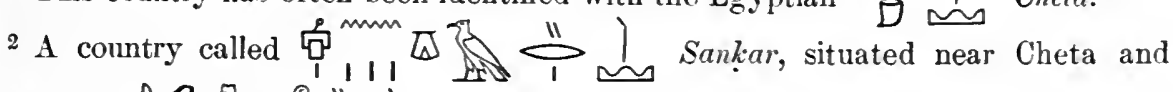
Alesa and 4 and probably represents the country called Shankhar by the Babylonians. Sankar

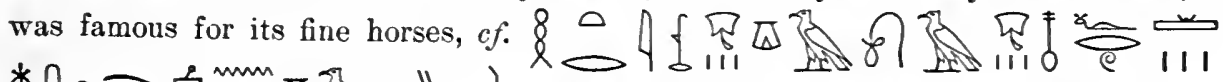

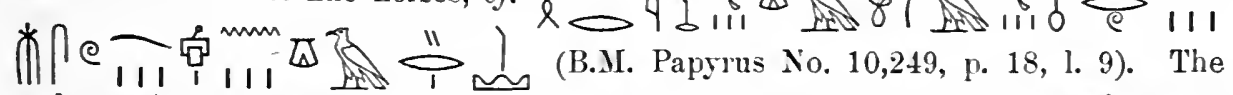
orthography of Shankhar is precisely the same as that of the Hebrew Shinar, the name having possibly shifted in process of time from the eastern frontier of Babylonia to the Singar hills, adjoining the country of the Khatti. The horses of the desert south of the hills are still famous. It may be conjectured that the site of Alashiya was near Kharran, but the name is not to be recognized in the geography of the district.

${ }^{3}$ Four letters of the King of Alashiya are preserved at Berlin (B., Nos. 11, 13, 15, 16), and three (?) at Gizeh (B., Nos. 12, 14, 17 (?)). 
prevent Amenophis from opening up any direct communication with his own neighbouring friends and allies.

In the last paragraph the king appears to say that he has given his messenger full power (?) to act on his behalf, and that he hopes that the Egyptian king will do likewise.

\section{6.-Letter from the King of Alashiya to the King of Egypt.}

After salutations, he complains that the Egyptian messenger did not come into his presence. He is anxious to hear if Amenophis is angry with him, and in his uncertainty he sends a special messenger and with him one hundred talents of bronze. Previously he had sent to Egypt, by the hands of an Egyptian messenger, a wooden couch plated with gold, a chariot decorated with gold, two horses, garments, precious stones, oil, etc.

Here follow eighteen lines so mutilated that it is impossible to give a connected rendering of them. But it appears that several of the gifts were lost on their way to Egypt.

After this break, the text seems to refer to a wish on the part of the King of Alashiya to make arrangements for the transport of merchandize, ${ }^{1}$ and to the passage of the Egyptian and Alashiyan messengers in safety. He complains that, while he sends to Amenophis everything that he wishes for from his country, Amenuphis gives him nothing in return, although he has been in the habit of sending gifts to the Egyptian king ever since he ascended the throne.

7.-Letter from the King of Alasiya [Alashiya] to the King of Egypt.

After the usual salutations, he announces the despatch to Egypt of a gift consisting of five talents of bronze (?) and five pairs of horses, etc. He has sent the messenger of the Egyptian king back to his country quickly, and he prays that Amenophis will send back

1 Compare the commercial treaty proposed by Amenophis III. to Kallimma-Sin, King of Karaduniyash (see pp. xxvii, xxviii). On a tablet at Gîzeh (B., No. 12, 11. $14 \mathrm{ff}$. ), the King of Alashiya introduces his merchant (tamgar) to Amenophis by letter. 
the Alashiyan messenger with equal speed; if he needs any further gifts and will write them on a tablet, they shall be sent to him without delay. He also urges Amenophis to send back the Alashiyan messenger with the much-needed money.

The end of the text is much mutilated, but enough remains to show that the letter was despatched to Egypt by a special mission consisting of four or five members, among whom were Kunîa, Itillûna, and Ushbarra (?). ${ }^{1}$

\section{8.-Letter from Tushratta, King of Mitani, ${ }^{2}$ to Amenophis III., ${ }^{3}$} King of Egypt.

This tablet is the largest and finest of the collection, and very few signs are wanting in the text, which is written in a bold, clear hand. The letter is divided into thirteen paragraphs, the contents of which are as follows :-

Par. I. "To Mimmuriya, the Great King, King of Egypt, my brother, my son-in-law, who loveth me, and whom I love, thus saith Tushratta, the Great King, thy father-in-law, who loveth thee, the King of Mitani, thy brother: 'I am well, and may it ke well with thee, with thy government, with my sister and thy other wives,

1 These names are not mentioned elsewhere in the Tell el-Amarna tablets.

2 The principal variant forms of this name are Mittânni, Mitani, and Mitan. A country also called Mi-ta-a-ni, in which Tiglath-Pileser I. went to hunt wild cattle, is mentioned in the annals of that king (see Rawlinson, Cuneiform Inscriptions, Vol. I, pl. 14, ll. $62 \mathrm{ff}$.). Whether the two countries are identical is doubtful. In line 17 of the famous stele which records the conquests of Thothmes III. (for the text see Mariette, Karnak, pl. 11, and Mariette, Notice de Bulaq, p. 80), mention is made of a country called the "country of the West and Phœnicia" F्ञा situated on the eastern border of Syria, facing the great Mesopotamian desert, and may well be compared with the Mitani over which, in later days, Tushratta ruled. In the list of nations conquered by Rameses III. about в.c. 1200, inscribed upon the outer wall of the Temple of Medinet Habu, the name of this country also appears to occur in the form Mâthena (see Dümichen, Historische Inschriften, pl. XII, No. 39, last row, and pl. XVII, No. 34; in the first of these places the name is giren side by side with that of Carchemish).

3 See Introduction, p. xxi. 
with thy children, with thy nobles, with thy chariots and horses, with thy land, and with everything which is thine. May peace be multiplied unto thee." "

Par. II. Tushratta calls to mind the great friendship which existed between his father Shutarna and Thothmes IV., King of Egypt, father of Amenophis, to which Amenophis himself greatly contributed by becoming the friend and ally of Shutarna. The friendship between Tushratta and Amenophis is ten times stronger than that between Amenophis and Shutarna. May Rimmon ${ }^{1}$ the god of Mitani, and Amen the god of Egypt, on behalf of each, prosper the friendship which they have established, and in the future make it to continue in its present happy state.

Par. III. He acknowledges the receipt of the despatch of Amenophis, by the hands of the messenger Manî, in which was written: "My brother, let thy daughter be my wife and mistress of Egypt." He received Manî with all tokens of friendship, wishing to please Amenophis. He also brought his daughter into the presence of Manî, who looked upon her and saw that she was fair and pleasing in his sight and rejoiced for the sake of Amenophis. $\mathrm{He}$ hopes that she will have a happy life in the land of Egypt, and prays that Ishtar the goddess of Mitani and Amen the god of Egypt may mould her to please the will of Amenophis.

Par. IV. Tushratta also acknowledges the receipt of a friendly despatch which Giliya ${ }^{2}$ brought back to Mitani from Amenophis. The contents pleased him so greatly that he exclaimed that, even if it were possible to dissolve all the friendship which had existed between them in times gone by, the words of this message ${ }^{3}$ alone would, for himself, suffice to re-establish their friendship for ever.

${ }^{1}$ In Babylonian, Tissub-billi, a name formed of Tissub, the native name of the god

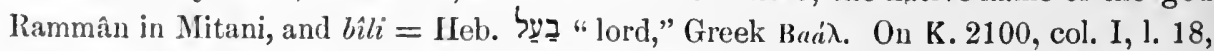
Ti-ish-su-ub appears to be the name of Rammân in the country of su-kI = Mitani (?).

${ }^{2}$ In a list of contributions in the Kouyunjik Collection of the British Museum (K. 8:47, Cul. IV, line 11) mention is made of a person called $Y \neg Y Y Y Y Y<Y$ Gi-lu-u-a. Gilûa and Giliya are probably the same name.

${ }^{3}$ The message of Amenophis was probably a promise to send gold, which seems never to have been fulfilled. 
Pars. V-VIII record the contents of a letter which Tushratta had sent to Amenophis previously to the receipt of the despatch just nientioned. He had written expressing the hope that there might be warm friendship between them, and that Amenophis would give proofs by his deeds that his friendship for Tushratta was ten times stronger than it was for Shutarna. He then asks Amenophis to send him more gold than he sent to his father, to whom he used to send much gold, including a libation bowl and vessels profusely decorated with gold ornaments; moreover, he sent to Tushratta himself an object in which gold was used as freely as if it were bronze. $^{1}$ Tushratta's grandfather promised to send Amenophis certain articles used in war or the chase. Tushratta is now getting these ready, and will deliver them to him complete in number and in good condition. Finally, he artfully represents that the gold for which he asks is to serve as his daughter's dowry. ${ }^{2}$

Par. IX. Passing on to matters of the present, he writes: "When my brother Amenophis has sent the gold, if I ask, 'Is it enough ?' the answer may be, 'Fully enough'; or I may ask, 'Is it the full amount?' and the answer may be, 'It is more than the full amount." " In the latter case ${ }^{3}$ Tushratta declares that he will be "very glad," but adds, after the oriental fashion, "With whatsoever my brother sendeth I shall be greatly pleased."

Par. X. Tushratta repeats the request in this and his former letter that the friendship between himself and Amenophis may be stronger than that between Amenophis and Shutarna, and he points out that his need for gold is twofold: (1) for payment of expenses incurred in sending to Egypt the articles of war and the chase which his grandfather promised Amenophis; and (2) as dowry for his daughter.

Par. XI, the longest in the despatch, consists for the most part of entreaties for more gold and that the quantity usually sent may

2 This appears to be the meaning of lines 37 and 38 . Par. VII is practically a repetition of Par. V.

2 It is doubtful which of Tushratta's daughters is here referred to.

3 Tushratta means that he would be very glad to hare more gold seut to him than the exact quantity agreed upon between them. 
be increased. The gods have done well in making gold as plentiful as dust in the land of Egypt; in the future may they make it still ten times more plentiful. Tushratta would not offend his brother Amenophis by asking for gold, but on the other hand he himself does not wish to be offended by having anything less than a large quantity of gold sent to him. In return, if Amenophis wishes for anything in the country of Mitani for his palace, let him send a messenger, and Tushratta will give it to him to take back. His palace and his country Mitani belong to Amenophis.

Par. XII. Tushratta announces the despatch of his messenger Giliya to Egypt, and begs Amenophis not to detain him but to let him return speedily. He will be very glad to hear of the despatch of a gift from Ameuophis by the hands of Giliya, but he is eager to know what arrangements Amenophis will make as to the amount and despatch of gifts to him in the future. In conclusion, Tushratta prays that Rimmon the god of Mitani and Amen the god of Egypt may make this letter and the answer of Amenophis to reach their respective destinations in safety; that the nature of their correspondence in the future may be of the same friendly character; and that their friendship may be as firm and close in the future as it is in the present.

Par. XIII enumerates the gifts which Tushratta sends to Amenophis by the hands of Giliya, viz.: one large golden object inlaid with lapis-lazuli; a large vessel of gold inlaid within with lapislazuli, weighing in all nineteen measures of gold and twenty measures of lapis-lazuli; a large vessel of gold inlaid within with khaluli-stones, weighing in all forty golden $z \imath z u$ of Ishtar, and fortytwo measures of khaluli-stones; ten pairs of horses; ten wooden chariots, with all their fittings complete; and thirty eunuchs.

9.--Letter from Tushratta, ${ }^{1}$ King of Mitani, to Amenophis III.

This almost complete letter is carefully written, and is divided into nine paragraphs, viz.:-

1 This letter was probably written soon after Tushratta became king of Mitani. 
Par. I. "Thus saith Tushratta, King of Mitani, thy brother, to Amenophis, King of Fogpt, my brother : ' I am well, and may it be "ivell with thee, and with Gilukhîpa ${ }^{1}$ my sister, with thy government, with thy wives, children, and nobles, and with thy body-guard, horses, chariots, and land."

Par. II refers to Tushratta's accession to the throne. On the death of his father Shutarna, his brother Artashumara became king, but was soon after slain by rebels who had conspired against him. Tushratta, though very young, gathered together all those who were favourable to his succession, and, by the help of the good fortune which stood by him, he succeeded in capturing the rebels, headed by one Pirkhi (?), and in slaying the murderers of his brother; he then ascended the throne and began to rule the kingdom of Mitani.

Par. III. Knowing that his father Shutarna and Amenophis were good friends, he ventures to send this despatch, and hopes that when Amenophis has read it he will feel favourably disposed towards him. Shutarna, by reason of his love for Amenophis, which exceeded that of Amenophis for Shutarna, gave him his daughter Gilukhîpa to wife. Now let Amenophis transfer the friendship which he had for Shutarna to himself.

Par. IV. Continuing the same subject, he claims this friendship, and feels sure that his claim will be allowed when Amenophis hears that the King of the Khatti had invaded Tushratta's territory, and that, Rimmon the god of Mitani having delivered him into his hand, he had slain bim.

Pars. V and VI announce that Tushratta is sending, as a gift selected from the spoil captured by him from the Khatti, a chariot, two horses, a youth and a maiden; in addition, he sends him five chariots and five pairs of horses from his own stables.

Par. VII. He sends as a gift for his sister Gilukhîpa a pair of gold bracelets (?), a pair of gold earrings, a golden toilet (?) bowl, and one full measure of choice oil for anointing.

Par. VIII. He announces the despatch of Giliya his messenger, accompanied by Tunip-ipri, and he begs that Amenophis will send

${ }^{1}$ See Iutroduction, p. xix. 
them back to him speedily, and that they may bring him word that Amenophis has sent him a gift to rejoice his heart.

Par. IX. In conclusion, he repeats his entreaty for the friendship of Amenophis, and hopes that he will send his messengers with return gifts for him, and that they may soon arrive.

10.-Letter from Tushratta, King of Mitani, to Amenophis III.

This letter, which is divided into five paragraphs, begins with the usual lengthy salutations, but also contains a greeting to Tâtumkhîpa, the daughter of Tushratta, who has become the wife of Amenophis. He addresses Amenophis as "my son-in-law, whom I love, and who loveth me," and refers to himself as "thy father-in-law, who loveth thee."

Pars. II and III refer to the going down of "Ishtar of Nineveh, lady of the world," 1 into the land of Egypt, beloved by Tushratta, both during his own reign and during that of his father. It would appear that the worship of this goddess had declined in Egypt, for Tushratta begs Amenophis to increase it tenfold.

Par. IV. He prays that Ishtar, the mistress of heaven, the goddess of Mitani, may protect both Amenophis and himself for a hundred years, and that the "lady of fire" 2 may give to them both great joy of heart and physical well-being.

Par. V. "Now Ishtar is a goddess to me, although she is not to my brother."

On the lower part of the Reverse are the remains of three lines of hieratic writing, the hieroglyphic transcript of which is as follows :-

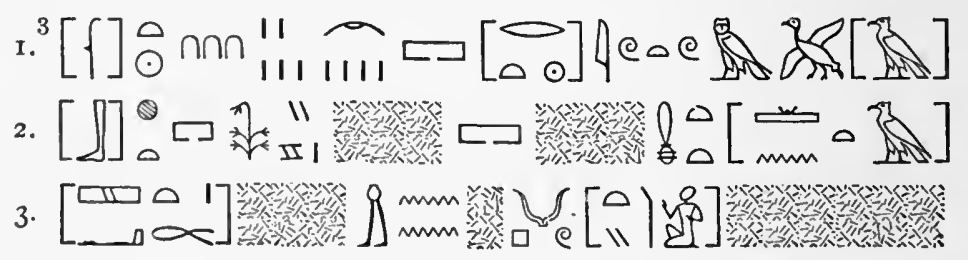

${ }^{1}$ Compare the title of the Egyptian goddess $8 \square \leftrightharpoons$ hent taui, " mistress of the world."

"Compare the title of the Egyptian goddess Bast 800 , "1nistress of flame." B., No. 23.

${ }^{3}$ The characters in brackets are added from a comparison with the docket on 
Renpit XXXVI äbeț IV pert autu em pa Bexet resi......... matet en ta śät...... a an en aputi.........

1. Year 36, mouth IV of pert, ${ }^{1}$ was [the king] in the

2. southern palace..... Copy of the

3. letter . . . [which] brought the messenger of . . .

11.-Letter from Tushratta, King of Mitani, to the "Queen of Egypt."

The text is in seven paragraphs, but is mutilated in several places ; and, as no one line is complete, it is impossible to make any connected version from it.

Par. I. Tushratta sends greeting to the " lady of Egypt," to her son Napkhurriya [afterwards Amenophis IV.], to the bride Tâtukhîpa (one of the wives of Amenophis III.), and hopes that it is well with all that belongs to her. The word kallatu, here translated ' bride,' has in the other Semitic dialects also the meaning of 'daughter-in-law;' but this meaning is unsuitable here, for in lines 8, 11 and 13 it is expressly stated that the husband of the lady to whom the letter is addressed" is "Mimmuriya" [Amenophis III.], and in the speech which Tushratta puts into the mouth of the Queen of Egypt, Mimmuriya is referred to as "my husband." The only queen of Egypt who could have been the mother-in-law of Tâtukhîpa was Mut-em-ua, the mother of Amenophis III. The letter, however, is not addressed to her; but probably to Thi, who is described on the Egyptian monuments as " royal daughter, royal sister, royal mother, and royal wife."3

Par. II refers to some friendly arrangement between the royal families of Mitanj and Egypt, which was known to Mani, an Egyptian messenger, and to everyone else.

In Par. III Tushratta refers to the queen's request, through the messenger Giliya, that he would not dissolve the frieudship which

\footnotetext{
1 I.e., the Coptic month Pharmutbi, which began on March 27.

2 See abore, p. xxi.

${ }^{3}$ See above, p. xix.
} 
had been maintained between the royal houses by Shutarna and Amenophis her husbaud. Par. IV seems to express a wish that this friendship may be made ten times stronger than before; and in lines 38,42, 46 and 51 Napkhurriya is mentioned. In Par. VI Iuni, a wife of Tushratta, is twice named; and in Par. VII the gift sent to the queen by Tushratta, consisting of three (or five) full measures of choice oil for anointing, and other things, is recorded.

On the lower part of the Reverse are the remains of two lines, in hieratic writing, too much defaced to be legible; on the left-hand edge the memorandum of an Egyptian scribe, which probably recorded the date of the receipt of this letter and some few characters of which still remain, is carried over from the foot of the tablet.

12. -Letter from Rib-Adda, ${ }^{1}$ governor of Byblos, ${ }^{2}$ to the King of Egypt. ${ }^{3}$

"Thus saith Rib-Adda to the lord and king of the world, the Great King, the king of the universe: "May the Lady of Byblus" give strength to the king, my lord $!^{5}$ Seven times and seven times do I prostrate myself before the feet of my Lord and my Sun."

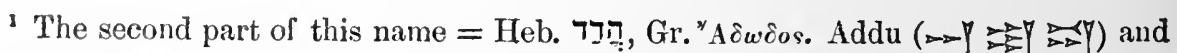

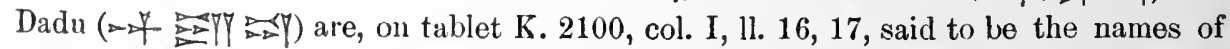
the god Rammân (Rimmon) in the country of MAR-KI (EYY $\langle$ KEY), for MAR-TU-Kr, i.e., probably the country now called Syria.

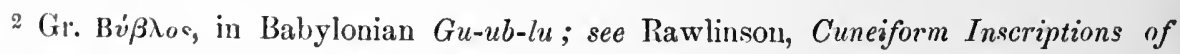
Western Asia, Vol. I, pl. 25, 1. 86 ; pl. 38, 1. 50; Vol. III, pl. 16, col. v, 1. 16; K. 1295 (see Catalogue of Konyunjik Collection, p. 262), etc. The forms of this name

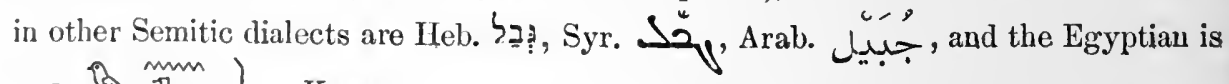
品 15 Kepuna.

3 'The rebellious state of the countries of Phœnicia, Syria, and Palestine, to be gathered from the contents of the letters of Rib-Adda, seems to indicate that they were addressed to Amenophis IV., under whose reign the Egyptians lost their former hold on their Asiatic dependencies; cf. supra, pp. xxii, xxiii.

4 In Babylonian, biltu sha Gubla, "Lady of Gebal"; compare בעלת גל in the insuription of יחומלר (Corpus Inscriptionu'n Semiticarum, T. I, pars. 1, No. 1,

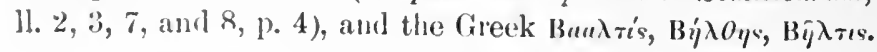

5 'This prayer is found only in Rib-Adda's letters. 
The city of Byblos, which from time immemorial has been the faithful handmaiden of the King of Egypt and of his ancestors, is now utterly lost, because the king has taken no thought for its safety. Would that he would protect that which belongs to his father's house! The people who are in Byblos are unfaithful and therefore are unfit to be the king's servants; moreover, the enmity of the rebels is great, and the gods have suffered our sons and our daughters to be led astray, and they have departed (?) to the land of Yarimuta. ${ }^{1}$ The people of the cities which are in the mountains and on the frontier have gone over to the enemy and have joined the rebels; only Byblos and two other neighbouring cities still remain faithful to him. Abd-Ashirta ${ }^{2}$ first captured one of them called Shigata, and then counselled the citizens of Ammiya, the other, to slay their governor and to become like him and to lead a free life. This they did and became rebels. Next, Abd-Ashirta sent to the soldiers in Bit-Ninib (?) saying: "Gather yourselves together, and let us go up against Byblos, and let us occupy the countries through which we pass, and let us appoint our own governors over them." Thus all the countries rebelled, and there were no more loyal people left in the land, and our sons and our daughters submitted to abide under the rule of the rebels. Unless the king takes immediate steps to protect his interests, the whole land will be in rebellion against him, and what then is to become of Byblos? The rebels have made a league amongst themselves, and Rib-Adda fears that there will be no one to deliver him out of their liands, for, being shut up in the king's territory in Byblos, he is like unto a bird shut up in a cage. Why does the king continue to be careless about his land? Rib-Adda has repeated everything to the king of Egypt, who has, however, paid no attention to his words. If the king has any doubt about the distress which has fallen on Byblos, let him make enquiries of

${ }^{1}$ Compare the names תị:, Joshua x. 3, and תivרי, 1 Chronicles riii. 14.

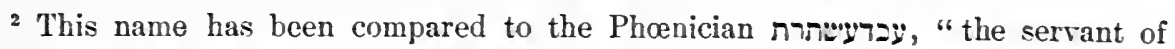

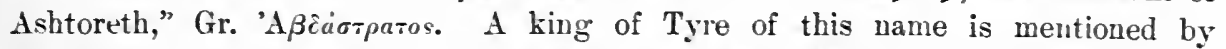
Josephus (Cont. Apion, I, 18, ed. Didot, T. II, p. $348=$ Müller's Hist. Graec., T. IV, p. 445 ff.). 
Amanappa, ${ }^{1}$ who both knows of it and has seen it. Would that the king would listen to the words of his servant and sive his life, for then could he protect his loyal city $!^{2}$ The king is merciful, and Rib-Adda prays day and night that he may be under his rule, for, if he is not, what is to become of him?

13.-Letter from Rib-Adda, governor of Byblos, to the King of Egypt.

It begins with the form of salutation as found in No. 12. RibAdda reports to the king that Aziru has acted in a hostile manner against his people, that he has taken twelve of them captive, and that he has set the price of their ransom at fifty pieces of silver. The forces which Rib-Adda sent to the city of Sumuru ${ }^{3}$ were made prisoners in the city of Tubuliya. ${ }^{4}$ The ships of Șumuru, Beyrut, ${ }^{5}$

${ }^{2}$ Compare the Egyptian name $\left.\bigcup_{\text {mm }}^{\text {mш }}\right|_{0} ^{\square} \dot{A} m e n-\dot{a} p t$.

${ }^{2}$ Here four lines of text are mutilated.

${ }^{3}$ In Babylonian and Assyrian, Șumuru and Șimirra; see Rawlinson, Cuneiform Inscriptions of Western Asia, Vol. II, pl. 53, l. 58 (K.276); Vol. III, pl.9, 1.46; pl. 10, No 2, 1. 13, No. 3, 1. 35 ; and K. 3042 (Catulogue of Koyuunjik Collection, p. 498), etc. The

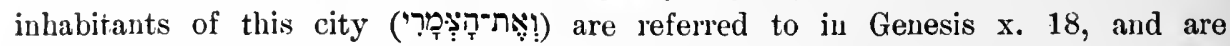
mentioned along with the Arvadites and Hamathites. A notice of Sumuru in the Egyptian inscriptions occurs in the Anuals of Thothmes III., who in the 30th year of his reign captured this town together with Kadesh and Arvad :

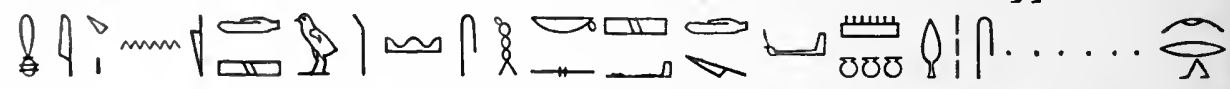

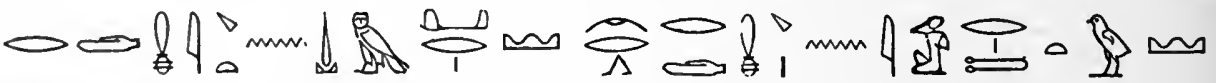
c he went to the town of Tchamâr; he went to the town of Arvad and did likewise" (Mariette, Karnak, pl. 13, l. 7). Șumuru represents the Símva of Strabo, XVI, cap. 2 (ed. Didot, 1) 641); for its position see Pliny, V, $20,77$.

4 The readiug of this name is doubtful ; if correct, however, reference is probably made to the city called $\underset{0}{\longrightarrow}$ Tepul in the Egyptian inscriptions.

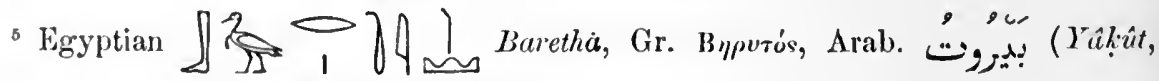
Vol. I. 1. 785), Syr. Sم. 
and Sidon ${ }^{1}$ were all lost off the coast of Amurri, ${ }^{2}$ and he was thereupon attacked by the fleet of Yapa-Adda and Aziru, who succeeded in soapturing his ship. In this strait he writes to the Egyptian king asking for help, and, telling him that his own people have now become disaffected, he begs him to do something to deliver him out of the hands of the enemy and, in any case, to answer this letter. When the city of Șumuru was attacked by the enemy, he took soldiers with him and went and delivered it; he then appealed to the Egyptian king for more troops, ${ }^{3}$ but when they arrived they were unable to enter the city because all the roads were blocked by the enemy. The rebel chief sat down before the city for two months, and meanwhile endeavoured to corrupt the loyalty of Rib-Adda. He again asks for more help, for the foe is mighty, and his officers fighting under him witbin the city are murmuring against him. He had been accused of having stirred up the land of Alashiya against the king, or of having given it over to the rebels; he now calls to witness the Egyptian officer Aman-mashashanu ${ }^{4}$ to support his story. Here the sense becomes obscure, and the difficulty is increased by the breaks in the text of the last ten lines. It seems however that Rib-Adda impresses upon the Egyptian king that Yapa-Adda and Aziru have made a league; he begs that certain people of his may be brought back from the land of Yarimuta; ${ }^{5}$ and he asks for fresh instructions.

${ }^{1}$ In Babylonian and Assyrian, Șidunnu and Sidunu; see Rawlinson, Cuneiform Inscriptions of Western Asia, Vol. I, pl. 35, No.1, 1.12 ; pl.38, 1l.35, 38, 48; pl.43, 1.13 ; pl. 45, col. I, 1l. 9, 40 ; Vol III. pl. 15, col. II, Il. 27-30 ; K. 1653 (Catalogue of Konyunjik Collection, p. 325), etc. The Egyptians called the town and it is the Homer.

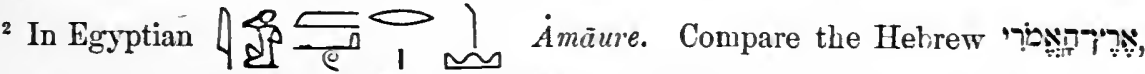
Judges x. 8. In these tablets Amurri appears to be the common name for Palestine. As "Alnurri" is everywhere used in these texts for the Phœnician sea coast, it is clear that it is the true reading of the Babylonian $Y\}$

3 The text is here mutilated.

4 This name is probably Egyptian; Aman $=4$ mm 1 . Amen, the name of the great national god of Egypt.

${ }^{5}$ See letter No. 12 (p. xlv). 
14.- - Letter from Rib-Adda, governor of Byblos, to the King of Egypt.

He complains that he has received no answer from the king. $\mathrm{He}$ has heard and knows what his people have done: how, when they were sent to his lord, they carried off his two horses without any written authority, and how others of them carried off the king's servants. How could he possibly prevent this, seeing that now he is absolutely without forces to protect the country, which is all in the hands of the rebels? He can do nothing, and the King of Egypt will never regain his hold upon the land. He had already asked more than once for soldiers and horses, but he had received no answer to his petitions. He reports that Abd-Ashirta, Yapa-Adda, and Zimrida "are alive"; and it would seem that they were in his power. Although the city of Șumuru has rebelled, and the city of Sarti (?) has fallen into the hands of Yankhamu, RibAdda promises that, so long as the corn holds out, he will defend the city of Byblos. In compliance with the king's orders he had despatched certain troops to Egypt, but on the road they deserted; and although he tried day and night to persuade them to return to the service of the king, and moreover sent two officers with this object, they still persisted in going over to the camp of Yankhamu. When they arrived there they said to him, "Rib-Adda is now in thy power; command thou what we shall do with him, and we will do it." The remainder of Rib-Adda's troops, in consequence of the defection of their comrades, refuse to obey orders, and he therefore announces his decision: "If thou, $O$ king, wilt not send me an answer, I will abandon the city, and I and my friends will cease to be thy subjects."

Parts of the text of the last five lines are wanting, and no connected sense can be gained from the characters which remain. In line 53 mention is made of a certain man Milkuru, or Ishkuru, who is also mentioned on a tablet at Berlin (No. 48, 1. 85).

15.-Letter from Rib-Adda, governor of Byblos, to Amanappa, ${ }^{1}$ a high official of the King of Egypt.

1 For other letters of Rib-Adda to Amanappa see Nos. 21, 22, 23 (pp. liii, liv). 
"To Amanappa, my father, thus saith thy son Rib-Adda: 'I prostrate myself before the feet of my father, and may the Lady of Byblos give thee favour in the sight of the king thy Lord." He asks why Amanappa does not report the state of affairs to the king, and why, having heard that the troops have abandoned their citjes and have gone out and become rebels, he has not set out to attack them in the land of Amurri. He asks if it can be possible that Amanappa does not know that Amurri has become a stronghold of the rebels, who now also hate Abd-Ashirta, his old enemy, and that they have banded themselves together and are waiting for the arrival of other troops to begin to fight against him. He exhorts Amanappa to join him in an attack upon them, especially as he is sure that all the governors are ready to attack Abd-Ashirta; for he had issued a proclamation to the citizens of Ammiya, saying, "Kill your governor, and rebel," whereupon the other governors said, "He will do this to us also, and then all countries will rebel." Rib-Addi begs Amanappa to report this matter to the king, "for thou art my father and master, and I trust in thee." He refers to some past services which he had rendered in connection with the city of Sumuru and which are known to Amanappa, and he begs him to ask the king to send help to Byblos as soon as possible.

16. -Letter from Rib-Adda, governor of Byblos, to the King of Egypt.

After the usual salutations, he entreats the king to listen to what he says :- "The people of Byblos, the members of iny house, and my wife counselled me to join the followers of Abd-Ashirta and to make a league with them; but I did not listen to thern. Moreover, I sent word to the king, my lord, and repeated my request for a company of soldiers to protect the city for the king, my lord; but no answer from the king ever reached me. In these straits I made up my mind, and I went to Ammunira ${ }^{1}$ [governor of Beyrut] for protection, for I feared the people of my own house; but he shut his door in my face, and now I must appeal again to the king for help. 'I await

1 For letters of this official, who appears to have been an Egyptian, see Nos. 26 and 27 (pp. lr, lvi). 
the arrival of the soldiers day and night, and if the king, my lord, does not seud help to me, I shall perish, and the king will lose a [faithful] servant."

The letter concludes with the promise that he will hand over into the custody of the king's officer his two sons and their wives, who were probably the inciters of those who wished him to join Abd-Ashirta.

17. -Letter from Rib-Adda, governor of Byblos, to the King of Egypt. ${ }^{1}$

After brief salutations, he tells the king that the hostilities carried on against the city by the rebels are very serious. $\mathrm{He}$ asks what steps he is to take, for Abd-Ashirta, the rebel, does as he pleases in the countries of the king. He has already sent a messenger with a despatch informing the king that the cities under his charge are in danger; that the enemy are marching upon them; that they have already captured the city of Beyrut, and are now coming on against him; and that in a very short time the foe will be at the gate, and that the people of Byblos will neither be able to come in nor go out. Thus the city will be captured, unless the king sends chariots and soldiers to deliver it. Rib-Adda would not disobey the king's commands, but he begs him to listen to his words: the city of Byblos and all the coast down to Egypt is falling into the hands of the rebels, and unless the king sends instructions to him forthwith he must surrender Byblos also to the foe. Let the king then send and deliver the city from the hands of Abd-Ashirta, that he (Rib-Adda) may once more rule over it. If only the king will send chariots and soldiers to deliver Byblos, which has ever been the king's loyal city, he is confident that he will be able to regain possession of the other cities which are already lost to the king.

'The last paragraph refers to some act of the messenger of the

1 The two characters of the Egyptian king's name actually remaining are ......ra-ri, which are probably part of a Babylonian form of the prenomen of Amenophis IV. See above, p. xliv, note 3 . 
King of Accho (?), ${ }^{1}$ and horses are mentioned; the breaks and obscurities of the text make a connected rendering of this part of the letter impossible.

18.-Letter from Rib-Adda, governor of Byblos, to the King of Egypt.

He prays for advice and assistance. In the days of the king's father, when Abd-Ashirta waged war against him, he sent to the King of Egypt for troops, and, because his request was granted, all the lands were quiet; and, notwithstanding Abd-Ashirta's large following, he was unable to capture the "loyal city Byblos." But now Aziru has gathered together the rebels, and is plotting mischief against Byblos. A break in the text here destroys the end of this passage. Mention is then made of Yankhamu; and Rib-Adda seems to request the king to deal with Abd-Ashirta as he deserves. It would appear that Khâib, governor of the city of Șumuru, had been forced, through the disobedience of the people under him, to surrender the city. Rib-Adda believes that the king will regret to learn this news, especially as Khâib was slain; and; in consequence of the fall of the city, Bikhura will not be able to maintain his position in Kumiți ${ }^{2}$ in fact, all the governors throughout the land will be slain, if assistance is not immediately forthcoming. He has before this duly informed the king of these facts, but he has received no answer. Finally he begs the king to send a stated number of soldiers and chariots to protect his land. The sense of the concluding portion of the letter is obscured through breaks in the text.

19.-Letter from Rib-Adda, governor of Byblos, to the King of Egypt.

1 In Babylonian and Assyrian, Ak-ku-u and $A-k u-u$; see Rawlinson, Cuneiform Inscriptions of Western Asia, Vol. I, pl. 38, 1. 40 ; Vol. V, pl. 9, I. 122 ; and K. 4444 (Catalogue of Kouyunjik Collection, p. 633). The Semitic forms of this name are: Heb.

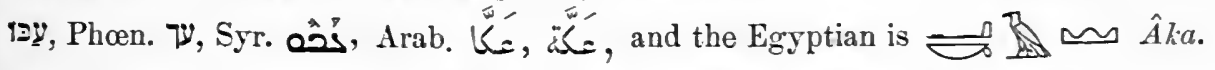

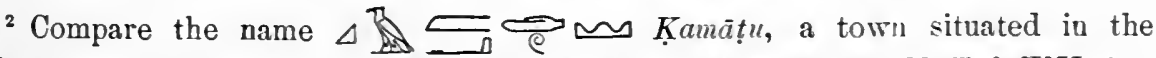
northern part of Phœnicia. See Brugsch, Geographische Inschriften, II, 'Taf. XIII, i. 
He prostrates himself "seven times and seven times" before the king, and prays that the "Lady of Byblos may give strength to the king, my lord." In answer to the king's command, that he should defend himself and the city under his charge, he asks, "Against whom shall I defend myself and the city?" In former times there was a garrison of the king's soldiers in the city, and the king sent corn from the land of Yarimuta ${ }^{1}$ to feed them. But now Aziru has overcome him in spite of his efforts, and has carried off the oxen and everything wlich he had. There is no corn to eat, and the officers and the soldiers have rebelled and have forsaken the city, and have gone to places where there is corn to eat. The king appointed him a "governor," but how can he be considered to be a "governor?" For the "governors" of all the other cities are now under the rule of others, and are bound to obey their soldiers, and he, too, and the cities in his charge, are in fact under the rule of Aziru. To whom is he to be "faithful," according to the words of the king's despatch? Moreover, the followers of Abd-Ashirta are in league with Aziru, and, as the king knows, they do what is good in their own eyes, and they have set on fire the cities of the king.

20.-Letter from Rib-Adda, governor of Byblos, to the King of Egypt.

He informs "his lord, the Great King, the king of the world, king of the universe," that he will continue to defend the country in the future as he has done in the past. A break interrupts the meaning of the next paragraph; but it seems that Bikhura, governor of the city of Kumiti, had sent a hostile force against Byblos. Rib-Adda therefore begs the king, if he loves his faithful servant, to send troops to defend the city in his own interest. Referring to the king's former order, Rib-Adda asks how it is possible for him to defend himself against Abdirama, Iddin-Adda, and Abdi-milki, followers of Abd-Ashirta, whom Bikhura has urged to come up against him, seeing that they have already made themselves master of all the king's territory. The letter concludes with a repetition of the request for troops. 
[In a tablet at Berlin (No. 134, 1. 4), Abdi-milki, one of the opponents of Rib-Adda, is called the governor of the city Shaskhi(mi), who at the request of the king of Egypt promises that his contingent of soldiers and horses and chariots shall join the royal army at the rendezvous.]

21.-Letter from Rib-Adda, governor of Byblos, to Amanappa, ${ }^{1}$ a high official of the King of Egypt.

The text of this tablet is so much mutilated that not a single line is complete. From the fragments which remain it seems that Rib-Adda prays that Amen, the great god of Egypt, may give Amanappa favour in the sight of the king. The fierceness of the enemy's attack is increasing; and it appears that supplies of corn had for the last three years become scarce in Byblos. Mention is made of the land of Amurri, whither Amanappa is asked (?) to send troops; of the land of Mitani ; of Yankhamu, who supplied Amanappa (?) with corn; and of the city of Șumuru. The letter ends with the usual request for troops.

22.-Letter from Rib-Adda, governor of Byblos, to Amanappa, a high official of the King of Egypt.

He asks why his conduct has been blamed (?). He had sent Amanappa's messenger, who was with him, into the presence of the king, and he had also supplied Amanappa with soldiers and chariots to defend the city of Beyrut (?), and he is therefore much griered to hear Amanappa's words of reproach. Beyrut appears to have fallen into the hands of the enemy, who are now about to attack Byblos. The concluding lines of the text are broken, but they seem to contain a petition for treops to protect Byblos.

23. - Letter from Rib-Adda, governor of Byblos, to [Amanappa], a high official of the King of Egypt.

After the usual salutations, in which the king is called the "sun of the countries," Rib-Adda explains why he was not able to obey Amanappa's orders in going to Șumuru to meet him. He asks 
Amanappa why, seeing that he knew the difficulties of his position, he told him to go up to that city. He is surrounded with foes on all sides; the city of Ambi has rebelled against him, through the influence of the Abd-Ashirta faction upon the governor and officers of the city; he is unable to fight against the enemy successfully, and he is stricken with fear. He further begs Amanappa to come to his assistance as soon as possible; and in the concluding passage, six lines of which are mutilated, he seems to reiterate his request for troops to defend the city of Byblos.

24.-Letter from [Rib-Adda, governor of Byblos] to the King of Egypt.

Although the first lines, which contained the name of the writer, are wanting, yet, judging from the contents of the letter, the style of writing, the material of which the tablet is made, and its shape, it is tolerably certain that it formed part of the correspondence of Rib-Adda.

Rib-Adda begins by informing the king that, notwithstanding that he had posted troops at Byblos, the city of Șumuru has been captured by the enemy and the soldiers from Byblos have been slain. If the king will have a care for his city of Byblos, let him send four captains and their companies, thirty chariots, and one hundred mercenaries (?) of various nations, and they will suffice to protect the city; if, however, the king does not speedily send troops to join those already under Rib-Adda, and food with them, the city itself will be captured and the inhabitants will be slain. Bîri, ${ }^{3}$ an officer of the Egyptian king, who had been sent to help Rib-Adda, had already been slain, and his followers were scattered. RibAdda's "eyes fell sick" when they saw these things, and he was sore afraid when he knew that Bîri could no longer help him. He had applied to Pakhamna[ta], ${ }^{2}$ an officer of the Egyptian king,

1 According to a tablet at Berlin (No. 160, 1. 4), Bîri appears to have been the governor of the city of Khashabu (or Kharabu?; cf. B., No. 154, 1. 43).

2 This name appears to be Fgyptian. In a tablet at Berlin (No. 80, 1. 22) he is called rabis sharri, "officer of the king," and, if the name Pakhanati be identical with Pakhamuata, he is also mentioned in lierlin tablet No. 97, $11.10 \mathrm{ff}$. 
for troops, begging him to send young men, or old men, or soldiers of any kind whatsoever; but this officer had turned a deaf ear to him, and therefore had happened what had happened. Pakhamnata himself saw the city of Șumuru destroyed; Rib-Adda begs the king to notice this fact. The condition of affairs in Byblos is very serious, for everything has been consumed; the troops have no corn to eat, and a number of them have been slain at the capture of Șumuru. Here the text becomes mutilated, and breaks off after the mention of Yankhamu.

25.-Letter from Rib-Adda, governor of Byblos, to the King of Egypt.

He asks for troops to defend Byblus and the neighbouring cities. He seems to be in league, or on terms of friendship, with Yankhamu, the Egyptian official, for he deprecates the charges which have been made against both himself and Yankhamu by certain people, and hopes that there may be peace. The text of this tablet is much mutilated.

26. - Letter from Ammunira, ${ }^{1}$ governor of Beyrut, to the King of Egypt.

After a brief greeting and expression of homage, he acknowledges the receipt of a despatch from the king, "his lord, his god," and his sun." In this despatch the king had commanded him to furnish a contingent to the Egyptian army; and now he, the king's loyal governor, informs him that in obedience to his orders he has sent a number of chariots, horses and men provided with all necessaries, and he prays that the king may be victorious over his foes and that his own eyes may see the triumph of his lord. He concludes by entreating humbly that, when the king has brought the war to a victorious close, he will reward his servant for his expense and trouble; he, "the footstool" of the king, his lord, will during the

1 This is probably a form of some Egyptian name like 4

2 In Babylonian iláni, literally "gods." See below, p. Ixi. 
absence of his soldiers endeavour to guard the city and garrison under his charge, until his eyes shall behold his soldiers returning to Beyrut.

27.-Letter from Ammunira, governor of Beyrut, to the King of Egypt.

He acknowledges the receipt of the king's " tablet," the contents whereof made his heart glad and his eyes bright. He is vigilantly guarding Beyrut for the "king his lord"; but still he awaits the arrival of the king's troops with anxiety. In respect of the "men of Byblos," he is carefully watching them until the king shall make his pleasure known concerning them. He next reports that certain Egyptian officials stationed in the land of Amurri have been evilly entreated by the followers of Rib-Adda. In conclusion he declares that his soldiers, his chariots and his horses are ready to join the king's native army from Egypt; and he repeats the usual formula of homage.

28. - Letter from Abi-milki, ${ }^{1}$ governor of Tyre, ${ }^{2}$ to the King of Egypt.

"To the king, my lord, my sun, my god, thus saith Abi-milki thy servant: "Seven times and seven times do I prostrate myself at the

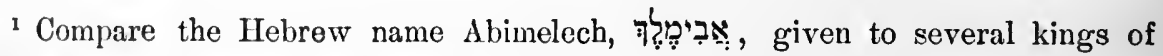
Philistia, Gath, Gerar, etc., Genesis, xx. 2, xxvi. 1; Psalm xxxiv. 1; Judges viii. 31.

${ }^{2}$ In Assyrian and Babylonian, Surr-ru; see Rawlinson, Cuneiform Inscriptions of Western Asia, Vol. I, pl. 35, No. 1, l. 12 ; Vol. II, pl. 67, rev. 1. 66 ; Vol. III, pl. 16, col. v, l. 13 ; Vol. V, pl. 2, I. 49 ; and K. 1292 (Catalogue of Kouyunjik Collection, p. 261),

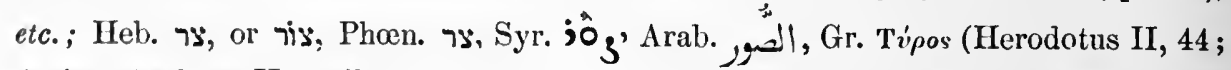
Arrian, Anabasis, II, 16 ff., etc.). The city of Tyre consisted of two parts : the island, furmed of two rocks which were made habitable by piling earth upon them, and the town on the mainland, called Palæ 'lyrus. The island was the more important part in the time of the XVIIIth dynasty, for it commanded the sea both north and south; the harbour on the north side of the rock was called the Sidonian, and that on

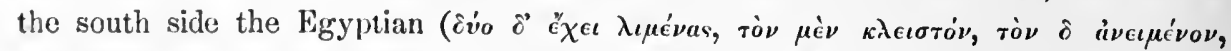

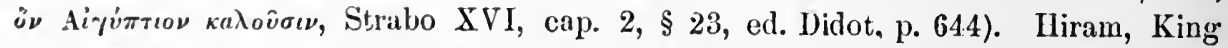
of Tyre (about ls.c. 950), enlarged the island by alding to it one of the small islands to the noith, and Alexander the Great joined it to the mainland (Arrian II, 16 ff.). 
feet of the king, my lord. I am the dust beneath the feet of the king, my lord, and that upon which he treadeth. O, my king and lord, thiou art like to the god Shamash and to the god Rimmon in heaven. Let the king give counsel to his servant ! Now the king, my lord,

Strabo says that the island was 30 stadia distant from the Palæ Tyrus and 200 stadia from Sidon (Strabo, loc. cit., § 24, ed. Didot, p. 645); and Pliny (V, 19) describes its position and circumference thus: "Tyrus quondam insula, praealto mari Dcc passibus dirisa.... circuitus $\mathbf{x} \mathbf{x}$ mill. pass. est, intra Palaetyro inclusa; oppidum ipsum xxı stadia optinet." Cf. also Map of Western Palestine (Palestiue Exploration Fund), London, 1880, pl. 1.

In the Egyptian inscriptions Tyre is called

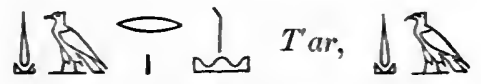

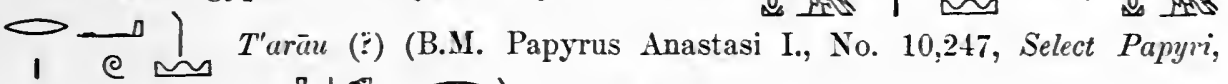

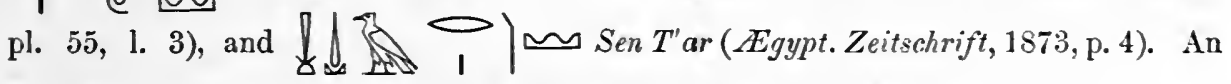
Egyptian, travelling through Syria, visited it and described it as :-

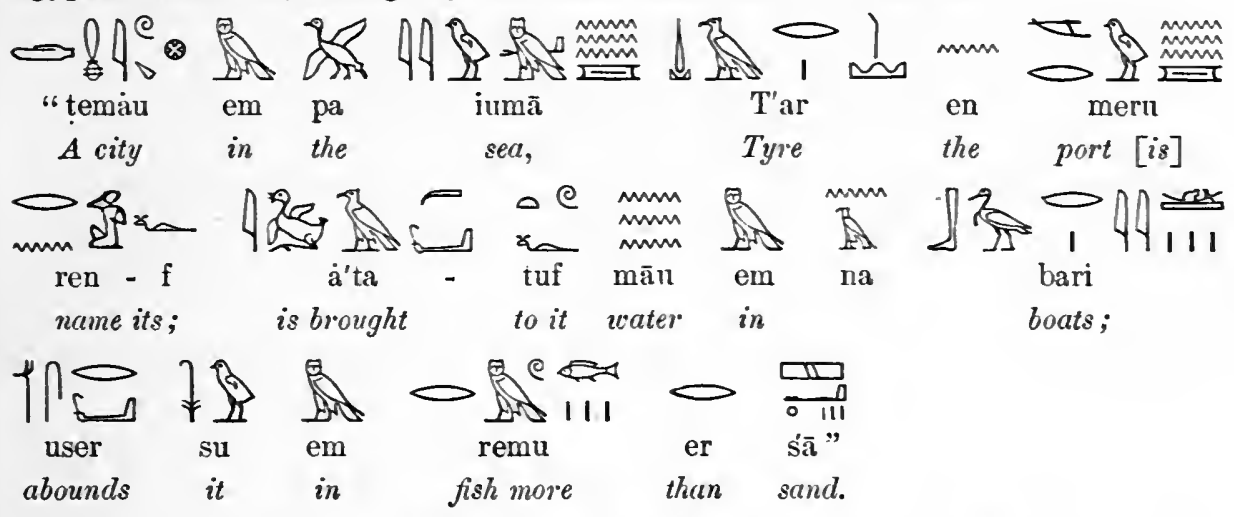

(For the hieratic text see Papyrus B.M., No. 10,247, Select Papyri, pl. 5̄j, 11. 1 and 2, and for a hieroglyphic transcript see Chabas, Voyage, p. 165 fi.)

The "city in the sea" can only refer to the island part of Tyre; and this iescription of its situation is also given by Ezekiel, who says that it is set "in the

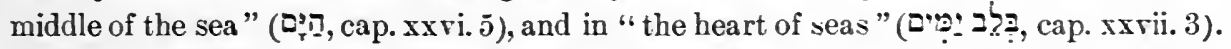
'The hieroglyphic passage quoted above shows that it was customary to supply the inhabitants of the rock of Tyre with water brought from the mainland in boats, and the desperate condition of Abi-milki, shut up on the bare rock, his wood and water supply from the mainland having been cut off, is evident; it also shows that as late as the XIXth, perhaps the XXth, dynasty, water was still carried to Tyre in boats as it was in the days of Amenophis III. The water which snpplied the town of Palæ Tyrus on the mainland appears to hare been brought from Ras el-'Ain, a few miles to the sonth of the town; and that the inhabitants also suffered from want of water in times of war is certain from the statement of Menander (quoted by Josephus, 
hath appointed me the guardian of the city of Tyre, the 'royal handmaid,' and I sent a report in a tablet unto the king, my lord; but I have received no answer thereunto. I am an officer of the king, my lord, and I duly report all that cometh to pass, be it favourable or be it unfavourable." Abi-milki then prays the king to let him have twenty additional soldiers to defend his city," and adds "let me come before the presence of the king, my lord, and behold his face," meaning probably that he is personified by his letter. $\mathrm{He}$ cannot have the twenty men without the orders of the King of Egypt; if the king will be graciously pleased to send this order, his servant Abi-milki will "live for ever."

Lines $27-40$ are broken, and it is not possible to make any connected sense out of them. It appears, however, that Aziru and his father Abd-Ashirta and Khâbi, three revolutionary agents in Syria, are mentioned in lines $35-37$. With line 38 begins a passage which seems to state that Zimrida (?) delivered the city of Șumuru to Aziru, and that in consequence "the king [of Egypt] did not eat from [the produce of] his city ${ }^{2}$ or from his land." When Abi-milki heard of the renown of the king and of the fame of his troops, he feared greatly, and all the countries round about trembled because they had not protected the king's interests. As soon as Zimrida knew that Abi-milki had been appointed governor of Tyre, he attacked and captured the city of $\mathrm{Sazu}^{3}$ (a place which was probably situated near Tyre), and therefore the supplies of wood,

Antiq. Jud., IX, 14, 2) that when the king of Assyria was besieging the city in the days of Elulaeus, King of Tyre, the water supply was cut off by the guards who had been posted by the rivers and aqueducts for that purpose, and that for fire years the Tyrians had no water except from the wells which they dug. Elulaeus, in Assyrian Lûl$\hat{\imath}$, is also mentioned in an inscription of Sennacherib; see Rawlinson, Cuneiform Inscriptions of Western Asia, Vol. I, pl. 38, 1. 35. Esarhaddon also besieged Tyre and cut off the supplies of meat and drink from its king Ba'lu; see K. 3082, obv."1. 14.

1 We are probably to understand twenty companies of soldiers.

"I.e., "receive the revenues of the city."

${ }^{3}$ A tablet at Gîzeh insscribed with a letter of Abi-milki, B., No. 99, ll. 11, 12, 28 ff., contains a petition to the King of Egypt that he will order his inspector in Syria to supply him with wood and water from the city of Sazu. The same letter relates that Sidon and Khazor have gone over to the enemy, and adds that the King of Egypt will now be able to judge of the desperate condition of 'lyre. 
water, etc., which Abi-milki drew from thence were cut off, and, as the Tyrians were unable to provide themselves in any other way, some of them died of want. Abi-milki then asks for fresh instructions.

The king of Egypt had ordered Abi-milki to report to him everything that he heard, and in obedience to this command he now writes :-Zimrida, governor of the city of Sidon, and Aziru, a disaffected Egyptian official, and the people of Arvad, ${ }^{1}$ had joined in a league and entered into a conspiracy and had gathered together their ships and chariots and soldiers and had made an attack upon Tyre, the "handmaiden" of the king"; but "the hand of the king obtained might and slew them," and they were unable to capture the city. But the city of Sumuru had been given to Aziru by command of Zimrida. "Concerning these things I have already sent a tablet to the king, my lord, but I have reseived no answer. I am surrounded on all sides with foes, and we have neither wood nor water."

In this desperate condition, unable to obtain supplies from the mainland, and only getting them with the greatest difficulty from his ships, owing to the blockading fleet, Abi-milki entreats the king to send him instructions, and also to take steps to protect both his city Tyre and his servant Abi-milki. In conclusion he sends this tablet by the hands of a common soldier, to whom he begs the king to give an immediate answer. The destitute condition of his household is shown by the fact that he is obliged to send the soldier without gifts for the king, instead of a proper envoy.

29.- Letter from Abi-milki, governor of Tyre, to the King of Egypt.

"To the king, my lord, my god, my sun, thus saith Abi-milki, thy servant: 'I prostrate myself' at the feet of the king, my lord,

1 In Babylonian and Assyrian, A-ru-a-da, or A-ru-ad-da, or Ar-ma-da, etc.; see Rawlinson, Cuneiform Inscriptions, Vol. I, pl. 25, 1. 86 ; pl. 28, col. I, I. 2; Vol II., pl. 76, rev. 1.60, etc. The other Semitic forms of this name are: Heb. Tي, Syr.

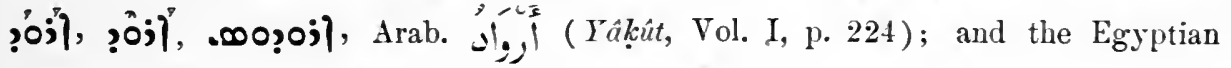

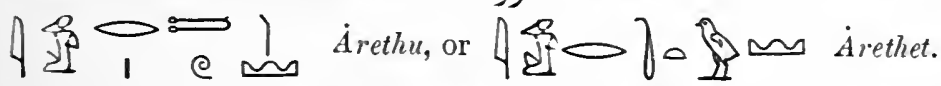

${ }^{2}$ Babylonian amtu, Heb. iș. Compare the use of this word by one distinguished person describing herself to another in 1 Samuel xxr. 25 . 
seven times and seven times; I am the dust under the feet of the king, my lord, the Sun-god, who riseth upon the world daily by the decree of the Sun-god, his loving father, who maketh it to live by his glad message, who shineth (?) in the country of the north (?), ${ }^{1}$ who maketh all lands to dwell in peace, strength, and abundance, who giveth his voice in heaven like the god of thunder, and all lands are consumed with terror at the sound of his voice." "2 He had sent a messenger to Egypt to bring back an answer from the king, and he trusts that it will be found favourable to himself when it arrives. He adds that not only himself, but also the governors of all the countries round about are anxious for a favourable answer. The King of Egypt appears to have ordered that Abi-milki should be the general of the troops, whereat he expresses his joy ("Yâyaya!") and homage. He has understood the king's commands, and they shall be duly carried out; the sun (i.e., the king) has arisen upon him, and glad tidings have come forth to him from the mouth of the king, his lord. If he had not received the order of the king, Tyre would have been lost, and the king's government and his name would have been blotted out from the land for ever; now that he has received the king's despatch, it will be well with Tyre and with the king's government and glory for ever. "Thou art my Sun who risest upon me, thou art the fortress of copper upon which I take my stand, and by the right hand (?) of the king I am strong, I am mighty, I am powerful. Thus I spake to the Sun-god, the father of my lord and king: "When shall I see his face?" "

Next, the actual object of the letter is stated:- "I will guard the city of Tyre, the great city, ${ }^{3}$ for the king, my lord, and I will hold it until the king shall send forth his power to help me, to give me water to drink and wood to warm myself withal. Moreover, Zimrida of Sidon sendeth daily an officer in the service of Aziru, the son of Abd-Ashirta, to bring back to him news of what the King of Egypt will do. 'Thus I send word to the king my lord, and I trust that, when he knoweth it, it may seem good in his sight."

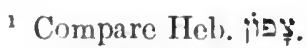

2 This unusual salutation appears not to occur elsewhere.

3 "Tyros, et magniturline et claritate ante omues urbes Syrie Phœnicesque memoralilis."-Q. Curtins IV, 2, 2. 
30.-Letter from Abi-milki, governor of Tyre, to the King of Egypt.

After addressing the king, "my lord, my god," with the usual compliments, he informs him that he is diligently guarding the city of the king under his charge. He repeats his intention of coming to Egypt (?) to meet the king, and he thinks that Zimrida will not be able to turn the city of Sidon away from its allegiance during his absence; for he would have the king to know that after Ziunrida had obtained authority he had become hostile. Next, he prays the king to defend the city. He has sent this letter by a messenger, and asks that he may be received with favour. He entreats the king not to forsake him, and to send him water to drink and wood for fuel, for the king knows that for some time past he has had neither wood nor water. To incline him to send help, he despatches with his messenger Ilu-milki ${ }^{2}$ five talents of pure (?) copper and other objects. In reply to the king's orders to report any news from the land of Canaan ${ }^{3}$ he writes :- "The king of the land of Danuna is dead, and his brother hath become king in his stead, and there is peace in his land. One half of the city Ugarit hath been burnt with fire and is destroyed. The soldiers of the land of Khatti are no longer here. Itagamapairi, governor of the city of Kidshi, ${ }^{4}$ and Aziru have rebelled, and are fighting against Namyawiza. Notwithstanding that Zimrida, the governor of Sidon and Lachish, hath gathered together ships and soldiers from the lands of Aziru, the son of AbdAshirta, if only the king will send four captains [with their companies], all will be well with me, and I shall see his destruction." He concludes with an earnest petition for help.

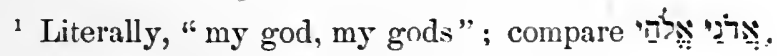

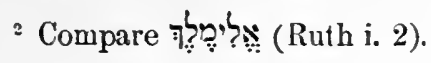

${ }^{3}$ Compare the Egyptian $\circlearrowright \frac{1}{1}$ Kanana, Heb.

4 Probably Kadesh on the Orontes, the inscriptions; see Brugsch, Geographische Inschriften, I, p. 67; II, p. 56 ; for the form

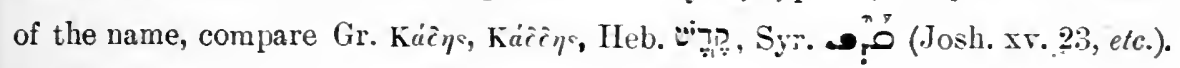


31.-Letter from Abi-milki, governor of Tyre, to the King of Egypt.

The top right-hand corner of the tablet is wanting, a large break also occurs in the middle of the letter through a fracture in the lower part of the tablet, and several of the lines which remain are nearly defaced.

After the usual greetings to the king, the "everlasting Sun-god," 1 he refers to orders received from him to go to Shalmayâti and salute him, and to supply him with water ; his servants have, however, not been able to carry out these instructions, and he therefore asks the king to take steps to have this done himself, as he has no water to give. Here there is a break of twelve lines, and the letter then continues with a request for instructions concerning the city of Tyı, "the city of Shalmayâti," and expresses readiness to obey the king's own commands. Abi-milki professes fidelity, and appears to ask for authority to defend Tyre, "the city of Shalmayâti." Here another break interrupts the sense of the letter. Then, after urging the king to send water to Tyre, he asks him to question his officer if there has not been a revolt in Șumuru; and concludes by telling him that, as the natives of Sidon and other cities have withdrawn to Sidon by ship, he also intends to go after them.

It is probable that Shalmayâti was a rival governor of Tyre, which Abi-milki henceforth calls the "city of Shalmayâti." He accordingly refuses lim water, and finally joins the people who have gone to Șumuru. ${ }^{2}$

1 In Babylonian, Shamash dâritum. Compare the title of the god Harpocrates,

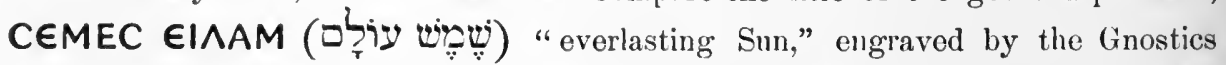
upon gems above figures of this god seated on a lotus flower. See King, Gnostics and their Remains, plate VII, No. 4, and plate facing i). 35 , No. 9.

2 Two letters of Abi-milki are preserved at Gîzeh (B., Nos. 98 and 99) and one at Berlin (No. 162). H3, No. 98 contains the usual salutations and expressions of fidelity, and entreats the king to send provisions; the principal contents of B. 99 are referred to on p. Iviii, note 3; and B., No. 162 expresses plcasure at the receipt of the king's despatch, and reports that he, Abi-milki, has received no supply of water and wood from Sidon and Arvad, for the text of lines 14 and 15 appears to read:- A⿱

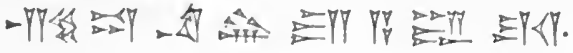


32.-Letter from Zitadna, governor of Accho, ${ }^{1}$ to the King of Egypt.

"Zitadna thy servant, the dust of thy feet, prostrates himself seven times and seven times before the feet of the king, my lord, my sun, my god." The concluding portion of the text is wanting.

33.-Letter from Abd-Ashirta, the rival of Rib-Adda, to the King of Egypt.

He expresses profound loyalty to the king, and wishes him to know that his enemies are prevailing against him. He hopes that he may find favour before the face of "the king his lord," and that he will send an officer to protect him. In conclusion, he has read and understood the despatch which the king had sent him, and according to his request he sends him ten women.

[In a letter of Abd-Ashirta preserved at Berlin (No. 97), he says that he was governor of the country of Amurri and of the cities of Șumuru and Ullaza, and that his general was Pakhanati, or Pakhamnata. ${ }^{2}$ ] For accounts of his movements see the letters of Rib-Adda.

34.-Letter from Abdi-Ashtati [Abd-Ashirta ? $]^{3}$ to the King of Egypt.

He has received the king's despatch, and has understood his words. He hopes that the King of Egypt will listen to the words of his servant: the last two lines, which probably contained these words, are wanting.

${ }^{1}$ In Babylonian, Gîzeh (B., No. 94, 1. 5) and another at Rerlin (No. 95, 1. 3); the latter tablet mentions the disaffection of [Zir]damyashda and his submission (?) to Namyawiza (see below, pp. lxxii, lxxiii, No. 43), and compares Accho to the city of Magdali in its loyalty.

${ }^{2}$ Cf. supra, p. liv, note 2.

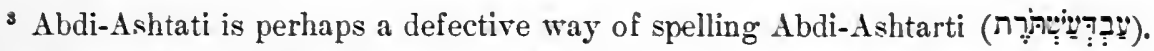
The peculiarities of style and writing in Nos. 33 and 34 prove that they were sent from the same person. 
35.-Letter from Aziru, ${ }^{1}$ the rebel, son of Abd-Ashirta, to the King of Egypt.

This tablet is in perfect condition. The text is divided into eight paragraphs.

Pars. I and II :- "To the great king, my lord, my god, my sun. I, Aziru, thy servant, prostrate myself at the feet of my lord, my god, my sun, seven times and seven times. O, my lord, I am thy servant, and as if I stood in the presence of the king, my lord, I will declare all that I have to say unto him. O, my lord, hearken not to wicked men who slander me before the king, my lord, for I am thy servant for ever."

Pars. III and IV relate to the king's complaint that Aziru had not treated his messenger $\mathrm{Khani}^{2}$ with proper respect, when he arrived in Tunip. ${ }^{3}$ Aziru defends himself: " My lord, I was dwelling in the city of Tunip, and I knew not whether Khani was coming or not; but, as soon as I heard that he was coming, I went forth to meet him, but failed to find him. When Khani shall return again to the king in peace, as in truth I hope he will, let the king ask him if my brethren did not receive him in friendship when he came into Tunip, when thy servant was away, and if Bitili ${ }^{4}$ did not give him oxen and other beasts, birds and sweet wine, and other things. Moreover, while he was on his journey back to Egypt, and while I was on my way to the king, I met with him on the road, and I lent him horses and mules which he needed for his journey, and he himself greeted me and received me as though he were my father and my mother. But in spite of this my lord doth write to me saying, 'Thou didst turn away from the presence of Khani.' But thy gods know, and the Sun-god knoweth, that I was not in the city of Tunip when he arrived."

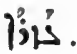

${ }^{1}$ For cognate forms of this name compare רע, Jeremiah xxviii. $1 ;$; 1 s's and

2 Compare Syr.

3 The Egyptian o f r manep.

4 In Babylonian Bi-ti-Ilu; $c f$. the Hebrew

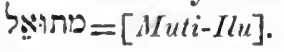


Pars. V and VI refer to some observations, unfortunately unknown to us, which the king of Egypt had made concerning the city of Sumuru. Aziru replies that the Kings of Nukhashshi ${ }^{1}$ have ever been hostile to him, and that by the order of Khatib ${ }^{2}$ they had captured all his cities, which up to the present time they had not given back (?). $\mathrm{He}$ promises that he will make them restore them speedily. $\mathrm{He}$ adds that Khatib has carried off half of the king's property which was under his care, and all the gold and all the silver which the king had sent to him.

Par. VII answers the king's question :- "Why hast thou received the messenger of the king of the land of Khatti, and my messenger thou hast not received?" Aziru craftily replies, "This is the country of my lord, and the king my lord hath appointed me one of the governors therein"; implying that he was only one of the king's servants, and was bound to receive in the king's name whosoever came into the land. The second part of the king's question Aziru omits to answer.

Par. VIII announces the despatch of this letter by the hands of the Egyptian messenger, with presents consisting of ships, choice oil, weapons, etc.

36.-Letter from Akizzi, governor of the city of Kaṭna, ${ }^{3}$ to Amenophis III.

It was divided apparently into eleven paragrapbs, the chief contents being as follows:-

Pars. I and II. Greeting of Akizzi to the "son of the Sun-god," his lord, followed by protestations of fidelity to the king and wishes for the success of everything that he may undertake.

Par. III. In times of old, ever since his fathers became vassals of the King of Egypt, his land has belonged to Egypt; his city Katna and he are now the loyal followers of Amenophis.

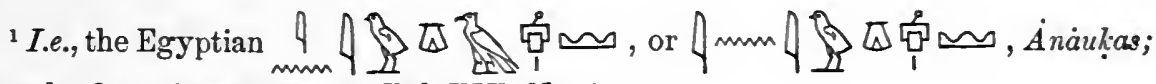
Brugsch, Geog. Inschriften, II, Taf. XIX, No. 97.

2 With this name $c f$. Syr. is' (?).

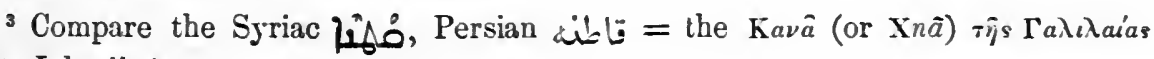
of St. John ii. 1. 
Par. IV. When the king's soldiers and chariots and horses came to his country, he gave them meat and drink, oxen, oil, honey, and everything that they needed. If Amenophis doubts his word, let him enquire of his officers concerning its truth.

Par. V. All lands tremble at the name of the soldiers and chariots of Egypt. If the king will send chariots and horses within the year, all the countries round abont will acknowledge him as lord, and he will also be able to take possession of the land of Nukhashshi. The exact sense of the next sentence is obscured by a break in the text of lines 22 and 23, but the drift seems to be that if the troops of Amenophis delay for any great number of days Aziru will gain possession of the land.

Par. VI. If the soldiers and chariots of Amenophis do not set out for Katna within this year, Akizzi will not be able to defend his city against Aziru.

Pars. VII [and VIII?] are wanting.

Par. IX. In days of old the King of Khatti was a vassal (?) of the King of Egypt, but now he has wasted with fire the cities under the protection of Egypt, and he has seized the gods of Egypt, and made prisoners of its liegemen.

Par. X. Certain people of the city of Katna have been made prisoners, and carried away captive by Aziru. Let Amenophis either send troops to rescue them or money to ransom them.

Par XI. This paragraph is one of the most interesting in the Tell el-Amarna tablets, as it suggests the origin of the worship of the Sun-god in Egypt. Akizzi states that Shamash, the Sun-god, the god of his fathers, became also the god of the ancestors of Amenophis, and that they called themselves after his name. This clearly has reference to the title "son of the Sun".which was adopted by nearly every king of Egypt, and indicates that Akizzi believed that the worship of the Sun was introduced into Egypt fron Asia. The King of Khatti has carried off the image of the Sun-god from Katna; Akizzi desires that the image of the god of his father shall return to him, and he prays the king to give heed to this matter, and to let him have as much gold as is needful to fulfil 
his desire. If Amenophis will do this, surely then " the name of my lord may, as in times of old, be taken from the name of the Sun-god."

37.-Letter from Akizzi, governor of the city of Katna, to Amenophis III.

The name of the writer is almost entirely defaced, and only traces remain of the last character, which appears to have been $z i$. There can hardly be a doubt that this and the preceding letter are from the same person, for the general shape of the two tablets and the style of the writing are identical ; there is a margin on the left hand side of the obverse and reverse in each tablet; the text in each is divided in a particular manner into paragraphs, which generally begin with the same word in each; and the city of Kaṭna is mentioned in both letters.

This letter is divided into eleven paragraphs. The text of the obverse is much mutilated, and no connected sense can be made out of paragraphs II-V.

Par. I contains the salutation, which may be restored from that of the preceding letter. Pars. II-V refer to certain disputes between Akizzi and the King of Khatti, in consequence of certain orders given to Akizzi by Amenophis; and Akizzi appears to ask Amenophis for troops to defend the country. In Par. V a certain Aitugama is mentioned; and a list of objects which were carried off by the enemy is given.

Par. VI. Tiuwatti, governor of the city of Lapana, ${ }^{1}$ and Arzawya, governor of the city of Rukhizi, ${ }^{1}$ have entered into a league with Aitugama, and have wasted the countries of the king with fire.

Par. VII. The King of Nukbashshi, the King of $\mathrm{N}_{1},{ }^{2}$ the King of

1 These cities are not mentioned elsewhere in the Tell el-Amarna tabiets, and their site is, at present, unknown; names like Aitugama and Tiuwatti, if these transliterations be correct, appear not to be Semitic.

2 In Egyptian " 11 M and as early as the reign of Thothmes I., about в.c. 1633, probably marked the boundary of the Egyptian territory on the east. The inssription on the tomb of 
Zinzar, and the king of the land of Kinanat (Canaan (?)) are, like himself, the friends and servants of the king, his lord.

Par. VIII. If Amenophis feels himself able to send troops to the countries of these kings, let him send them without delay, and let them go there to establish a league (?) between those kings and him self. If he wishes them to give him gifts or tribute, let him send his ambassador with his troops, to take back whatever the king desires.

Par. IX. If Amenophis cares for the people of these lands, let him send troops and messengers.

Par. X. Let the king know that Arzawya, governor of the city of Rukhizi, and Tiuwatti, governor of the city of Lapana, who are now dwelling in the country of Ubi, ${ }^{1}$ which belongs to the King of Egypt, and Dasha, who is dwelling in the land of Am, are sending daily to Aitugama, and are advising him to "go and [capture] the whole country of Ubi."

Amen-em-heb at Karnak states that Thothmes III., about B.c. 1600, slew 120 elephants

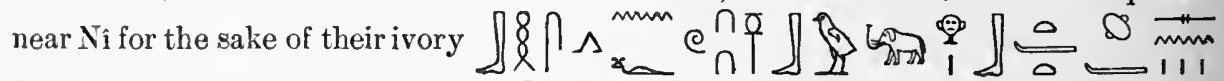
(A.g. Zeitschrift, 1873, p. 5), and in the thirty-third year of his reign, having crossed orer to the eastern side of the Euphrates, "he set up his memorial slab in Neherna

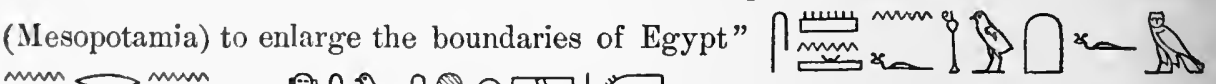

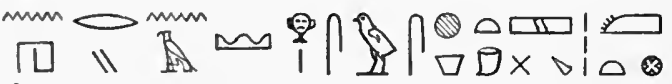

(Lepsius, Auswahl, pl. xii, 1. 21), by the side of the stele set up by his ancestor Thothmes I. (Brugsch, Geschichte Agyptens, Leipzig, 1877, p. 312). When Amenophis II. made an expedition to Mesopotamia in the early years of his reign, he arrived on the 10th of the month Hathor at " the city of $\mathrm{N} \hat{\mathrm{i}}$, and behold the Asiatics of this town, men as well as women [were] upon theil. walls to praise his majesty" tesc $\Leftrightarrow 44_{1}^{\circ}$ mm " 至 3 (Maspero, AEg. Zeitschrift, 1879, p. 57, 1.11).

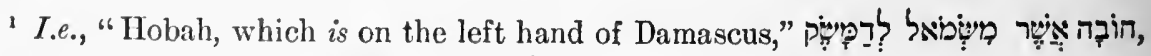
(Genesis xiv. 15), and the Egyptian 8$]_{e}^{e}$, Brugsch, Geog. Inschriften, II, Taf. XXII, No. 204. Line 63 of this letter also states that Damascus was situated in the laud of Hobah. 
Par. XI. Just as Damascus, ${ }^{1}$ which is situated in the country of Ubi, is terror-stricken at the league of the enemy, and is lifting up its hands in supplication at the feet of the king, so likewise does the city of Katna lift up its hands. He begs the king to give life to his messenger by granting his petition; and if only he will send troops to Katna, he will be able to keep his hold upon the city.

38.-Letter from Shubandi, 2 the governor of a city, to the King of Egspt.

After lengthy expressions of loyalty to the king, he acknowledges the receipt of a despatch from him; and, in obedience to his commands, which he has fully understood, he is guarding the territory under his charge with all diligence.

\section{9.-Letter from Shubandi to the King of Egypt.}

After the usual salutations, he acknowledges the receipt of instructions which the king has sent him, and he is watching with all diligence the king's country under his charge.

\section{0.-Letter from Shubandi to the King of Egypt.}

Serious illness has prevented his fulfilling the duties of the government and defending the cities referred to in the king's despatch. Because of the increasing hostility of the foe, he has appointed Abdi milki to carry out his orders, and he will send him to meet the king when he is about to come. The text of the concluding portion of the letter is much mutilated, but the lines appear to have had reference to the enemy's attacks.

1 In Babylonian and Assyrian, Di-ma-ash-kị, Di-mash-ǩa; see Rawlinson, Cuneiform Inscriptions, Vol. I, pl. 35, No. 1, 1l. 16, 21; Vol. V, pl. 9, 1]. 8, 12; K. 530 (Catalogue, p. 124), K. 542 (Catalogue, p. 126), etc. The cognate forms of this name

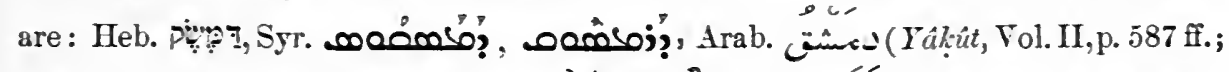

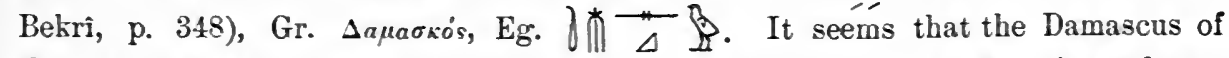
the text (whether it was on the site of the modern city or uot) was situated near the country called by the Egyptians of Irif Tu-ni-ip.

${ }^{2}$ Two letters of this officer are preserved at Gizeh (B., Nos. 116 and 117), and one at Berlin (B., No. 120). 
41.-Letter from the inhabitants of the city of Tunip to the King of Egypt.

The city and country of Tunip are first mentioned in Egyptian annals of the reign of Thothmes III. (about B.c. 1600). This king captured the fortress of Tunip on his fifth expedition, which took place in the twenty-ninth year of his reign, and made prisoner its governor, and carried off much booty, which he sent in ships to the land of Egypt (Lepsius, Auswahl, pl. XII). Twelve years later Thothmes utterly destroyed Tunip, because its inhabitants had joined the great league of Syrian cities against the power of Egypt. About one hundred years later Amenophis III. captured Tunip, Kadesh, and the other principal cities of the league (Lepsius, Denkmäler, III, Bl. 88a). In the fifth year of the reign of Rameses II., about B.c. 1333, Tunip was again captured by the Egyptians (Recueil de travaux, tome VIII, p. 127). It lay to the south of Aleppo (cf. 1100 口品 Chilbu her meht Tunep, "Aleppo to the north of Tunip"), and on the borders of the land of the Cheta ( $c f$.

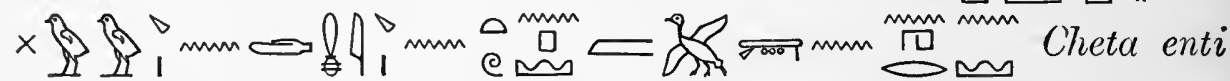
em uu en temà en Tunep em pa ta en Neheren, "Cheta which is on the border of the city of Tunip in the land of Mesopotamia"; Brugsch, Recueil, tome II, 54, No. 2, 1. 4). There seems to be no proof, at present, that Tunip is identical with the city of Damascus, but there is no doubt that these places were situated near each other.

The letter is divided into eleven paragraphs :-

Par. I contains the usual salutations.

Par. II. The city of Tunip appeals to the King of Egypt and asks if it was not in times of old under the protection of Manakhbiryaa name which appears to represent the prenomen of Thothmes III.,

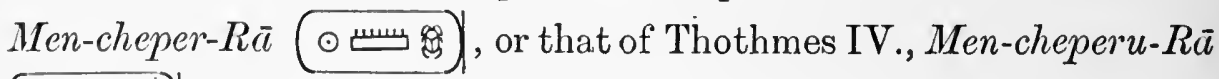

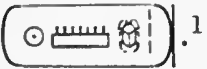

1 According to a Berlin tablet (No. 30, obv. 4) the name appears to be spelt $M a-n a-a k h-b i-y a$, the $r$ of cheper or cheperu being unrepresented in the cuneiform transcript. 
Par. III. The gods worshipped in the city of Tunip are the same as those of Egypt, and the form of worship of the two countries is the same; ${ }^{1}$ let the king consult his ancient documents, and see if Tunip has not always been loyal to Egypt.

Par. IV. They have sent, twenty tablets to the king, and the messengers who carried them are detained in Egypt; they ask the king to send one of them back to them, viz., a certain Yaki-Adda.

Par. V. If the king is willing for Yaki-Adda to return to Tunip, why should he be delayed in coming?

Pars. VI and VII seem to indicate that the messengers with the tablets from Tunip have been intercepted by Aziru in the country of Khatat, ${ }^{2}$ and that the inhabitants fear that, as he has gathered together his soldiers and chariots, he will come and do to Tunip what he did to the city of $\mathrm{Ni}^{3}{ }^{3}$

Par. VIII. When the King of Egypt hears the news of the troubles which Aziru has caused, he will be grieved just as they are. They beg that the king will send help to them.

Par. IX. The king will be grieved to hear also that when Aziru obtained possession of the city of Șumuru, which belonged to the king, the people became traitors and did as it pleased Aziru.

Par. X. "And now thy city Tunip is weeping, its tears are flowing," and the strength of the people is not enough to prevent its capture.

Pur. XI. They have now sent to their lord and king, the King of Egypt, as many as twenty despatches, but not one answer from the king has reached them.

1 Thothmes III., on the capture of Tunip in the 29th year of his reign, entered the chamber where offerings were usually made, and sacrificed oxen, calves, ducks, etc.,

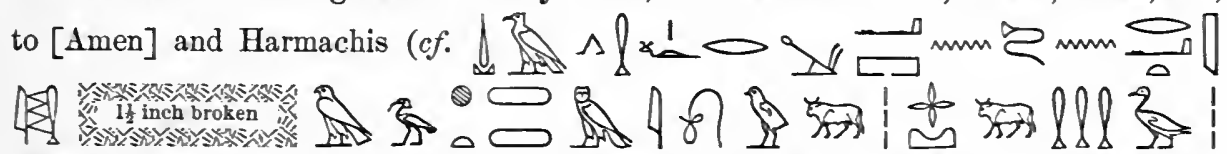

Lepsius, Auswahl, pl. XII, 1. 2 ; Brugsch, Recueil, tome II, pl. 56, No. 6; and Mariette, Karnak, pl. 13, 1.2). This seems to hare been the foundation of the worship of gods of Egypt in Tunip, and it is probable that the inhabitants of Tunip _refer to this event in their letter.

2 Equiralent to Khatti(?).

For note on this city see abore, p. Ixvii, note 2. 
42.-Letter from the city of Irkata, ${ }^{1}$ near Sumuru, to the King of Egypt.

"Thus saith this letter from the city of Irkata to the king our lord: "The city of Irkata and the nobles (?) thereof prostrate themselves at the feet of the king their lord seven times and seven times.'" The people of the city of Irkata declare to the Sun-god that they know the wishes of the king, their lord, and that they are therefore diligently guarding their city. The king sent his messenger Abbikha to them with orders that they were to guard their city against the followers of [Abd-Ashirta], ${ }^{2}$ the enemies of the king, and they now wish to assure him that they are his faithful servants. In proof thereof, they send thirty (?) horses, etc., as gifts. By this action they hope that the king will learn what their disposition is towards him. The King of Egypt appears to have sent a despatch to a certain country called Shanku, whereupon the inhabitints of a city who were previously well disposed to those of Irkata suddenly became hostile to them. They therefore entreat the king to send help to his servants, that they may overthrow the king's foes and make them "eat dust." They have shut their gates against the king's enemies, and they assure the king of their urgent need, because the foe is mighty against them.

43.-Letter from Namyawiza (?), governor of the city of Kumiți (?), to the King of Egypt.

The text is broken off both at the beginning and end. The rebels have attacked a city, and have captured the horses and chariots therein, and have declared themselves independent of the King of Egypt. Such things being done, Namyawiza feels as if he were dead; and he has no followers. Behold, too, Biridashwi has fomented rebellion in the city of Inuamma, ${ }^{3}$ which has closed

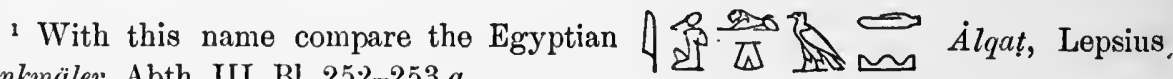
Denkmäler, Abth. III, Bl. 252-253 a.

2 Compare B., No. 77, 1. 9 ff., where it is said that the fullowers of Abd-Ashiı ta have departed to take the cities of Sumuru and Irkata. ${ }^{3}$ Compare the name of the fortress in Upper Rethennu
$\bar{a} a-m \bar{a} u$, Brugsch, Geogr. Inschriften, II, 40.
} 
its gates against him. Biridashwi has captured the chariots belonging to the city of Ashtarti, ${ }^{1}$ and has given them to the rebels instead of to the king. The governor of the city of Buzruna and the governor of the city of Khalunni made a league with Biridashwi, and determined to slay Namyawiza. Namyawiza, however, took refuge in Damascus, and, when attacked by Arzawya, declared himself to be a servant of the King of Egypt. Arzawya then went to the city of Gizza, made prisoners the followers of Azi[ru ?], and, having captured the city of Shaddu, gave it into the hands of the rebels, instead of to the King of Egypt. Moreover, Itakkama ravaged the country of Gizza, and Arzawya, in league with Biridashwi, wasted the country of Abitu. Namyawiza prays the king to send troops to defend his territory. He will meanwhile guard the city of Kumiti, hoping soon to see the arrival of the Egyptian troops.

\section{4.- Portion of a letter to the King of Egypt.}

The text is, presumably, part of a letter which corered more than one tablet, but the name of the person addressed and that of the writer are wanting, and the customary salutations are omitted. It appears that a certain Khâya who had promised to send ships, manned with their full fighting crews, to the country of Amurri, had failed to keep his word, owing apparently to the machinations of Abd-Ashirta. The ships from Arvad which have been left in the writer's charge are without crews, and he therefore recommends the king to use the other ships from Arvad which he has with him in the land of Egypt. The sense of the next few lines is obscured by breaks in the text, which here contains a speech of Khâya, ending with the question, "To whom do the people of the cities of Sidon and Beyrut belong, if not to the king?" The writer advises the king to use his authority, and to appoint for himself in each city a man who shall have charge of the shipping, so as to counteract the influence of Abd-Ashirta in preventing the manning

"I.e., the city of "Ishtar"; the Egyptian form of the name of this goddess is $\rightleftharpoons 0$ A Astharthet. 
and departure of ships. The King of Egypt had ordered Sidon, Beyrut and Arvad to send a number of ships to Amurri, but never a ship came, and therefore the writer advises him to seize AbdAshirta and to keep him under guard near him, and to pay heed to the words of his faithful servant.

45.-Letter from the governor ${ }^{1}$ of the city of Byblos (?) to the King of Egypt.

He complains that the king does not trust his city Byblos, the city of his fathers, and that Aziru the rebel has made a league with the king of the land of Ammiya, and the king of the land of $\mathrm{N} \hat{1}$, and that he is acting contrary to the interests of the king in the king's countries. The next eighteen lines are mutilated, and it is impossible to make connected sense from what remains. $\mathrm{He}$ is still the king's faithful servant, and asks him to send a company of thirty [or] fifty men to protect Byblos, and entreats him not to place any trust in anything that Aziru tells him. He himself will send to the king any news he can collect concerning the rebel Aziru.

46. - Letter from a governor of a city to the King of Egypt.

The people of the country of Kinza made a league with the [King of] Khatti, and set out to capture certain cities under the rule of the King of Egypt in the country of Am. He has, however, defended these cities against them, and is holding them for the King of Egypt as before.

The text of this tablet is defaced in places, and the parts of the lines on the obverse which run round to the reverse have been wilfully defaced by cutting away the edges of the tablet.

47.-Letter from Abdu-kar-shi (?), governor of the city of Khașur, ${ }^{2}$ to the King of Egypt.

1 The beginning of this letter may be restored according to the reading of B., No. 91, 1. 3, where, however, the order of the names of the city of Gebal (?) and the governor is reversed.

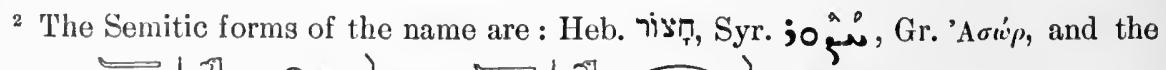

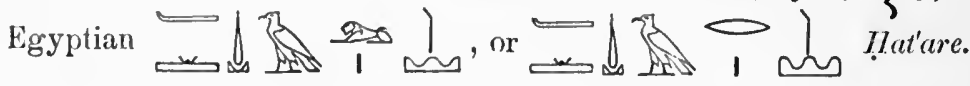


$\mathrm{He}$ will diligently guard the cities of the king until his arrival. When the despatch of the king came to him, it was as if Shamash the Sun-god had risen upon him and was shining upon him with all his noonday splendour. He is making all arrangements necessary for the king's coming. After lines 15-17, which express his joy at the arrival of the king's messenger with the glad tidings of his master's coming, the text is so mutilated that it is impossible to make any connected sense out of it.

48.-Letter from Abdu-kar-shi (?), governor of the city of Khașur, to the King of Egypt.

$\mathrm{He}$ is a faithful follower of His Majesty, and is upholding his authority in his own city and in the other cities subject to the king. $\mathrm{He}$ asks the king to decide what he is to do in respect of the city.

49.- Letter from Yapakhi, governor of the city of Gezer, ${ }^{\mathrm{I}}$ to the King of Egypt.

After the usual compliments, he acknowledges the receipt of orders from the king's envoy, which he has fully carried out. He begs the king to take active measures for the protection of Gezer and the country round about, for the king's enemies are growing powerful, and he fears that they will soon overcome him.

50.-Letter from Yapakhi, governor of the city of Gezer, to the King of Egypt.

After the usual compliments, he'acknowledges the receipt of a despatch from the king, and informs him that his youngest brother has left him and joined his forces to those of the enemy in the city of $\mathrm{Mu}[\mathrm{ru}$ ? $]$ khazi. The enemy are acting against him; he therefore begs for instructions how to deal with his brotlier and his allies.

51.-Letter from Yapakhi, governor of the city of Gezer, to the King of Egypt.

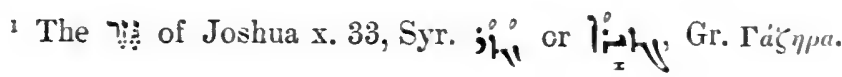


The text cannot, with our present knowledge of the language employed in these tablets, be translated, owing to the very rare words and unknown ideographs which occur in it. Yapakhi acknowledges the receipt of a despatch from the king, which pleased him greatly. He then appears to refer to events of a hostile character in a neighbouring district, and to the arrival of help from the king, whereby his mind was set at rest.

52.-Letter from Widya, governor of the city of Askelon, ${ }^{1}$ to the King of Egypt.

$\mathrm{He}$ is vigilantly guarding the city under his charge; he is also sending to the king meat and drink, oxen, etc., together with his customary tribute, apparently in answer to a remonstrance from the king.

53.--Letter from Widya, governor of the city of Askelon, to the King of Egypt.

$\mathrm{He}$ is vigilantly guarding the city under his charge. In answer to a remonstance from the king, he sends gifts, iucluding women (?).

The king is addressed by the titles: 1 . Shamash sha ishtu samî,

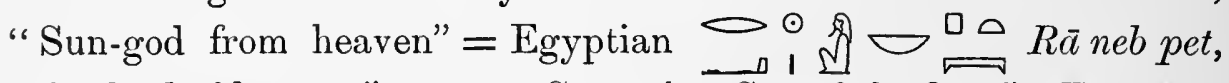
"Rā, lord of heaven"; 2. mär Samash, "Son of the Sun "=Egyptian

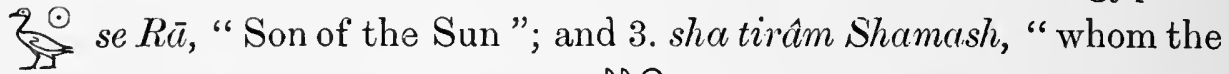
Sun-god loveth "=Egyptian $\simeq \mathcal{H}_{\text {i }}^{\odot}$ meri Rā, "beloved of Rā."

54.-Letter from Widya, governor of the city of Askelon, to the King of Egypt.

1 In Babylonian and Assyrian, Is-ka-(al)-lu-ná; see Rawlinson, Cuneiform Inscriptions, Vol. I, pl. 38, 11. 58 and 63; Vol. III, pl. 16, col. 5, 1. 1j. An inhabitant of

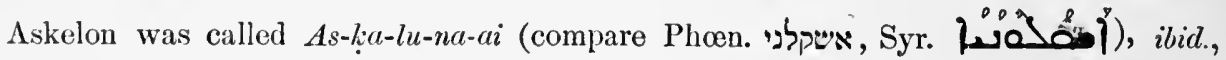
Vol. II, pl. 67, 1. 61. The other Semitic forms of the name of the town are: Heb.

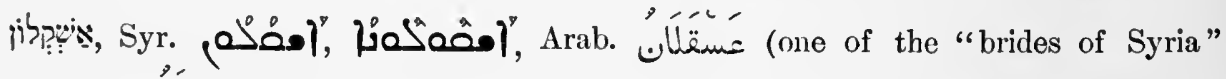

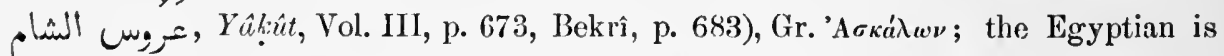

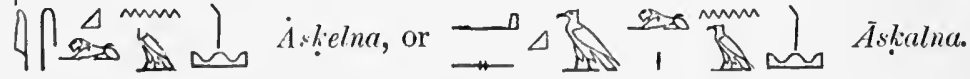


In obedience to the king's orders, he has supplied his soldiers with meat, drink, oil, oxen, etc., and everything that they needed he gave unto them. "How is it possible for me to be an officer of the king, my lord, the Son of the Sun, and not to obey his words?"

55.-Letter from Pu-Adda, governor of the city of Urza, ${ }^{1}$ to the King of Egypt.

$\mathrm{He}$ is vigilantly guarding the territory under his care. Apparently to disprove a charge of neglect of duty, he sends an extract from a letter which he had written to a neighbouring governor named Shashikhashi(?), warning him not to help certain men on their way, as they were enemies of the king. He concludes by protesting his devotion.

56.-Letter from Pu-Adda, governor of the city of Urza, to the King of Egypt.

$\mathrm{He}$ is vigilantly guarding the territory under his charge, and passes day and night in carrying out the orders of the king. It appears that the king remonstrated with him as to his conduct towards a certain officer named Rianapa, ${ }^{2}$ who, as we know from a letter of Widya, ${ }^{3}$ had been appointed governor of a neighbouring city. Rianapa's duties probably included the supervision of Widya, $\mathrm{Pu}$-Adda, and other governors of the Egyptian territory along the coast of Syria. Pu-Adda now assures the king that he will regard Rianapa as His Majesty, "mighty like the Sun-god in heaven," especially as he has been commanded by the king so to do.

57.-Letter from Yabitiri ${ }^{4}$ to the King of Egypt.

He professes his devotion to the king. "I look here and I lock there, and behold it is dark; but when I look towards the king, my

1 The position of this city is unknown.

${ }^{2}$ Compare the Egyptian name $\operatorname{mm}_{2} 404$ 通 Renappa, Lieblein, Dict. Noms, p. 297.

${ }^{3}$ Berlin Tablet, No. 122, 11. $16 \mathrm{ff}$.

- The name Yabitiri is not Semitic, but may be Egyptian. 
lord, it is light. The tile which is trodden upon may give way; but I shall never give way beneath thy feet. Let the king, my lord, ask his minister Yankhamu if I am feeble, and let him give me leave to come to Egypt." He wishes to leave Palestine for Egypt in order to obtain an appointment in the immediate service of the king, whom he entreats to ask of Yankhamu if he did not do his duty well as governor of Gaza ${ }^{1}$ and Joppa. ${ }^{2} \mathrm{He}$ has been in command of the king's soldiers for a long time, and wherever they have been he has been with them. "The yoke of the king, my lord, is upon my neck, and I will bear it."

58.- - Letter from the king of a district of Palestine, to the kings of Canaan, the "servants" of his "brother" the King of Egypt.

$\mathrm{He}$ is about to send his messenger Akiya to his "brother, the King of Egypt," to tell him that he, and whatever he hath, is at his disposal. He proposes to send his messenger by way of the lands of Canaan, held by native kings under the rule of Egypt, and he has instructed him to carry quickly to Egypt whatever gifts the kings of Canaan will entrust to him for the King of Egypt. In conclusion he refers to the fondness of Egyptians for presents. Akiya may be relied upon to use with the best effect any gifts which they may place in his hands.

On the lower part of the Reverse is a faint impression of a hæmatite Babylonian cylinder seal, which measured about $\frac{7}{8}$ in. in length by $\frac{7}{16}$ inch in diameter, and upon which was engraved four lines of Babylonian characters and some winged figures. The seal made one revolution and a half. The one character which can be distinguished may be or or

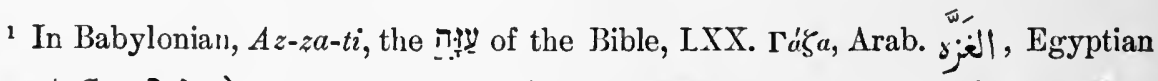

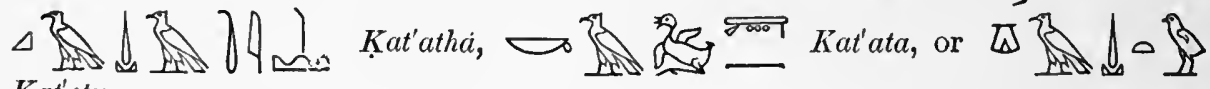
Kat'etu.

2 In Babylonian and Assyrian Ya-ap-pu-u, or Ya-pu-u (see Rawlinson, Cuneiform Inscriptions of Western A sia, Vol. I, pl. 38, I. 66), Heb. i, Syr, Arab.

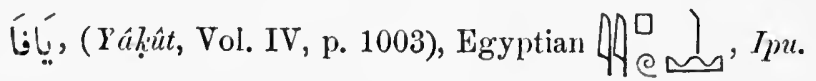


59.-Letter from Wyashdata, "the faithful servant of the king," to the King of Egypt.

All the possessions which were entrusted to him have been destroyed by the people of the city of Tada, ${ }^{1}$ near Beyrut (?). They have also made a raid upon his cattle and have carried them off. $\mathrm{He}$ has therefore made a defensive league with Biridiwi, governor (?) of Megiddo. ${ }^{2}$

60.-Letter from Bayawi to the King of Egypt.

Yankhamu has failed to do his duty (?), and in consequence the rebels have seized all the country round about. He entreats the king to make his country to "live again."

On the Obverse, at the top left-hand corner, appear to be traces of an Egyptian seal impression.

61.-Letter from Labawi, governor of a city probably near Jerusalem, to the King of Egypt.

He reports the arrival of certain troops, but they, instead of protecting his people, have dealt with them roughly. He is left with only one officer, and he fears that this man will slander him to the king. He will fight as long as he is able and will encourage the troops. He will never retreat, even the breadth of a thumb (?), even if the city were to be taken twice over. The meaning of the last part of the letter is obscure.

62.-Letter from Milkili, governor of a city probably near Jerusalem, to the King of Egypt.

He informs the king of an act of tyranny on the part of Yankhamu, a high official in the Egyptian service. It appears that Yankhamu, after seizing Milkili's goods, had forcibly carried off his wives and

1 This name is restored from a tablet at Berlin, B., 58, line 80, in which the city is mentioned in connection with Beyrut.

${ }^{2}$ See a tablet at Berlin, No. 114, 1. 4. This seems to be the only passage where the city over which Biridiwi ruled is mentioned. 
children. Let the king remember this deed against Yankhamu, and send chariots and troops for Milkili's protection. The conclusion seems to refer to the king as his only protector.

63.-Letter from Milkili, the governor of a city probably near Jerusalem, to the King. of Egypt.

$\mathrm{He}$ has understood the king's despatch, and begs that some native Egyptian soldiers may be sent to protect the city. The meaning of the last two lines is doubtful.

64.-Letter from Mut-Adda, governor of a city, to his superior officer, Yankhamu, a high official of the King of Egypt.

When he reports that the enemy have disappeared, it is a certain fact that they have disappeared; and when he reports that the governor of the city of Bikhishi has fled before the inspector of the king (i.e., Yankhamu), it is also certain that he has fled. "May the king, my lord, live; may the king, my lord, live!" The enemy have taken possession of the city of Bikhishi and have occupied it for the last two months. If Yankhamu does not believe it, let him ask Bininima and Wishuya and others. The city of Ashtarti was safe under the rule of the Egyptians until the arrival (?) of the god Merodach. The following cities have rebelled: Udumu, ${ }^{\mathrm{i}}$ Aduri, ${ }^{2}$ Araru, Mishtu, Magdalim, ${ }^{3}$ Khinianabi, Șarkișabtat, Khawini, and Abishima. The tablet which Yankhamu had sent to him he had passed on to the governor of Bikhishi ; but, before Yankhamu could arrive, the city had been captured, and the report of its fill had been brought.

${ }^{1}$ I.e., Edom. In Babylonian and Assyrian. U-du-mu; see Rawlinson, Cuneiform Inscriptions, Vol. III, pl. 16, col. V, 1. 14; Vol. V, pl. 7, 1. 109, etc. The Semitic forms

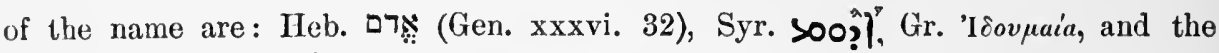
Egyptian 4 通

2 I.e., Addar, רָָָ Joshua xv. 3.

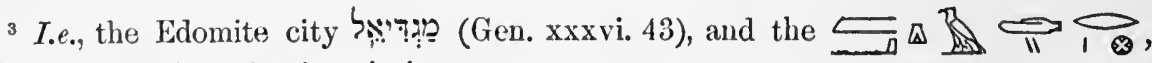
Makatil of the Egyptian inscriptions. 
65.-Letter from Shibti-Adda, an officer, to the King of Egypt.

He has understood the king's despatch, and in answer to enquiries concerning the fidelity of Yankhamu, a high Egyptian official, he states that he is " a faithful servant of the king, and the dust of the king's feet." The condition of the city under his charge is guod.

66.-Letter from Shum-Addu, governor of a city, to the King of Egypt.

After salutations, he acknowledges the receipt of a despatch from the king asking for grain, and informs him that the men who thresh corn have, during these last days, driven away their overseers, and he cannot therefore obey the king's command; he appeals to the evidence of the king's inspector to support his statement. He appears to have intended originally to add some further remark, which began with the words $u$ shumma, "and whether"; but, changing his mind, he partially erased them.

\section{7. - Letter from Shuardata, governor of a city, to the King of Egypt.}

Although he has sent off every available soldier to join the Egyptian troops, he is nevertheless guarding the cities of the king as well as he is able; he has also sent gifts to the king. A little further on, he repeats his expressions of loyalty to the king, and acknowledges the receipt of a despatch containing certain orders.

The tablet upon which this letter is written has suffered from abrasion, probably of old standing. The corners have been rubbed away, the writing on the Obverse is defaced, and on the Reverse it is almost entirely wanting.

68. - Letter from Shuardata, governor of a city, to the King of Egypt.

$\mathrm{He}$ is defenceless, having sent all his troops to join the king's army. He therefore prays the king to deliver him and his city; the handmaiden of the king,'

${ }^{1}$ For this title of a city compare No. 28 (abore, p. lix, and note 2). 
69.-Letter from Shuardata, governor of a city, to the King of Egypt.

He is carrying out with diligence the king's orders.

70.-Letter from Tâgi, the father-in-law of Milkili, to the King of Egypt.

He protests fidelity to the king, and is anxious that all the principal highways of the king should continue to be under the superintendence of his " brother" (Milkili ?), for then not a thumb's breadth(?) of them would be any longer unsafe. Let the king ask of his own officer if, in times past, the roads under his charge have not been safe. "Behold, we are thine, and whether we raise our eyes to heaven, or cast them down to the earth beneath, our heads are in thy hand." He repeats his prayer that the highways should be under his "friend's" jurisdiction; he himself is protecting the interests of the king.

71.-Letter from an officer (whose name is lost) to the King of Egypt.

A certain Bîya the son of Gulati $^{1}$ had taken prisoners the troops which the writer had sent to Joppa to protect the king's interests. In obedience to the king's orders to follow the instructions of his commander, he has delivered the city and expelled the rebel Bîya. If the king chooses to visit it by day or by night, he will find it prepared to receive him.

72.- Continuation(?) of a letter, which apparently occupied more than one tablet, from an official to the King of Egypt.

He spoke, it appears, to his brethren, saying: "If the gods of the king, our lord, grant it, we will capture Labawi alive and will bring him before the king, our lord." His mare was brought to him and he mounted her, and galloped off" in pursuit of Labawi, who was with an official named Wyashdata. ${ }^{2}$ When he had come up with

1 This is the name of his mother.

${ }^{2}$ No. 59 was written by this same Wyashdata. 
him he learned that he had alreudy been made prisoner in Megiddo ${ }^{1}$ by Zurata. He disputed the capture with Zurata in the name of the king, but Zurata kept possession of his prisoner and told him that he intended to send Labawi direct to Egypt on board ship. Zurata, however, actually took him to his own house in the city of K hinatuna, and set him free, although he had received the price of the ransom from the writer of the letter; and Labawi and a companion Addamikhir then went home. The writer asks what he is to do (i.e., in order to recover the money which he has expended in the king's name), seeing that he has been deceived by his comrade Zurata, and that Labawi has escaped from his hands.

73.- - Letter from the governor of a city to the King of Egypt.

By day and by night he is forced to submit to the attacks of the king's ewemies upon the cities under his charge. As to the city of Magdalim, he is unable to control (?) the inhabitants. The soldiers of the city of Kukbi have made a league against him, and there is no one to deliver him out of their hands. The report which Abbikha, ${ }^{2}$ an envoy in the Egyptian service, sent to the king, saying that the gates of all the cities under his charge were captured by the enemy, he indignantly asserts to be false. The end of the text is broken off.

74.--Letter from Dagan-takala to the King of Egypt.

He entreats him to deliver him out of the hands of his foes.

75. - Letter from Dashru to the King of Egypt.

He acknowledges the receipt of the king's despatch, which he thoroughly understands. The rank which Dashru held in the Egyptian king's service, and the situation of the city or district in which he lived, cannot be ascertained.

1 In Babylonian and Assyrian, $M a-g a-c l u-u$ and $M a-g i-d u-u$; see Rawlinson, Cuneiform Inscriptions, Vol. II, pl. 53, 11. 56 (K. 276) and 58(K. 1521). The Semitic forms

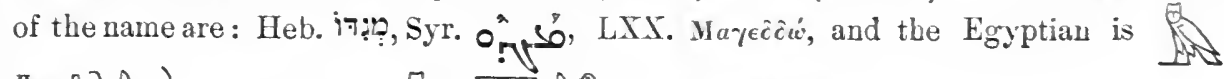

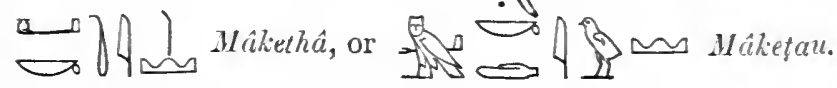

2 An embassy of this officer to Irḳata, a city near Șumuru, is mentioned iı No. 42 (ste abore, p. 1xxii). 
76. - Letter from Zidriara to the King of Egypt.

$\mathrm{He}$, who is but "dust and mud," acknowledges the receipt of the king's despatch, which he has understood, and has carried out its orders with all diligence.

77.-Letter from Shatiwi, the governor of a city, to the King of Egypt.

He is diligently guarding the city and district of Inishași... (?). $\mathrm{He}$ has sent his daughter to the king to become a member of his household. Some half-dozen lines in the middle of the text are defaced.

78. -Letter from an officer of the city of Gubbu, ${ }^{1}$ to the King of Egypt.

In obedience to orders, he and the forces under his command have set out to join the king's army and to march with it wherever it may go.

79.-Letter, or appeal, from an unknown person, addressed probably to some high official.

The writer demands that the accusation brought against him may be referred for judgment to the King of Egypt; if the king will duly enquire into the matter he is certain to give him a just and favourable judgment; he will accept as final the decision of no other person.

The two ines of writing which run along the left-hand edge appear to be part of a document which had previously occupied the tablet and had been erased to make room for this letter.

80. - Letter from an officer to the King of Egypt.

After the usual salutations, he complains that, in consequence of the withdrawal (?) of the Egyptian troops from the cities round about, the whole country has become disaffected. If the king has

1 The position of Gubbu is unknown; the name may be a mistake for Gublu, i.e., Byblos. 
any doubt about this, let him ask his commander-in-chief concerning the things which have happened in his land, and whether the Egyptian troops have not forsaken him.

81. - Letter from an officer (whose name is lost) to the King of Egypt.

$\mathrm{He}$ acknowledges the receipt of certain instructions, and announces the despatch of certain objects required by the king.

82.-Mythological text relating to the goddess Irishkigal, who is known only from the Tell el-Amarna tablets, her messenger Namtâru, and a rumber of gods.

The style of the fragment upon which this text is inscribed proves that the tablet when complete differed in shape from those usually employed for letters and despatches. Both Obverse and Reverse were carefully ruled; and the lines of writing depend from the ruled lines. Before the tablet was baked, small holes were pierced here and there, on both sides, probably to provide outlets for steam and to prevent cracking or blistering. At intervals of a few words, red dots were added, possibly in Egypt, and apparently to mark punctuation; though they sometimes occur in the middle of words. ${ }^{1}$ The close similarity of this tablet, written about B.C. 1500, to those of Assurbanipal's library at Nineveh, in regard to form, ruling, puncturing, etc., proves that Assurbanipal, about B.C. 650, adopted the traditional form of tablets in making copies of the old hymns, litanies and prayers.

The text forms one of the two or three mytholngical compositions which were found at Tell el-Amarna, and which now unfortunately exist only in a fragmentary state. There are preserved in Berlin four, and at Gîzeh two, mythological fragments (B., Nos. 234-237, and B., No. 239), all of which probably belong to this text. If this be not the case, their text forms part either of a duplicate or of a continuation.

The custom of marking short members or sentences with red dots was common in Egypt. For examples on papyrus see Sallier ii., B.M. No. 10,1 २2, and Mariette, Les Papyrus Egyptiens du Jusée de Boulaq, fol., Paris, 1871, tome I, pl. 34. 
Three of these fragments (B., Nos. 234 and $239 \alpha, \beta$ ) mention the goddess Irishkigal, and their text certainly refers to the subjectmatter of our fragment. As to the other three fragments, if they do not form part of the same text, at least they do not appear to belong to the mythological text B., No. 240.'

The meaning of a large portion of the present text is doubtful, but it would seem that it opens with the account of the gods sending a messenger to their sister Irishkigal, offering to bring her to the place of their abode. In reply she sends her messenger Nanitâru, the plague god, who performs certain acts in presence of the gods. The goddess herself also accepts the invitation to visit them. The home of the gods had fourteen gates, each one of which was guarded by a god. The names of the guardians of the first two gates are wanting, but those of the gods of gates 3-13 are Mutabriḳa, ${ }^{2}$ Abdâ, Râbișa, ${ }^{3}$ Dirid, Ilûtu, Binna, Șîdana, Miḳid, Bîrapari, Um(?)ma, Lîba. What happened in the abode of the gods is, owing to the mutilation of the text, unknown, but it appears that a quarrel arose between Irishkigal and her husband Nergal, in the course of which he treats her with such violence that she is forced to beg for her life. Nergal drops his hand and weeps. Irishkigal appeals to him: "Thou art my husband; I am thy wife. Take unto thyself the sovereignty of the whole wide world, and stablish all good things of wisdom by thy hands; then shalt thou be lord, and I shall be mistress." Nergal listened to all that the goddess had said, and kissed her while her tears were flowing; and whatsoever she wished to have done was done from that time forth for evermore.

1 This interesting, but very mutilated text appea:s to record the incident of the breaking of the "wings of the South wind".(B., No. 24), obv. 1. 6) by Adapa Y 7$\}$ find out why the South wind ceased to blow for seven days (1.6).

2 "Lightning" (?).

3 See Rawlinson, Cuneiform Inscriptions, Vol. IV, pl. 15*, lines 28, 48b; pl. 16, No. 1, l. 16 ; pl. 21, No. 1 (B), I. 13 ; pl. 29, No. 1, rev. l. 26 ; K. 5005̆, l. 6; K. 507٪, Col. III, 1. 3; K. 5269, Col. I, I. 8; K. 5312, Col. II, I. 8 (Catalogue, pp. 682, 687, 703. 706), etc. 


\section{BIBLIOGRAPHY.}

*Adrer, C., Note on Babylonian Inscription disconered at Tell el Amarna and now in the British Museum: The American (Philadelphia, Pa.), June 16th, 1888.

Aus alten Zeiten: Vossische Zeitung, Sonntags-Beilage No. 25, add. to No. 283, June 17 th, 1888.

*Babylonisch-assyrische Keilschrift-Briefe aus Egypten: Archiv für Post und Telegr., 1888, pp. 682-683.

BaLL, C.J., The letter of the king of Arzapi to Amenophis III.: The Academy, Vol. 36, 1889, No. 916, pp. 343-344.

Bezold, O., Babylonisch-assyrische Keilschrift-Thontajeln aus Aegypten: Beilage zur Allgemeinen Zeitung, 1888, No. 291, pp. 4281-4282.

Milkili: Zeitschrift für Assyriologie, Vol. VI, 1891, p. 166.

Birks, E. B., The name "Moses": The Academy, Tol. 34, 1888, No. 845, p. 27.

Boscawex, IV. St. Ch., The Tel el Amarna tablets: The Babylonian and Oriental Record, Vol. III, No. 12, 1889, pp. 286-288.

Vol. V, No. 5, pp. 114-119.

An Erratum: ibidem, No. 6, p. 144.

Some letter's to An.enophis III.: ibidem, No. 8, pp. 174-179.

Brows, F., Babylon and Egypt, B.c. 1500: Presbyterian Review, Vol. IX, 1888 pp. 476-481.

Brüswow, R. E., Die Mitâni-Sprache : Zeitschrift für Assyriologie, Vol. V, 1890, pp. 209-259.

Budge, E. A.W., On cuneiform despatches from Tûshratta, king of Mitanni, Burraburiyash the son of Kuri-Galzu, and the king of Alashiya, to Amenophis III, king of Egypt, and on the cuneiform tablets from Tell el-Amarna: Proceedings of the Society of Biblical Archæology, Vol. $\mathrm{X}, 1888$, pp. 540-569.

Colliss, G. W., "Mosheh" and "Mâsu": The Acadeny, Vol. 33, 1888, No. 842, p. 435 .

Coxper, C. R., The king of Arzapi's ietter : ibidem, Vol. 35, 1889, No. 875, p. 98.

* The asterisk indicates that the reference has not been rerified at first hand. 
Costers, C. P., The Tell Amasta tablets: Quarterly Statement of the Palestine Exploration Fud, 1864, pp. 2:-30.

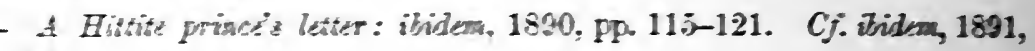
F. 1 15\%.

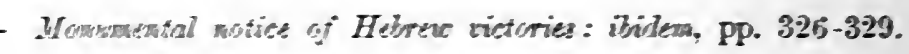

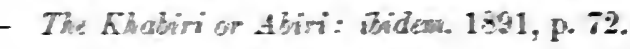

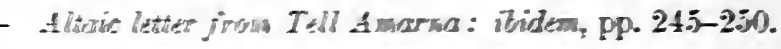

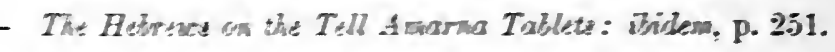

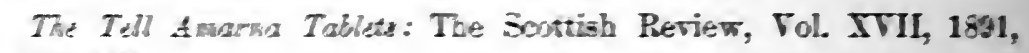
Pp. $202+218$.

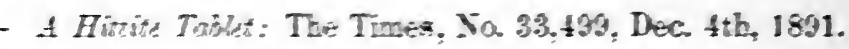

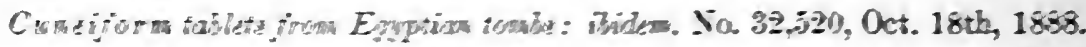

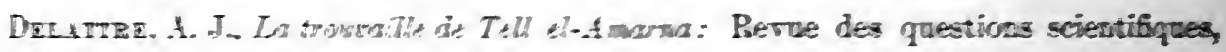
Tol ITT. 18. pa 14\%-181.

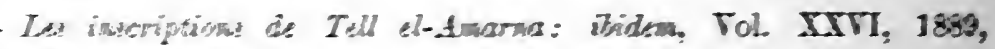
Fon. 78 .

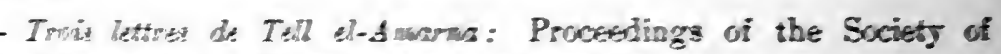

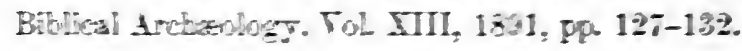

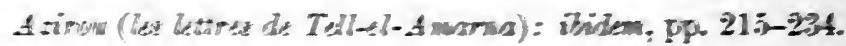

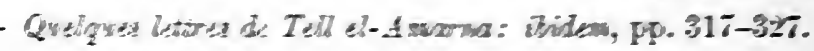

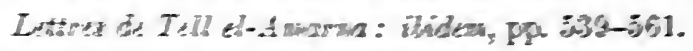

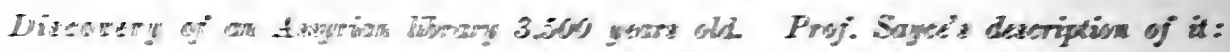

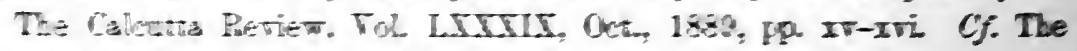

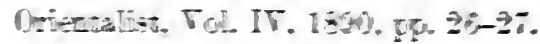

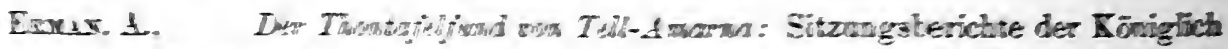

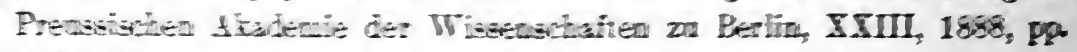

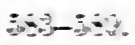

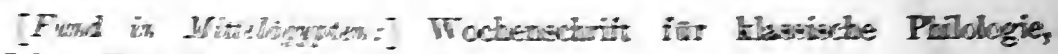

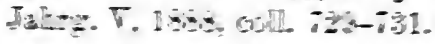

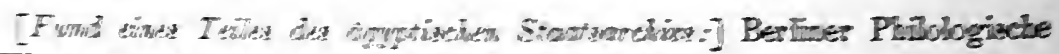

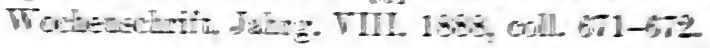

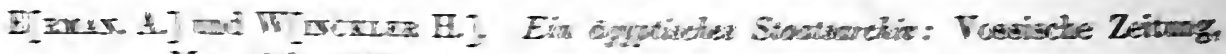

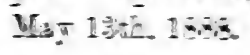

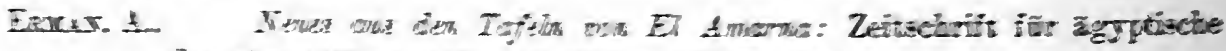

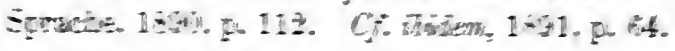

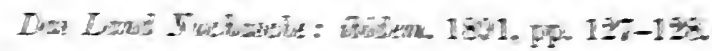

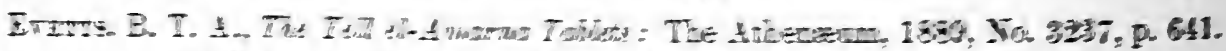

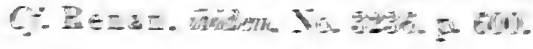

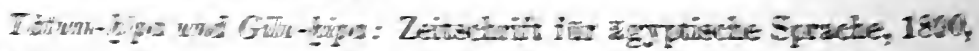




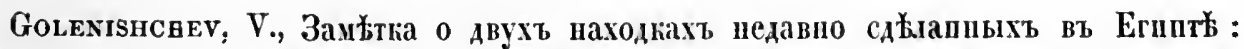
Заппски Восточнаго Отдъенія Императорскаго Русскаго Арxеологиचескаго Оо̆щества, Vol. III, 1888, pp. 121-126.

HaLÉvy, Jos., La correspondance d'Aménophis IV et la Bible: Revue des études juives, Vol. XX, 1890, pp. 199-219; Vol. XXI, 1890, pp. 43-72.

La correspondance d'Aménophis III et d'Aménophis IV, transcrite et traduite: Journal asiatique, $8^{\text {me }}$ série, Vol. XVI, pp. 298-354; 402-462; Vol. XVII, pp. 87-133; 202-273; Vol. XVIII, pp. 134-185; 510-536.

Howorth, H. H., Thuip and the land of Naharina: The Academy, Vol. 39, 1891, No. 976, p. 65. Cf. T. K. (Geyne, R. Maclagan, A. Neubauer, and H. G. Tomkins, ibilem, No. 977, p. 91; No. 980, pp. 164-165; No. 981, pp. $187-188$; No. 982 , p. 213 ; No. 983 , p. 236 ; No. 98.4 , p. 260 ; No. 985 , p. 284.

[JAstrow, M. jr.], Cunciform tablets in Egypt: Harper's Weekly, Vol, XXXII, 1888, p. 735 .

The cuneiform tublets of Tell el-Amarna: The Nation (New York), 1889, No. 1245, pp. 380-382.

Jensen, P., Vorstulien zur Entifferung des Mitanni: Zeitschrift für Assyriologie, Vol. V, 1890, pp. 166-208; Vol VI, 1891, pl. 34-72.

- IJana(i)-Hiana und Mitanni: ibidem, Vol. VI, 1891, pp. 342-345.

Aus dem Briefe in der Mituni-Sprache: Zeitschrift fur agyptische Sprache, 1890, p. 114.

*Jounston, J., Light fion Cuneiform Inscriptinns at Tel-el-Amarna: The Sunday School Times, Vol. XXXI, 1889, p. 515.

Königliche Museen zu Berlin. Mittheilungen aus den orientalischen Sammlungen. Heft I-III : Der Thomtafelfmul von El Amuma. IIerausgegebon von Hugo Wixckisı. Nach den Originalen autographirt von Lubwig AвEL. Berlin, 1889-1890.† Cf. also Verzeichnis der vorderasiatischen Altertümer und Gipsubgüsse, Berlin, 1889, pp. 103-109.

Lemmann, C. F., Aegypten und Vorderasien im zueiten vorchristlichen Juhrtansend. Nach nengefundenen keilinschrijtichen Urkmulen im Berliner Mruseum: Kölnische Zeitung, June 4th, 1888.

Die in Aegypten neugefundenen keilschriftichen Documente: Hamburgischer Correspondent, Jume 20th, 1888.

Aus dem Funde von Tell el Amarna: Zeitschrift für Assyriologie, Vol. III, 1888, pp. 372-406; Vol. IV, 1889, Pp. 82-86.

Les tablettes de Tell-el-Amarna: Journal des Débats, Oct. 12th, 1858.

Navilue, E., Documents babyloniens décourerts en Eigypte: Bibliothèque miverselle et Revue suisse, Vol. XLV, 1890, pp. 595-611.

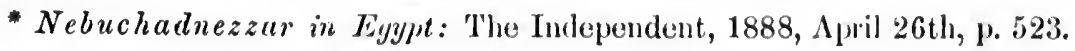

t In the present Edition this work is quoted as "B."; e.g., "B. 99, 2" (p. 143) refers to tho Berlin Edition, plate 99, line 2. 
Oppert, J., Les tablettes de Tell-Amarn: Comptes rendus de l'Académie des Inscriptions et Belles-lettres, Ser. IV, Vol. XVI, 1888, pp. 251-254.

Rosen, V., ІІовъйшія открытія вт Египть и IОжпой Арабіи : Записки Восто'паго Отдхиенія ІІмераторскаго Русскаго Археологическаго Оошества, Vol. III, 1889, pp. 270-272.

*S. S. M., Ancient Letter Writing. Royal epistles sent from Babylonia to Egypt: The New-York Times, Feb. 17th, 1889.

SAyce, A. H., Babylonian Tablets from Upper Egypt: The Academy, Vol. 33, 1888, No. 831, pp. 246-247. p. 315 .

The Babylonian tablets in the Boulaq Museum: ibidem, No. 835, The name of Moses in the cuneiform tablets of Tel el-Amarna: ibidem No. 840 , p. 397 ; $c f . i b i d .$, Vol. 34, No. 844, p. 11.

Letters from Egypt: ibidem, Vol. 34, 1888, No. 869, pp. 424-425; Vol. 35, 1889, No. 872, p. 47.

The tablets of Tell el-Amarna: The Athenæum, 1888, No. 3183, p. 554 ; No. 3184 , p. 593.

* __ Literary Correspondence between Asia and Egypt in the Century before the Exodus: The Independent, 1888, June 28th, p. 801.

The discovery of correspondence between Asia and Egypt in the century before the Exodus: The Guardian, No. 2219, 1888, p. 869.

Babylonian Tablets from Tel el-Amarna, Upper Egypt: Proceedings of the Society of Biblical Archæology, Vol. X, 1888, pp. 488-525.

- Recent oriental discovery: Contemporary Review, Vol. LIV, 1888, pp. 299-301.

The cuneifor'm tablets of Tel el-Amarna, now preserved in the Boulaq Museum: Proceedings of the Society of Biblical Archæology, Vol. XI, 1889, pp. 326-413.

Letters from Syria and Palestine before the age of Moses: Transactions of the Lancashire and Cheshire Antiquarian Society, Vol. VII, 1889, pp. 1-25.

Letter's from Palestine before the Age of Moses: The Newbery House Magazine, Vol. I, 1889, pp. 257-263. p. 64 .

The language of Mitanni: The Academy, Vol. 37, 1890, No. 925,

The language of Aram-Naharaim and the Su of the Assyrian tablets: ibidem, No. 939, p. 305. No. 964, p. 366 .

The Language of Mitanni: Zeitschrift für Assyriologie, Vol. V, 1890, pp. 260-274. 
SAYce, A. H., Letters to Egypt from Babylonia Assyria, and Syria, in the fifteenth century B.C.: Records of the Past, New Series, Vol. III, [1890,] pp. $5 \check{5}-90$.

Correspondence between Palestine and Egypt in the fifteenth century B.c.: ibidem, Vol. V, [1891,] pp. 54-101.

- Jerusalem before the Exodus: The Sunday School Times, Vol. XXXII, 1890 , p. 787.

The cuneiform inscriptions of Tel el-Amarna: Transactions of the Victoria Institute, Vol. XXIV, No. 93, 1890, pp. 12-27.-Translated into French.

Les tablettes cunéiformes de Tel el-Anarna: Revue archéologique, Vol. XIV, 1889, pp. 342-362.

Southern Palestine in the 15th century B.c.: The Academy, Vol. 39, $1 \measuredangle 91$, No. 979, p. 138.

The parentage of Queen Teie. Ancient touns in Palestine: ibidem, No. 981 , p. 187.

The Amorites and Hebrews in early cuneiform inscriptions: ibidem, Vol. 40, 1891, No. 1013, p. 291.

The mention of a Ionian Greek in the tablets of Tel el-Amarna: ibidem, No. 1015, p. 341.

Scheil, Fr. V., Une tablette de Tel-Amarna: Recueil de travaux, Vol. XIII, 1891, pp. 73-74.

Légende chaldéenne trouvée à El-Amarna: Rerue des rel., MarchApril, 1891.

(Amelúti) sabê Ya-ı-du: Journal asiatique, $8^{\text {me }}$ série, Vol. XVII, pp. $347-34 !$.

Schiaparelli, E., [Tell-el-Anarna]: Giornale della Società Asiatica Italiana, Vol. II, 1888 , pp. 154-15̆5.

Schrader, Eв., [Eine phönicisch-assyrische Abd-Aschera-Tafel von Tell-el-Amarna]: Zeitschrift für Assyriologie, Vol. III, 1888, pp. 363-364.

SpIegelberg, W., Brief an C. Bezold: Zeitschrift für Assyriologie, Vol. VI, 1891, p. 166.

Tablets of Tel el-Amarna relating to Palestine in the century before the Exodus: Biblia (New York), Vol. III, 1890, pp. 68-69.

The cuneiform tablets from Tell-el-Amarna: The Athenæum, 1888, No. 3182, pp. 518-519; No. 3183, pu. 554-5̄5̄; No. 3184, p. 593.

Tiele, C. P., Over de Spijkerschrift-Tafels onlangs te Tell-el-Amarna geronden: Verslagen en Mededeelingen der Koninklijke Akademie van Wetenschappen, Afdeeling "Letterkunde," 3亍de Reeks, Deel VI, 1889, pp. 140-149.

Un' importante scorperta egizio-babilonese: Civiltì cattolica, rol. XI, quad. 915, 1888 , pp. 313-322.

* Une correspondance babylonienne du XVe siècle arant notre ève déccuverte dans la Hauie Egypte: Univers, Nov. 27th, 1888. 
Wiedemanx, A., Tell el Amarna. Thontafelnfund: Jahrb. d. Vers. von Alterthumsfreunden in den Rheinlanden, part LXXXV, 1888, p. 177.

Wixckler, H., Keilschriftlocumente aus Aegypten: Nationalzeitung, 1888, May 19th, No. 292.

Berichtigung: Berliner Philologische Wochenschrift, Jahrg. VIII, 1888, col. 804; cf. ibidem, col. 706 .

- Aus Briefen an C. Bezold: Zeitschrift für Assyriologie, Vol. III, 1888, pp. 424-426; Vol. V, 1890, p. 296. 405.

Bemerkung zu den el-Amarna-Briefen: ibidem, Vol. IV, 1889, pp. 404-

Vorarbeiten zu einer gesammtbarbeitung der el-Amarna-texte: ibidem, Vol. VI, 1891, pp. 141-148.

Bericht über die Thontafeln von Tell-el-Amarna im Königlichen Mnseum zu Berlin und im Museum von Bulaq: Sitzungsberichte der Köнiglich Preussischen Akademie der Wissenschaften zu Berlin, LI, 1888, pp. 1341-1357.

Verzeichniss der aus dem Funde von el-Amarna herrührenden Thontafeln: Zeitschrift für ägyptische Sprache, 1889, pp. 42-64.

Der Thontafelfund von Tell el-Amarna: Berliner Philologische Woshenschrift, Jahrg. IX, 1889, coll. 578-580, 609-612.

Satarna, König von Naharina in den el-Amarna-Briefen: Zeitschrift für ägyptische Sprache, 1890, pp. 114-115.

Znmens, H., Internationale Fürstencorrespondenz vor dr'eiunddreissig Jahrhunderten: Vellagen und Klasing's Nene Monatshefte, 1890, pp. 58-64. 1890 .

Die ältesten Schriftstücke aus Jerusalem: Kölnische Zeitung, Oct. 1st,

Das Verhältnis des assyrischen Permansivs zum semitischen Perfect und zum ägytischen "Pseudoparticip" untersucht unter Benutzung der El-Amarna-Texte: 'Zeitschrift für Assyriologie, Vol. V, 1890, pp. 1-22.

Briefe aus dem Funde in El Amarna in Transscription und Übersetzung: ibidem, pp. 137-165.

Kanaanäische Glossen : ibidem, Vol. VI, 1891, pp. 154-158.

- Die Keilschriftbriefe aus Jerusalem : ibidem, pp. 245-263.

Palëstina um des Jahr $1400 \mathrm{v}$. Chr. nach neuen Quellen: Zeitschrift des Deutschen Palïstina-Vereins, Vol. XIII, 1891, pp. 133-147. 


\section{LIST OF TABLETS.}

I. LetTER Froy EGTPt.

Letter from Amenophis III., King of Egypt, to Kallimma-Sin, King of Karaduniyash

\section{LetTERS FroM BABYLONiA.}

Letters from Burraburiyash, King of Karaduniyash, to Amenophis IV., $\begin{array}{lllllllll}\text { King of Egypt. } & \text {. } & \text {. } & \text {. } & \text {.. } & \text {.. } & \text {.. } & \text {. } & 2-4\end{array}$

III. Letters from Alashrya.

Letters from the King of Alashiya to the King of Egypt $\quad$. $\quad$. $\quad 5-7$

\section{Letters froy Mitant.}

Letters from 'Tushratta, King of Mitani, to Amenophis III., King of $\begin{array}{lllllllllll}\text { Egypt .. } & \text {. } & \text {.. } & \text {. } & \text {.. } & \text {.. } & \text {. } & \text {. } & \text {.. } & 8-10\end{array}$

Letter from Tushratta, King of Mitani, to a wife of Amenophis III., $\begin{array}{llllllll}\text { King of Egypt. } & \text {. } & \ldots & \ldots & \ldots & \ldots & \ldots & \text {.. }\end{array}$

\section{Letters froji Phoentcia and Stria.}

Letters from Rib-Adda, governor of Byblos $\quad \ldots \quad$.

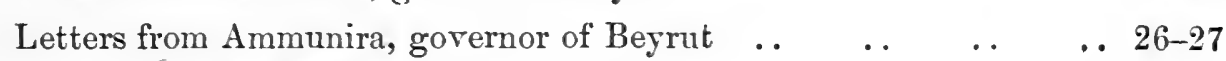

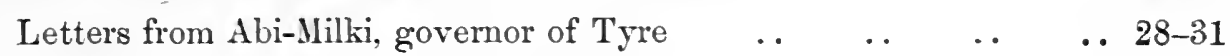

Letter from Zitadna, governor of Accho $\quad$.

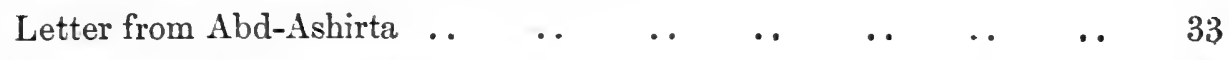

$\begin{array}{lllllllll}\text { Letter from Abdi-Ashtati .. } & \ldots & \ldots & \ldots & \ldots & \ldots & \ldots & 34\end{array}$

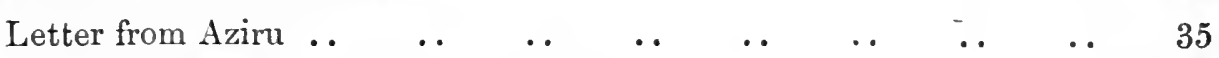

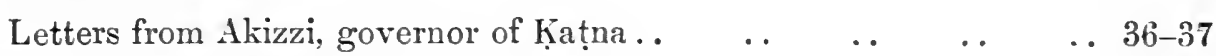

$\begin{array}{llllllllll}\text { Letters from Shubandi } & \ldots & \ldots & \ldots & \ldots & \ldots & \ldots & \ldots & 38-40\end{array}$ 
Letter from the inhabitants of the city of Tunip

Letter from the inhabitants of the city of Irḳata

Other letters. .

\section{Letters from Palestine.}

Letters from the governor of the city of Khașur .. $47-48$

Letters from Yapakhi, governor of Gezer

.. 49-51

Letters from Widya, governor of Askelon

.. $52-54$

Letters from Pu-Adda, governor of Urza

.. $55-56$

Letter from Yabitiri

57

$\begin{array}{lllllllll}\text { Letter from Akiya .. } & \ldots & \ldots & \ldots & \ldots & \ldots & \ldots & \ldots & 58\end{array}$

$\begin{array}{lllllllll}\text { Letter from Wyashdata } & \ldots & \ldots & \ldots & \ldots & \ldots & \ldots & \ldots & 59\end{array}$

$\begin{array}{lllllllll}\text { Letter from Bayawi } & \ldots & \ldots & \ldots & \ldots & \ldots & \ldots & \ldots & 60\end{array}$

$\begin{array}{lllllllll}\text { Letter from Labawi } & \ldots & \ldots & \ldots & \ldots & \ldots & \ldots & \ldots & 61\end{array}$

$\begin{array}{llllllllll}\text { Letters from Milkili. . } & \ldots & \ldots & \ldots & \ldots & \ldots & \ldots & \ldots & 62-63 \text {. }\end{array}$

$\begin{array}{llllllllll}\text { Letter from Mut-Adda } & \ldots & \ldots & \ldots & \ldots & \ldots & \ldots & \ldots & 64\end{array}$

$\begin{array}{lllllllll}\text { Letter from Shibti-Adda } & \ldots & \ldots & \ldots & \ldots & \ldots & \ldots & \ldots & 65\end{array}$

$\begin{array}{lllllllll}\text { Letter from Shum-Adda } & \ldots & \ldots & \ldots & \ldots & \ldots & \ldots & \ldots & 66\end{array}$

$\begin{array}{lllllllll}\text { Letters from Shu'ardata } & \ldots & \ldots & \ldots & \ldots & \ldots & \ldots & \ldots & 67-69\end{array}$

$\begin{array}{llllllllll}\text { Letter from Tâgi } & \ldots & \ldots & \ldots & \ldots & \ldots & \ldots & \ldots & \ldots & 70\end{array}$

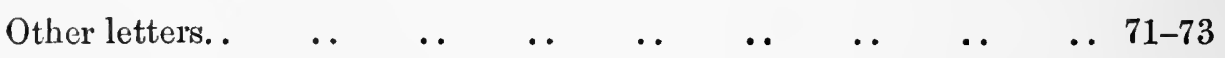

VII. LETTERS FROM UNKNOWN DISTRICTS.

$\begin{array}{lllllllll}\text { Letter from Dagan-takala .. } & \ldots & \ldots & \ldots & \ldots & \ldots & & \ldots & \mathbf{7 4}\end{array}$

$\begin{array}{lllllllll}\text { Letter from Dashru } & \ldots & \ldots & \ldots & \ldots & \ldots & \ldots & \ldots & 75\end{array}$

$\begin{array}{lllllllll}\text { Letter from Zidri'ara } & \ldots & \ldots & \ldots & \ldots & \ldots & \ldots & \ldots & 76\end{array}$

$\begin{array}{llllllllll}\text { Letter from Shativi } & \ldots & \ldots & \ldots & \ldots & \ldots & \ldots & \ldots & 77\end{array}$

Letter from an officer of the city of Gubbu (?).. $\quad \begin{array}{llllll} & \ldots & \ldots & \ldots & 78\end{array}$

$\begin{array}{lllllllllll}\text { Other letters. } & \ldots & \ldots & \ldots & \ldots & \ldots & \ldots & \ldots & & \ldots & 79-81\end{array}$

VIII. Mythological Text.

Part of a mythological legend relating to Nergal, Irishkigal and Namtar.. 
T E X T S. 


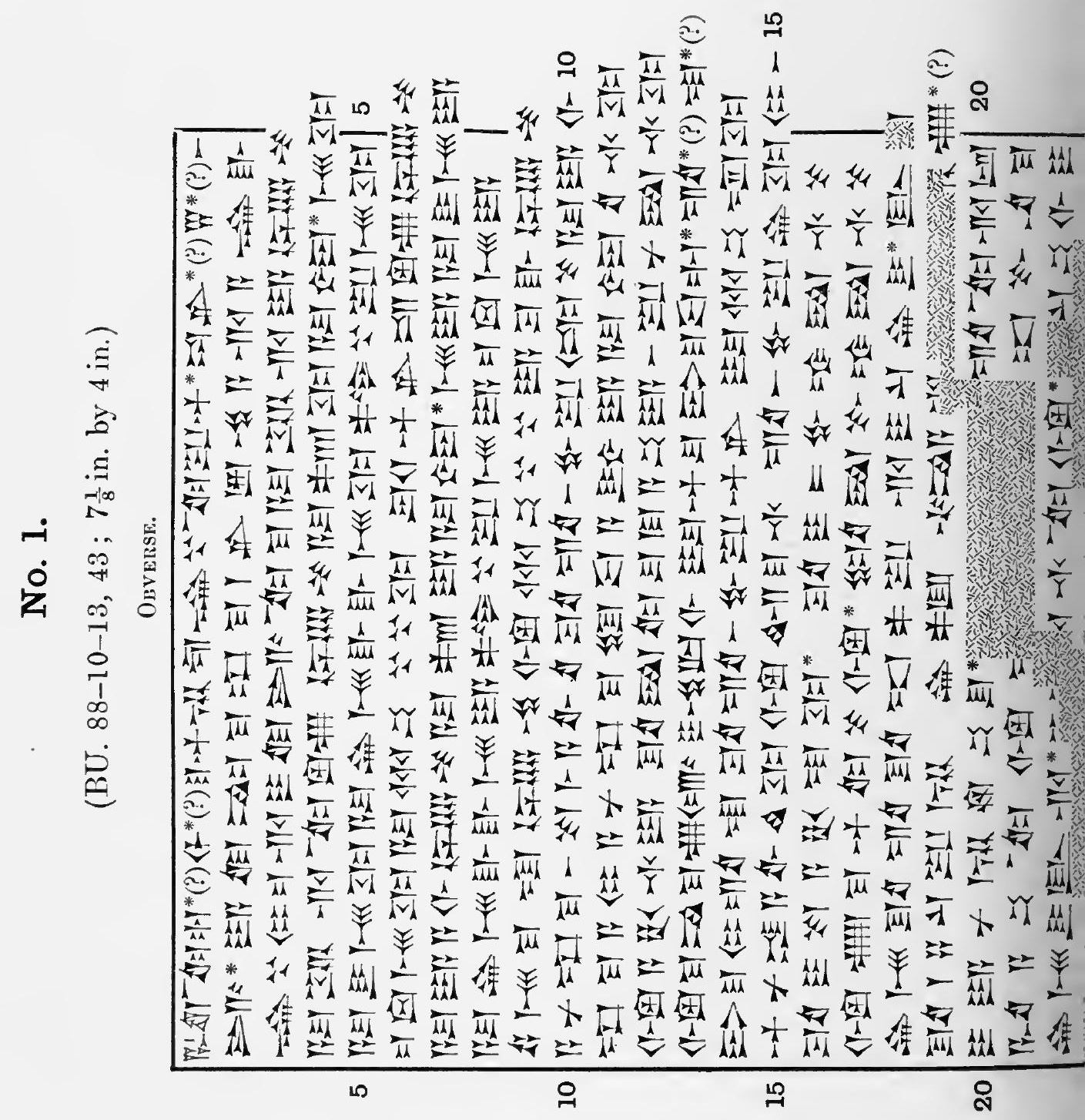




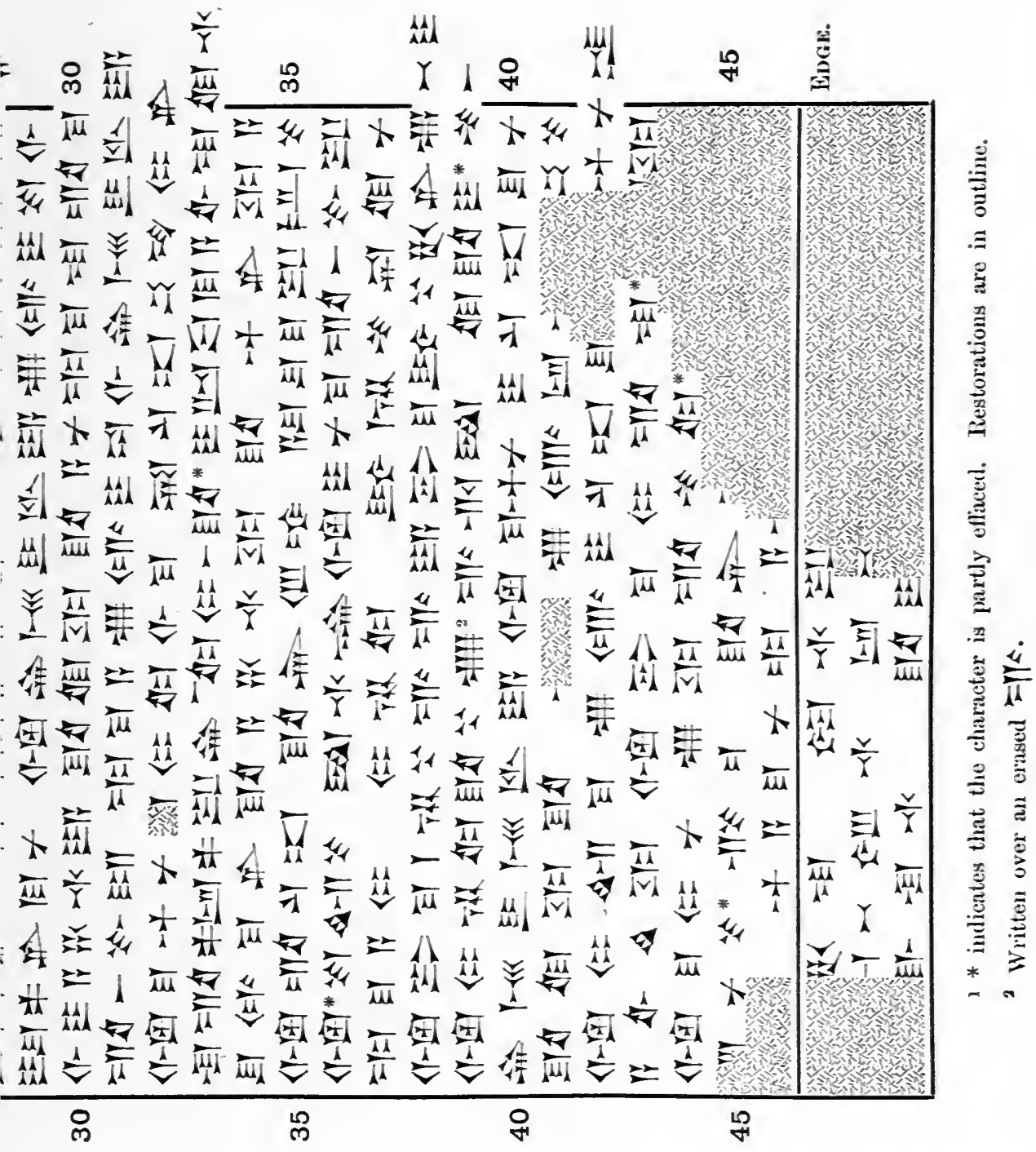



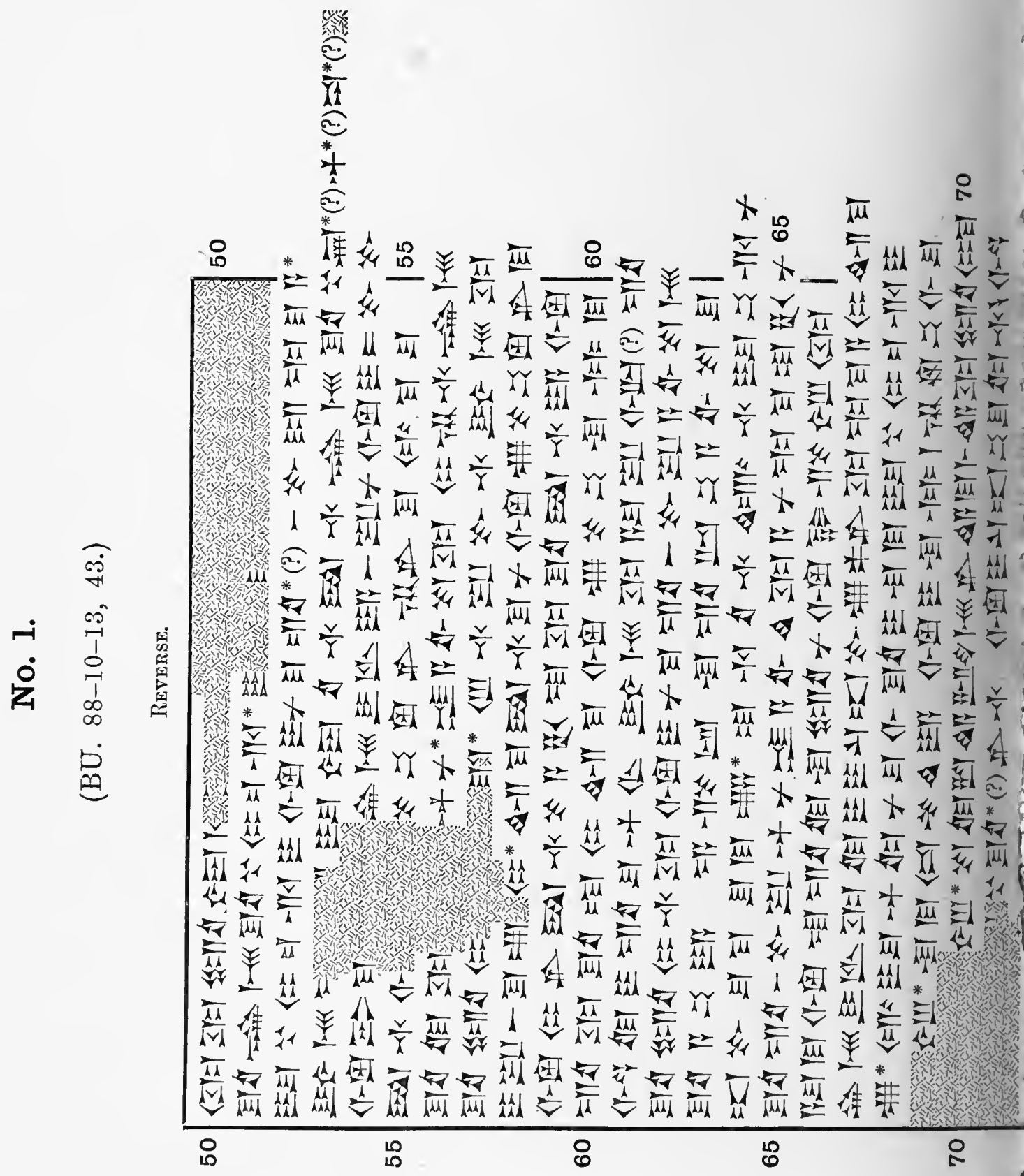
No. 2.

(BU. $88-10-13,81 ; 4 \frac{3}{8}$ in. by $2 \frac{3}{4}$ in.)

Obverse.

Y

〈I

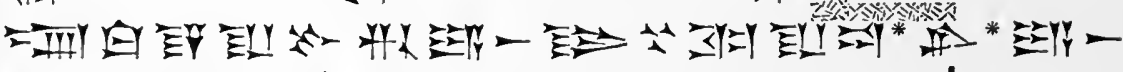

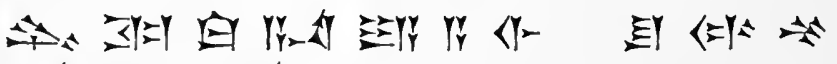

Y Y

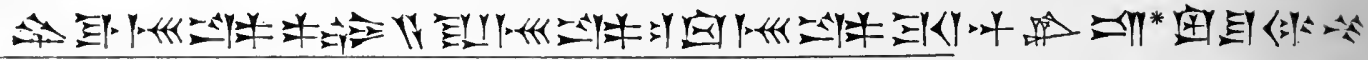

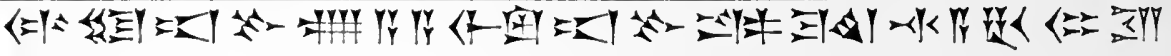

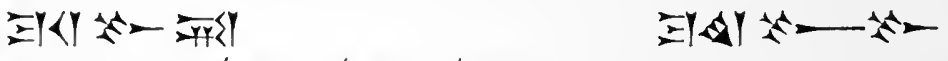

E

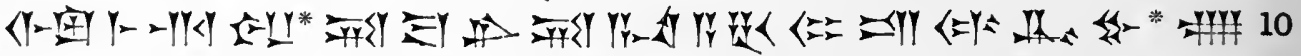

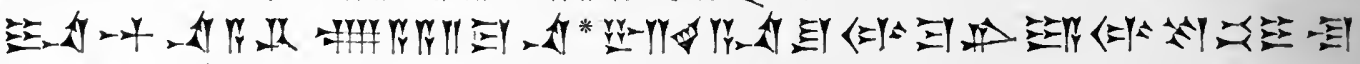

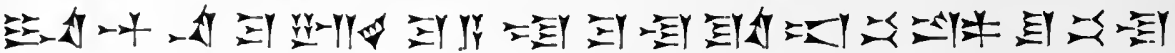

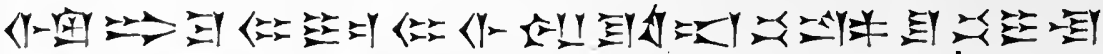

명

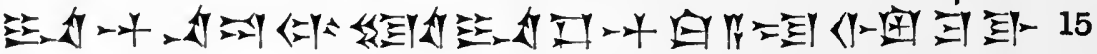

许

$\langle T$ -

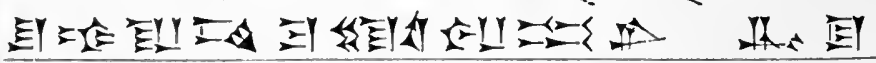

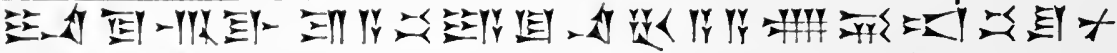

YY.

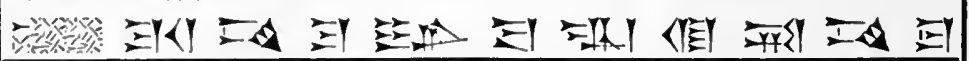

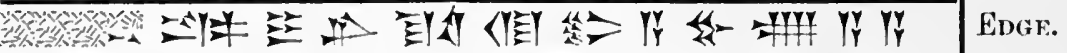

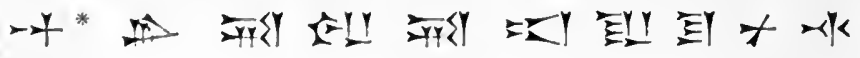

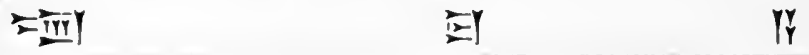


No. 2.

(BU. 88-10-13, 81; see plate 24.)

Reverse.

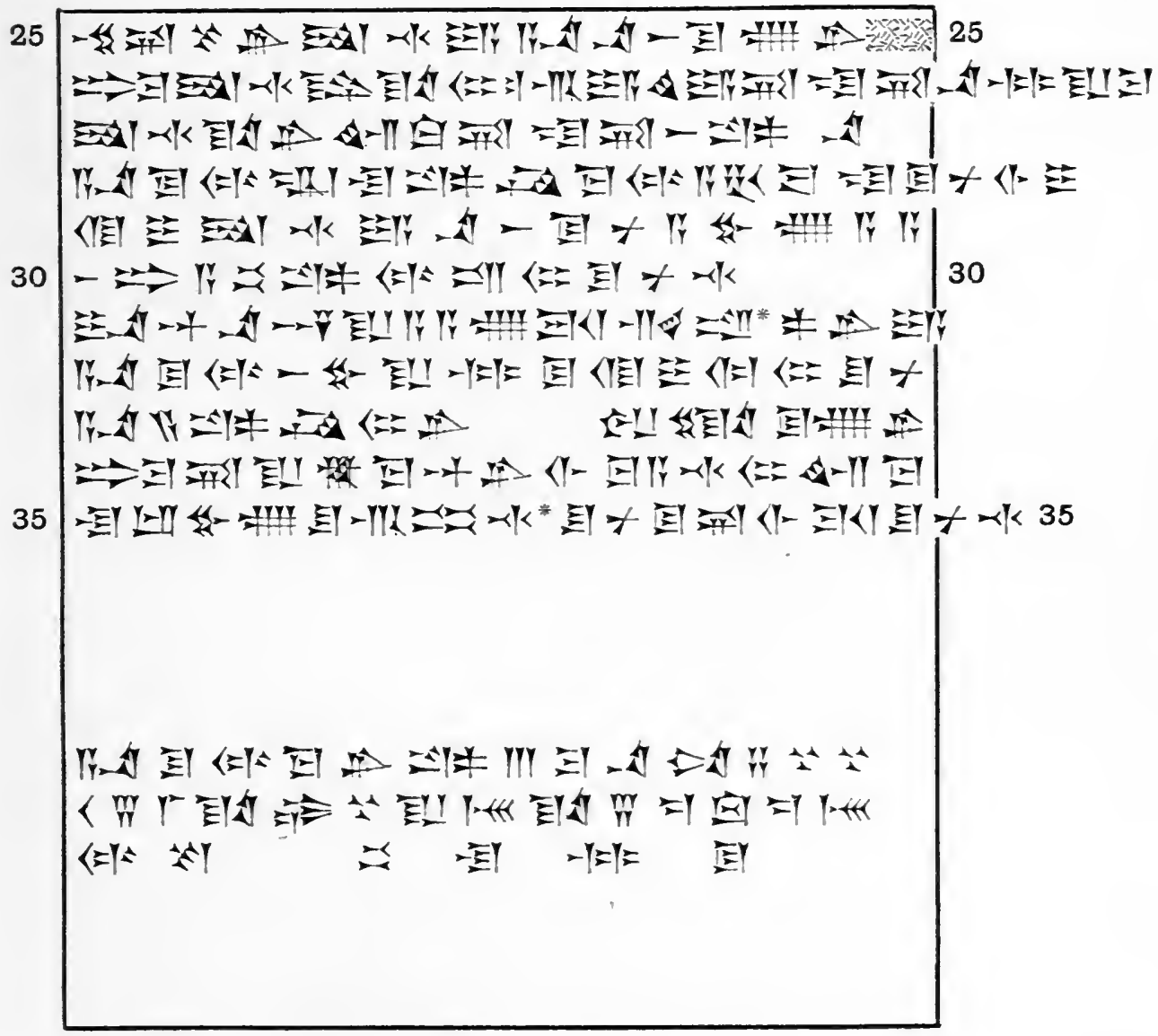


No. 3.

(BU. $88-10-13,46 ; 5 \frac{1}{8}$ in. by $2 \frac{3}{4}$ in.)

Obverse.

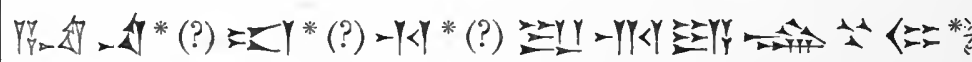

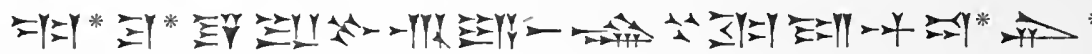

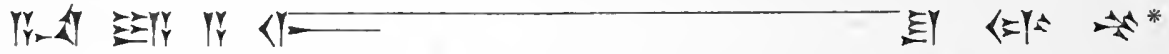

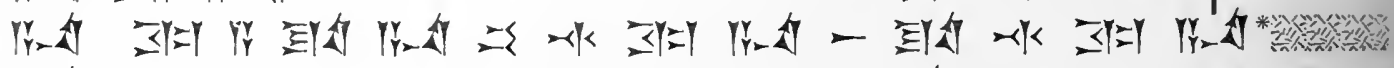

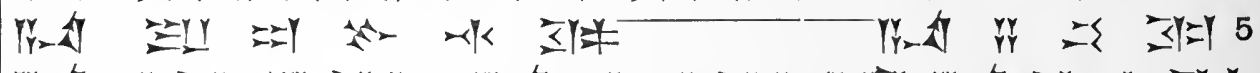

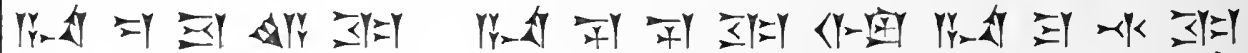

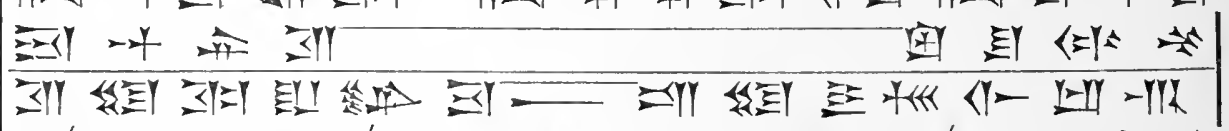

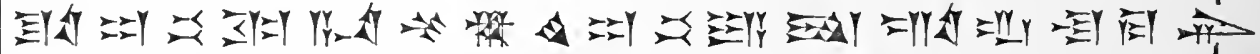

YY

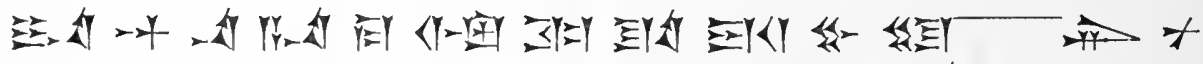

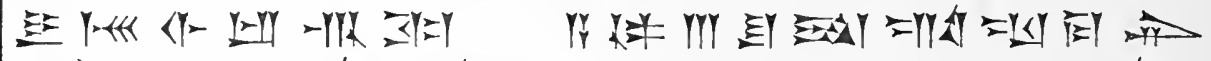

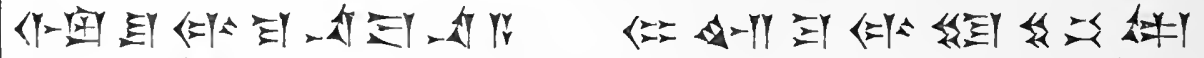

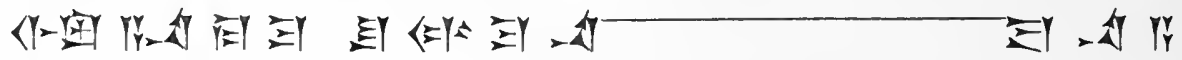

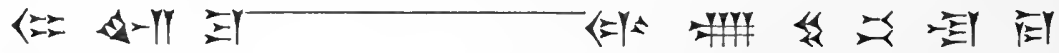

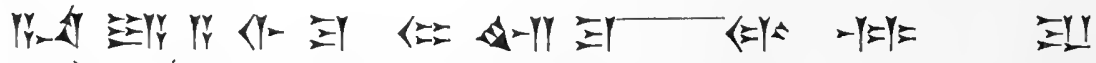

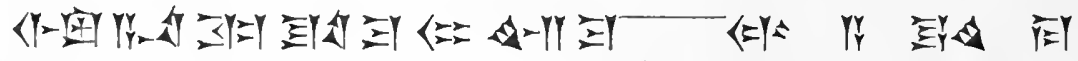

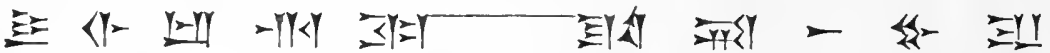

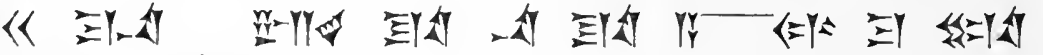

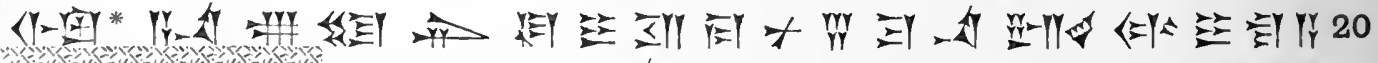

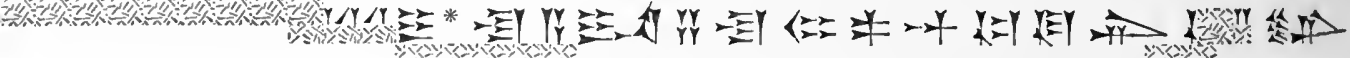

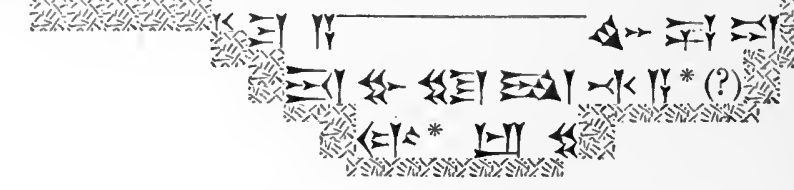


No. 3.

(BU. 88-10-13, 46; see plate 10.)

Reierse.

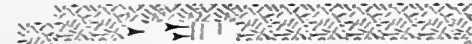

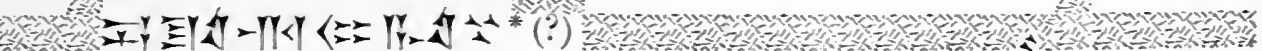

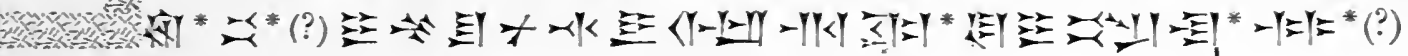

然角

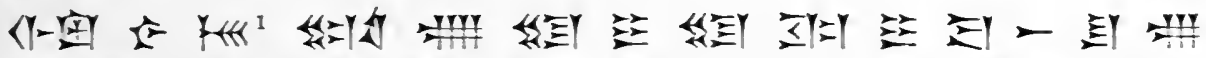

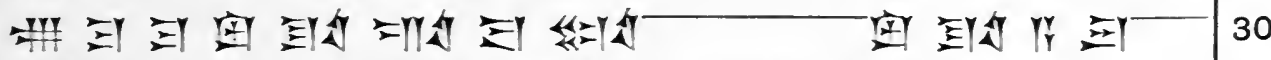

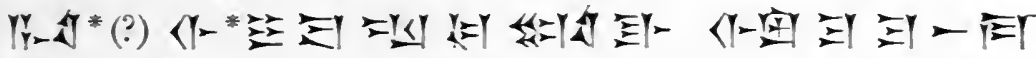

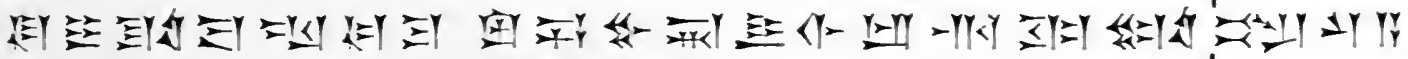

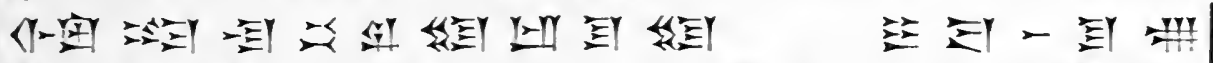

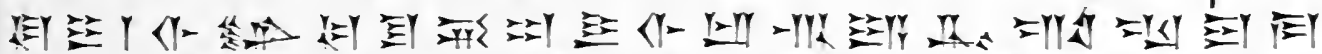

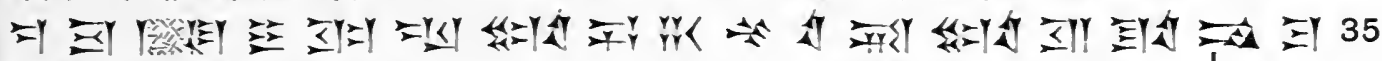

Y Y

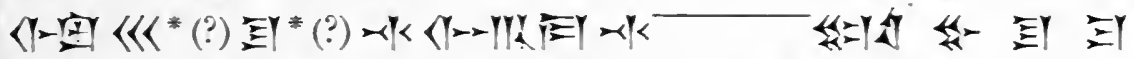

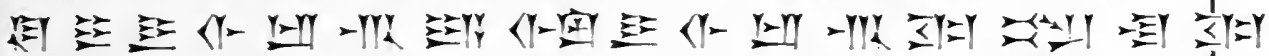

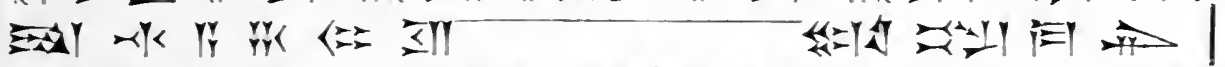

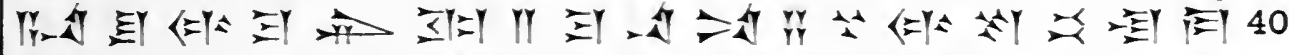

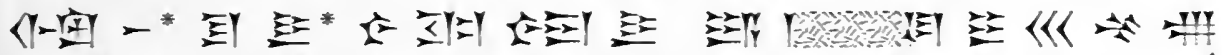

Y

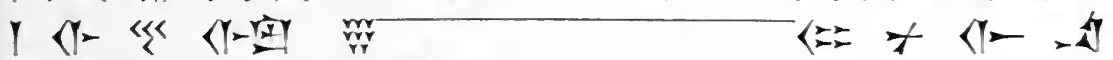

YY

$\langle Y-$ 不

然

1 Probably corrected from $\&$. 
No. 4.

(BU. $88-10-13,21 ; 6$ in. by $3 \frac{5}{8}$ in.)

Obverse:

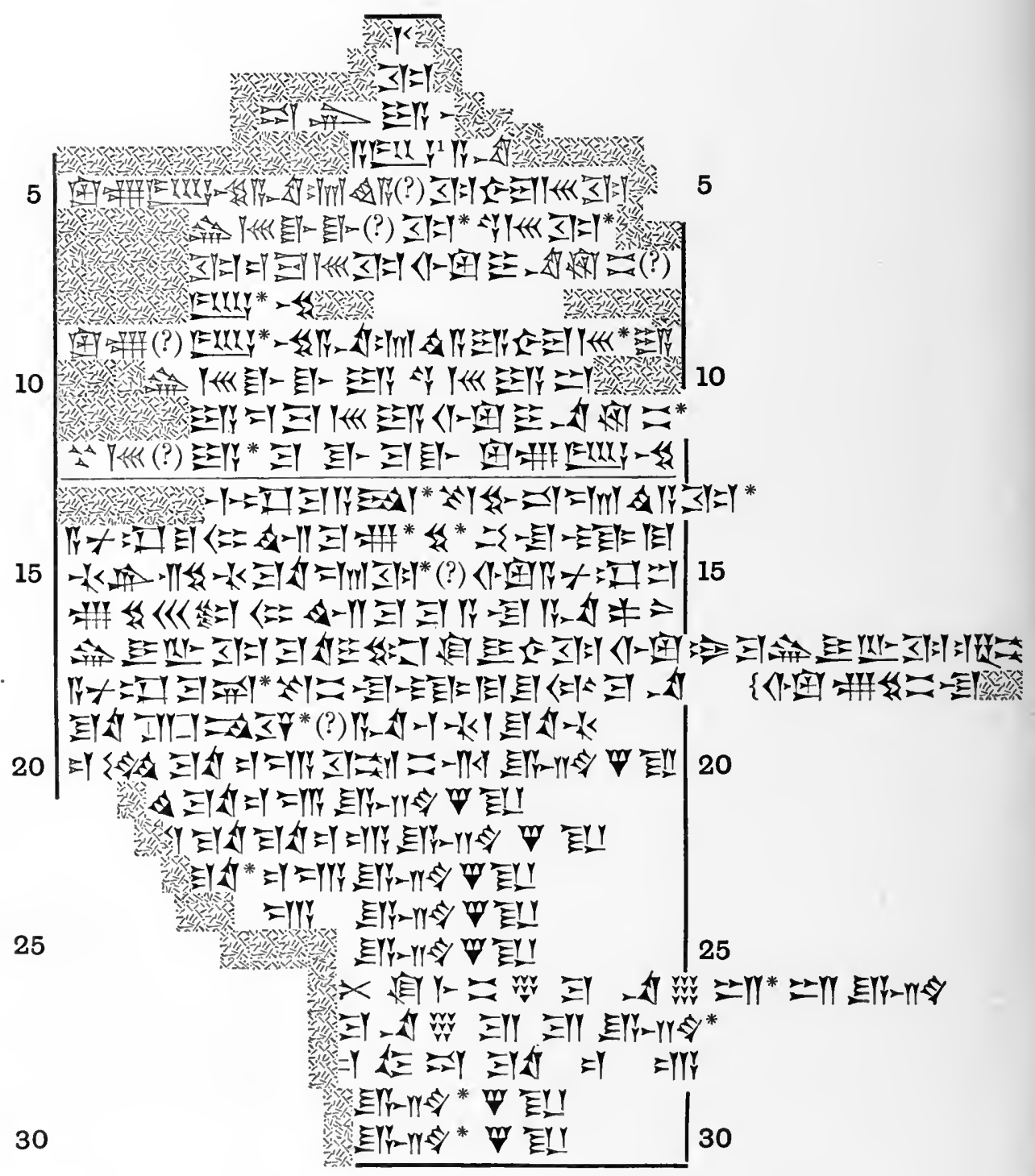

1 - 4 appears to be omitted 
No. 4.

(BU. 88-10-13, 21.)

RETEREE.

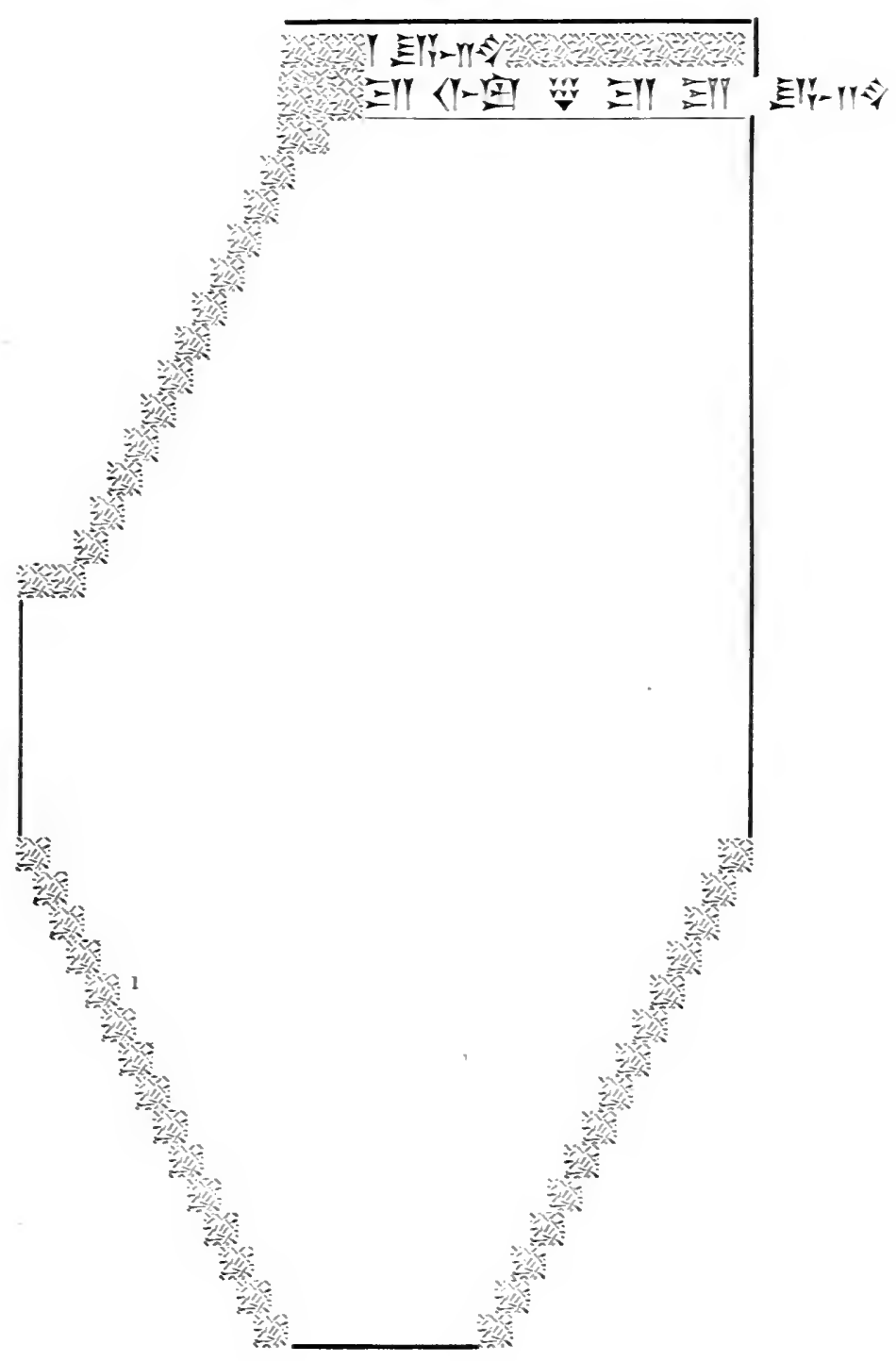

1 Here an impression of a scarab, inscribed with 


\section{No. 5.}

(BU. $88-10-13,37 ; 5 \frac{5}{8}$ in. by $3 \frac{3}{4}$ in.)

Obverse.

将出

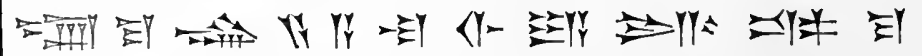
防出 荛

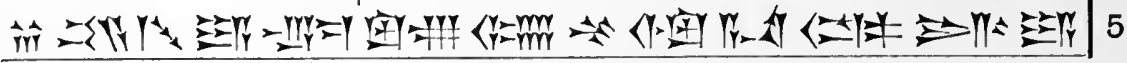

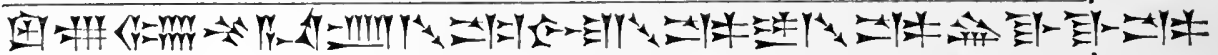

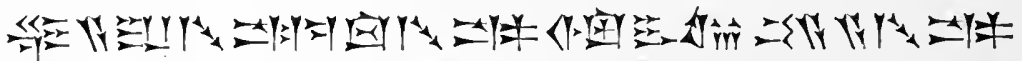
- M Y Y

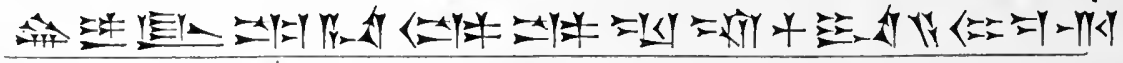
10 =YY Yr.

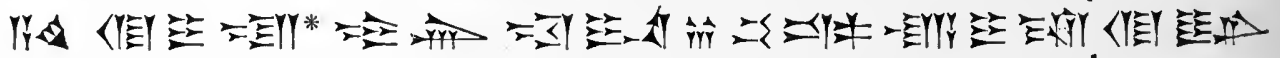

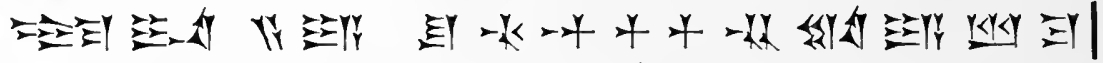

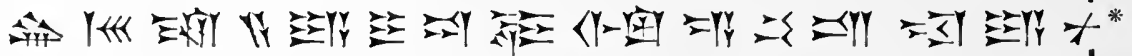

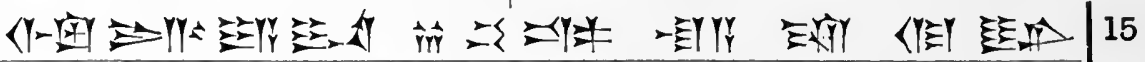
ล⿵人一

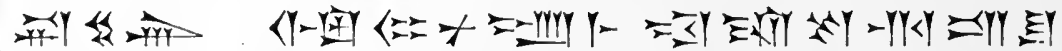
DME

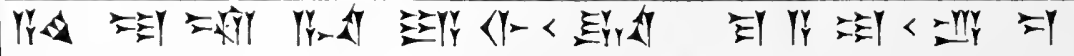

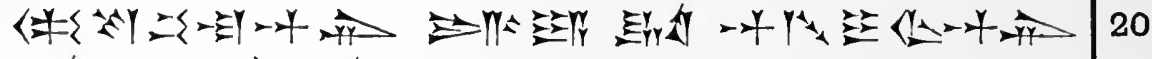
Yr-

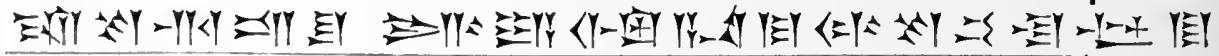

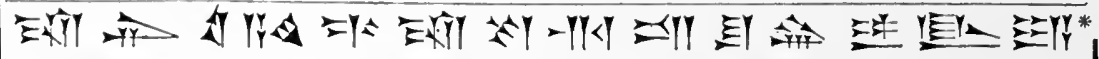

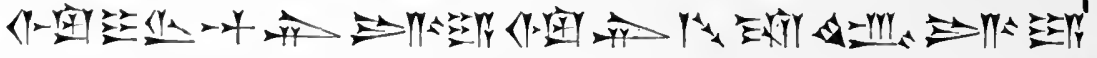

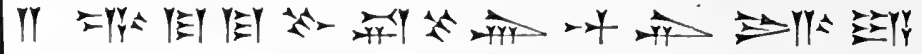

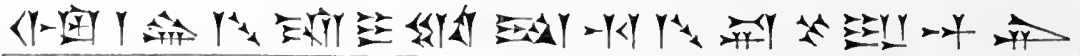

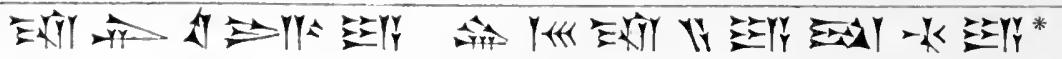
运

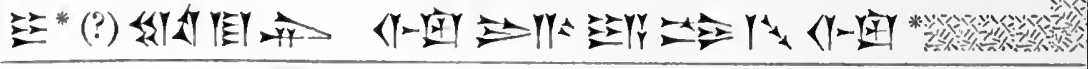


No. 5.

(BU. 88-10-13, 37 ; see plate 8.)

Reverse.

30

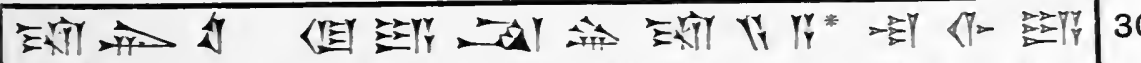

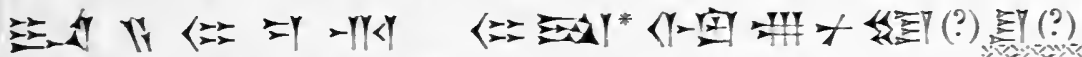

登-4

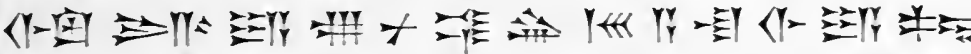

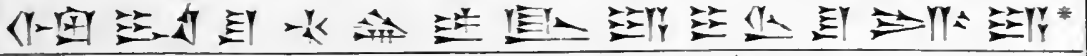

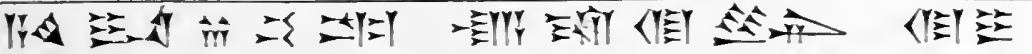

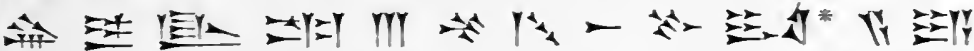

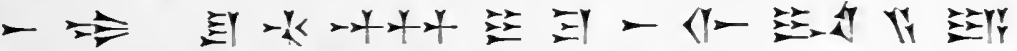

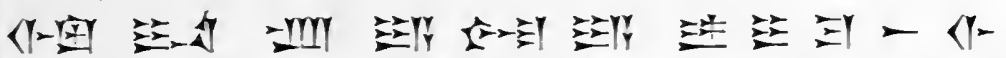

EN $r$ U

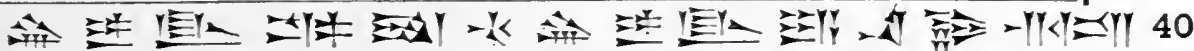

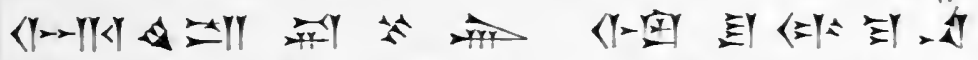

Exy Dri

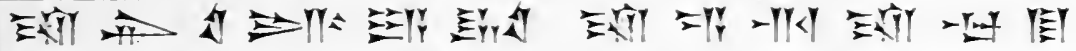

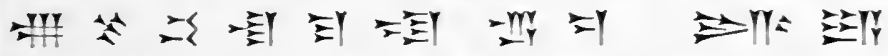

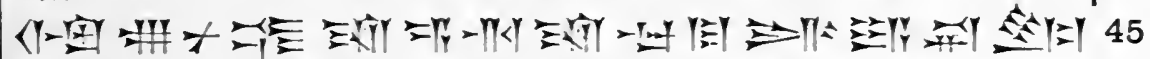

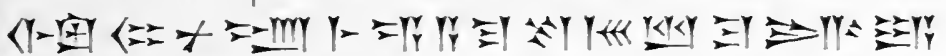

ral

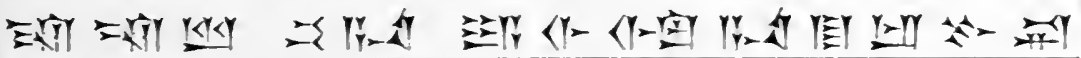

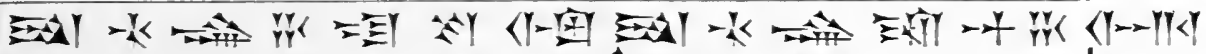

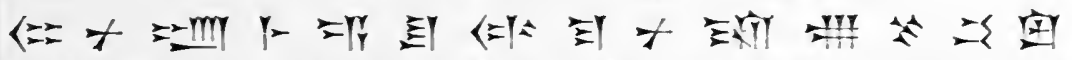

Yrô

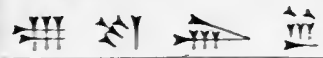

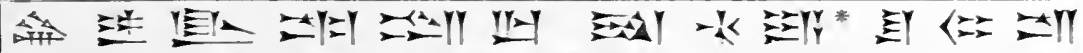

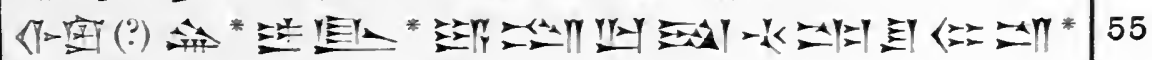




\section{No. 6.}

(BU. $88-10-13,38$; $5 \frac{3}{8}$ in. by 3 in.)

Obversl:.

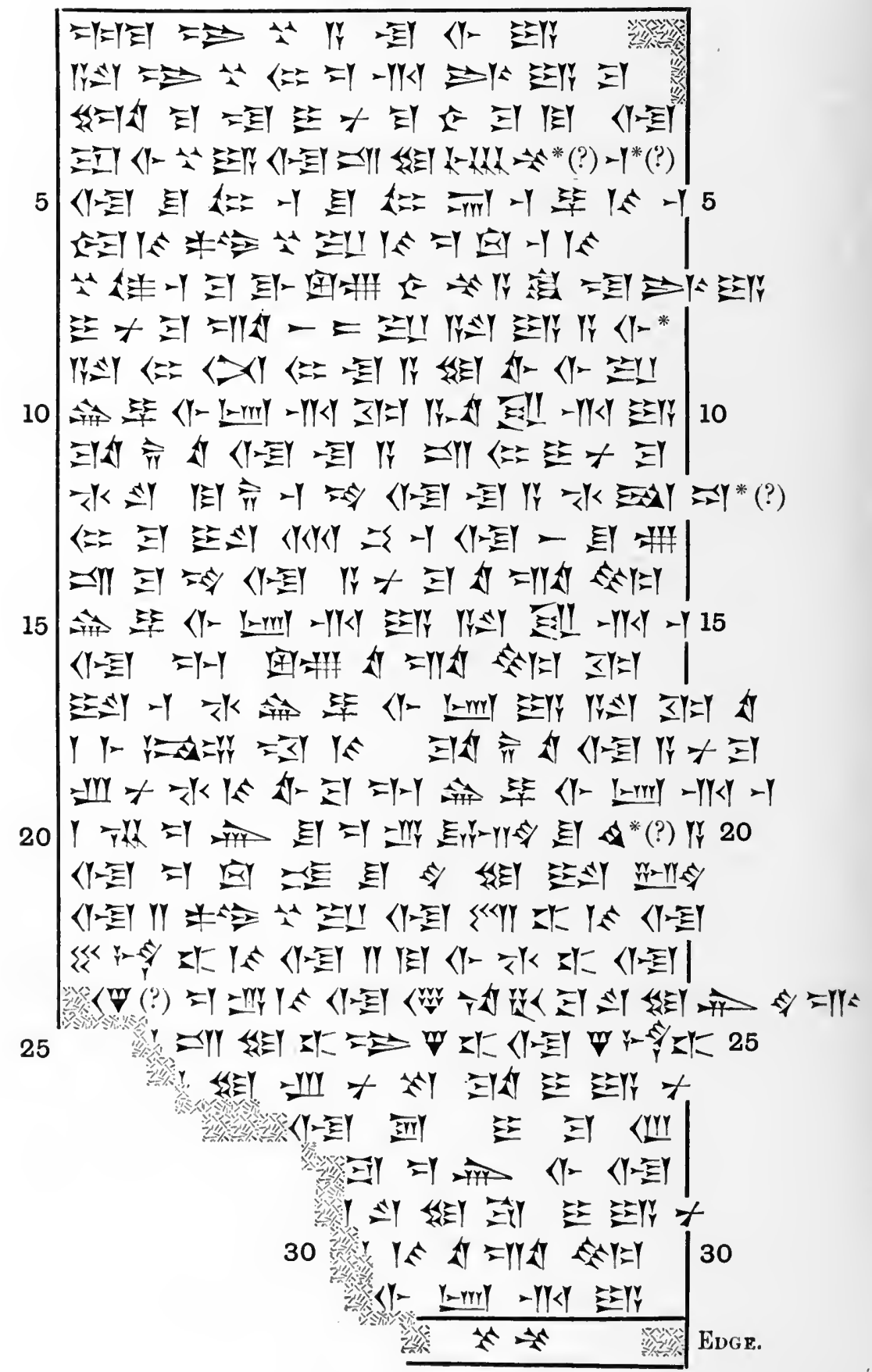


No. 6.

(BU. 88-10-13, 38.)

Reverse.

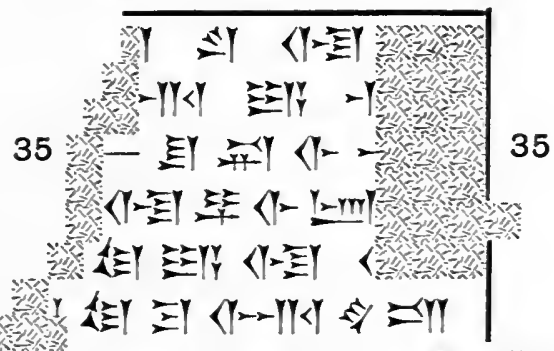

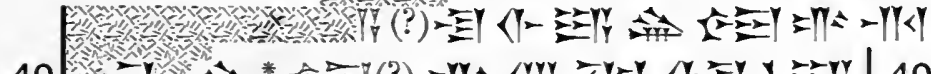

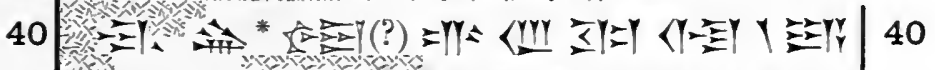

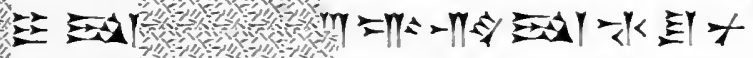

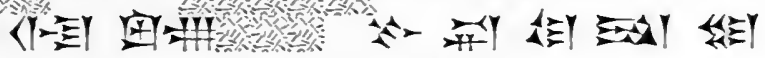

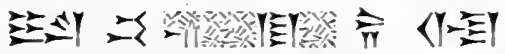

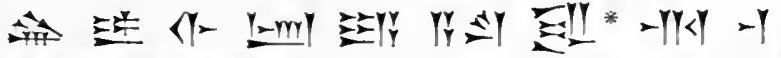

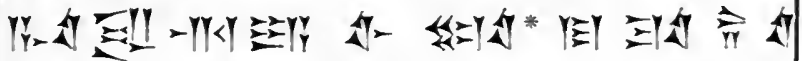

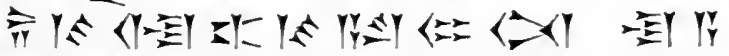

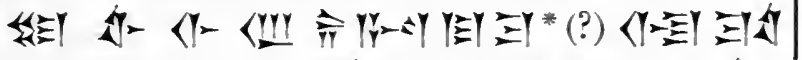

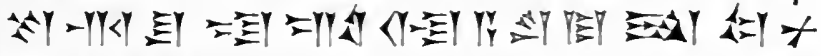

$$
\begin{aligned}
& 50 \text { (T-E) }
\end{aligned}
$$

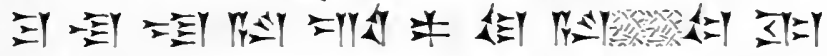

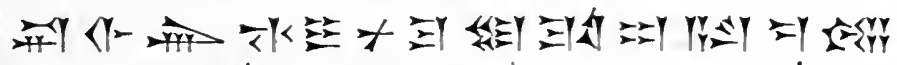

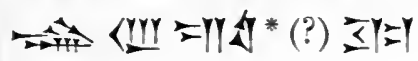


No. 7.

(BU. $88-10-13,48 ; 4$ in. by $2 \frac{3}{4}$ in.)

Obverse.

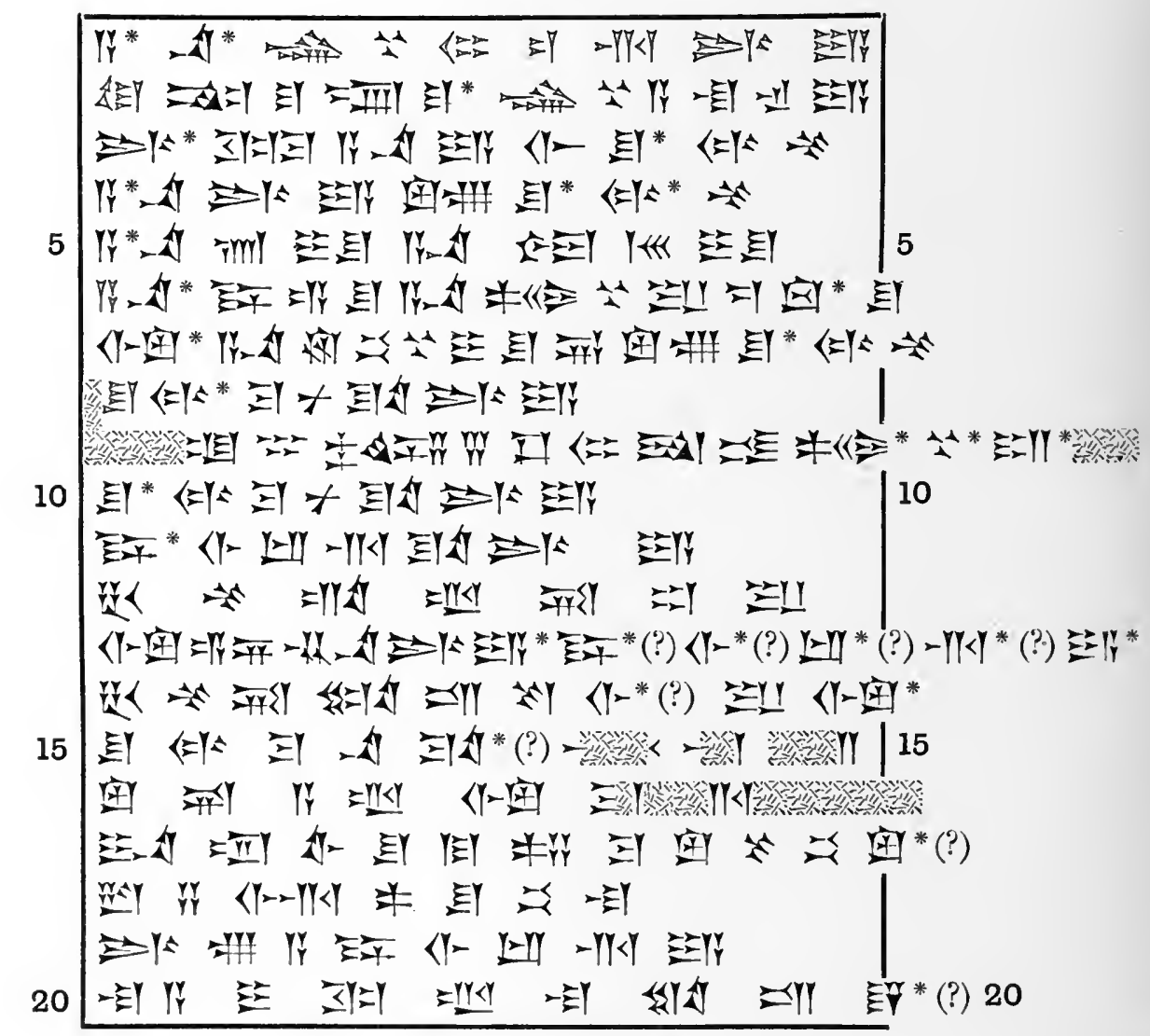


No. 7.

(BU. 88-10-13, 48.)

REVERSE.

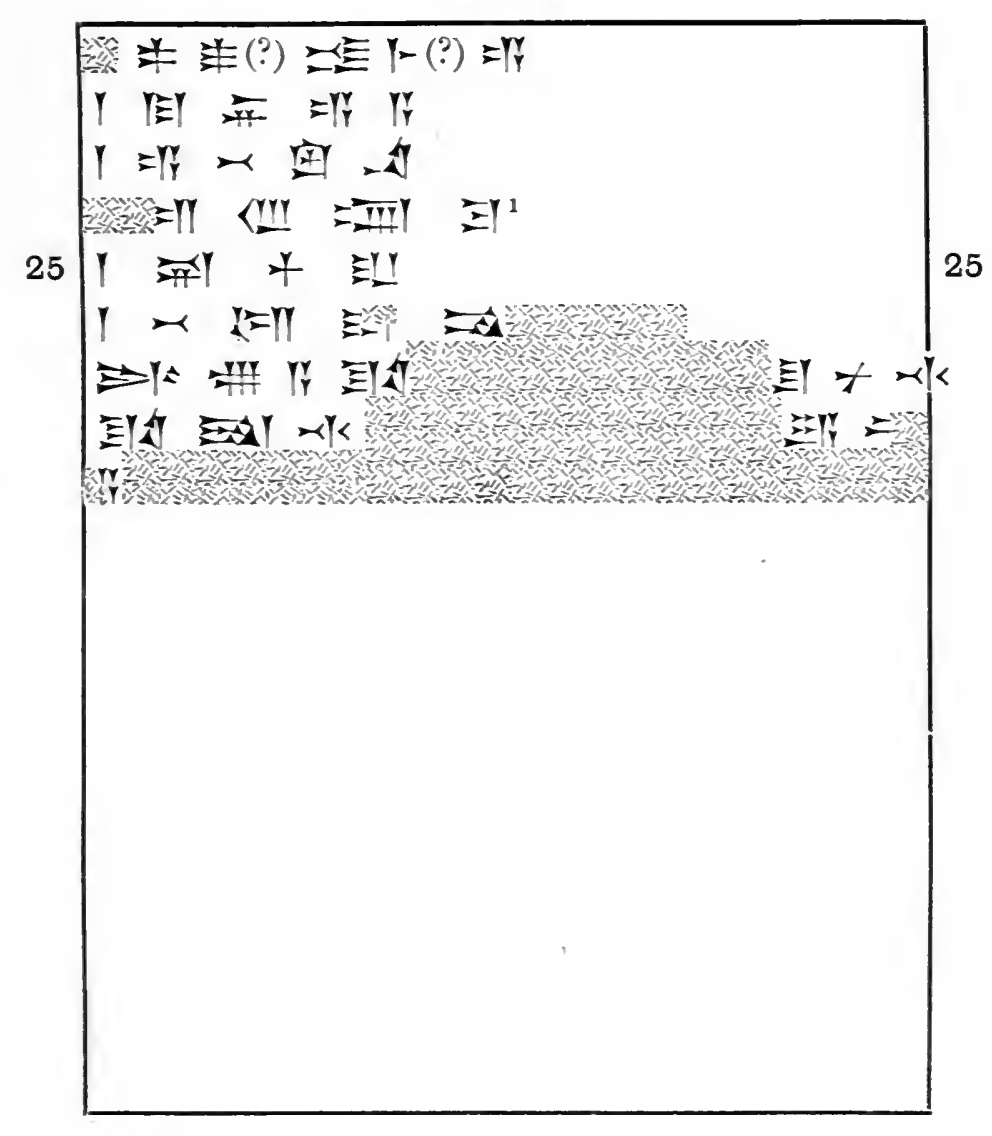

1 Lines $24 \mathrm{ff}$. are considerably defaced, and the transcript is dombtful. 


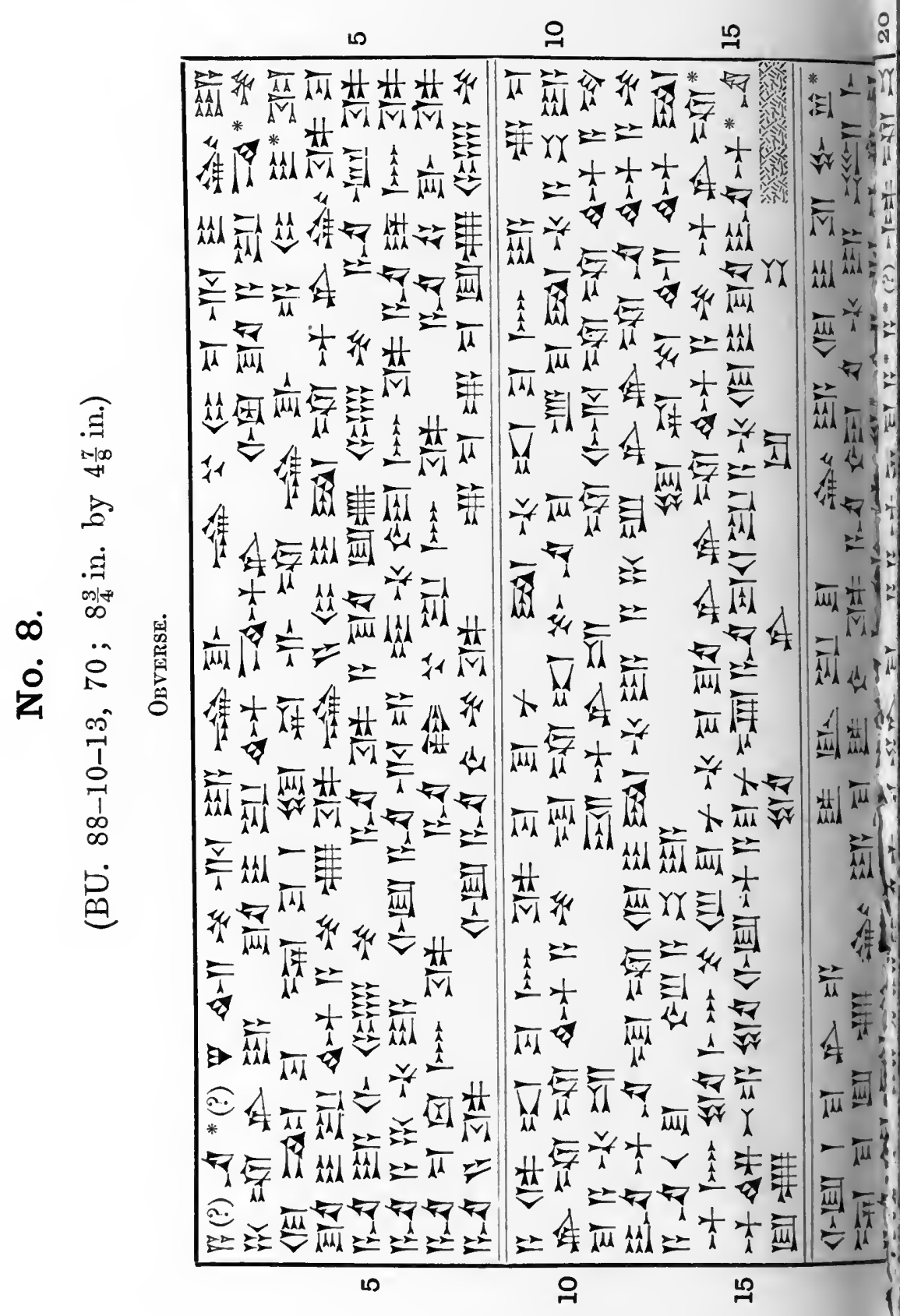




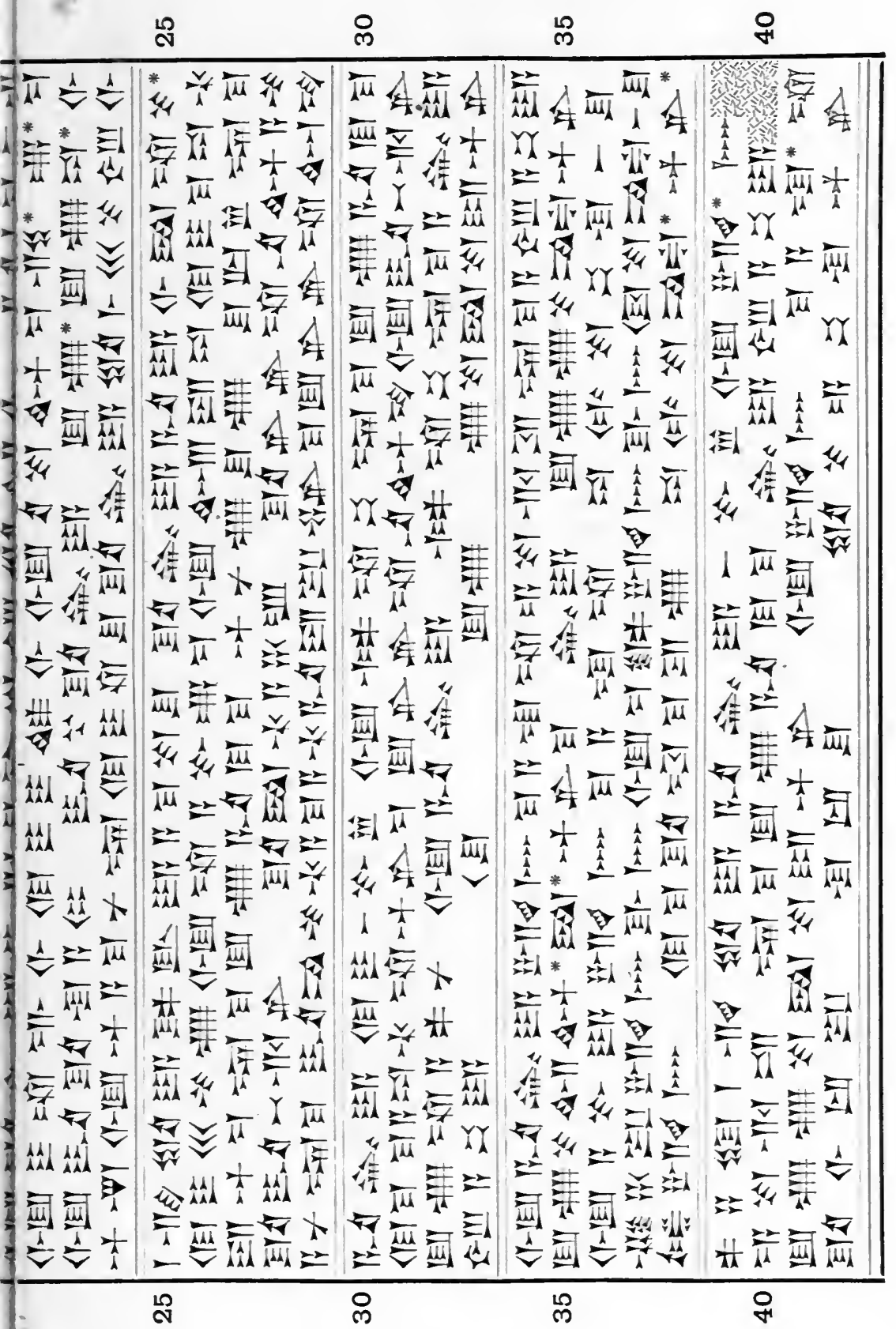




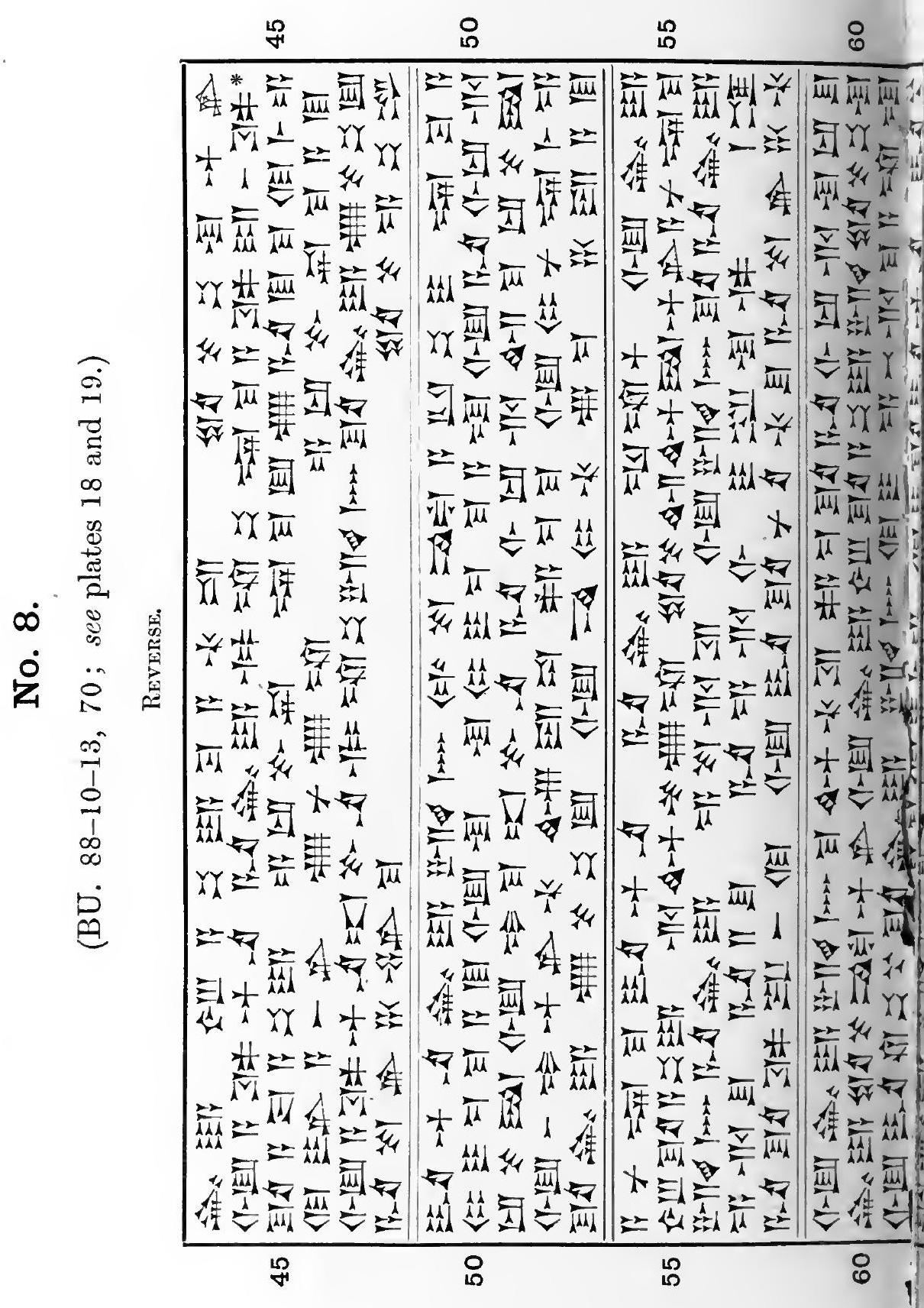




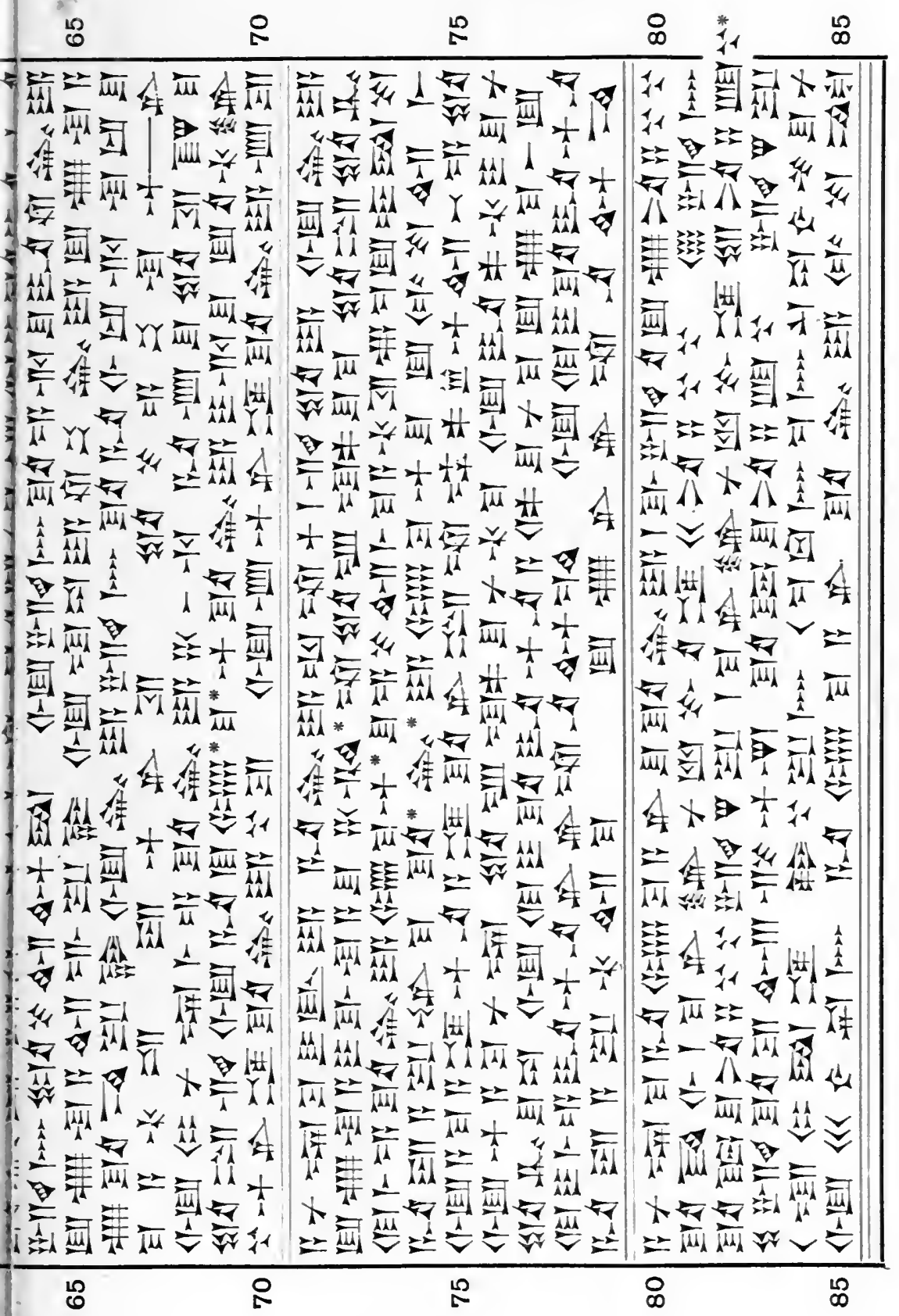




\section{No. 9.}

(B. $88-10-13,79 ; 4 \frac{7}{8}$ in. by $3 \frac{1}{8}$ in.)

\section{Obverse.}

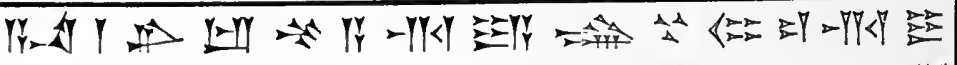

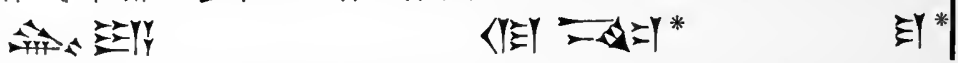

EYYY EY U स ती

5 Yr-4 YY YYK 次 YY.

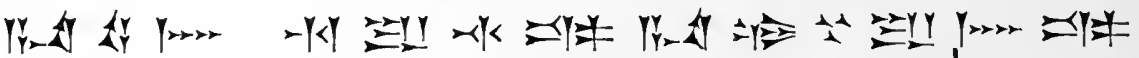

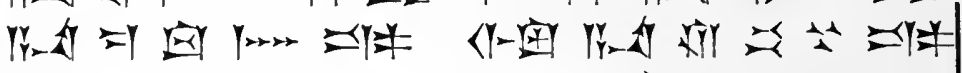

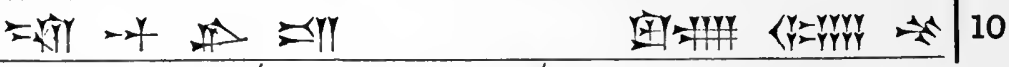

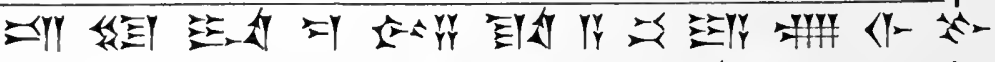
$\langle T$ -E⿵ =

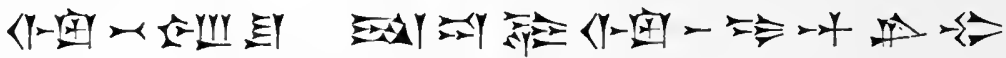
登Y

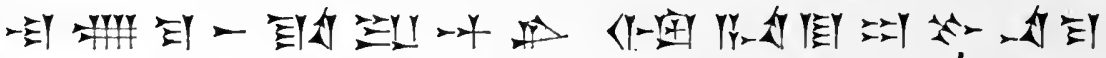

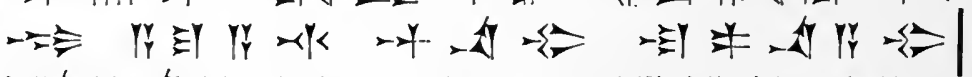

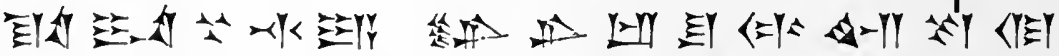

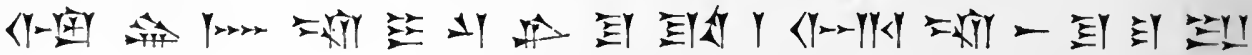
세 यह|

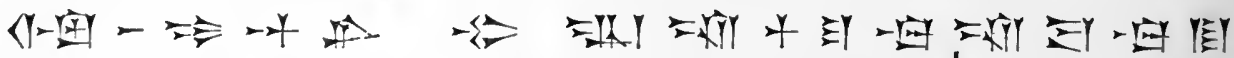

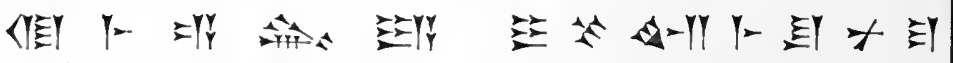

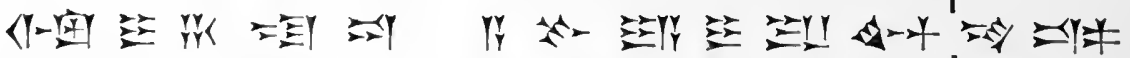

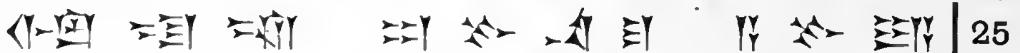

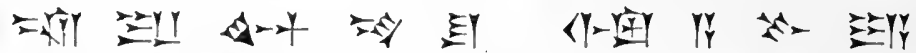

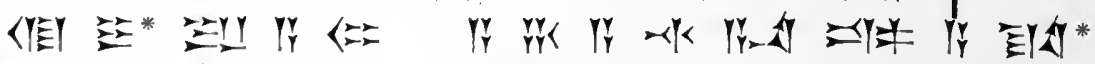

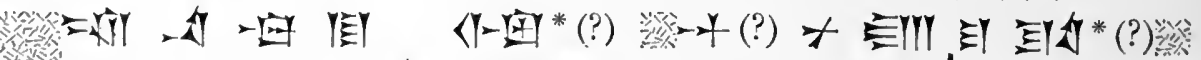

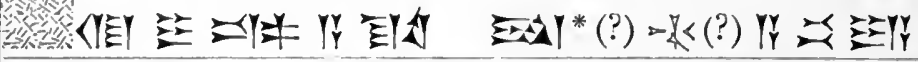

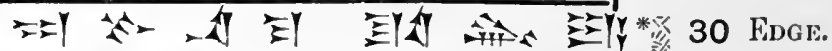

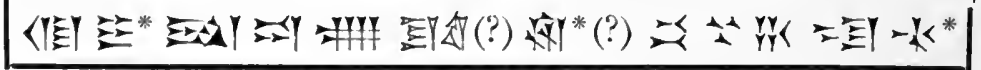


No. 9.

(BU. 88-10-13, 79.)

REVERSE.

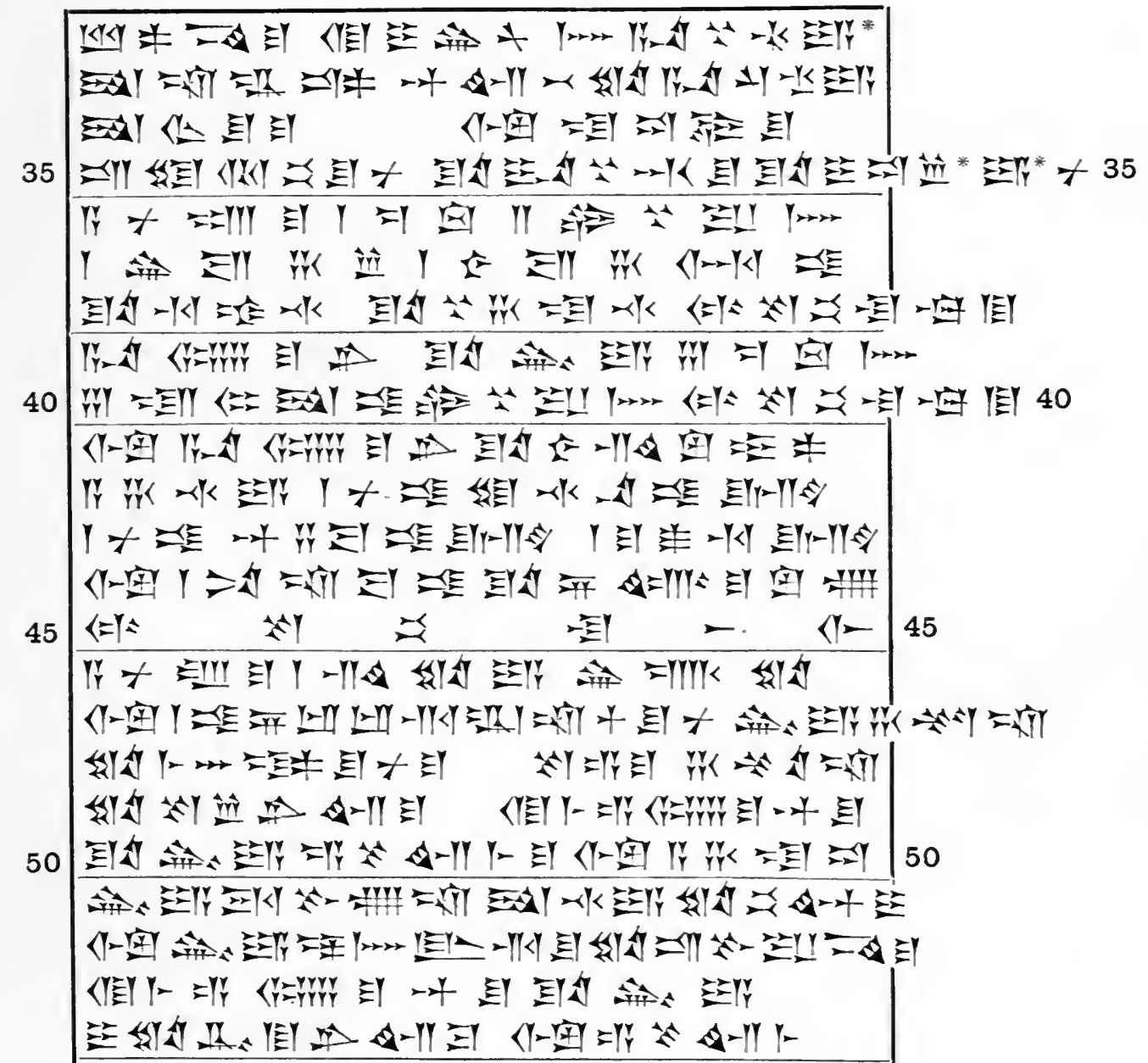




\section{No. 10.}

(BU. $88-10-13,78 ; 3 \frac{7}{16}$ in. by $2 \frac{13}{16}$ in.)

Obverse.

$Y_{Y}^{*}$ -

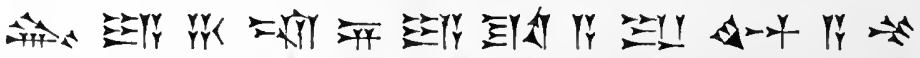

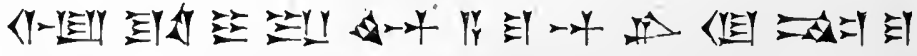

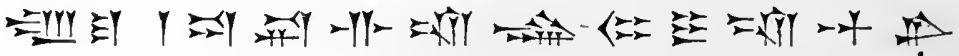

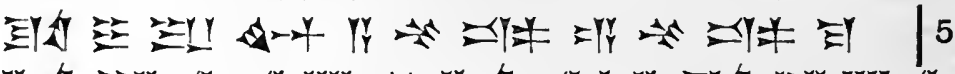

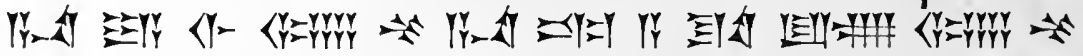
Yro

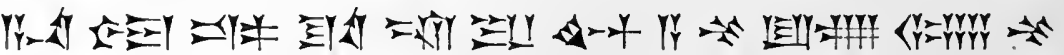

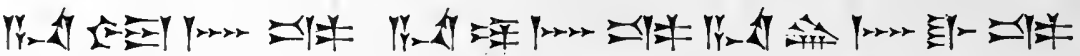

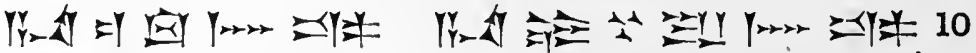

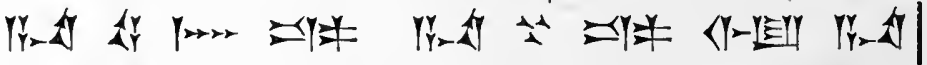

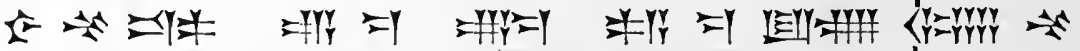

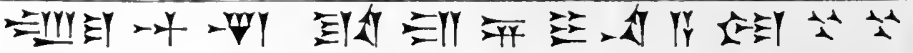

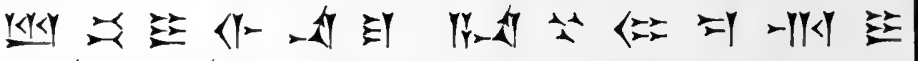
IEY

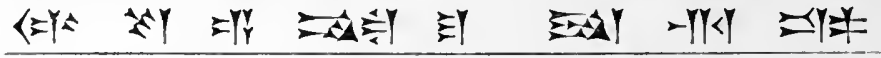

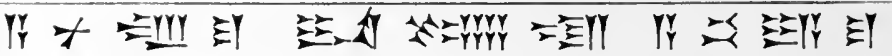

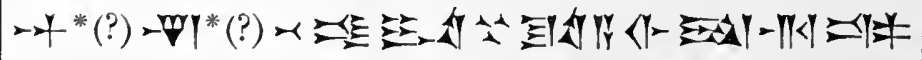

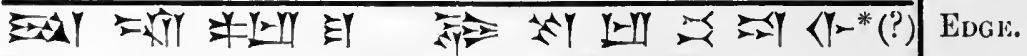


No. 10.

(BU. 88-10-13, 78 ; see plate 23.)

REVERSE.

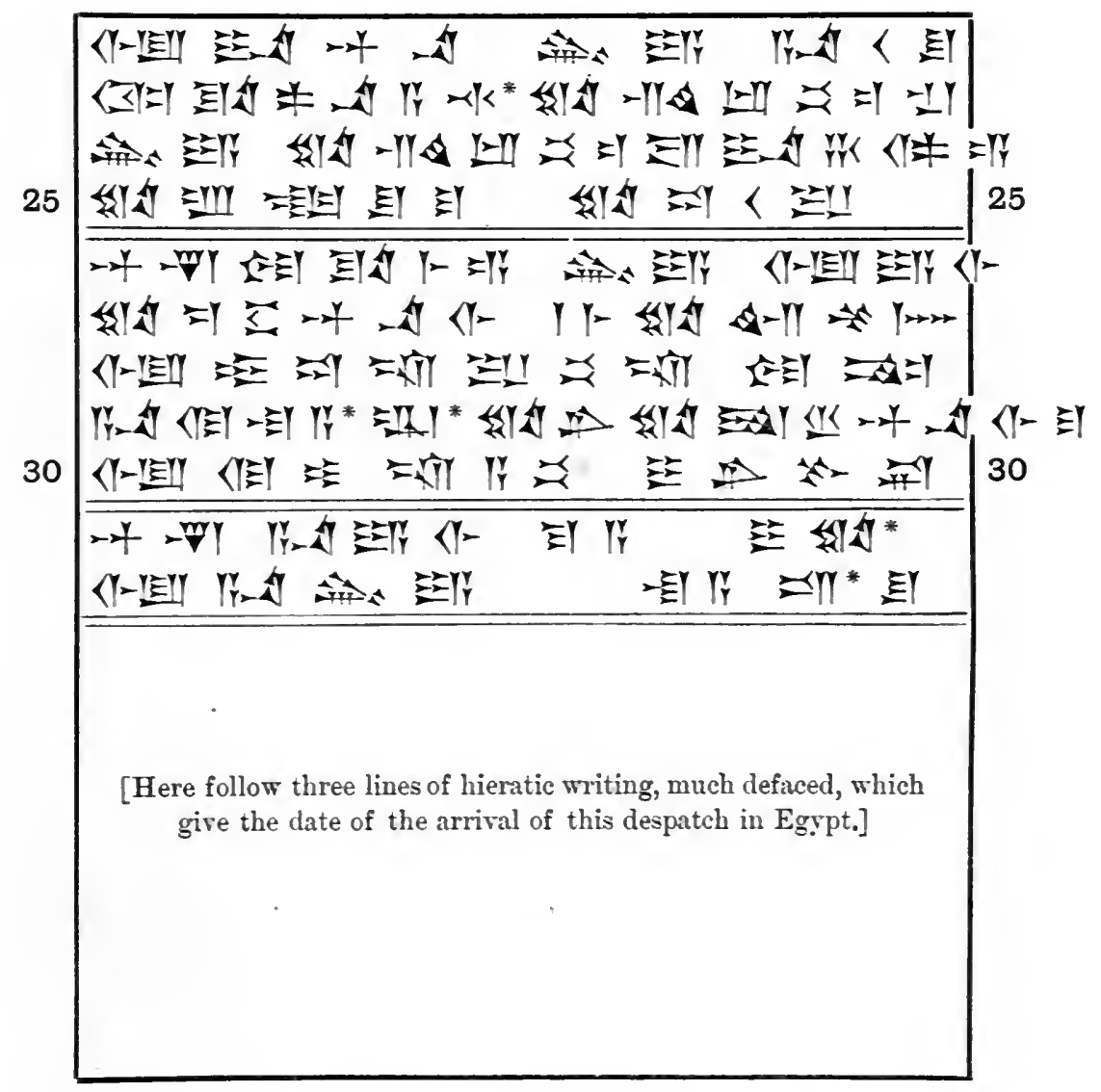




\section{No. 11. \\ (BU. $88-10-13,39 ; 5 \frac{1}{2}$ in. by $3 \frac{3}{4}$ in.)}

Obverse.

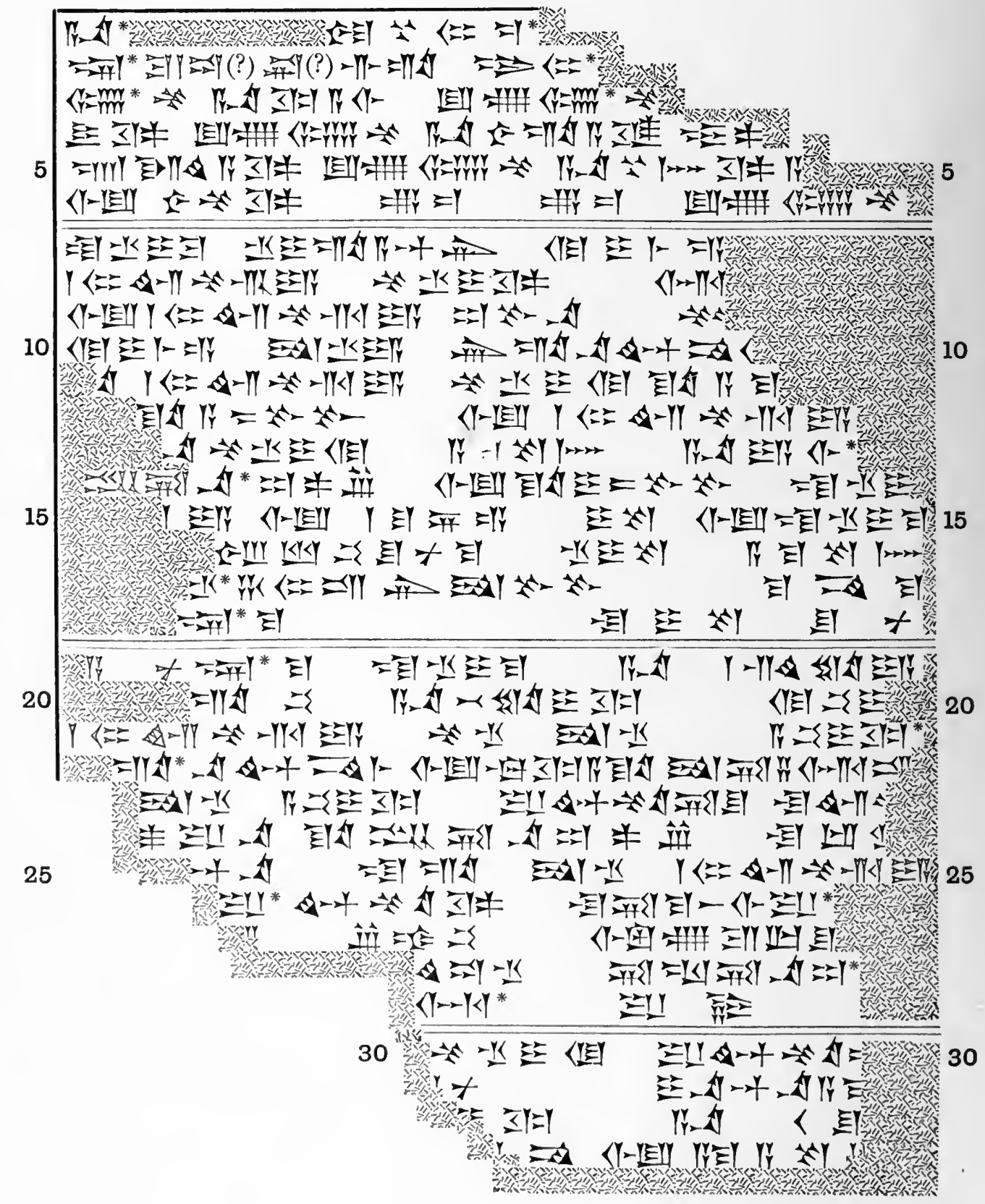




\section{No. 11.}

(BU. 88-10-13, 39; see plate 9.)

REVERSE.

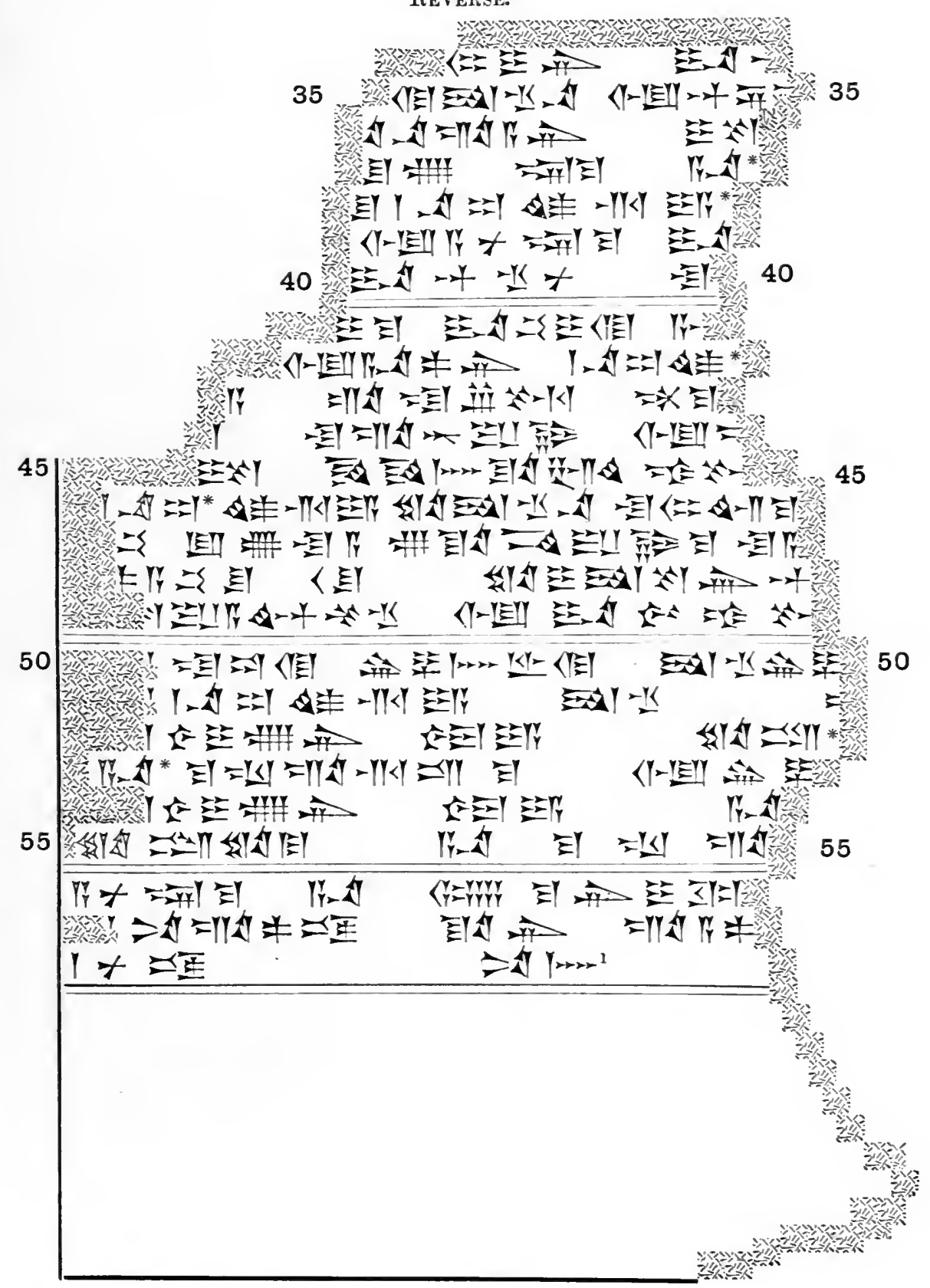

1 On the lower part of the Reverse are two lines of hieratic writing, much defaced, and on the left-hand edge a few hieratic characters are also visible. 
No. 12.

(BU. $88-10-13,72 ; 3 \frac{1}{1} \frac{1}{1}$ in. by $3 \frac{3}{16}$ in.)

ำ

Obverse.

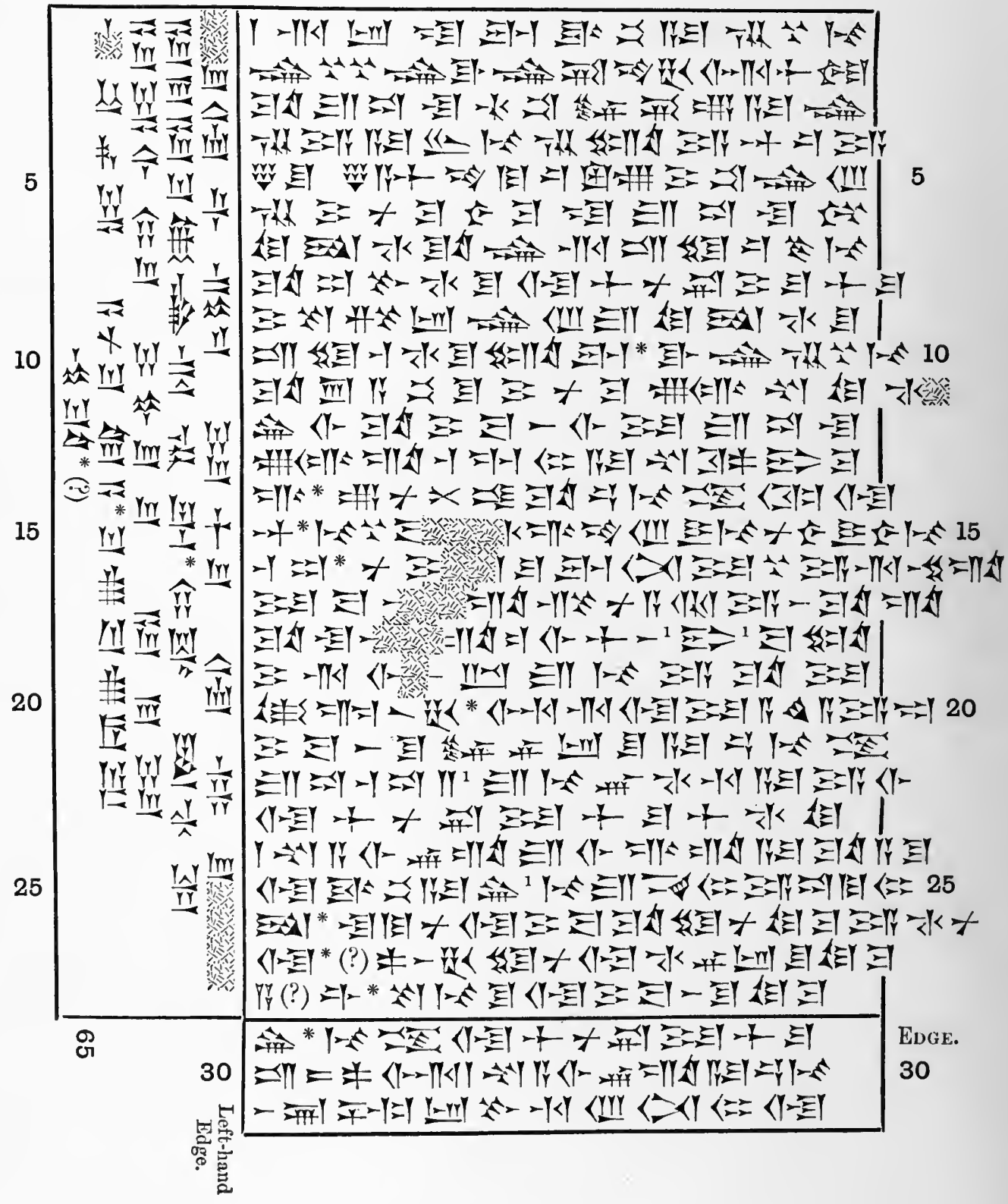

1 Written over an erasure. 
No. 12.

(BU. 88-10-13, 72; see plate 20.)

Peterse.

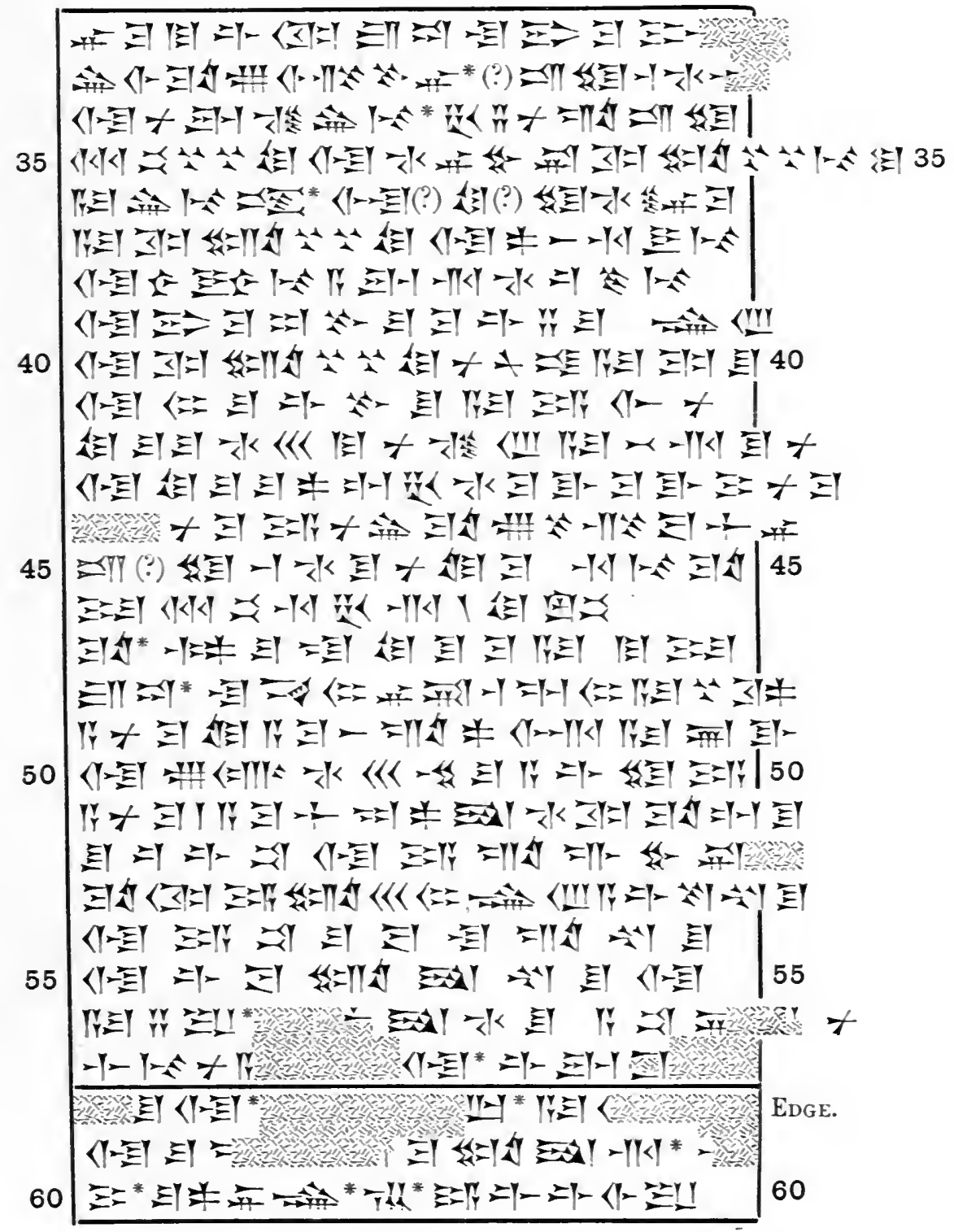




\section{No. 13.}

(BU. $88-10-13,53 ; 4 \frac{5}{8}$ in. by $3 \mathrm{in}$.)

Obverse.

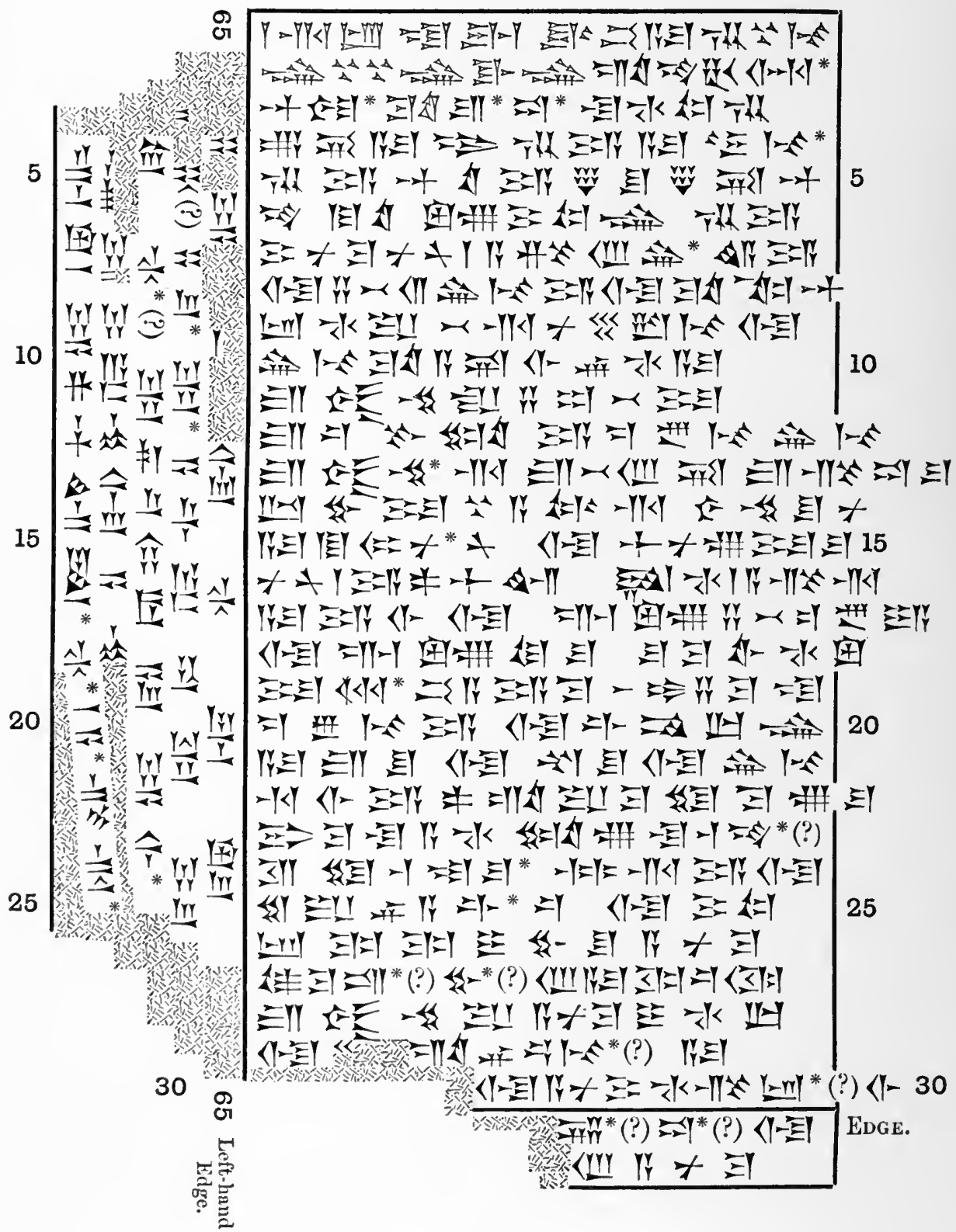


No. 13.

(BU. $88-10-13,53$.

Reverse.

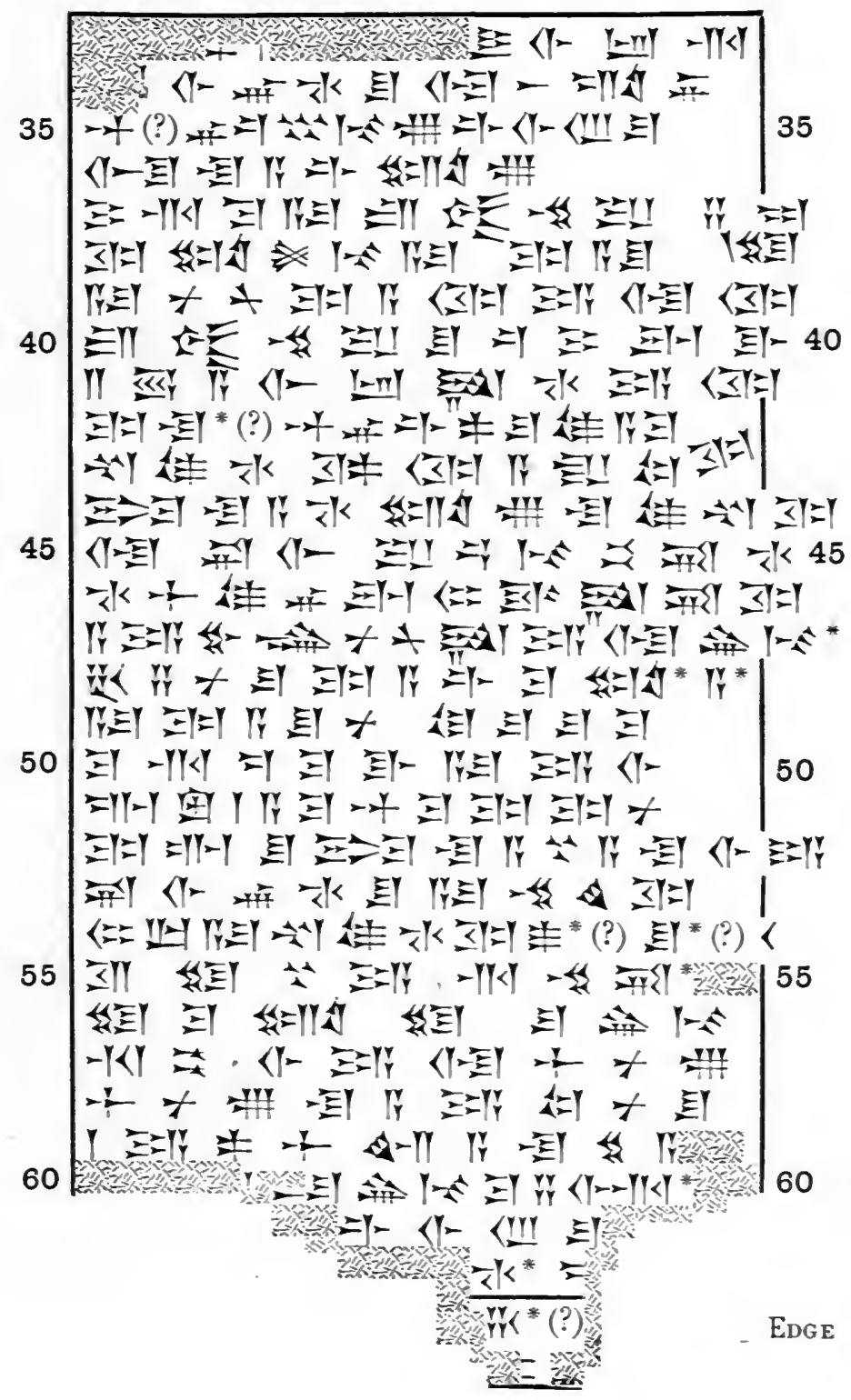




\section{No. 14.}

(BU. $88-10-13,58 ; 3 \frac{3}{4}$ in. by $2 \frac{3}{4}$ in.)

Obverse.

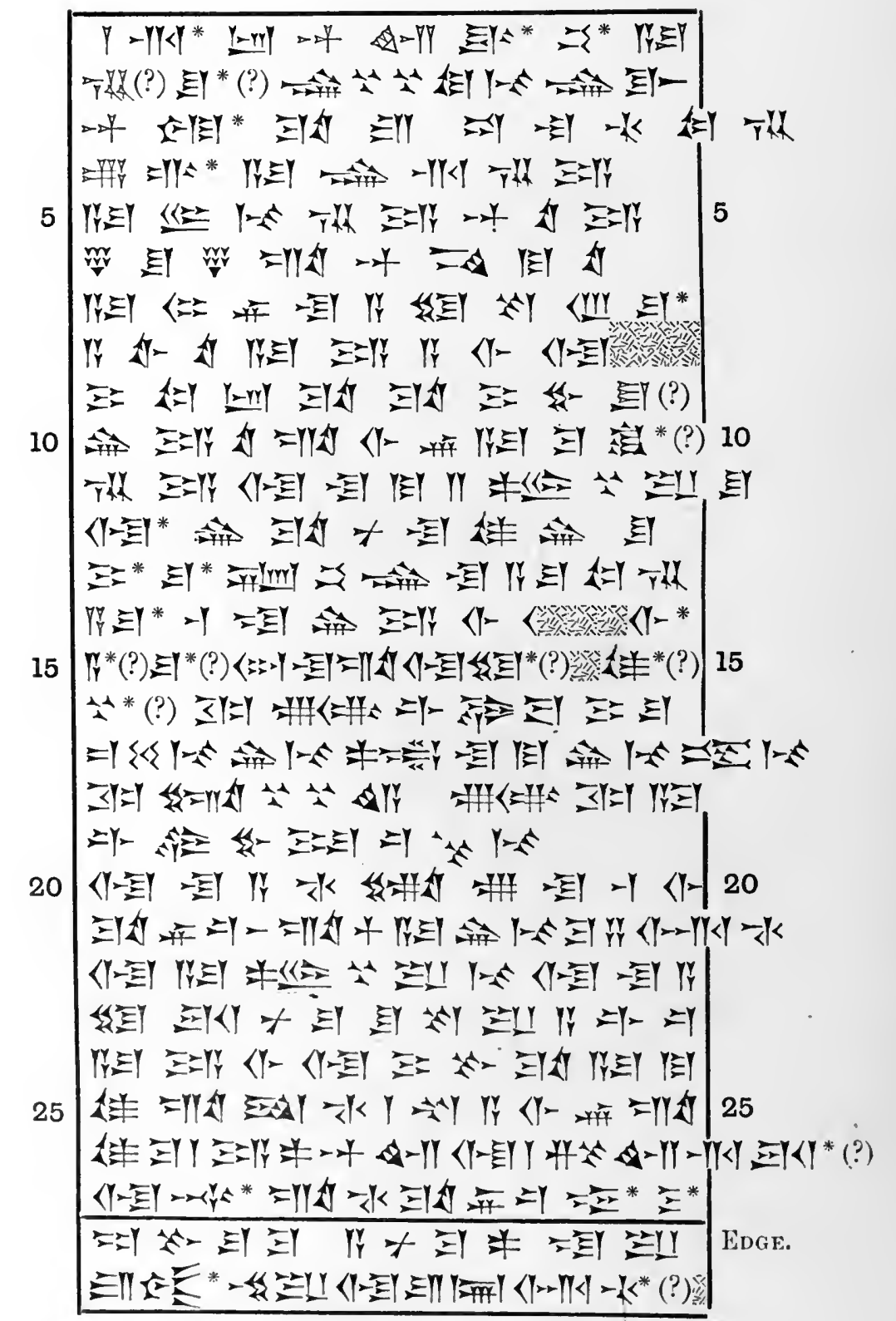




\section{No. 14.}

(BU. 88-10-13, 58; see plate 13.)

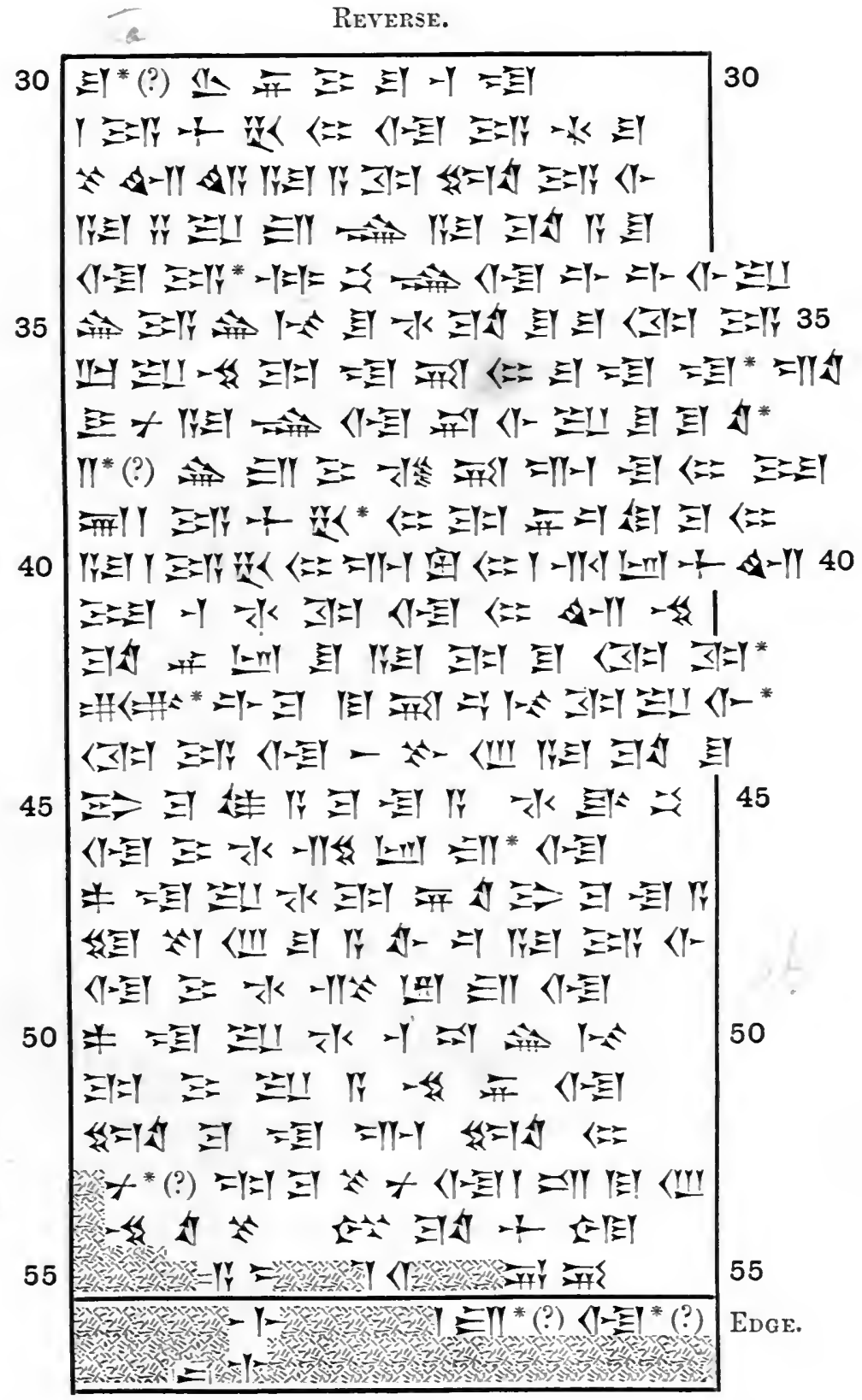


No. 15.

(BU. $88-10-13,77 ; 2 \frac{3}{4}$ in. by $2 \frac{3}{8}$ in.)

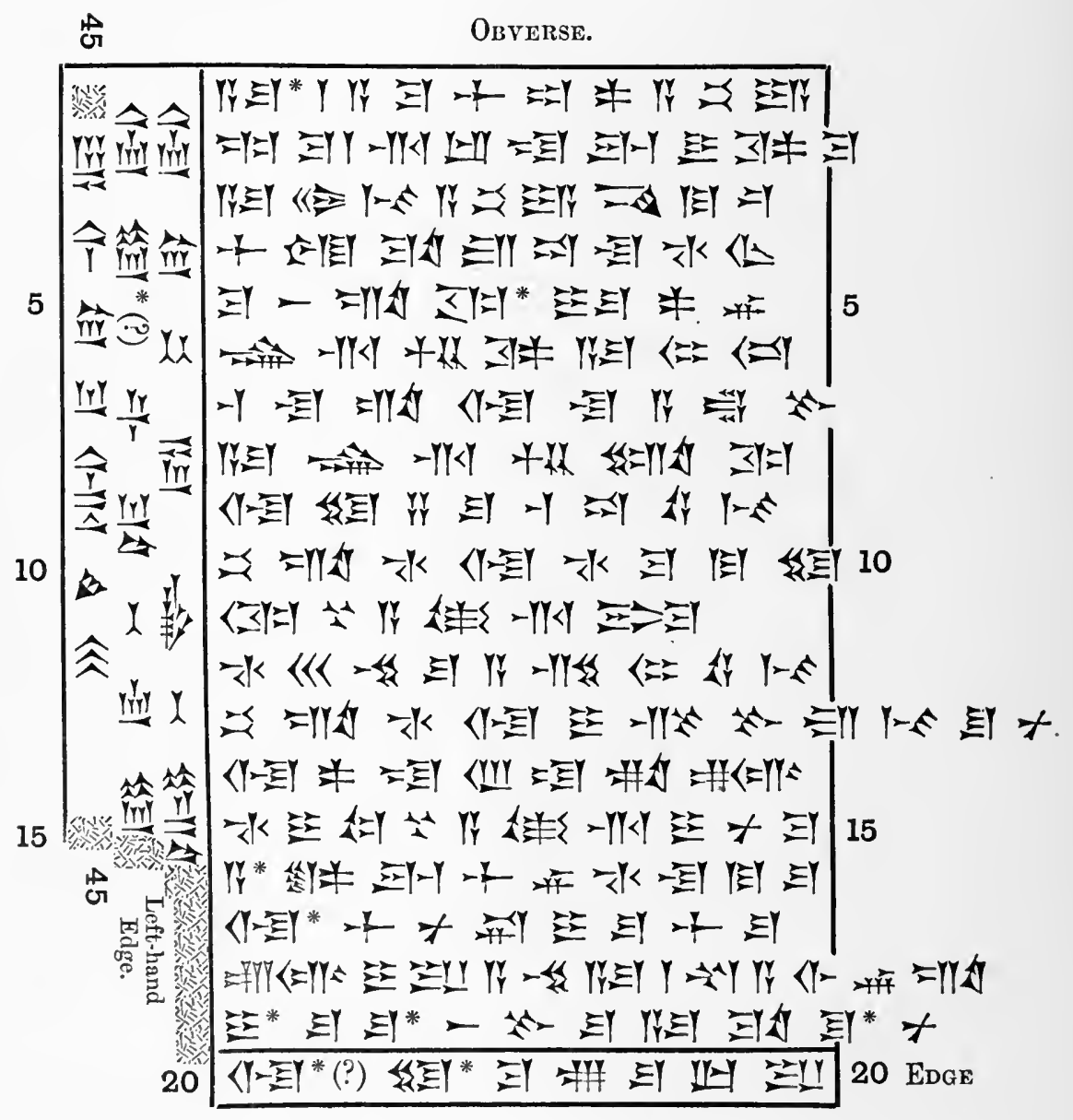


No. 15.

(BU. 88-10-13, 77.)

RFverse.

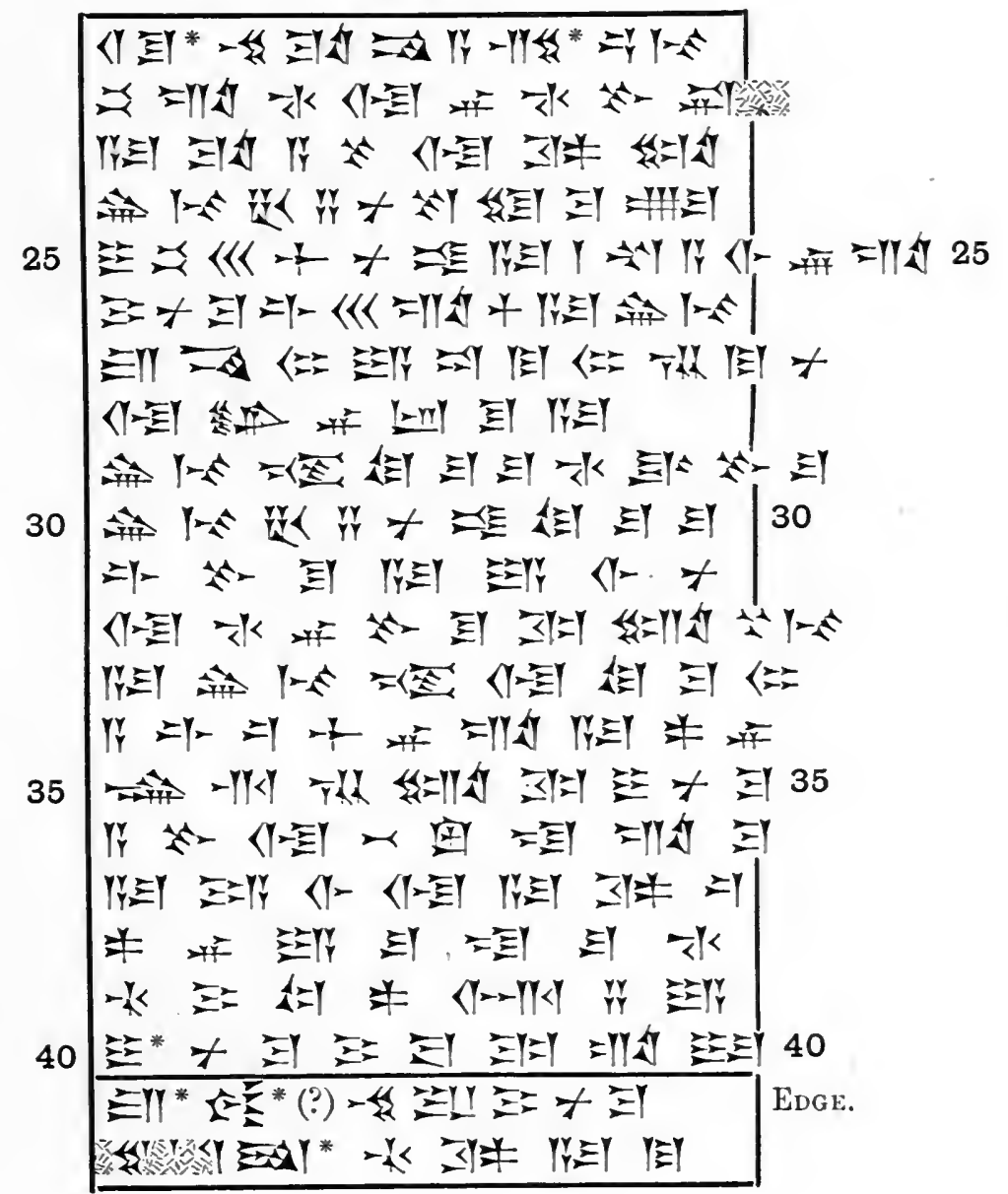




\section{No. 16.}

(BU. $88-10-13,73 ; 3 \frac{5}{8}$ in. by $2 \frac{5}{8}$ in.)

Obverse.

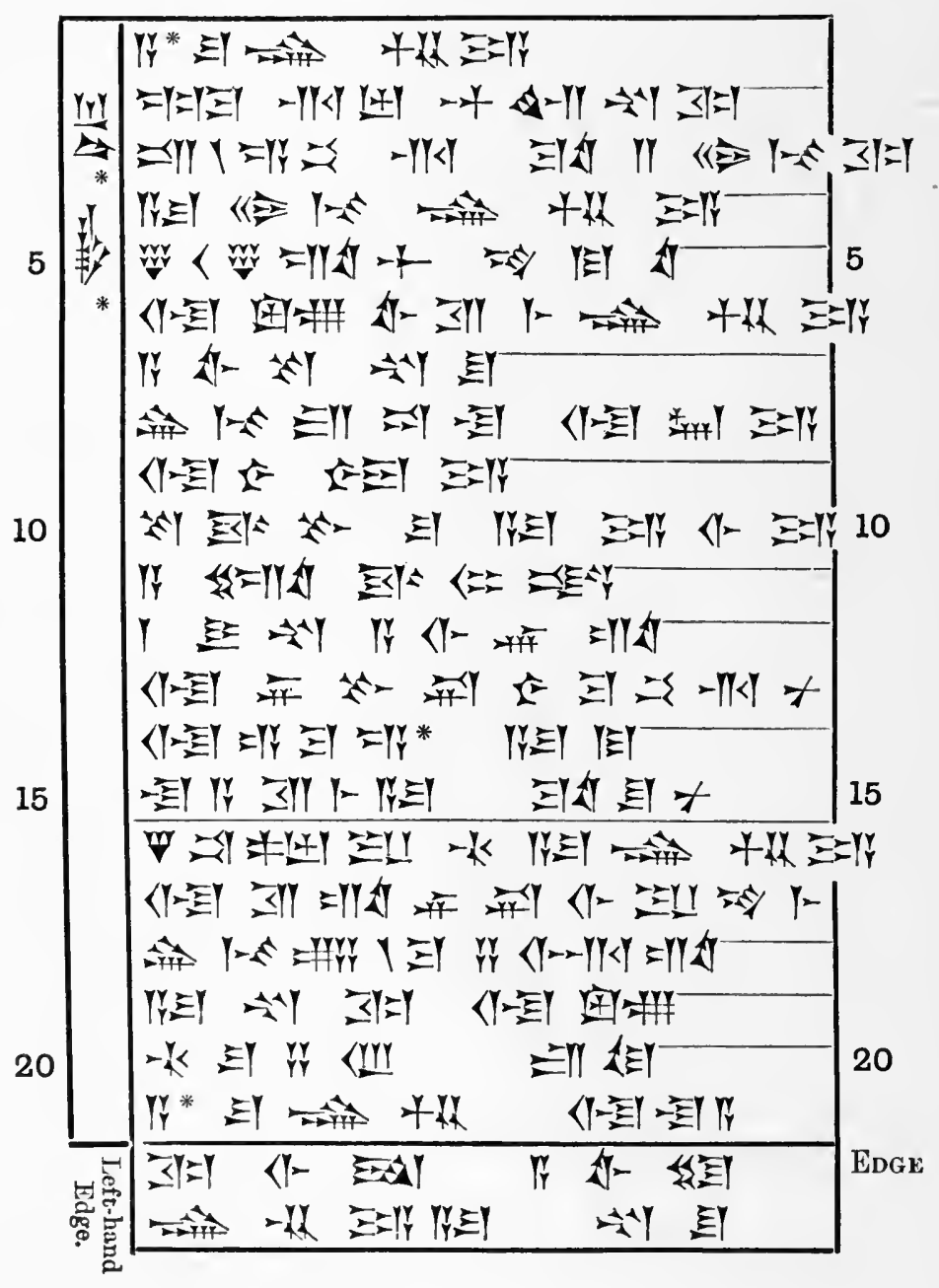


No. 16.

(BU. 88-10-13, 73; see plate 20.)

Reverse.

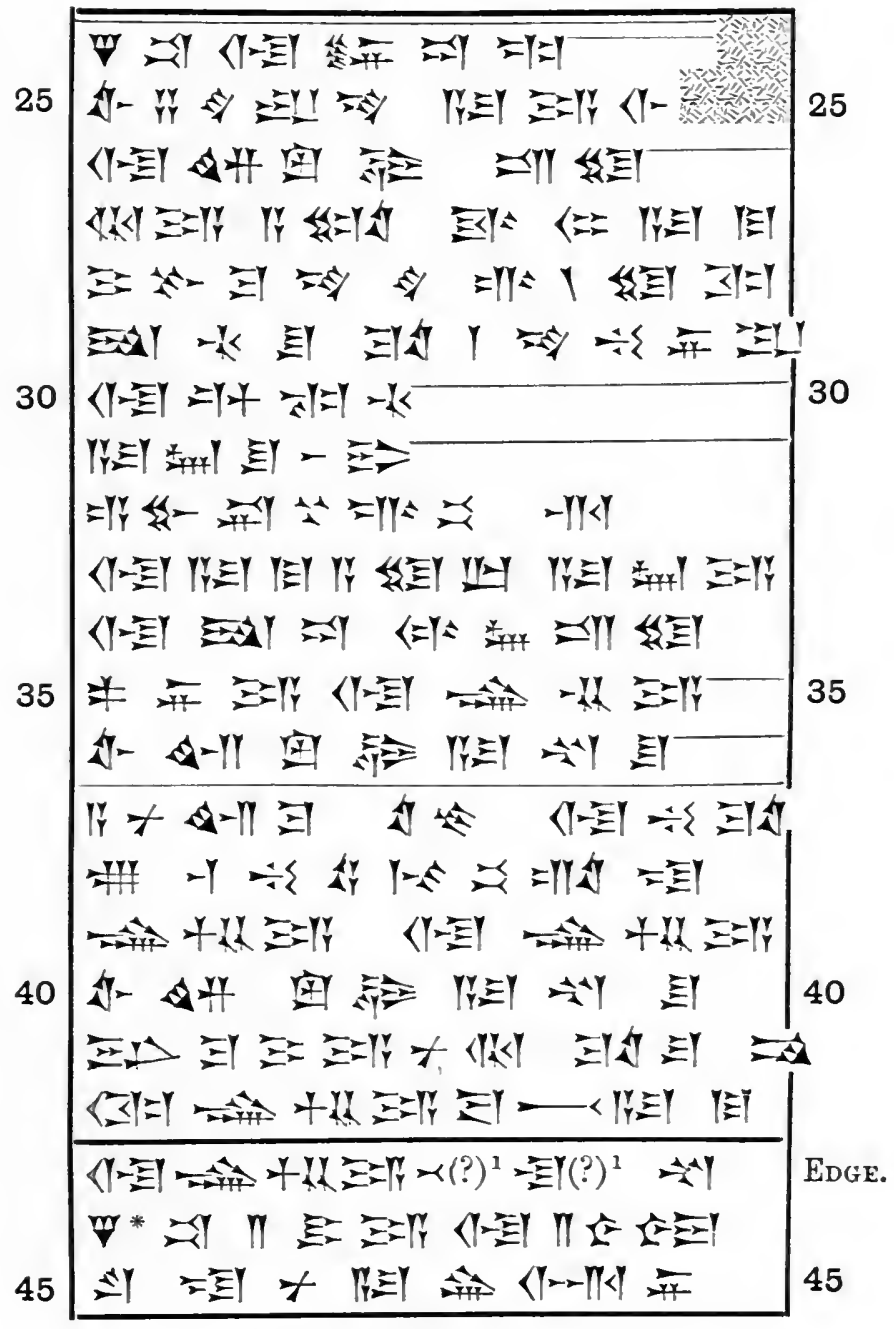

1 Written over an erasure. 


\section{No. 17.}

(BU. $88-10-13,47 ; 4 \frac{1}{4}$ in. by $2 \frac{3}{4}$ in.)

Obverse.

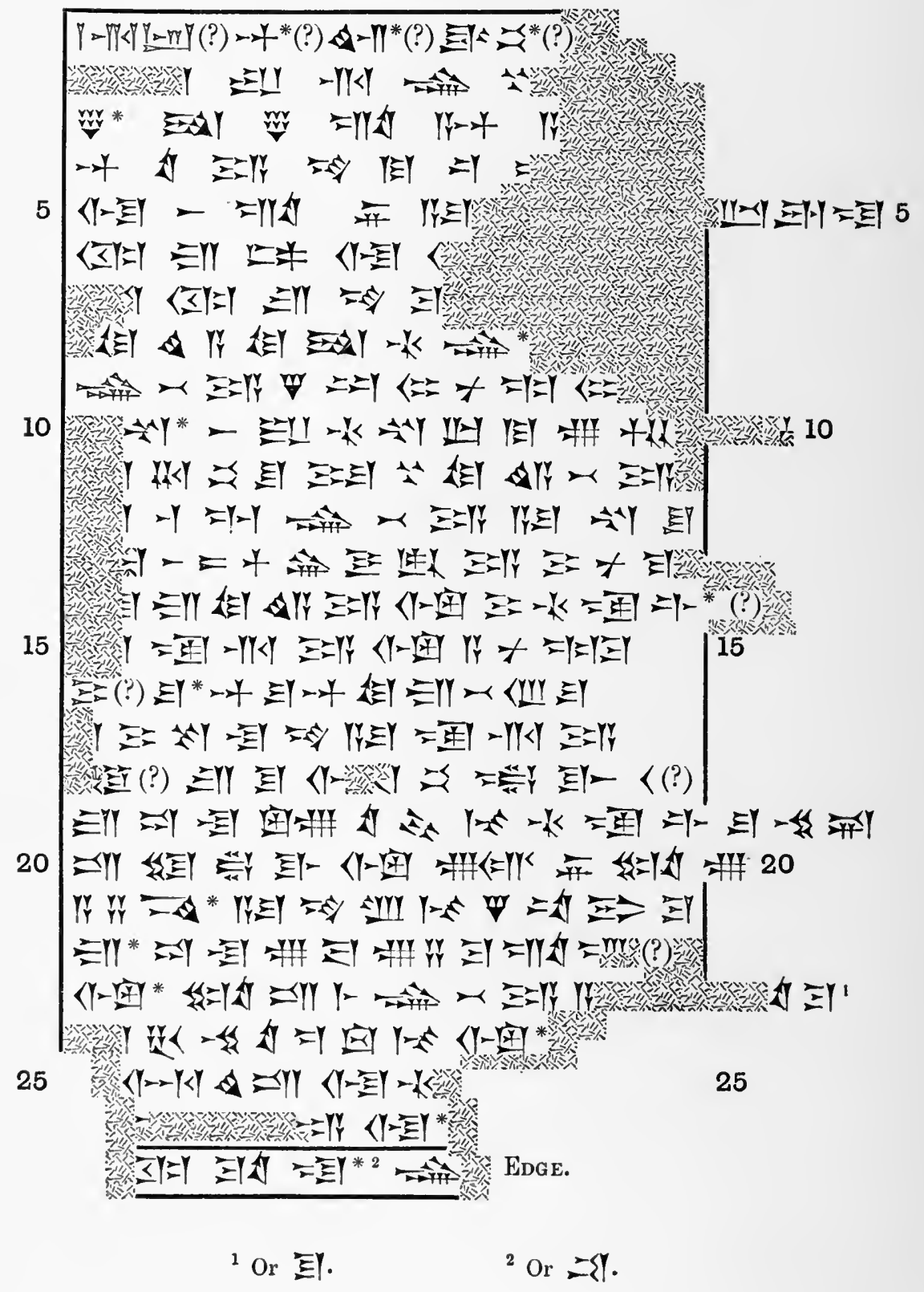


No. 17.

(BU. 88-10-13, 47.)

Reverse.

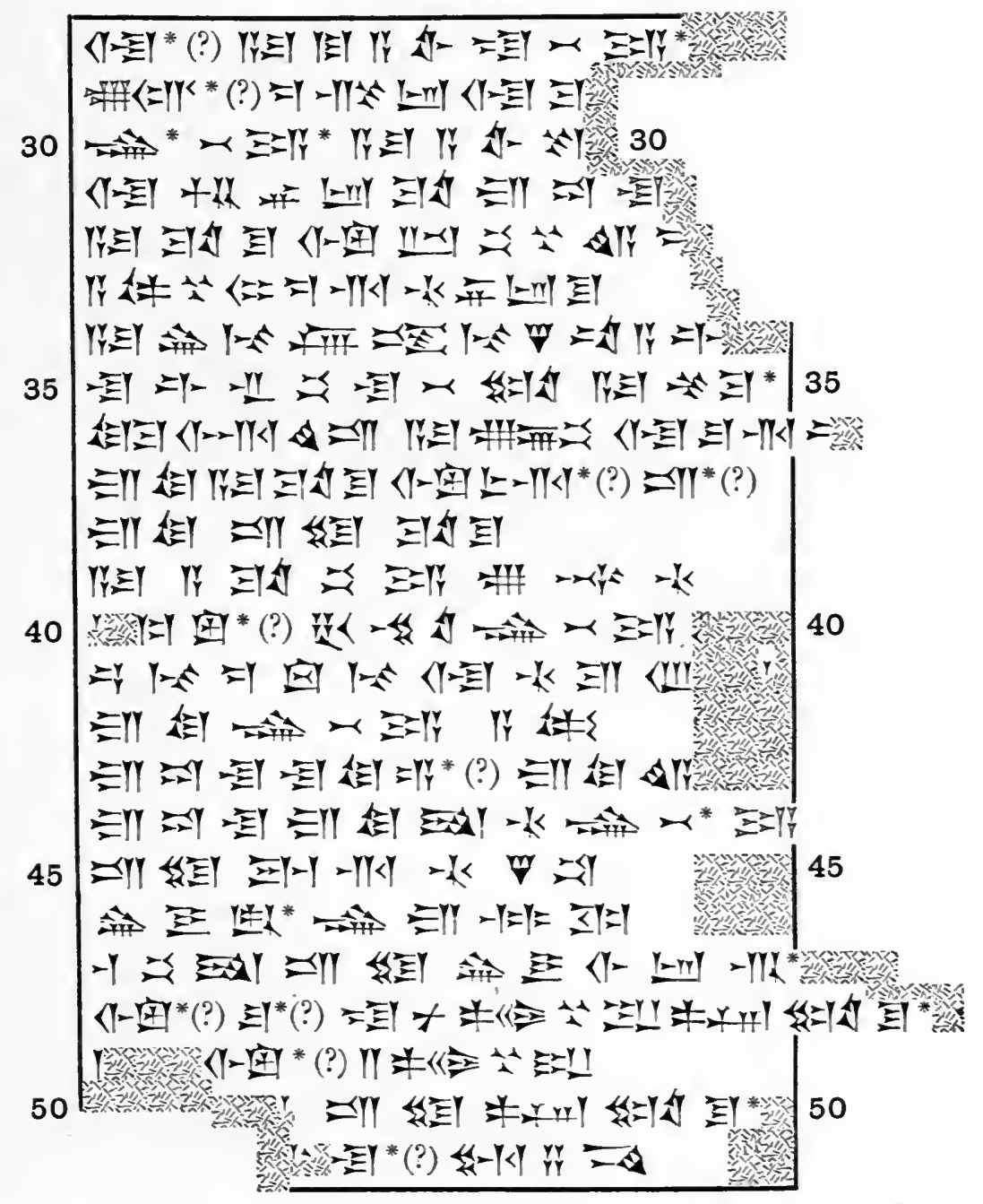




\section{No. 18.}

(BU. $88-10-13,40$; $4 \frac{3}{8}$ in. by 3 in.)

OBverse.

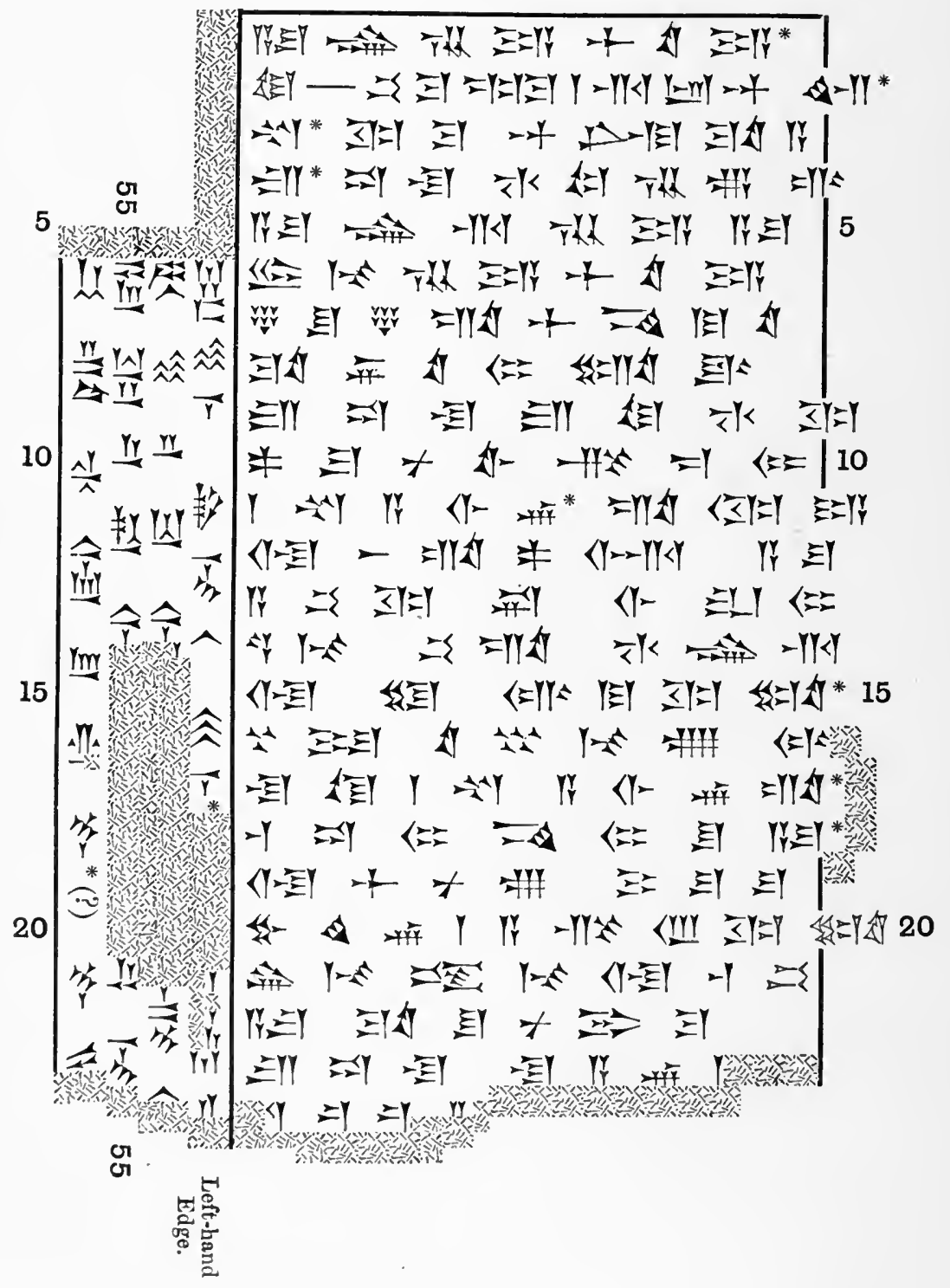




\section{No. 18.}

(BU. 88-10-13, 40.)

Reverse.

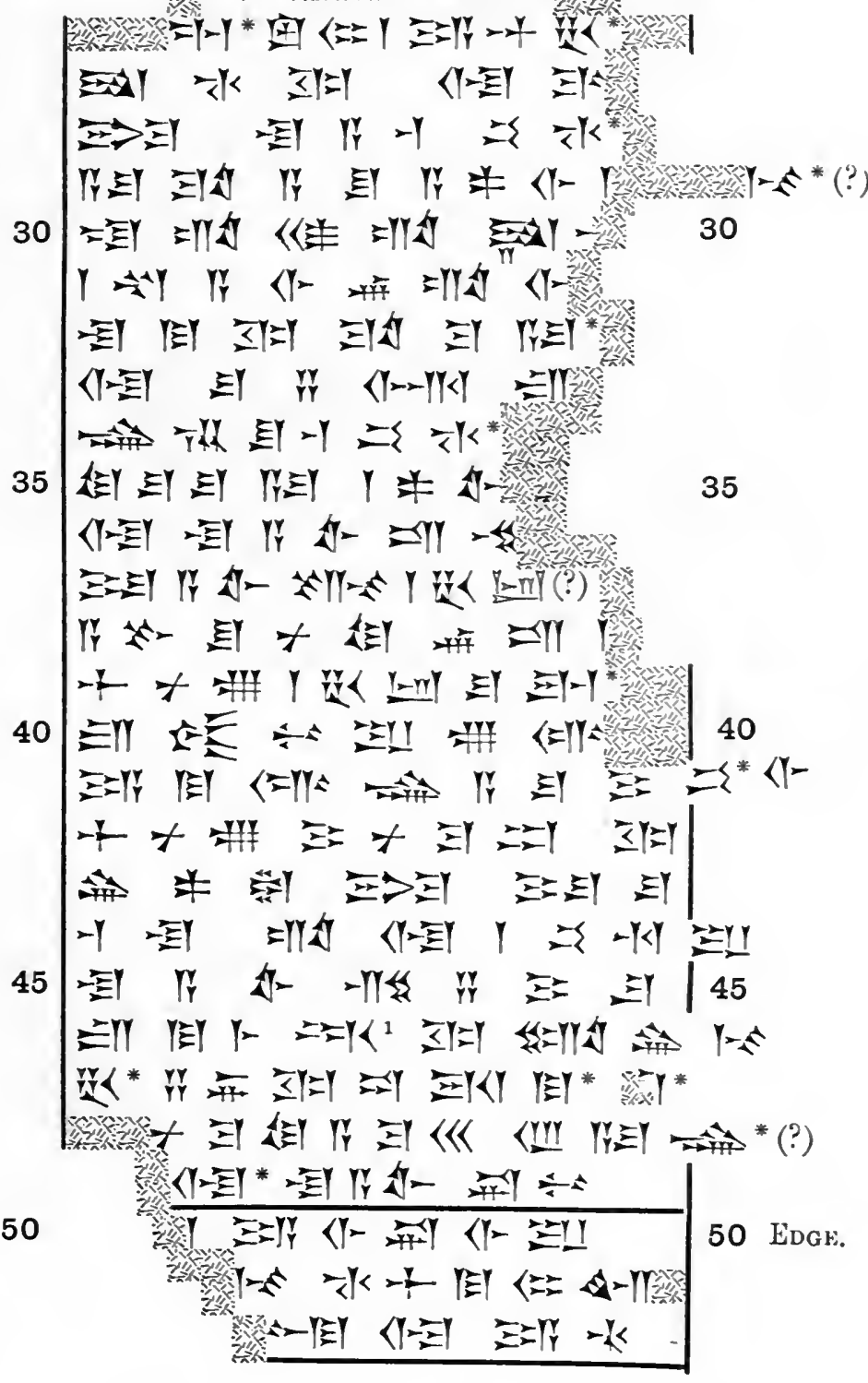

1 After this sign there follows an erasure. 


\section{No. 19.}

(BU. $88-10-18,44 ; 4 \frac{1}{2}$ in. by $2 \frac{7}{8}$ in.)

OBversf.

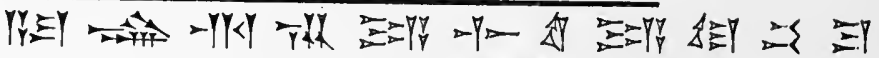

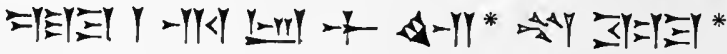

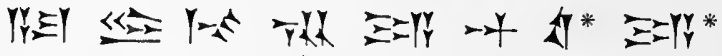

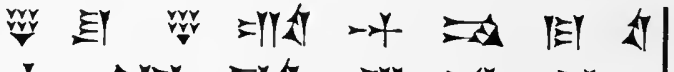


No. 19.

(BU. 88-10-13, 44 ; see plate 10.)

Reverse.

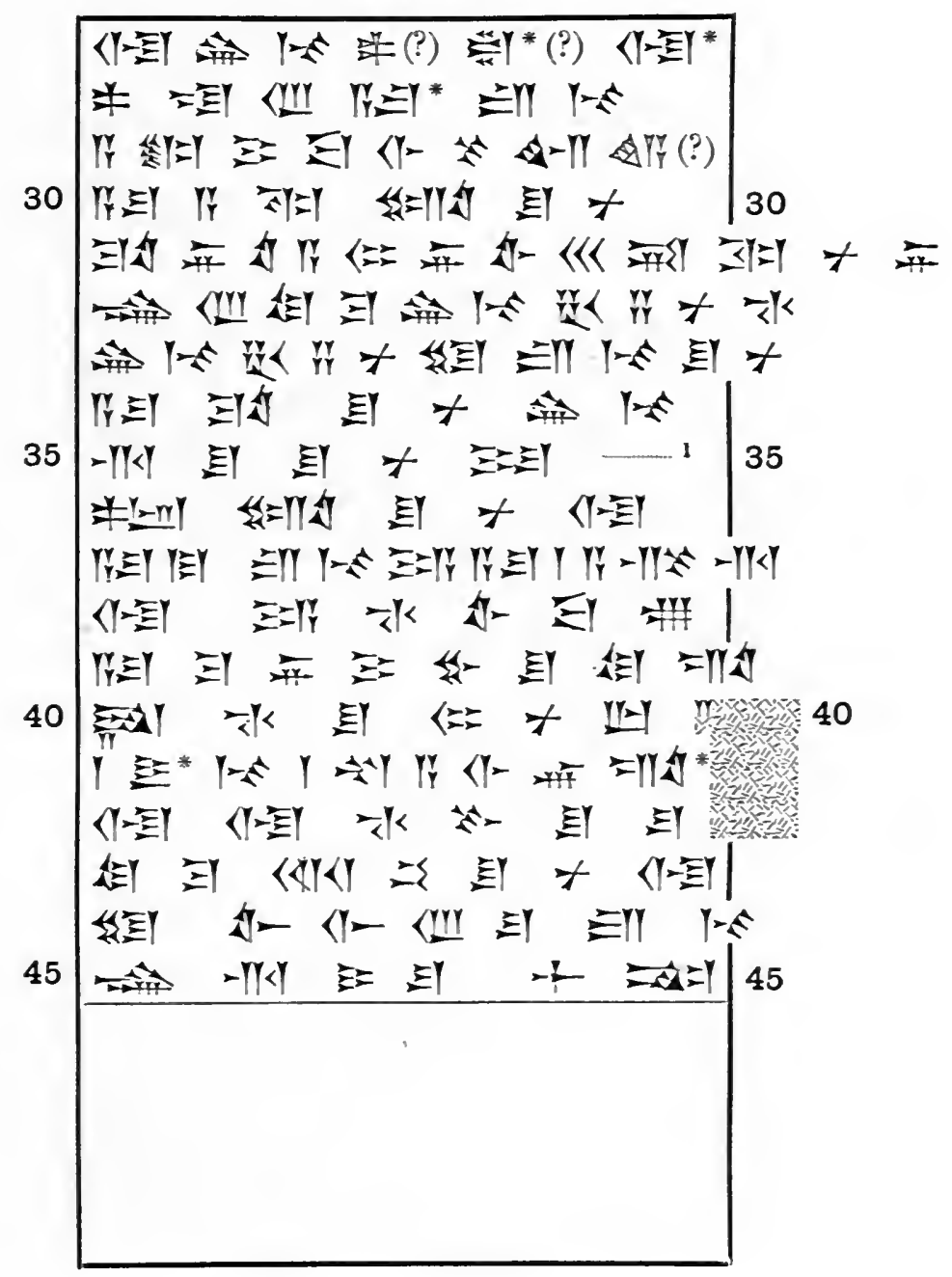

1 Here the scribe began to write s̆aplı̌sınu, but erased it; the traces of the first character $(|y-m|)$ are visible. 
No. 20.

(BU. $88-10-13,68 ; 3 \frac{5}{8}$ in. by $2 \frac{3}{4}$ in.)

Obverse.

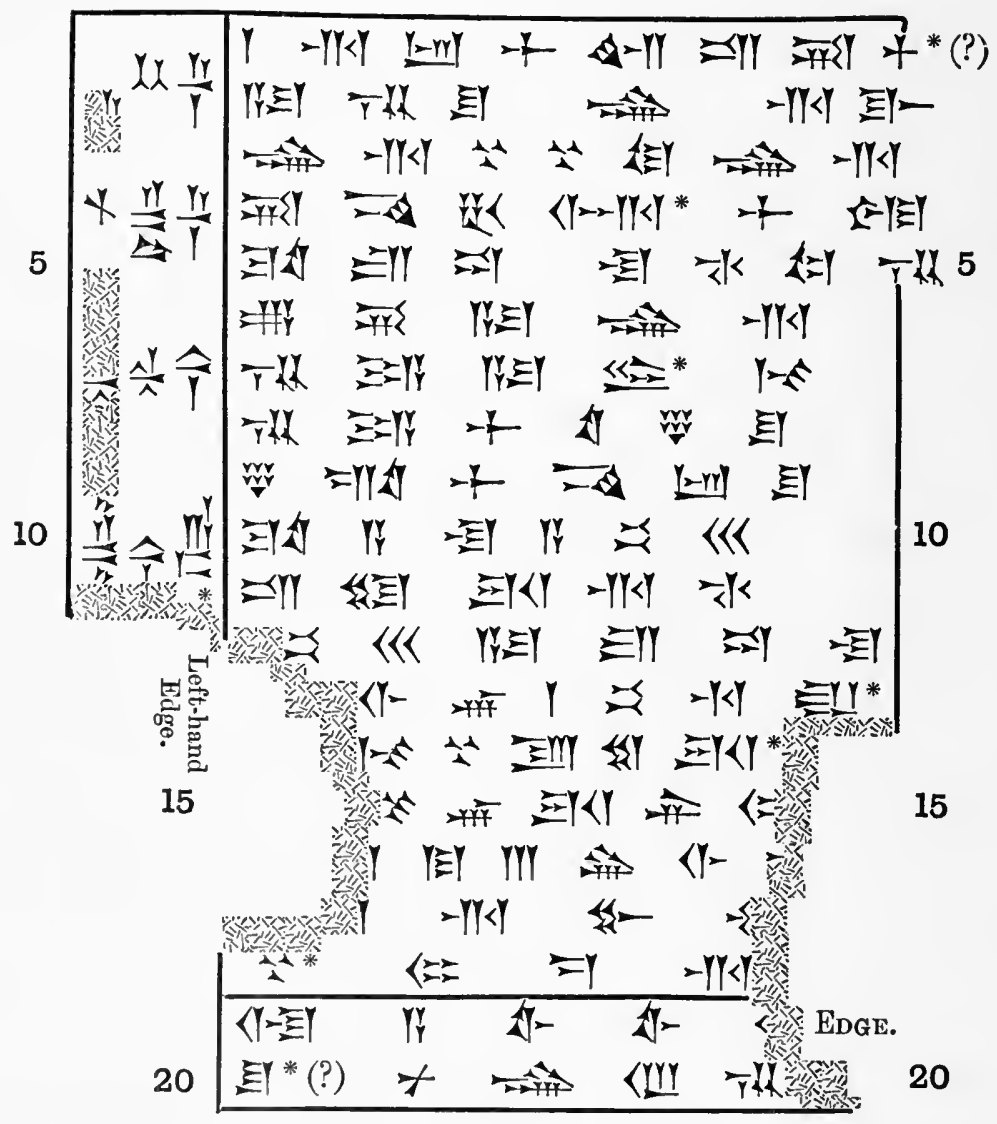


No. 20.

(BU. $88-10-13,68$.

Reverse.

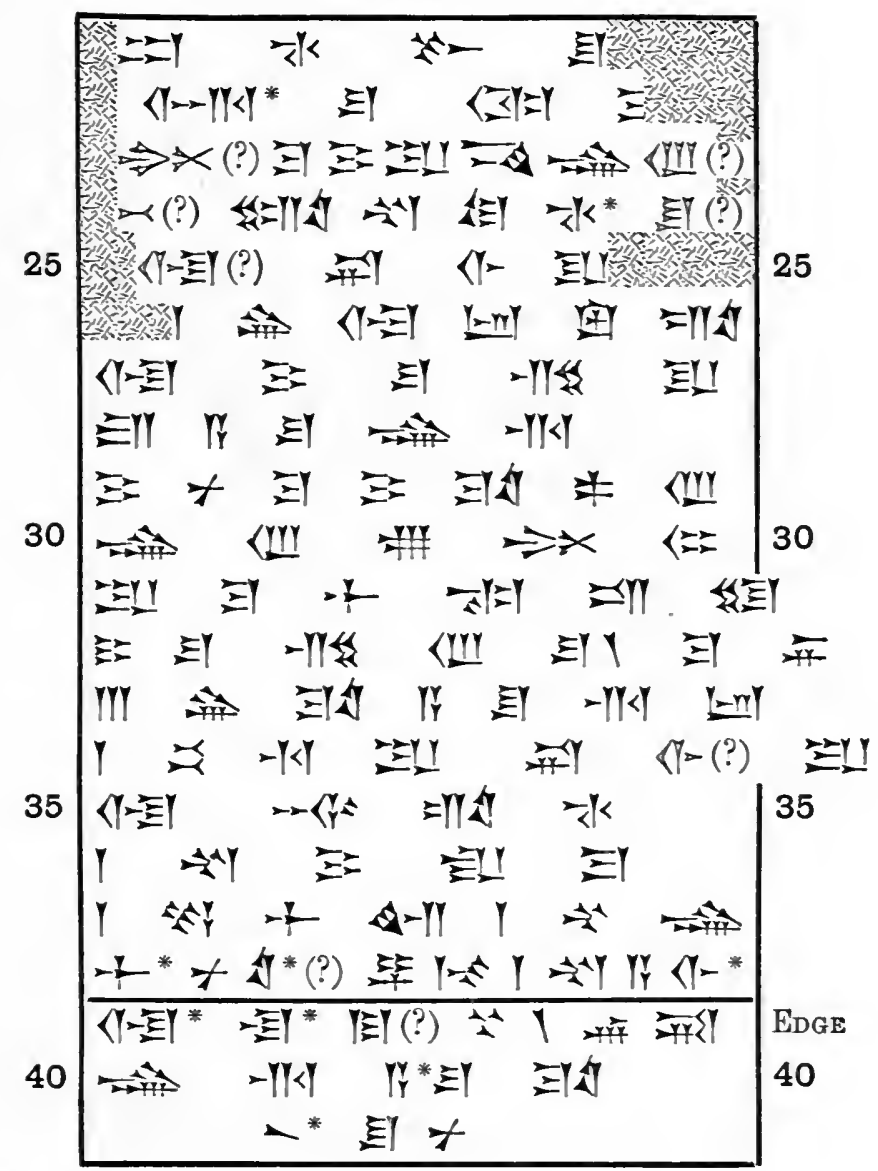


No. 21.

(BU. $88-10-13,63 ; 3 \frac{1}{4}$ in. by $2 \frac{1}{16}$ in.)

Obverse.

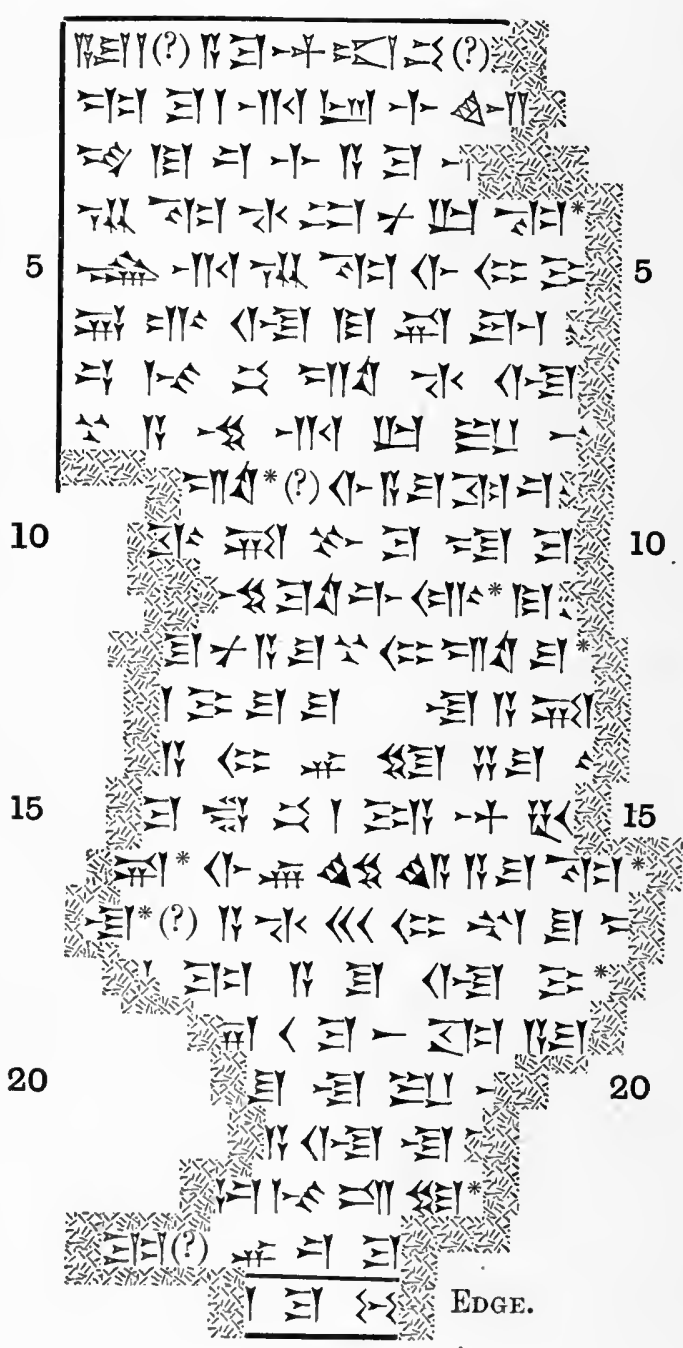


No. 21.

(BU. 88-10-13, 63.)

Reverse.

25

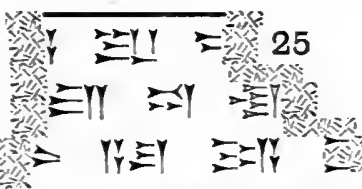

管

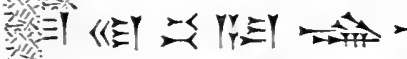

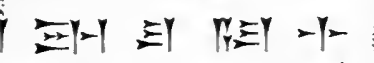

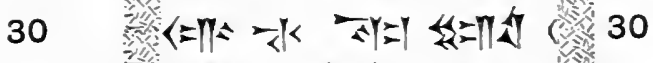

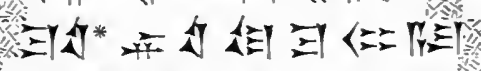

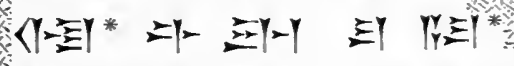

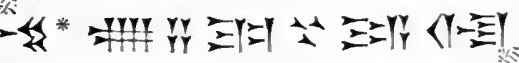

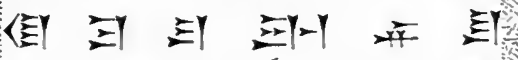

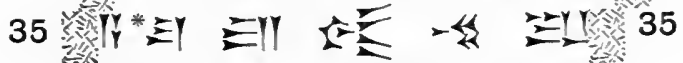

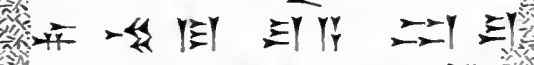

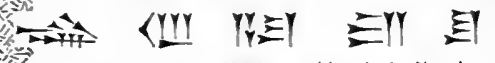

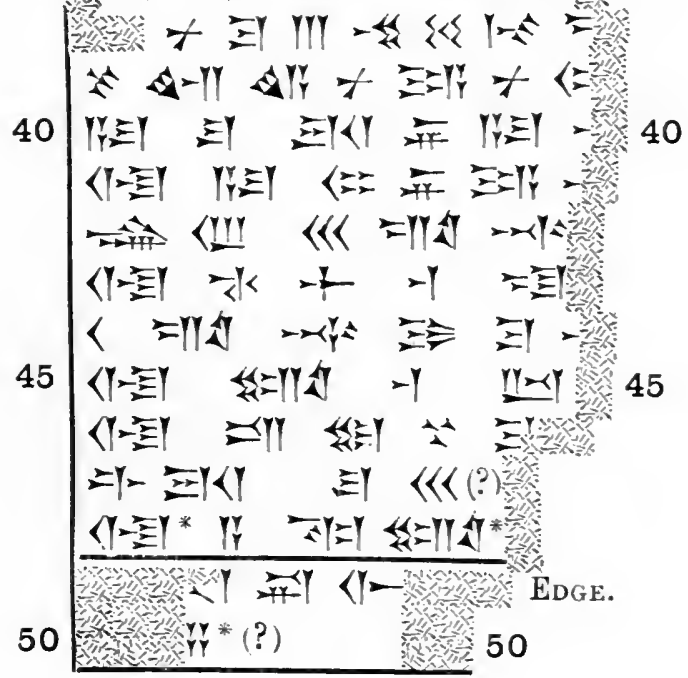




\section{No. 22.}

(BU. $88-10-13,31 ; 2 \frac{1}{4}$ in. by $2 \frac{1}{4}$ in. ; see plate 6. )

Obverse.

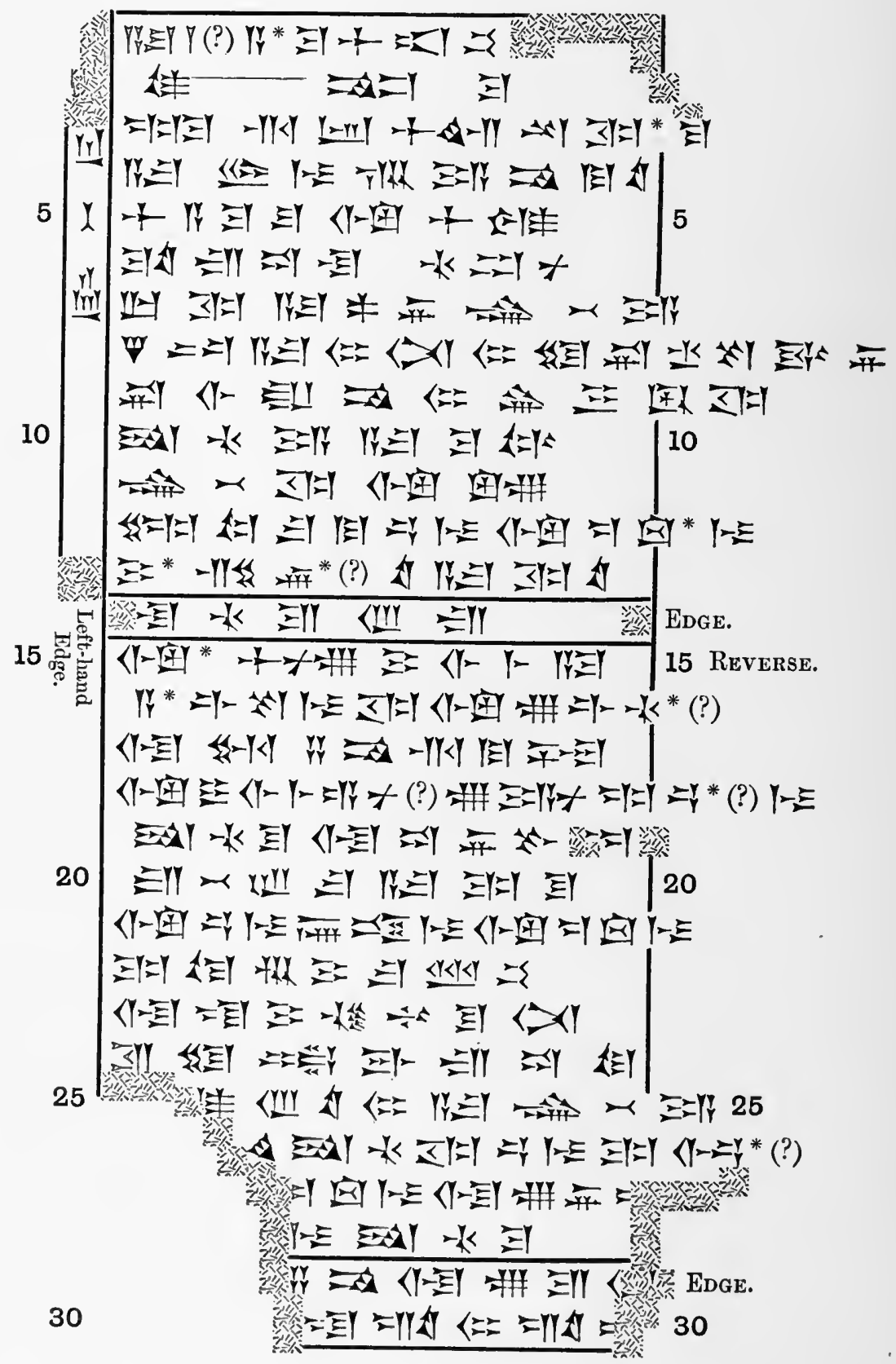


No. 23.

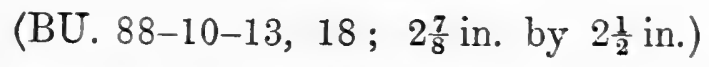

Obrerse.

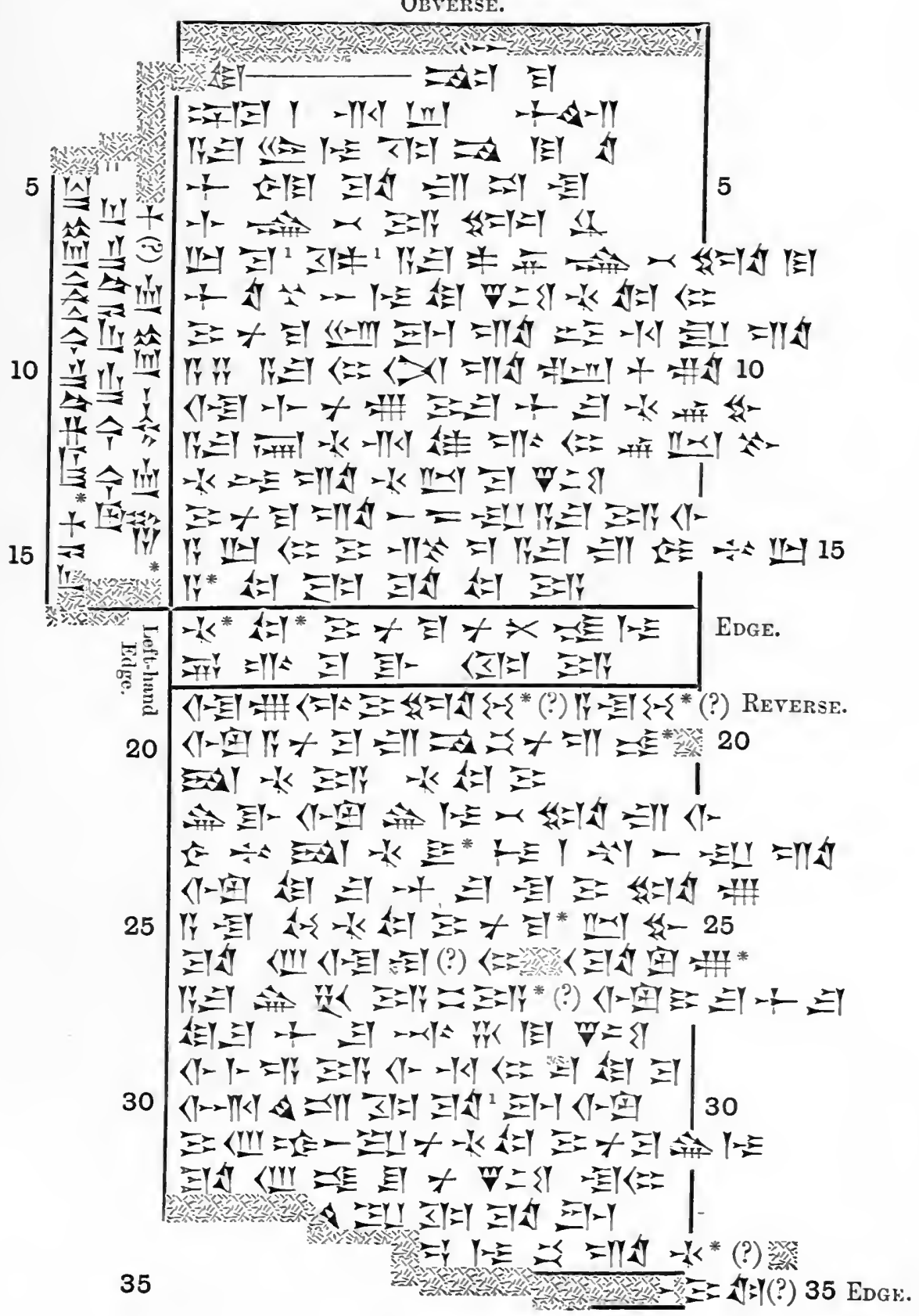

1 Writlen over an erasure. 


\section{No. 24.}

(BU. $88-10-13,42 ; 3 \frac{3}{8}$ in. by $2 \frac{11}{16}$ in.)

Obverse.

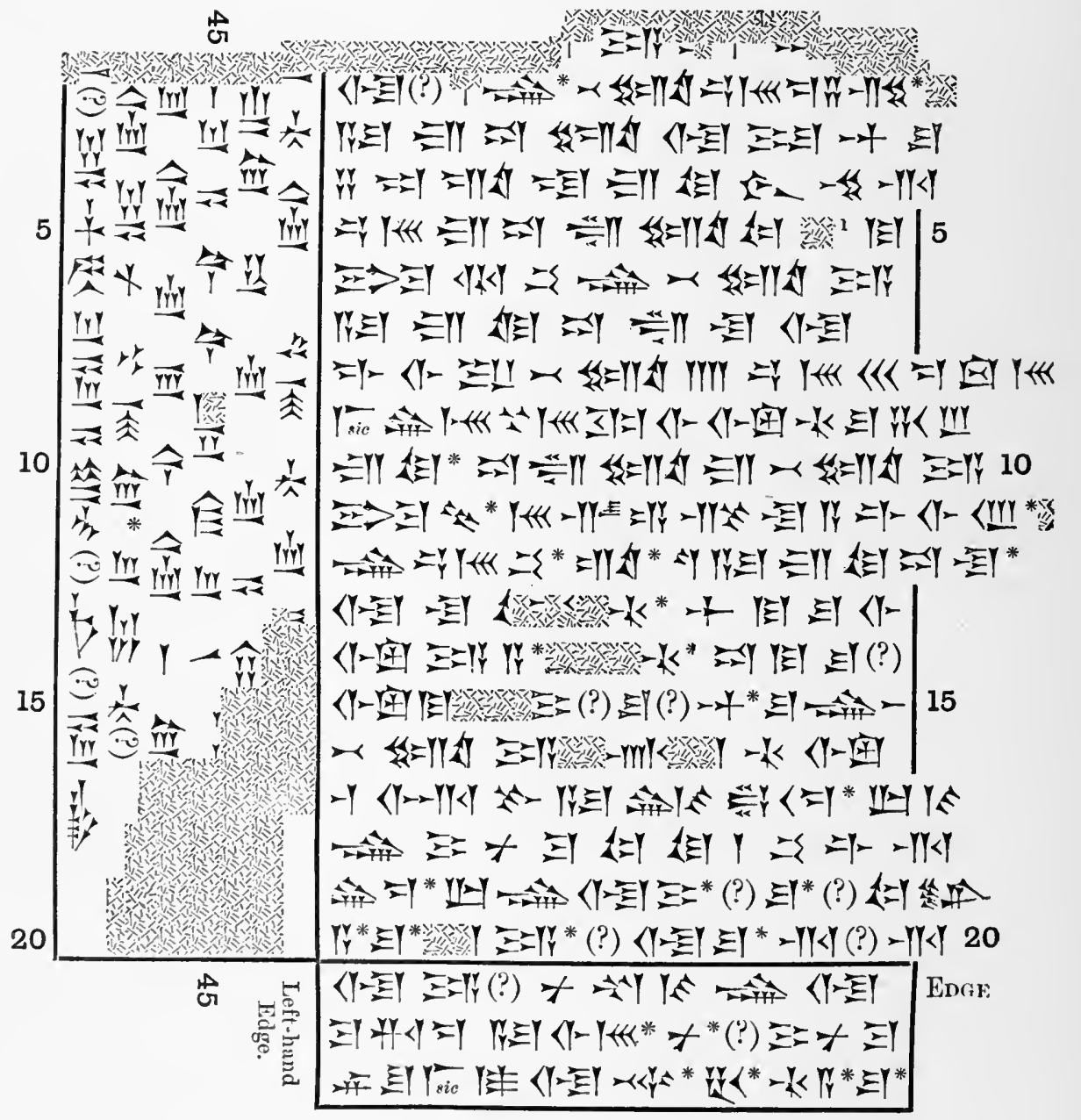

1 Erased by the scribe 
No. 24.

(BU. 88-10-13, 42.)

Reverse.

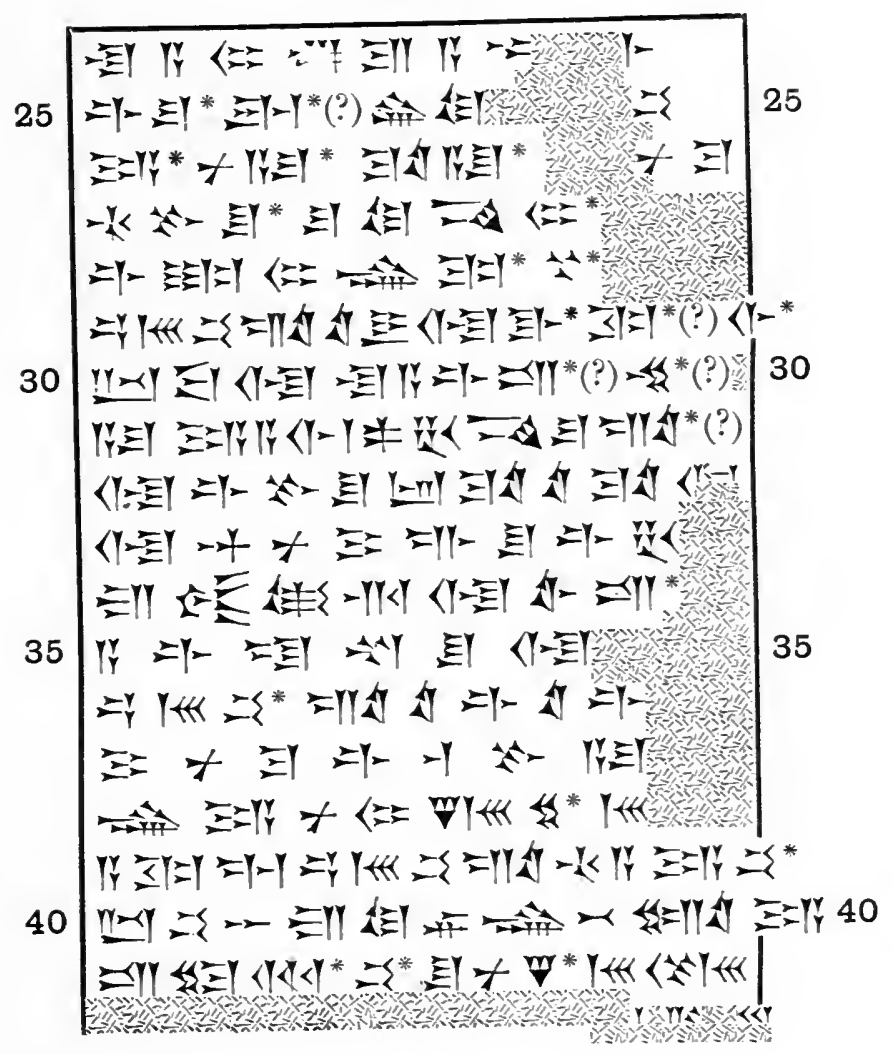



No. 25.

(BU. $88-10-13,32 ; 2 \frac{3}{4}$ in. by $1 \frac{7}{8}$ in.)

Obverse.

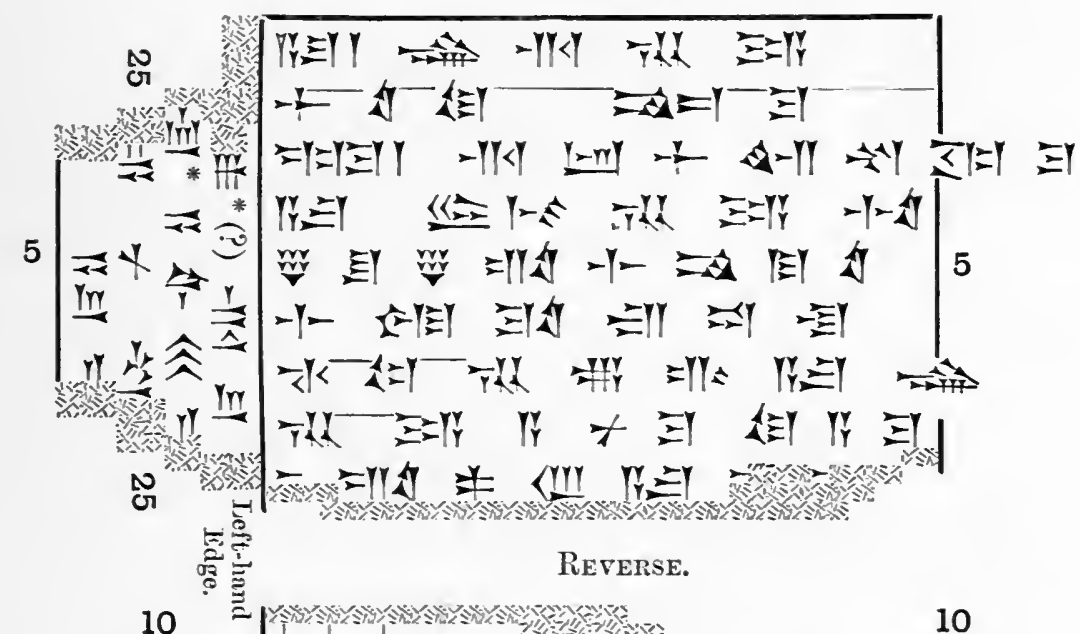

10

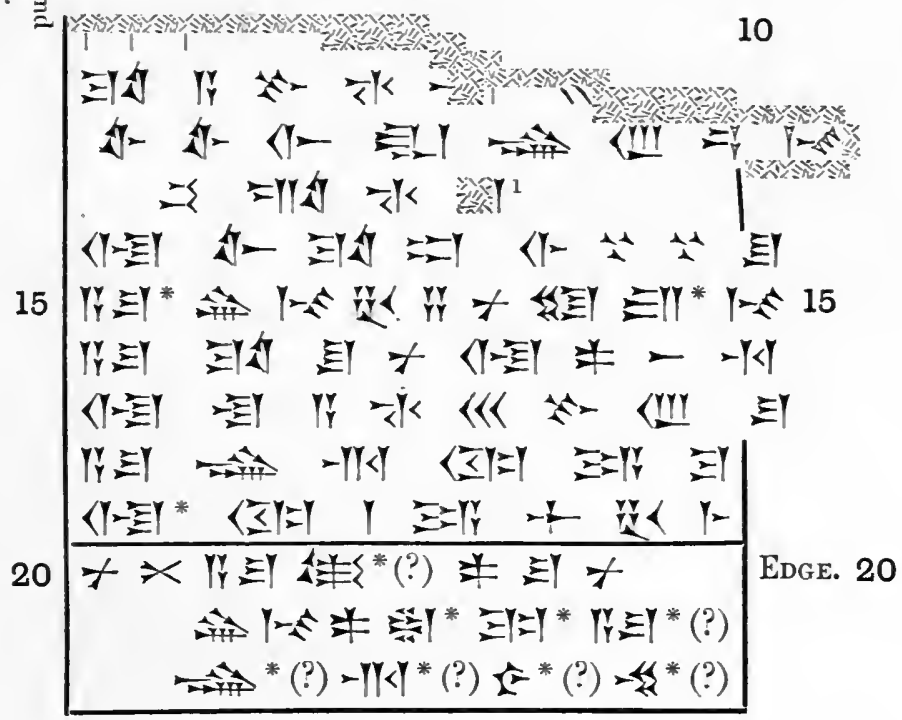

1 This line, which is written in smaller characters than the other parts of the text, appears to have been inserted after the scribe had finished the letter. 


\section{No. 26.}

(BU. $88-10-13,80$; $3 \frac{3}{4}$ in. by $2 \frac{7}{8}$ in.)

OBVERSE.

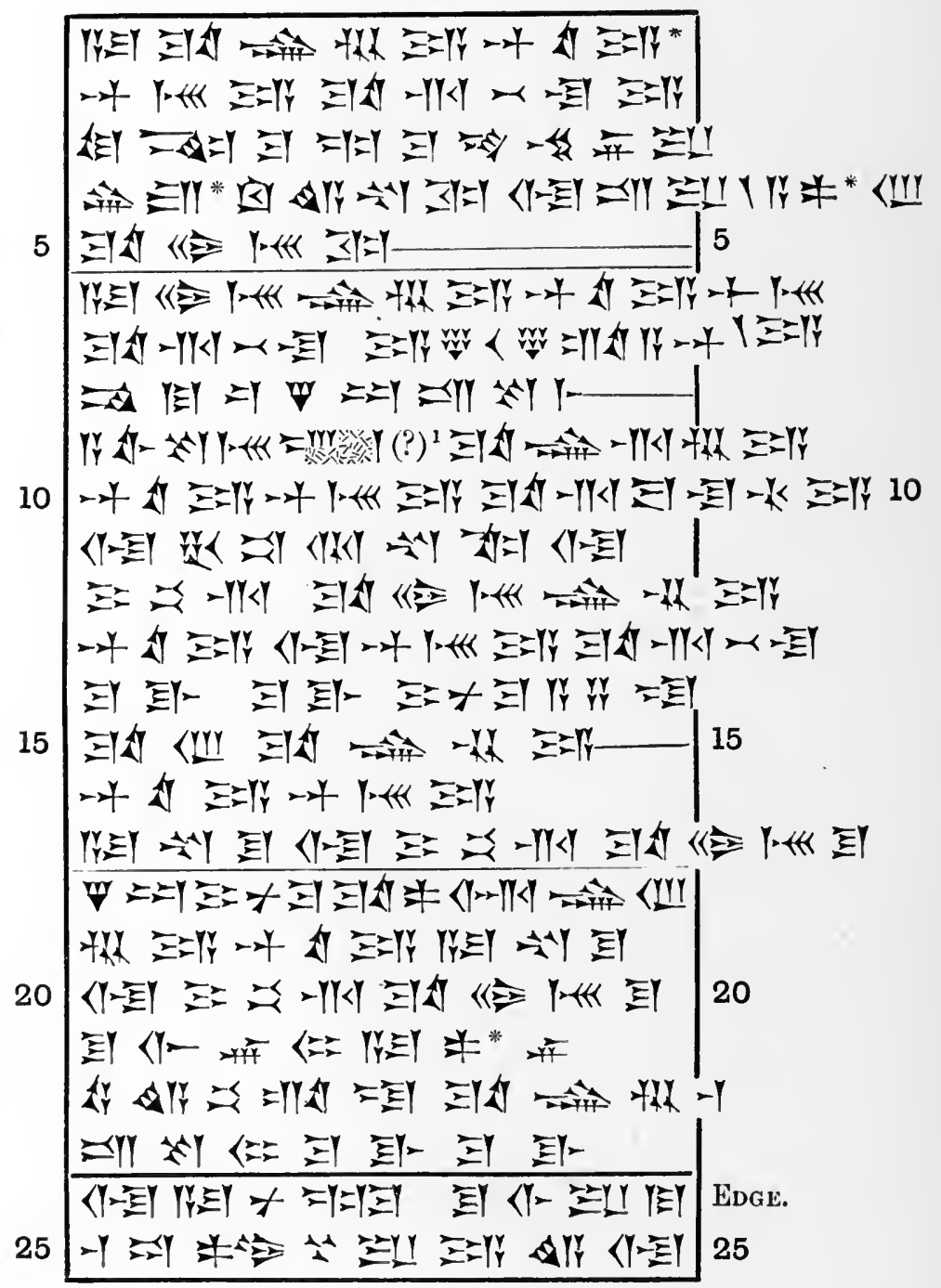

1. Corrected, or erased, by the scribe. 
No. 26.

(BU. 88-1.0-13, 80 ; see plate 23.)

Reverse.

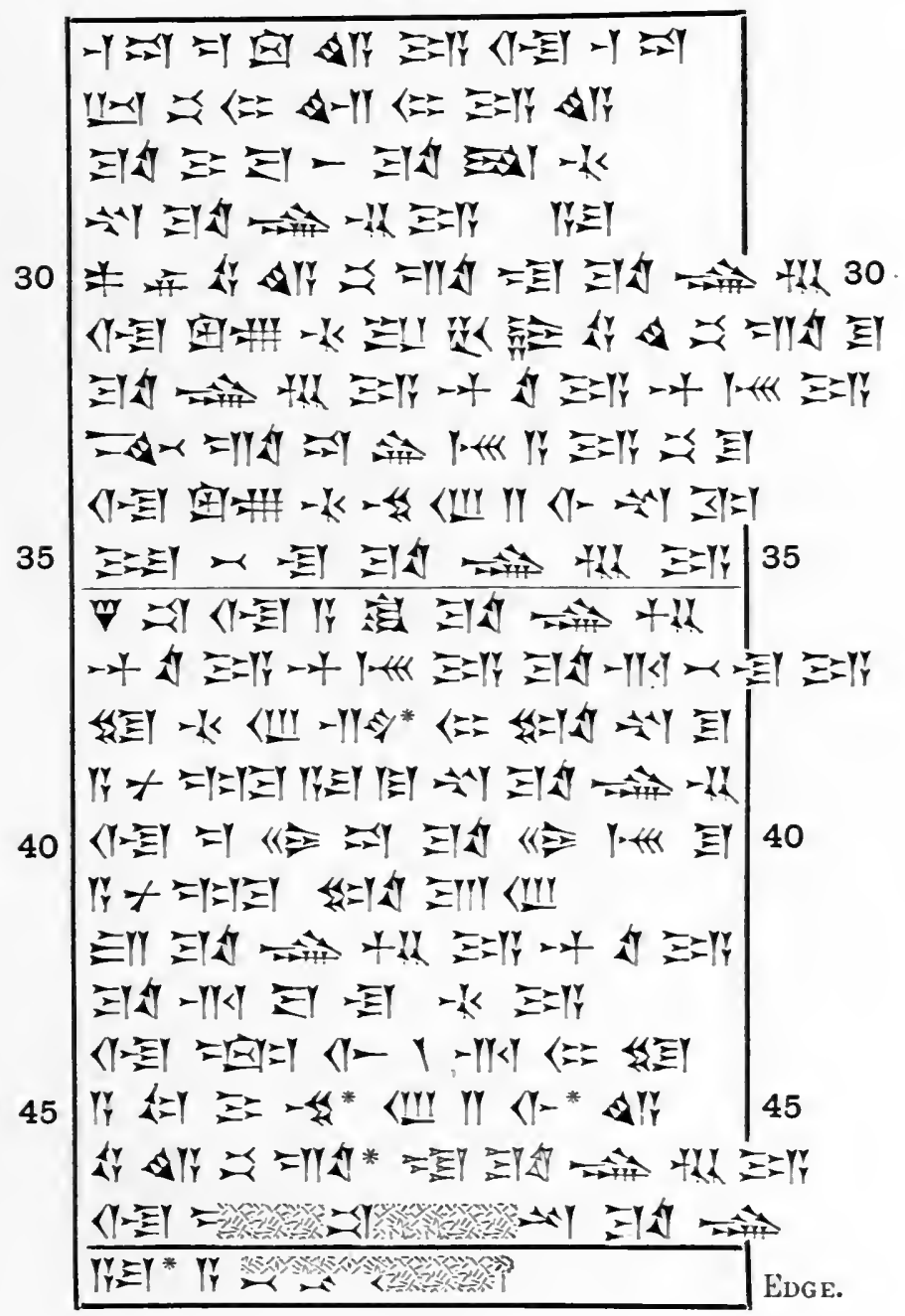


No. 27.

(BU. $88-10-13,7 ; 3 \frac{5}{8}$ in. by $2 \frac{7}{8}$ in.)

Obverse.

\begin{tabular}{|c|c|c|}
\hline 5 & 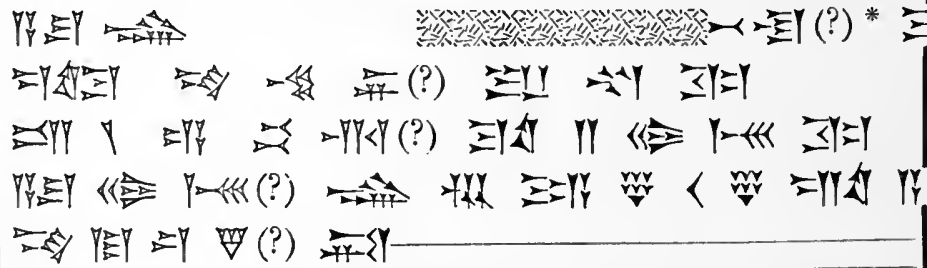 & -4 \\
\hline 10 & 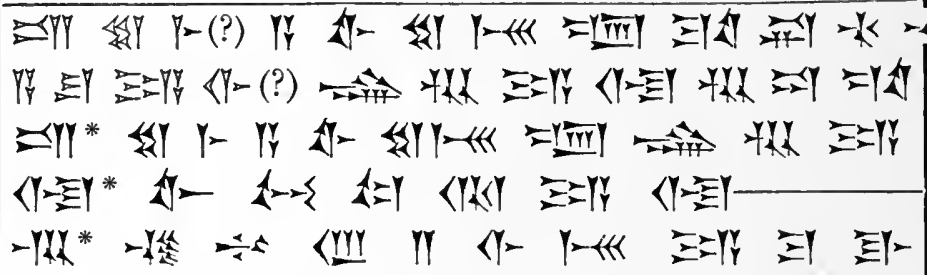 & 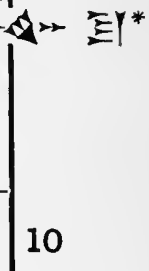 \\
\hline & 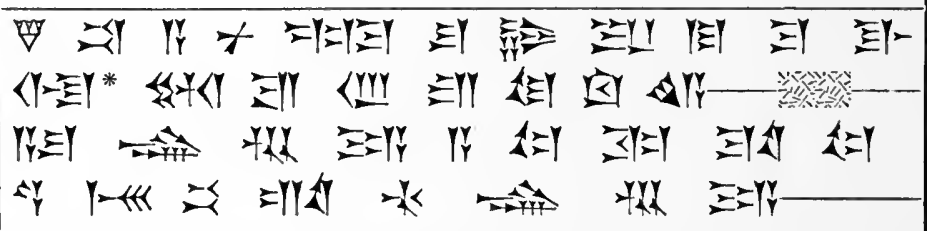 & \\
\hline 20 & 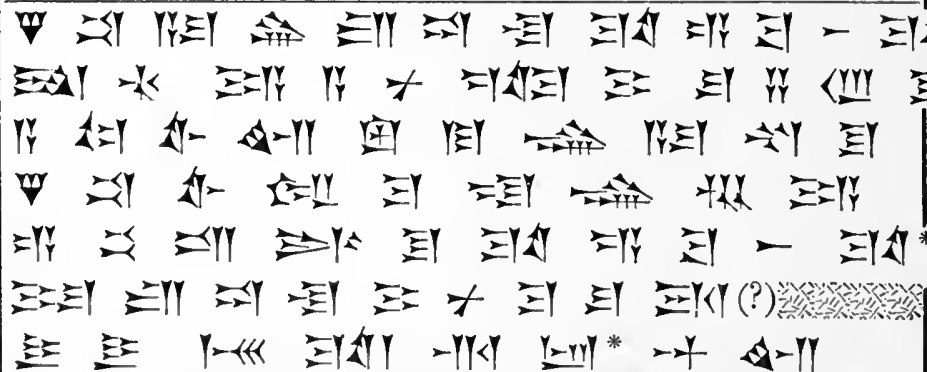 & 15 \\
\hline & 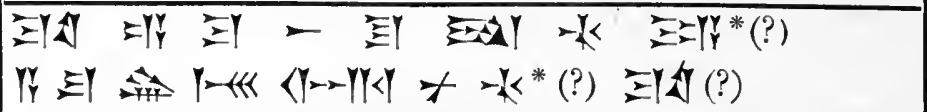 & EDGE. \\
\hline
\end{tabular}


No. 27.

(BU. 88-10-13, 7 ; see plate 2.)

Reverse.

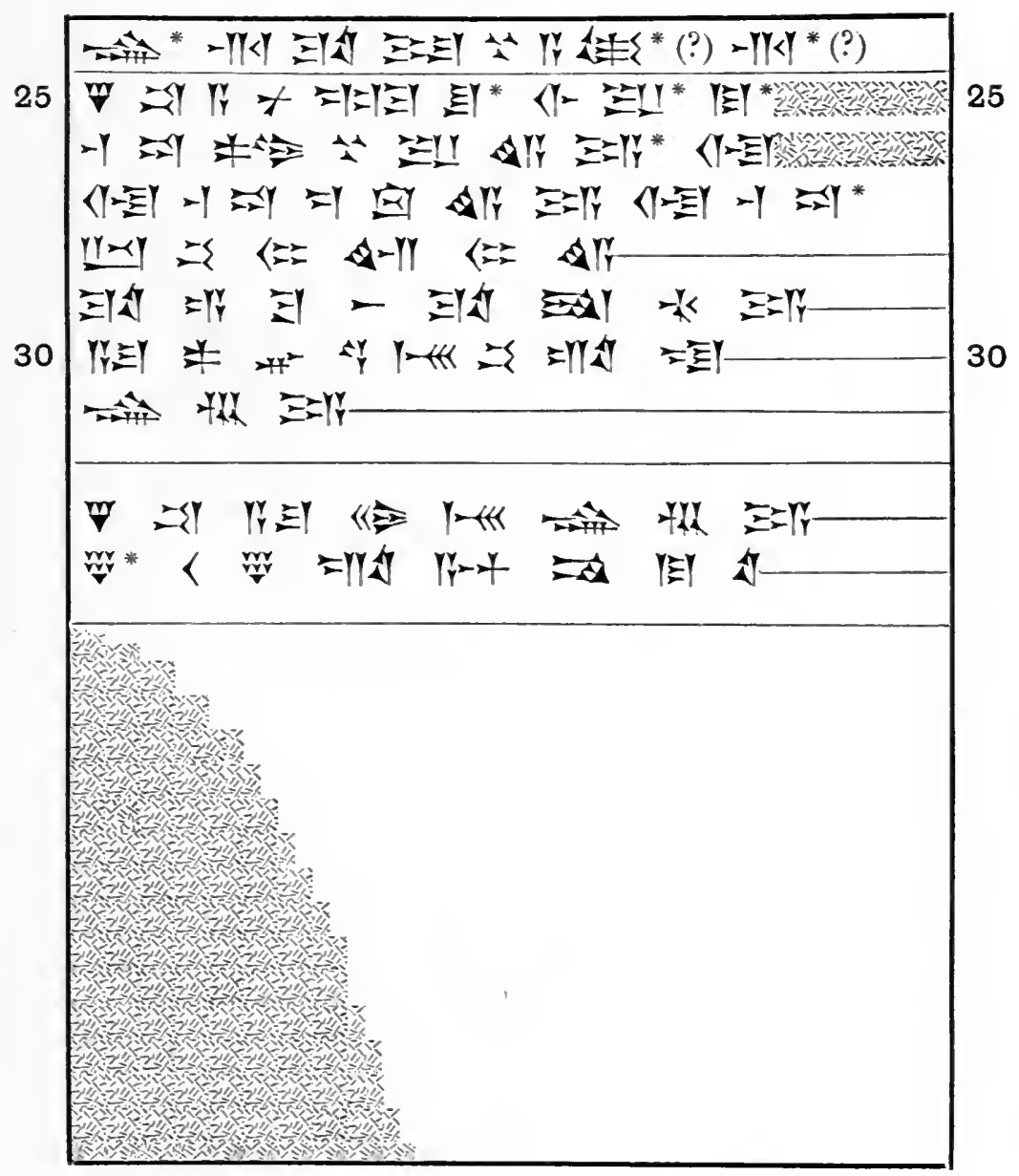


No. 28.

(BU. $88-10-13,60 ; 4 \frac{3}{8}$ in. by $2 \frac{1}{2}$ in.)

○ OBVERE.

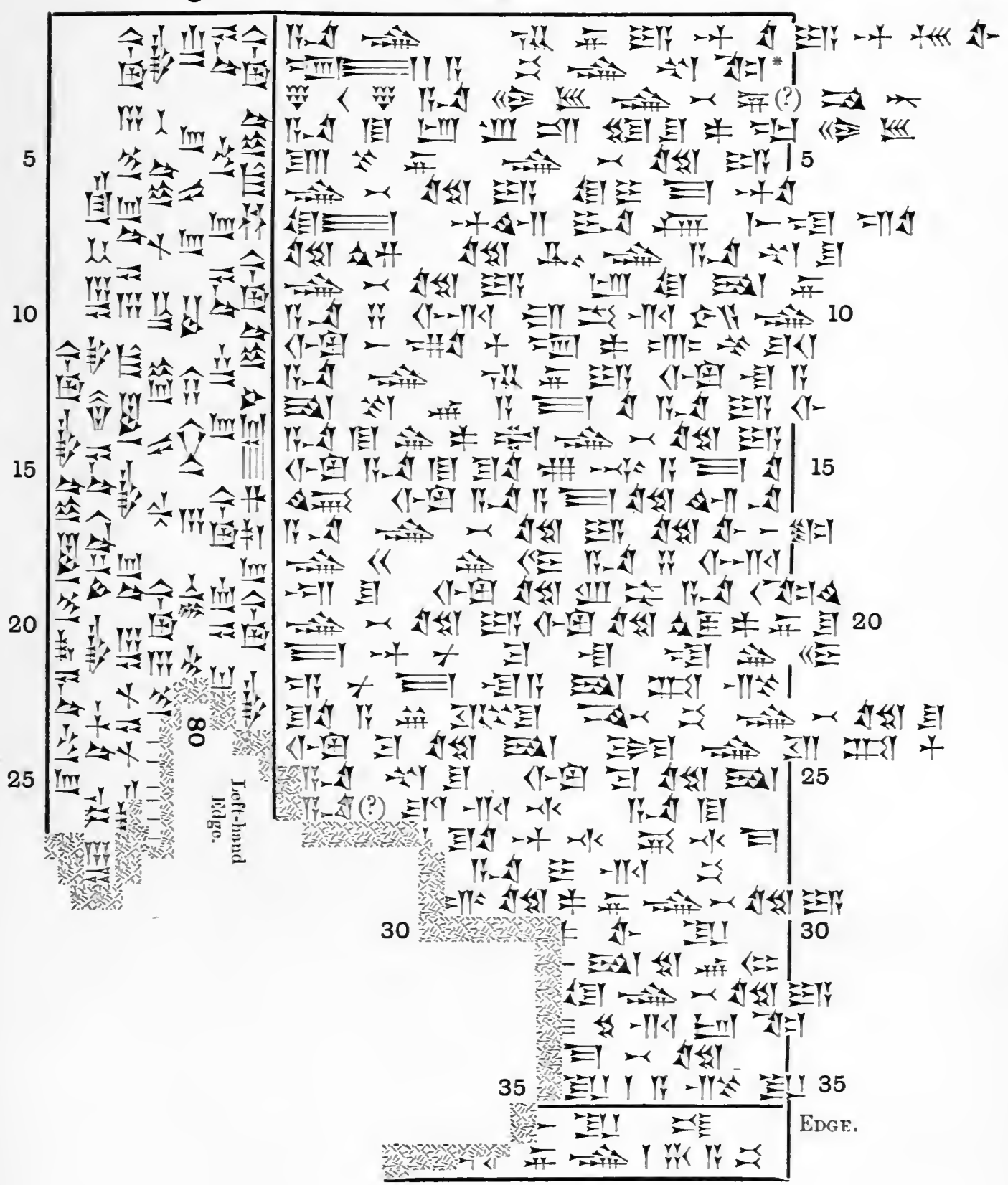




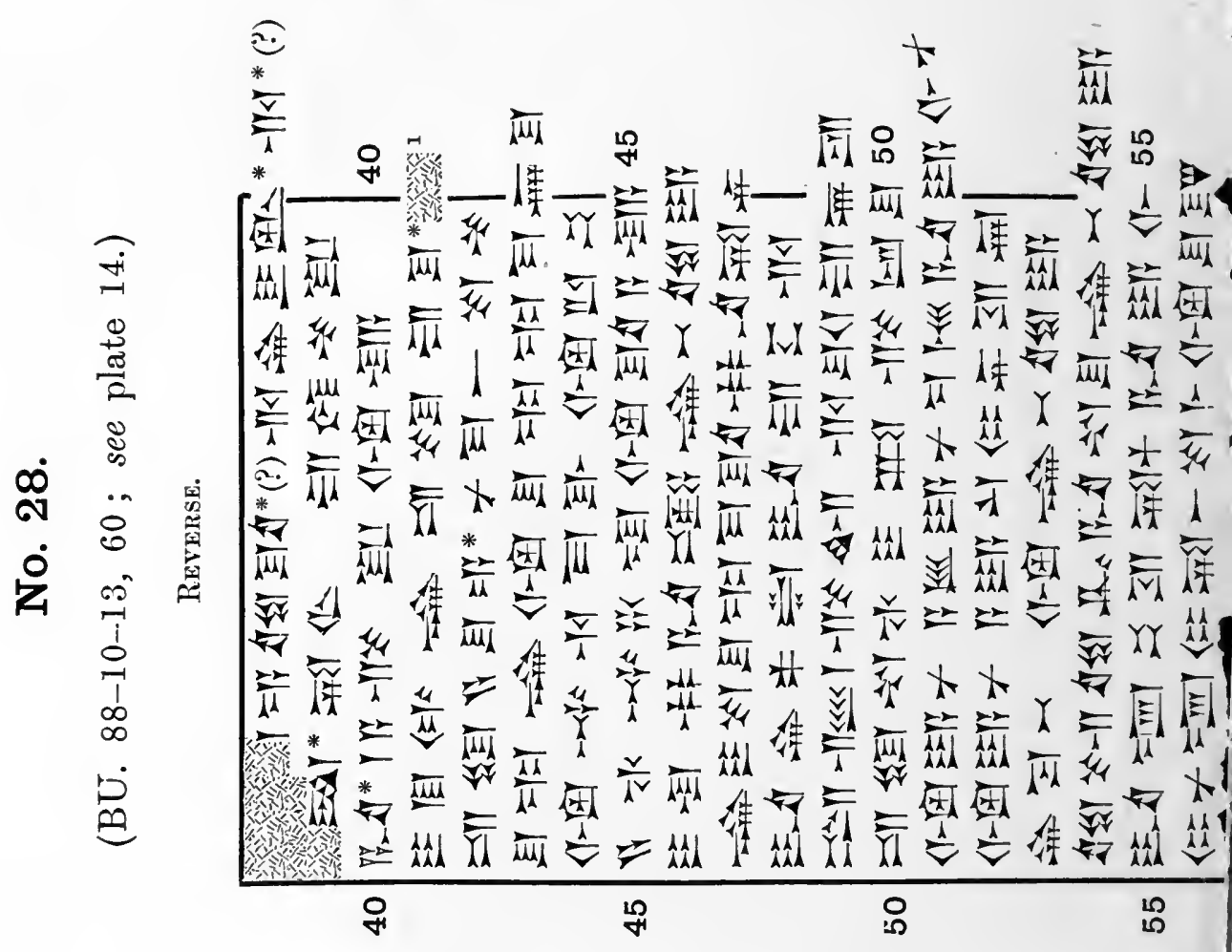




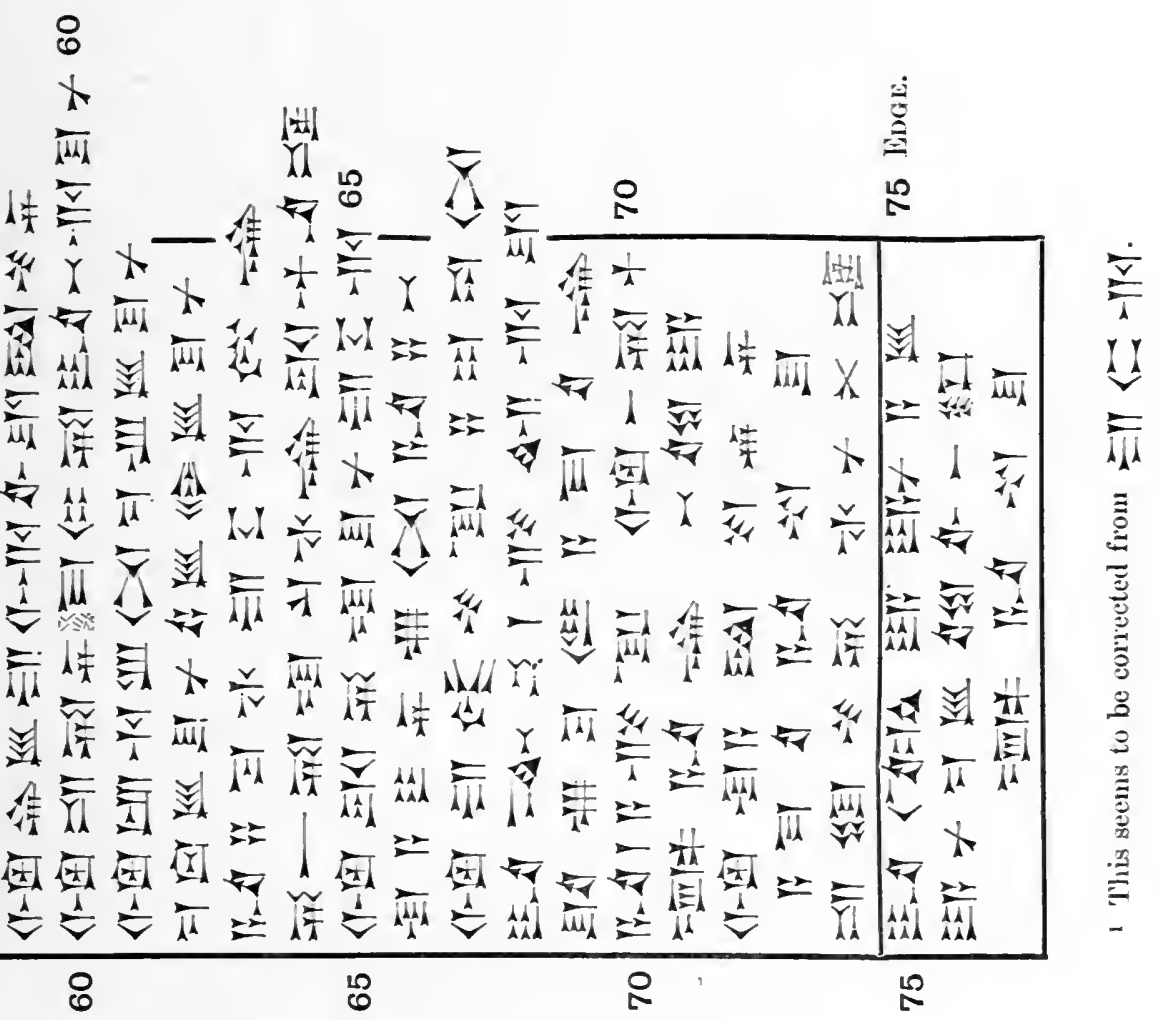




\section{No. 29.}

(BU. $88-18-13,51$; $3 \frac{1}{2}$ in. by $2 \frac{1}{4}$ in.)

ธิ

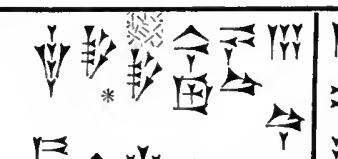

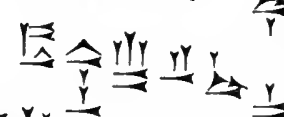

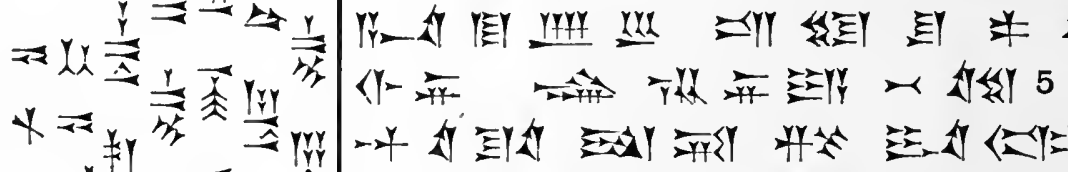

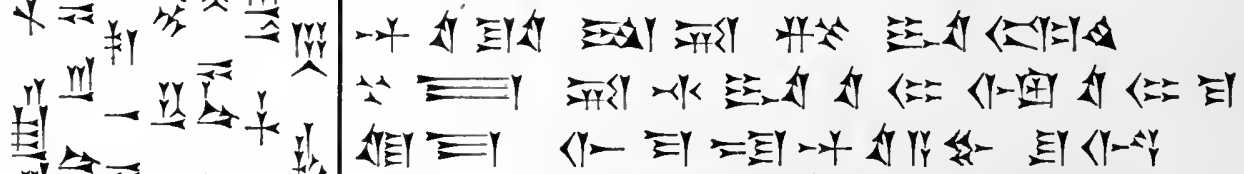

10

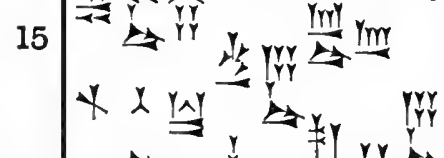

my $\Rightarrow$ Im

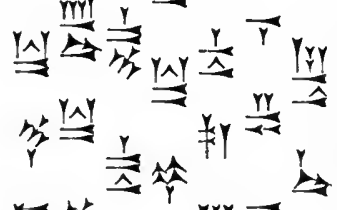

些等

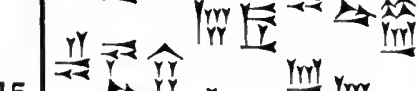

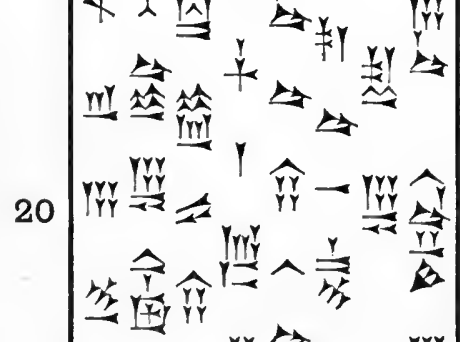

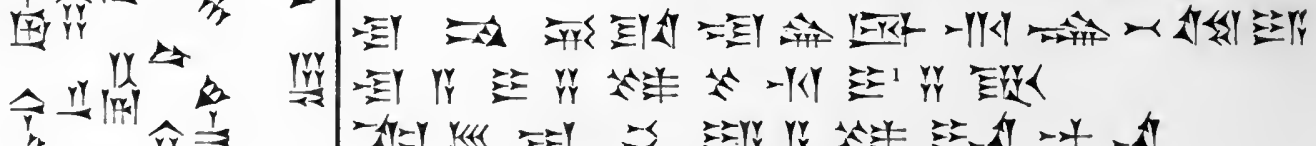

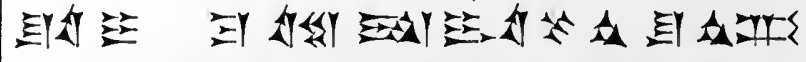

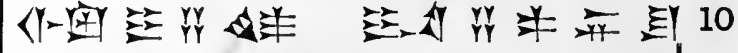

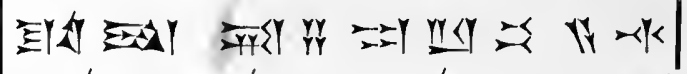

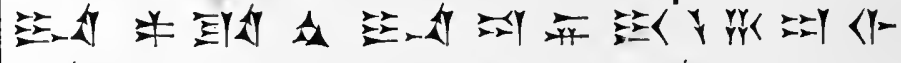

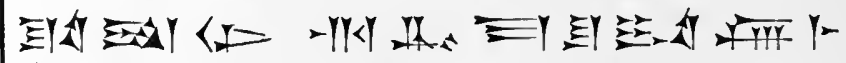

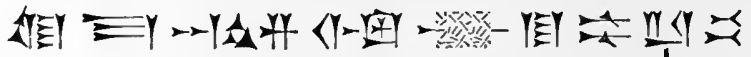

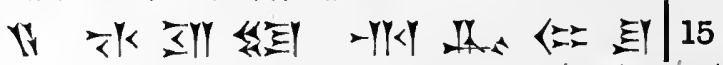

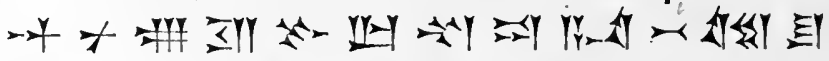

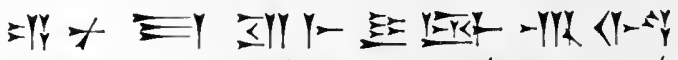

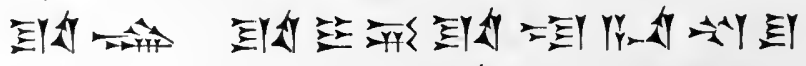

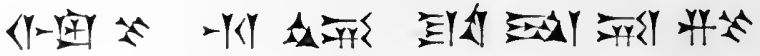

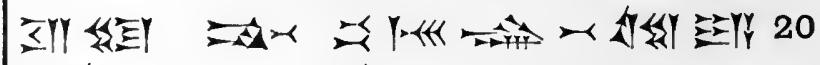

Yr.

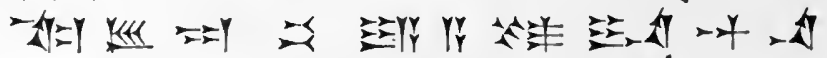

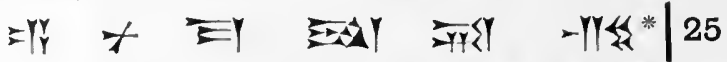

25

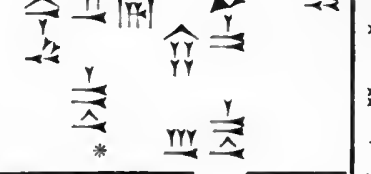

ธี

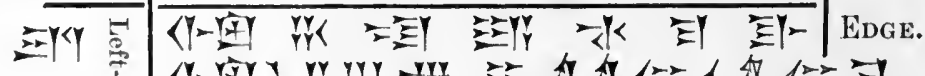

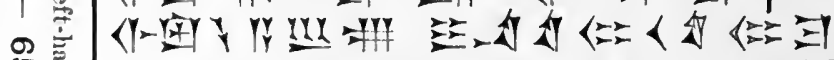

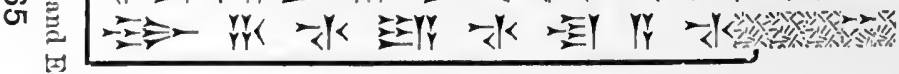


No. 29.

(BU. 88-10-13, 51; see plate 11.)

Reterse.

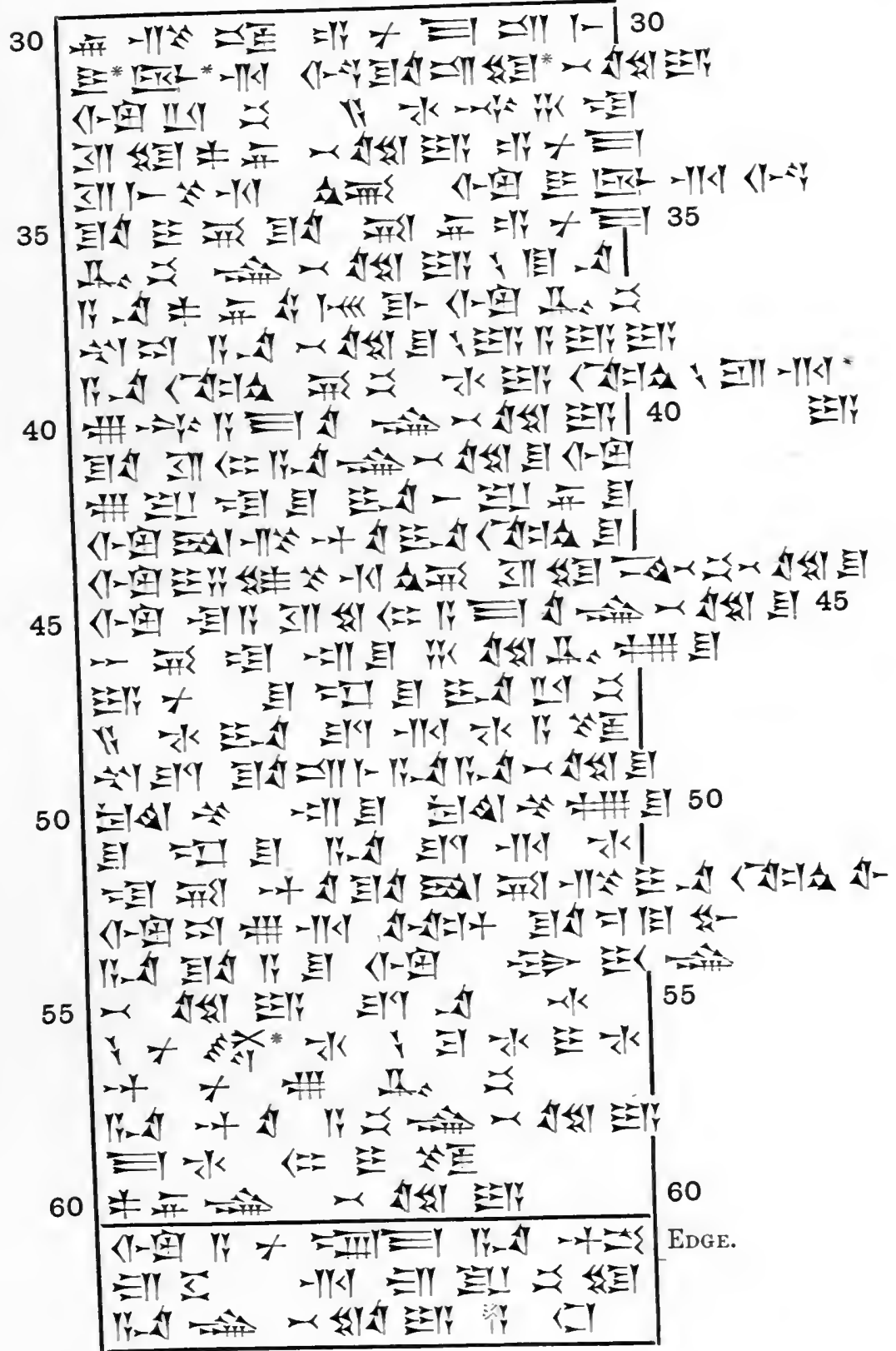




\section{No. 30.}

(BU. $88-10-13,56 ; 4 \frac{1}{2}$ in. by $2 \frac{1}{2} \mathrm{in}$.)

ธิ

OBverse.

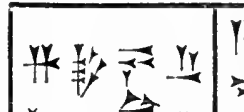

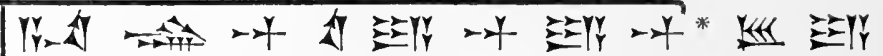

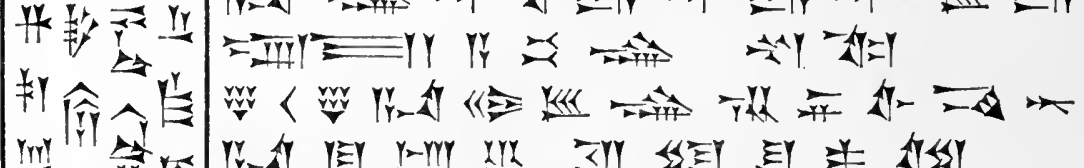

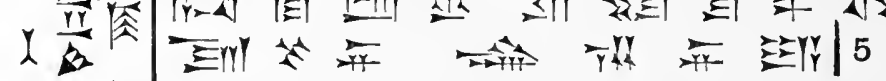

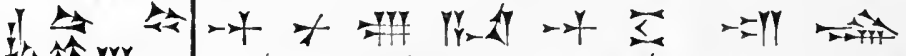

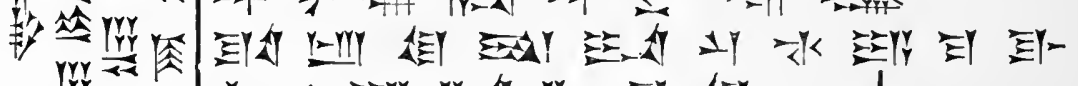

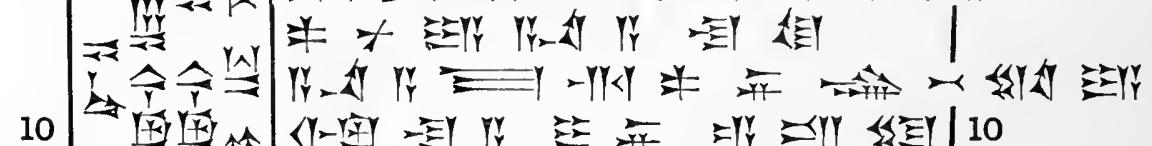

$\langle Y-$ 过

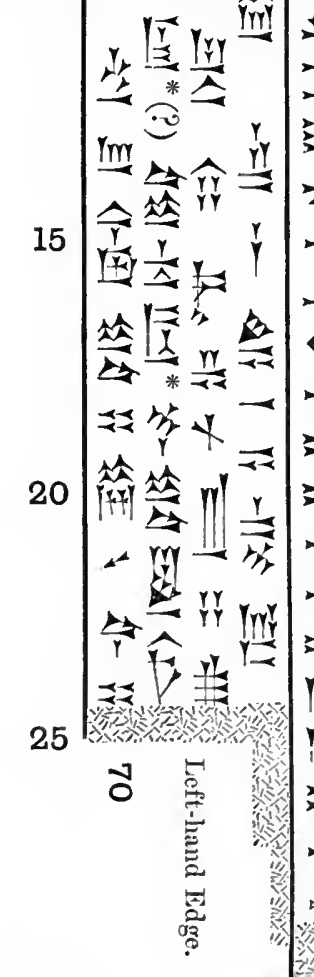

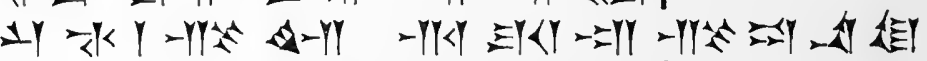

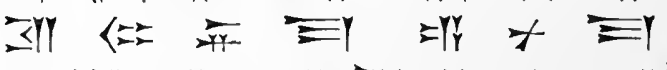

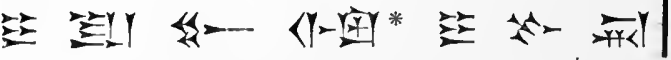

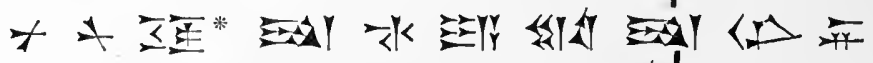

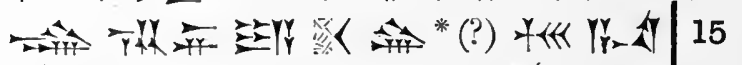

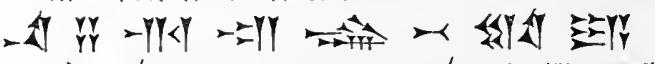

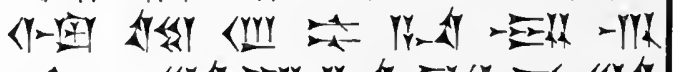

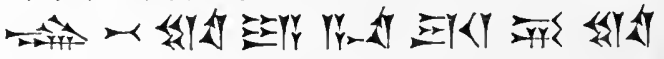

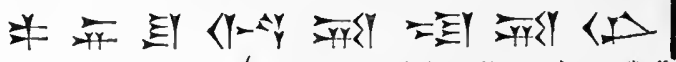

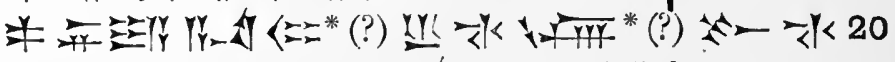

$\rightarrow$ r

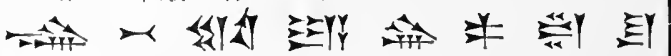

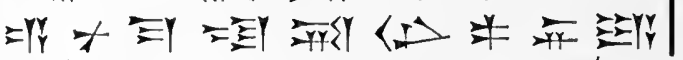

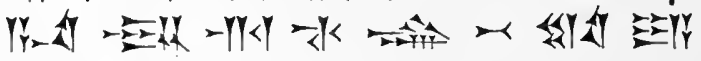

Yr $x$ Dry

30

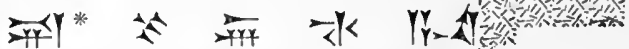

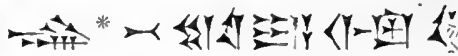

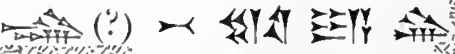

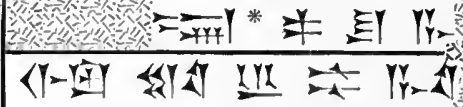

30. EDGE.

$\Rightarrow$ Trस 
No. 30.

(BU. 88-10-13, 56; see plate 13.)

Reverse.

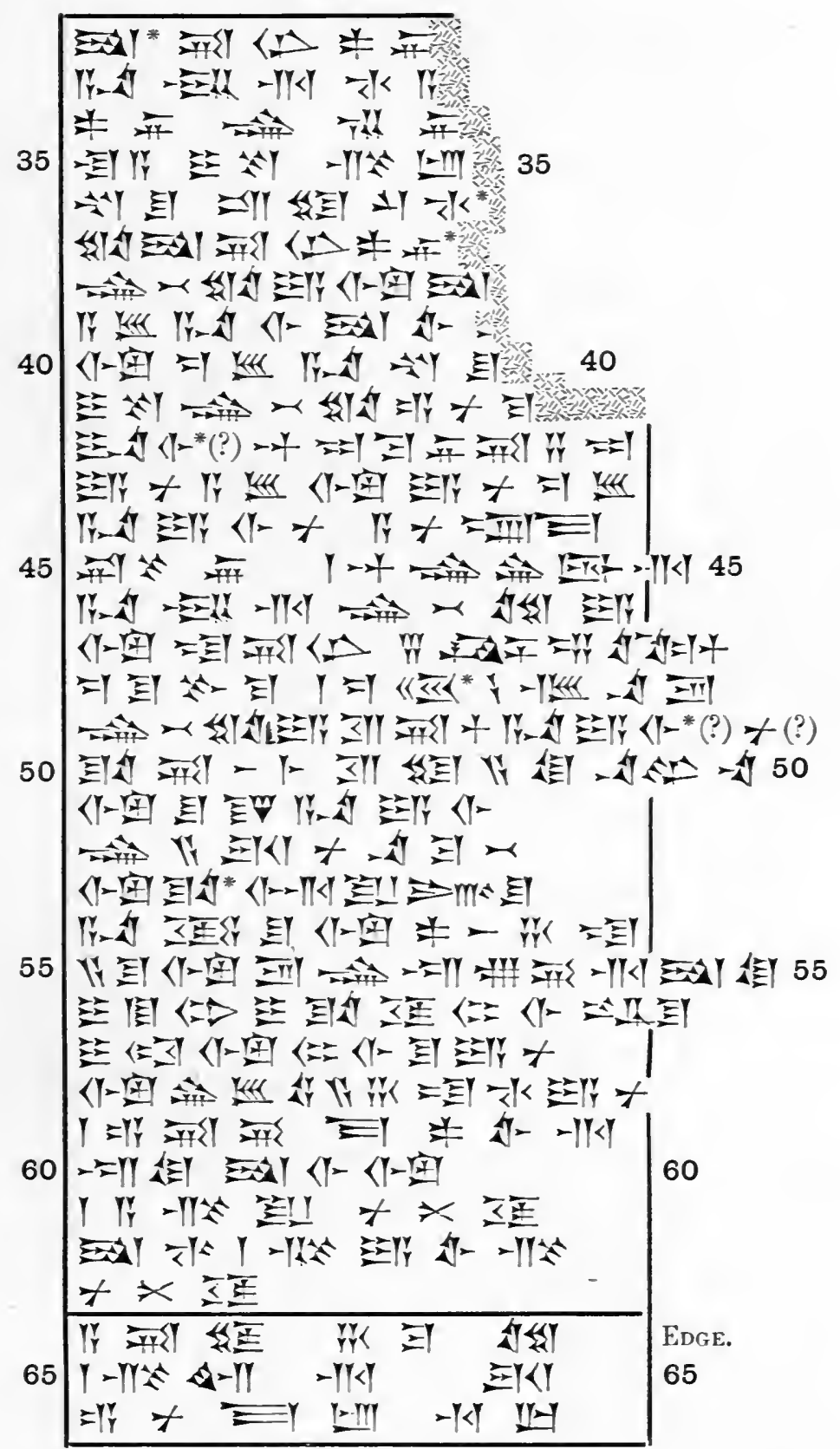


No. 31.

(BU. $88-10-13,26 ; 4$ in. by $2 \frac{1}{8}$ in.)

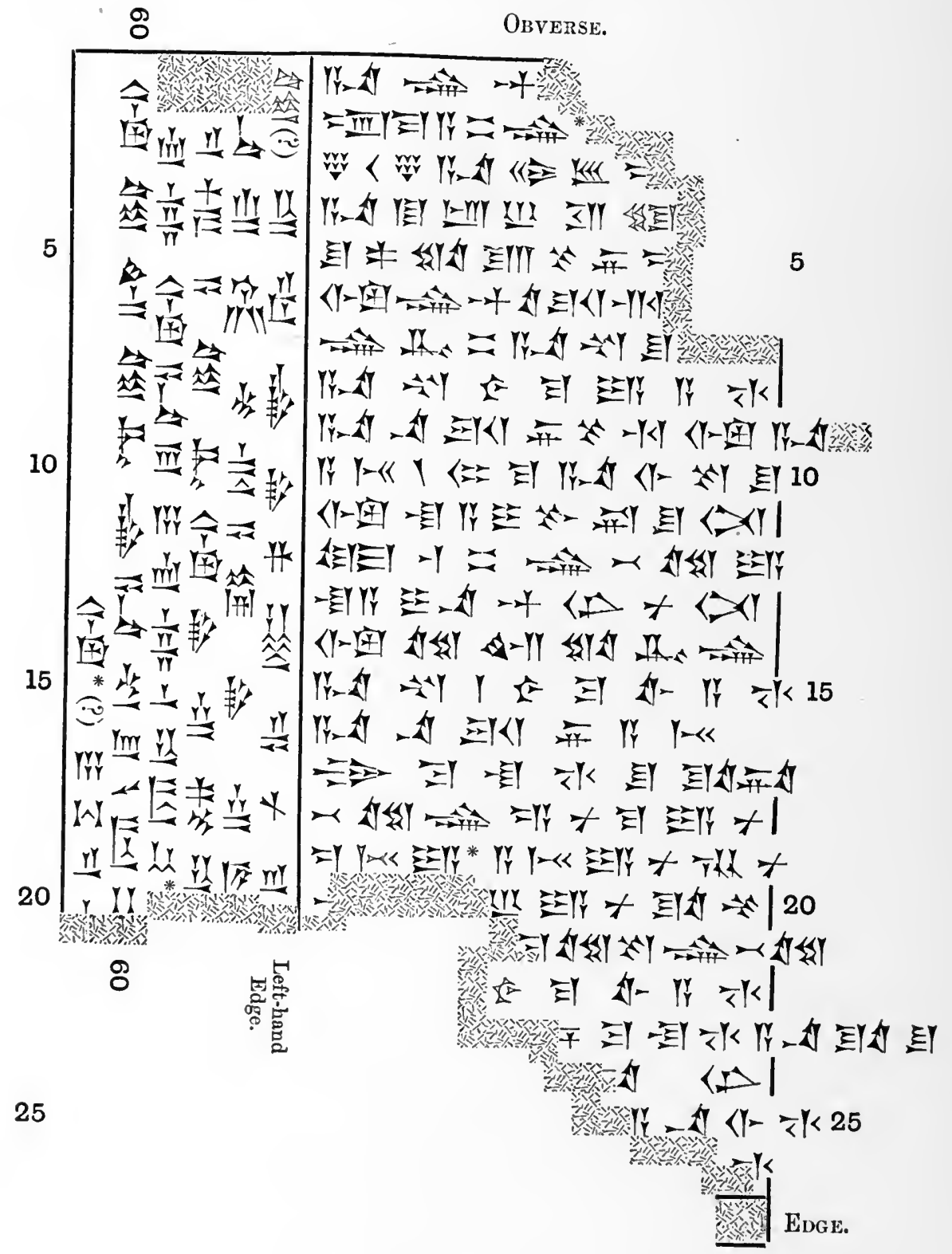




\section{No. 31.}

(BU. 88-10-13, 26.)

Reverse.

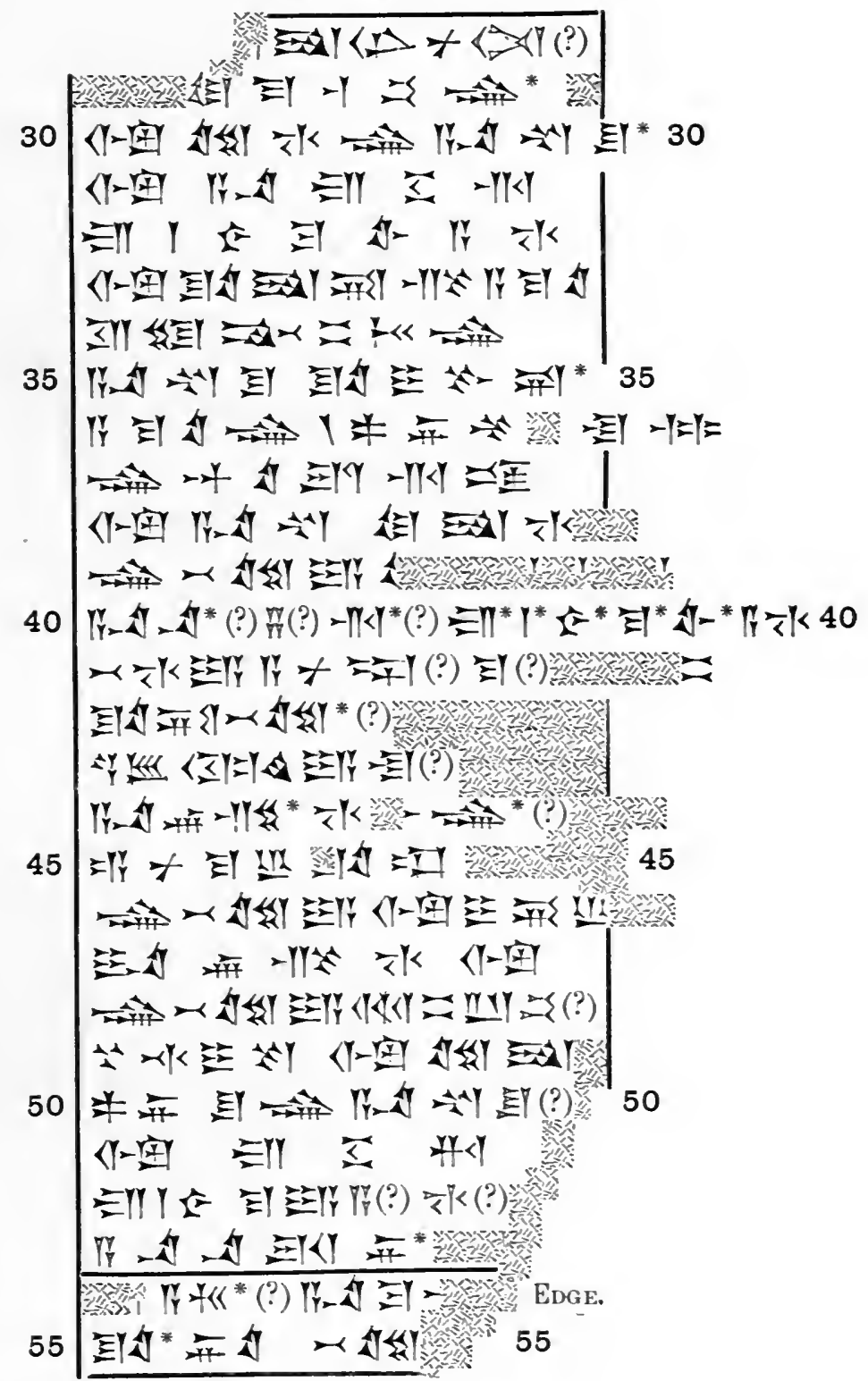


No. 32.

(BU. $88-10-13,20 ; 2 \frac{1}{2}$ in. by $2 \frac{1}{2}$ in. ; see plate 6. )

OBverse.

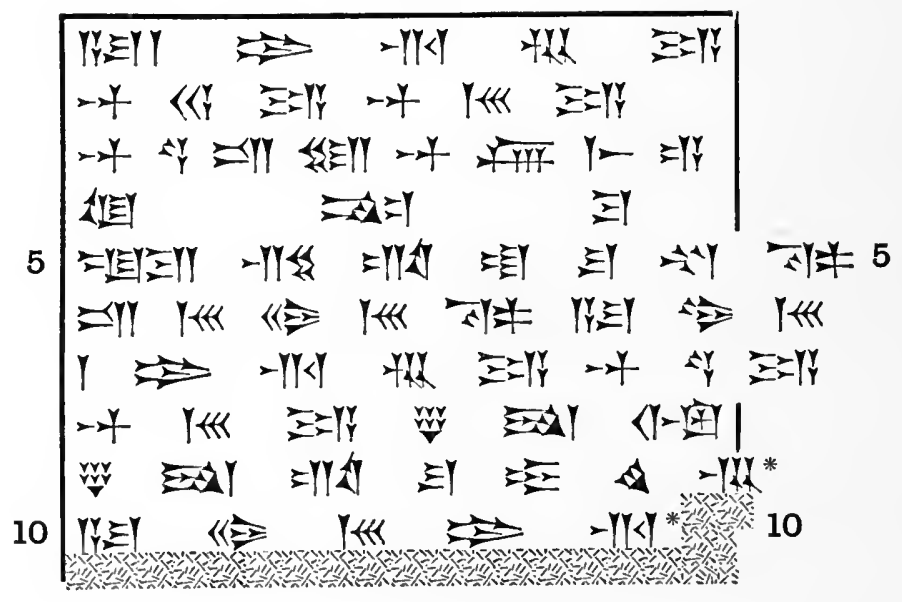

(Reverse blank.) 
No. 33.

(BU. $88-10-13,49 ; 3 \frac{3}{8}$ in. by $2 \frac{5}{8}$ in. ; see plate 11.)

ObTerse.

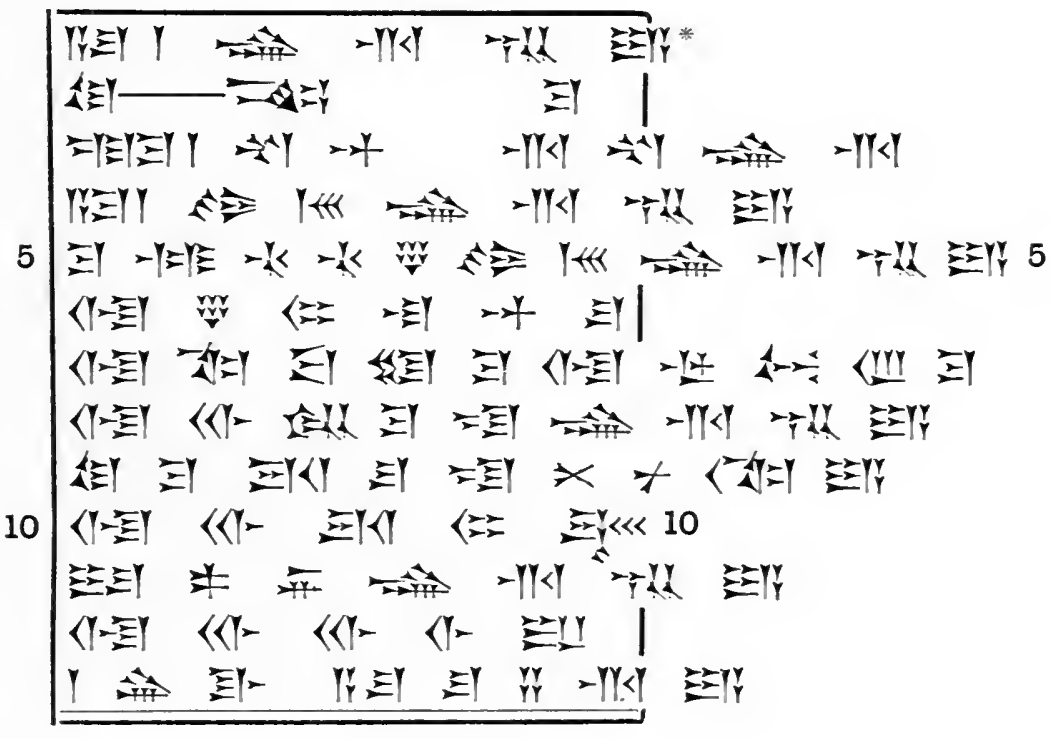

Reverse.

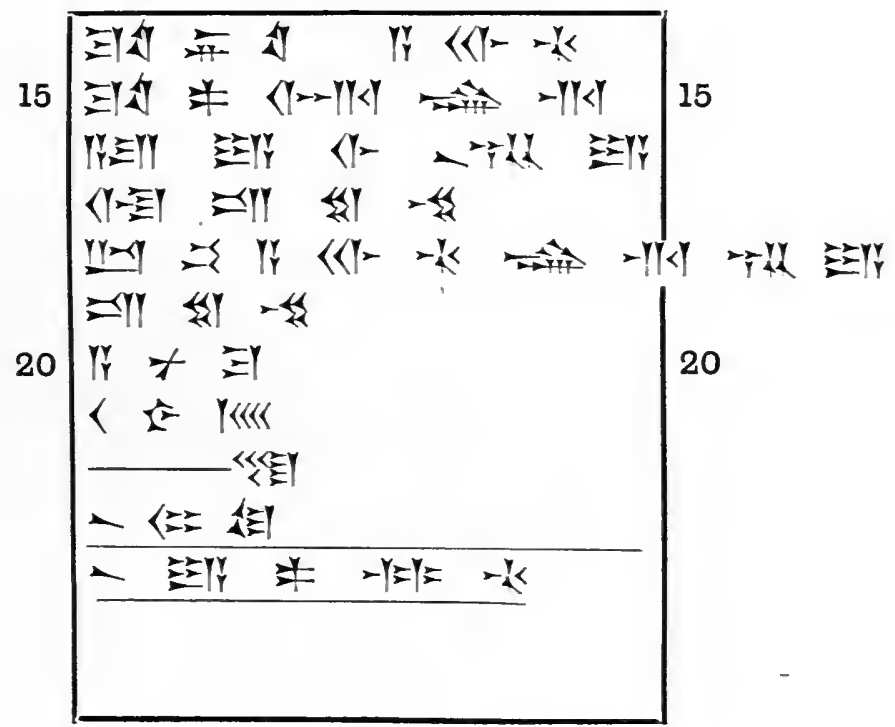





\section{No, 34 .}

(BU. $88-10-13,62 ; 3 \frac{1}{8}$ in. by $2 \frac{1}{2}$ in. ; sce plate 15.)

Obverse.

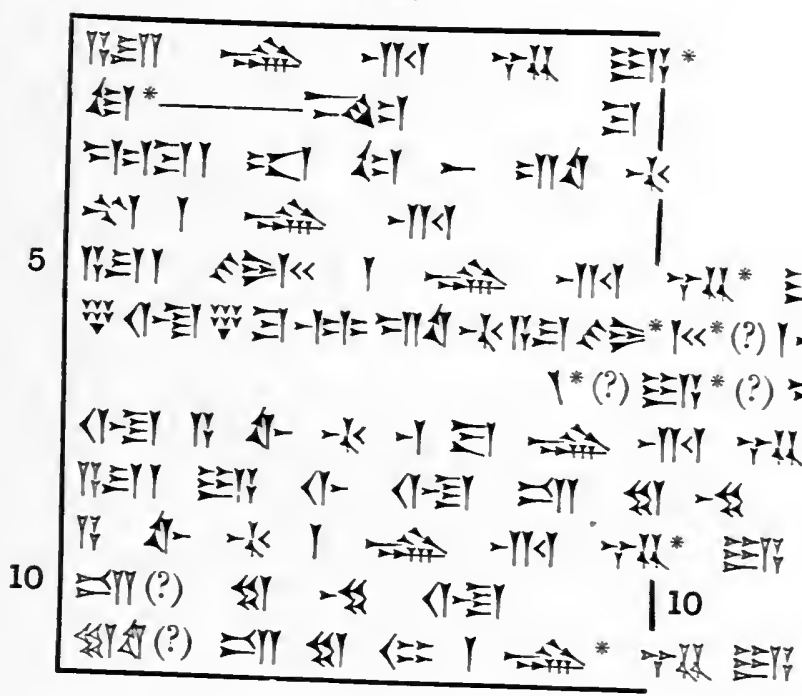

Reverse.

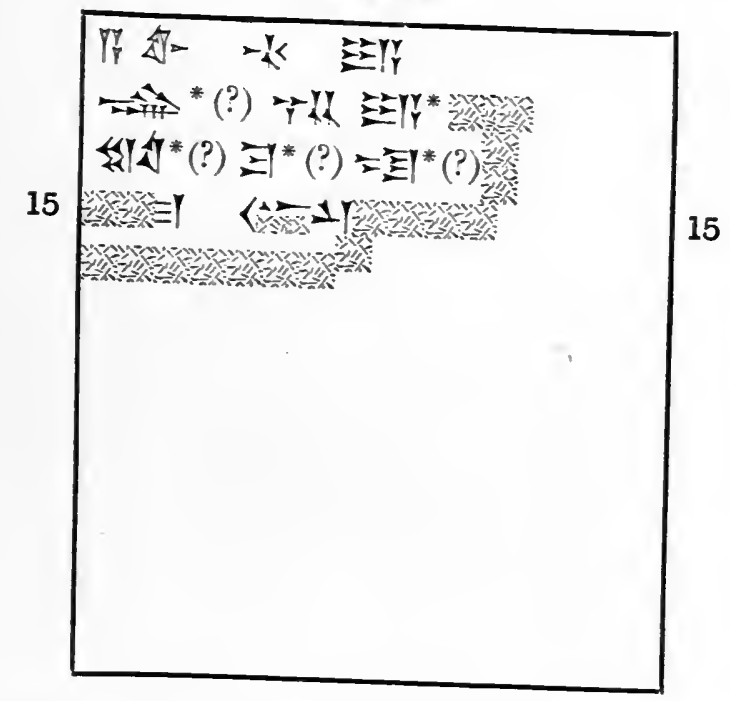

1 This line is much defaced, and the readings of many of the characters are doubtful. 


\section{No. 35.}

(BU. $88-10-13,76 ; 5 \frac{1}{4}$ in. by $3 \frac{1}{4}$ in.)

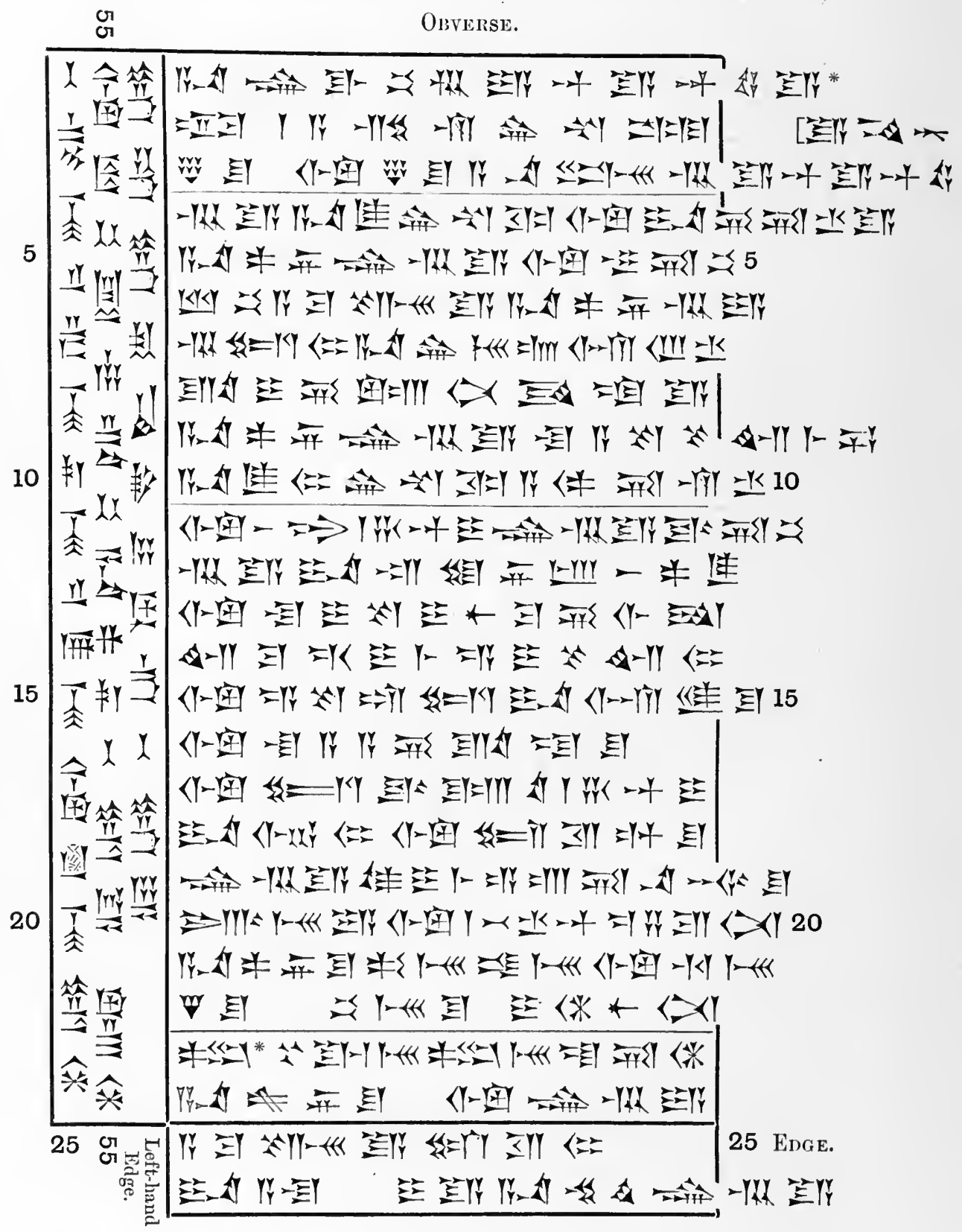


No. 35.

(BU. 88-10-13, 76 ; see plate 22.)

Reverse.

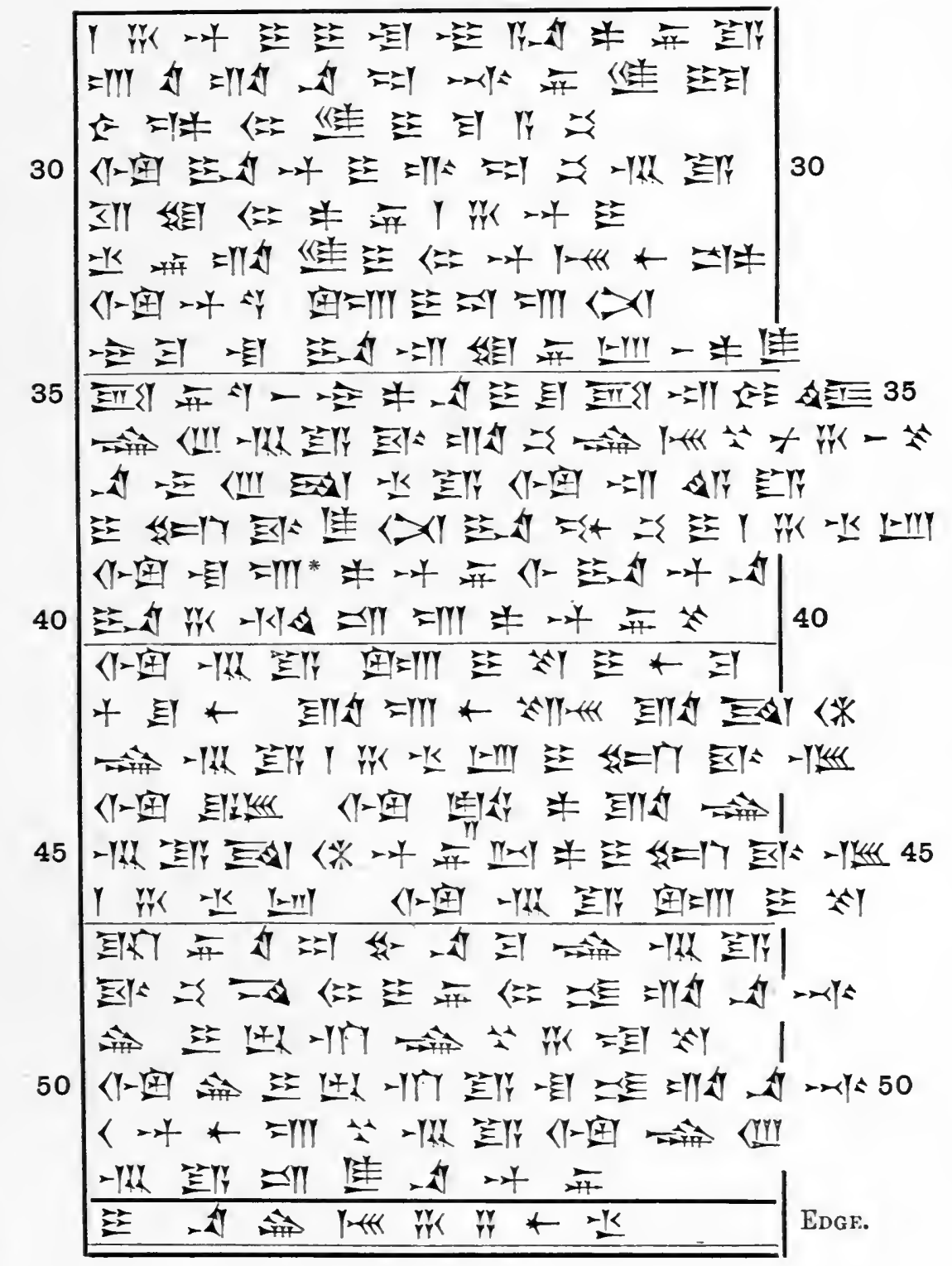


No. 36.

(BU. $88-10-13,55 ; 4 \frac{1}{4}$ in. by $3 \frac{1}{8}$ in.)

Obverse.

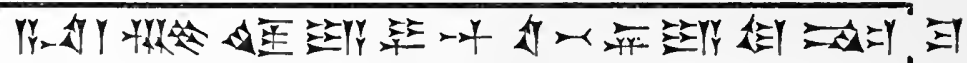

=IITYY Y Y

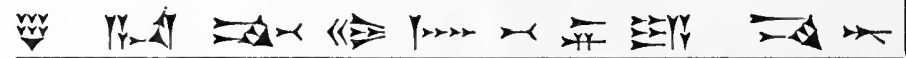

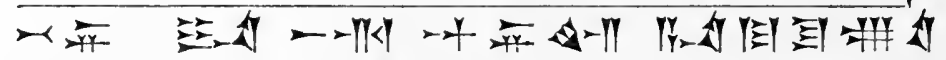

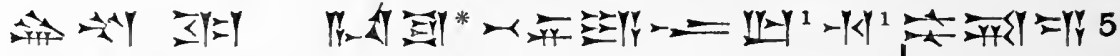

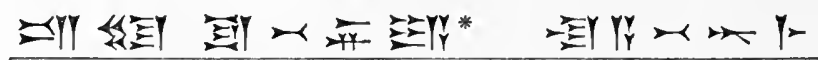

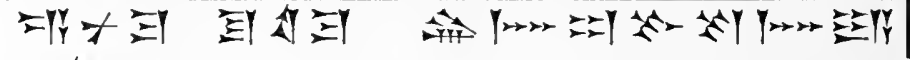

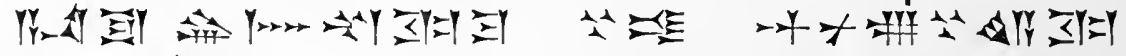

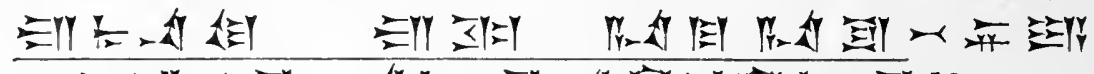

出要

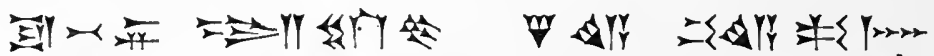

ZE

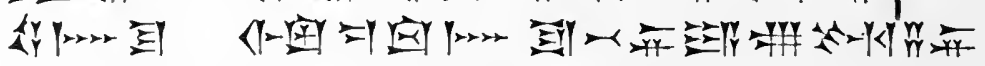

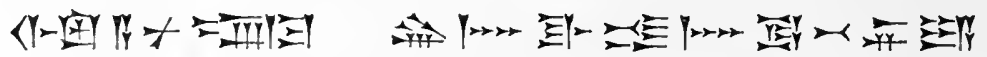

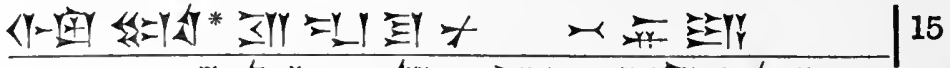

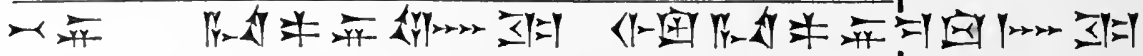

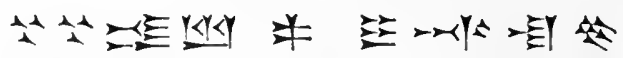

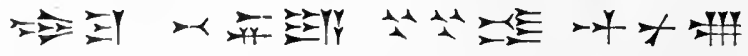

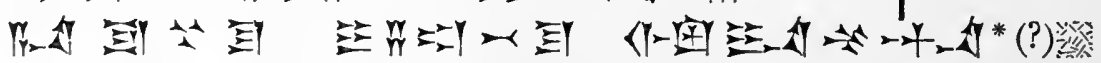

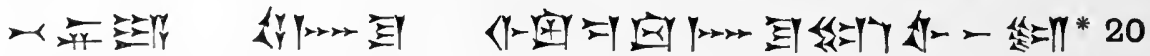

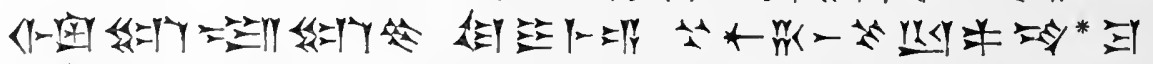

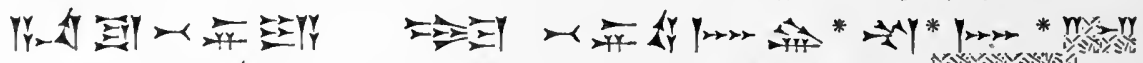

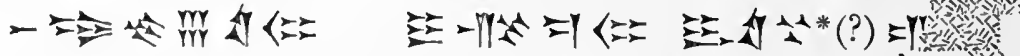

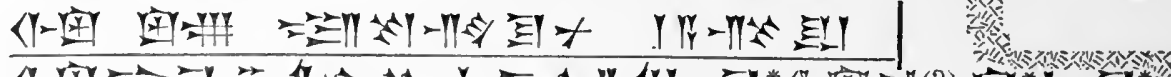

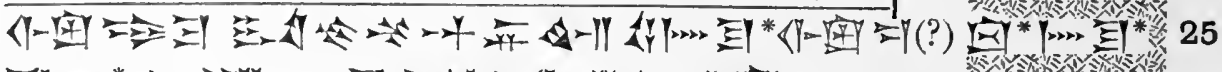

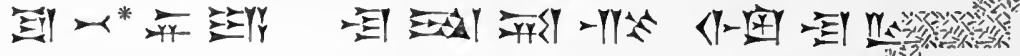

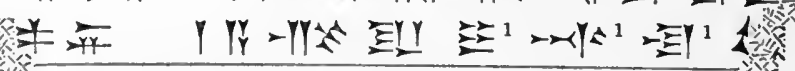


No. 36.

(BU. 88-10-13, 55.)

Reverse.

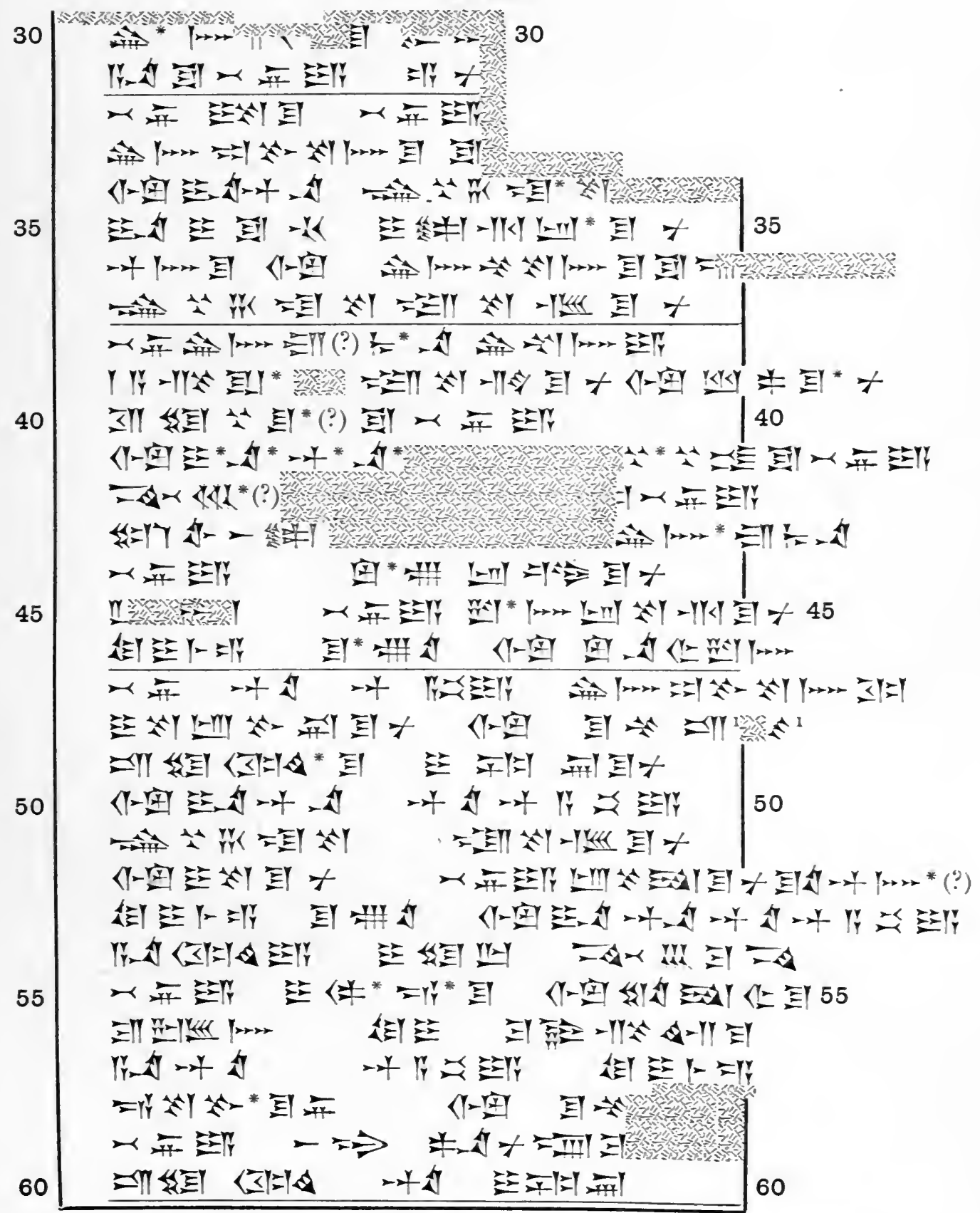

I Erased by the scribe, who probably intended to write EIY \&EY here. 


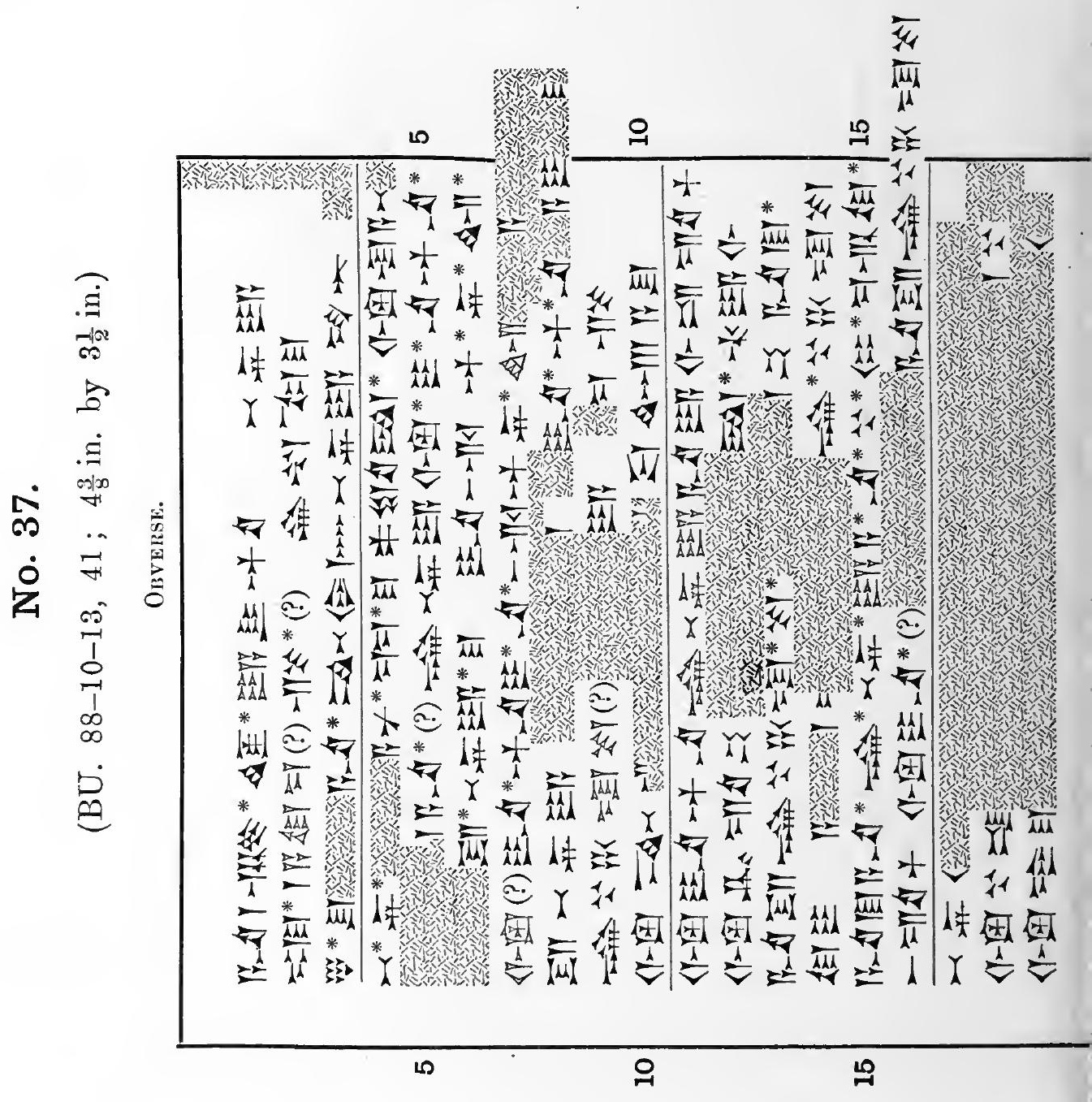




\section{No. 37.}

(BU. 88-10-13, 41.)

REVERSE.

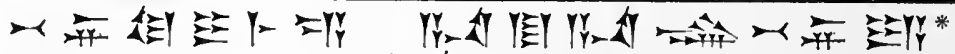

ry

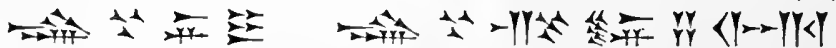

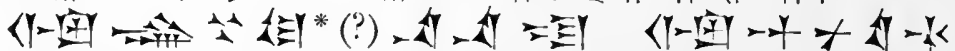

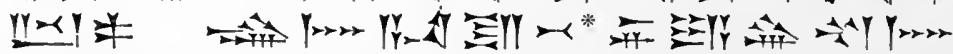

作些F=

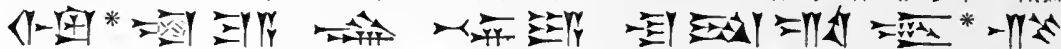

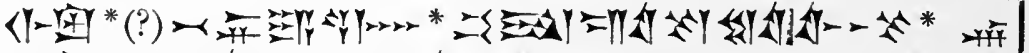

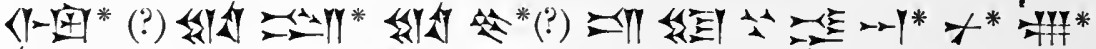

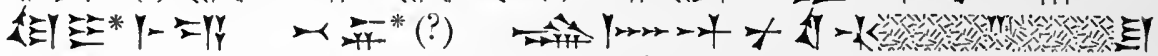

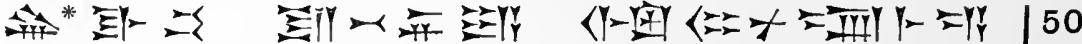

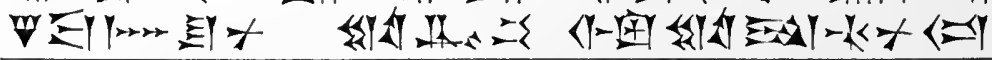

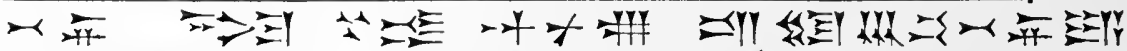

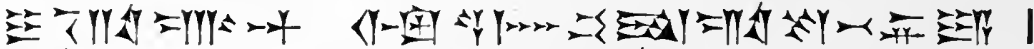
然出出-

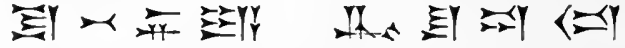

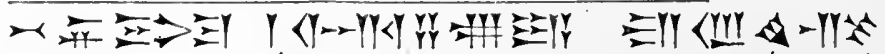

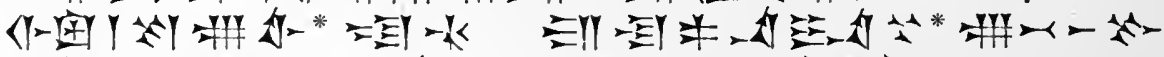

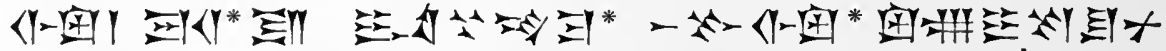

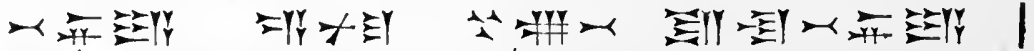

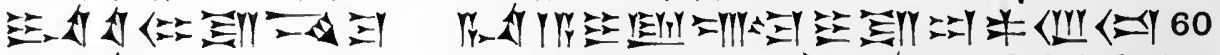

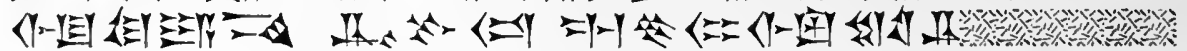

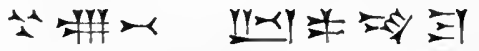

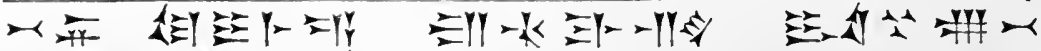
Y.4 r.

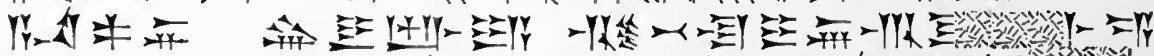

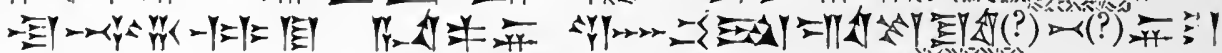

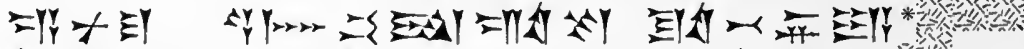

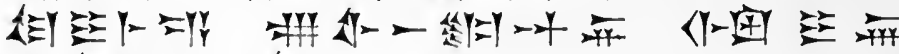
E. 
LETTERS FROM SHUBANDI.

79

No. 38.

(BU. $88-10-13,6 ; 3 \frac{3}{8}$ in. by $2 \frac{7}{8}$ in.)

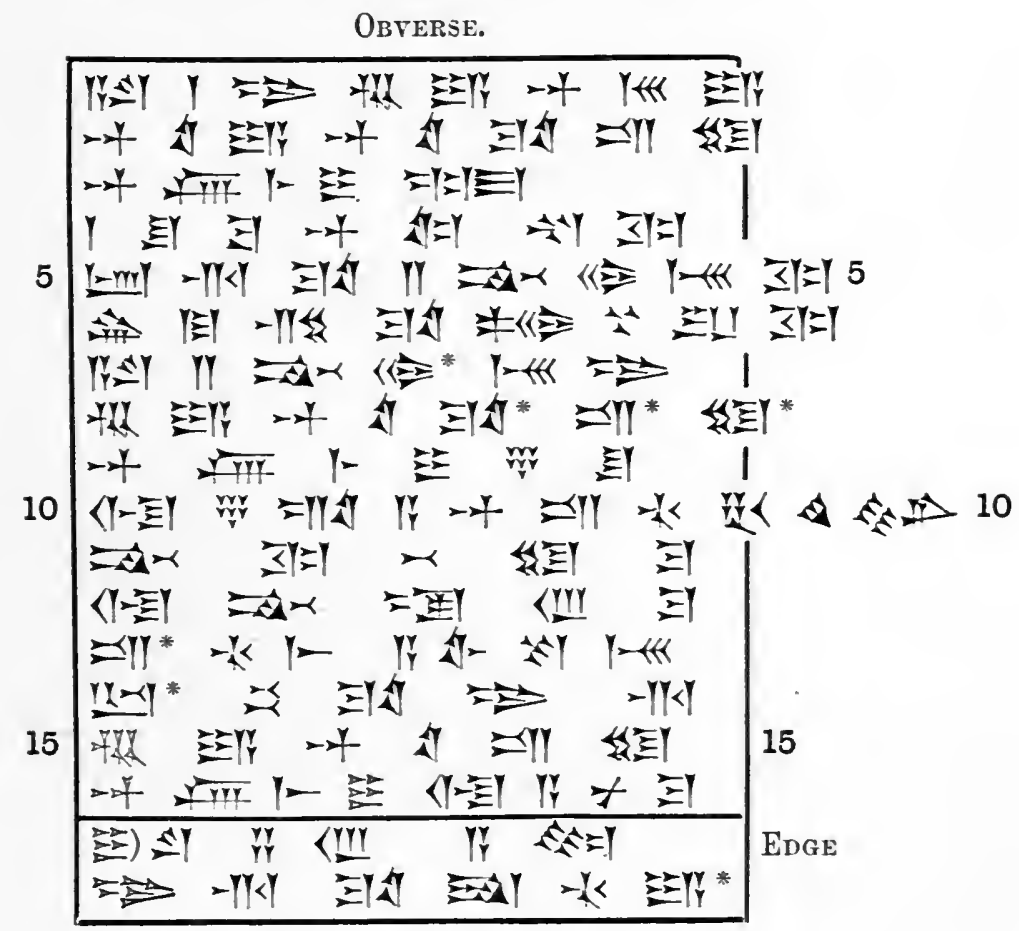

Reverse.

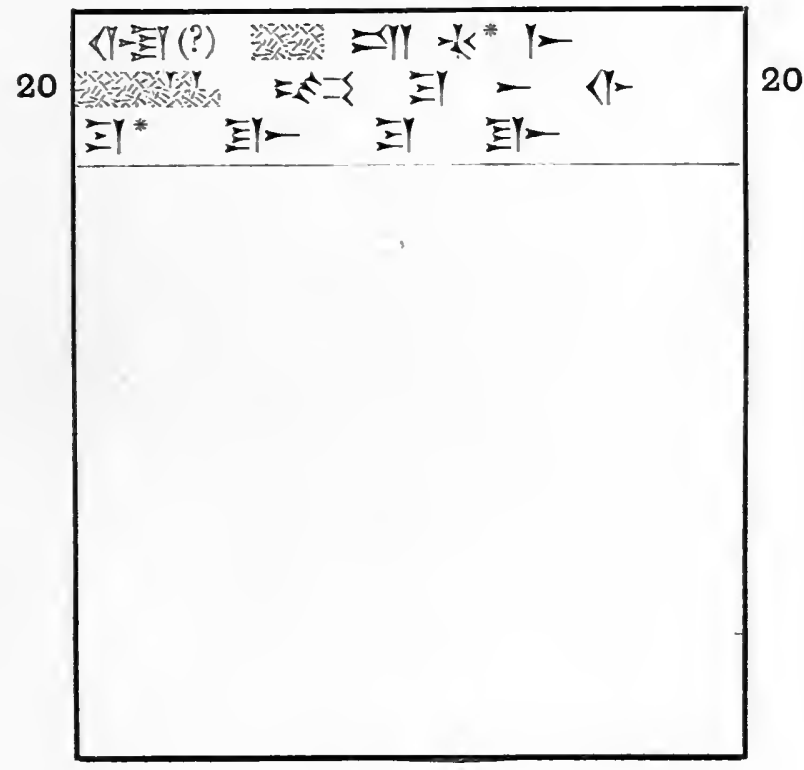


No. 39.

(BU. $88-10-13,52 ; 3 \frac{3}{4}$ in. by $2 \frac{5}{8}$ in.)

Obverse.

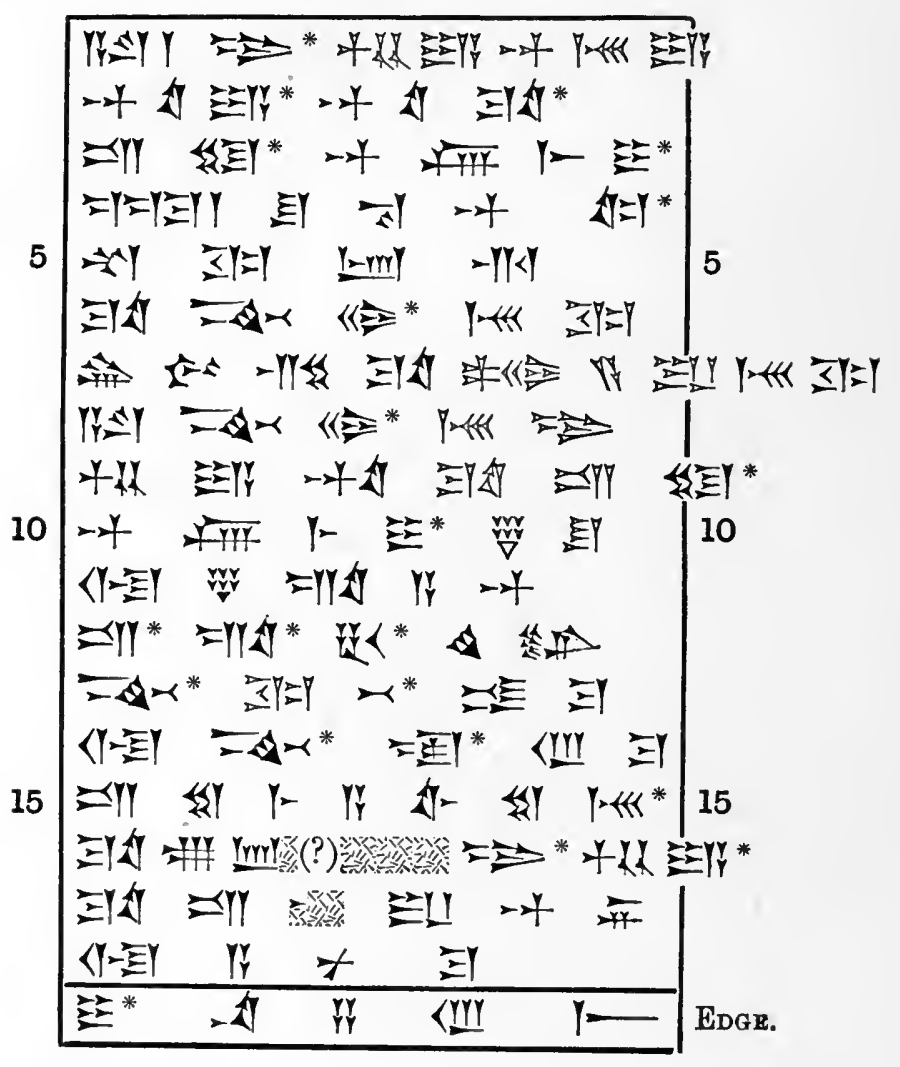


No. 39.

(BU. 88-10-13, 52 ; see plate 12.)

Reverse.

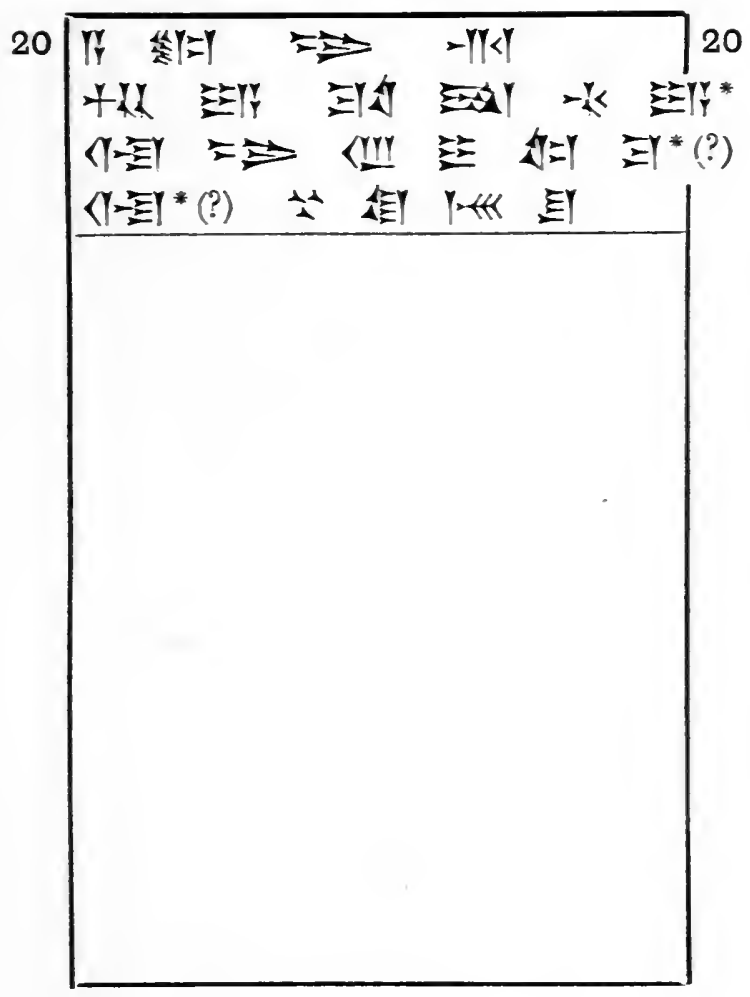


No. 40.

(BU. $88-10-13,3 ; 4$ in. by $2 \frac{7}{8}$ in.)

Obverse.

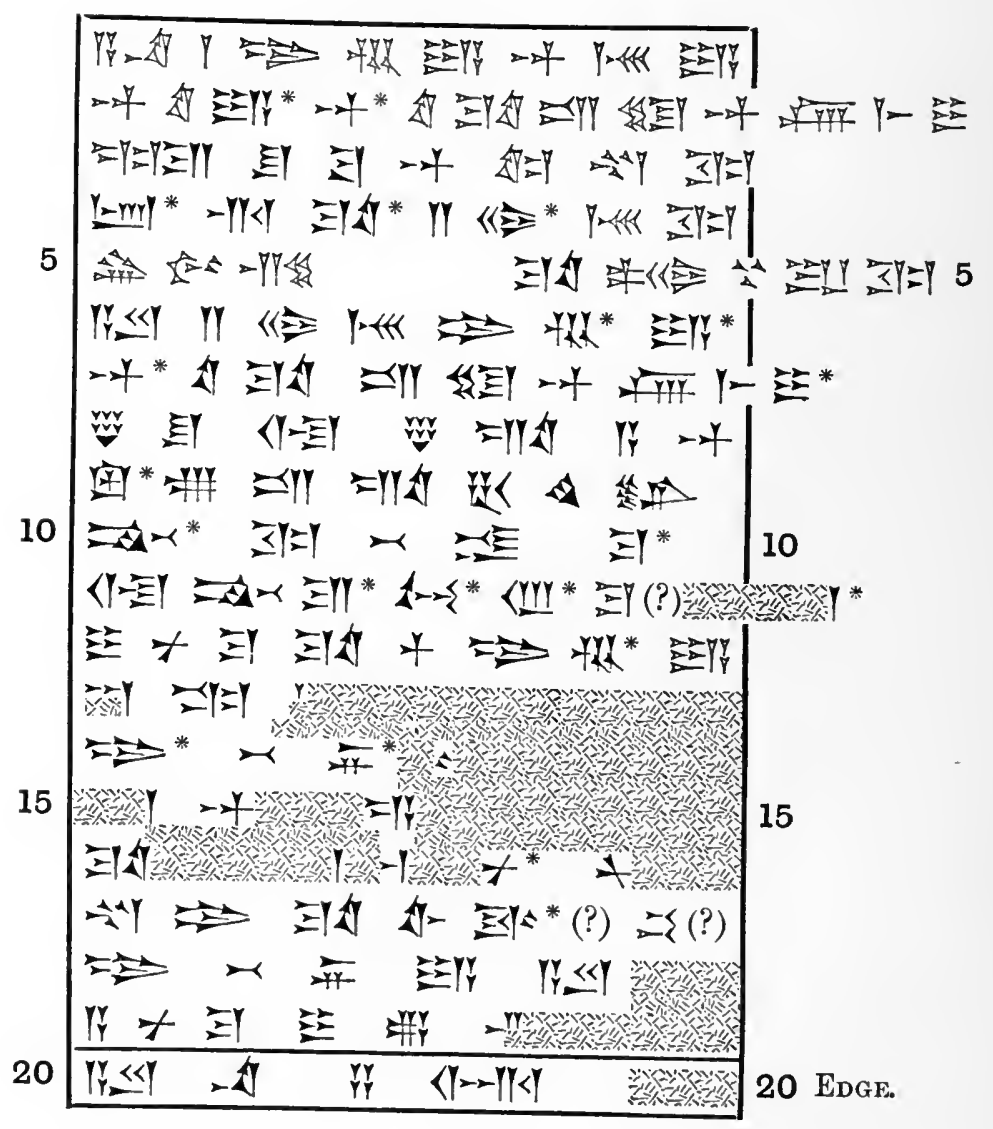


No. 40 .

(BU. 88-10-13, 3.)

Reverse.

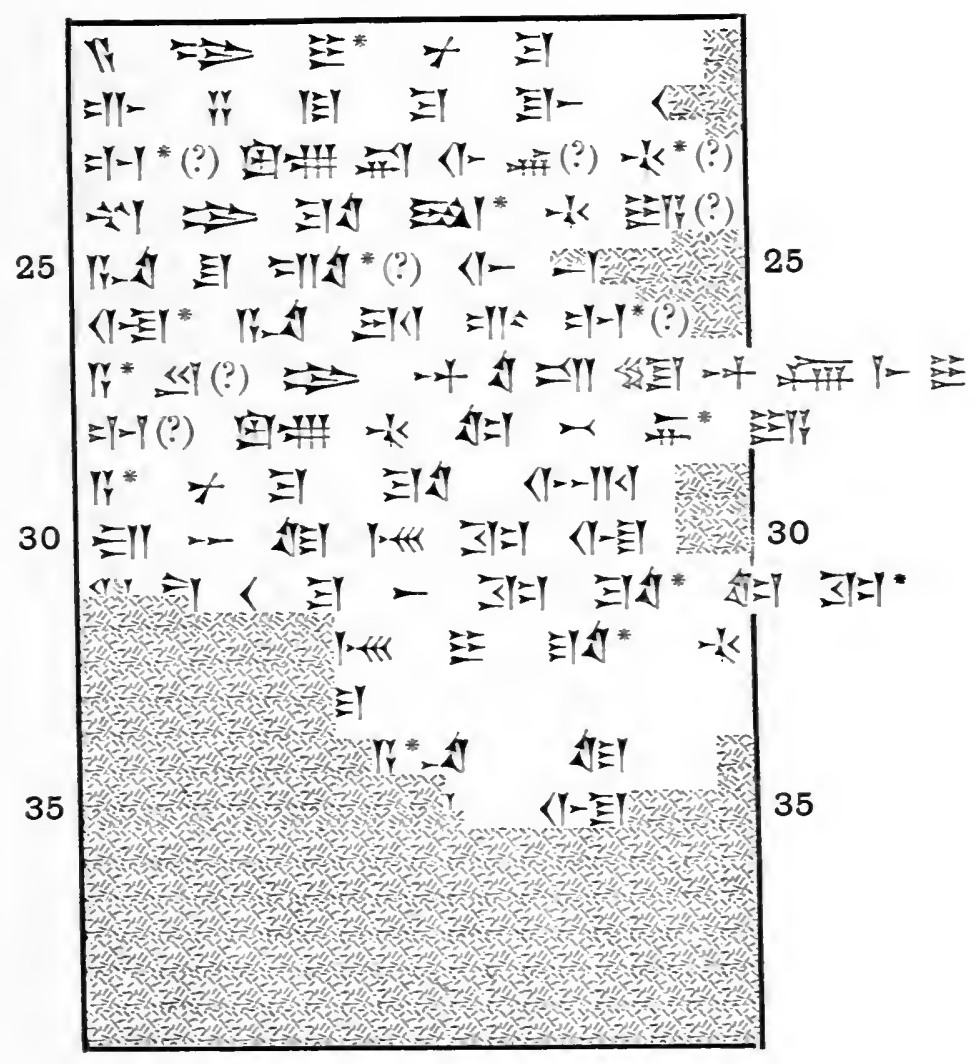




\section{No. 41.}

\section{(BU. $88-10-13,71 ; 4 \frac{1}{2}$ in. by $3 \frac{1}{4}$ in.)}

OBVERSE.

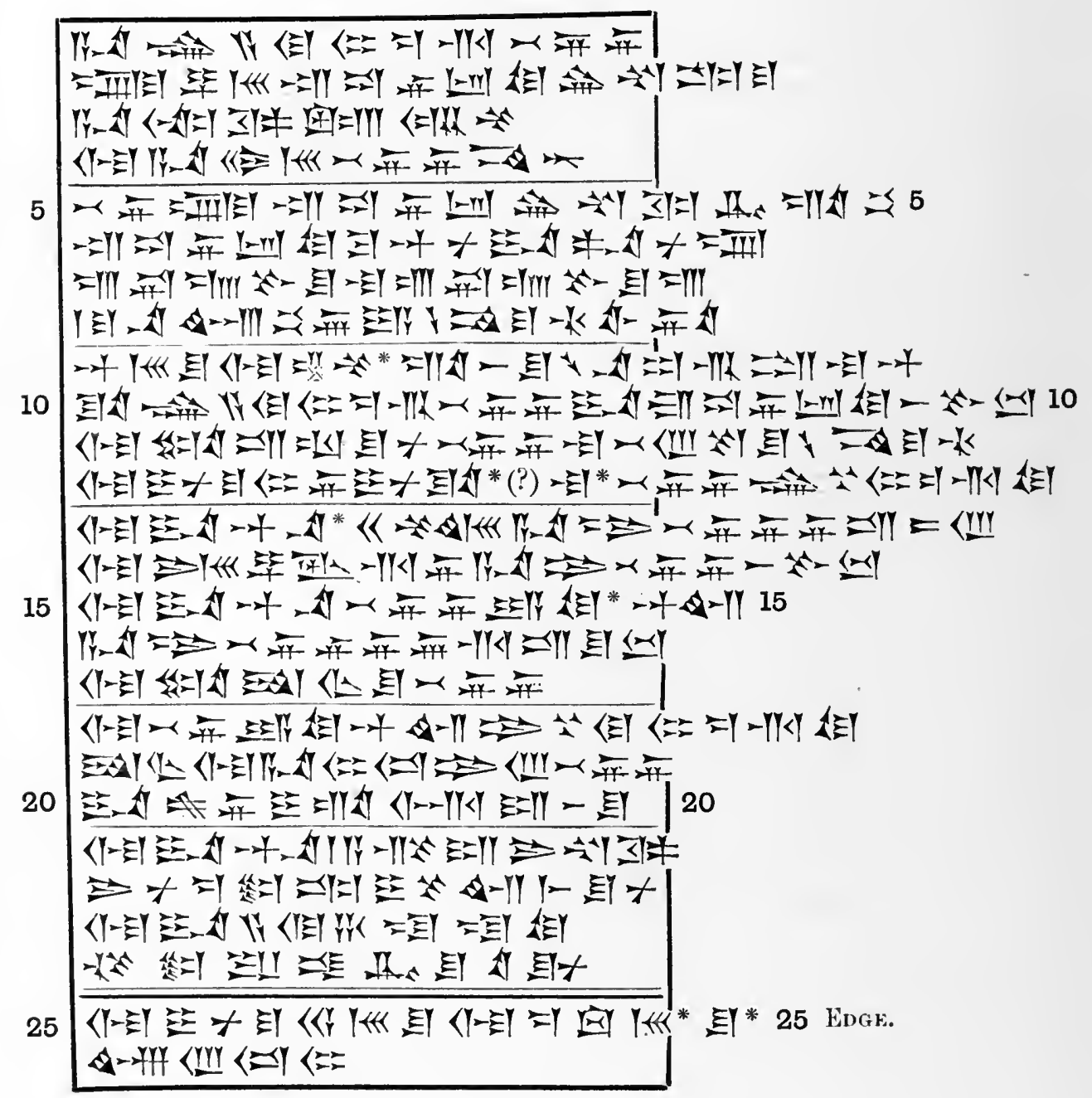




\section{No. 41.}

(BU. 88-10-13, 71.)

Reverse.

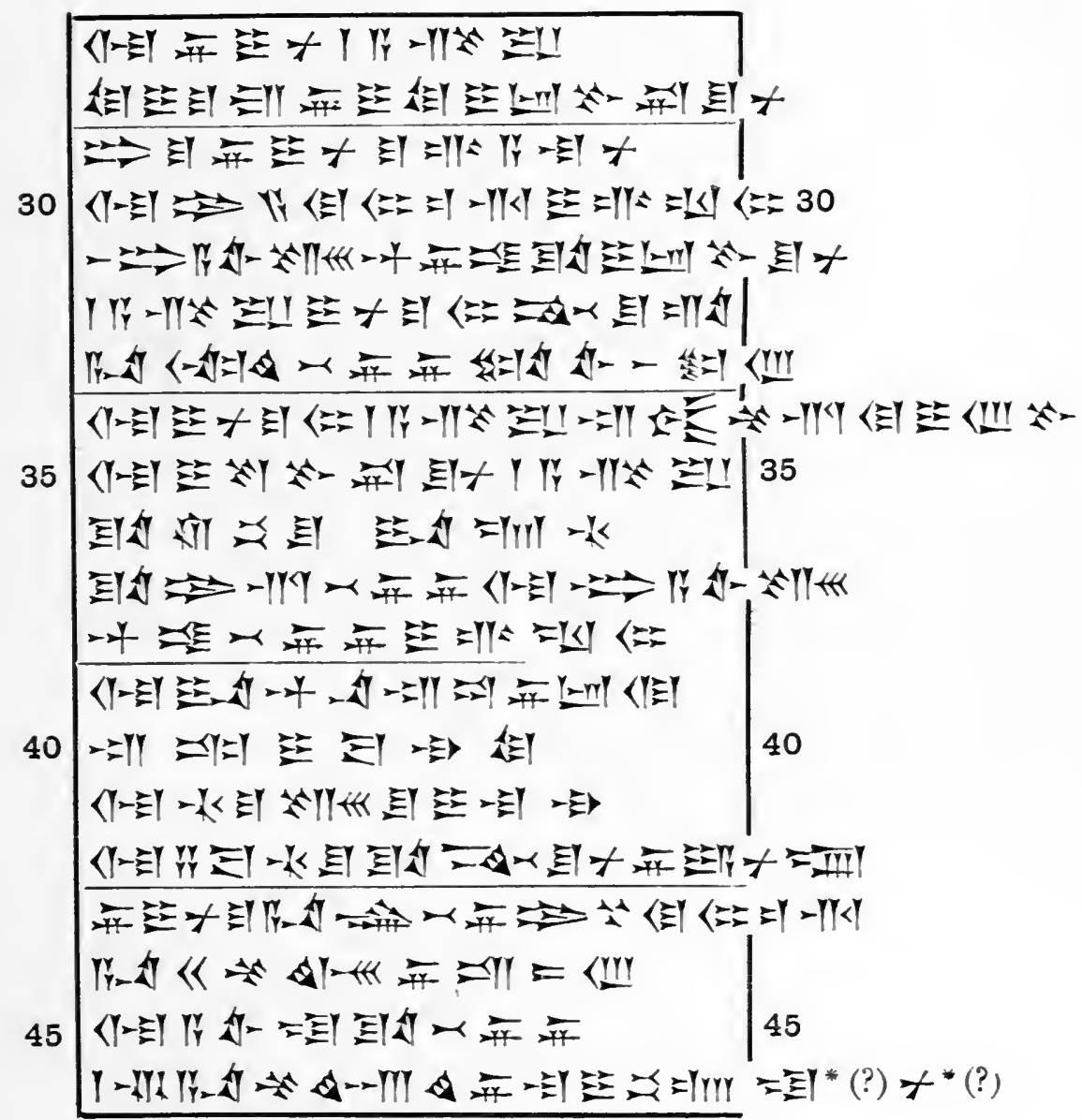




\section{No. 42.}

(BU. $88-10-13,13 ; 3 \frac{3}{8}$ in. by $2 \frac{1}{2}$ in.)

OBVERSE.

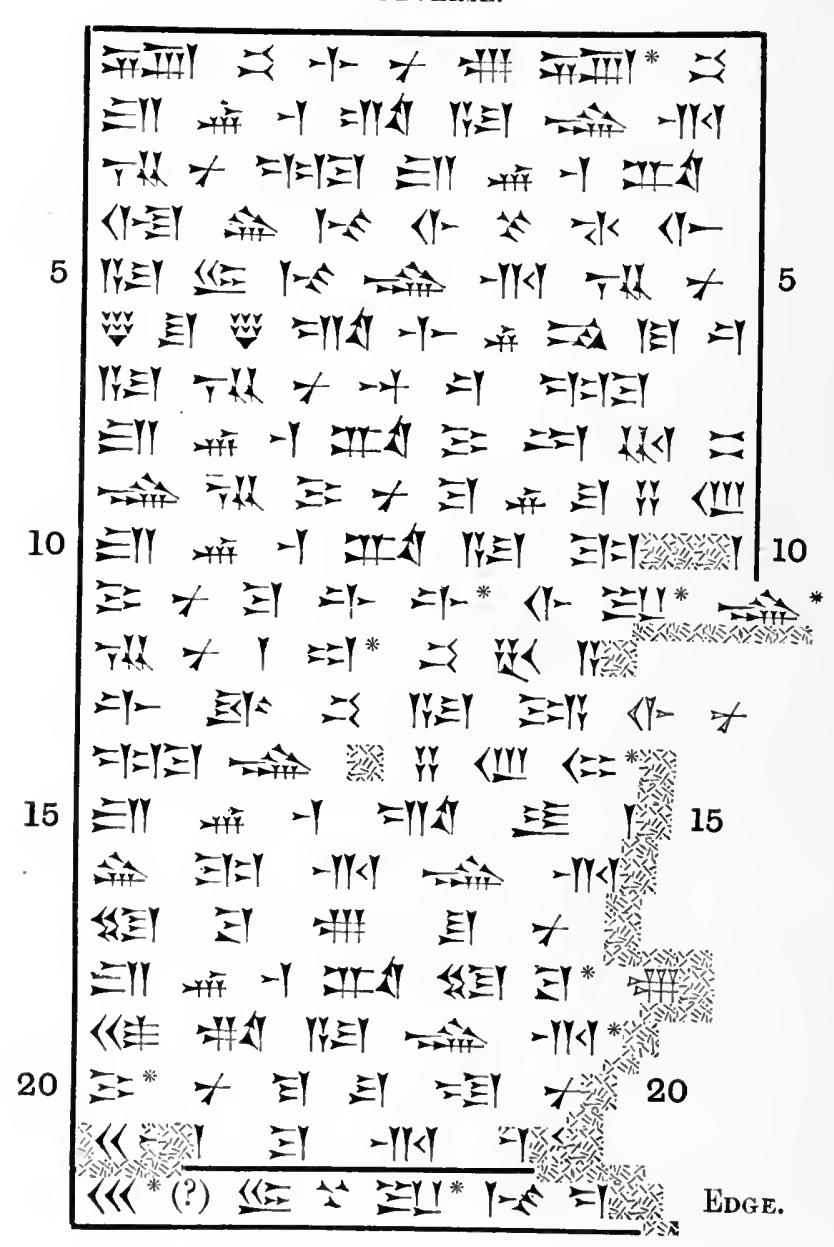


No, 42.

(BU. 88-10-13, 13; see plate 4.)

REverse.

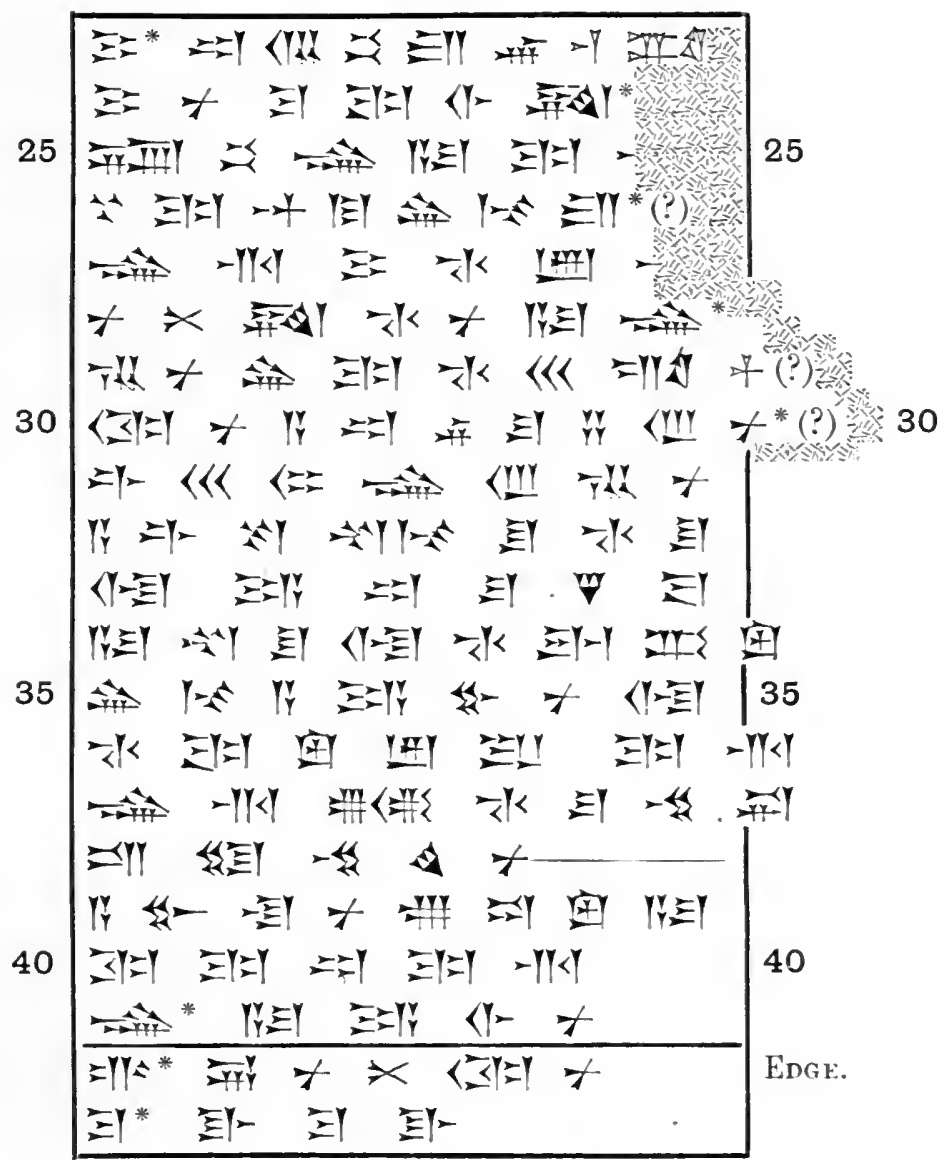




\section{No. 43.}

(BU. $88-10-13,11 ; 3 \frac{5}{8}$ in. by 3 in.)

ObVerse.

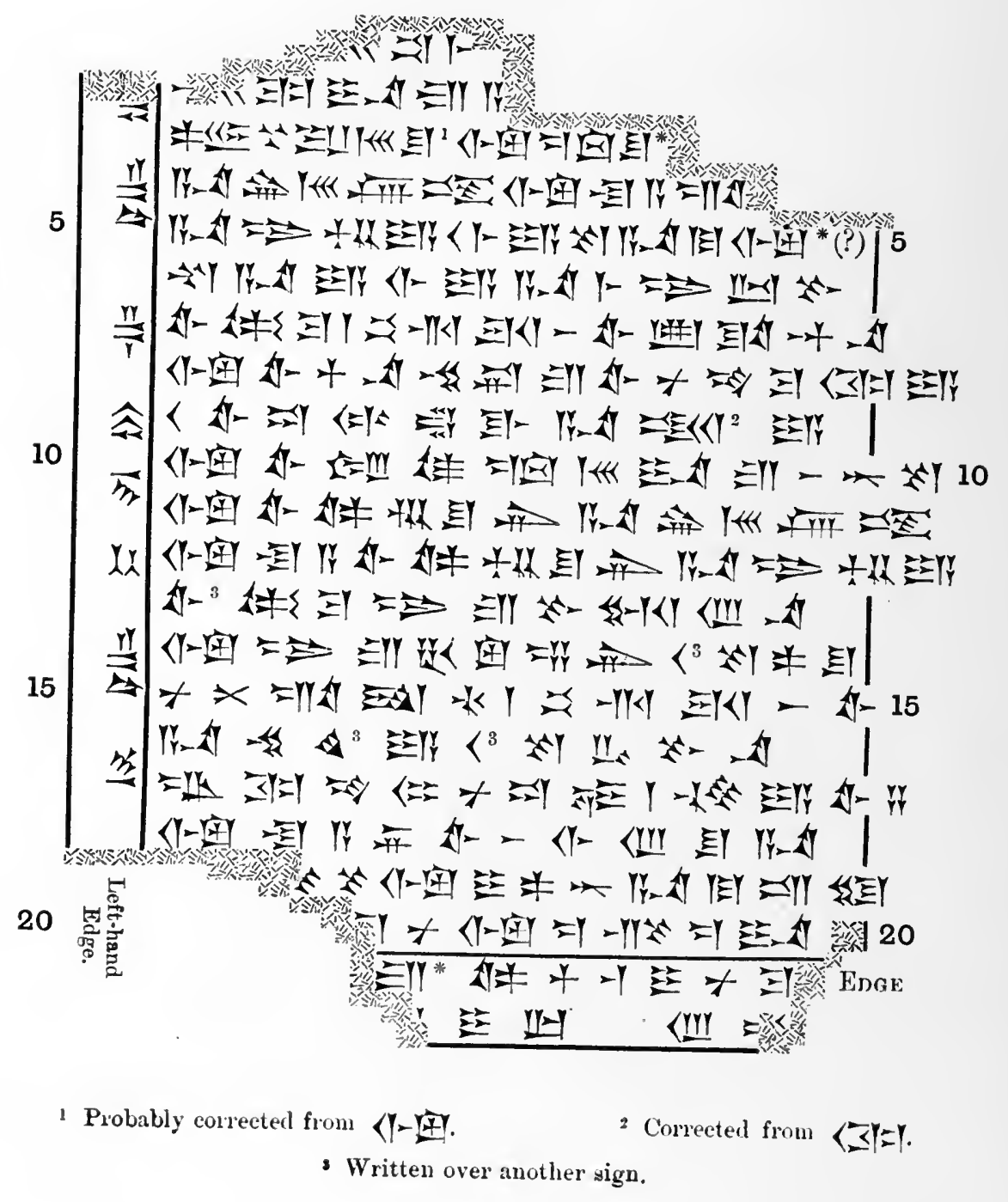


No. 43.

(BU. 88-10-13, 11; see plate 3.)

Reverse.

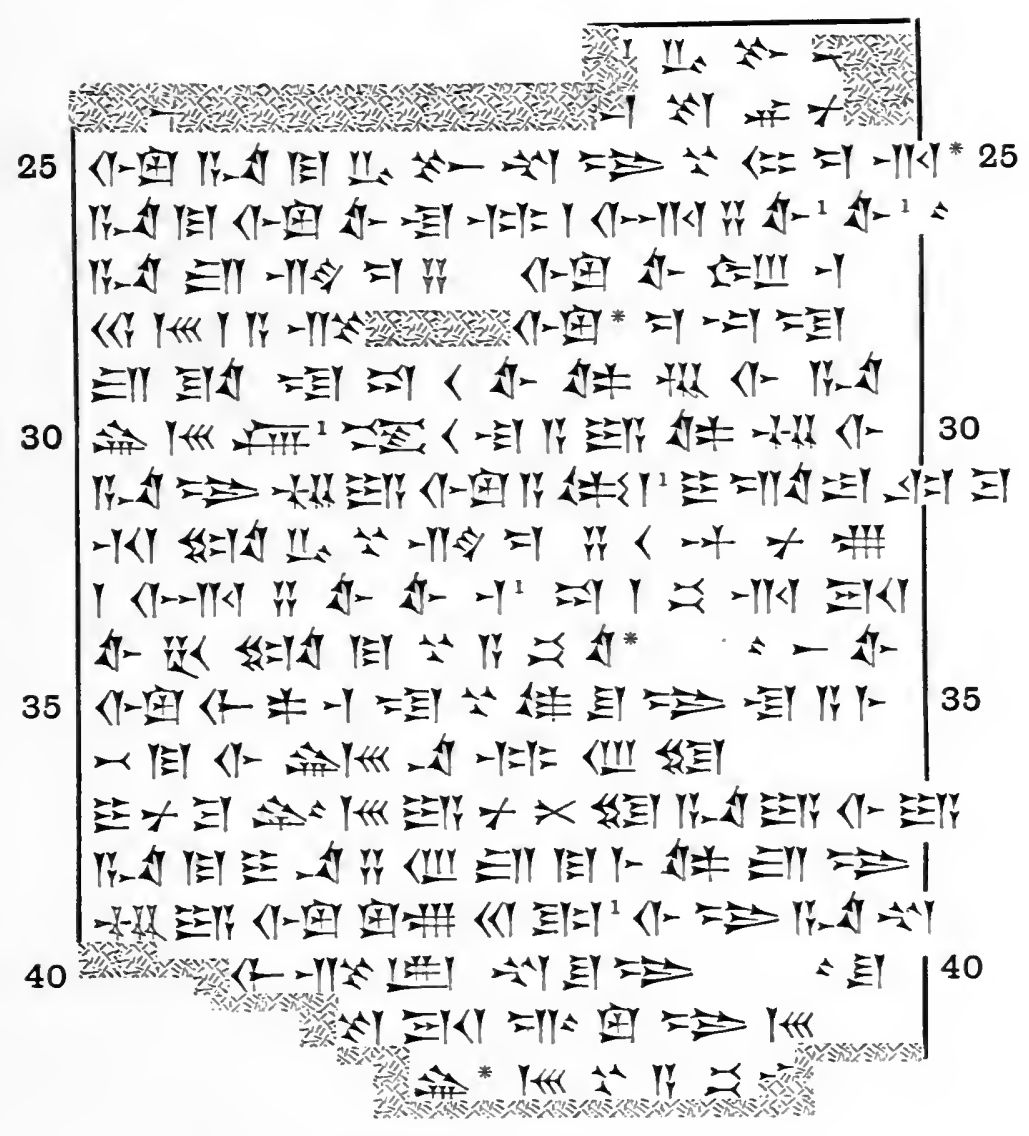

1 Written over another sign. 


\section{No. 44 .}

(BU. $88-10-13,17 ; 3 \frac{1}{8}$ in. by $2 \frac{5}{8}$ in.)

Obverse.

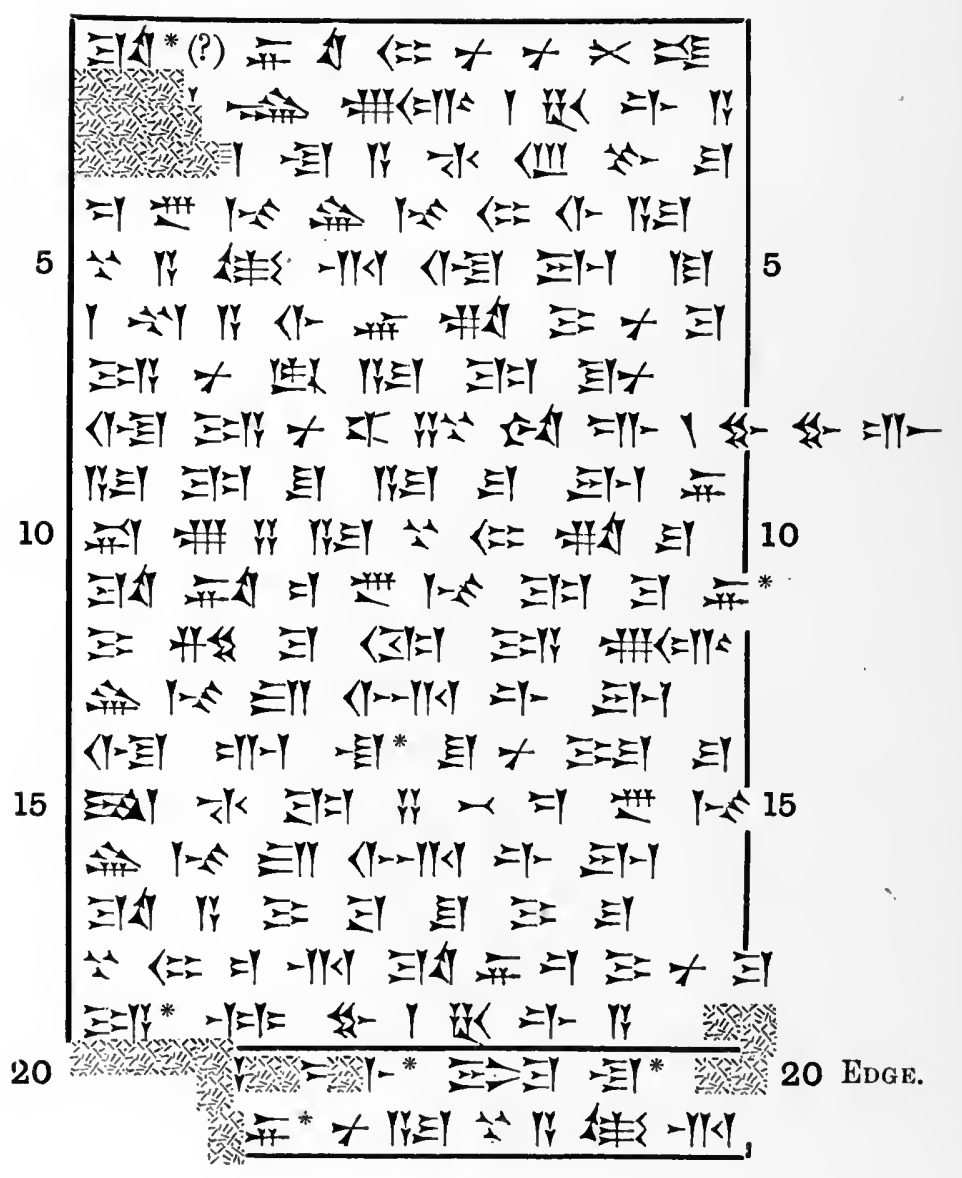


No. 44.

(BU. 88-10-13, 17.)

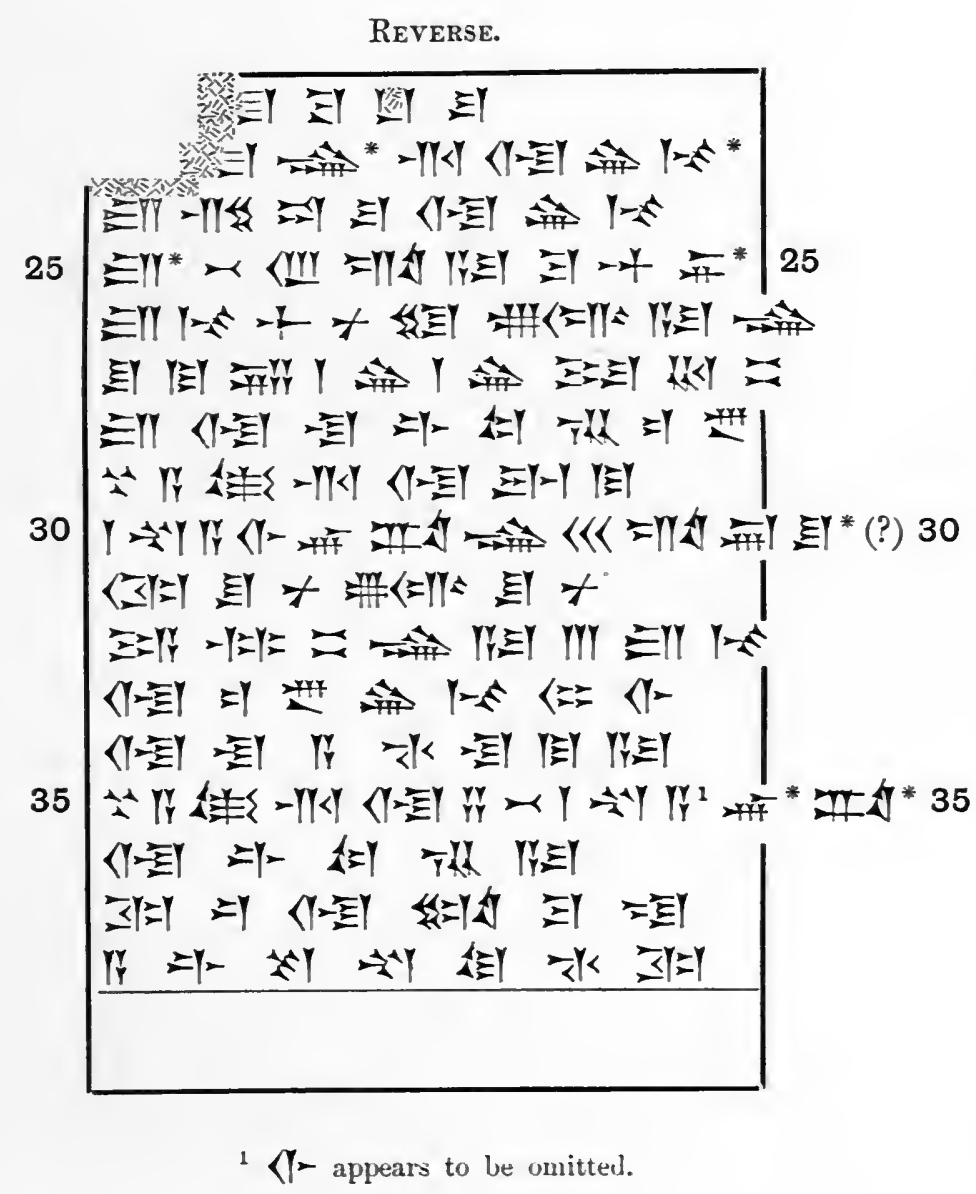


No. 45.

(BU. $88-10-13,12 ; 3 \frac{7}{8}$ in. by $2 \frac{7}{8}$ in.)

Obverse.

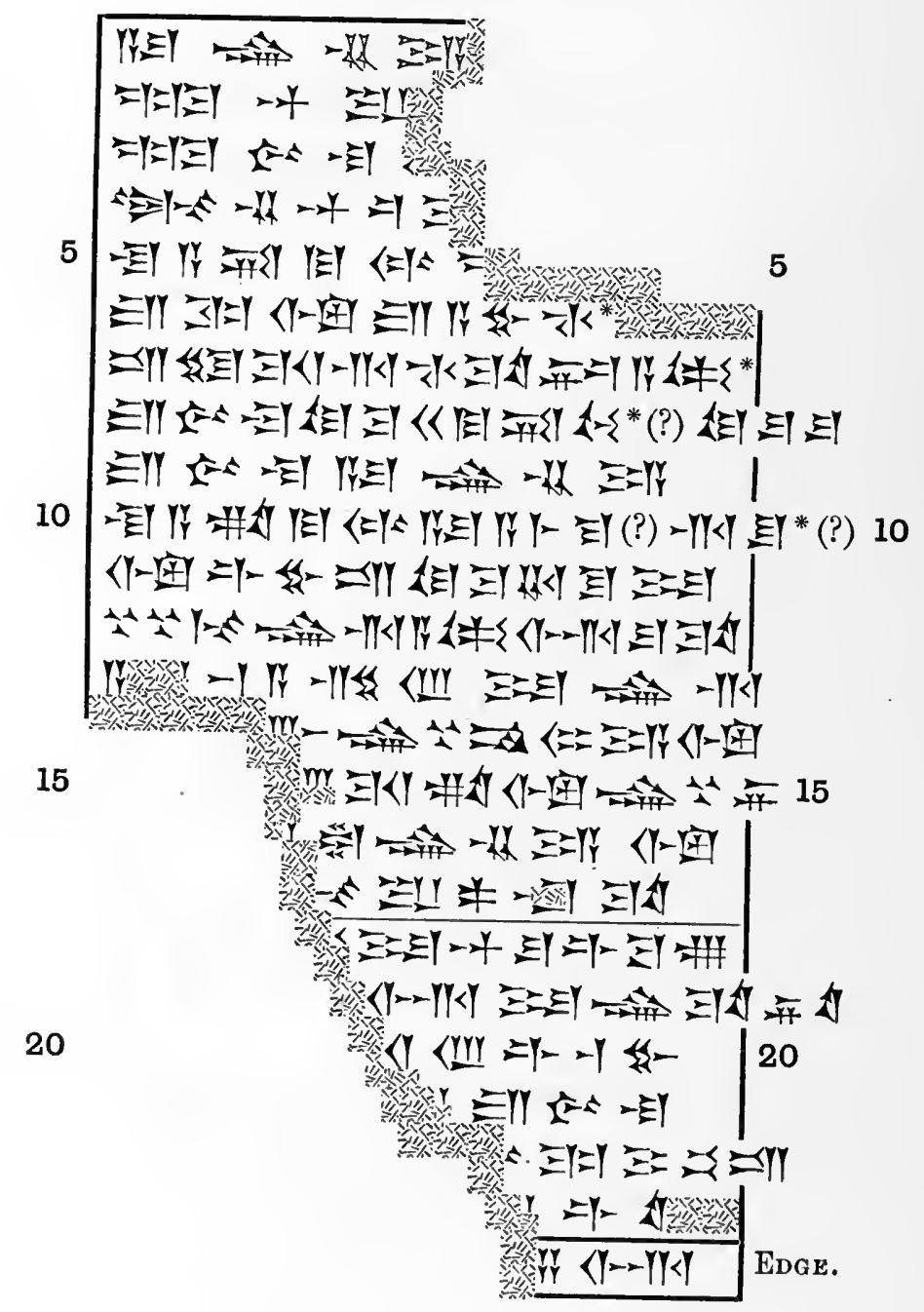


No. 45 .

(BU. 88-10-13, 12; see plate 4.)

Reverse.

25

棌

25

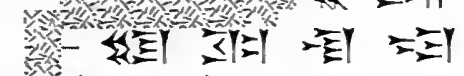

出

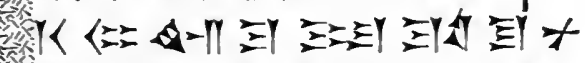

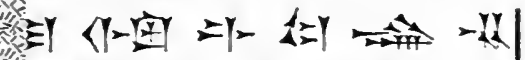

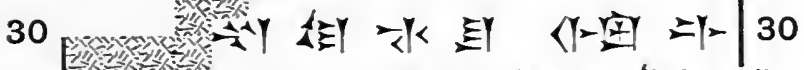

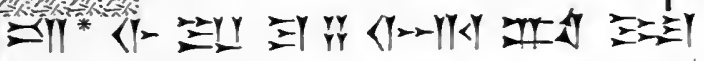

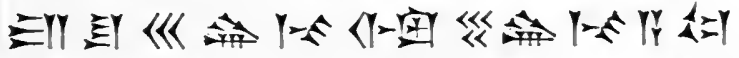

EII $=-1$ -

EDEY

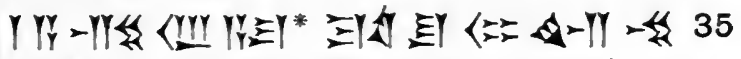

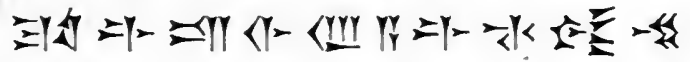

《i-

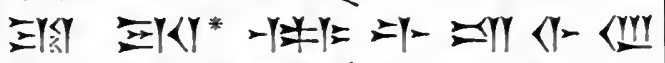

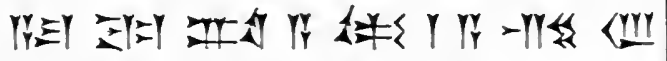

40

$\langle Y-2 M<Y \Rightarrow-Y X Y Y$ 



\section{No. 46 .}

(BU. $91-5-9,82 ; 2 \frac{1}{3}$ in. by $1 \frac{11}{16}$ in.)

Obrerse.

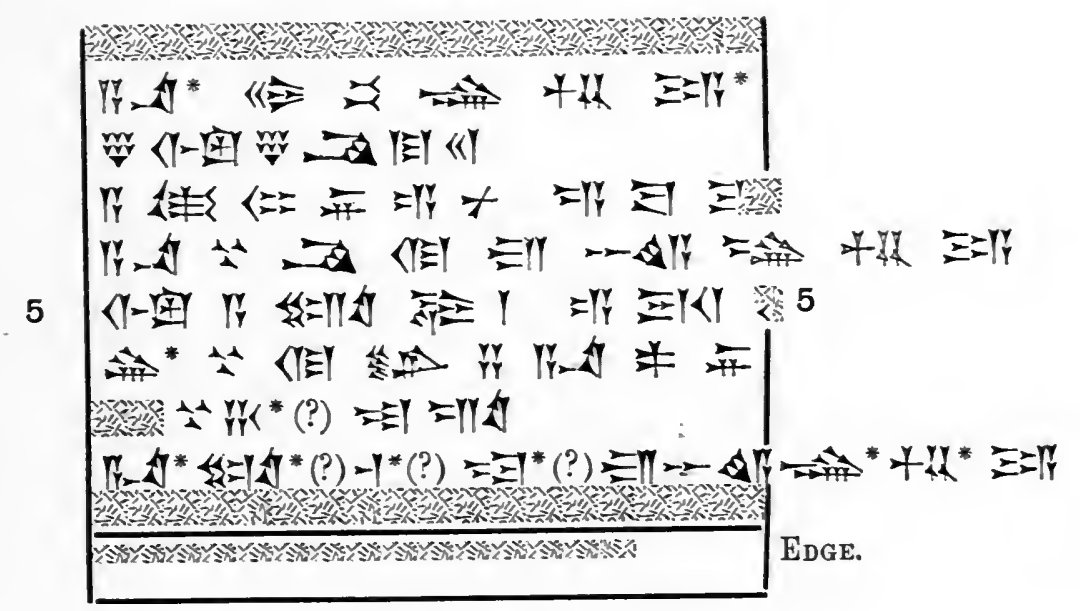

Reverse.

10

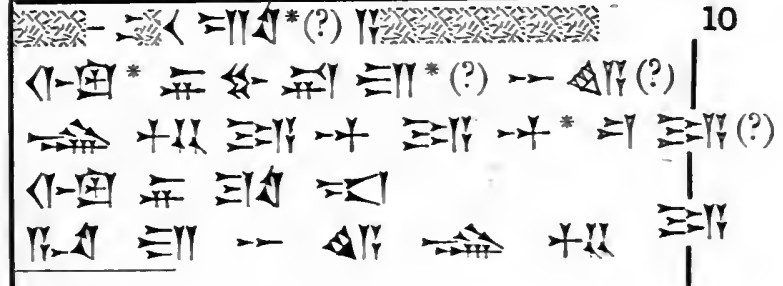


LETTERS FROM THE GOVERNOR OF THE CITY OF KHAṢUR. 97

No. 47.

(BU. 88-10-13, 27.)

Reverse.

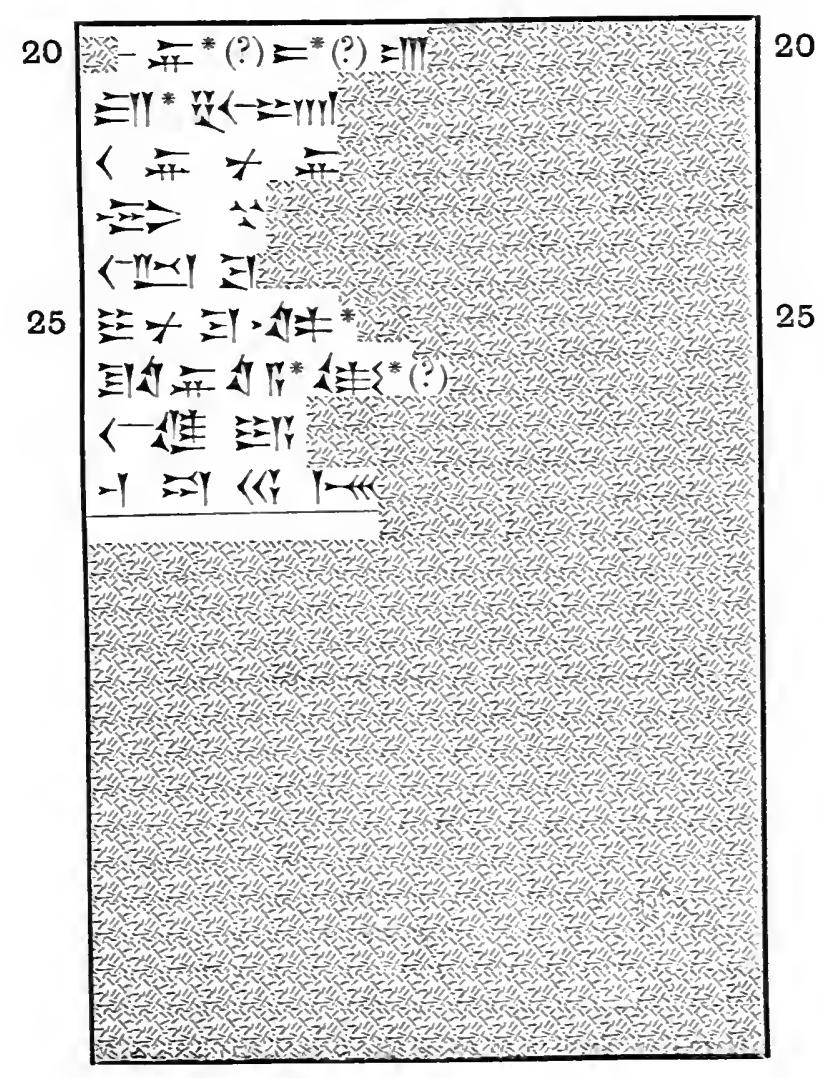


No. 48.

(BU. $88-10-13,65 ; 3 \frac{1}{4}$ in. by $2 \frac{5}{8}$ in.)

OBVERSE.

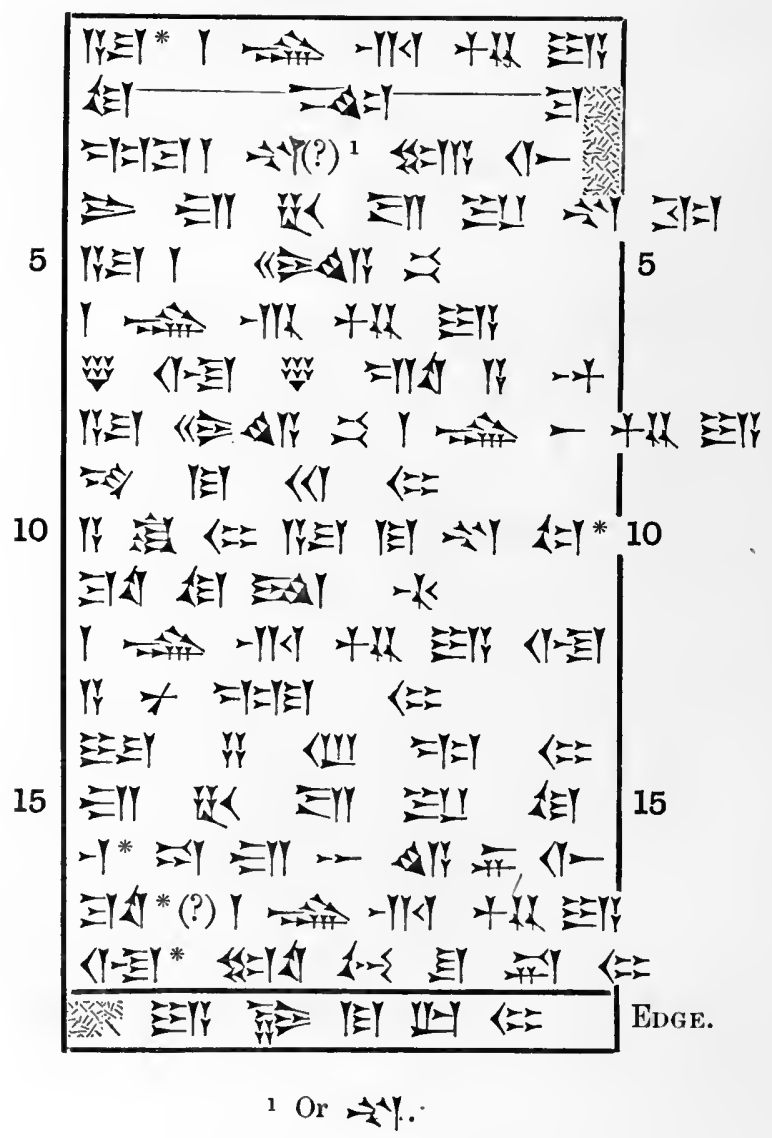


LETTERS FRON THE GOVERNOR OF THE CITY OF KHAṢUR. 99

No. 48 .

(BU. 88-10-13, 65; see plate 16.)

Reterse.

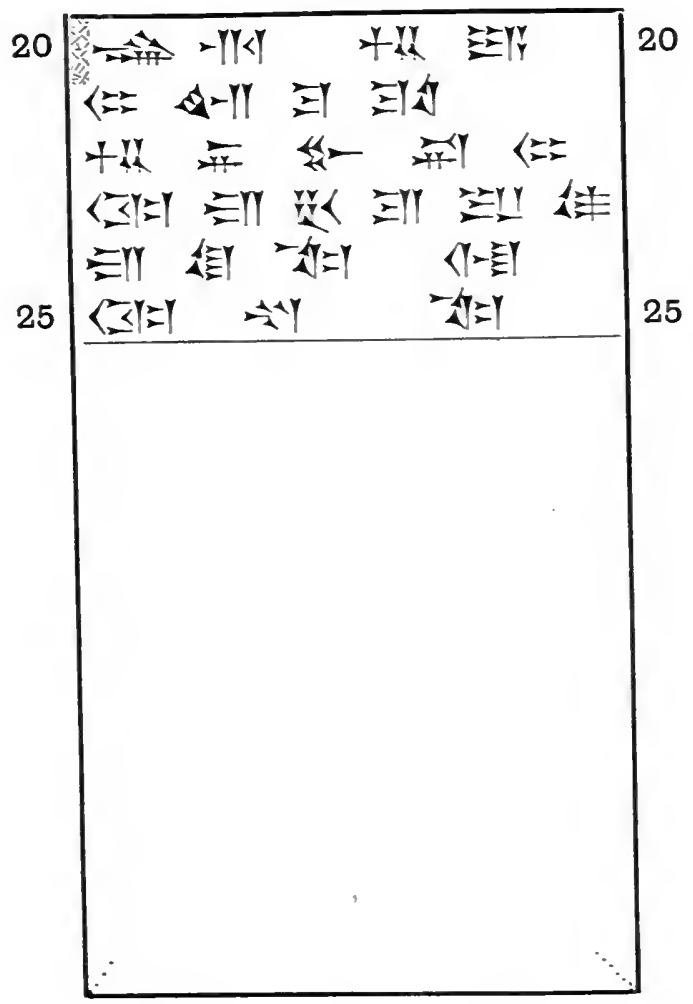




\section{No. 49.}

(BU. $88-10-13,45 ; 4 \frac{1}{4}$ in. by $3 \frac{1}{8}$ in.)

Obverse.

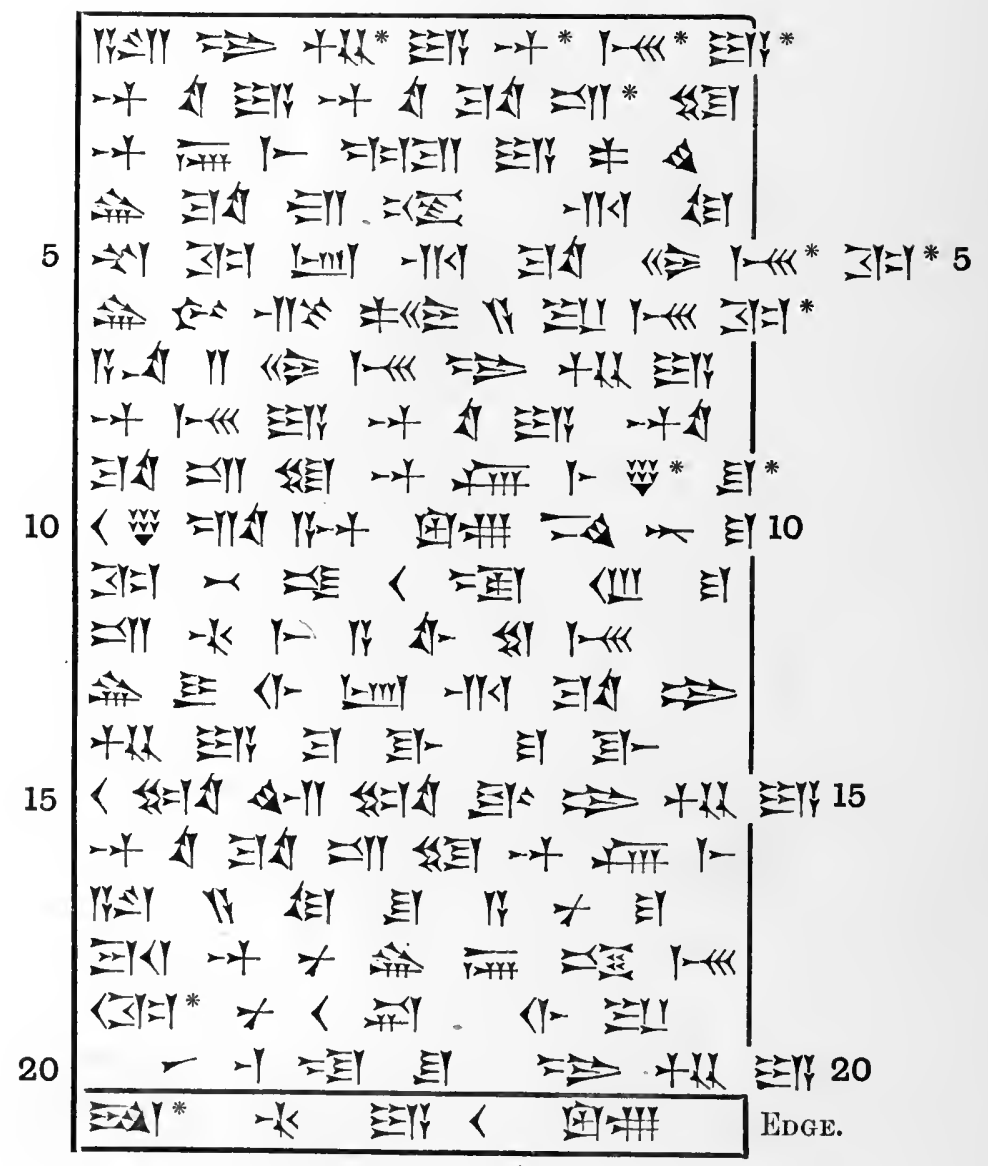


No. 49.

(BU. 88-10-13, 45.)

Reverse.

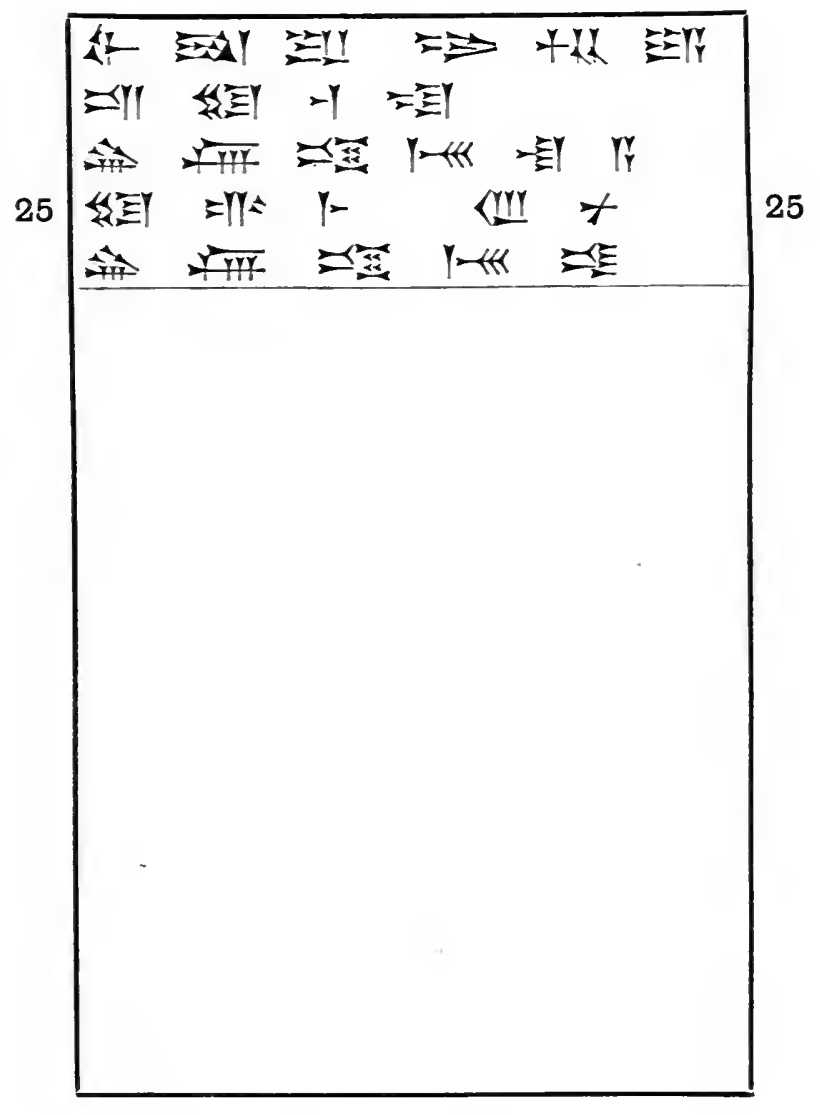


No. 50.

(BU. $88-10-13,22 ; 4 \frac{5}{8}$ in. by $3 \frac{3}{8}$ in.)

Obverse.

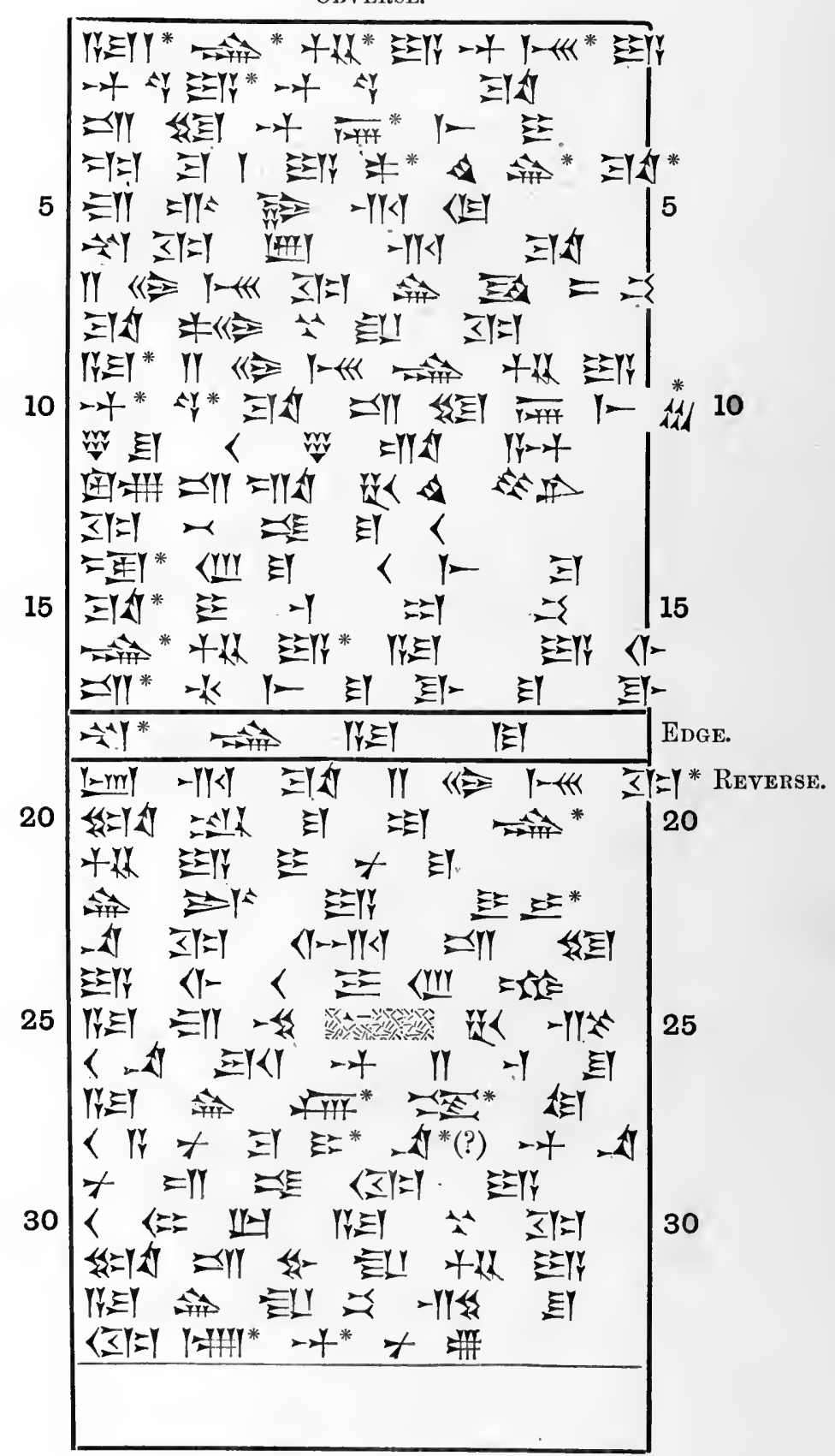


No. 51.

(BU. 88-10-13, 16; 3 in. by $2 \frac{1}{2}$ in. ; see plate 5.)

Obverse.

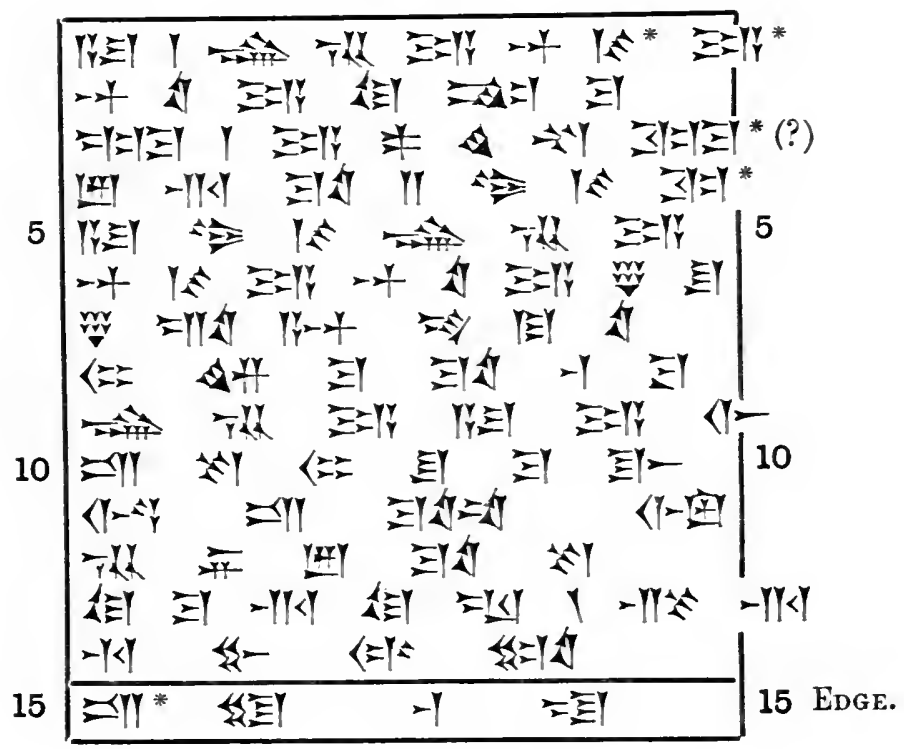

Reverse.

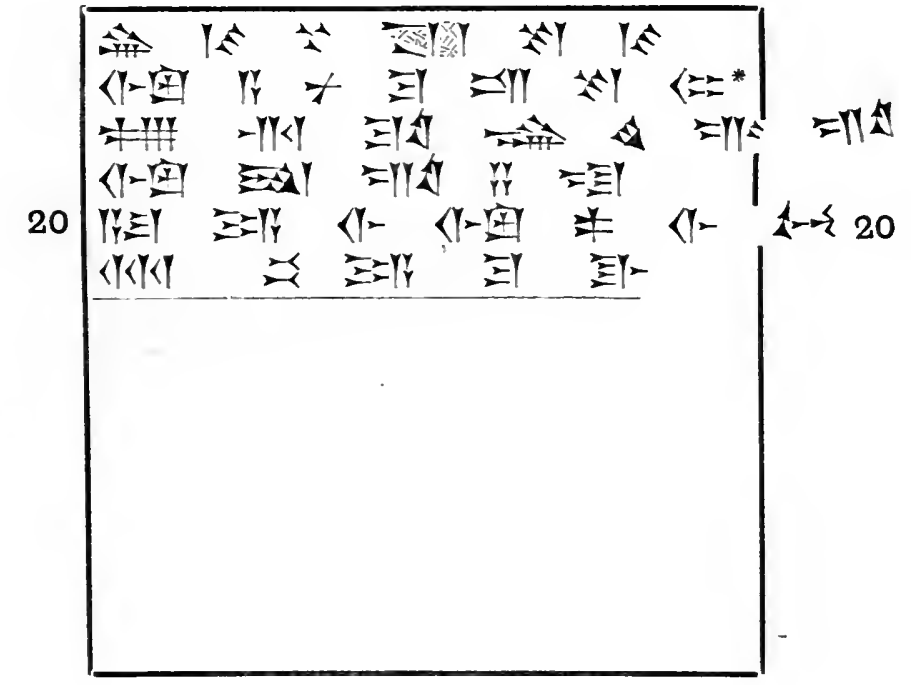




\section{No. 52.}

(BU. $88-10-13,59 ; 3 \frac{5}{8}$ in. by $2 \frac{7}{8}$ in.)

Obverse.

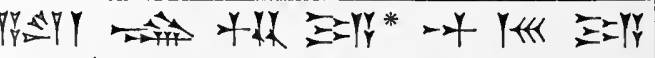

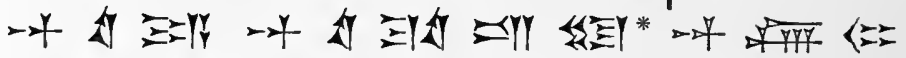

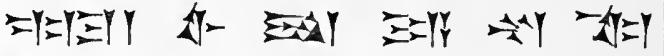

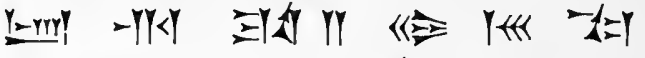

齐

YYAI II

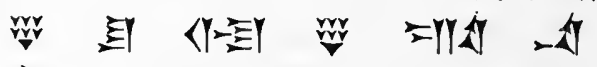

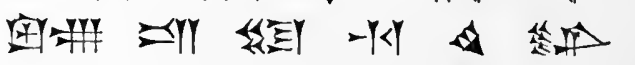

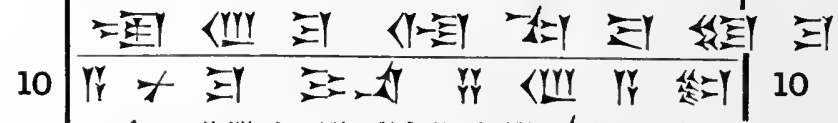

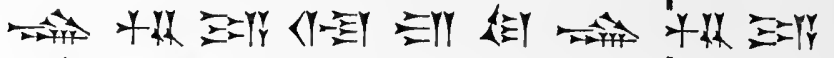

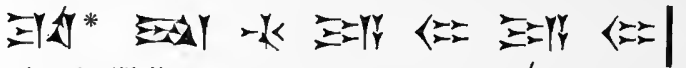

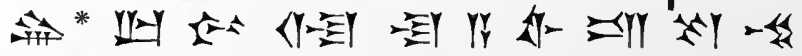

Ir 4 -

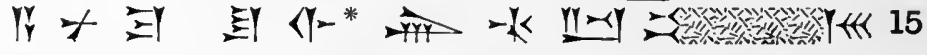

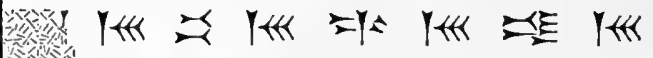

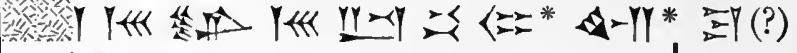

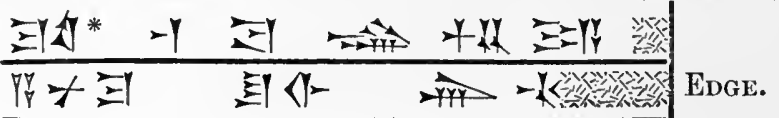


No. 52.

(BU. 88-10-13, 59 ; see plate 14.)

ReVERSE.

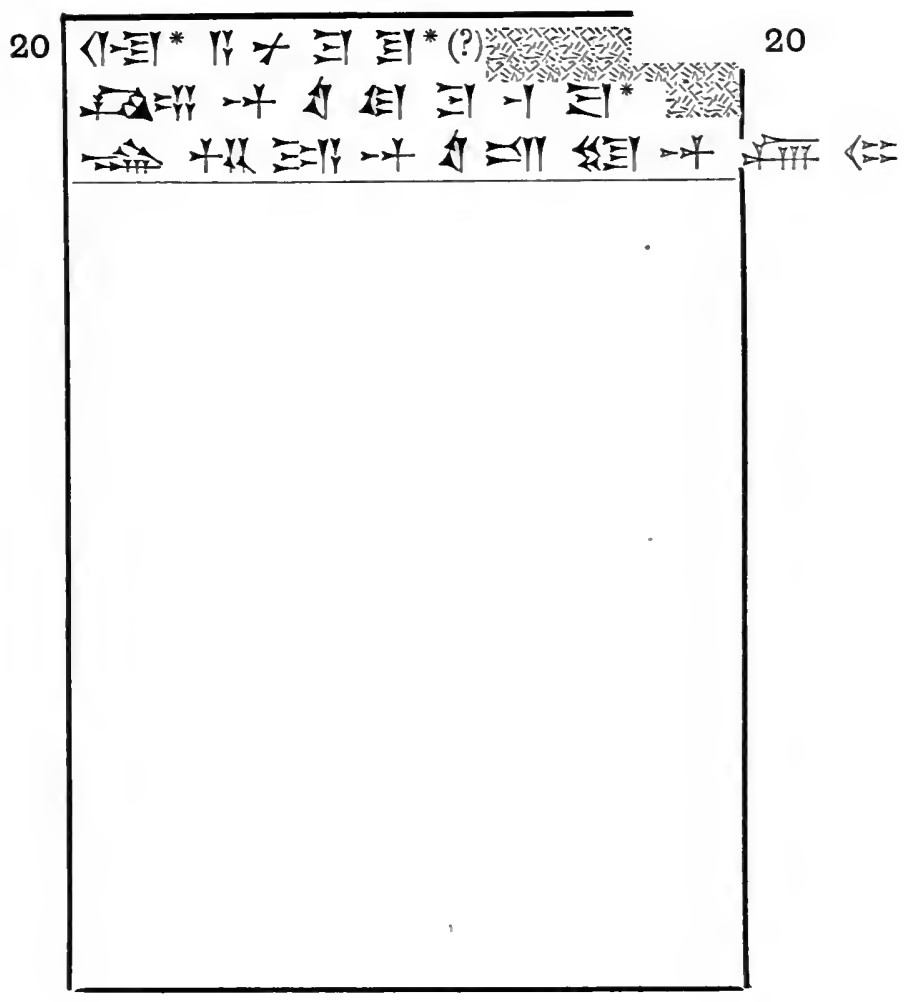


No. 53.

(BU. $88-10-13,14 ; 3 \frac{1}{4}$ in. by $2 \frac{3}{4}$ in.)

Obverse.

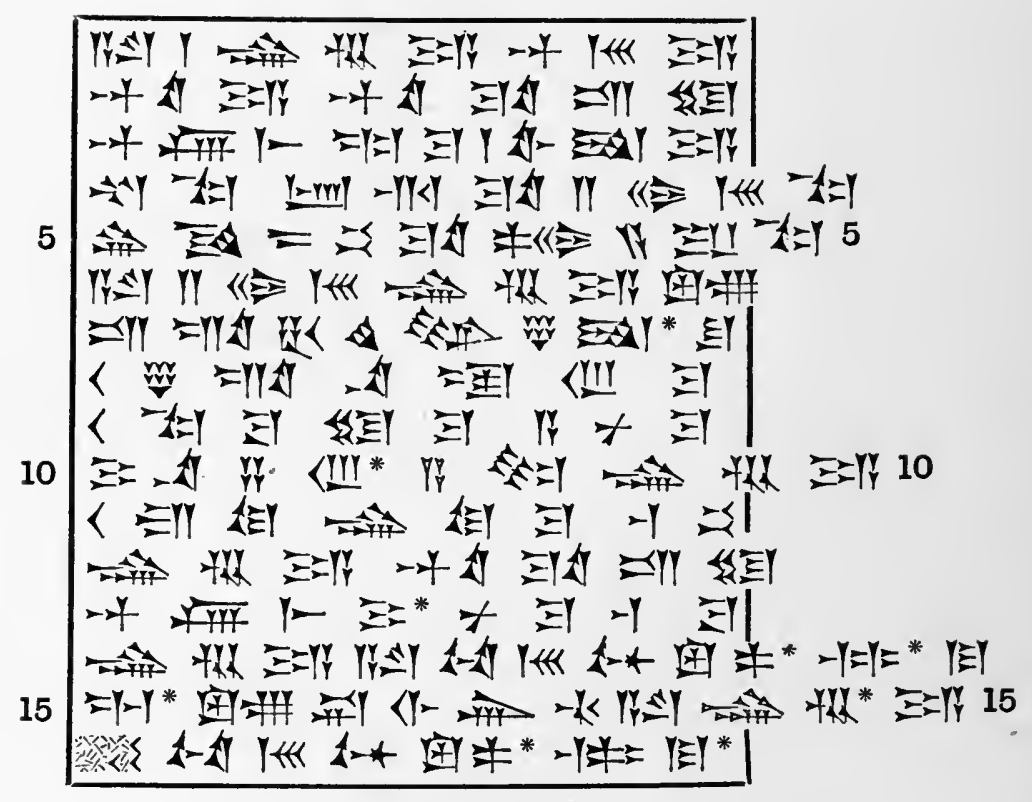

Reverse.

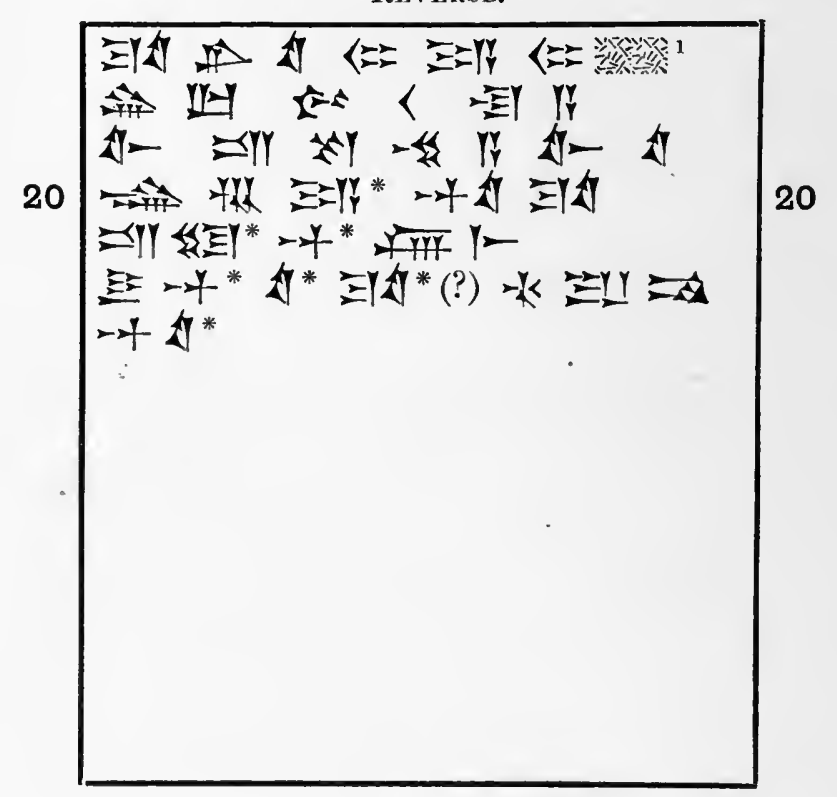

1 Here the scribe began to write character are visible, 
LETTERS FROM WIDYA.

107

No. 54.

(BU. $88-10-13,75 ; 3 \frac{1}{4}$ in. by $2 \frac{3}{4}$ in. ; see plate 21 .)

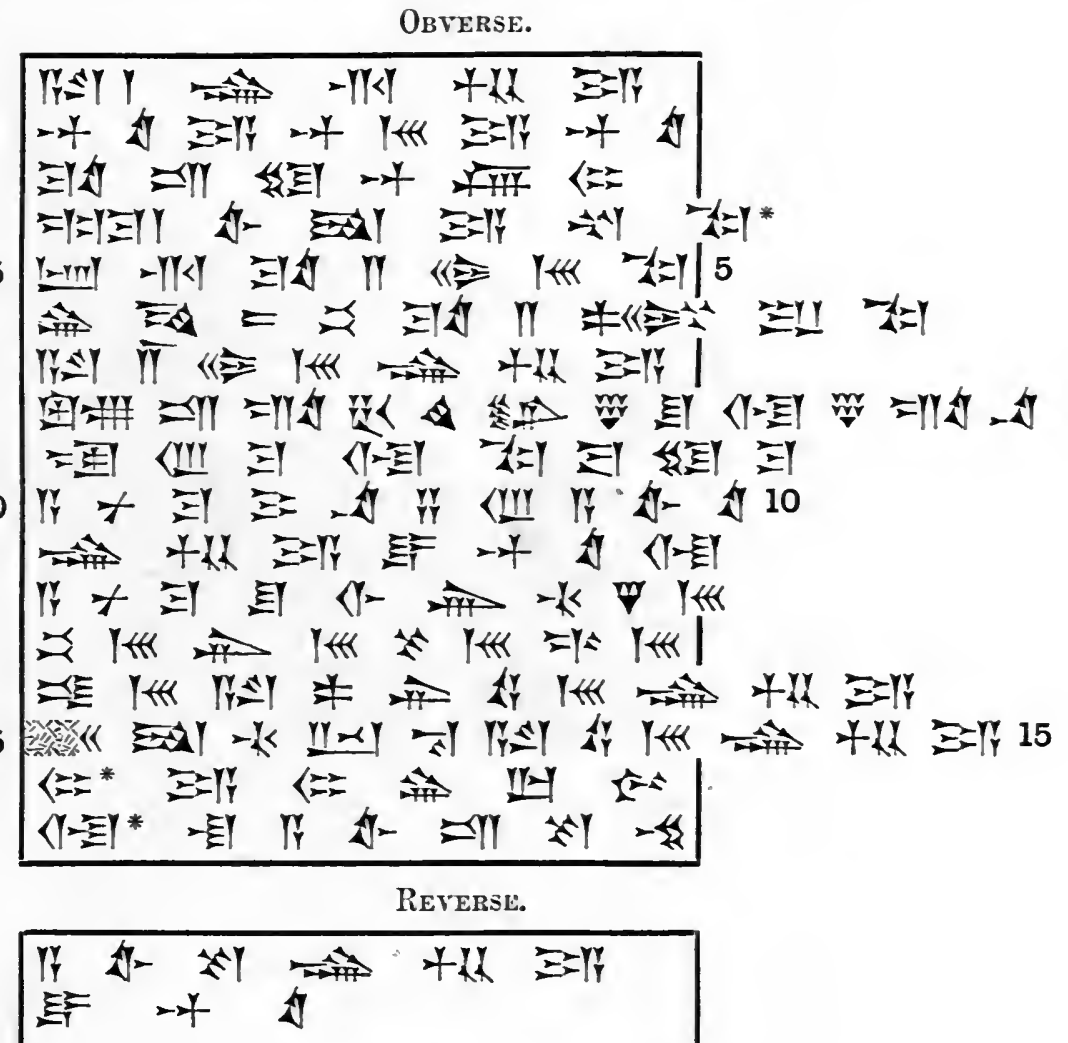


No. 55.

(BU. $88-10-13,2 ; 3 \frac{7}{8}$ in. by 3 in.)

Obverse.

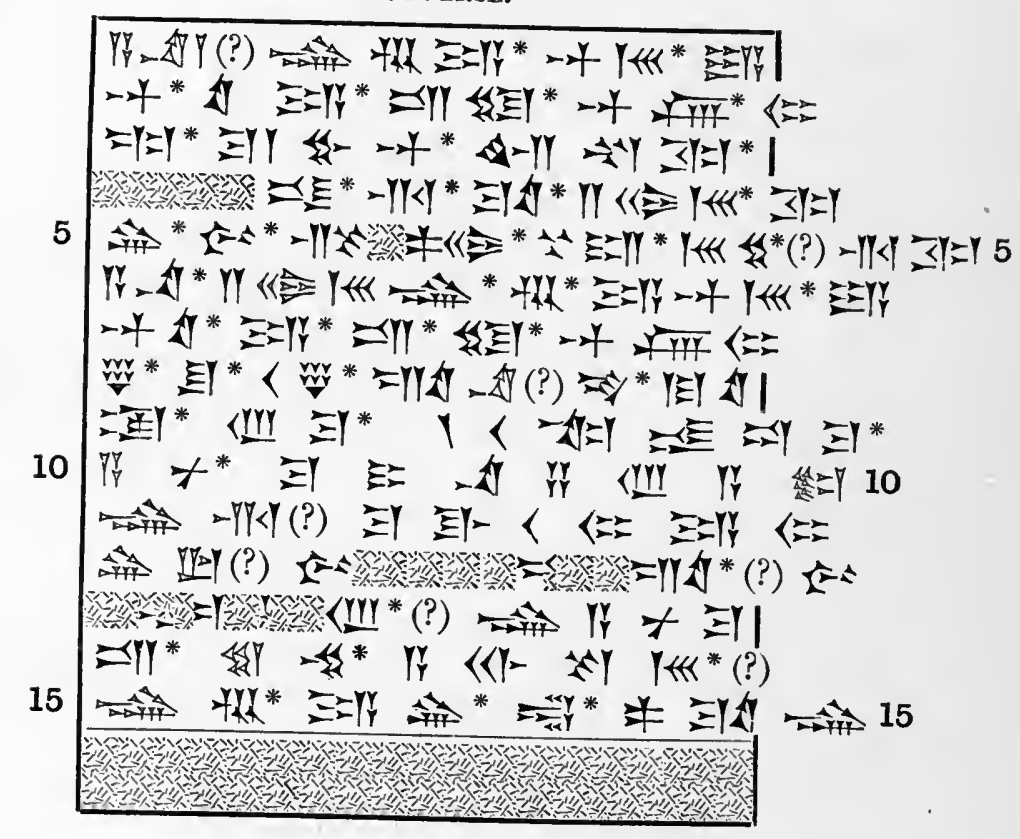

Reverse.

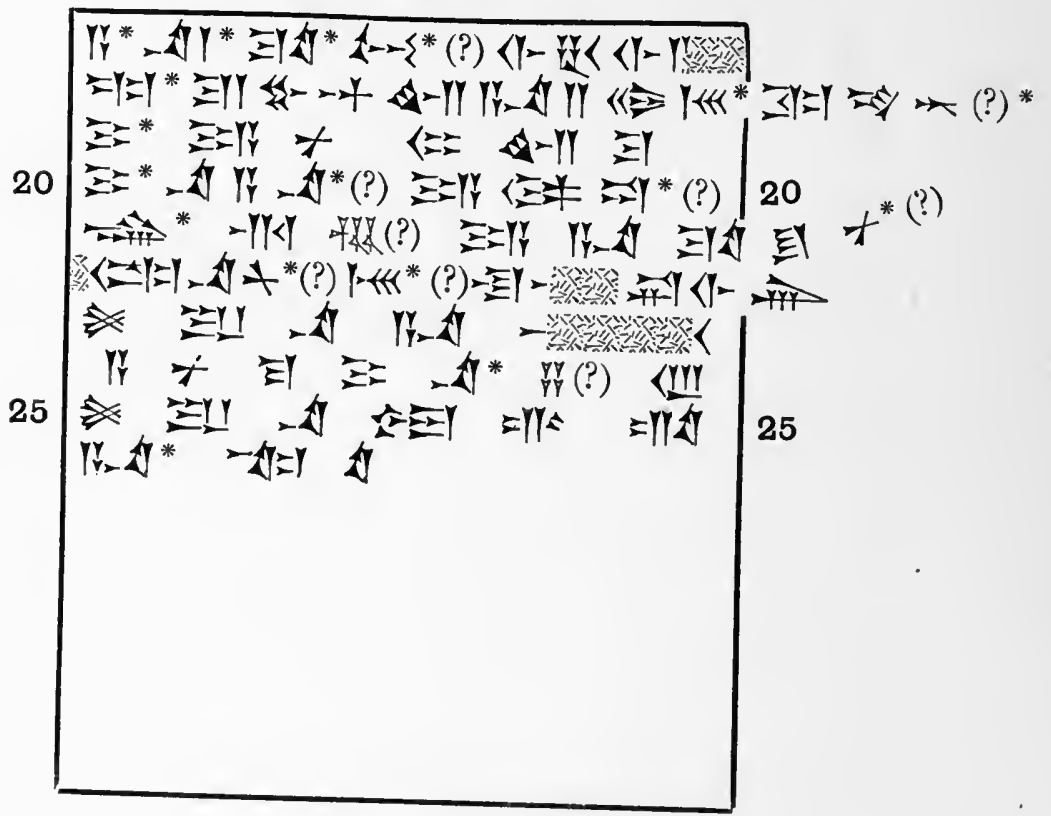




\section{No. 56.}

(BU. $88-10-13,10 ; 3 \frac{3}{4}$ in. by 3 in.)

Obterse.

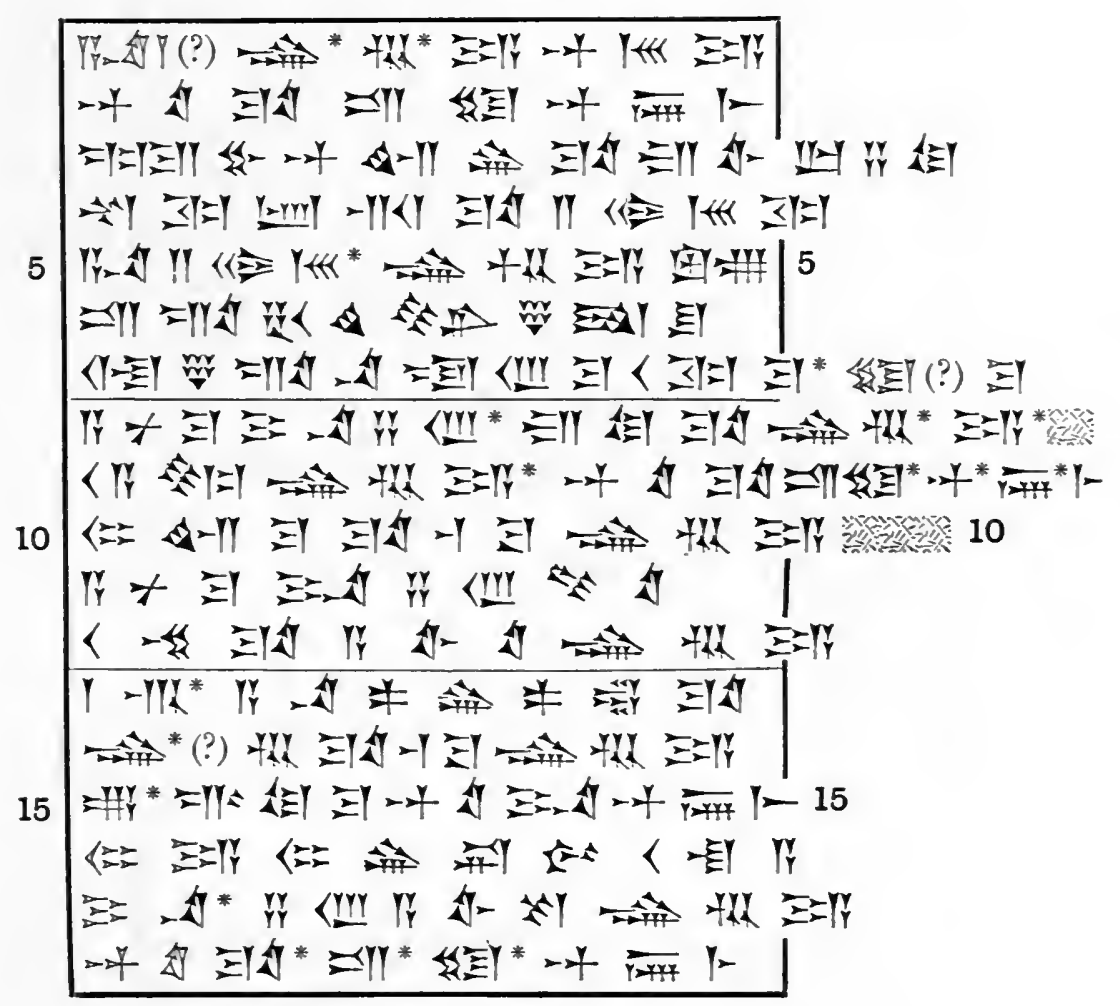

(REverse BLANK.) 
No. 57.

(BU. $88-10-13,57 ; 4 \frac{1}{4}$ in. by $3 \frac{1}{8}$ in.)

Obverse.

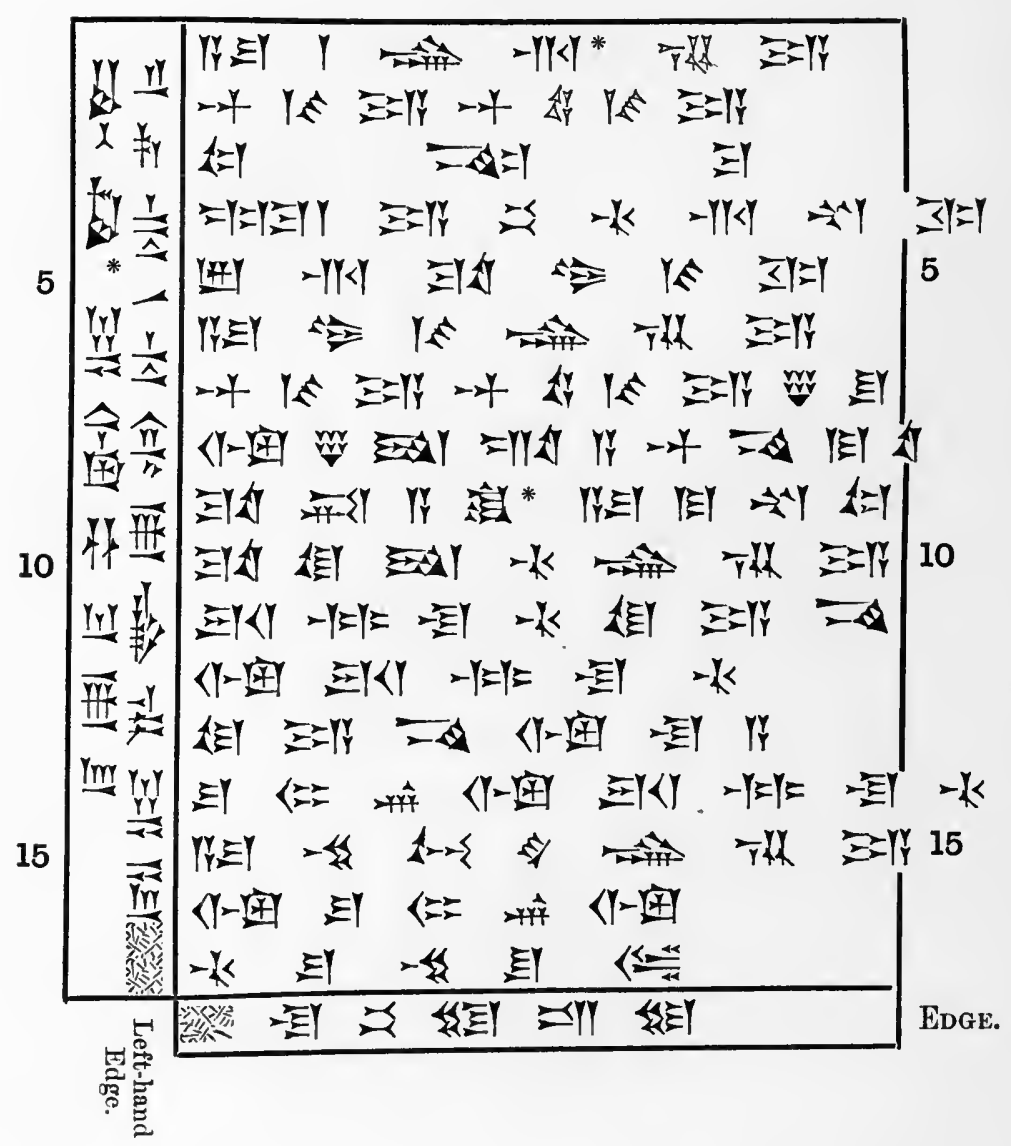




\section{No. 57.}

(BU. 88-10-13, 57.)

Reverse.

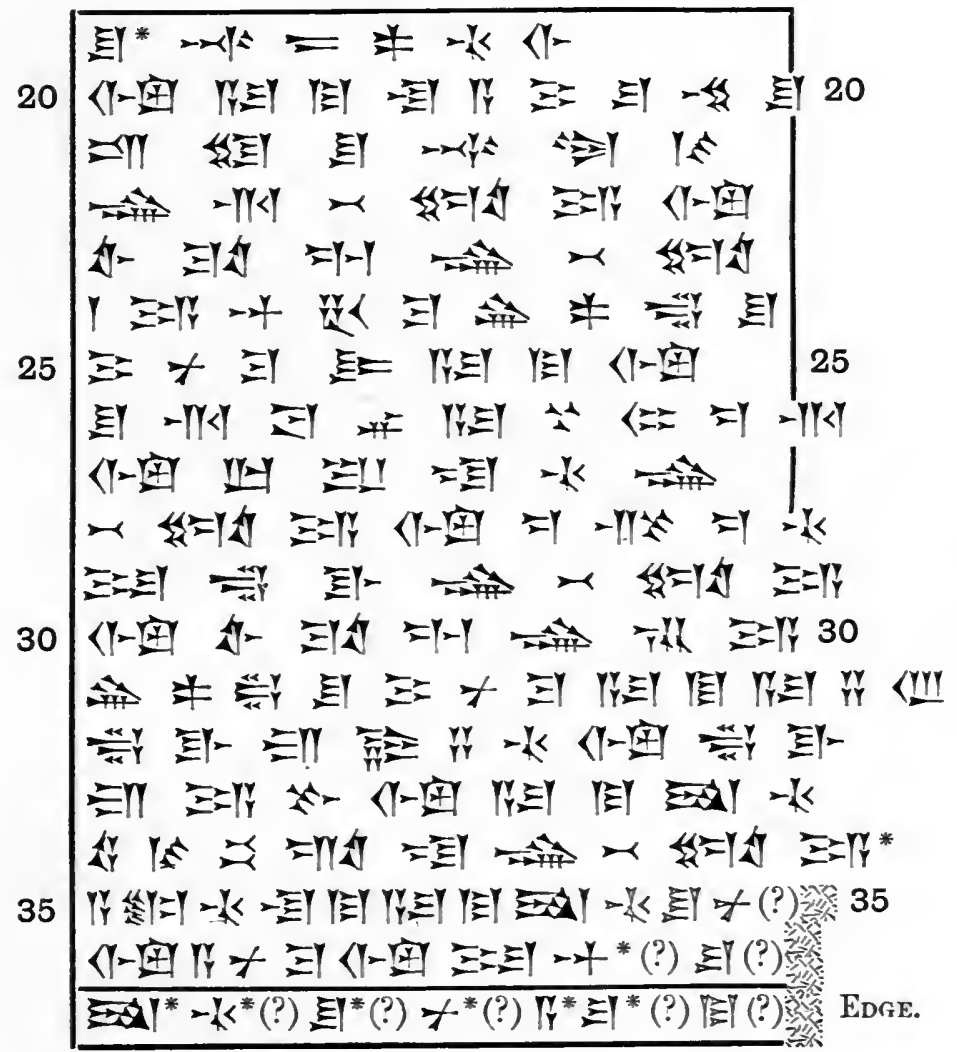




\section{No. 59.}

(BU. $88-10-13,29 ; 2 \frac{3}{8}$ in. by $2 \frac{3}{16}$ in.)

Obverse.

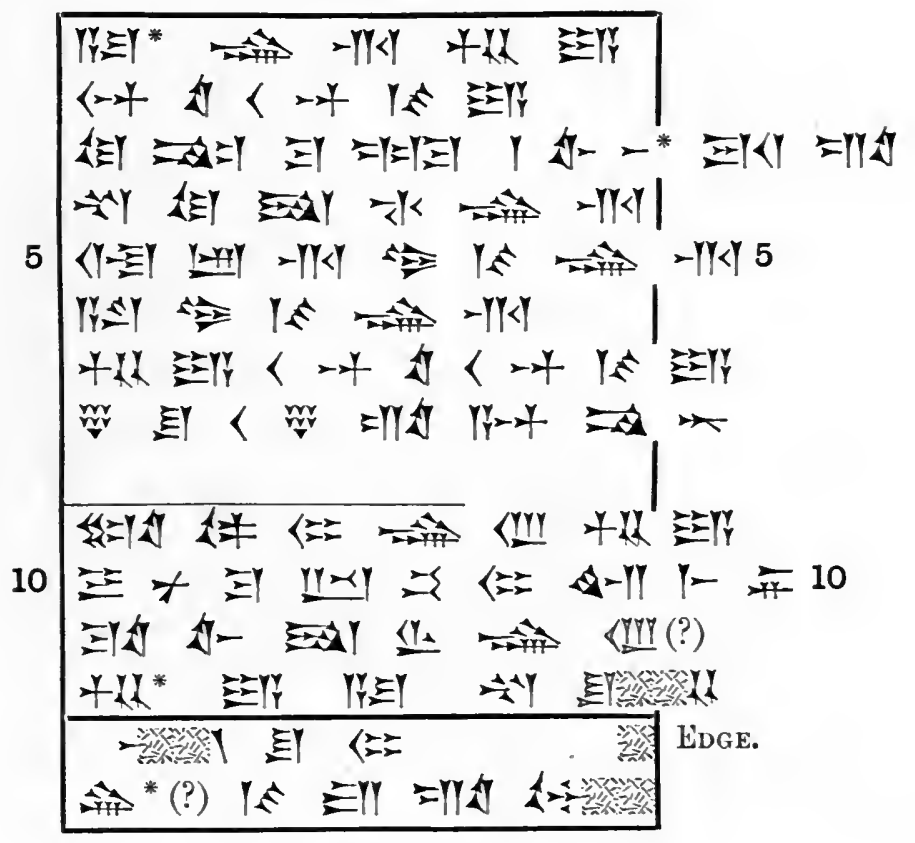

Reverse.

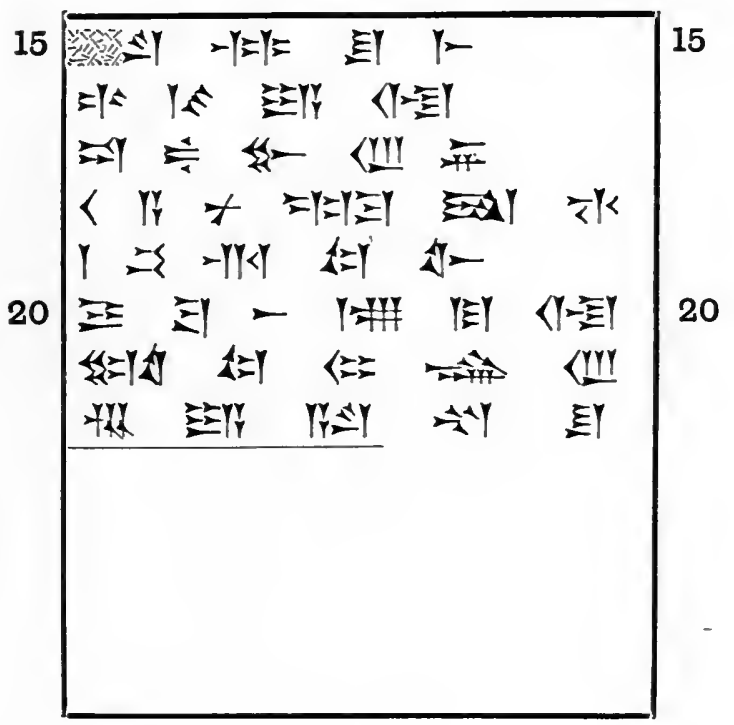



No. 60.

(BU. $88-10-13,34 ; 2 \frac{7}{8}$ in. by $2 \frac{3}{8}$ in. ; see plate 7 .)

ObVerse.

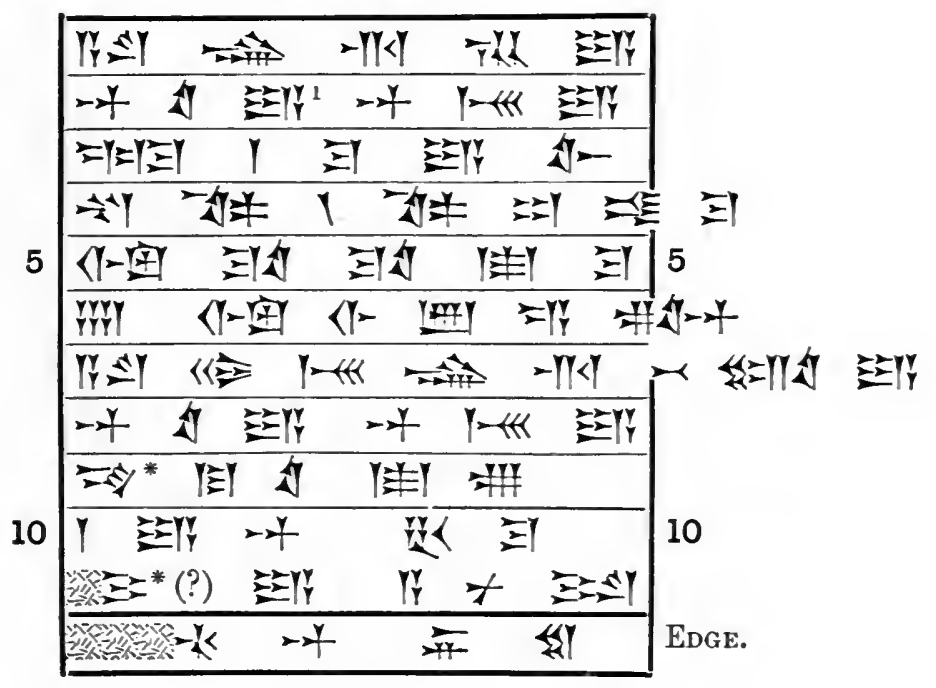

Reverse.

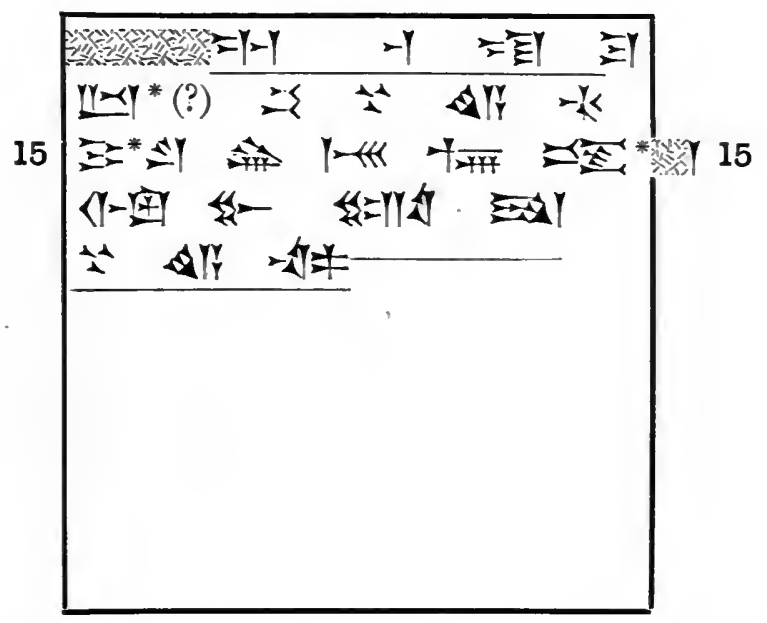

1 Partly effaced by what appears to be the impression of an Egyptian seal. 


\section{No. 61.}

(BU. $88-10-13,74 ; 2 \frac{3}{4}$ in. by $2 \frac{7}{16}$ in.)

Obverse.

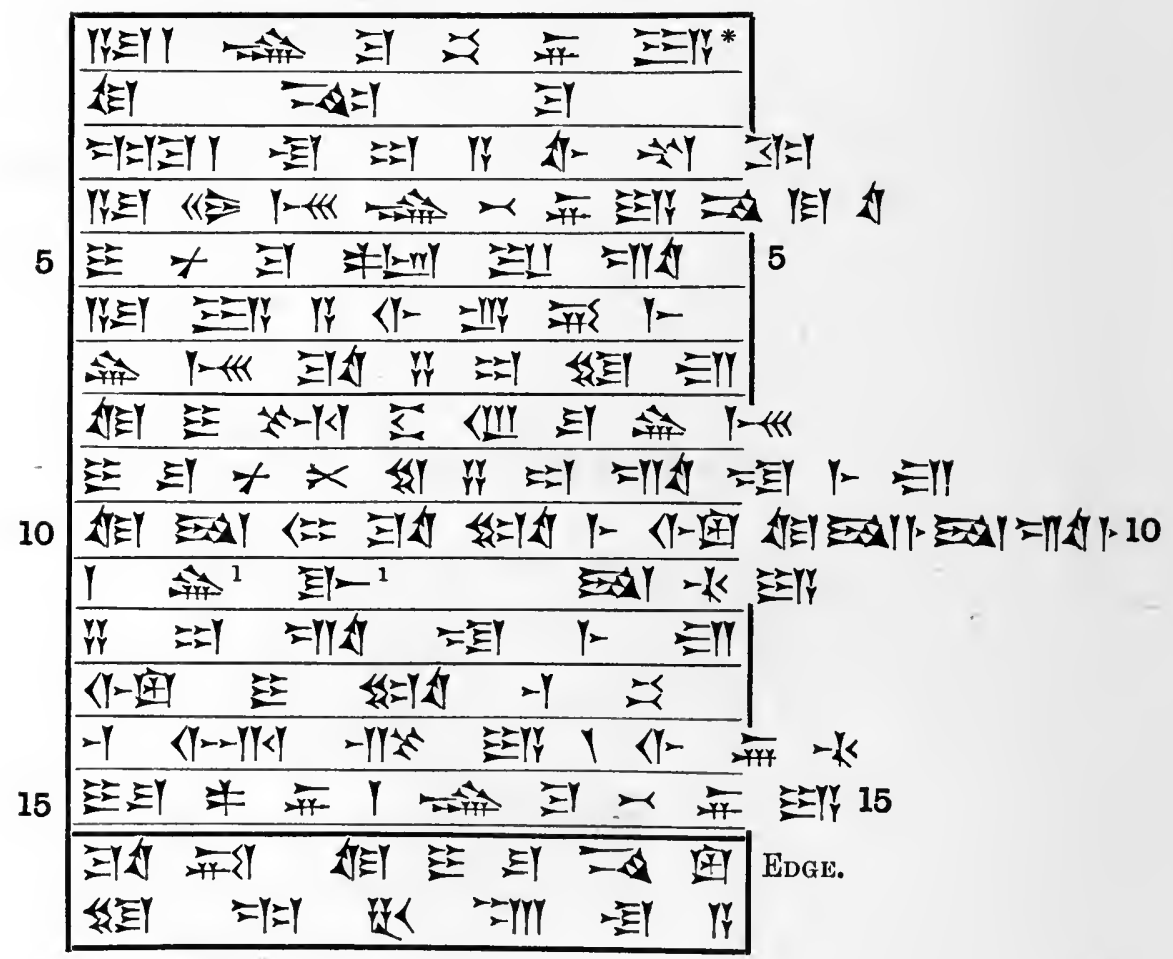

l Written over an erasure. 
No. 61.

(BU. 88-10-13, 74; see plate 21.)

ReVERse.

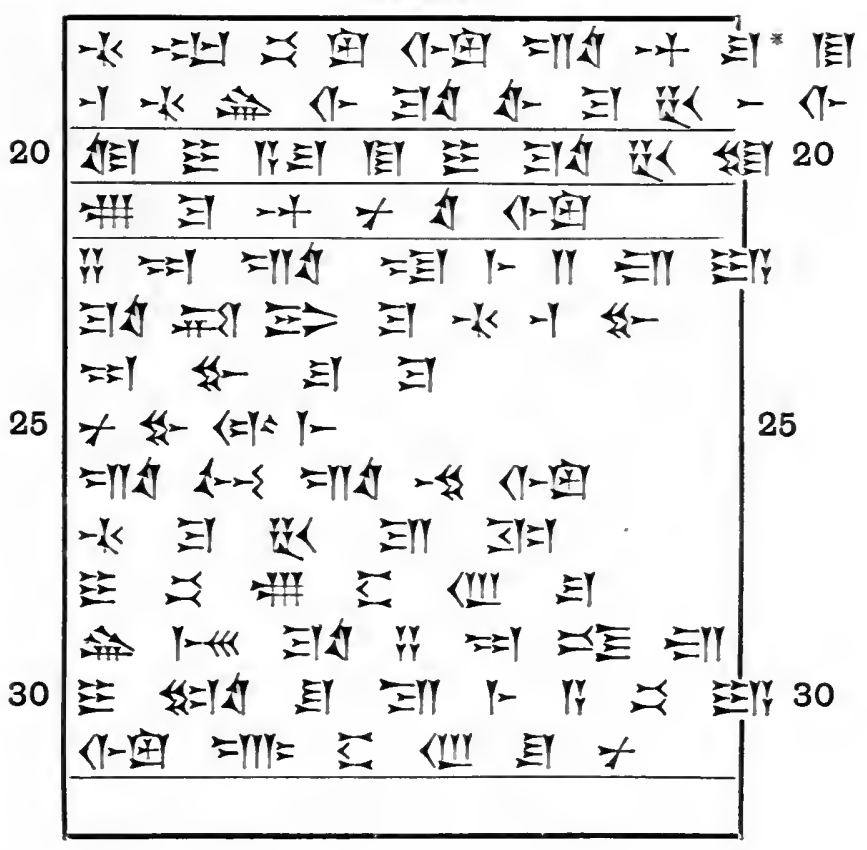




\section{No. 62.}

(BU. $88-10-13,8 ; 3 \frac{1}{2}$ in. by $2 \frac{5}{8}$ in. ; see plate 2. )

Obverse.

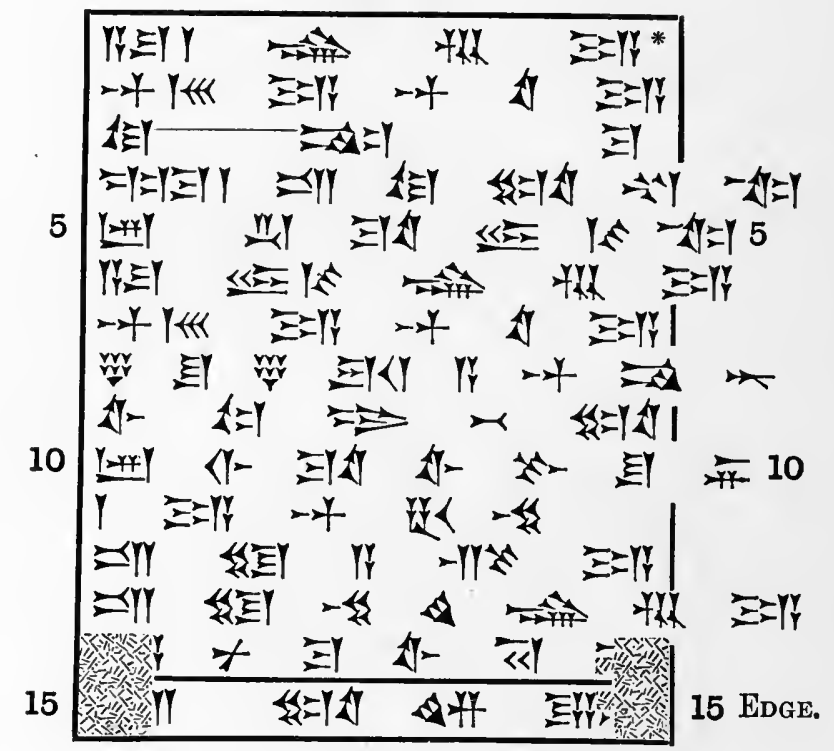

Reverse.

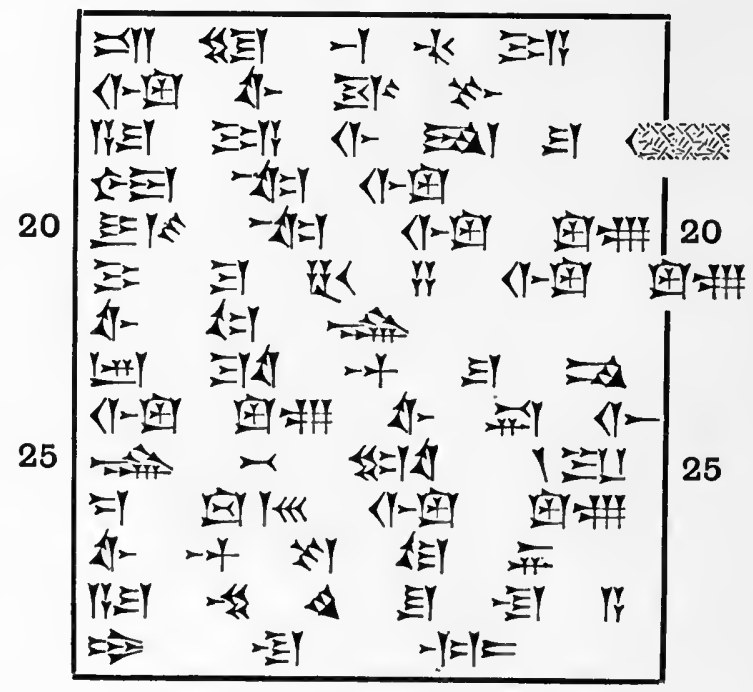


No. 63.

(BU. $88-10-13,50 ; 3 \frac{1}{4}$ in. by $2 \frac{3}{8}$ in.)

Obterse.

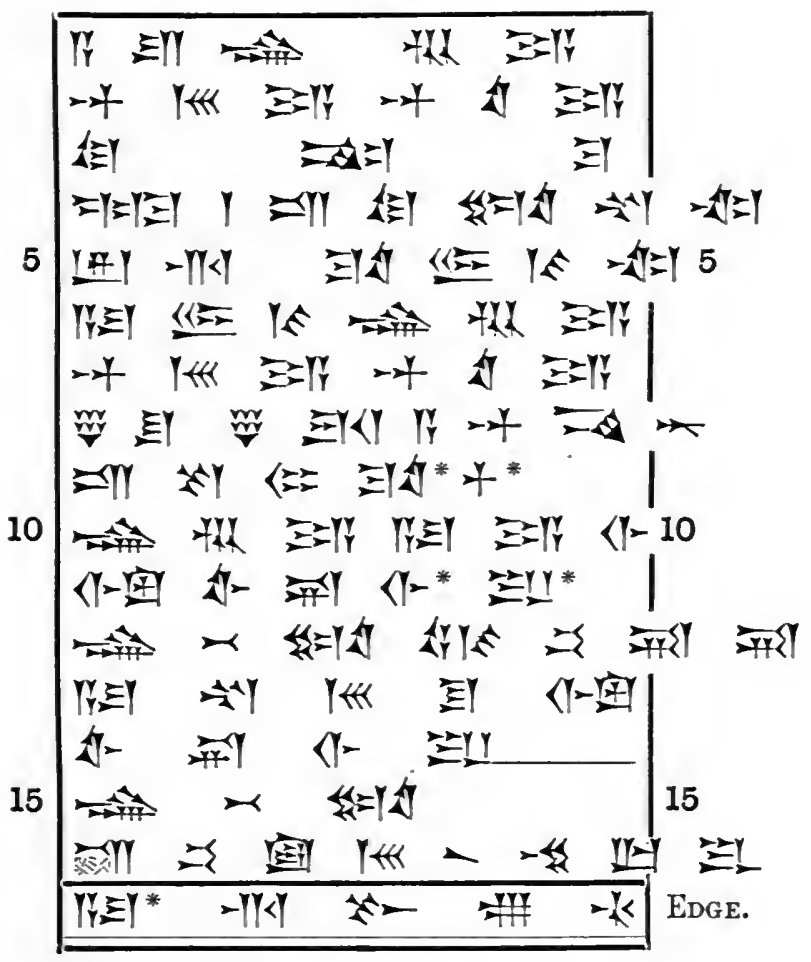

(Reverse blaxk.) 


\section{No. 64.}

(BU. $88-10-13,15 ; 3 \frac{1}{16}$ in. by $2 \frac{5}{8}$ in. ; see plate 5. ) $\underset{\sigma}{\omega}$ Obverse.

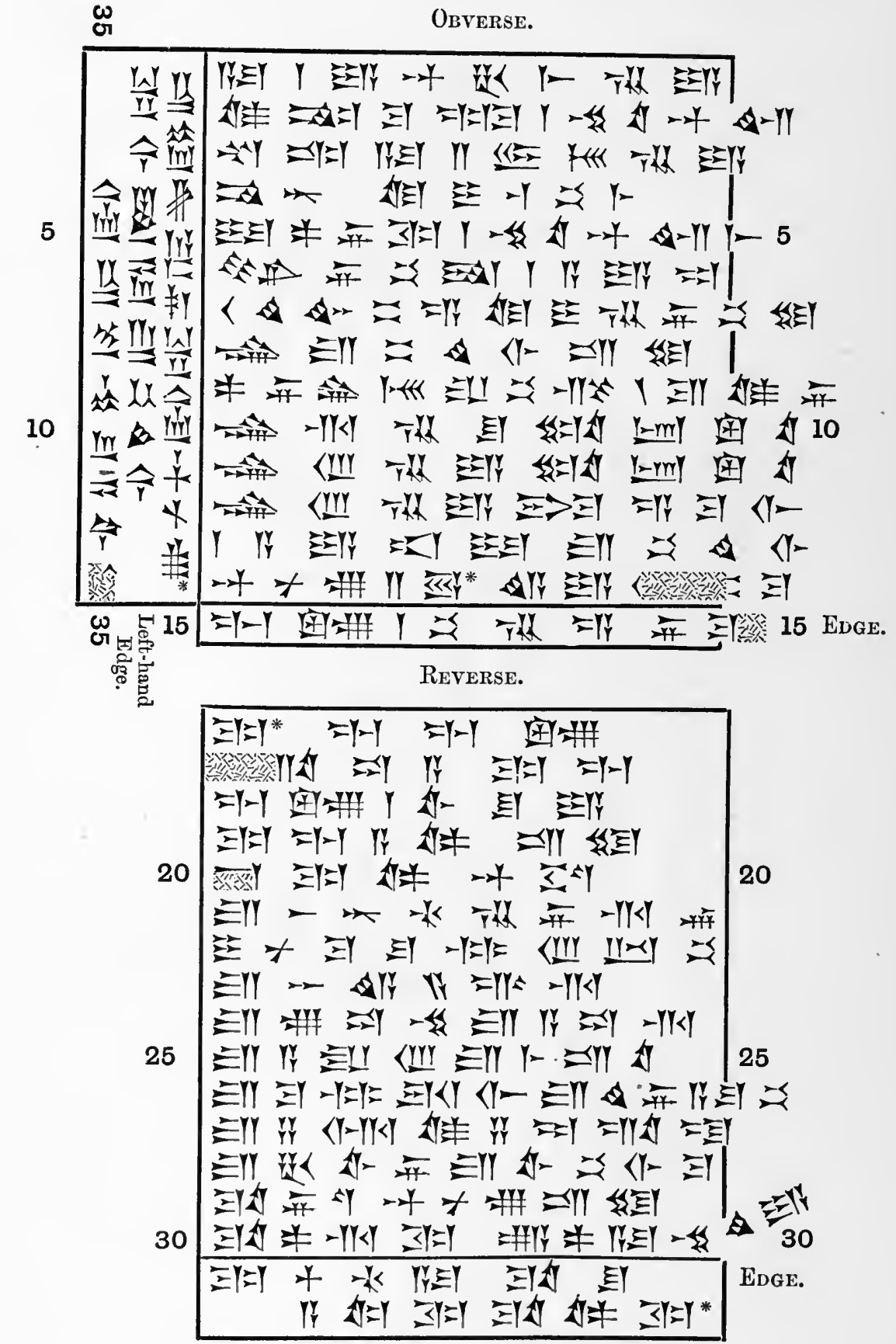


No. 65 .

(BU. $88-10-13,36 ; 2 \frac{3}{4}$ in. by $2 \frac{1}{2}$ in.)

Obverse.

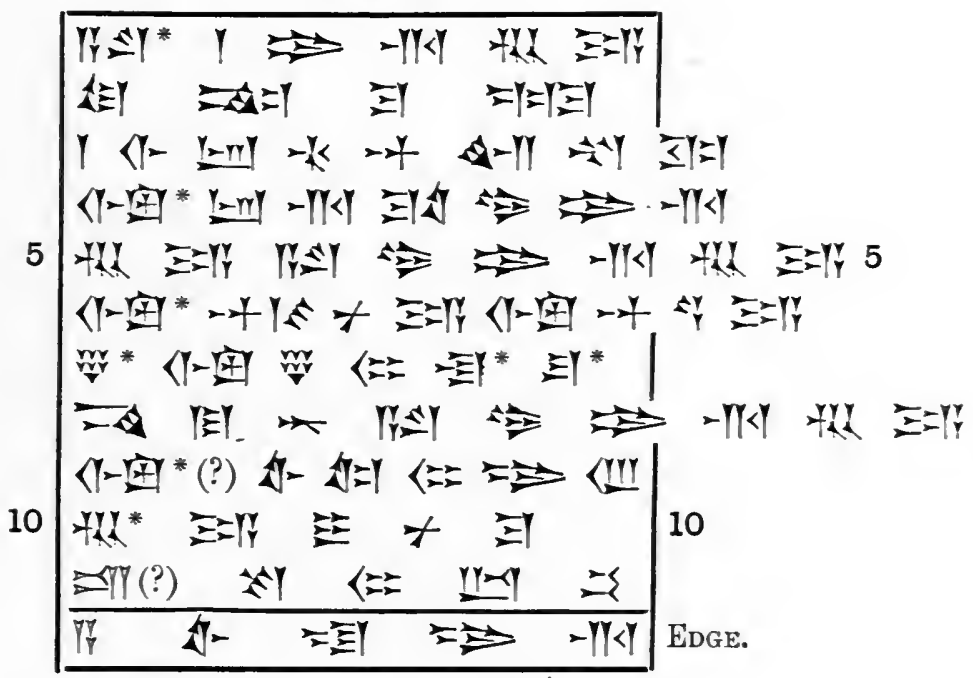

REVERSE.

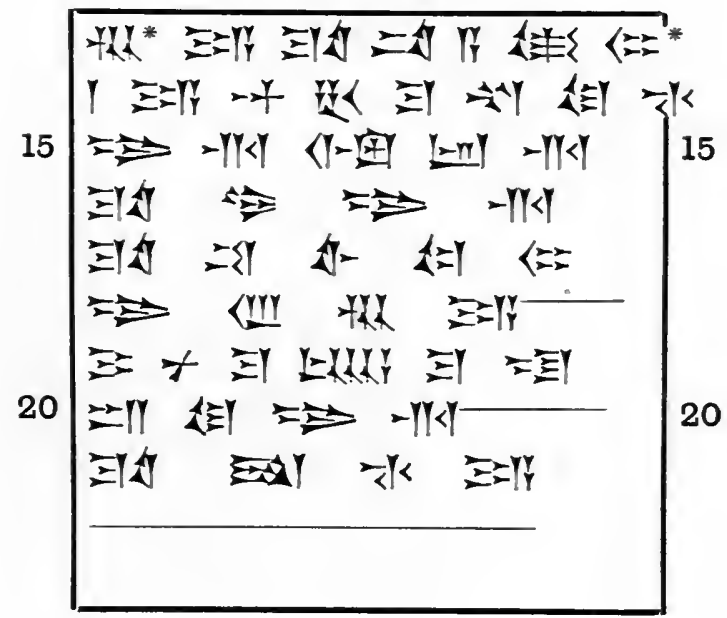




\section{No. 66.}

(BU. $88-10-13,61$; 3 in. by $2 \frac{3}{8}$ in. ; sce plate 15. )

Obverse.

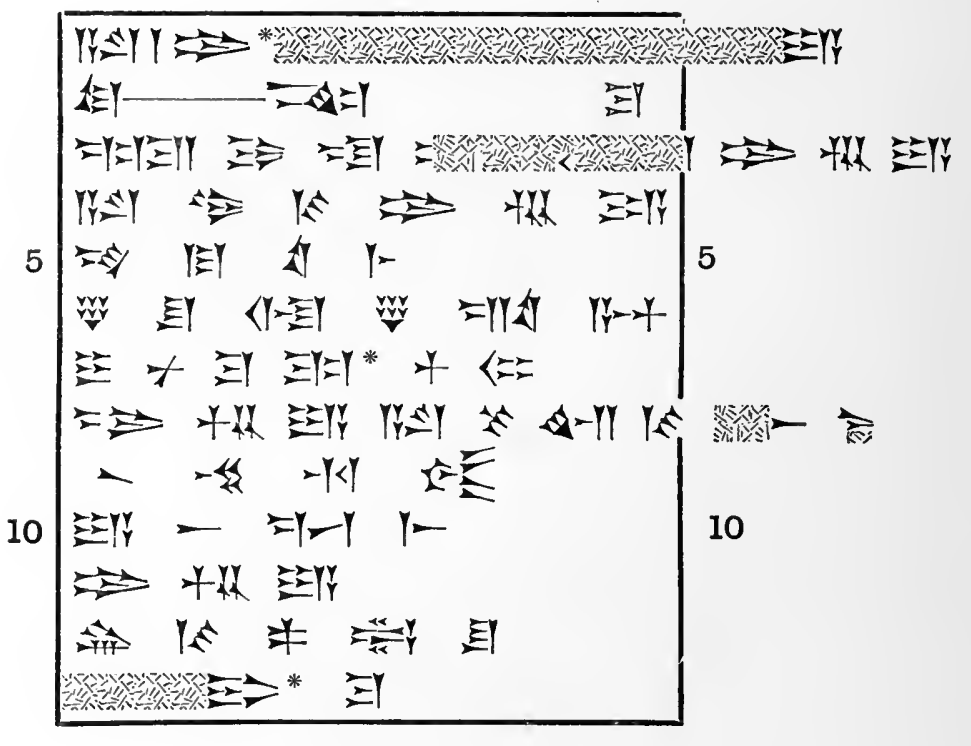

Reverse.

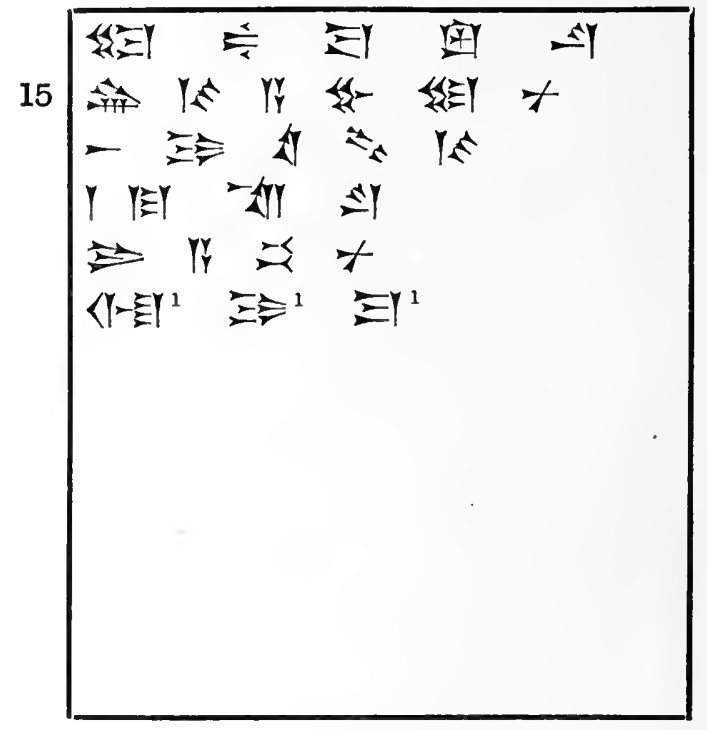

1 Erased by the scribe. 
No. 67.

(BU. $88-10-13,5 ; 4$ in. by $3 \frac{1}{\mathrm{~s}}$ in.)

Obverse.

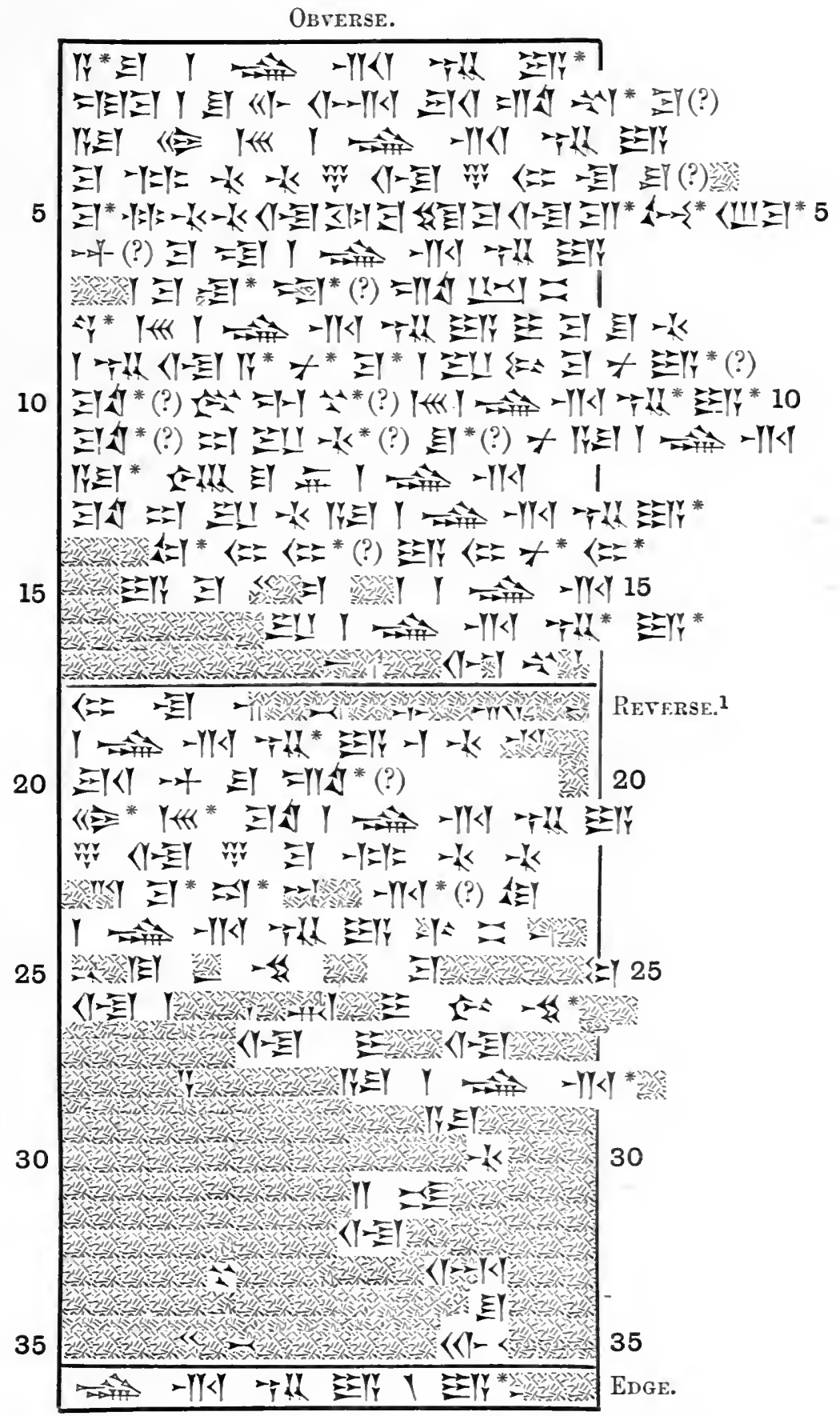

1 The characters on Reverse are much defaced; the realing is therefore donbtful. 
No. 68.

(BU. $88-10-13,54 ; 3 \frac{3}{8}$ in. by $2 \frac{5}{8}$ in.; see plate 12 .)

Obverse.

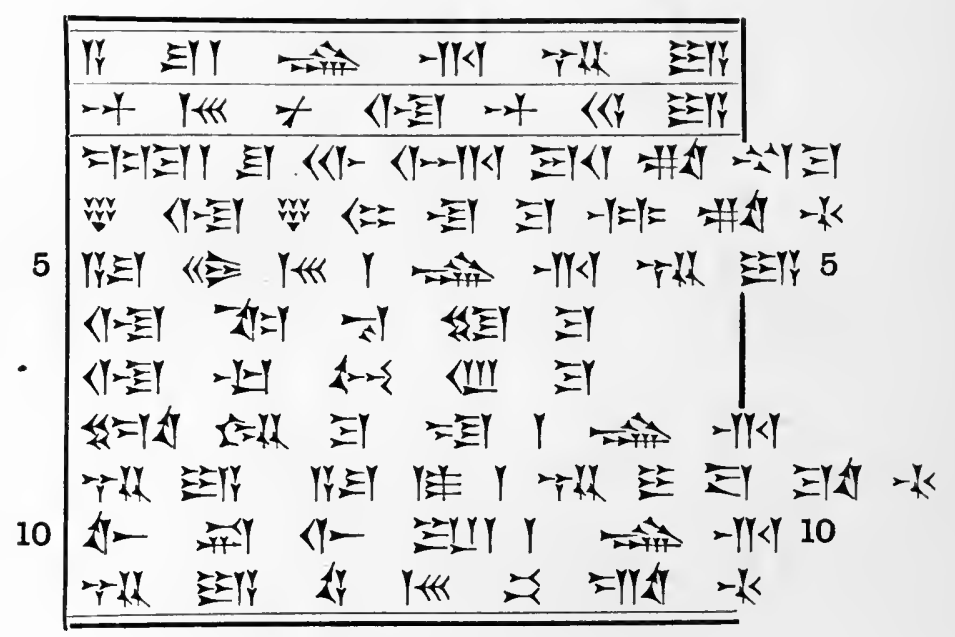

Reverse.

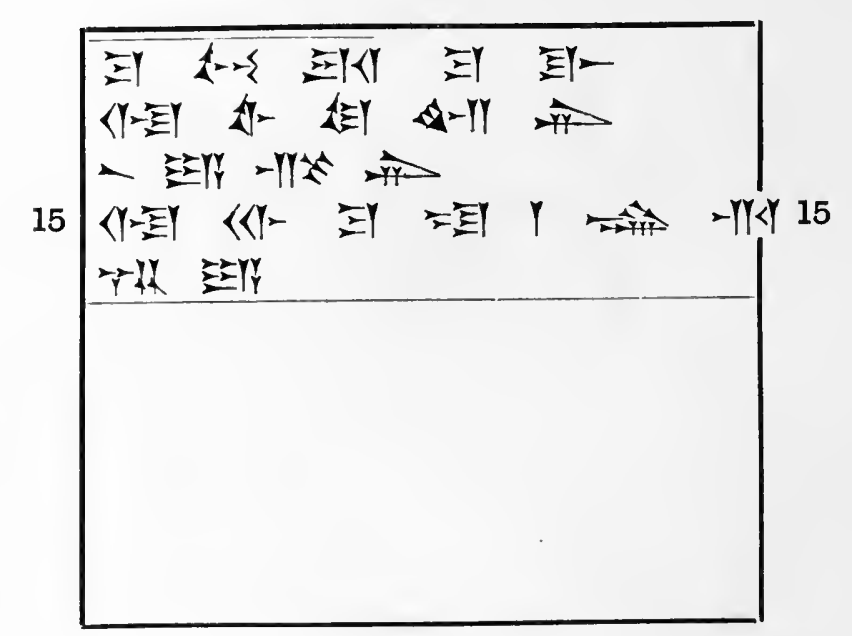




\section{No. 69.}

(BU. $88-10-13,19 ; 3$ in. by $2 \frac{1}{2}$ in. ; see plate 5.)

ObVerse.

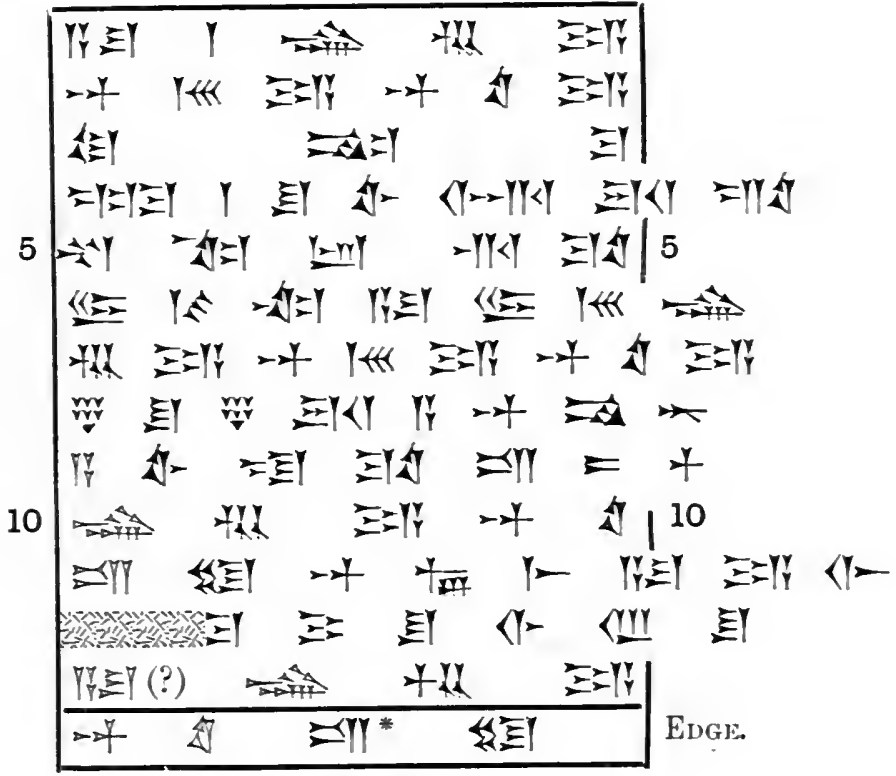

Reverse. ${ }^{1}$

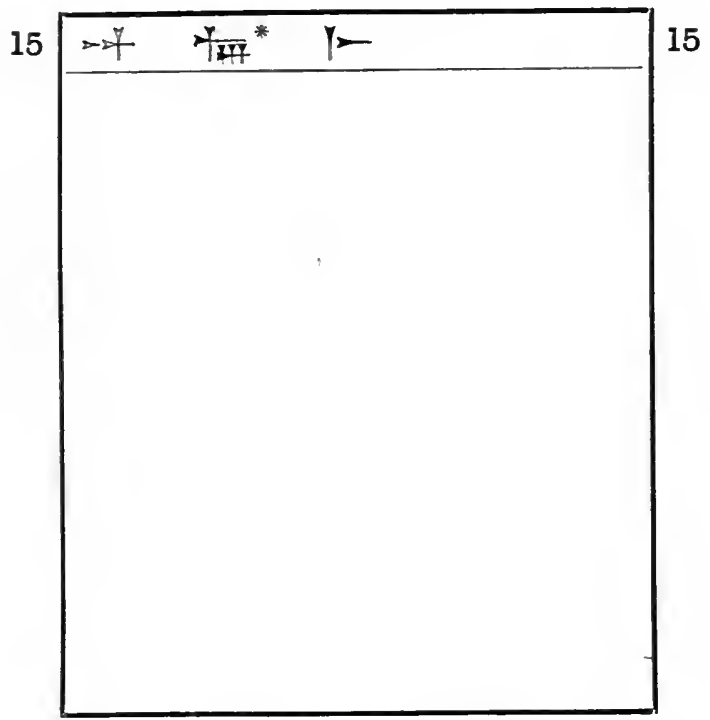

1 On plate 5 the tablet is photographed upsile down to show the ends of lines $4,6-8$, 11-12 of the Obrerse. 


\section{No. 70.}

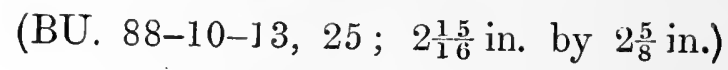

Obverse.

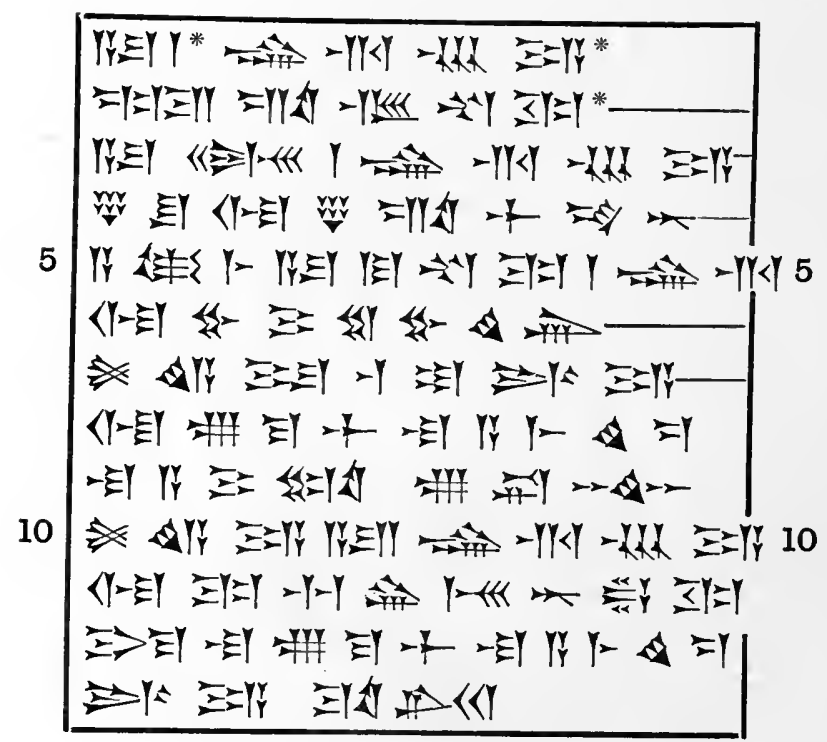

Reverse.

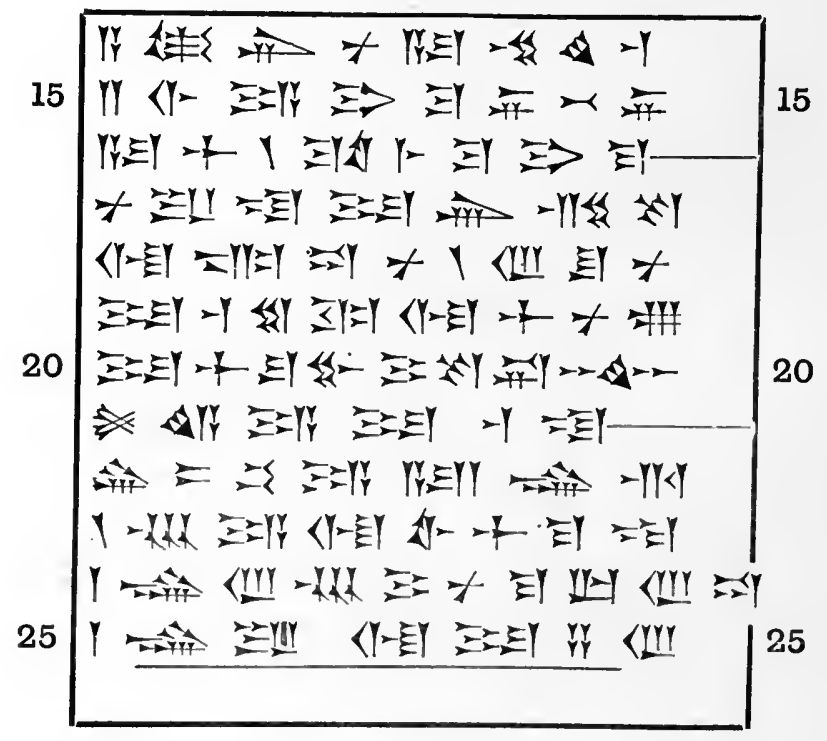


No. 71.

(BU. $88-10-13,1 ; 3 \frac{3}{8}$ in. by $2 \frac{5}{8}$ in. ; see plate 1.)

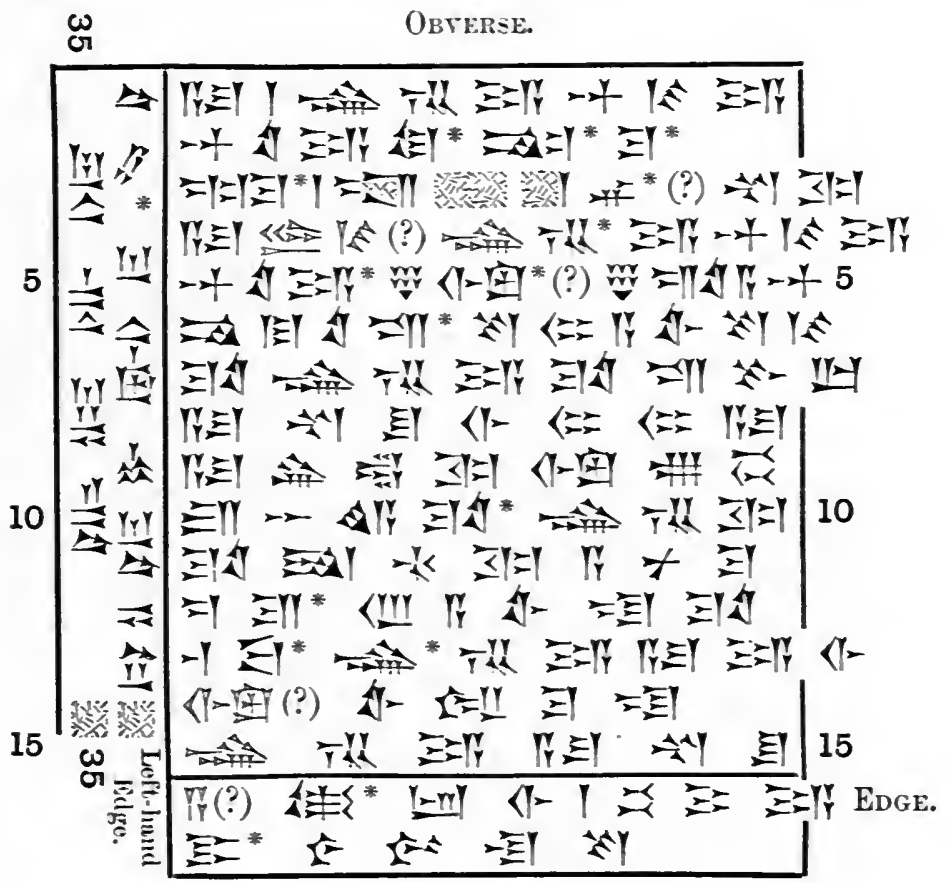

ReTerse.

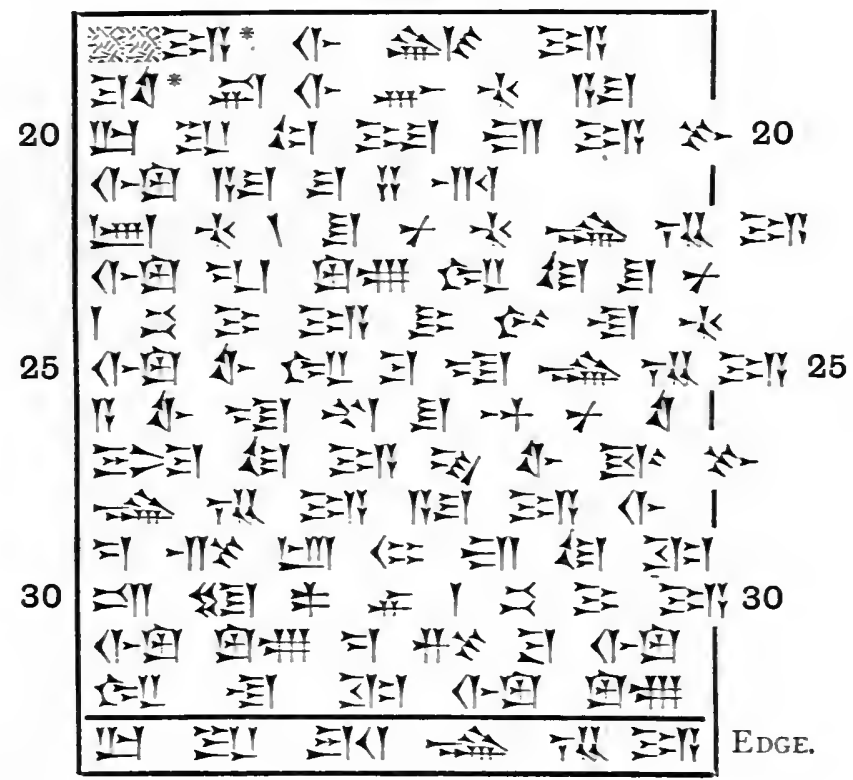


No. 72.

(BU. 88-10-13, $9 ; 3 \frac{5}{8}$ in. by $2 \frac{1}{2}$ in.)

UBVERSE.

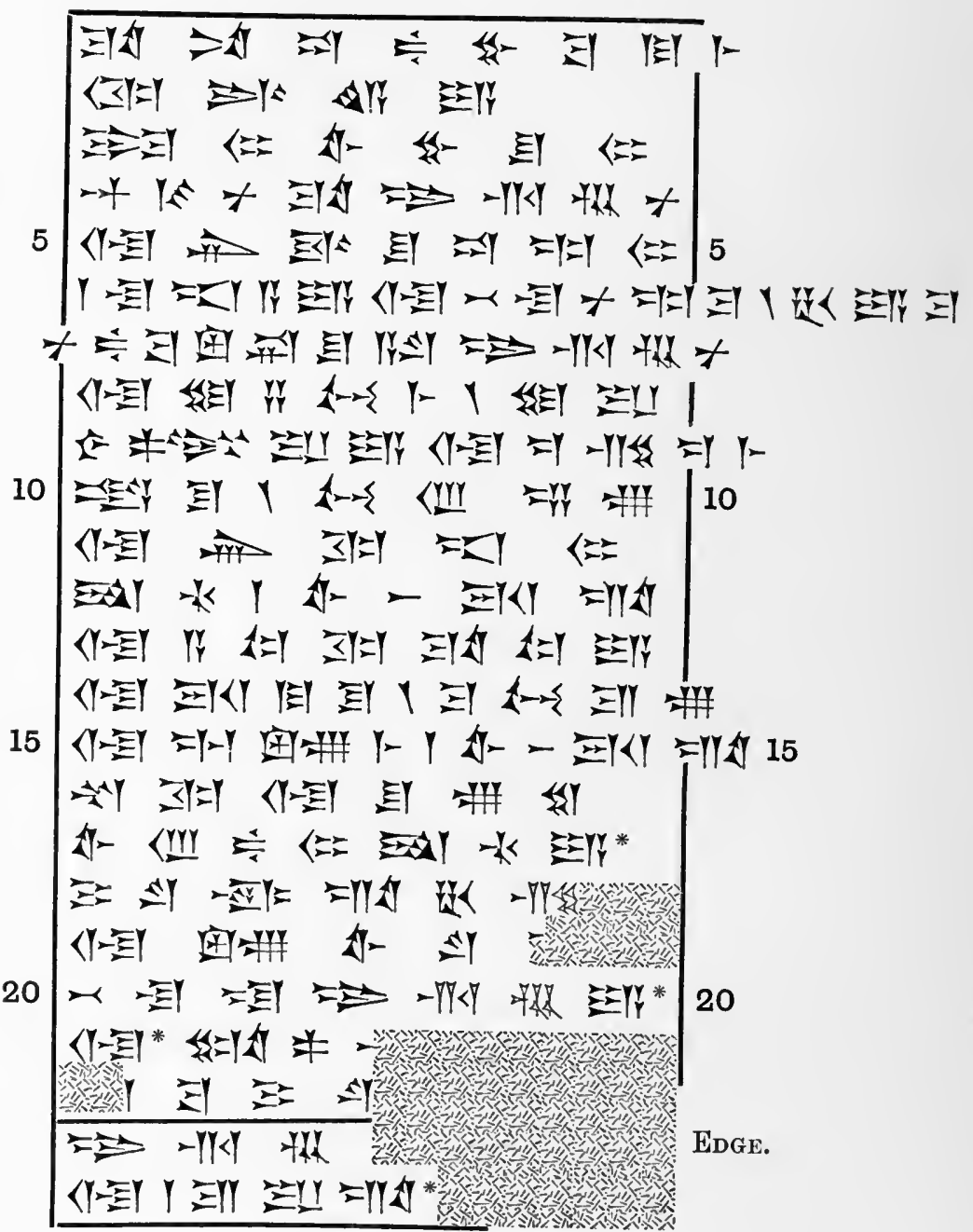


No. 72.

(BU. 88-10-13; 9; see plate 3.)

Reverse.

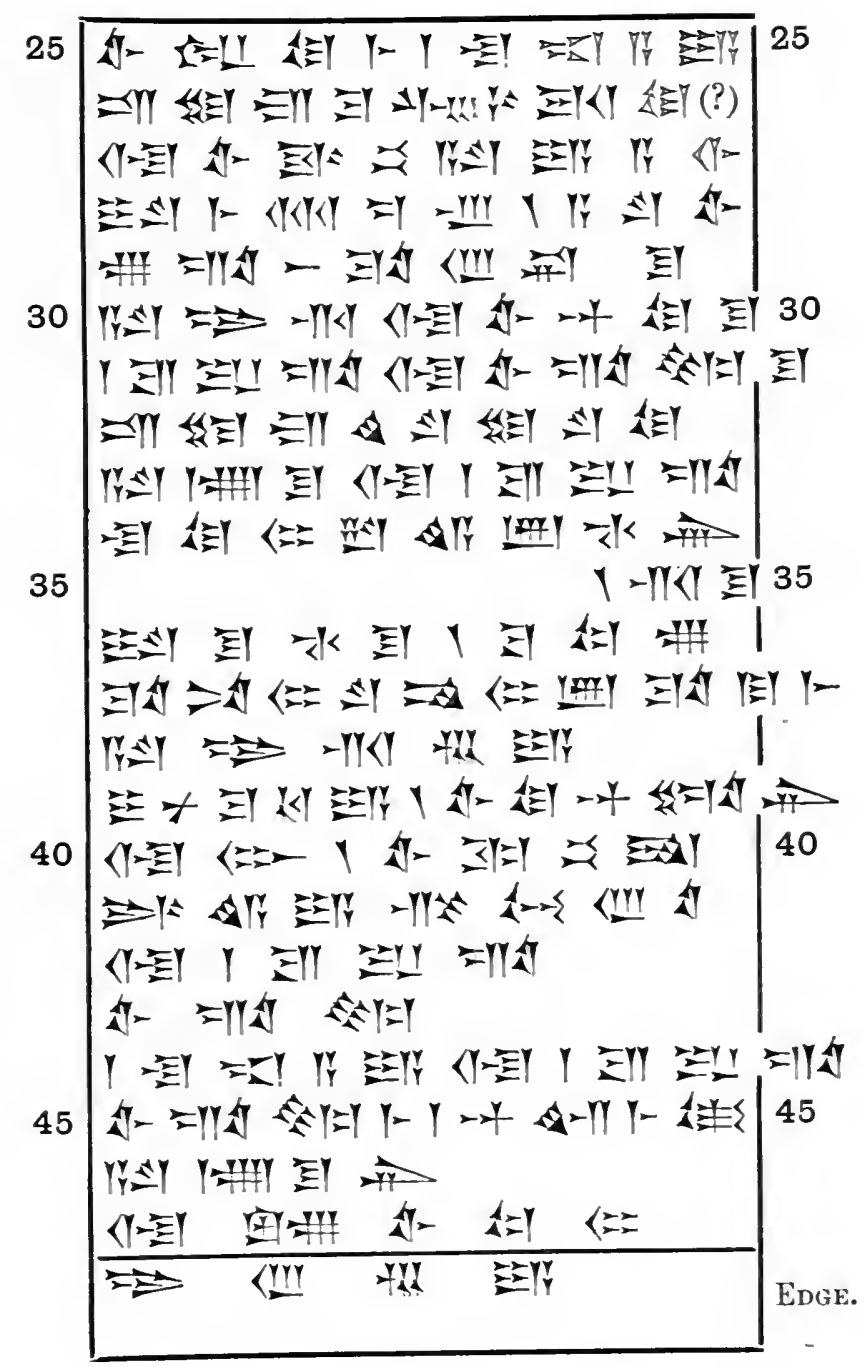


No. 73.

(BU. $88-10-13,33 ; 2 \frac{3}{8}$ in. by 2 in.)

Obverse.

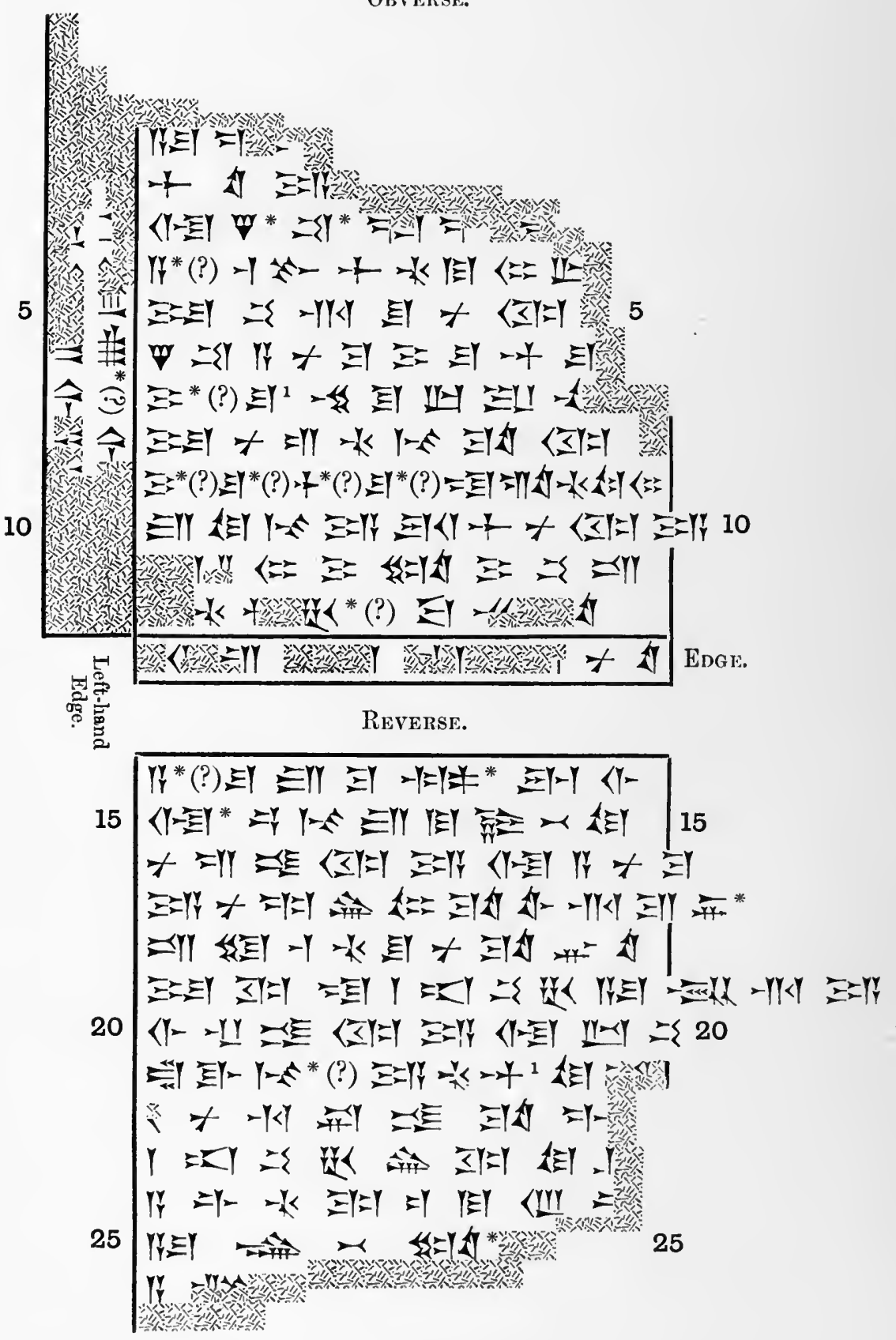

1 Written over an erasure. 


\section{No. 74.}

(BU. $88-10-13,4 ; 3 \frac{11}{16}$ in. by $2 \frac{5}{8}$ in. ; see plate 1.)

Obverse.

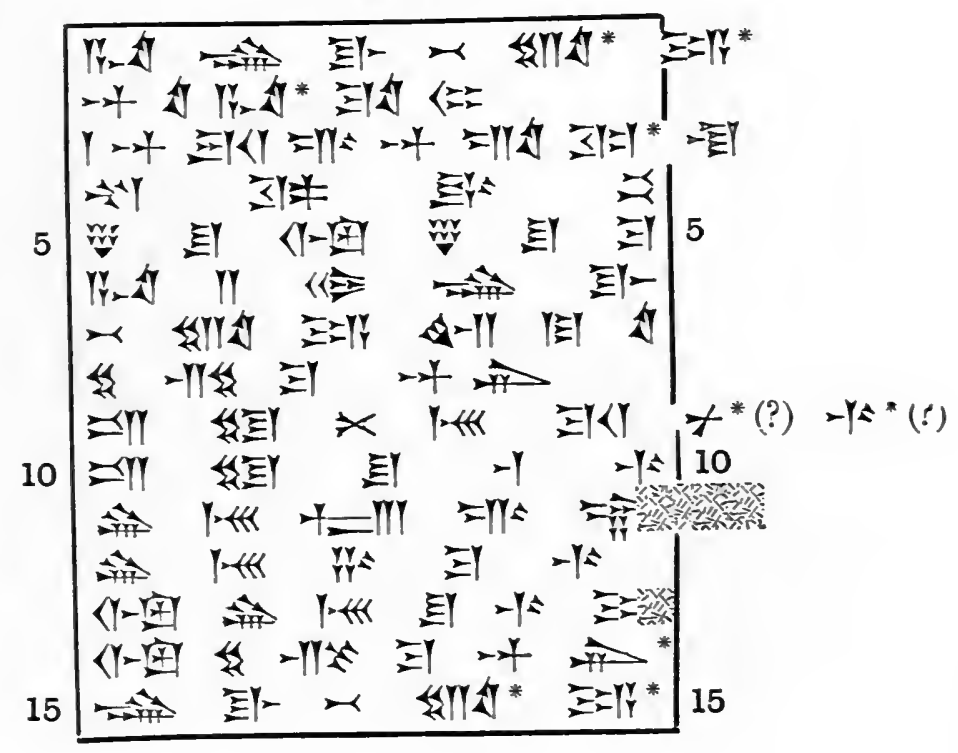

Reverse.

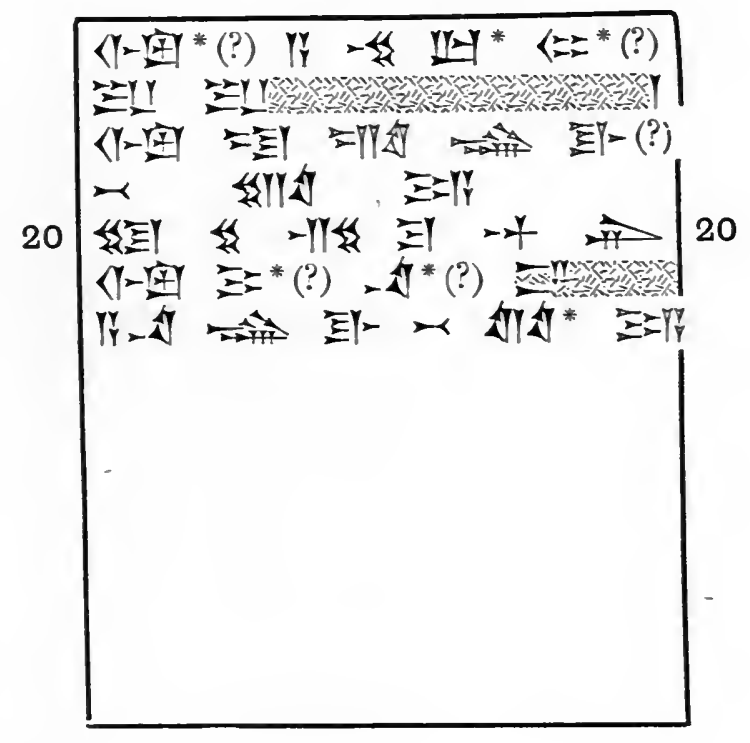


No. 75.

(BU. $88-10-13,66 ; 2 \frac{1}{2}$ in. by $2 \frac{1}{8}$ in. ; see plate 16.)

Obverse.

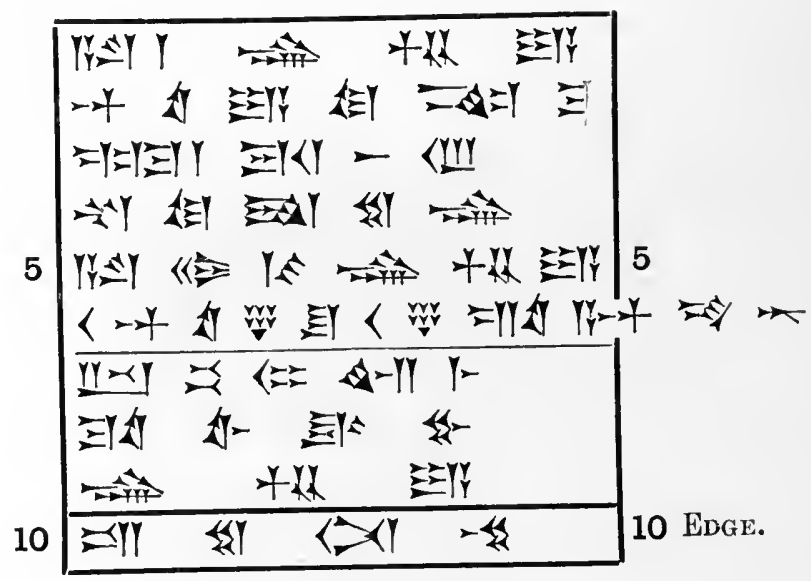

(KeVERSE BLANK.) 
No. 76 .

(BU. 88-10-13, 23; $2 \frac{1}{2}$ in. by $2 \frac{3}{8}$ in. ; see plate 6 .)

ObTerse.

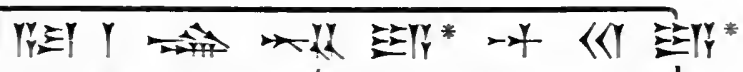

$$
\begin{aligned}
& \text { - }
\end{aligned}
$$

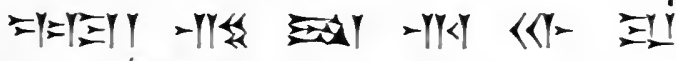

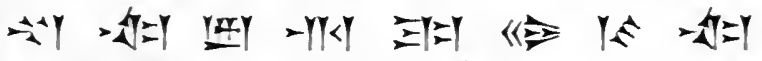

$$
\begin{aligned}
& 5 \text { रा-它 사 } \Rightarrow \\
& Y Y=Y \text { UEY } Y \text { WXX } \\
& \text { - }
\end{aligned}
$$

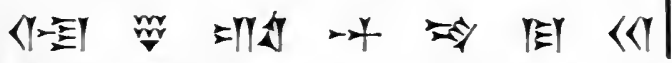

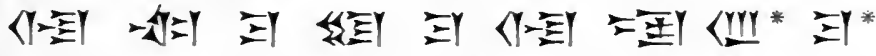

$$
\begin{aligned}
& 10 \text { ZII } \\
& \text { WK }
\end{aligned}
$$

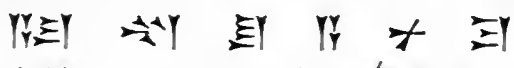

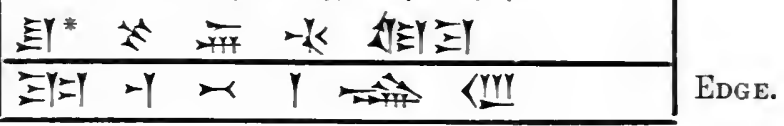

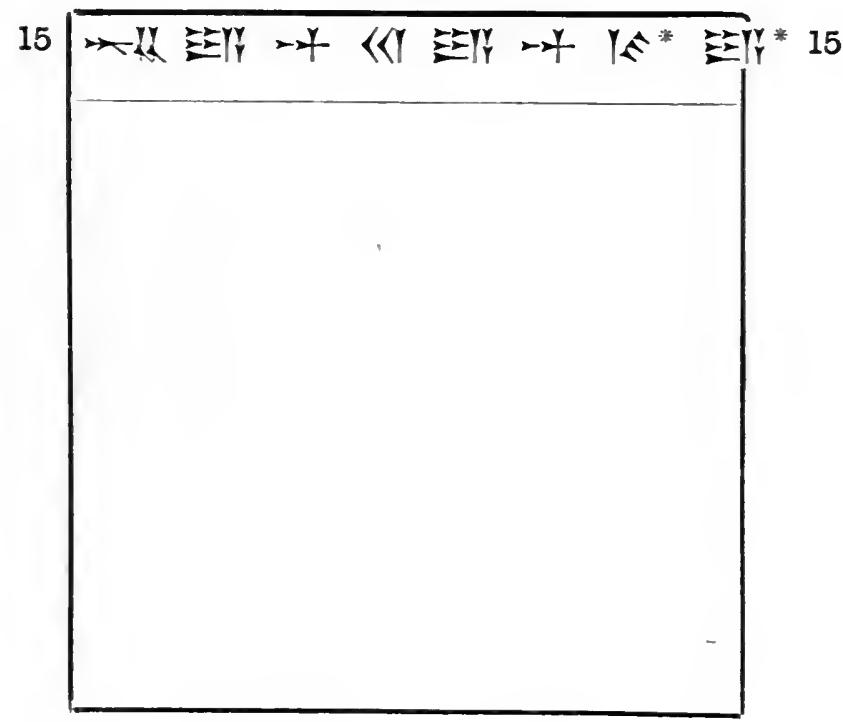




\section{No. 77.}

(BU. $88-10-13,67 ; 2 \frac{7}{16}$ in. by $2 \frac{1}{8}$ in.)

Obverse.

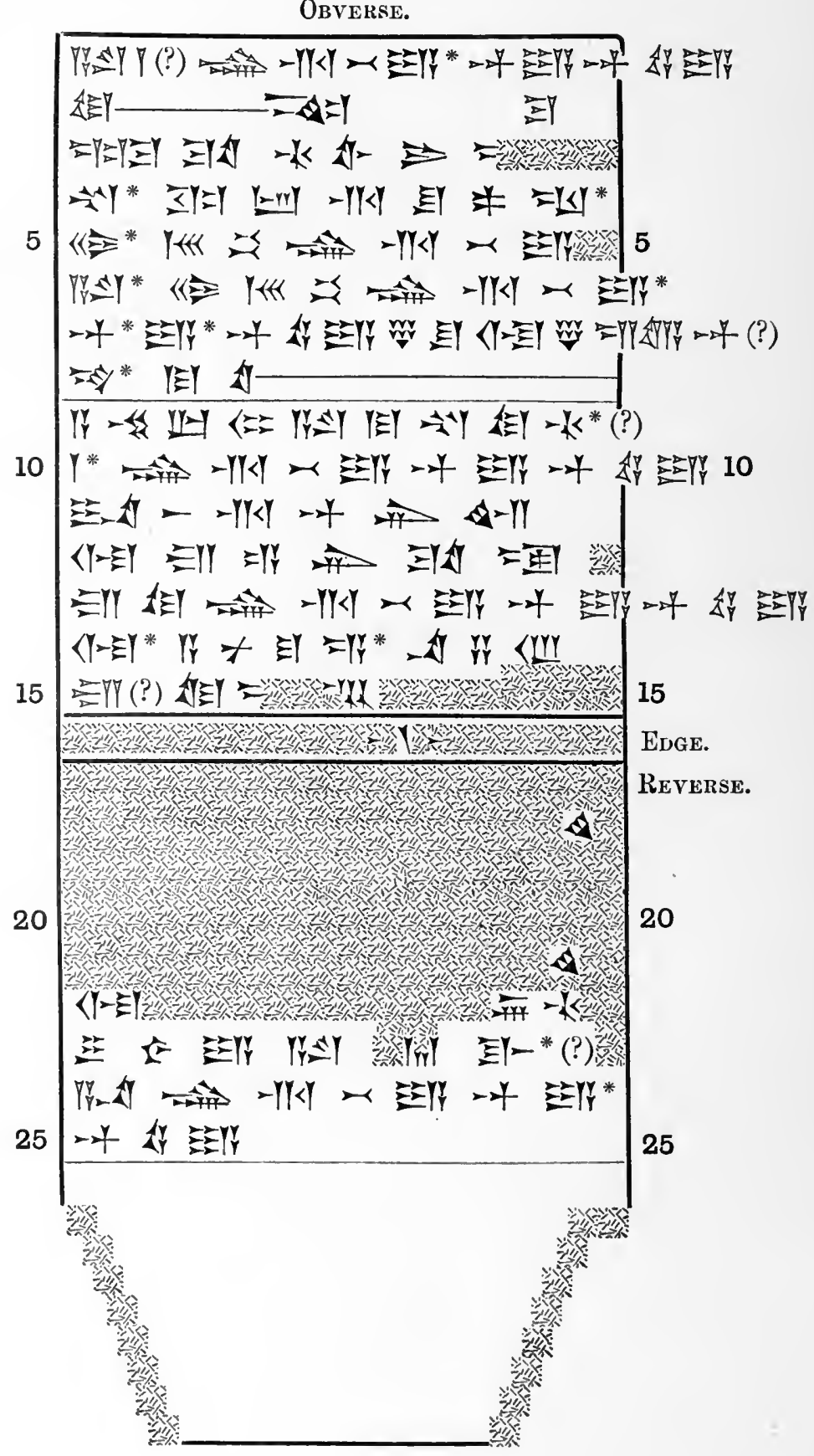


LETTER FORM AN INHABITANT OF THE CITY OF GUBBU (?). 135

No. 78.

(BU. $88-10-13,35 ; 2 \frac{5}{8}$ in. by $2 \frac{3}{16}$ in. ; see plate 7. )

OBverse.

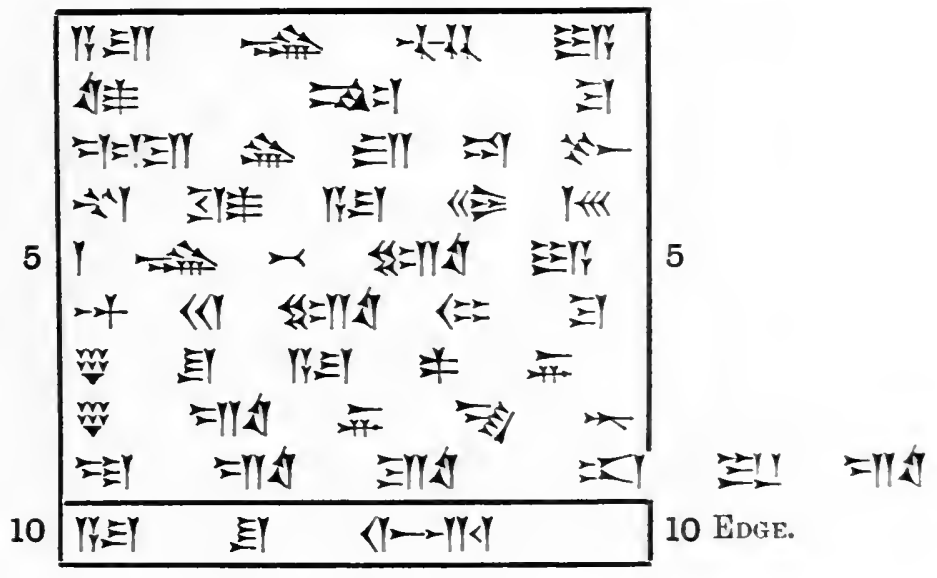

Reverse.

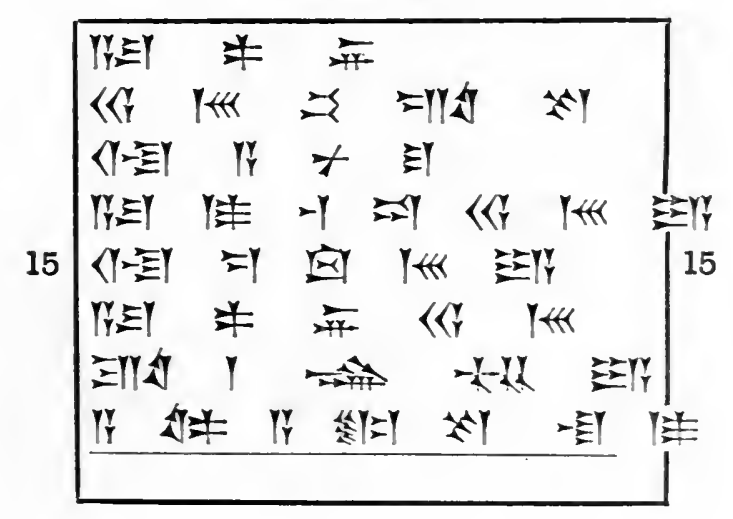


No. 79.

(BU. $88-10-13,30 ; 2 \frac{3}{8}$ in. by $2 \frac{3}{16}$ in. ; see plate 6. )

Obverse.

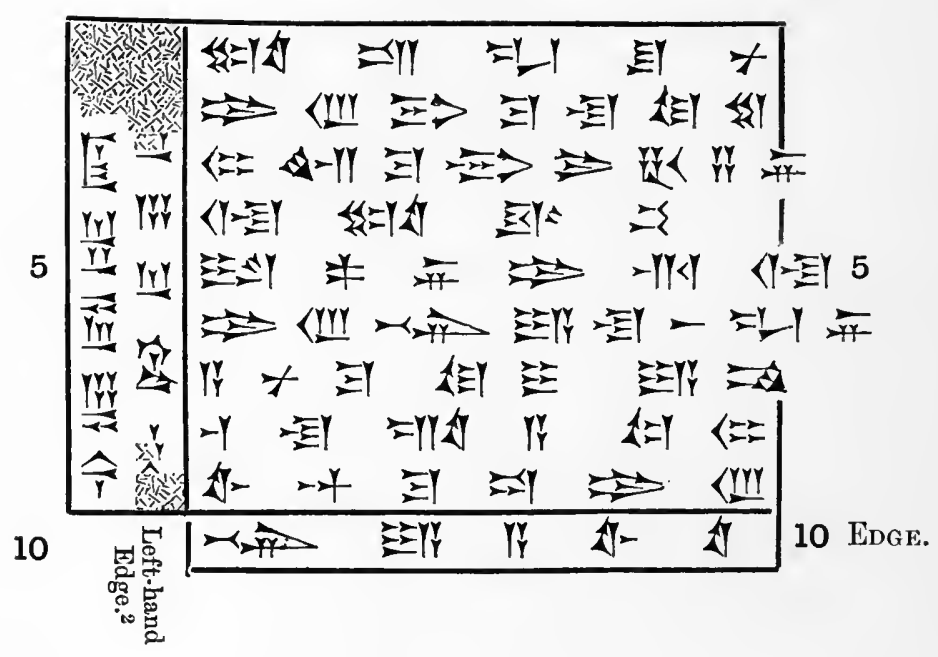

Reverse.

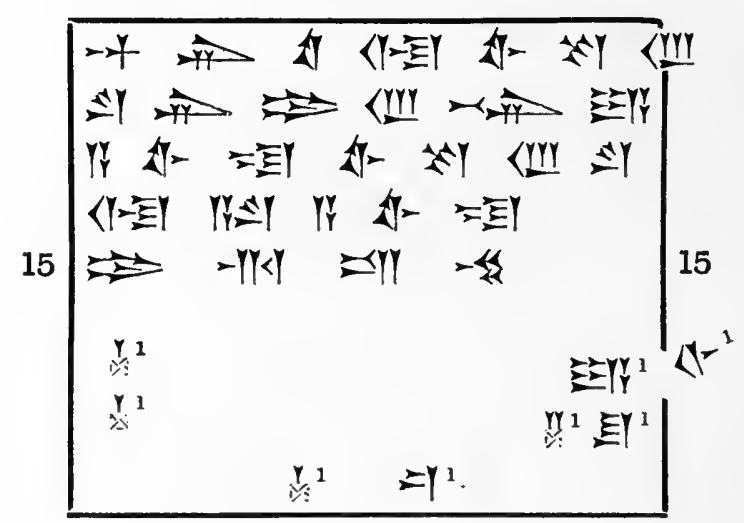

1 These traces of characters belong to a letter which the scribe wrote upon the Reverse and afterwards erased.

2 The scribe omitted to erase these lines, which belong to another letter previously written on this tablet. 
No. 80.

(BU. $88-10-13,24 ; 3$ in. by $2 \frac{1}{4}$ in.)

Obterse.

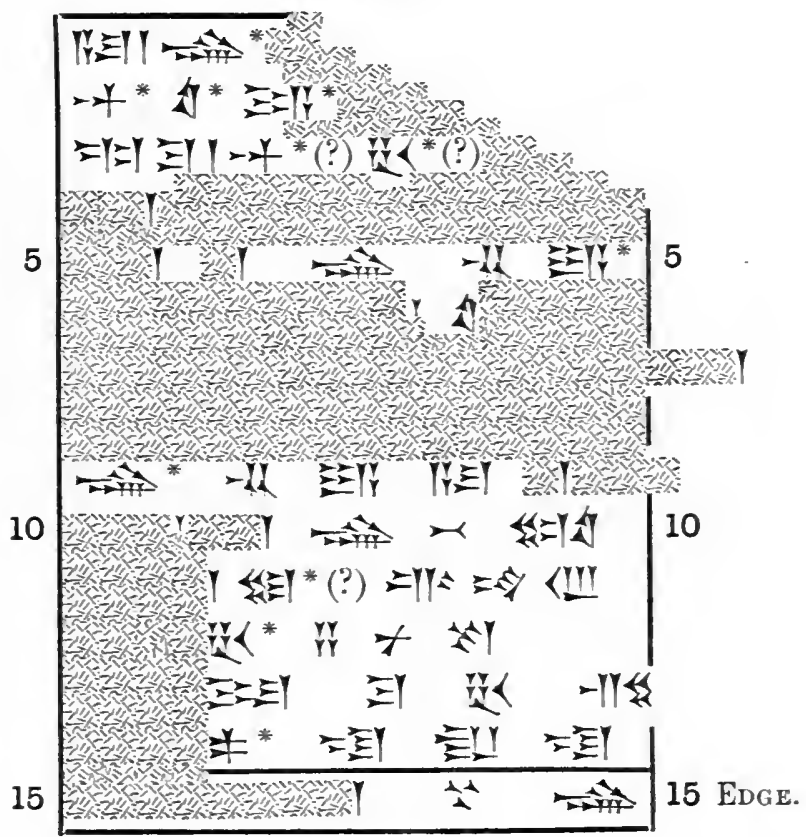

Reverse.

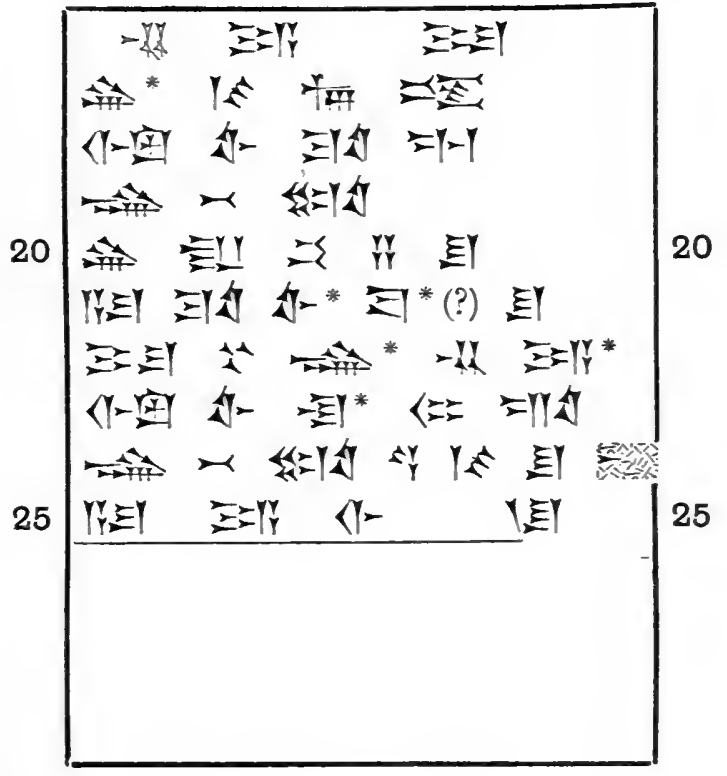



No. 81.

(BU. $88-10-13,28 ; 3$ in. by $2 \frac{1}{2}$ in.)

Obferse.

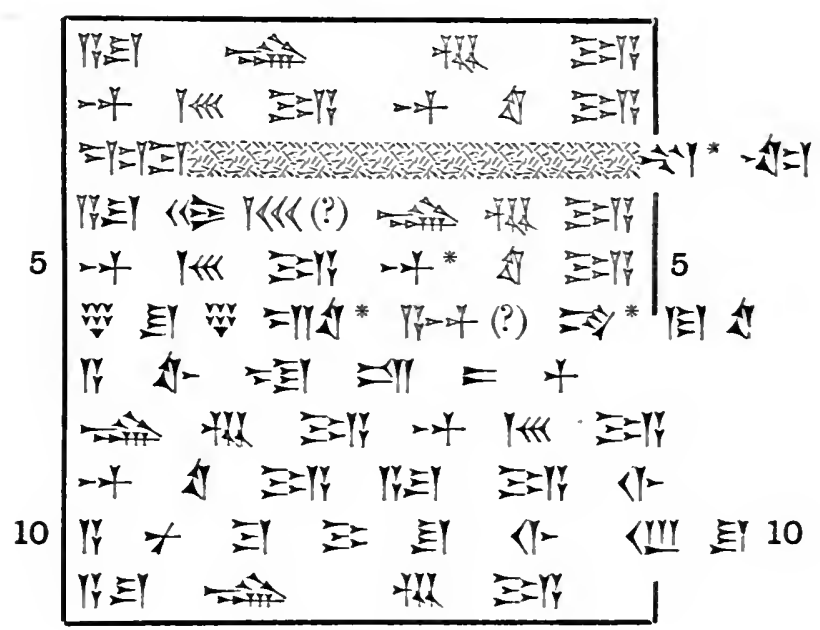

(REVERSE BLANK.) 


\section{No. 82.}

(BU. $88-10-13,69 ; 4 \frac{1}{4}$ in. by $4 \frac{1}{8}$ in.)

Onverse.

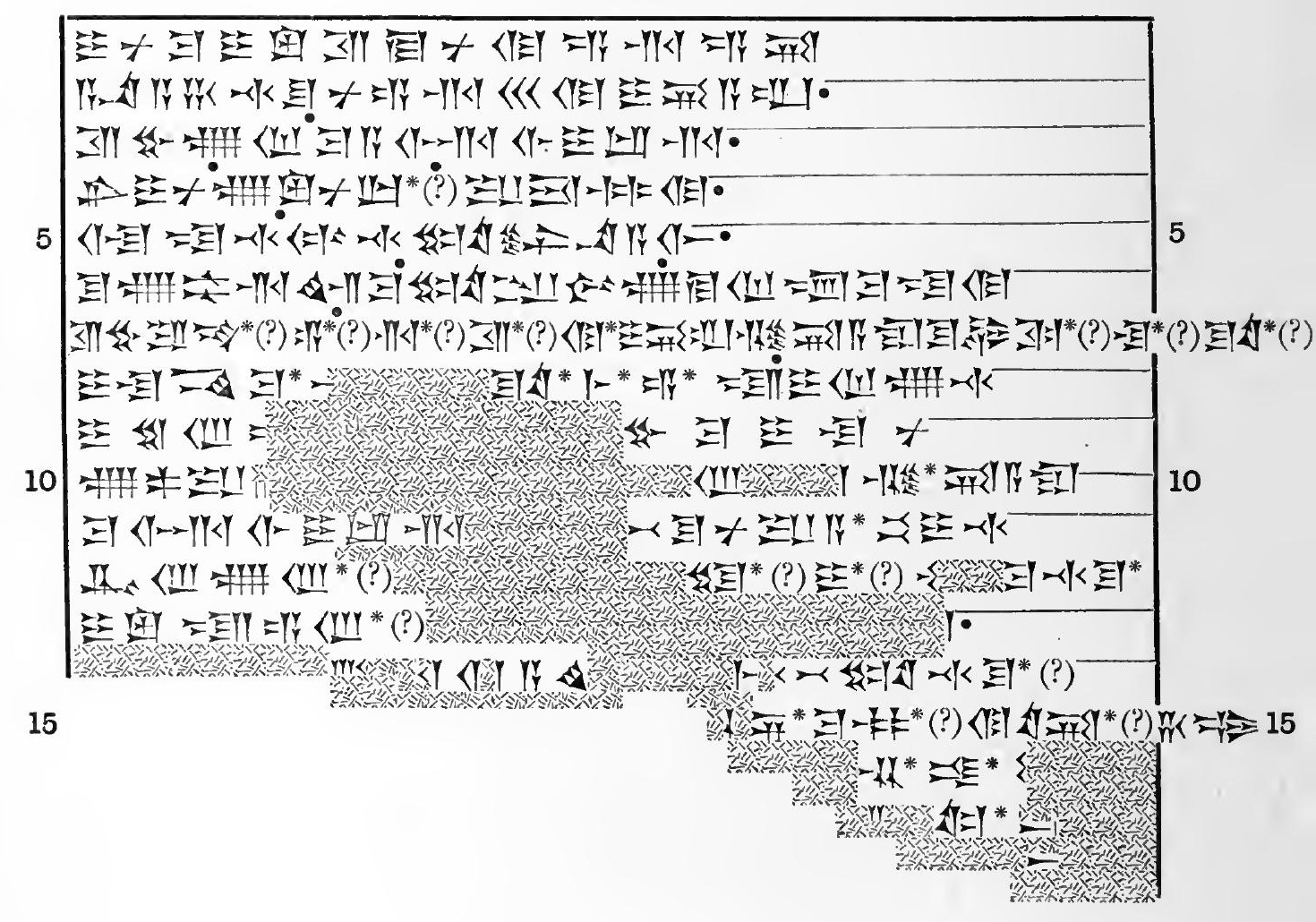


No. 82.

(BU. 88-10-13, 69; see plate 17.)

REVERSE.

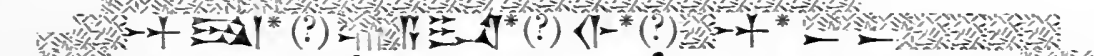

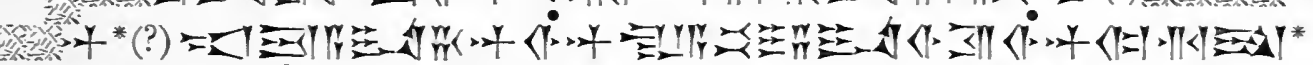

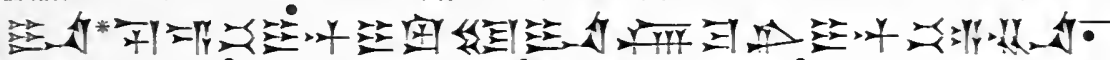

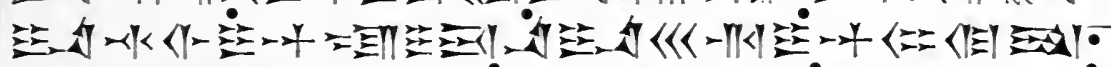

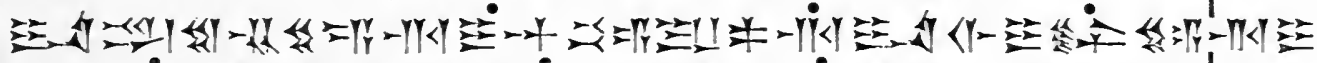

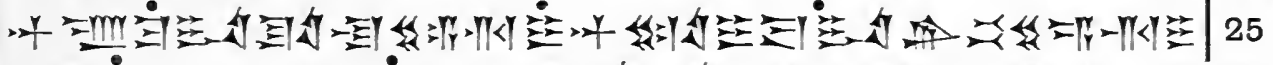

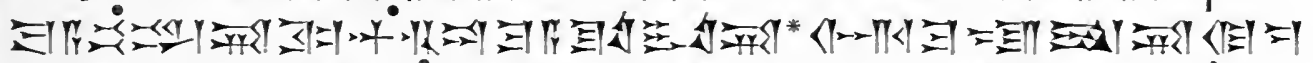

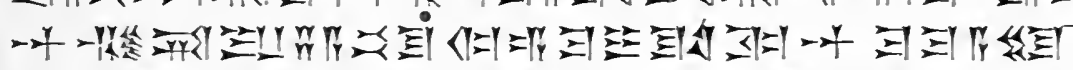

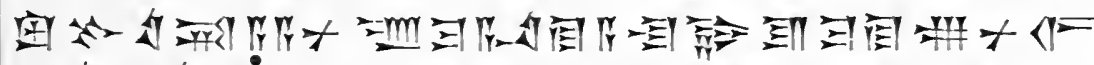

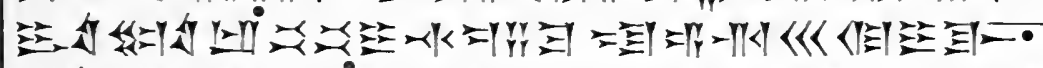

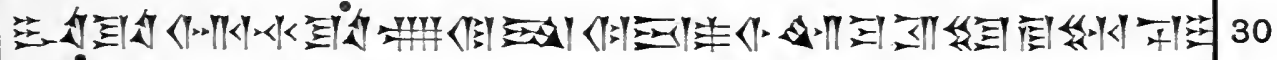

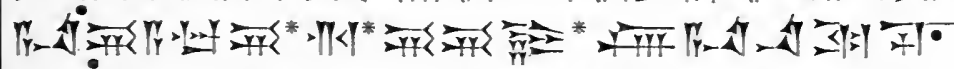

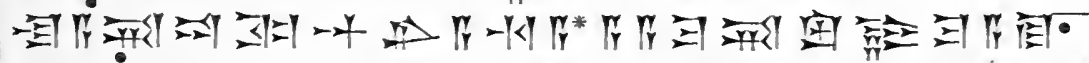
-

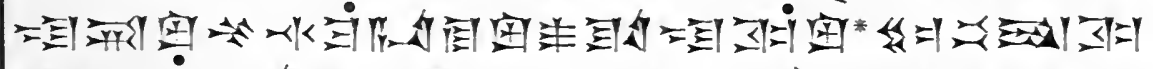

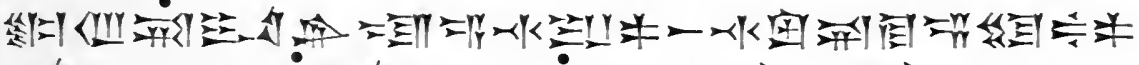

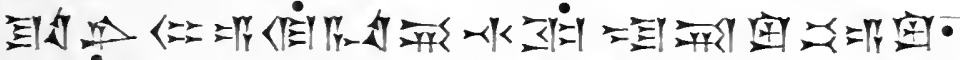

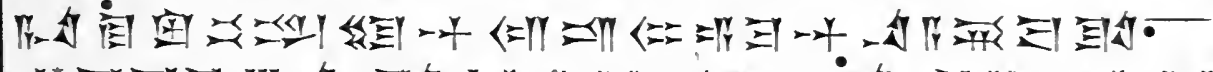

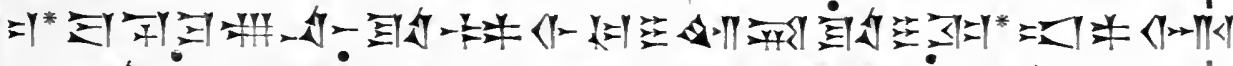

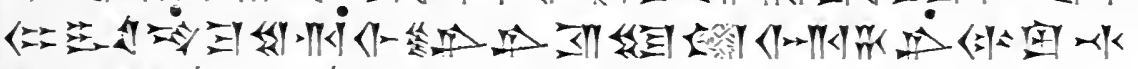





\section{LIST OF PROPER NAMES.*}

\section{N}

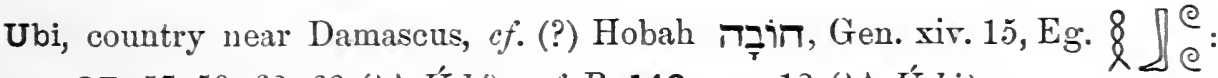

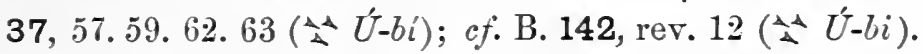

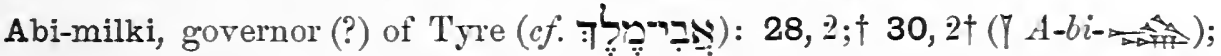
29,$2 ; \dagger 31,2 ; \dagger c f$. B. $99,2 \dagger(A-b i$ - $)$; $c f$. also B. $[98,2 \dagger] ; 162,2 \dagger$ ( $A$-bi-mil-ki).

Abdâ: 82, 21 ( $\rightarrow$ (?) $A b-d a-a)$.

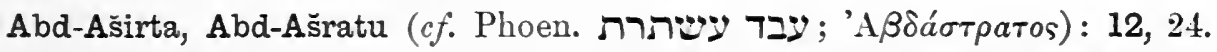
$30 ; 14,25 ; 15,18.25 ; 18,11.17 .31 ; 19,41 ; 20,38 ; 44,6.30$. [35, ši omitted]; of. B. 41, 27; 42, 12. 33; 45, 27. 36; 48, [64.] 68; [49, obv. 23?;] 51, obv. 24; 52, obv. 9. [rev. 14.] 26; [53,12?. 28?;] 54, 18 . $21 ; 60,18 .[47 ;] 61,13 .[68 ;] 72,17 ; 74,8 ; 75,[12] .22 .[44 ;][76,36 ;]$

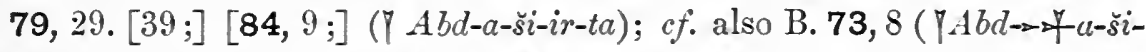
$i r-t i)$; B. 86, obr. 5; [214, 12] ( $(A b d-a-s ̌$ i-ir-ti); B. 71, 70; 76, 65 (Abd$a-s ̌ i-i r-t i)$; B. 71, 19 (Abd-p $a-s ̌ s i-i r-t i)$; B. 51, obv.11.19; [66,7;] 77,9; 89, 7. 18. 47. 58 (Abd-a-ši-ir-ta);-16, 12 ; cf. B. 60, 8 (

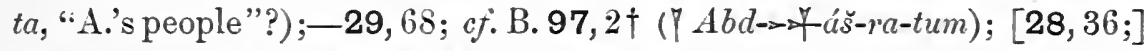
cf. B. 50, obv. $19 ; 184,30$ († Abd-ášs-ra-tum); [17, $10 ;]$ B. 58, 29. [38?.]

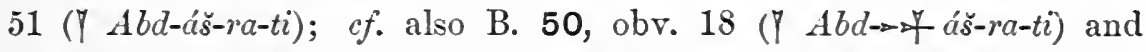
B. 58, 103. [116 ?]; 71, 56. 68 (Abd-ášs-ra-ti); 23, 23 († Abd-ášs-ra-ta);

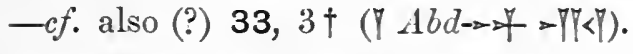

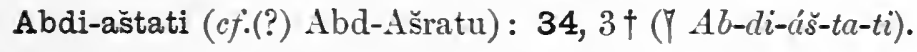

Abdi-kar\$i(?): 48, 3,† († Abdi(?)-kar(or tir ?)-ši).

Abdi-milki, son of Abd-Aširta : 20,37; cj. B. 134, $3 \dagger$ ( $\mathrm{Abdi}$ );-40, 17. 24 (Abdi-

Abdirama, son of Abd-Aširta: 20, 36 ( $(A b d-i-r a-m a)$.

* The numbers printed in thick type refer to the numbers of the tablets, and the others to the lines. E.g., "12, 24. 30 " = No. 12, lines 24 and 30. Restorations of lost portions of the names are indicated by the numbers within square brackets. † marks a passage in which the person is named as the writer, or sender, of the tablet, while $\ddagger$ is used for the person addressed. Homophonous signs hare been distinguished by means of accents. References hare been giren (e.g., " B. 41, 27 ") to the passages in the Berlin edition in which the names in this List also occur. 
Abbiḩa: 42, $12 ; 73,19.23$ ( $7 A b-b i-h a c)$.

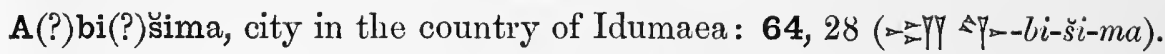

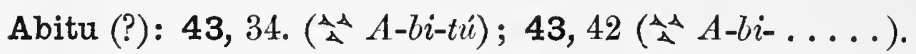

Yabitiri, governor (?) of Joppa and Gaza: 57, $4 \uparrow(\uparrow Y a-b i-t i-r i)$.

$\mathrm{U}($ ?)garit, country, or city, in Phœenicia (?): 1, 39 (今ᄉ $\hat{A}$-ga-ri-it); 30, 55

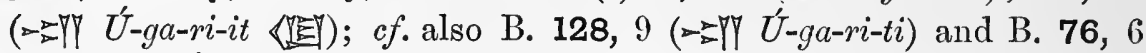
( $=$ - Y U U $\left.U^{\prime}-g a-r i-t i\right)$.

Ida ....: 46, 5 (ҮÍ $-d a-\ldots . .$.$) .$

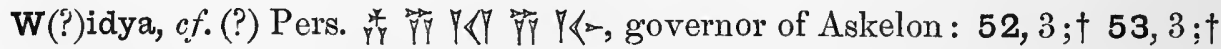
54,$4 ; \dagger c f$. B. $[118,4 ; \dagger] 119,5 ; \dagger 121,5 ; \dagger 122,3 \dagger(Y$ s $\$-i d-y a)$.

Adda-mihir: 72, 45; cf. B. 167, $2 \dagger(7 \rightarrow \not$ Adda-mi-hir); cf. also B. 168, $3 \dagger$

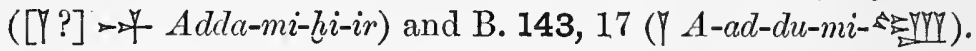

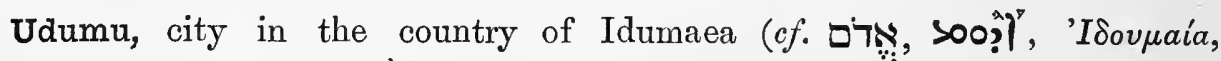

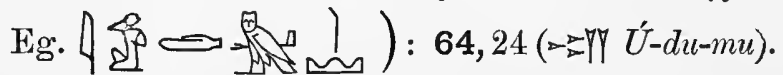

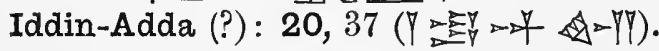

Aduri, city in the country of Idumaea (cf. רָָ

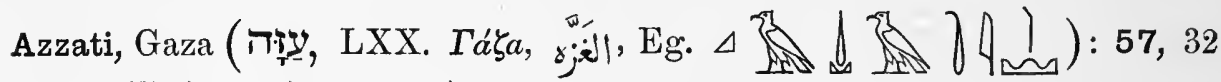
$\left.\Leftrightarrow \rightarrow p^{-} A z-z a-t i\right)$.

Aziru, son of Abd-A širta (cf. 24 ; $\left[34,8 ; 45,13.35 .39 ; 66,51 .{ }^{x}\right.$ [ [62]; cf. B. 34, $2 \dagger ; 35,2 \dagger ; 37$, $2 \nmid ; 38,2 . \dagger 38 ; 41,26$; [45, 47 ?;] 76, 9; [83,8;] 91, 10.21 († $A-z i-r u)$; cf. also B. 58, 23.35 (A-zi-ru); 13, 16. $69 ; 19,37$; 29, 68; 35, 2†; cf. B. $31,2 \dagger ; 34 a, 4 \dagger ; 39,11.27 .35 ; 40,2 \uparrow ; 45,39 ; 58,46$. 60. 71. 94.106 . 110.114; 91, 9; 128, 7 ( $A$-zi-ri); 28, 35. 40.58.70; 30, 61. 67; 36, 24. 27. 39 ; 41, 21. 27. 32. 34. 35 ( $A-z i-r a)$; 43, 28 ; cf. B. 36, $3 \dagger ; 69$, 15 ; 71, 21 (?) (\rceil $A-z i-\ldots .$.$) ; -cf. also (?) B. 45, 33$ († $A-z a-r u)$.

A'ițu(?)gama: 37, 28. 37. 60 ( $(A-i-t u(?)-g a-m a)$.

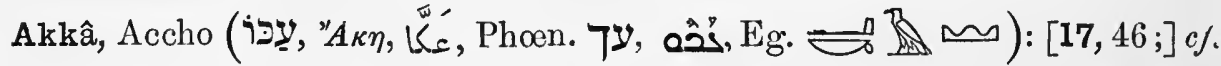
B. 94, 5; 95, 3. [16?] 29 ( $\Rightarrow$ P Ak-ka (促); cf. also B. 8, 19; 93, 4

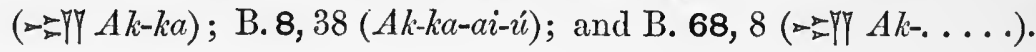

Akiya: 58, $3(7 A-k i-y a)$.

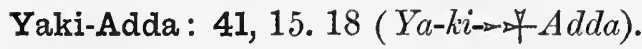

Akizzi, governor of the city of Qața: 36, $2 \uparrow ;[37,2 \dagger]$; cf. B. 229, $2 \dagger(7$ $A-k i-i \tilde{\boldsymbol{\gamma}}-z i)$.

Ilûtu(?): 82, 22 ( $\nrightarrow$ 年 I-lu-tu).

Ili-milku (cf. (צ. 


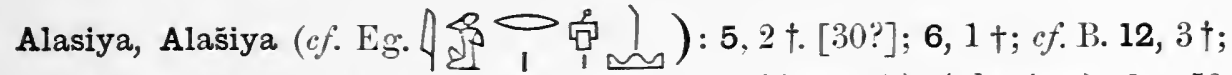

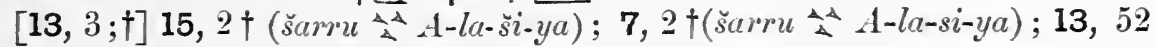
(AA A-la-ši-ya); 13, 59 (A-la-ši-a[-a?]); 5, 33; [6, 39?] (A-la-ši-ya); cf. also B. 11, 2† (s̆arri(ri) ÂA $A-l a-s ̌ s i-y a)$.

Am (P), Amma, Ammiya: 46, 4 ; cf. B. 143, 16;160,9;163, 8 (ㅅㅅ Am (值); 17, $7(\leadsto-1 \mathrm{Am}-m a) ; 37,58$ (A $A m-m a) ; 12,25 ; 15,27$; [cf. B. 89, 13] $\Leftrightarrow$ A Am-mi-ya); 45, 14;cf. B. 91, 11 ( A Am-mi-ya).

$\mathrm{Um}(?) \mathrm{ma}: 82,25$ ( $\rightarrow$ 年 $U m($ ?)-ma).

Ambi : 23, 20; cf. B. 60, 11. 40; 72, 31; 74, 19 ( $\rightarrow$ - Am-bi); cf. also

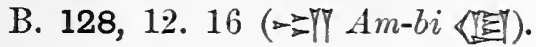

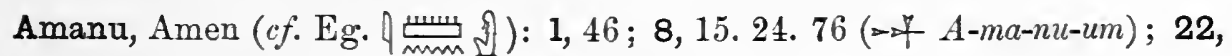
5 ( $\rightarrow$ - $A-m a-n a) ; 21,3(\rightarrow$ - $A-m a-a n \ldots . .$.$) .$

Aman-mašašanu (?): 13, 51 ( 7 A-ma-an-ma-šác-šá-nu ?).

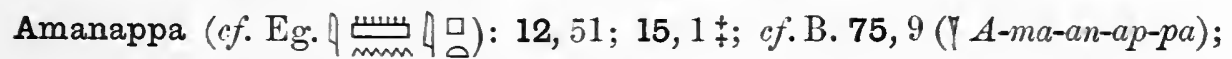
$[21,1$ ? ; 22, $1 \ddagger]$ ( $7 A-m a-a n-a b-b i)$.

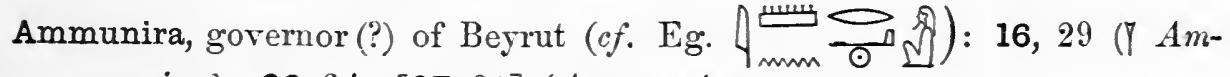
$m u-n i-r a) ; 26,3 \dagger ;[27,2 \dagger]($ Am-mu-ni-ra).

Immûriya : see Mimmûriya.

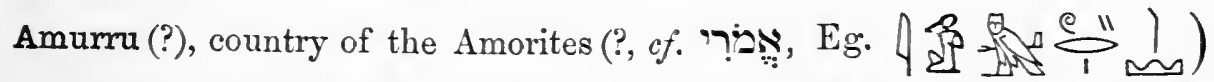
21, 8 (AА $A$-mu-ri); 13, 14 ; 15, 11. 15; 27, 24 ; 44, 5. 21. 29. 35; cf. B. 45, $63 ; 48,69 ; 92$, rev. $32 ; 97,8 .[15$ ?] ; 146, $16 ; 184,39$ (A) A-mur-ri); cf. also B. 69, 17 (AA A-mur-ra); B. 77, 10 (^A-mur-ra-a); B. 92,

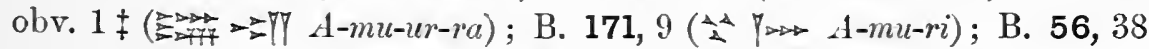
(A $A$-mur-....); and (?) B. 34, 14 (A $A$ A-mur-ra (?).....).

Iuni, a wife of Tušratta: 11, 52. 54 ( $I$-úni ).

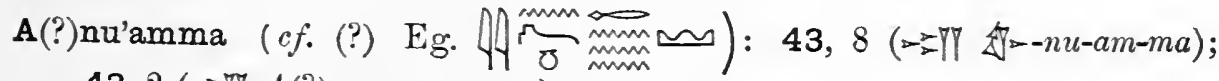
43, $2 \Leftrightarrow=\pi($ ? $)-\ldots \ldots \ldots . .$.

Yanhamu, envoy of Amenophis IV.: 62, 11; cf. B. 48, 23 ; 52, rev. 4; 61, 73; 101, obv. 13. rev. 12; 184, 22; 185, [ว.] 7.11. 13. [22] († Ya-an-ha-mu);

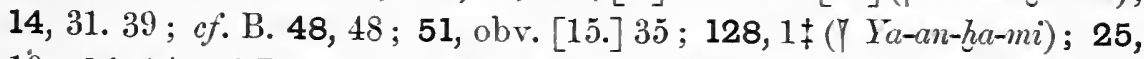
$19 ; 64,1 \ddagger ; c f$. B. 45, 61 ( ( Ya-an-ha-mí); 14, 40 († Ya-ha-mi); [24, 48]; 57,$24 ; 60,10 ; 65,14 ;$ cf. B. 43, 36. 37; $[110,25]$ (Y Ya-an-ha-ma); 18,$26 ; 21,15$ (7 Ya-an-ha-.....);-cf. also B. 102, 28 ([7?] Í-in-ha-mu); and B. 105, rev. 11 ( $($ AY -2 -in-hu-mu).

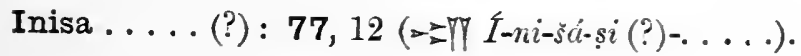




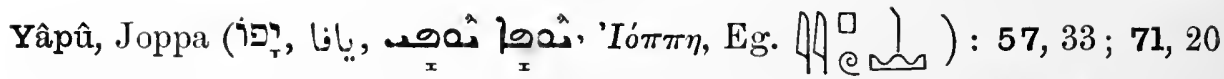

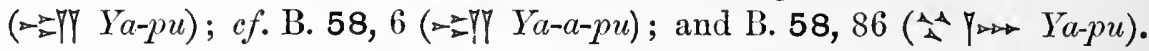
Yapa-Adda, probably of Alašiya: 13, 16. 59. 69; 14, 26 ; cf. B. 44, rev. 28 ; $[45,65] ; 48,[29] 42 ;$.51 , obv. 30. edge 3 ; 61, [26.] 52 ; 63, 31. 34. 44;

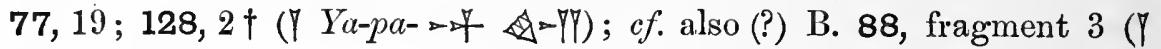

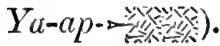

Yapahi, governor (?) of Gezer : 49, 3†; 50, 4†; 51,3† ( $Y$ Ya-pa-hi ).

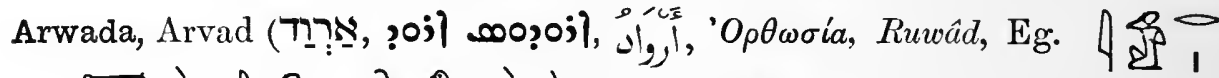

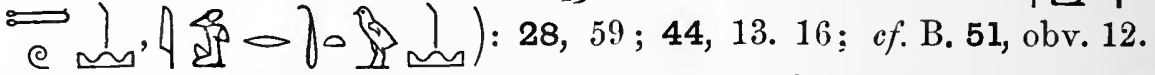

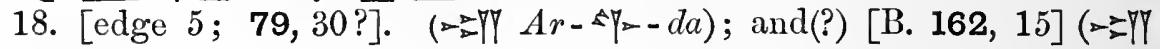
$A-r a-d a)$.

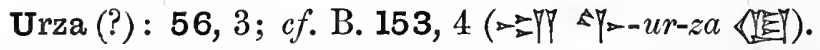

Arzawya, Arza'(u)ya (?): 37, 36. 56 ( $\left(A r-z a-\imath^{\prime}-y a\right)$; 43, 26. 33 ; cf. B. 125,

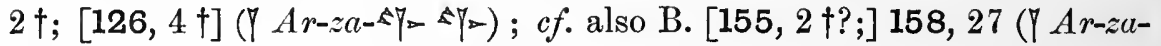
$\left.\Delta P_{-}\right)$; and 105, obv. 7 ( $\left.A r_{-}-z \alpha-\hat{-A} Y_{-}\right)$.

Yarimûta (cf. יר: $): 12,16 ; 13,55 ; 19,17 ; c f$. B. B. 57, rev. 1 ;

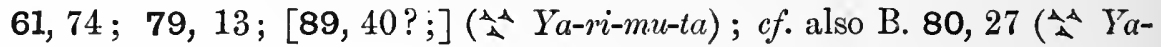
$r i-i m-m u-t a)$.

Irqata; city, or country, in Syria ( $f f . \mathrm{Eg} .4 \underset{\mathrm{D}}{\Delta} \longrightarrow$ ) 42,2 †. 3. 8, 10.

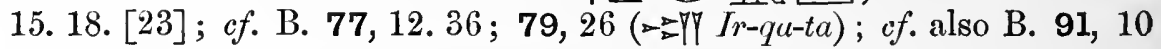
(A A $I r-q a-t a)$; and (?) B. 158, $22(\rightarrow$ I Ir-qat (?)-. . . .).

Araru: 64, $25(\rightarrow>Y A-r a-r u)$.

Iriškigal, heroine of a mythological legend : 82, 2 ( $($-ri-ís-ki-i-ga-a-al); 82, $7(\dot{I}(?)-r i(?)-i s(?)-k i-i-g a-a l) ; 82,29$ (t-ri-iš-ki-i-gal); cf. B. 234, rev. 1; 239, a, 4. $6(1-r i-i s ̌-k i-g a l)$.

Artaššumara: 9, 19 ( $(A$-ta-ás̆-šú-ma-ra).

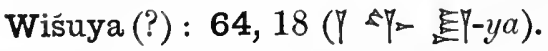

Ušbarra (?) : 7, 25 ( $(U \breve{s}-b a r-r a) ; c f .(?)$ B. 158, 15(\rceil $U \breve{s} \ldots \ldots \ldots \ldots \ldots)$.

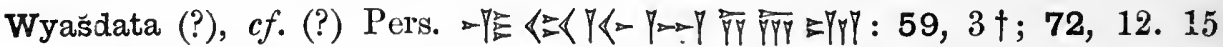
( $\nabla \wedge \nabla>-a ́ s-d a-t a)$.

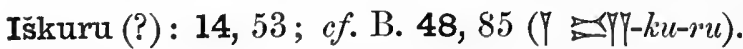

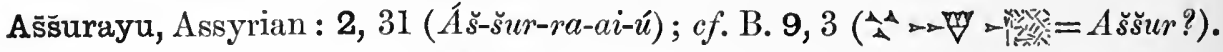
Ištar $(c f . \mathrm{Eg} . \rightleftharpoons$

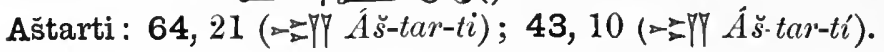

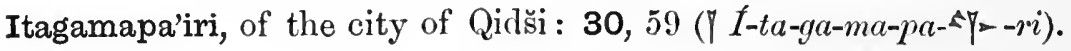


Itakkama: 43, 31 ( I I-ta- $\$$-ka-ma); cf. B. 91, 25 ( ( I-ta-ka-ma); 142, obv. $2 \dagger(\rceil$-tak-ka-ma); rev. 20 (1-tak-ka-ma).

Itillûna (?) : 7, 23(\rceil $f-\triangleright-l u-n a)$.

Bîya: 71, 16. 24. 30 († Bi-i-ya).

Bayawi (?) : 60, 3†; cf. B. 195, 3† ( $\geqq\rceil-y a-40)$.

B(?)uz(?)runa: 43, 13 ; cf. B. 205, $12 \Leftrightarrow\rceil 7$ Bu-uz-ru-na).

Bihura (?): see Pihura.

Bihišsi (?): $64,8.13 .34\left(\leadsto \prod B i-h i-s ̌ i\right)$.

Bîl-ra (?)m . . . . (?) : 7, 26 († Bi-

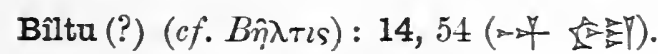

Binna : 82, 22 ( $\rightarrow$ 卉 Bi-i-in-na).

Bininima ..... (?) : 64, 15 ( $(B i-i n-i-n i-m a-\ldots .$.$) .$

Bi'ri, Bîri, of the city of Hašabu: 24, 18 ( $(B i-5 \nabla=-r i)$; $c f$. B. 160, $3 \dagger$ ( $(\mathrm{Bi}$ $i-r i)$; and B. 45, 61 ( $(B i-r i)$.

Burra-buriyaś, king of Kara-Duniyaš : 2, $3 \dagger ; 3,2 \dagger ;$ cf. B. 4, 3†; [7, $2 \dagger ; 78$. $3 \uparrow(B u r-r a-b u-r i-y a-a ́ s)$; cf. also B. 188, obv. 7 ( $(B u r-r a-b u r-y a-a ́ s)$; B,

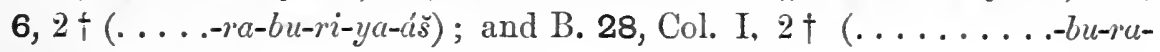
$r i-y a-a ́ s)$.

Biridiwi (?), of Megiddo: 59, 19 : cf. B. 111, obv. $3 \dagger ;[113,3 \dagger ;]$ 114, $3 \dagger$; $115,3+\left(\nabla B i-r i-d i-\hat{A} \nabla_{-}\right)$.

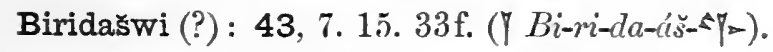

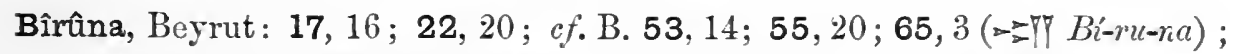

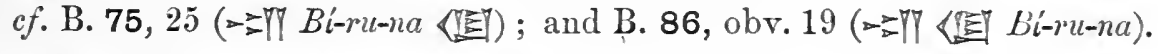

Birapari (?) : 82, 24 ( -7 - Bi-i-ra-pa-ri).

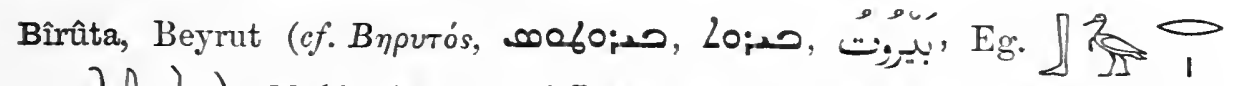

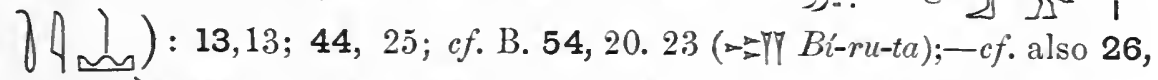

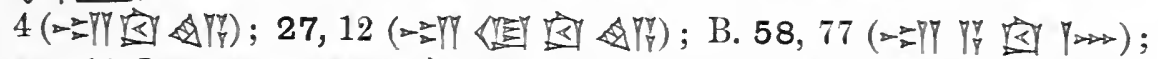

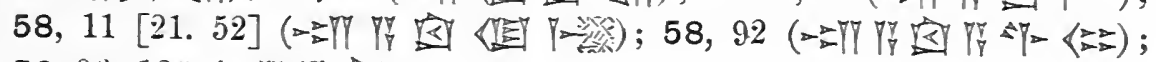

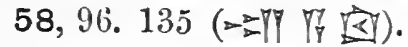

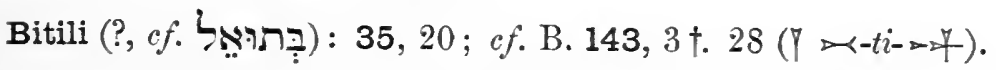

Bît-NIN.IB.: 12, 31 (EMTP

Gubbu : see Gubla. 
ג

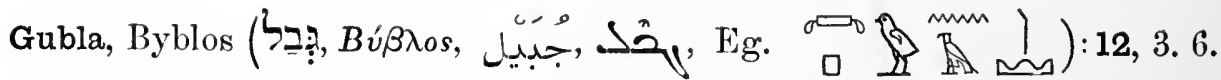
12. $32.48 ; 13,3 ; 14,3 ; 15,4 ; 16,8 ; 17,19$. 22. [31.] 43. 44; 18, 4. 9. $23 ; 19,5 ; 20,5.12 ;[21,26 ;] 22,6 ; 23,5 ; 25,6 ; 27,15.20 ;$ cf. B. 41 , $4 ; 42,4 ; 43,4 ; 44$, obv. 4 ; $[45,3 ;] 46,5 ; 47$, [1?.] 4; 48, 4. 37. 53. [85]; 49, obv. 3 ; 50, obv. 5; 51, obv. 3 ; 52, obv. 2; 56, 13. 20. 35; 58, 123 ; 59, obv. 4 ; 60, 51; 61, [4.] 48. 66; 62, [3.] 9.13. [33]; 65, 2.11; 66, 4; [67, obv. 4;] 70, 4; 71, 31; 73, 20.22.36. 37; 74, 4; 75, 4. 24; 77,$17 ; 79,8 ; 80,10.26 ; 81,9 ; 83,6 ; 84,16 ; 89,9 ; 91,2.6 .16$; $184,19.24 \Leftrightarrow$

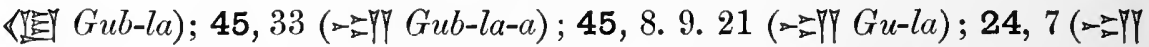

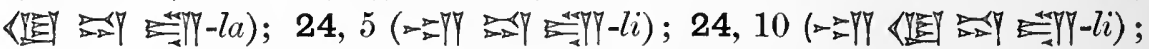
78, 3 (?; $\rightarrow$ PY $G u b$ (?) scribe); 22, 24 ( $\Leftrightarrow$ Y Gub (la omitted by the scribe); B. 52, rev.

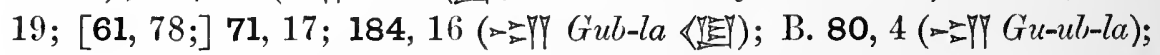

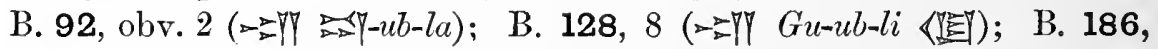

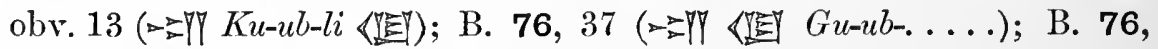

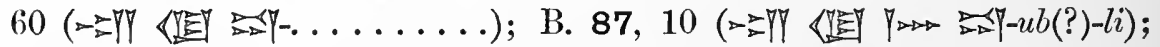

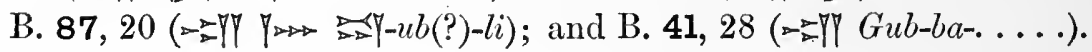

Gagaya (?): 1, 38 (소 Ga-ga-ya).

Gidši : see Qidši.

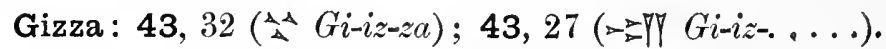

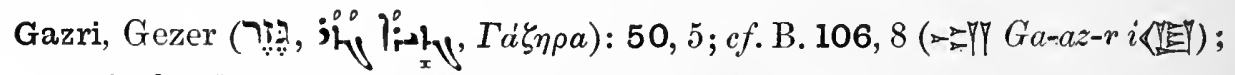
cf. also B. 103, 14 (

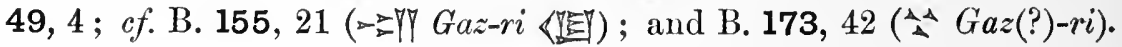

Gula ..... (?): 45, 3† (?, Gu-la-....). See also Gubla.

Gulati: 71, 17 (Gu-la-tí); 71, 24 (Gu-la-ti).

Giliya, envoy of Tušratta: 8, 25. 39. 71; 9, 46;11, 19; $c f$. B. 22, obv.

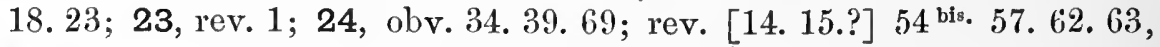
64. 66. 68. 74; 27, Col. IV, 20. [21.] 36. 37 († Gi-li-ya); cf. also B. 27. Col. I, 91. 100; Col. II, 7; Col. IV, 26. 27 († Gi-li-i).

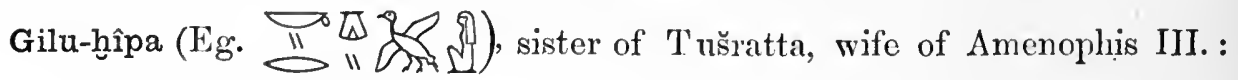
9, 5.41 ( Gi-lu-hi-pa).

Gurrumma (?): 7, 24 (「† ?] Gur (?)-ru-um-ma). 


\section{7}

Dagan-takala "Dagon's trust" : [74,3†; cf. B. 129, $2 \dagger$ ( $>$-7 Da-ga-anta-ka-la); cf. also B. 129,9.13 († Da-ga-an-ta-ka-la).

Dâdu-hîpa: see Tâtu(m)-hîpa.

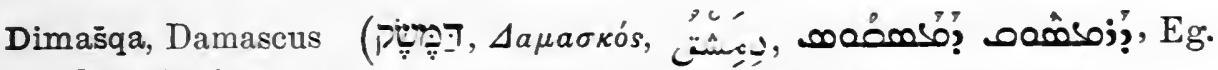

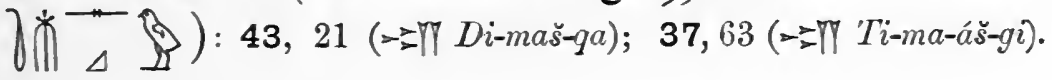

Dunib : see Tunip.

Danuna: 30,52 (A⿱ $\mathrm{A} D a-n u-n a)$.

Dirid (?) : 82, 21 ( -27 Di-ri-id).

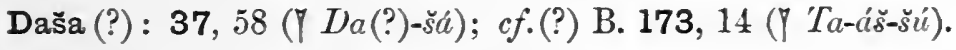

Dašru: 75, 3†; cf. B. 127, $3 \dagger$ (§ Da-ášs-ru).

Dušratta: see Tušratta.

i

Zidri'ara (?): 76, 3†; cf. B. 140, 3†; 141, $2 \dagger$ (ך Zi-id-ri-Ap--ra).

Zimrida, of Sidon: 14, 26; 28, 49. 57. 68; 29, 66; 30, 11. 65; cf. B. 77, 18; 104, 43 ( $(Z i-i m-r i-d a) ; c f$. also B. 123, $5 \dagger$ ( $(Z i-i m-r i-d i)$; and B. 90, $4 \dagger$ ( $Z$ Zi-im-ri-id-di).

Zinzar: 37, 42 (소 Zi-in-za-ar).

Zaqara (?): 1, 19 († Za-qa-ra).

Zurata: 72, 24. 31. 33. 42. 44; cf. B. [48, 21?;] 93,3†; [145, 4†?] (Y Zu-ra-ta). Zitadna, of Accho : 32, $5 \dagger$ ( ( Zi-ta-ad-na); cf. B. 94, 4†; 95, 3† († Za-ta-ad-na).

$\pi$

H. Ha (?)-.....).

Hुâya(?): 44, 2. 19 († Ha-AY-a); cf. also (?) B. 144, 8. [15?] († Ha-a-ya); B. 57, rev. 14. 20; [219; rev. 3?] († Ha-ya); B. 6, 36. 37 († Ha-ai); and B. $31,1 \ddagger(\rceil H(H a-a-i)$.

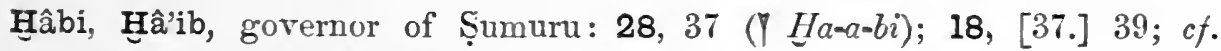
B. 41,$16 ; 66,9$ († Ha-ib).

Ḩazura: see Haşura.

Halunni : 43, 14 ( $\geq \prod$ Hुa-lu-un-ni).

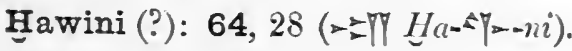


Hanigalbî, Hananalbi, Hanigalbat( $(\hat{\mathrm{u}}): 1,38$ (Aᄉ Ha-ni-gal-bi-i); cf. also B. 144, 10 (솟 Ha-na-gal-bú); B. 144, 20 (AᄉA Ha-na-gál-bú); B. 22, obv. 17; 24, obv. 49 (ÂA II

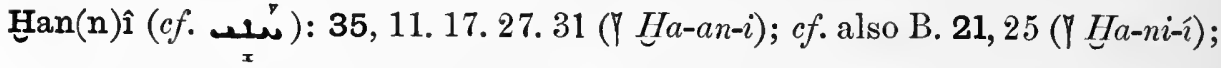
B. 92, rev. 11. 18 († HUa-an-ni); B. 92, rev. 29 (?, H(t-an-ni); and B. 117, 12; 176, 18. [21 ?] († Ha-an-ya).

Hini'anabi : 64, 26 ( $\Rightarrow$ p H Hi-ni-a-na-bi).

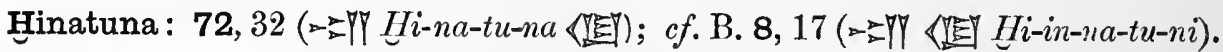

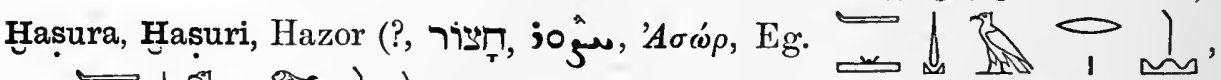

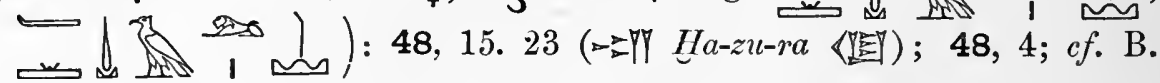

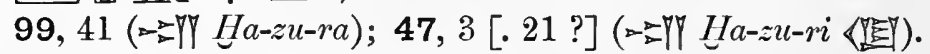

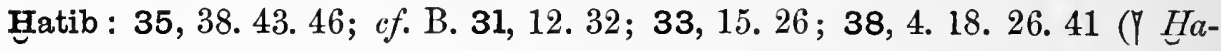
$t i-i b)$.

Hatti, Hatta ( $f$. Eg. $\odot$ ) $): 35,49 ; 36,[34] .37.51 ; 37,[9$.$] 13. 14. 16;$ cf. B. 30 , rev. 4 ; 31, 21 ; 32, 11. 20; 33, 18. 29, 38, 21. 24; 143, 14 ; [163,11? ;] 173, 39 (소 Ha-at-tí) ; 5, 49 (Ha-at-tí); 9, 31. 38; 30, 58 (솟 Ha-at-ti); 46, 7 (?); cf. B. 91, 31f. (Aᄉ Ha-at-ta); cf. also B. 159, obv.

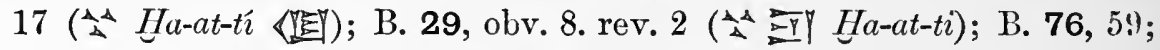
86, obv. 4 (A P Ha-ti); B. 79, 34 (Ha-ti); B. 18, obv. 2 (?, . . . .

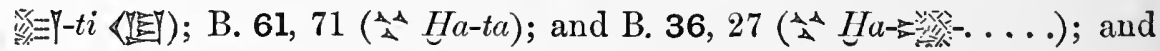

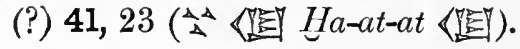

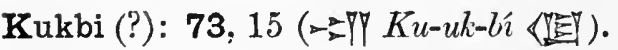

Kukana (?): 66, 17 († Ku-ka(?)-na).

Kallimma (?)-Sin, king of Kara-Duniyaš : 1, 1†; [cf. B. 1, 3†; 2, $2 \uparrow]$ ( $\mathrm{Ka}$-al (?)-lim-ma-m-7 Sin).

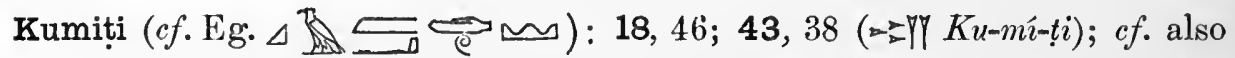

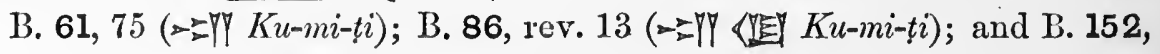

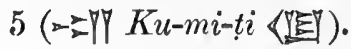

Kunî̀a (?): 7, 22 († Ku-ni-i-a).

Kinza: 46, 6; cf. B. 163, 10 (A $K i-i n-z a)$; cf. also B. 160, 12; 229 (=232, sul 233), 12.16 ( - - $Y$ Y Ki-in-za).

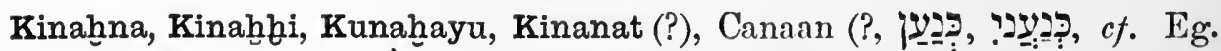

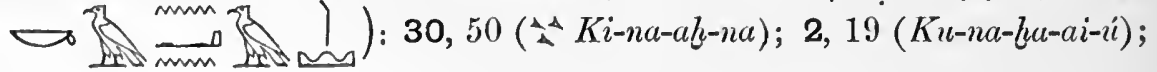


37, 43 (소 $K i-n a-n a-a t) ; 58,1$ Aै $K i-n a-a-a h-[n a ?$ ?]); cf. also B. 8, 15 . 17. [25]; 28, Col. II, 25; 92, obv. 41 (A $K i-n a-a h-h i$ ); and (?) B. 52, rev. 13 (A $\mathrm{A} K i-n a-n u[$ read $a h$ ? ]-ni).

Kuri-galzu, father of Burra-buriyaš, king of Kara-Duniyaš : 2, 19; cf. B. 6, 43 (Ku-ri-gál-zu).

Kara-Duniyaš, country in, or near, Babylonia: 2, 3; cf. B. [6, 2;] 144, 21;

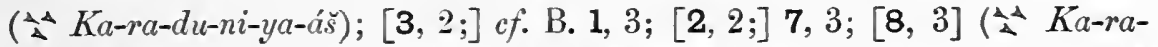

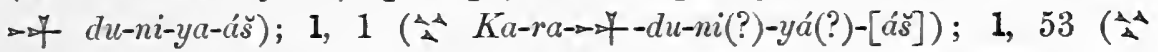

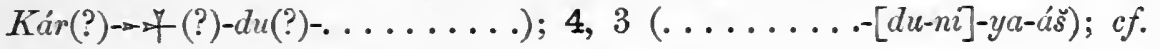
also B. 164, 7 (

Kara-indas̆, king of Kara-Duniyaš: 3, 8 (Ka-ra-in-da-ás̆).

Kitši : see Qidši.

\section{$\zeta$}

Lî̉ba: 82, 25 ( $\rightarrow$ † $L i-i-b a)$.

Labay(a), Labawi (?), adversary of Abdi-țâba (?) of Jerusalem: 72, 6. [25.] 44; $c f$. (?) [B. 111, rev. 10] († La-ab-a-ya); 61, 3†; cf. B. 100, 30; 105, obv. 6 ; 111, rev. 6 ; 115, 11. 17. 29. 38. 41; 154, 6. 14. [38.]; 169, 28 f.;

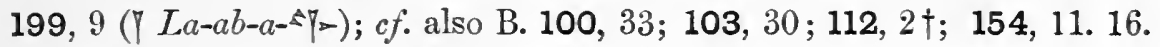
26. 30. [35. 53] (La-ab-a-AY=).

Lapana: 37, [35.] $57(\rightarrow-7$ La-pa-na).

M(?)ayawi(?): see Bayawi.

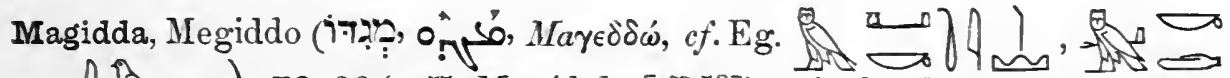
4 $\leadsto): 72,26(\Rightarrow$ Ma-gid-da [

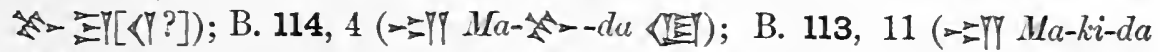

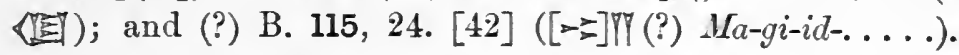

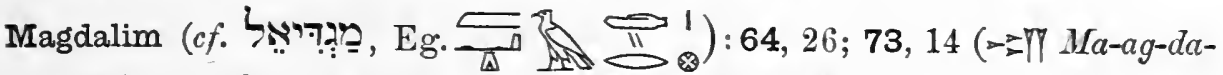

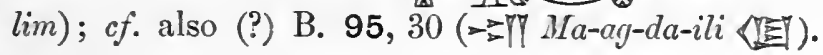

Milk-ili, son-in-law of Tâgi : 62, 4†; 63, 4†; $c f$. B. 108, 3†; 109, 4†; 110,4†; 112, 29 ( (Mil-ki-li); cf. also B. 103, 29 ( ( Mil-ki->7); B. 105, obv. 5. $11 ; 112,27 ; 154,53 ; 199,12$ († Mil-ki-lim); B. 106, 6. [26]; 149, 16 († Mil-ki-ln); and B. 149, 6 ( ( Mi- $\left.\rightarrow-\frac{7}{4}-k i-7\right)$.

Milimtu : see Mištu.

Milkuru : see Iškuru. 
Mimmûriya, Nimmûriya, Nammurya, Nibmuriya, Nibmuariya, Immûriya,

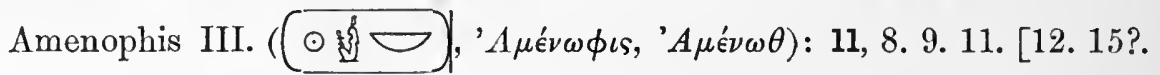

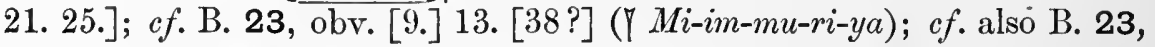

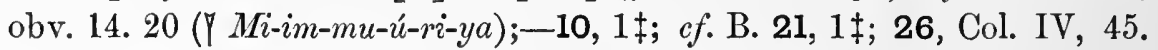
47 ( $(N i$-im-mu-ri-ya); $c f$. also B. 24, obv. 6. 8. 11. 12. 16.18. 21. [24.] 25. 28. 31. 35. 36. [37.] 47. 48 bis. 50. [51.] 53. [55.] 61. 62. 66. [68?. 73. 75; rev. 10. 42.?]; [27, Col. I, 1†] ( $\ N i-i m-m u-\imath-r i-y a)$; B. 27, Col. I, 92

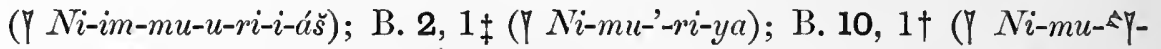

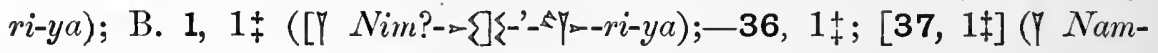
mur-ya);-1, $2 \dagger(\gamma N i-i b-m u-a-r i-a) ; 9,1 \ddagger(\gamma N i-i b-m u-a-r i-y a) ; c f$. B. 22, obv. $1 \ddagger(\ldots \ldots \ldots . m u-u-a-r i-y a) ;-8,1 \ddagger(\ldots .$. \% $i m-m u-r i-y a)$; $c f$. also B. 27, Col. III, 104 ( $(I m-m u-u-r i-y a)$; B. 27, Col. III, 106 ( $I m-m u-u-r i-a ́ s)$; B. 27, Col. IV, 128 ( $(I m-m u-u-r i-i . \neg$ ४); and B. 28, Col. I, $1 \ddagger(. \ldots \ldots \ldots .-r i-a)$.

Manî, messenger of Amenophis III. (cf. Eg. 래 11, 15 ; $c f$. B. 21, $24 ; 22$, obv. 8. 14. 18. 19. 23 ; rev. 23 bis. $25 ; 23$, obv. [7.] $13 ; 24$, obv. 70. 78. 86. 89; rev. 73. [80?]; 27, Col. I, 61. 79; Col. II, 13. 19. 126; Col. IV, 26. 35. [62?] ( $M a-n i-\imath)$; $c f$. also B. 27, Col. I, 67; Col. II, 7. 67. 96. 101. 105. 110. 121; Col. IV, 52. 54. 55. $57(\gamma M a-n i-i n)$; B. 27, Col. II, 16. 112; Col. IV, 20. 21. 27. 85 ( $(M a-$

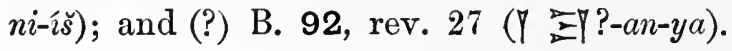

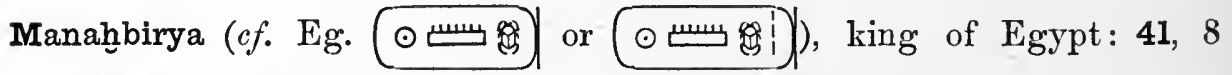
( $M a-n a-a h-b i-i r-y a) ; c f$. B. 30, obv. 4 ( $(M a-n a-a h-b i-y a)$.

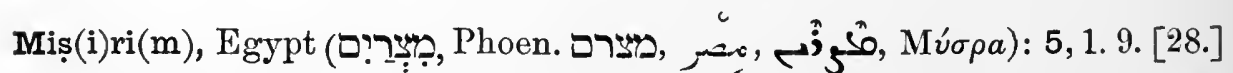
$31 ; 6,2 ;[7,1$ ? $] ; 17,33 ; 20,18 ; 28,69 ; 43,25 ; 44,18 ; 57,26 ; c f$. B. 9 , 20. $[23] ; 11,1 ; 12,1 ;[13,1 ;] 15,1 ; 30$, obv. 2.4 ; rev. $6 ; 39,20.22$. 27. $[32] ; 42,67 ; 45,13.49 .54 ; 47,37 ; 51$, obv. 21 ; edge $1 ; 52$, rev. 12.15 ; 57, obv. $20 ; 95,31 ;[177,17$ ?; $] 183,8 ; 184,17 ; 218$ (=225), obv. 6 (A) $M i-i s ̣-r i) ; 1,[52] .68 ; 2,[1] ; 8,1 ;[9,1 ; 10,1.14 ; 11,1.2$; 58, 4. 8. 10; cf. B. $[1,1$ ?; $] 2,1$; $[3,6 ;] 6,1 ;[7,1$ ?; $] 8,2 ; 21,2 ; 22$, obv. 9. 16. 17; rev. 14; 23, obv. [1.] 24; [24, rev. 80;] 26, Col. IV, 45. 47 (A) $M i-i s ̣-r i-i) ; 2,26$ (Mi-iṣ-ri-i) 1, 3 [.51]; [cf. B. 18, obv. 3] (A) $M i$ -

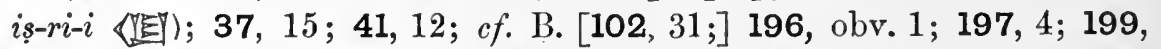

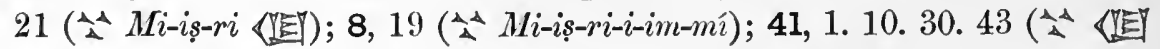

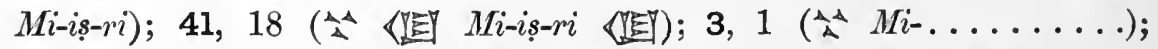

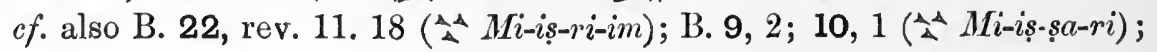


B. 27, Col. I, 93 (소 Mi-zi-ir-ri); B. 27, Col. III, 105 (Aᄉ Mi-iz-zi-ir-ri);

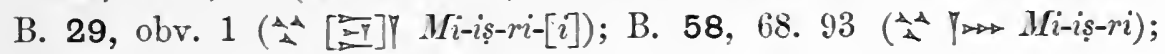

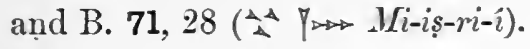

Miq(?)id: 82, 23 ( $\sim 7$, Mi-ki-id).

Marduk: 64, 20 ( $\circ$ 平

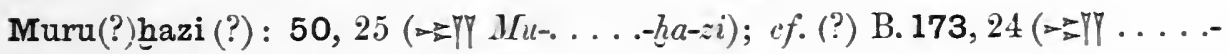
$m u-h i-z i)$.

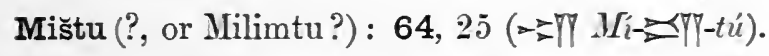

Mutabriq(?)a: 82, 20 ( $\sim$ 年 Multa-ab-ri-ga).

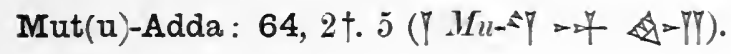

Mitani, district in Mesopotamia ( $f f$. Eg. [9, 3?] (A) Mi-i-it-ta-an-ni);10,4 (Mi-i-ta-an-ni);21,12;44,10; cf. B. 52, obv. 6 ; 53, 20; 61, 70; 74, 14 (A $M i$-ta-na); cf. also B. 27, Col. III, 104 (AA Mi-i-it-ta-a-an-ni); B. [24, rev. 77?;] 26, Col. IV, 44 (Mi-i-ta-a-an-ni); B. 173, 37 (A Mi-it-ta-an-na); B. 79, 36 (A Mi-it-

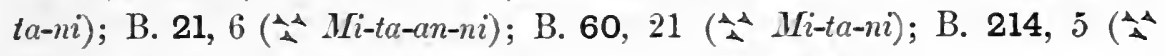
$M i-t a-a n$ ); and B. 22, obv. 3; 25, Col. IV, 67 (A $M i-i-\ldots \ldots \ldots$. . .

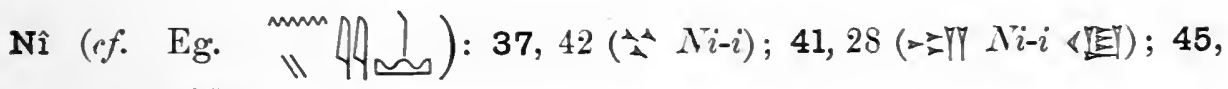
15 (As $\mathrm{Ni}$ ).

Nibmu(a)riya: see Mimmûriya.

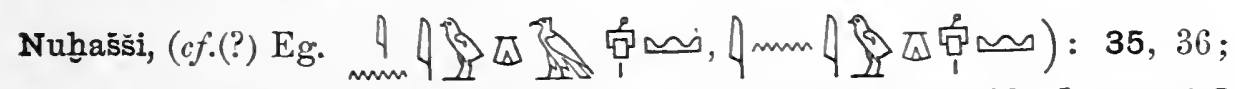
36,21 ; 37, 41; cf. B. 30, obv. 5; 31, 21; 32, 20 ; 33, 38; [34a, 26 ;]

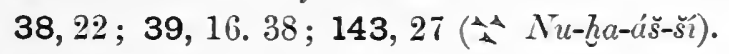

Namyawi (P) za: 43, $17 ; c f$. B. 95, 27; 96, 4†; 142, obv. 6; rev. 2. 9 :

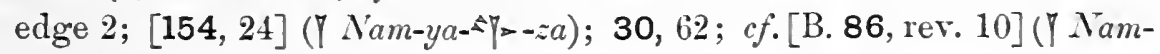
$\left.y a-A P_{-}-z i\right)$.

Nammurya, Nimmûriya: see Mimmûriya.

Namtâra: 82, 7. 10 (Nam-ta-a-ra); 82, 27 ( - 年 (Nam-ta-ra).

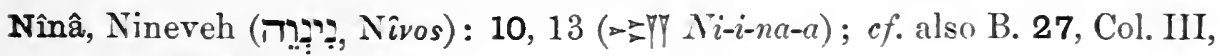
$98(\therefore$ Y N $N i-i-n u-a)$. 


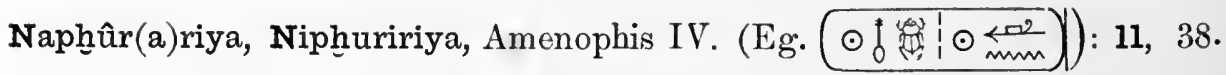
[42. 46.] 51; cf. B, 23, obv. 39 († Nu-ap-hur-ri-ya); 3, $1 \ddagger(N a$ (?)-ap (?)$h u(?)-r a-r i-y a) ; 2,1 \ddagger(N i-i p-h b u-u r-r i-r i-y a)$; cf. also B. 24, obv. [61? 63?

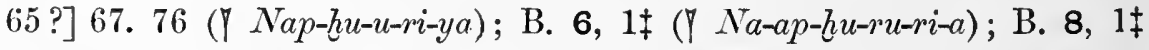

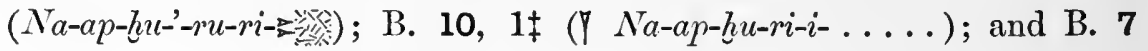
$1 \ddagger(\ldots \ldots \ldots+r u-r u-r i-y a)$.

Nirgal : 5, 13, 37; 82, 33, 37 ( $\rightarrow$ * $<\geqslant p$ ).

Sazu (?): 28, 49; cf. B. 99, 11. $30\left(\rightarrow \frac{>7}{} S a-\approx u\right)$.

Sarti(?): 14, $29(\sim \Gamma P a(?)-a r-t i(?))$.

פ

$\mathrm{Pa}^{\prime} \ldots \ldots \ldots$. . 18, 35 ( $\left.\mathrm{Pa} \mathrm{-}^{-}-\ldots \ldots \ldots \ldots\right)$. .

Pu-Adda, of the city of Urza: 55, 3†. 18; 56, 3†; cf. B. 153, 3† ( $\nabla$ Pu$\rightarrow$ - 4 - $($ ) ).

Puzruna: see Buzruna.

Pahamnata: 24, 31; [cf. B. 80, 22] († Pa-ḩa-am-na-ta); cf. also (?) B. 97, 10. 32 ( $>P a-h a-n a-t \hat{\imath})$.

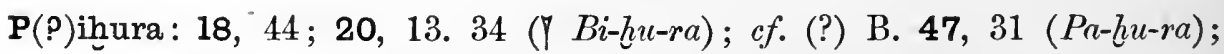
B. 103, 45 († Pa-ú-ru); B. 142, obv. 17 († Pu-hu-ri); B. 142, obv. 18 (Pu-hu-ru); and B. 105, rev. 4 († Pu-ú-ru).

$\operatorname{Pir}(P) \operatorname{hi}(P): 9,12$ († Â-

\section{$\dddot{3}$}

Șîdana: 82, 23 ( $\neg 7$ Și-i-da-na).

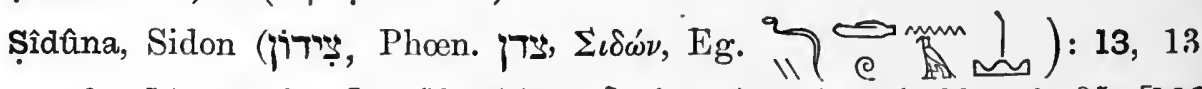
$28,57$; 29, 67 ; [31, 58; 44, 24 ; $]$ cf. B. 48,$71 ; 54,22$; 99, 25 ; [162,

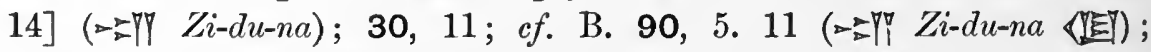
cf. also B. 99, $40(-5 Y Y i-d u-n u) ;$ B. 92, obv. $12(--p Y Z i-t u-n a)$; and

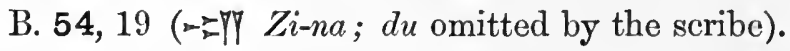

Ṣuharti, daughter of Kallimma (?)-Sin of Kara-Duniyaš: 1, 80. 97 (Zu-h̆a$a r-t i)$; $c f$. also B. 1, 7 (Și-ha-ar-ti). 


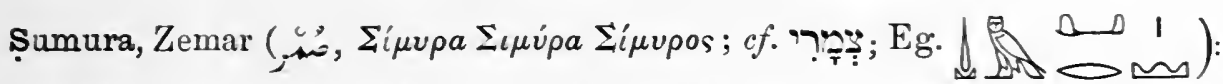
13,11 . 28. 37. $40 ; 14,29 ; 15,41 ; 18,40 ; 21,35 ; 28,39.67 ; c f$. B. 41 , 15. $34 ; 42,47.63 ; 45,11$. [41.] $46 ; 48,36.52 ; 51$, obv. 7. 8. 10. 30 ; edge 4 ; [52, rer. 30 ?; $] 56$, [6? ? $] 11 ; 57$, rev. $15.19 .22 ; 60,15.33$. $45 ; 61,11 .[18] .24 ;[62,19 ;] 66,5 ; 69,16 .[22] ; 72,16 ; 74,35 ; 77$, 11. 14. 27. 35. [39.] $46 ; 83,34 ; 89,48 ; 91,15.18 ; 128,4 \Leftrightarrow$ Su-mu-ra) ; 13, 13; 31, 57; cf. B. $34 a, 28$; [58, 33. 35; ] 97, 23; 128,

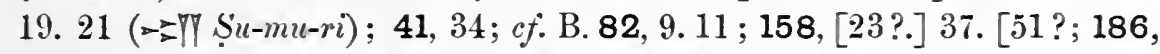

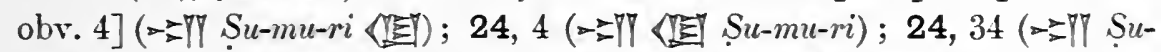

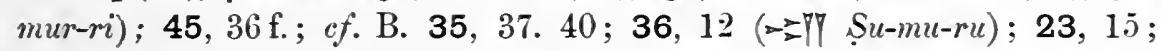

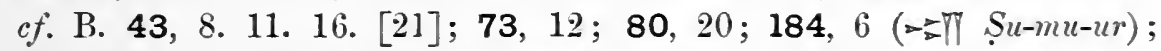

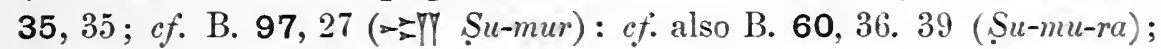

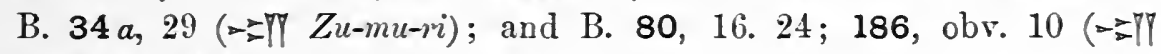
Su-mu-ur (E) .

Șarki-şabtat (?): 64, $27\left(\rightarrow=\prod a-a r-k i-s a-a l-t a-a t\right)$.

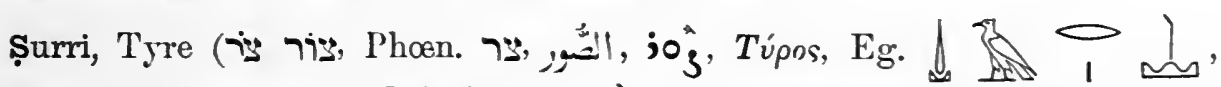

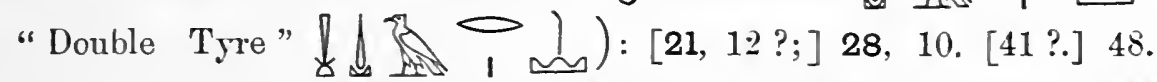
63. 65 ; 29, 62 ; 31, 31. 51 [cf. B. 49, obv. 17. 22; rev. 16. 20] $\Leftrightarrow=7 p$

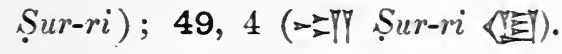

\section{$P$}

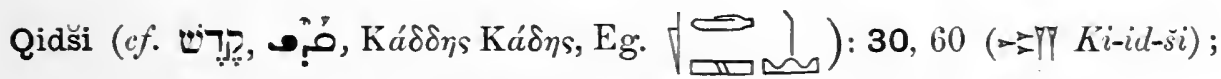

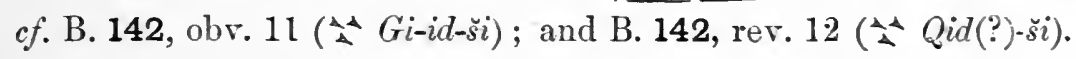

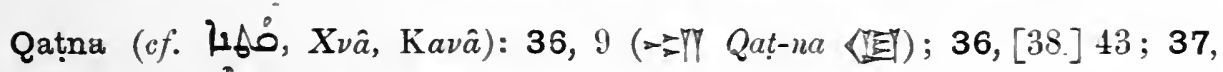
64. $70(-$ TP Q Q - -na).

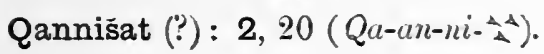

Ra........ (?): 45, $2 \nmid(-7 R a-\ldots \ldots \ldots)$.

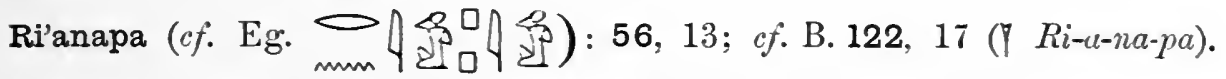
Rib(?)-Adda, governor of Byblos: 12, $1 \dagger ;[13,1 \dagger ;] 15,2 \dagger(\rceil$ Ri-ib-ad-da); $14,[1 \dagger] 40 ;.[17,1 \dagger] ; 18,2 \dagger ; 19,2 \dagger ; 20,1 \dagger ; 21,2 \dagger ; 23,3 \dagger ; 25,3 \dagger ;$ 27,$21 ; c f$. B. $[41,1 \dagger ; 42,1 \dagger ;] 43,1 \dagger .14 .31 ; 44$, obv. [1†.] 19 ; [rev. $5 ; 45,1 \dagger ;] 46,4 \dagger ;[47,1 \dagger ;] 48,[2 \dagger]$.24 ; [49, obv. $1 \dagger ; 51$ obv $1 \dagger$; 
52, obv. $1 \dagger ;$; 53, 3†; [55, 2†; 57, obv. 1†; 59, obv. [2†.] $24 ; 60,3 \dagger$; $62,2 \dagger .[6.18 ;] 63,2 \dagger ;[64 a, 1 \dagger ;] 72,2 \dagger ; \quad[74,1 \dagger ; 75,1 \dagger ;] 77,2 \dagger$; $[79,1 . \dagger 17$ ?;81, 2†; $82,1 \dagger ;[84,1 \dagger ; 85,2 \dagger]$ ( $(R i-i b \rightarrow-4$ -

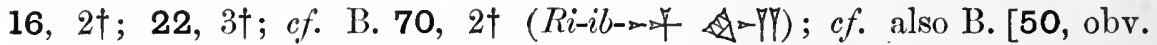
$1 \dagger$; rev. 7 ;] 58, 67 ( $(R i-i b$-ad-di); B. 58, 1†; 73, 3† )Ri-ib-ad-di); B. 76, $1 \dagger(\rceil R i-i b-i d-d i)$; B. 71, $1 \dagger(\rceil R i-i b-a d-\ldots .$.$) ; B. 80, 1 \dagger(. . . .-$ $i b-h a-a d-\ldots .$.$) ; and B. 86, obv. 1 \uparrow(\ldots . .-i] b(?)-\mathrm{ad}-\ldots .$.$) .$

Râbiṣa: 82, 21 ( $\rightarrow$ f $R a-a-l i-i-s a)$.

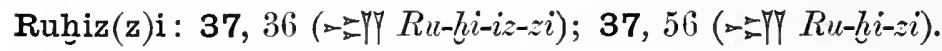

Rammân: 28, 7 ; 29, 14 (॰7) 壮).

Rip-Adda: see Rib-Adda.

Rîqa, envoy of Kallimma(?)-Sin : 1, 18 (Ri-i-qa) ; 1, 96 (Ri-ka).

\section{ت4}

Šu'ardata: $67,2 \dagger ; 68,3 \dagger ; 69,4 \dagger ; c f$. B. [100, 4†;] 101, obv. 3†; rev. 16; $\left.[107,4 \dagger ;] 110,12 ; 190,5 \dagger(\rceil \breve{S} \iota-\hat{A}_{Y}-a r-d a-t a\right) ; c f$. also B. 106, 6. [26] ( $९$ S̆ú-ar-da-tum).

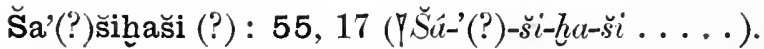

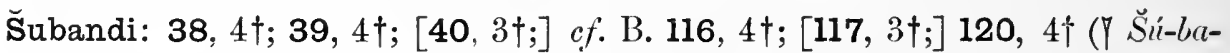

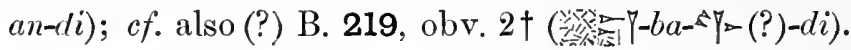

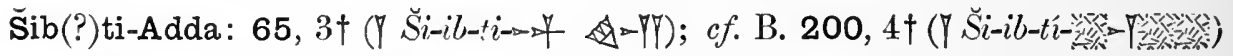

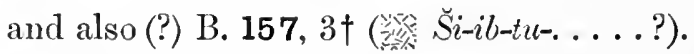

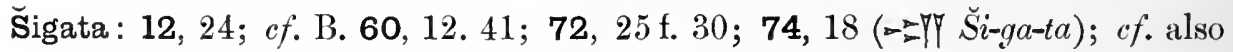
B. 128, 11. 17 ( $\therefore$ -

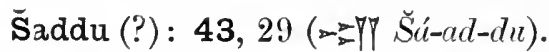

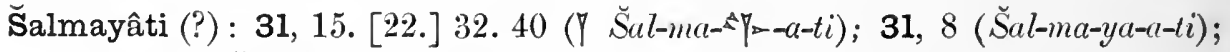
31, 52 († $\breve{S} a l-m a-y a-[a-t i ?])$.

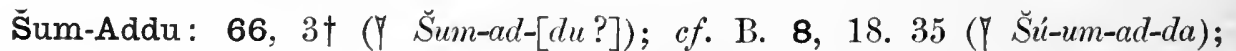

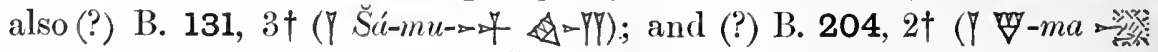

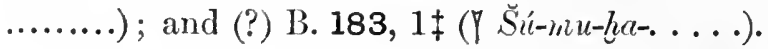

Samas̆ : 20, 8 ; 25, 2. 4 ; 28, 6. $83 ; 29,6.8 .43 .52 .58 ; 31,6.37 ; 32,3$; 35. 33 ; 36, 1. 47. 50.53. 57. $60 ; 37,1 ; 38,2.8 .15 ; 39,2.9 ; 40$, [2.] 7. $27 ; 42,7 ; 45,4 ; 47,9 ; 49,2.8 .16 ; 50,2.10 ; 52,2.14 .21$. 22 ; 53, 2. 12.20. 22. 23 ; 54, 2. 11. $19 ; 56,2.9 .15 .[18]$; 59, 2.

$69,10 .[14] ; 74,2 ; 75,6 ; 78,6$ (-4 4 ).

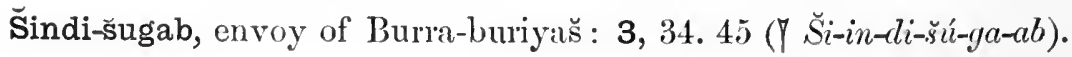


Sanhar, a country near the land of Hatti ( $c f$. Eg. 㿾

5, 49 (Š́l-an-ha-xr).

Šanku (?): 42, 26 (소 Šá-an-ku).

Šatiwi (?): 77, $3 \dagger\left(\check{S}_{a} \dot{a}-t i-\hat{A} Y_{\infty}\right)$.

Šutti : 4, 19 († Šú-ut-ti); cf. (?) B. 104, [19.] 22 († S̆í-ú-ta).

ת

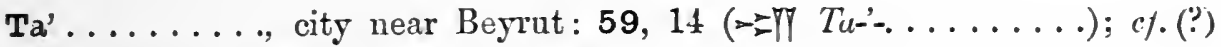

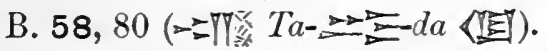

Ti'uwatti (?) : 37, 35. 57 ( $\left.7 T^{\prime} i-u^{\prime}(?)-\mathrm{A}^{\top}-(?)-a^{\prime}-t i\right)$.

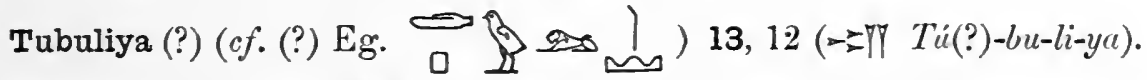

Tâgi, father-in-law of Milk-ili : 70, 2†; cf. B. 105, obv. 11; 149, 8; 199, 6 ( $\left.T_{a-g i}\right) ; c f$. also B. 156, $4 \nmid$ († Ta-a-[gi]).

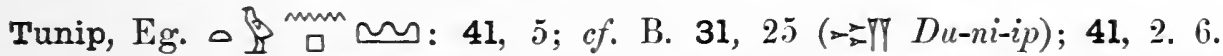

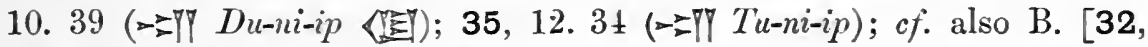
23;] 33, 39. 41 ( $\approx$ T T Tinn-ni-ip).

Tun(?)nipipri : $9,4 i$ ( $($ Tun(?)-ni-ip-ip-ri).

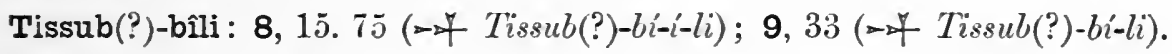

Tušratta, king of Mitani, contemporary with Amenophis III.: 8, $3 \dagger$ ( $(T u$ $u \check{s}-r a t-t a) ; 9,3 \dagger(\rceil$ Tu-išs-i-rat-ta); 10, 4†; [11, 2†; cf. B. 21, 5†; [22, obv. 3†; 23, obv. 2†;] 27, [Col. I, 3†;] Col. III, 103. 107; [Col. IV, 127] ( $(D u-u s$-rat-ta); cf. also B. 25, Col. IV, 67 (. . . .-urs-rat-ta); and B. 26, Col. IV, 44 ( $(D u-i s$-rat-ta).

Tâtu(m)-hîpa, daughter of Tušratta, wife of Amenophis III.: 10, $7 ; 11,4$ ( Ta-a-tum-hi-pa); cf. also B. 23, obv. 20 ( Da-a-du-hi-i-pa); B. 23, rev. 55 ( Ta-a-tum-hí-i-pa); B. 24, obv. 3. 35 [bis]; 27, Col. III, 103; Col. IV, 89 (Ta-a-du-hi-i-pa); B. 24, obv. 32 ( Ta-du-hi-pa); and B. 26, Col. IV, 46 Ta-tum-hi-pa).

$$
\text { ni (?): } 71,3 \dagger(7 \ldots \ldots \ldots-n i(?)) \text {. }
$$





\section{LIST OF PLATES.}

\begin{tabular}{|c|c|c|c|c|c|c|c|c|c|c|c|c|}
\hline Plate. & & $\begin{array}{l}\text { Registration } \\
\text { Number. }\end{array}$ & & & so. & Plate. & & $\begin{array}{l}\text { Registration } \\
\text { Number. }\end{array}$ & & & & No. \\
\hline 1. & BU. & $88-10-13,1$ & . & .. & 71 & 11. & BU. & 88-10-13, & 51 & .. & . & 29 \\
\hline$"$ & " & $88-10-13,4$ & .. & .. & 74 & 12. & $"$ & 88-10-13, & 52 & .. & . & 39 \\
\hline 2. & , & $88-10-13,7$ & .. & $\cdots$ & $2 \pi$ & $"$ & , & 88-10-13, & 54 & $\cdots$ & . & 68 \\
\hline , & " & $88-10-13,8$ & . & . & 62 & 13. & , & 88-10-13, & 56 & . & . & 30 \\
\hline 3. & $"$ & $88-10-13,9$ & . & $\cdots$ & 72 & ", & $"$ & 88-10-13, & 58 & . & . & 14 \\
\hline$"$ & " & $88-10-13,11$ & . & . & 43 & 14. & $"$ & 88-10-13, & 59 & .. & .. & 52 \\
\hline 4. & , & $88-10-13,12$ & $\cdots$ & . & 45 & $"$ & " & 88-10-13, & 60 & . & .. & 28 \\
\hline$"$ & , & $88-10-13,13$ & .. & . & 42 & 15. & $"$ & $88-10-13$, & 61 & . & . & $61)$ \\
\hline 5. & , & $88-10-13, \quad 15$ & .. & . & 64 & , & , & $88-10-13$, & 62 & . & . & 34 \\
\hline , & " & $88-10-13,16$ & . & $\cdots$ & 51 & ", & $"$ & 88-10-13, & 64 & . & . & 58 \\
\hline$"$ & , & $88-10-13,19$ & $\cdots$ & . & 69 & 16. & , & $88-10-13$ & 65 & .. & $\cdots$ & 48 \\
\hline 6. & , & $88-10-13,20$ & . & . & 32 & , & $"$ & $88-10-13$, & 66 & . & . & 75 \\
\hline " & , & $88-10-13,23$ & $\cdots$ & $\cdots$ & 76 & 17. &, & 88-10-13, & 69 & $\cdots$ & . & 82 \\
\hline ,. & $"$ & $88-10-13,30$ & . & . & 79 & 18.19 & 9. ", & $88-10-13$ & 70 & . & . & 8 \\
\hline " & $"$ & $88-10-13, \quad 31$ & .. & $\cdots$ & 22 & 20. & $"$ & 88-10-13, & 72 & . & . & 12 \\
\hline 7. & ", & $88-10-13,34$ & . & .. & 60 & , & " & $88-10-13$, & 73 & .. & . & 16 \\
\hline$"$ & $"$ & $88-10-13,35$ & .. & .. & 78 & 21. & ", & $88-10-13$, & 74 & $\cdots$ & $\cdots$ & 61 \\
\hline & , & $88-10-13,37$ & . & . & 5 & " & ", & $88-10-13$, & 75 & . & .. & 54 \\
\hline 9. & ", & $88-10-13,39$ & $\cdots$ & - & 11 & 22. & , & 88-10-13, & 76 & .. & . & 35 \\
\hline 10. & , & $88-10-13,44$ & . & . & 19 & 23. & " & 88-10-13, & 78 & . & .. & 10 \\
\hline & ", & $88-10-13,46$ & $\cdots$ & . & 3 & & " & 88-10-13, & 80 & $\cdots$ & $\cdots$ & 26 \\
\hline 11. &, & $88-10-13,49$ & . & .. & 33 & 24. & , & $88-10-13$, & 81 & .. & .. & 2 \\
\hline
\end{tabular}





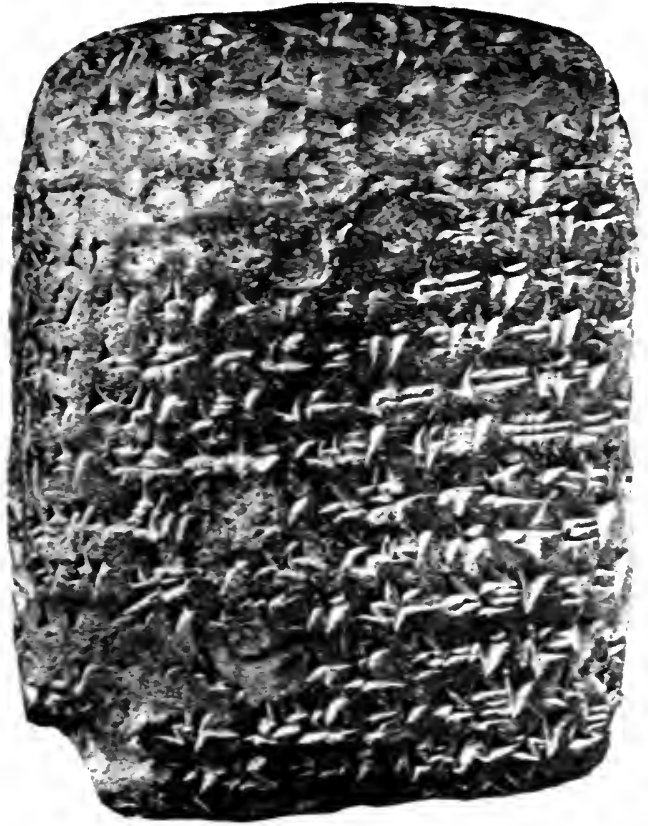

ORVERSE

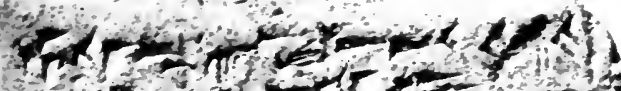
rofror $=1-1=0$

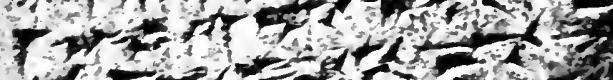
$1+1-1+1,13$ t - - - r t

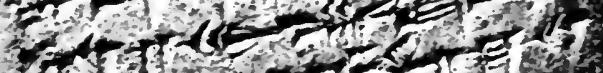

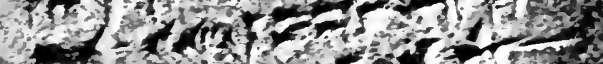
17. If

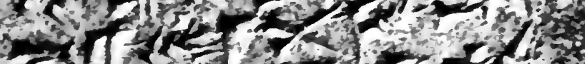
$1106=-2$

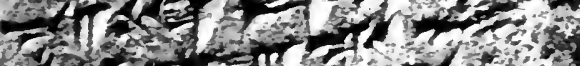

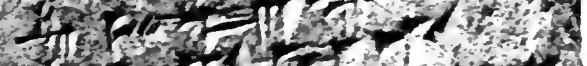

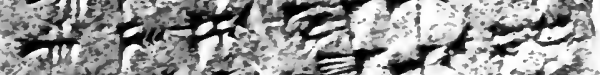
HP $7 f\left(x, y+x^{2}+2\right.$

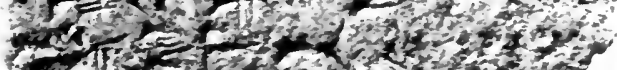

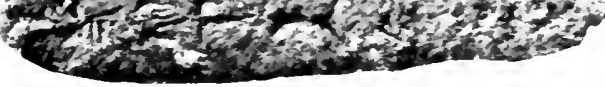
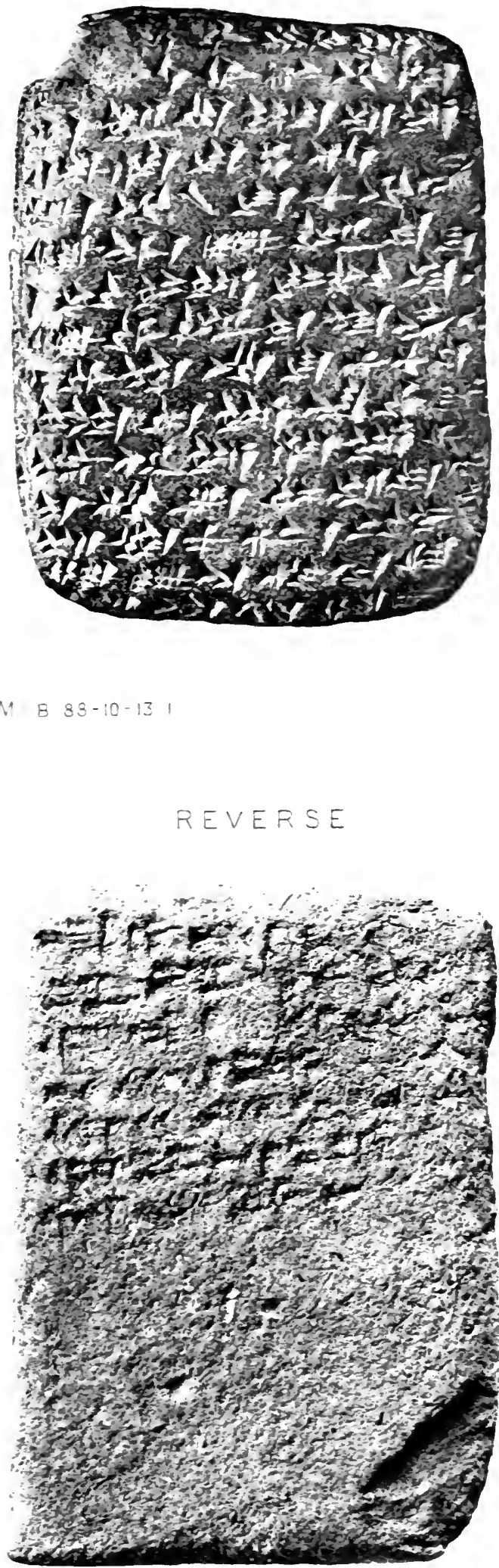


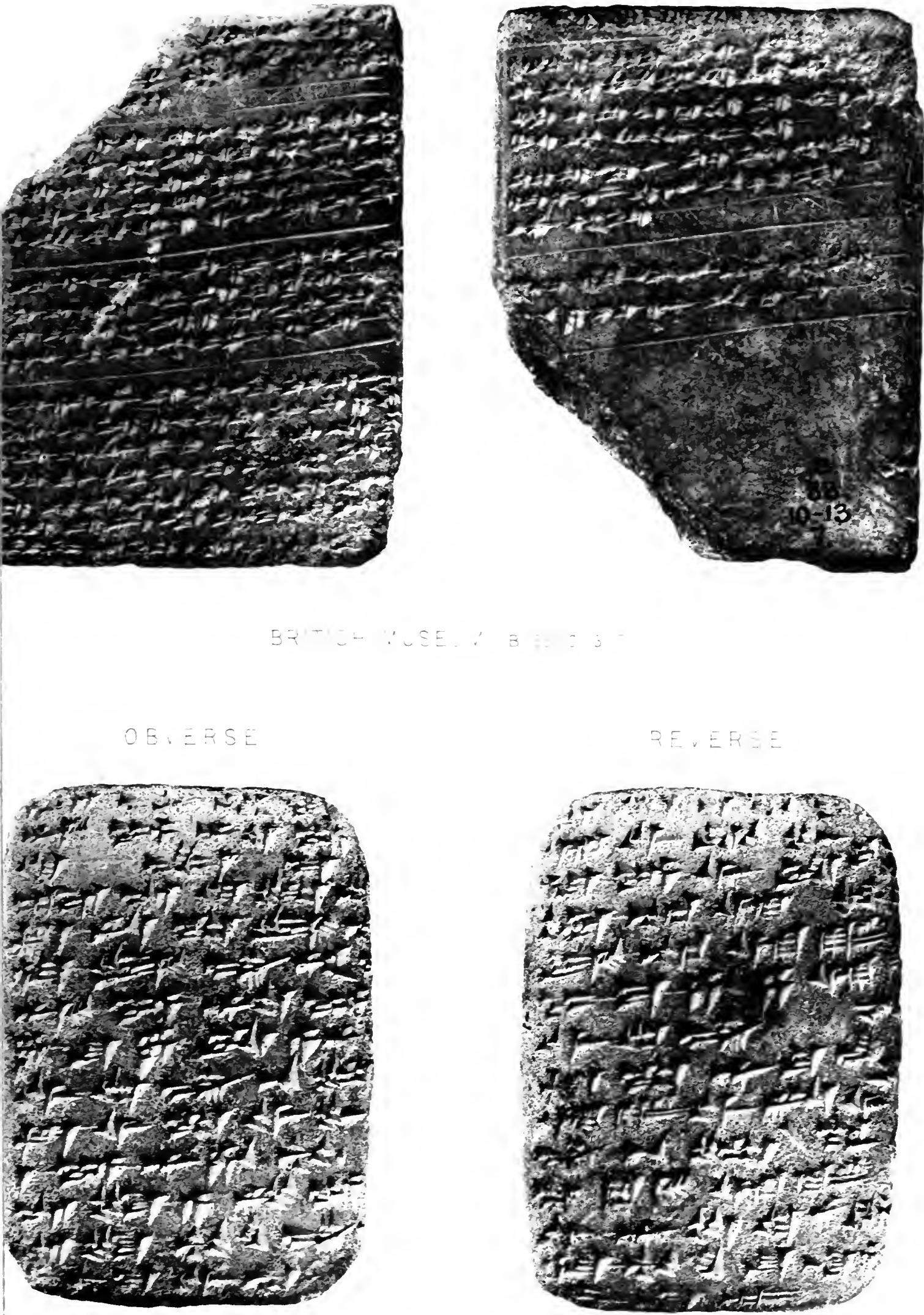


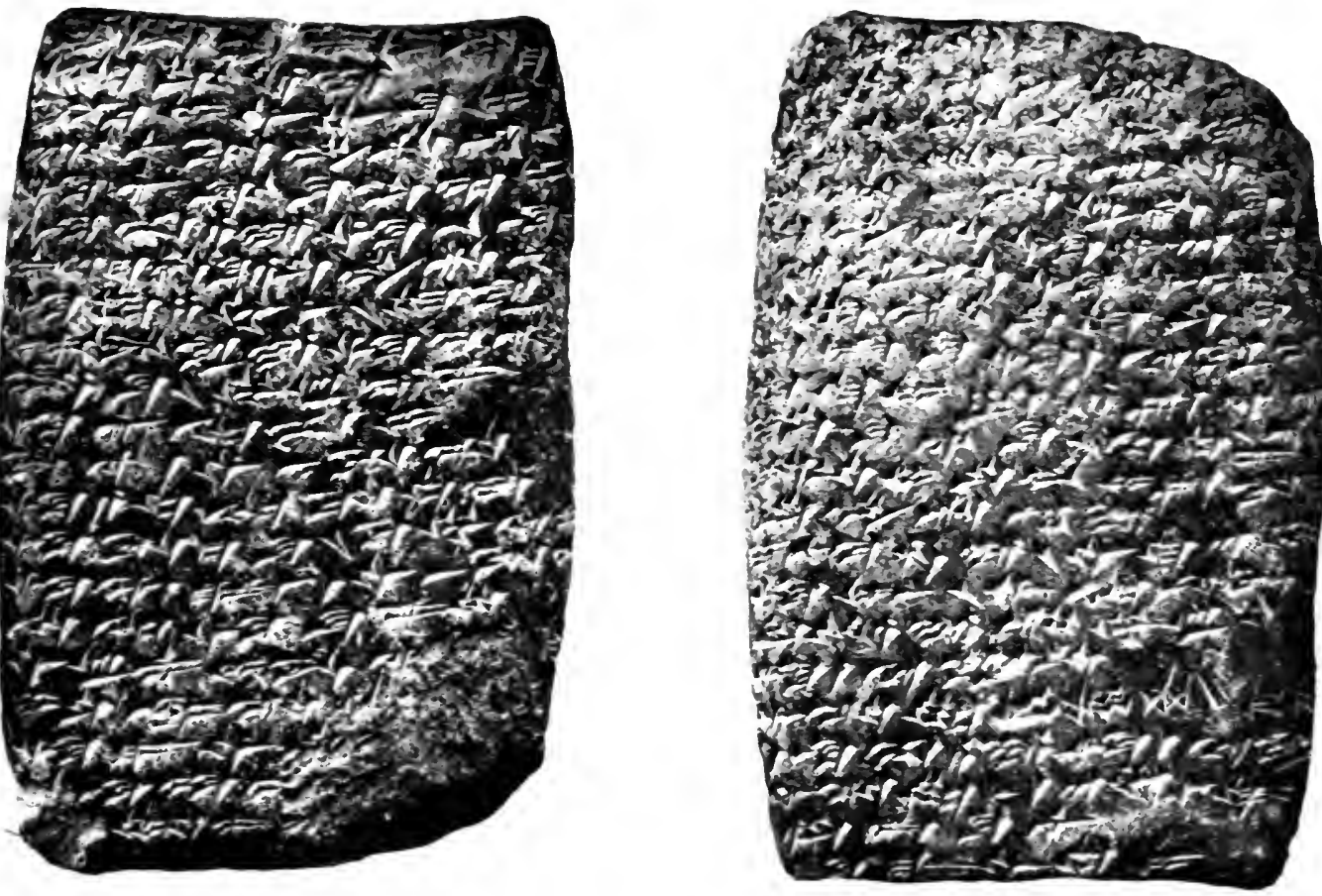

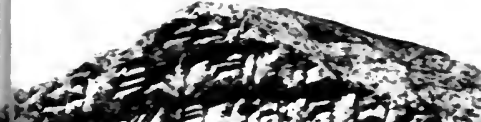

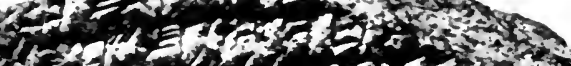

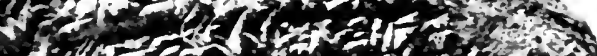

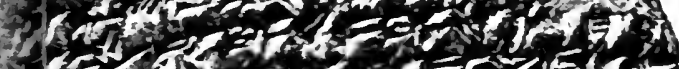

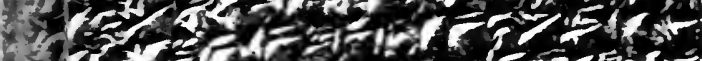

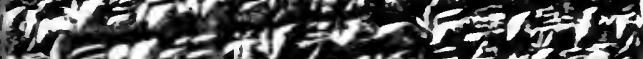

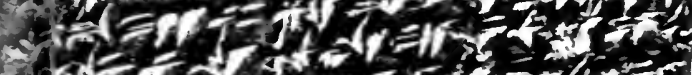

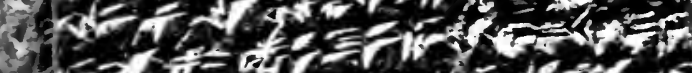
1 ron 1 - or

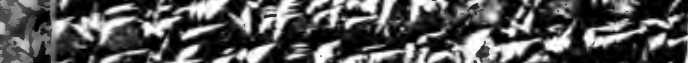

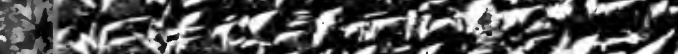

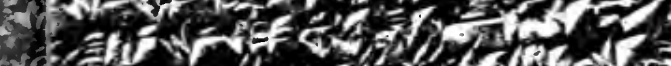

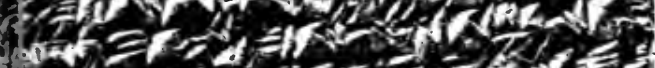

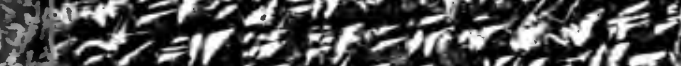

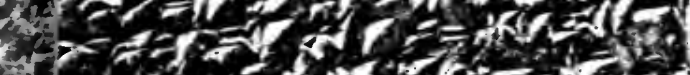

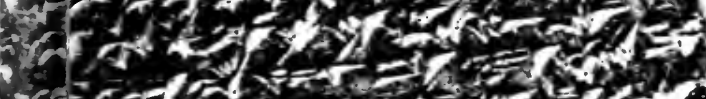

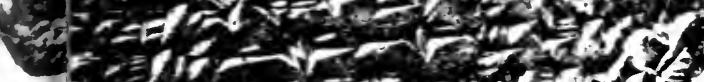

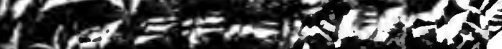
ind $=0,20$ 



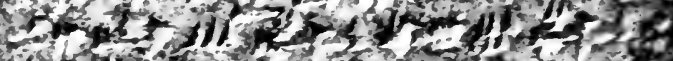

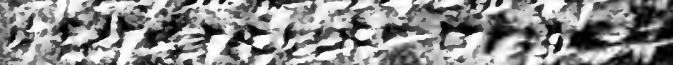

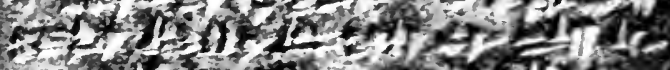

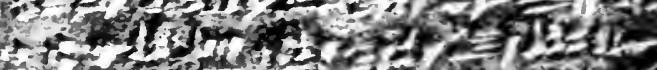

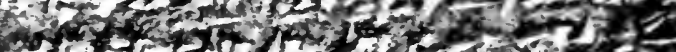

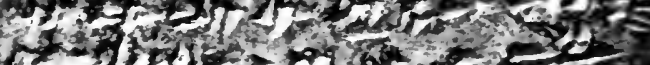
$(2-13 x)=204020$

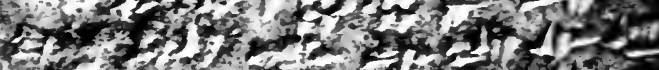

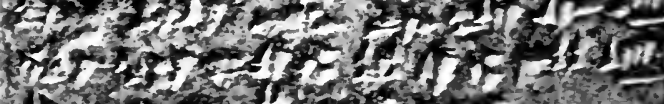

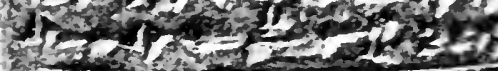

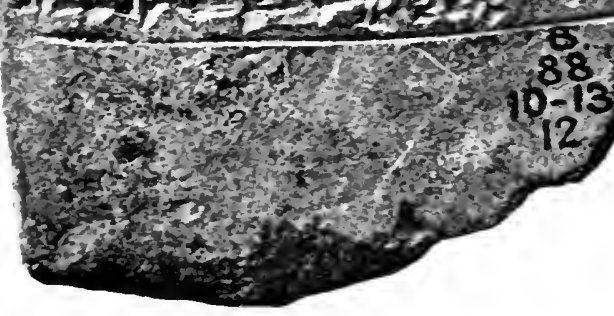

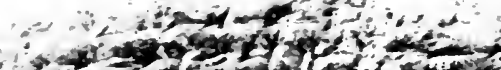

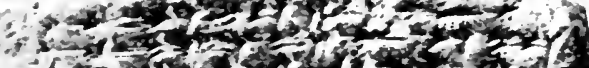

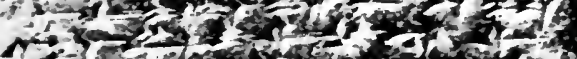

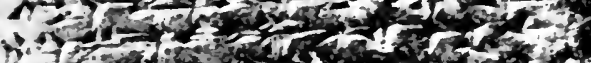

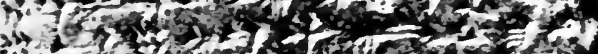

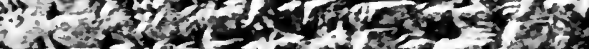

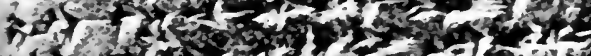

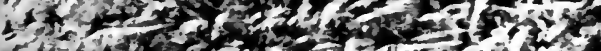

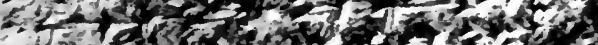

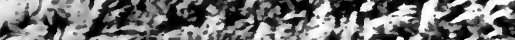

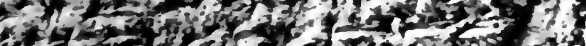

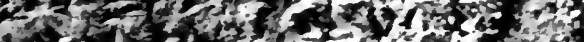

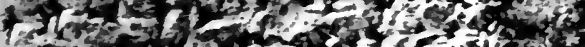

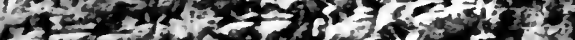

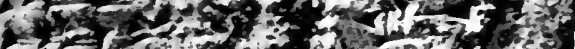

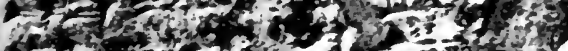

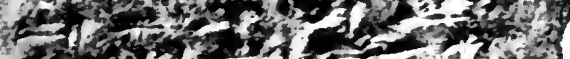

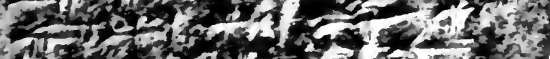

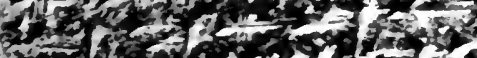

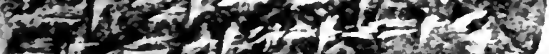

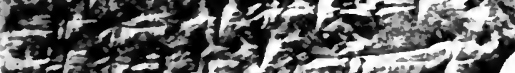
-

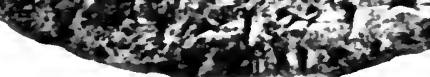

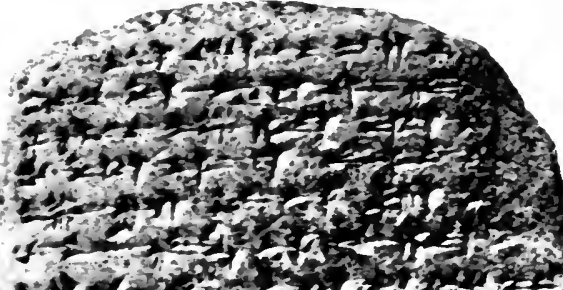

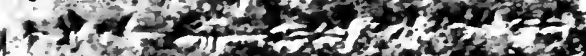

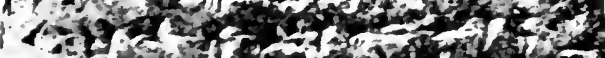

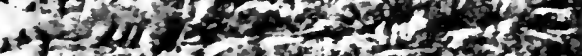

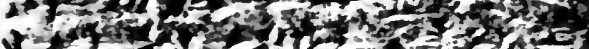
K.t.

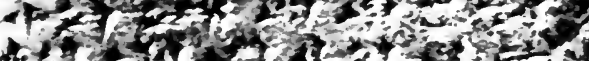

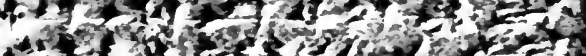

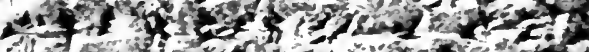

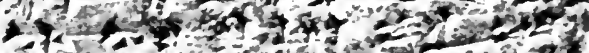

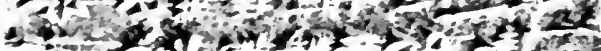
- 3.

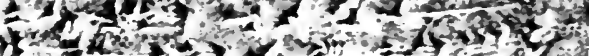

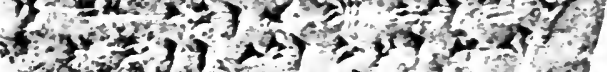

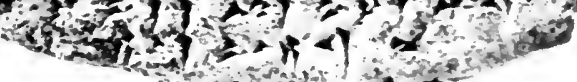





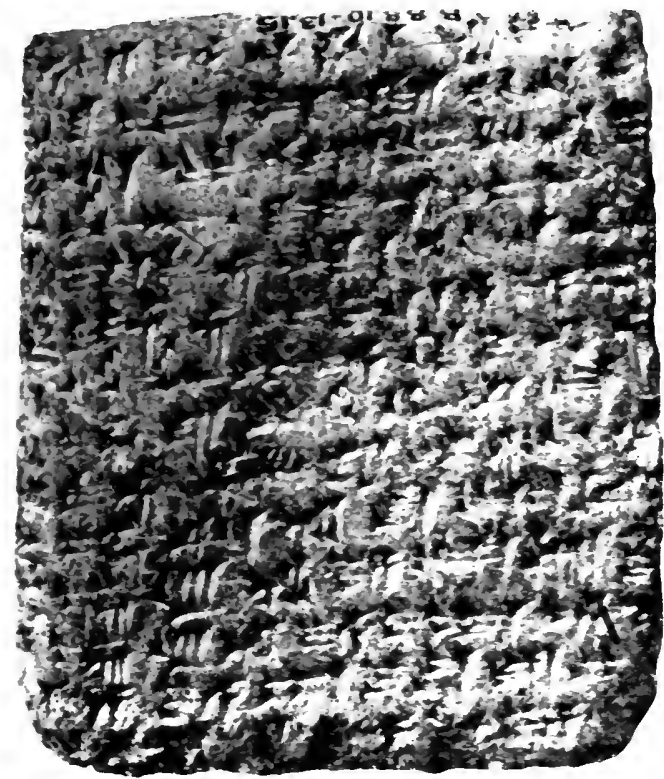

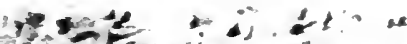

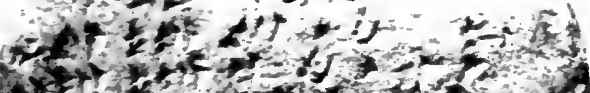

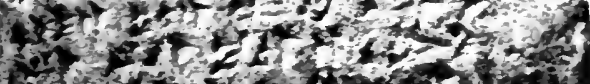

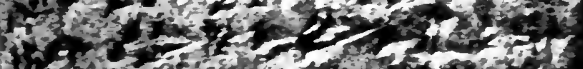

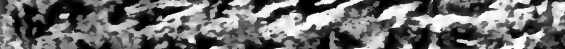

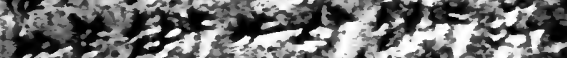

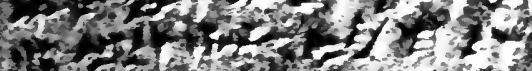

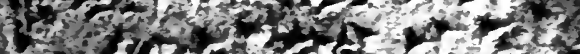

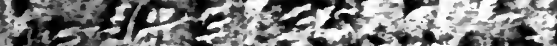

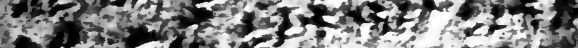

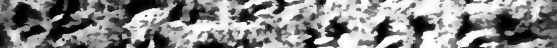

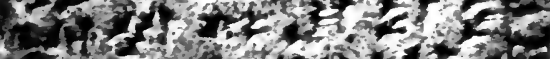

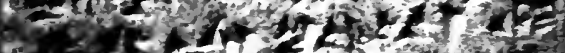

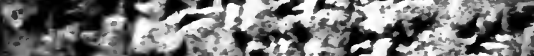

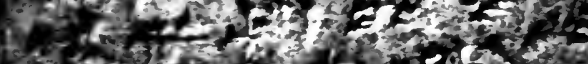

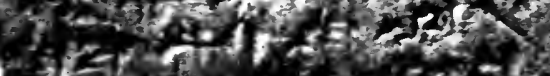

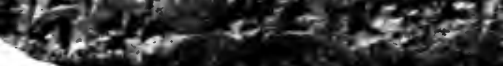

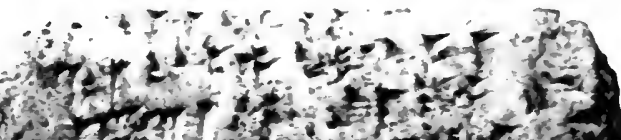

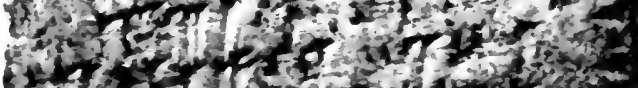

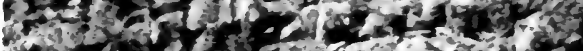

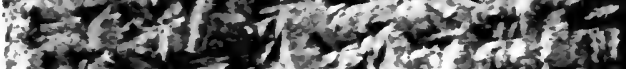

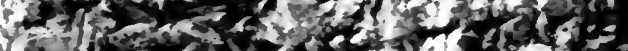

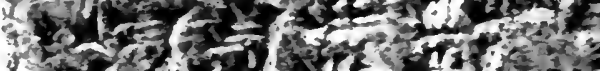

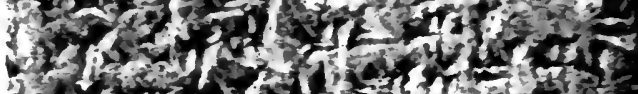

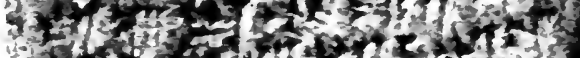

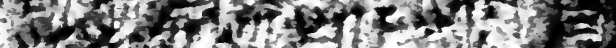

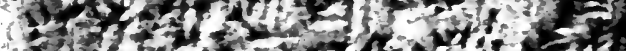

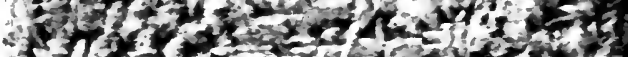

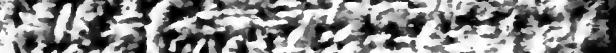

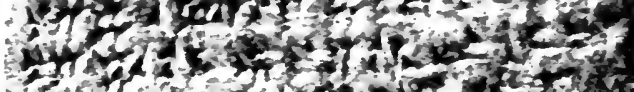

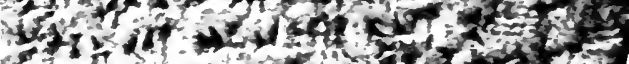

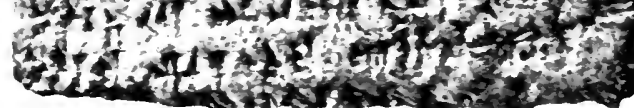
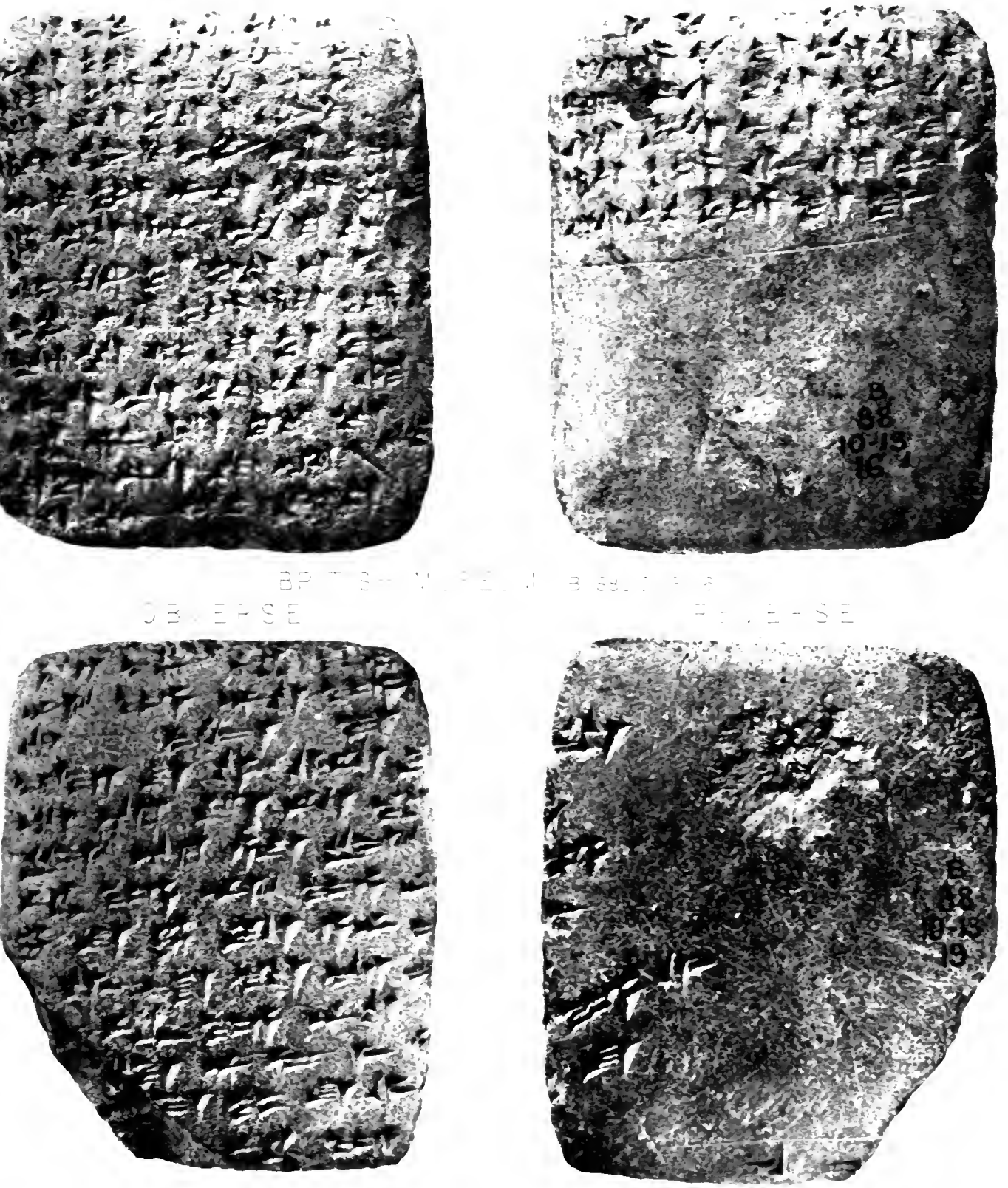



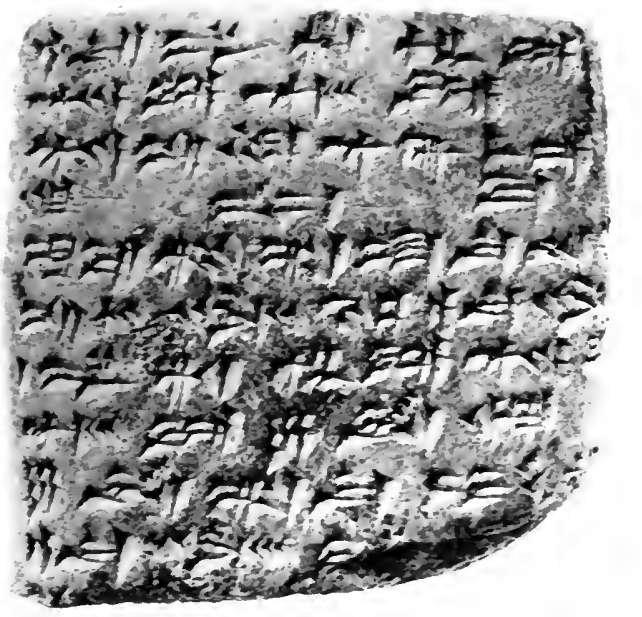

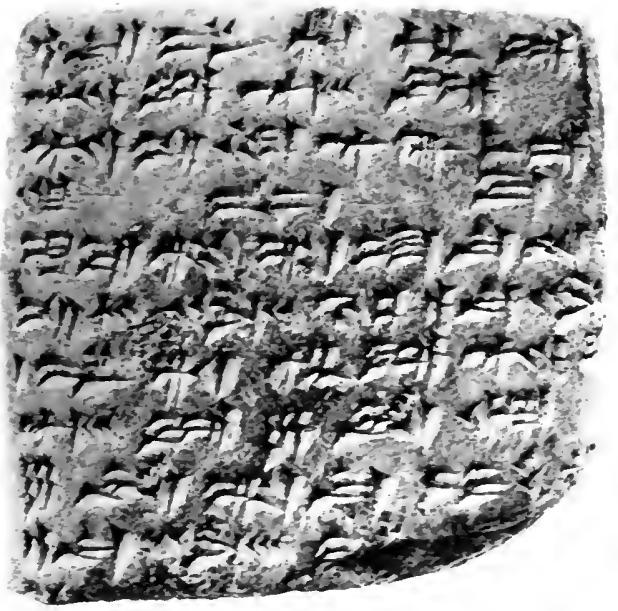

ERITISH MUSEUM

OBVERSE

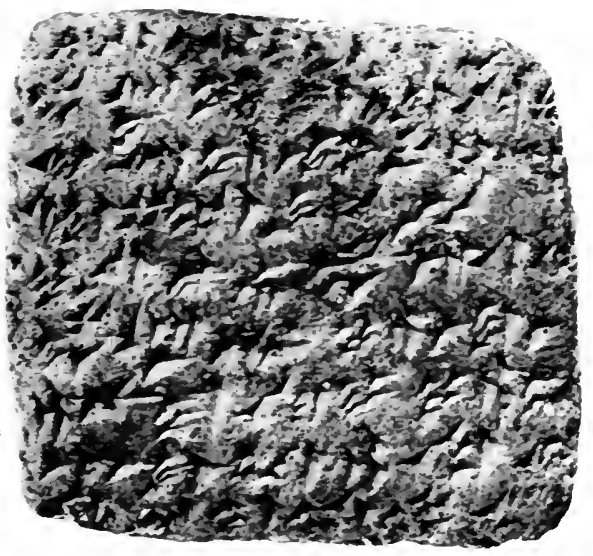

OBVERSE

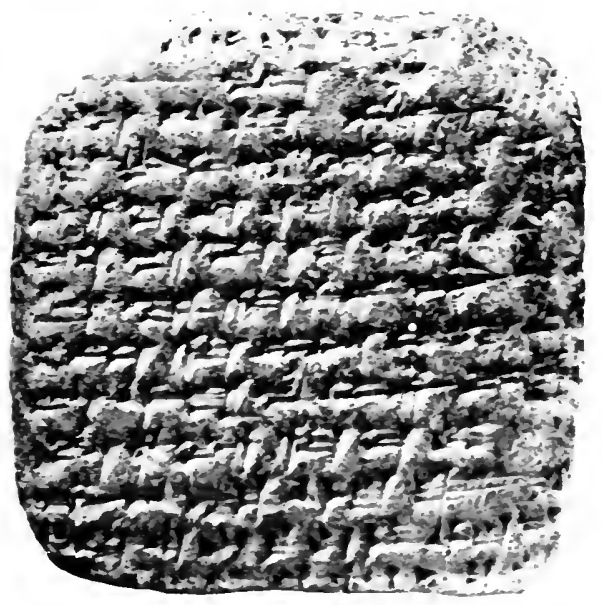

\section{BRITISH}

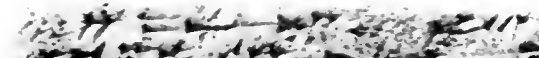

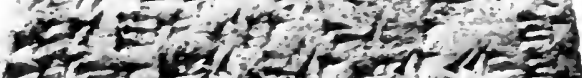
$-251.320147$

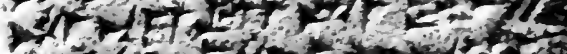

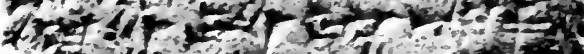

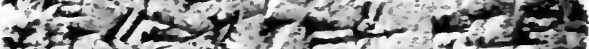
7 -

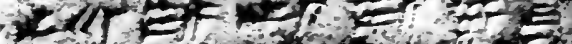

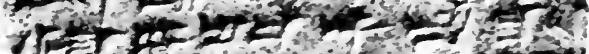
$1-2-40+1+4=2+10=2$ T. $15 .-25$

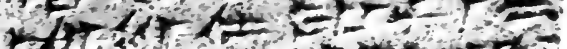

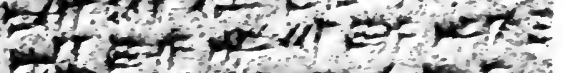
$13-2-125$

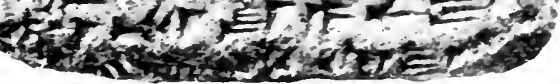

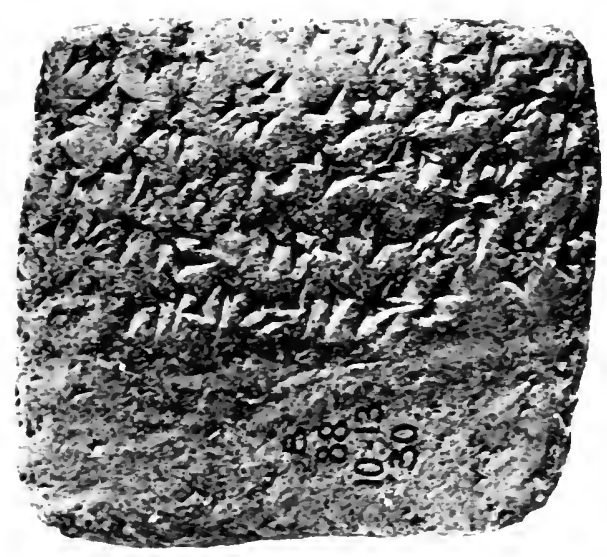

$3 R \cdot S H$ 

OBVERSE

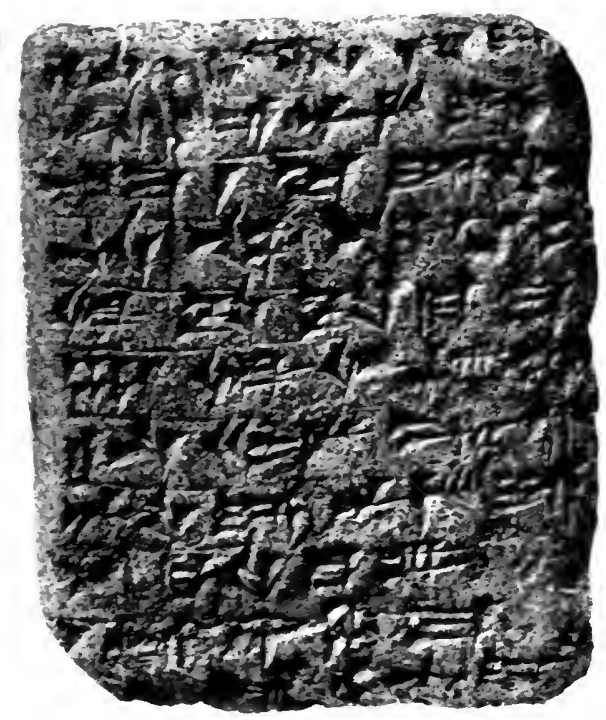

\section{OBVERSE}

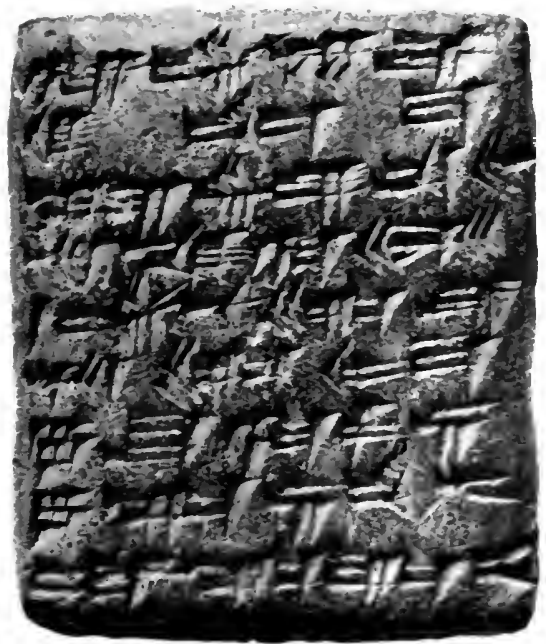

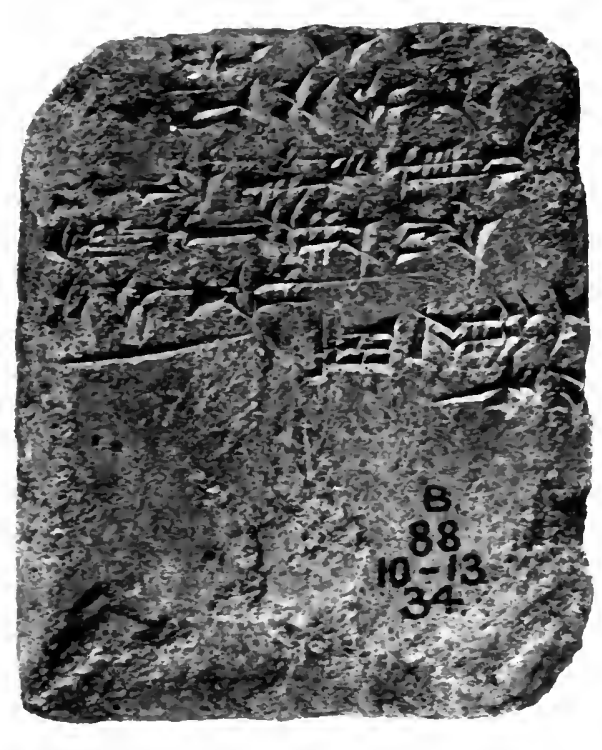

REVERSE

\section{BRITISH : USEUW. B. 88.10 .13 .34}

$$
\text { REVEDSE }
$$

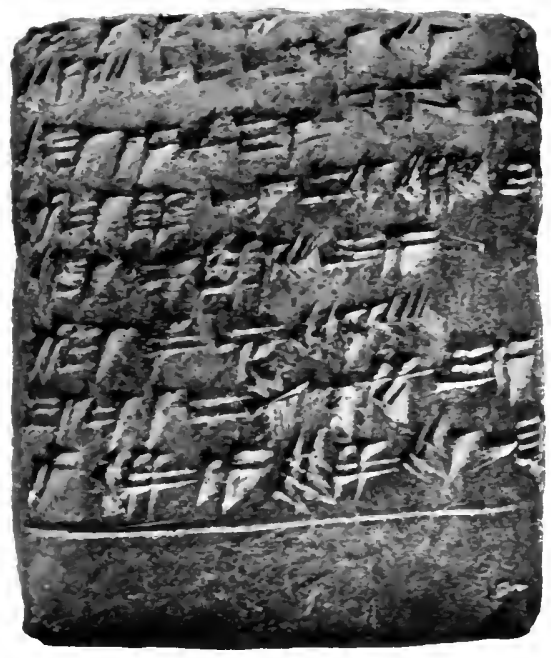





\section{s.

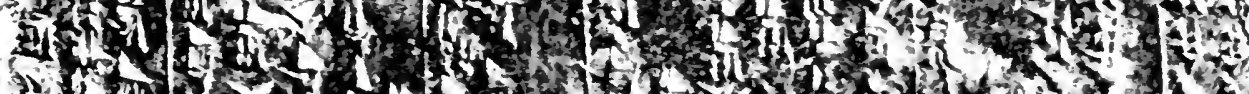

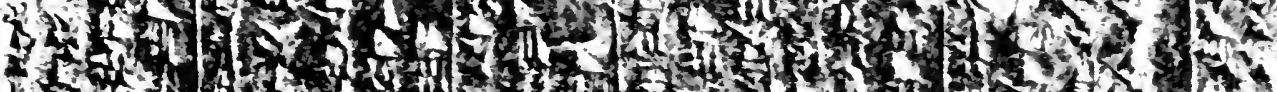

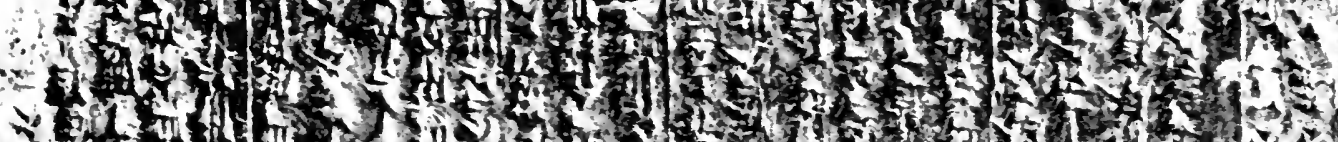

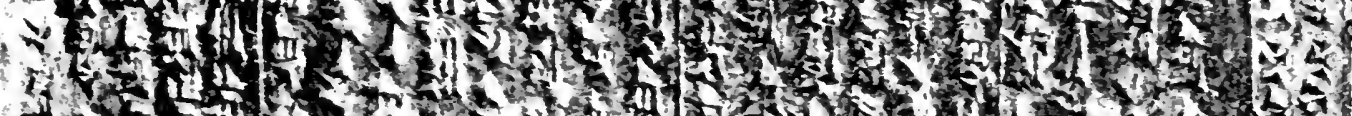

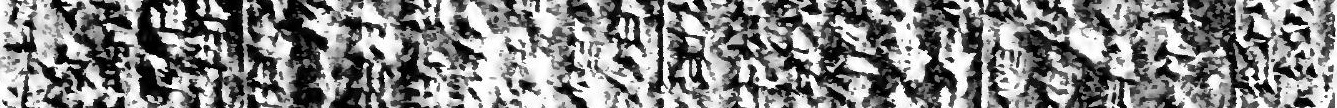

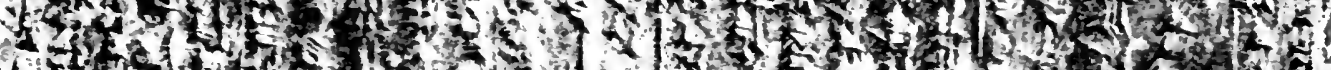 4 (1)

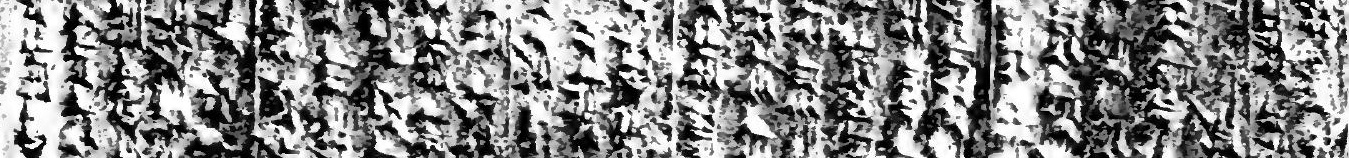

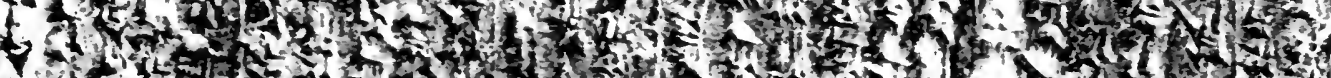

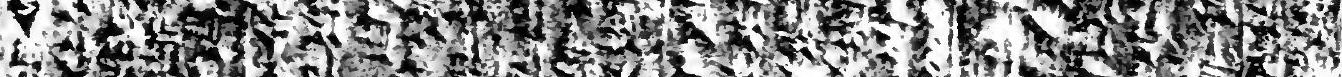

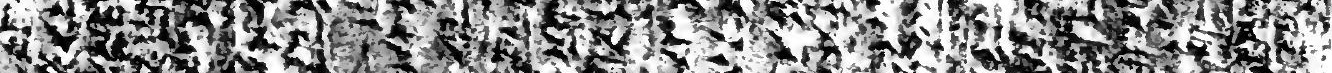

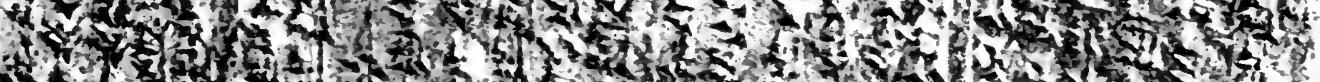

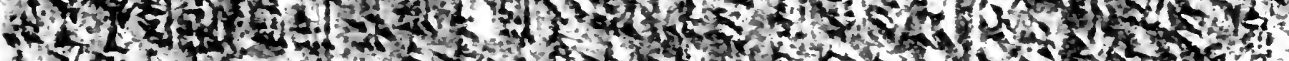

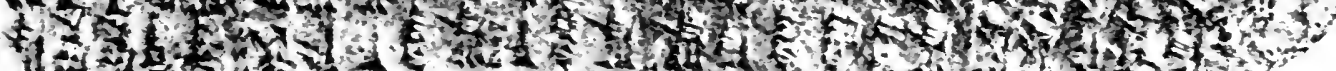

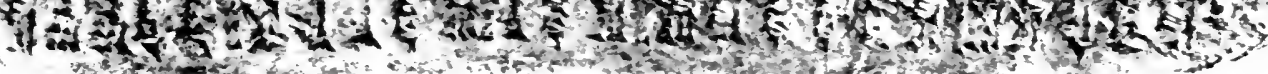

\footnotetext{
Fo

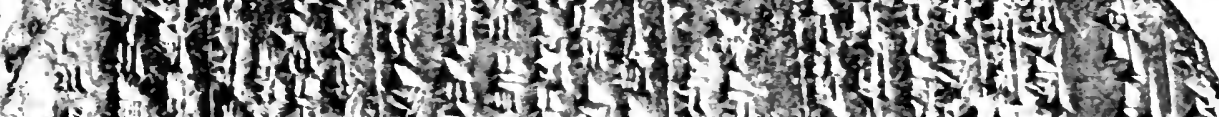

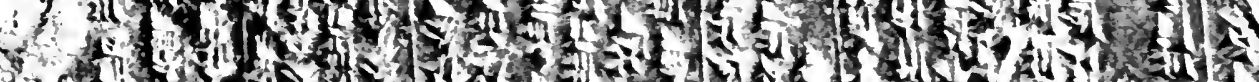

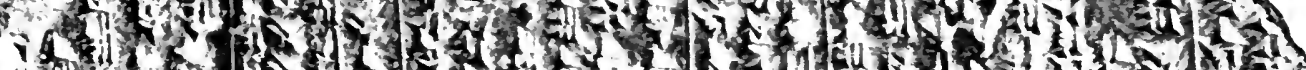
1.5.

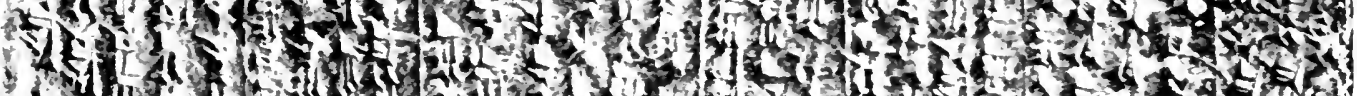
Fill 13,4 . R.

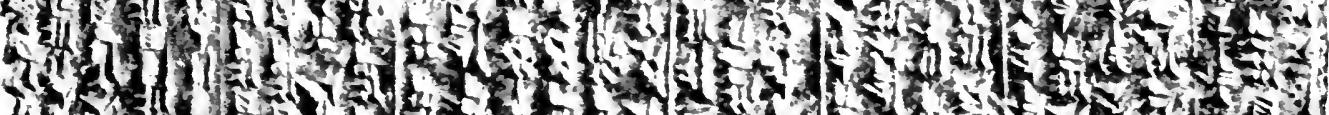

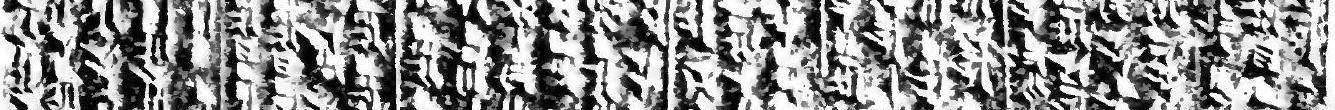

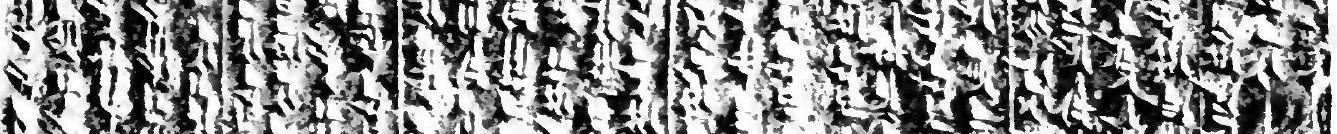

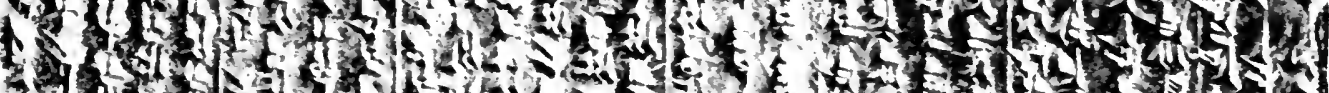
7.

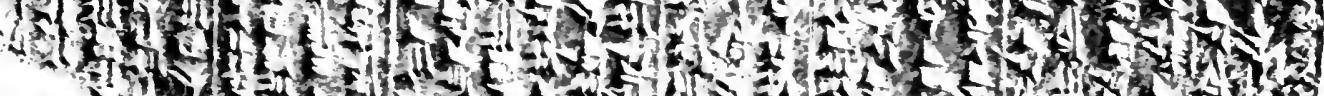

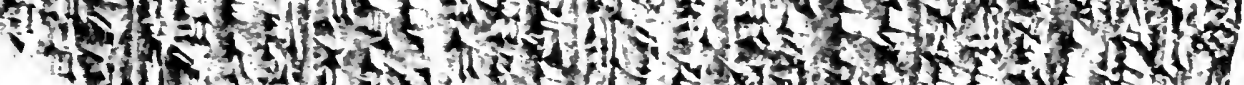

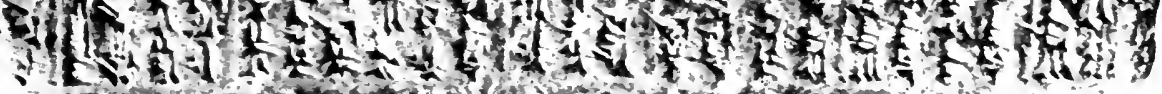




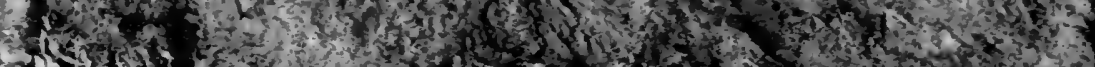

An

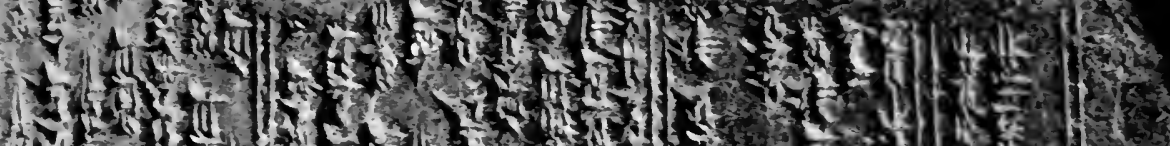

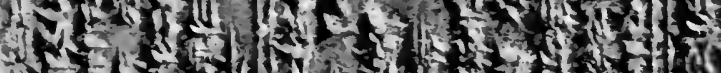

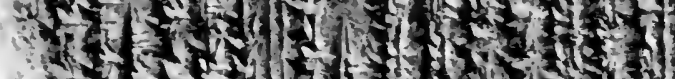

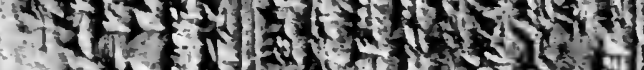

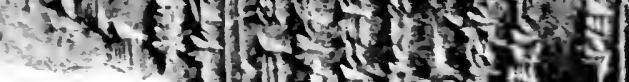
,

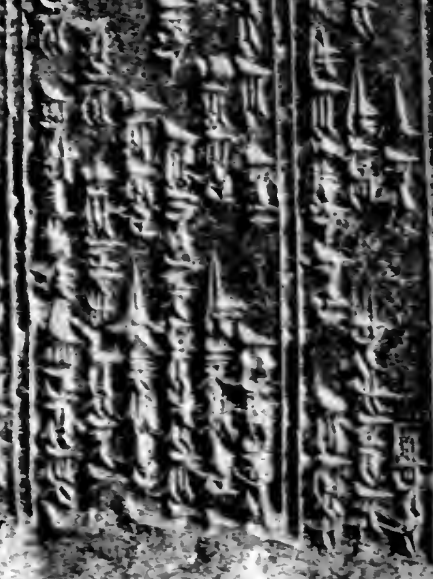

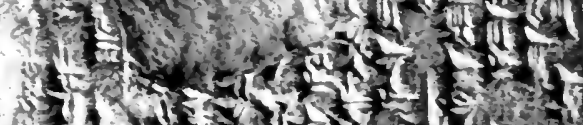

M I 15 ,

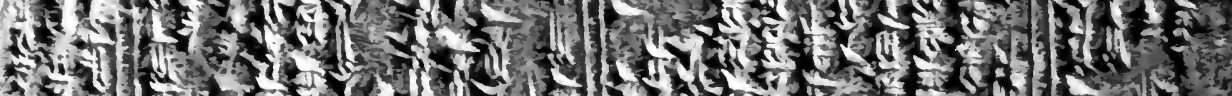

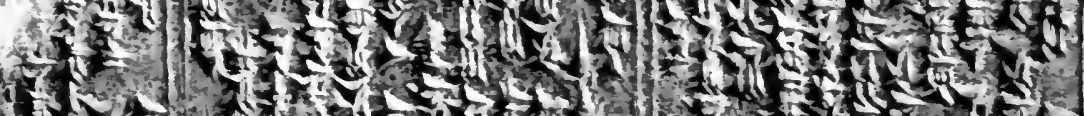

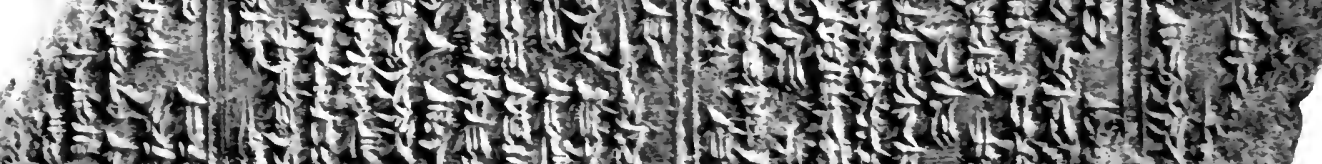

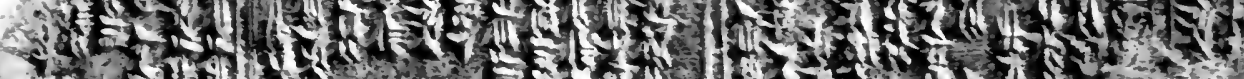

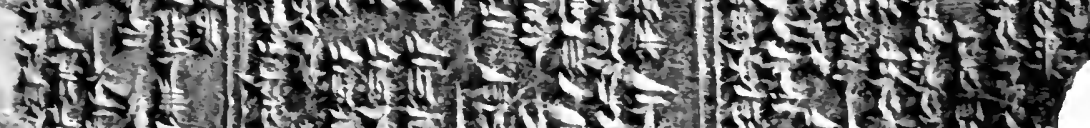

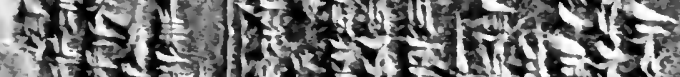
M.

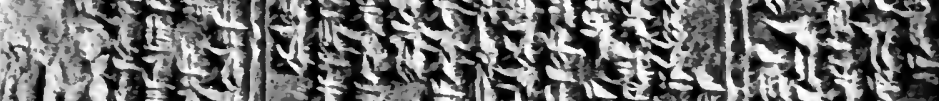

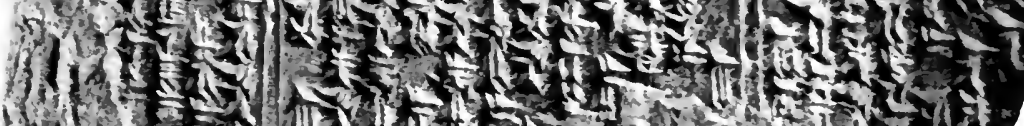

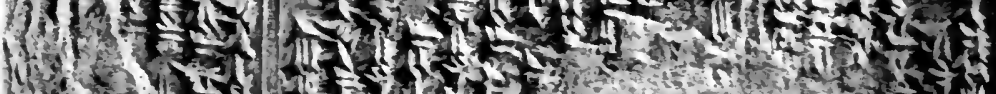

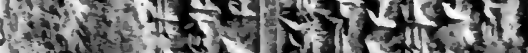

30
140

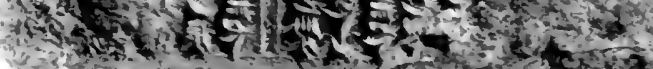




$$
\text { - }
$$




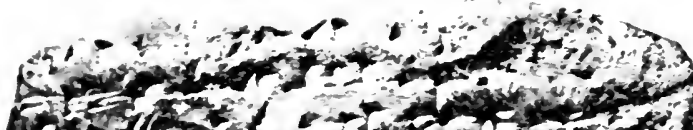

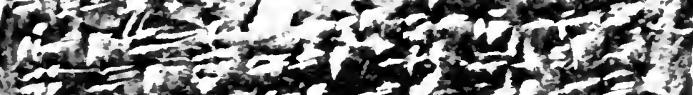

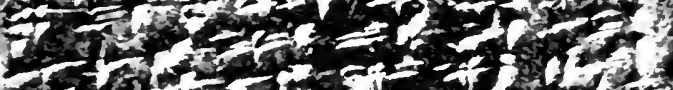

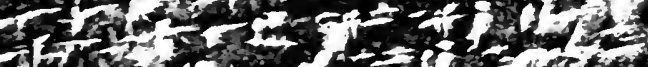

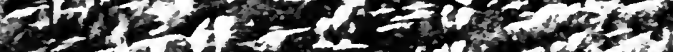

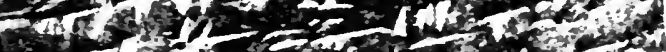

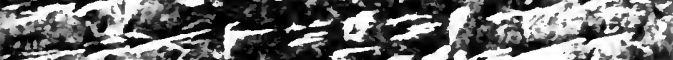

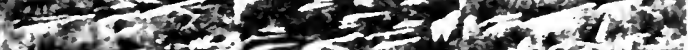

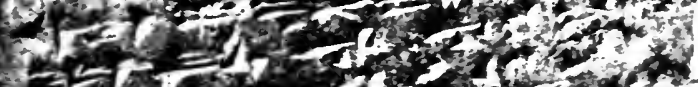
the 1010 If

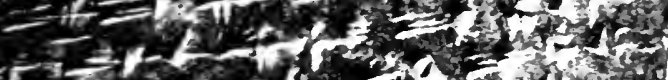

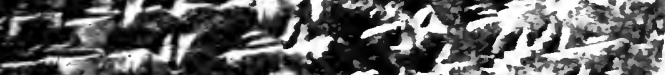

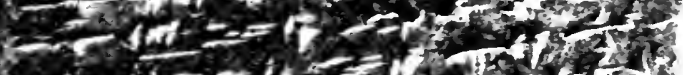

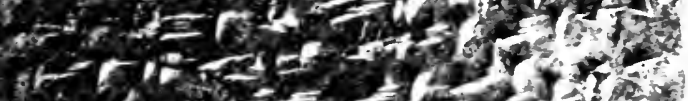
2.

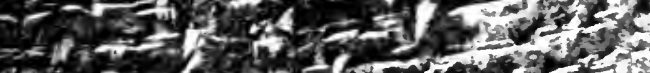

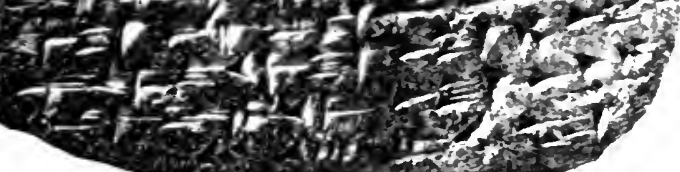

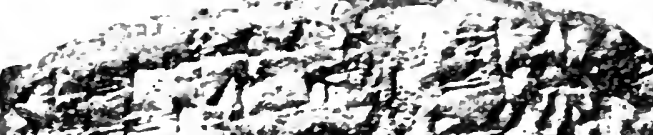

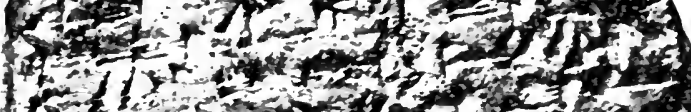

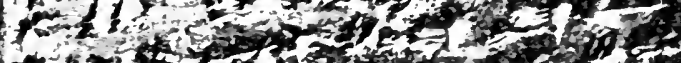

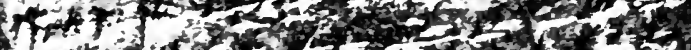

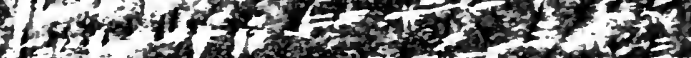

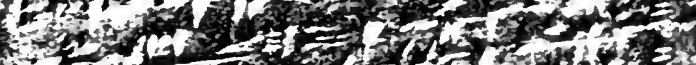

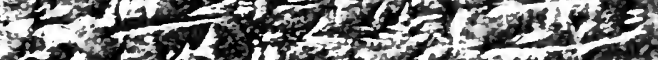

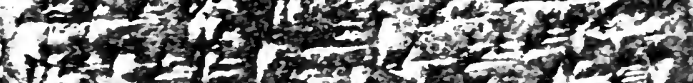

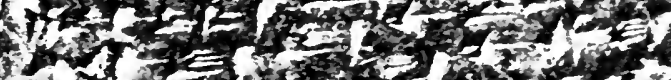

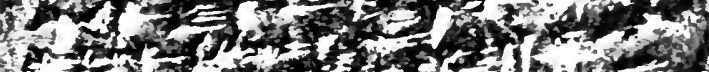

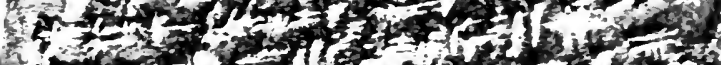

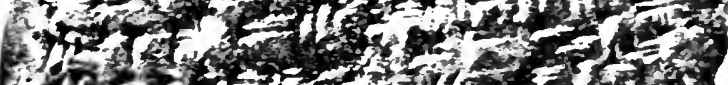

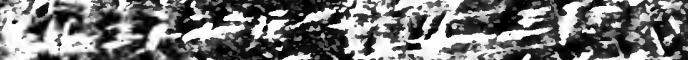
1.

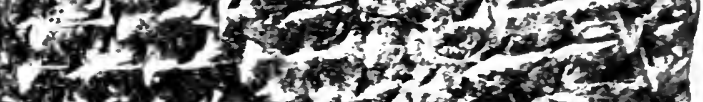

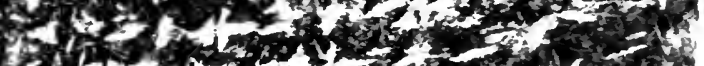
Th $=5$.

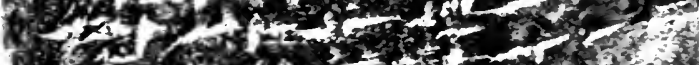

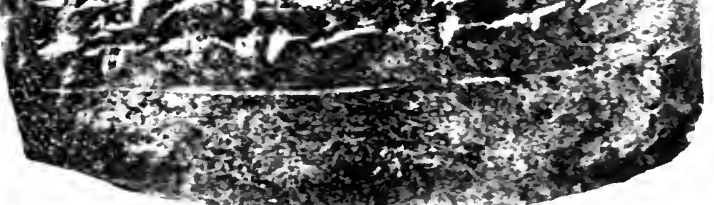

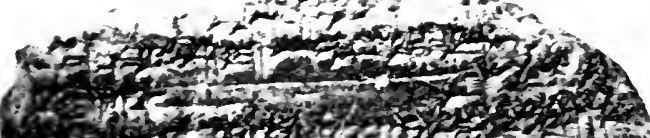
1)

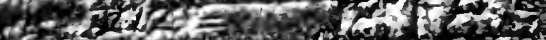

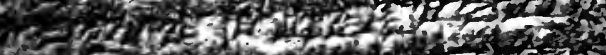
oncon

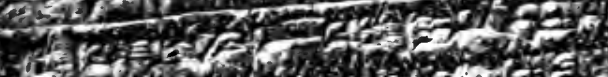

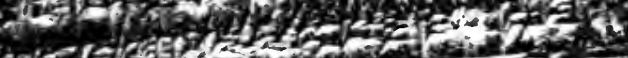
strencios

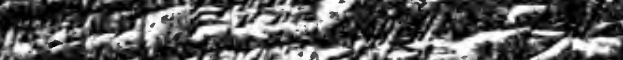

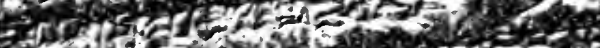

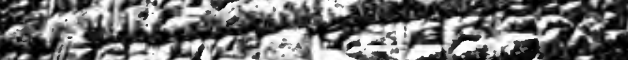
3.

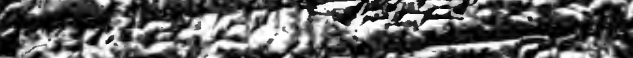

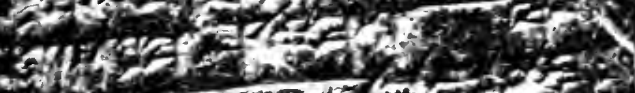

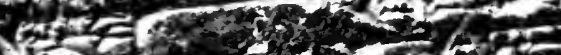

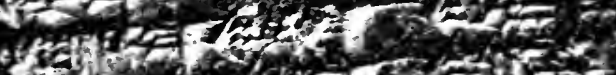
I1 zrang

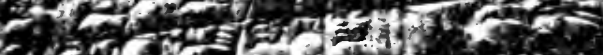

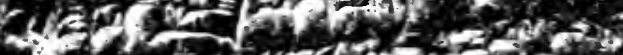

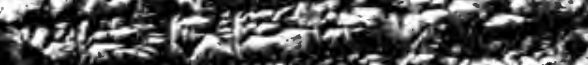

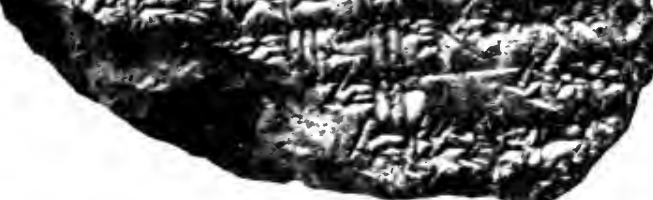

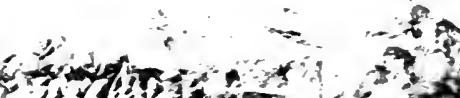

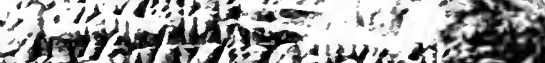

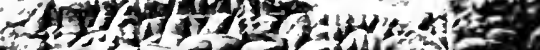
m

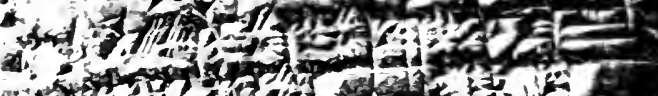
-

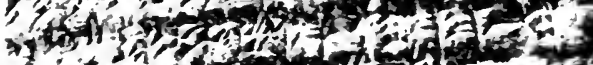
dn

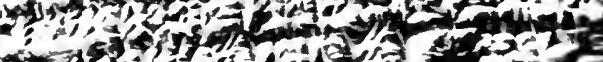

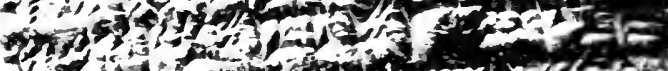
or (6) -

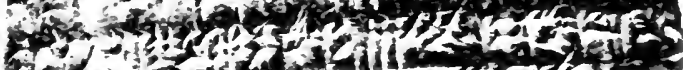
Q

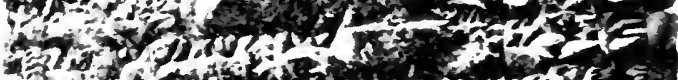

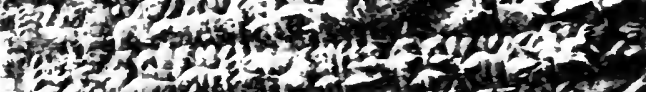

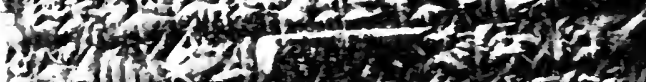
4. D

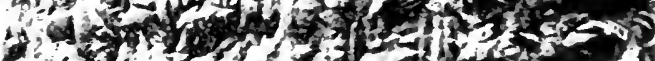

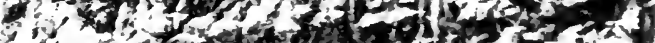

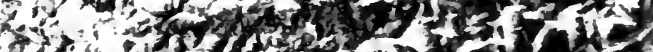

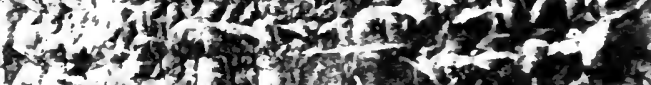

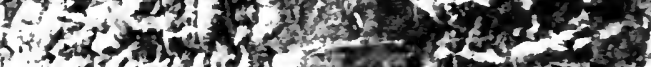

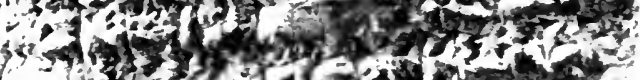
3. 



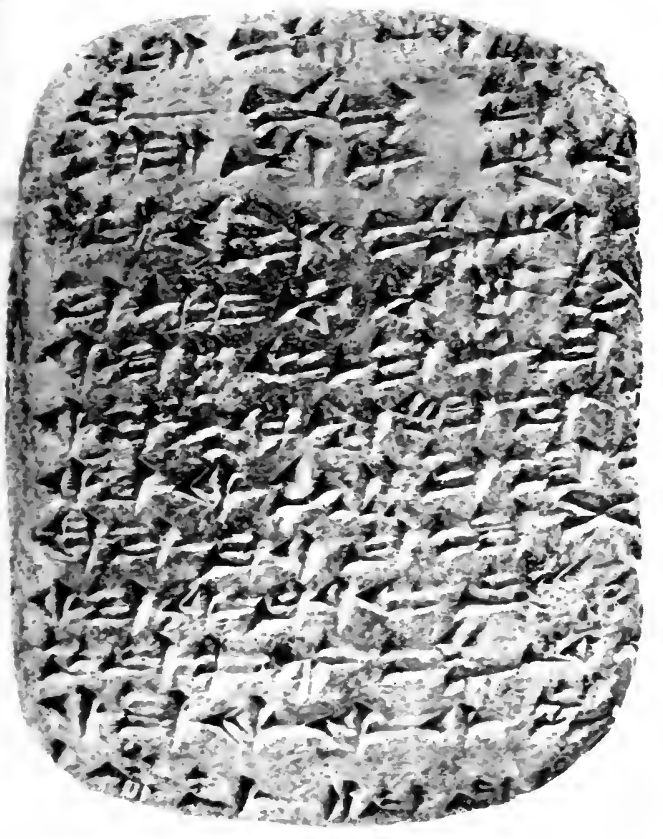

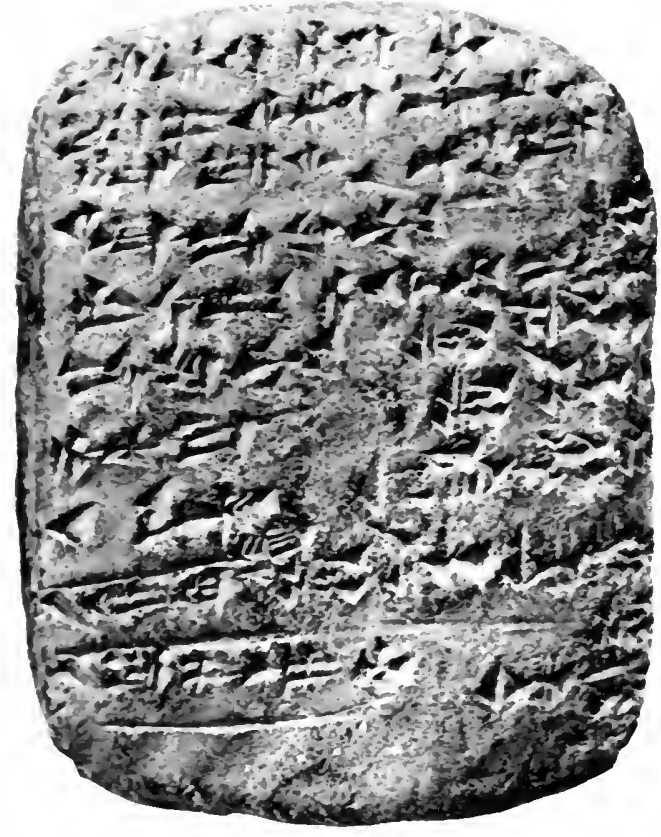

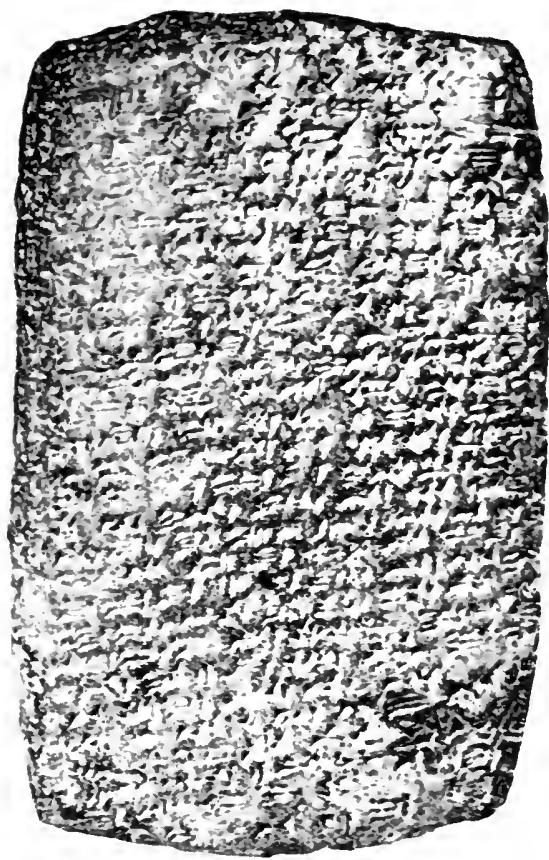




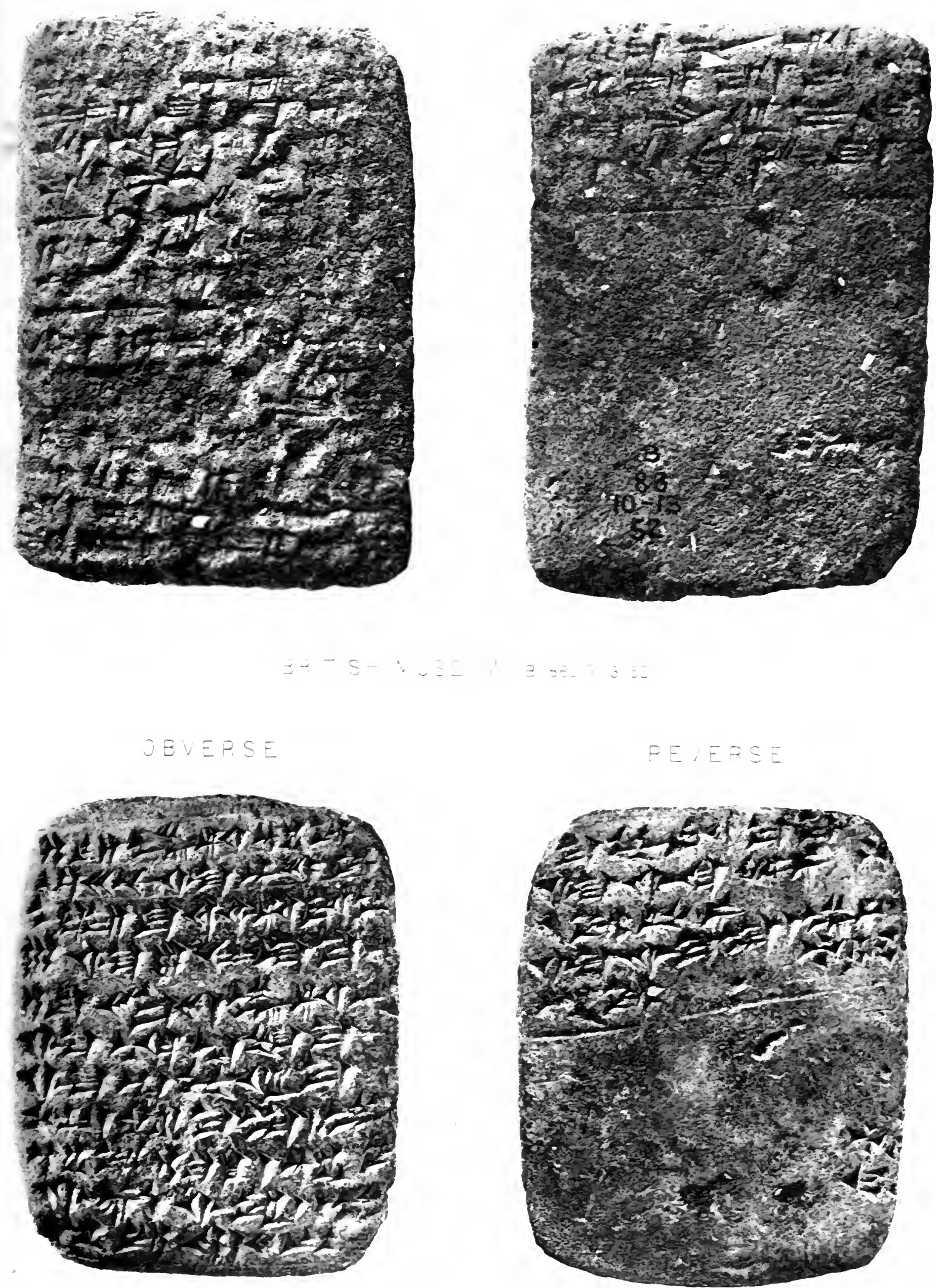



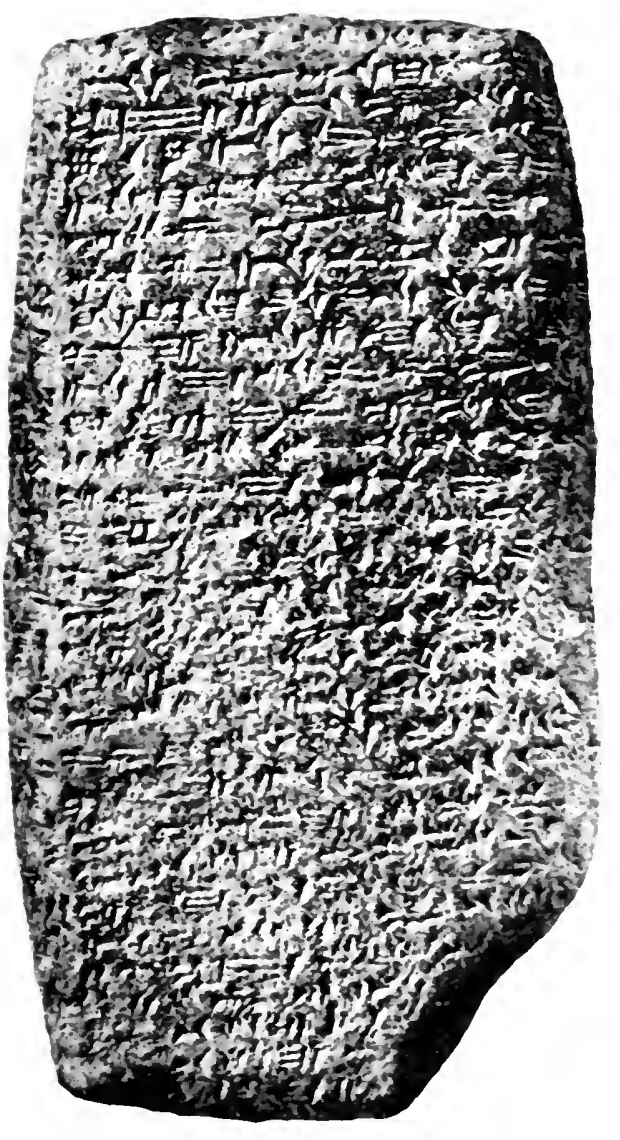

\section{OBVERSE}

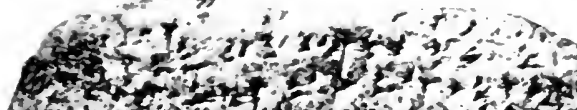

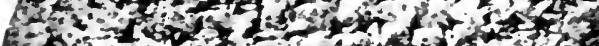

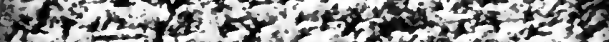

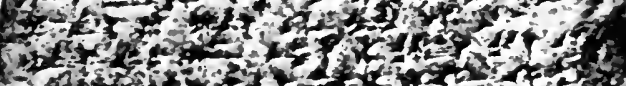

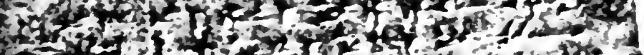

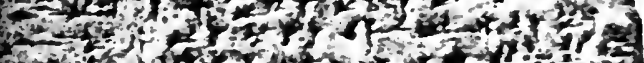

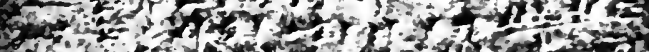

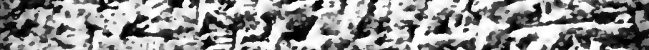

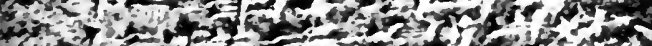

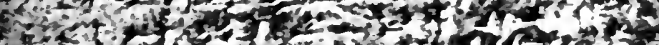

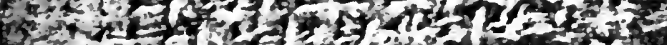

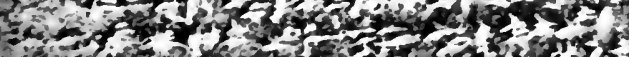

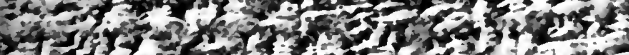

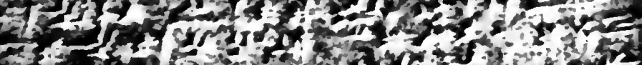

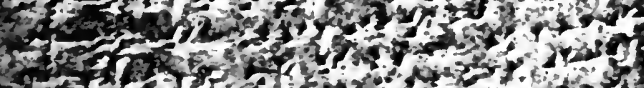

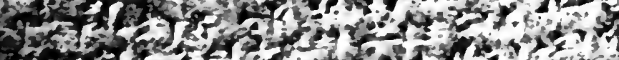

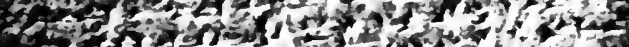
7 (3)

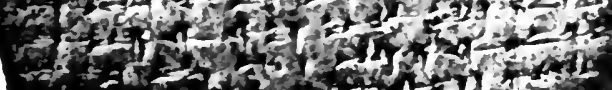

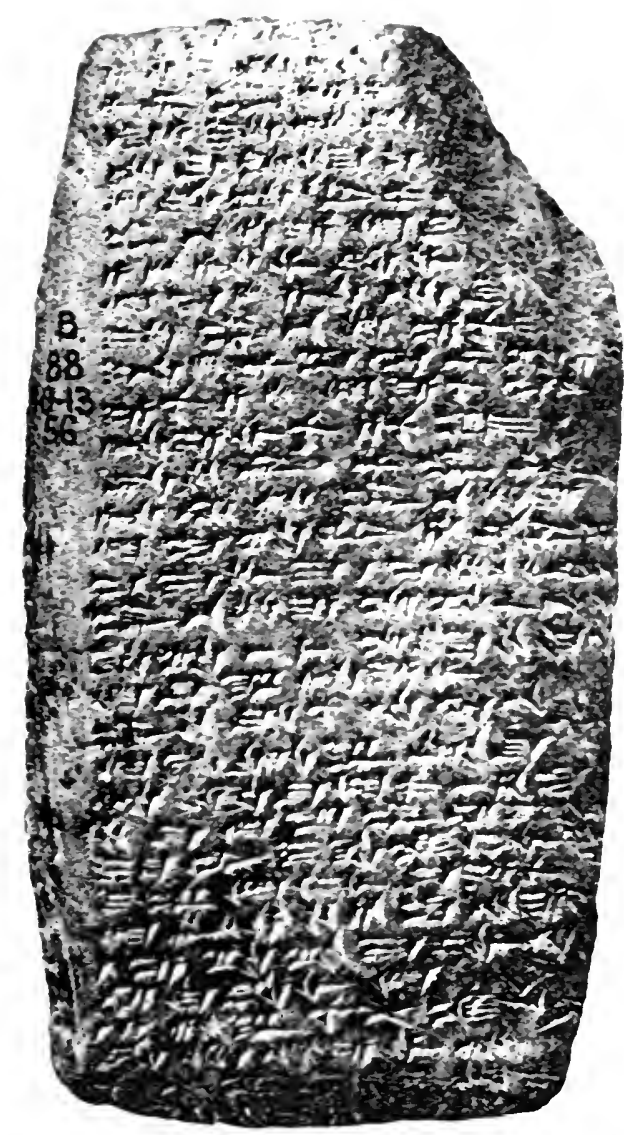

fon-

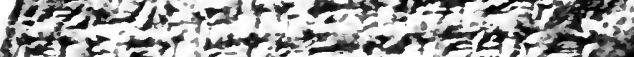

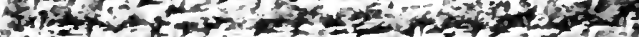

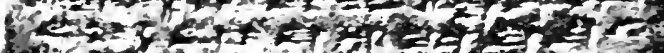

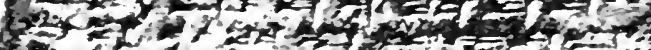

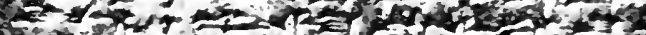

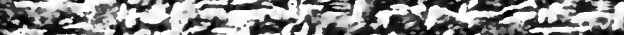

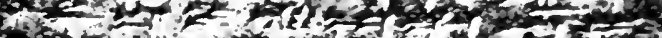

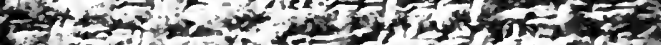

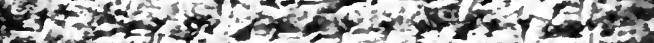

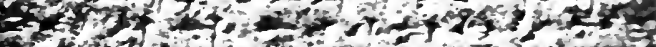

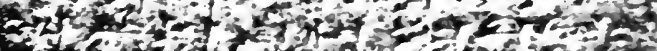

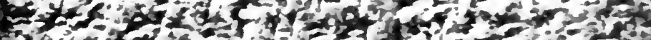

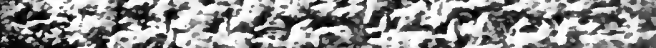

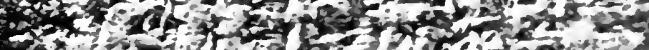

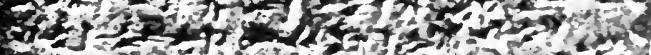

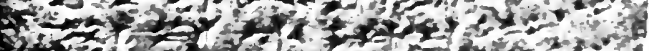

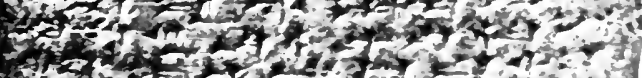

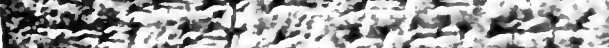

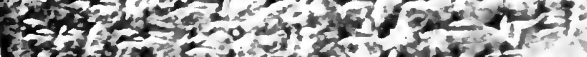

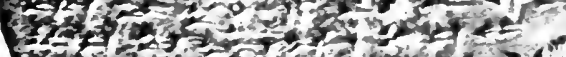

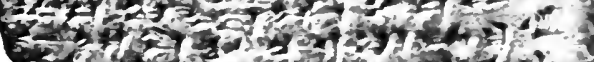

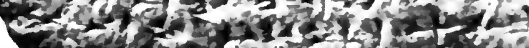





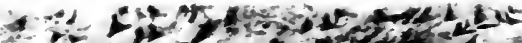

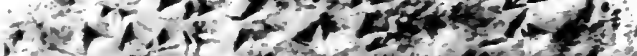
- J

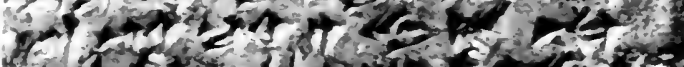

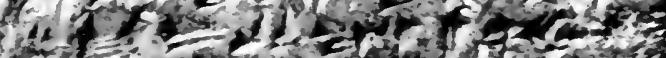

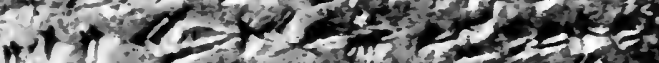

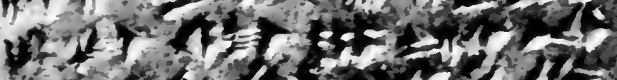

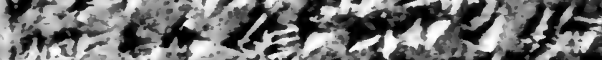

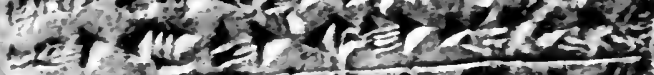

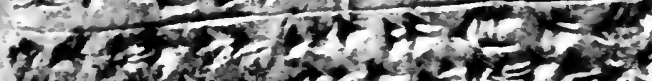

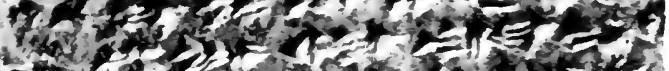

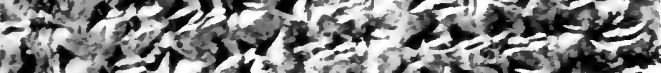

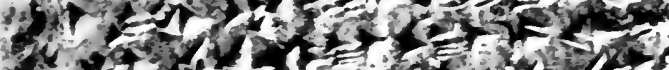

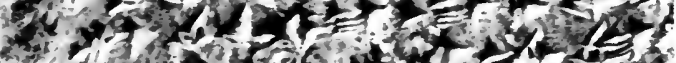

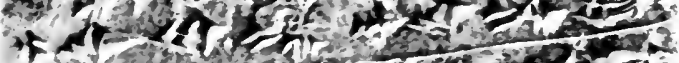

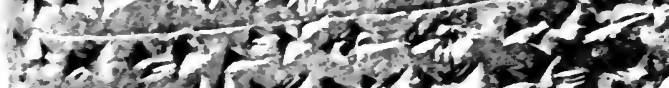

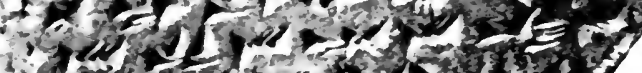

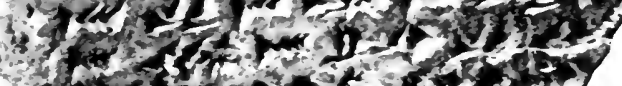

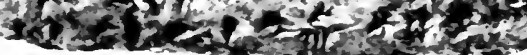

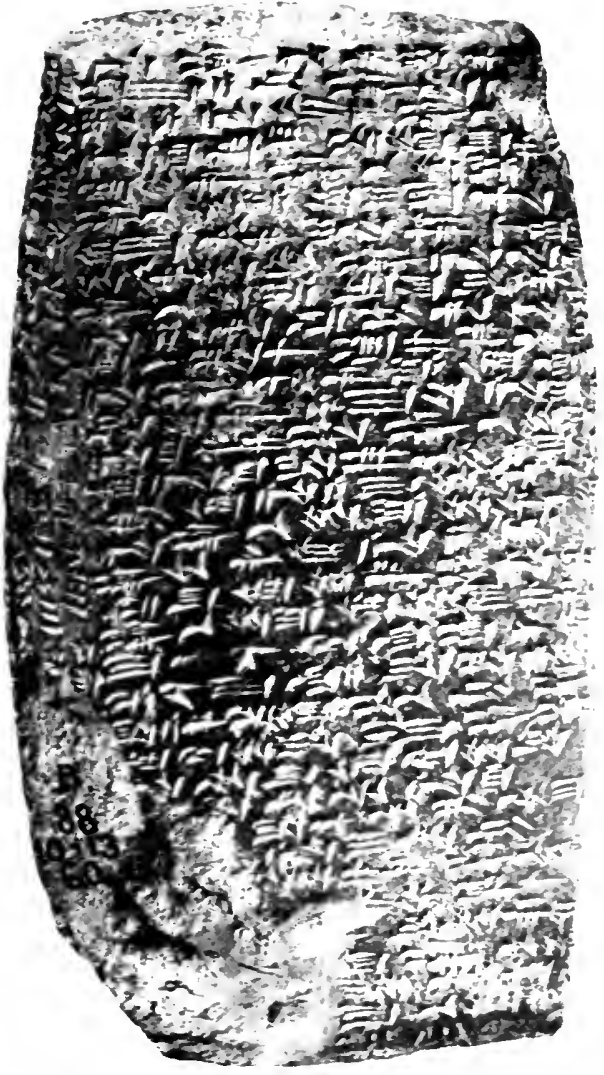

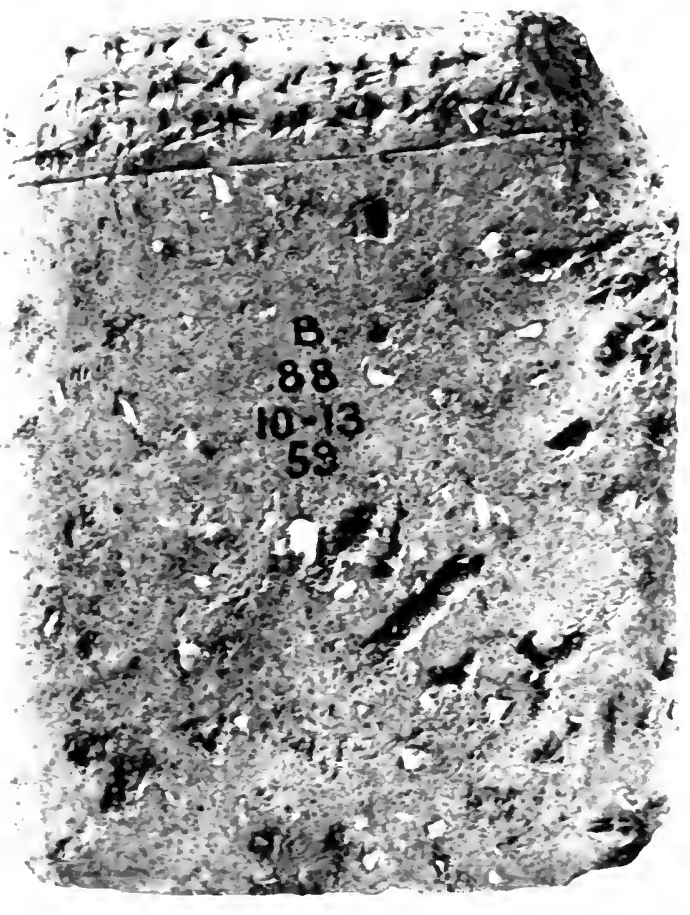




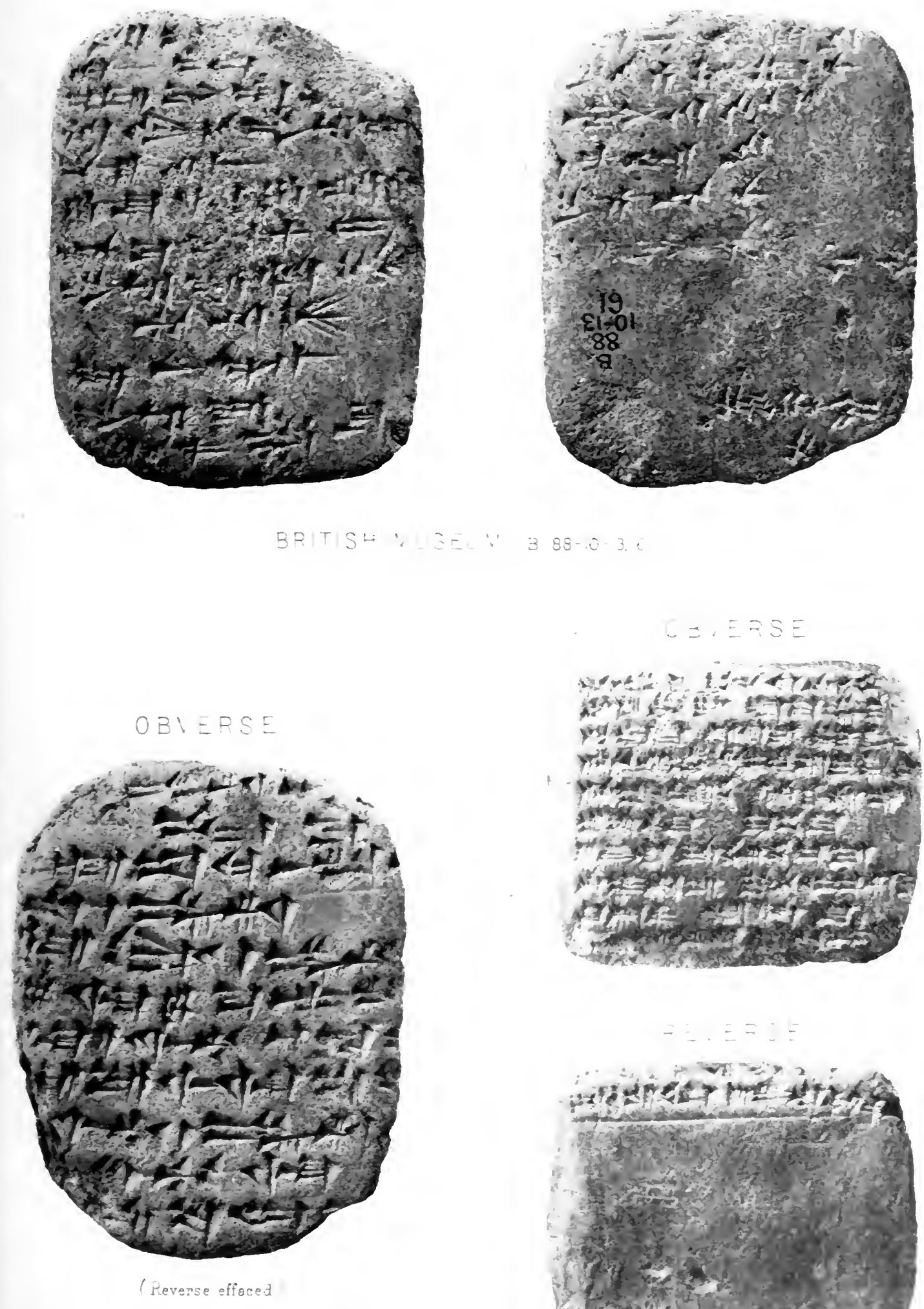

BRITISH ILLEUN B. $8 E$
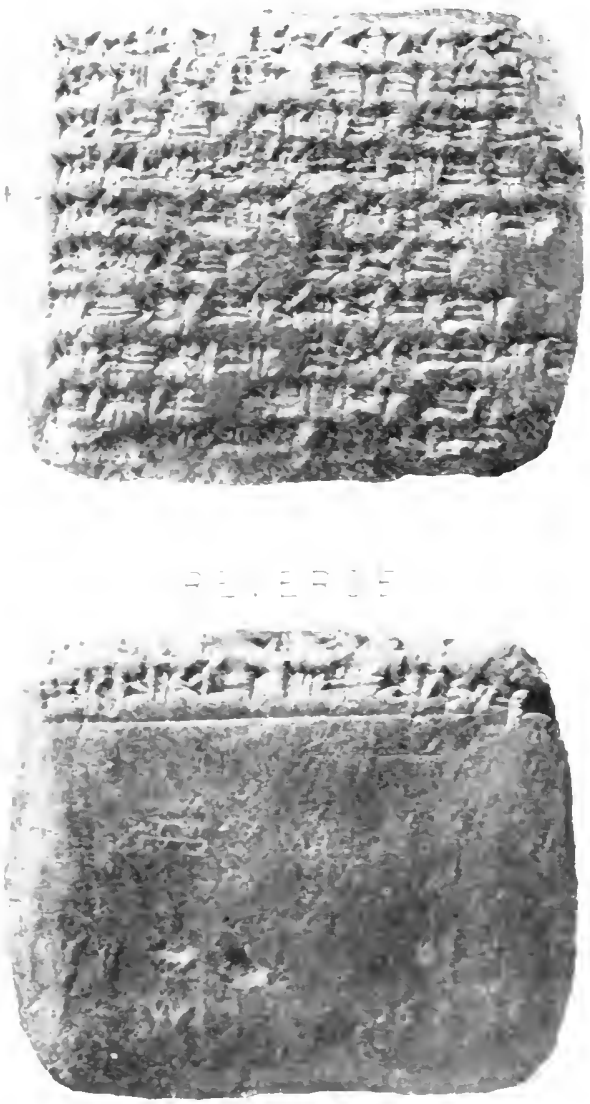



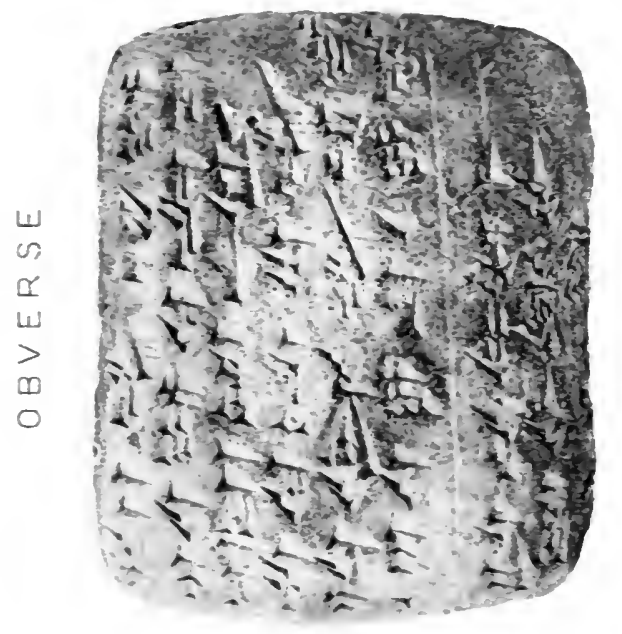

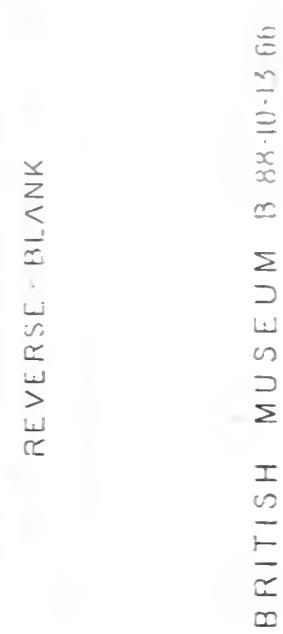
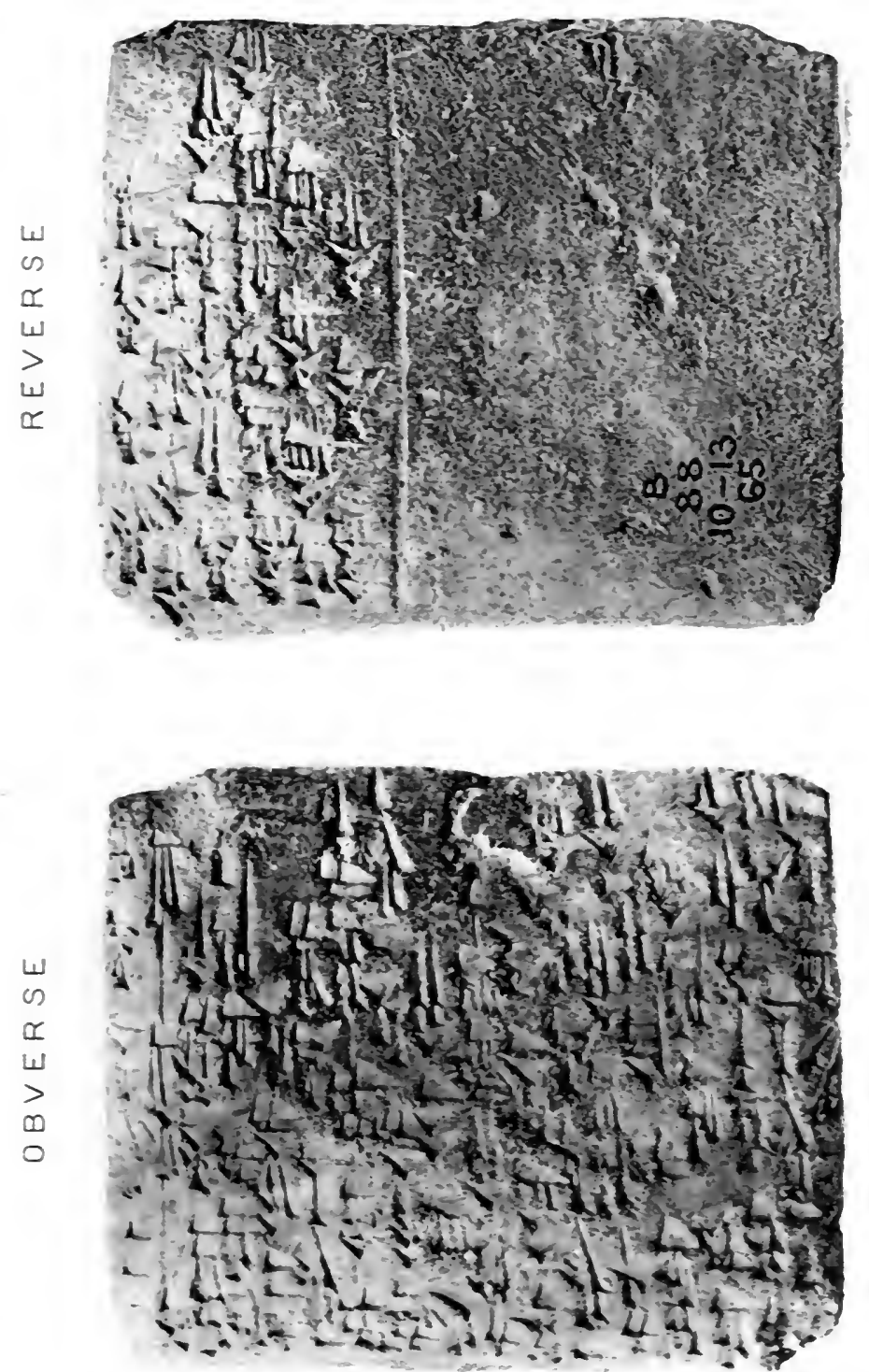


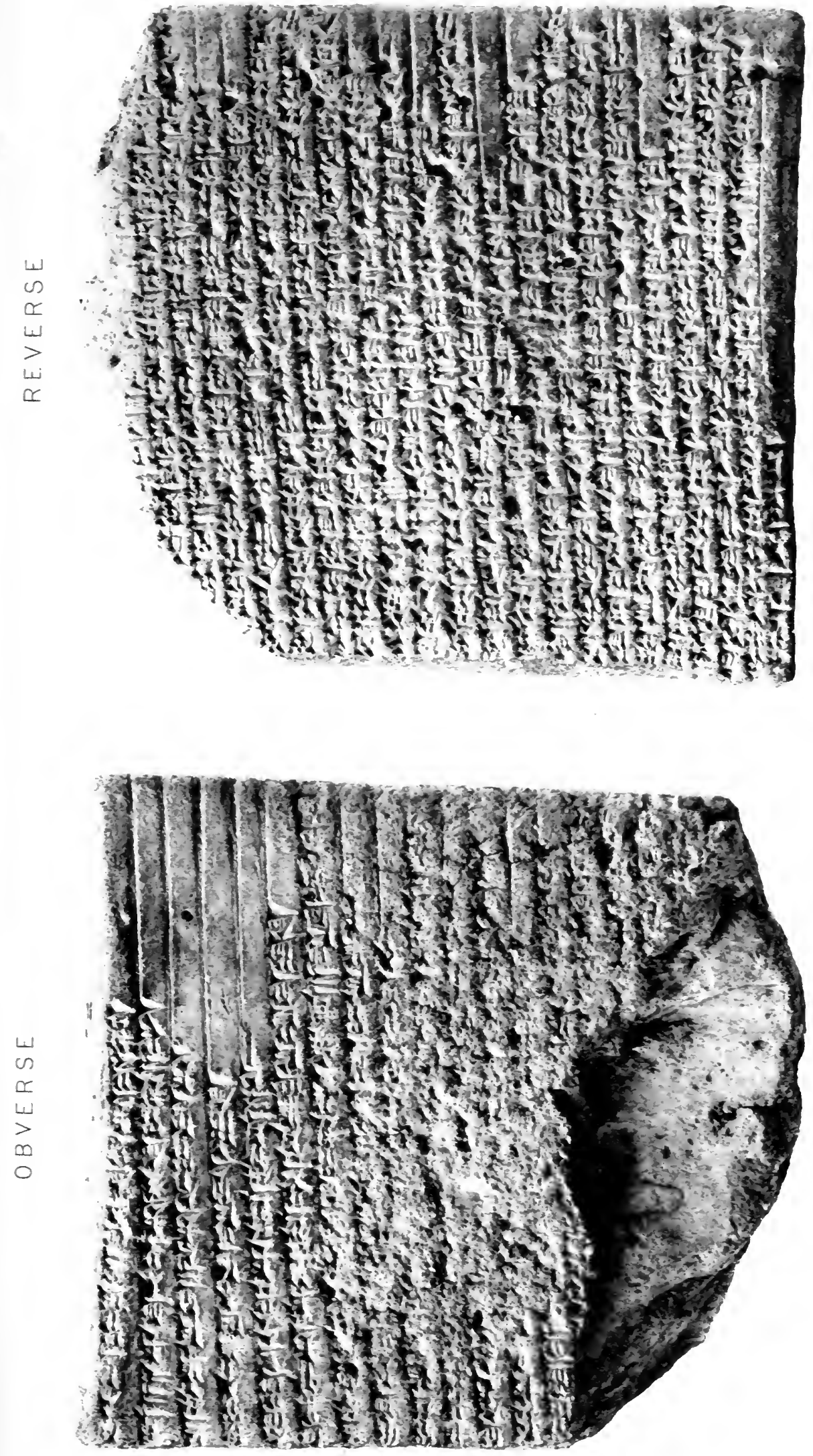



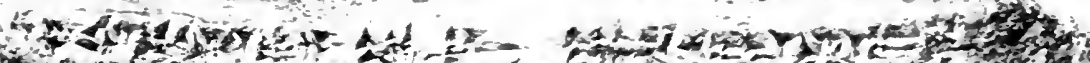

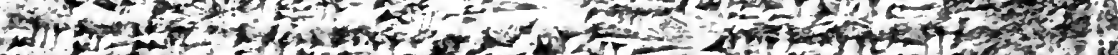

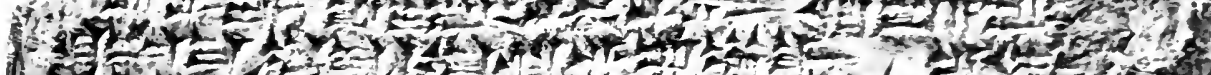

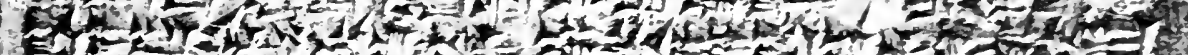

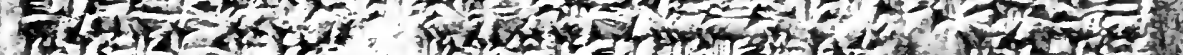

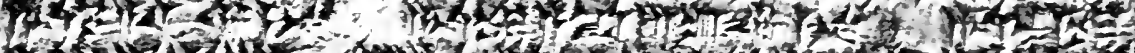

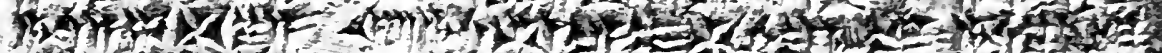

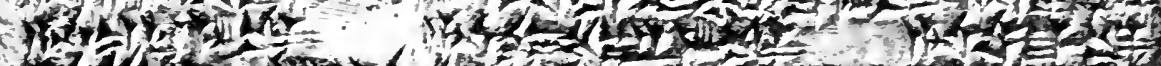

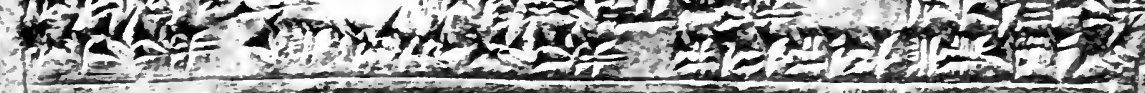

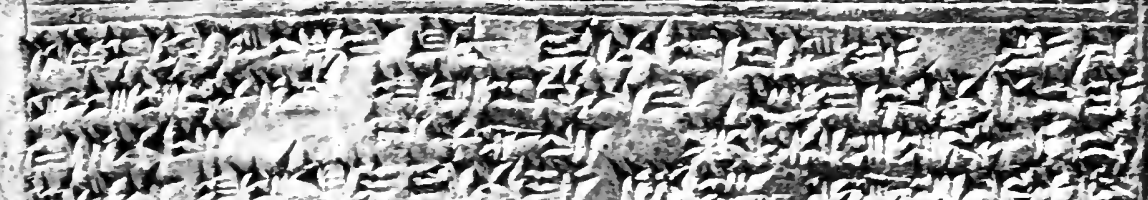

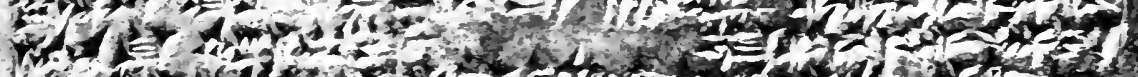

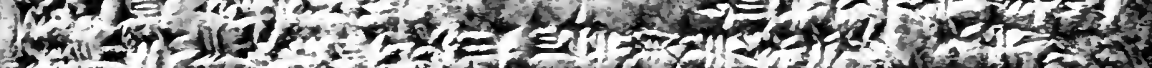

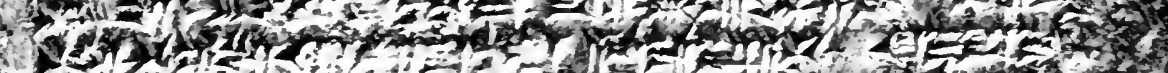

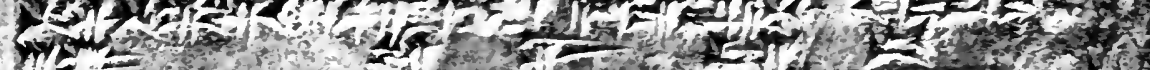

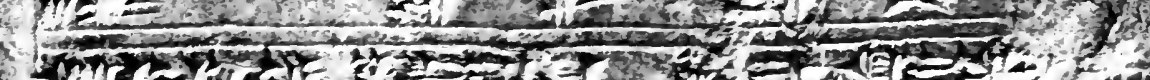
1.

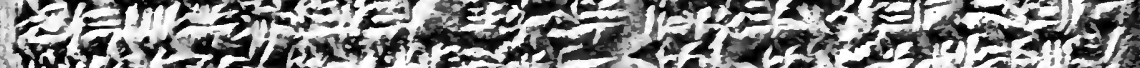

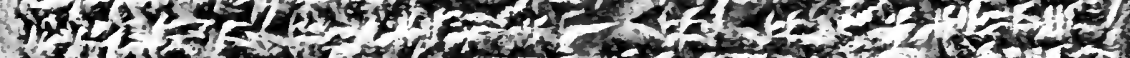

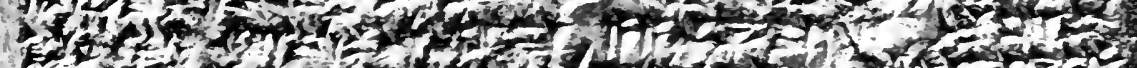

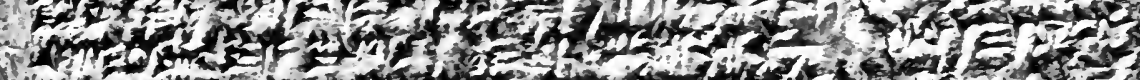

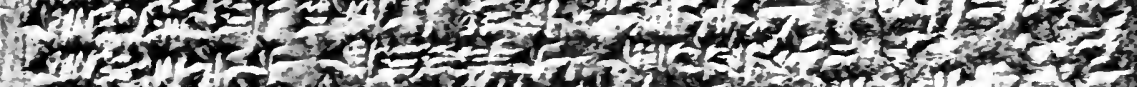

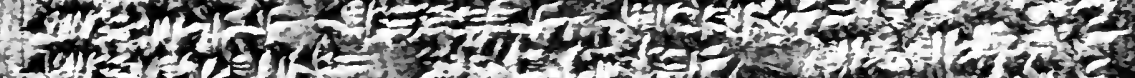

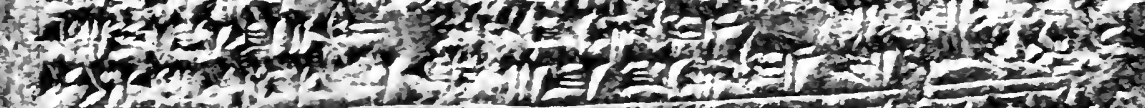

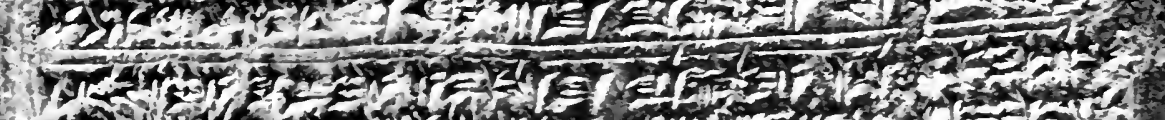

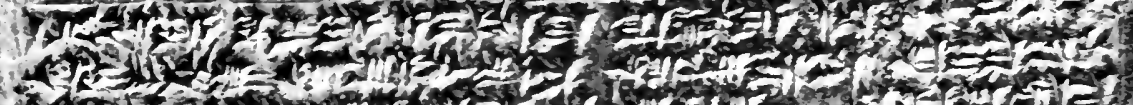

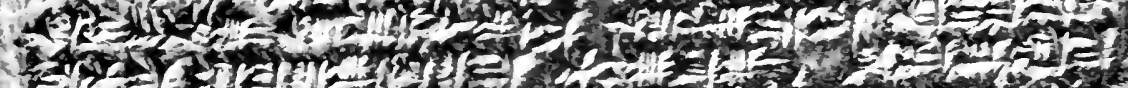

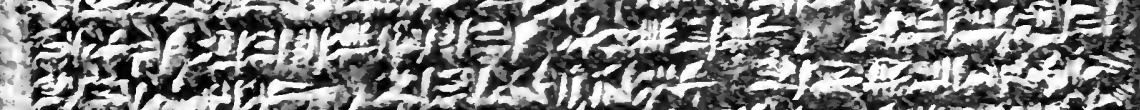
Ex

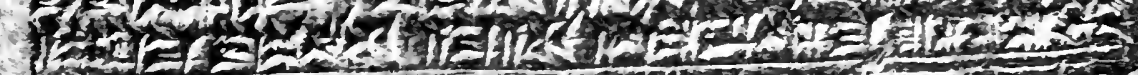

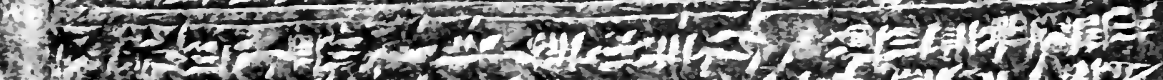

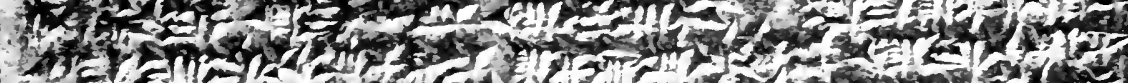
1. (1) 1 का

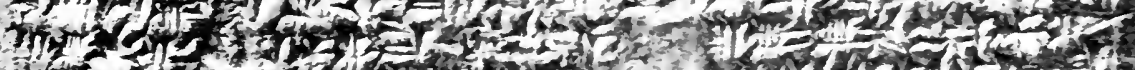
$4+140$.

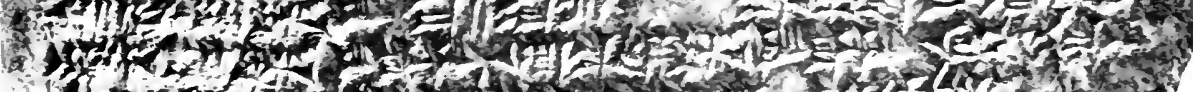

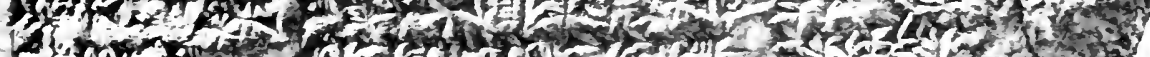

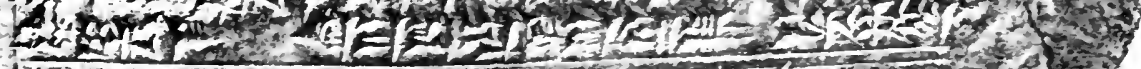

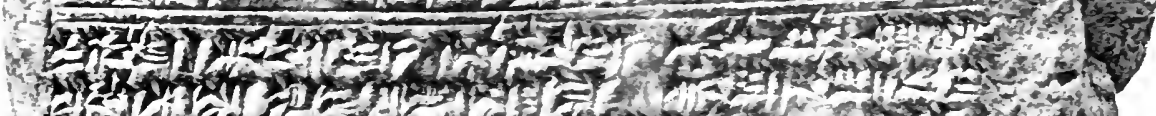

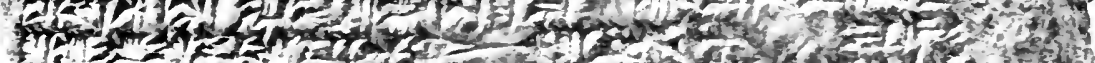

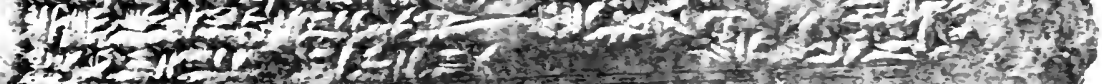




$$
\text { . }
$$




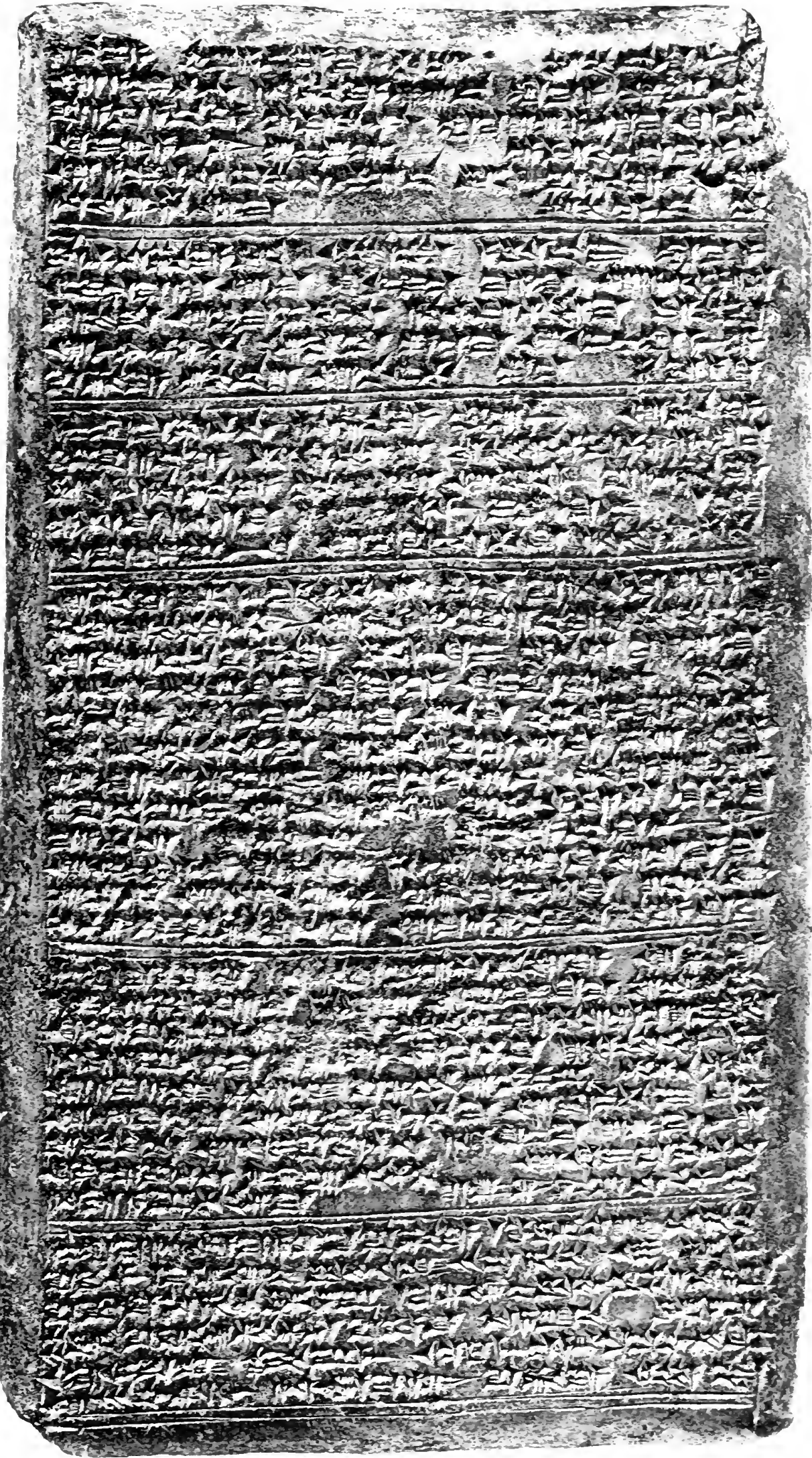





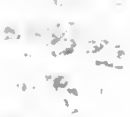


OBVERSE

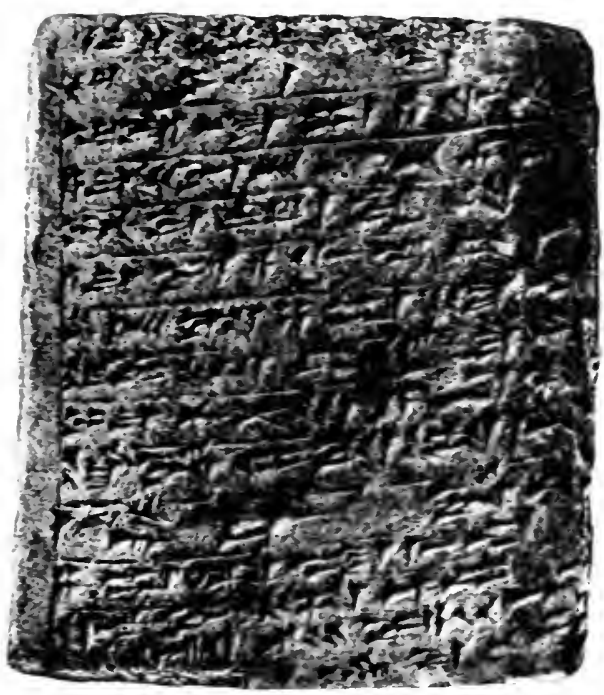

BRITISH MUSEUM.
REVERSE

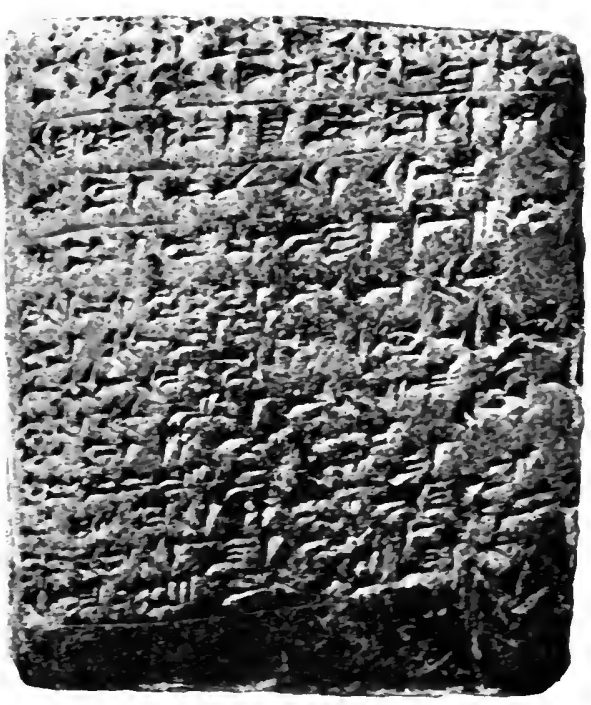

B. $88-10-13.74$.

\section{OBVERSE}

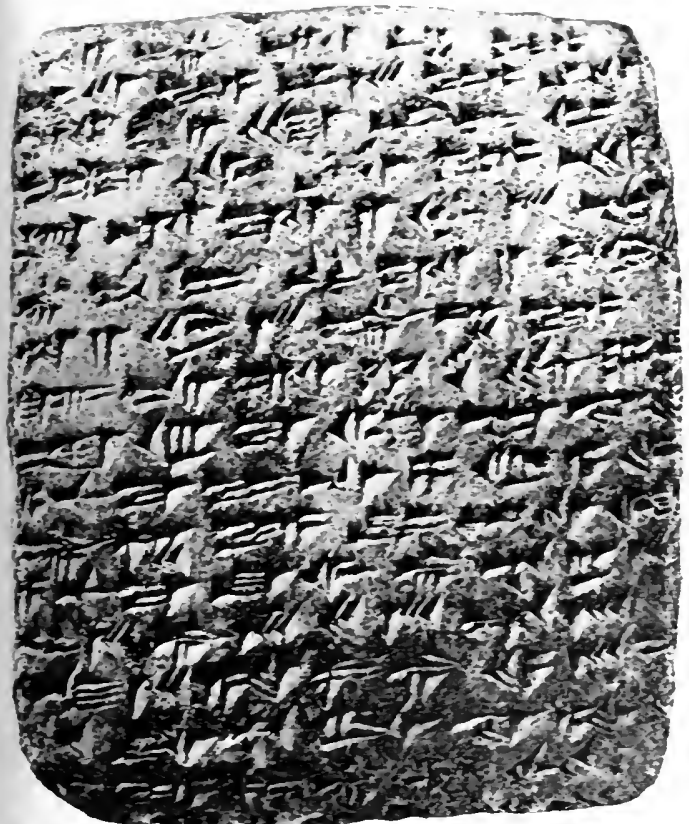

REVERSE

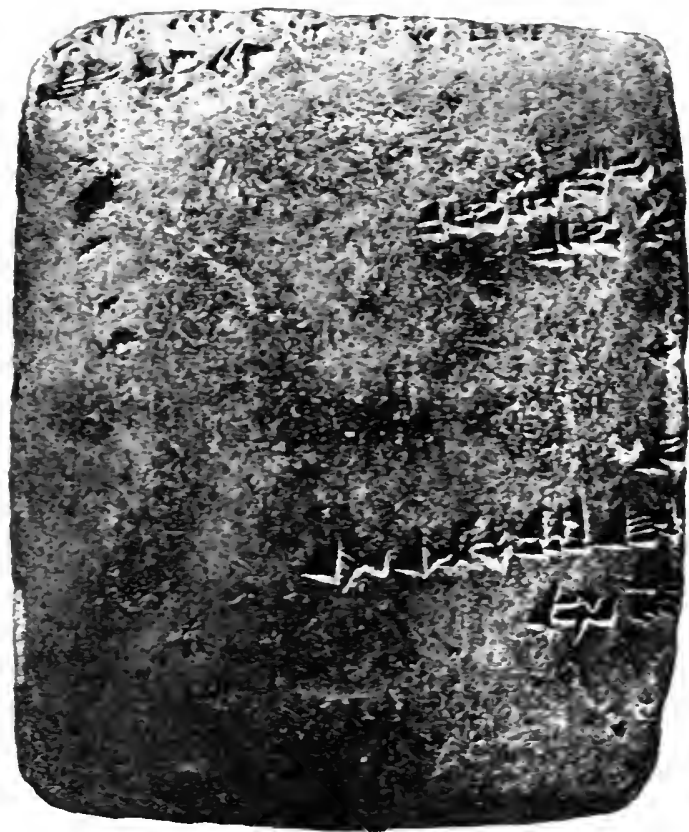




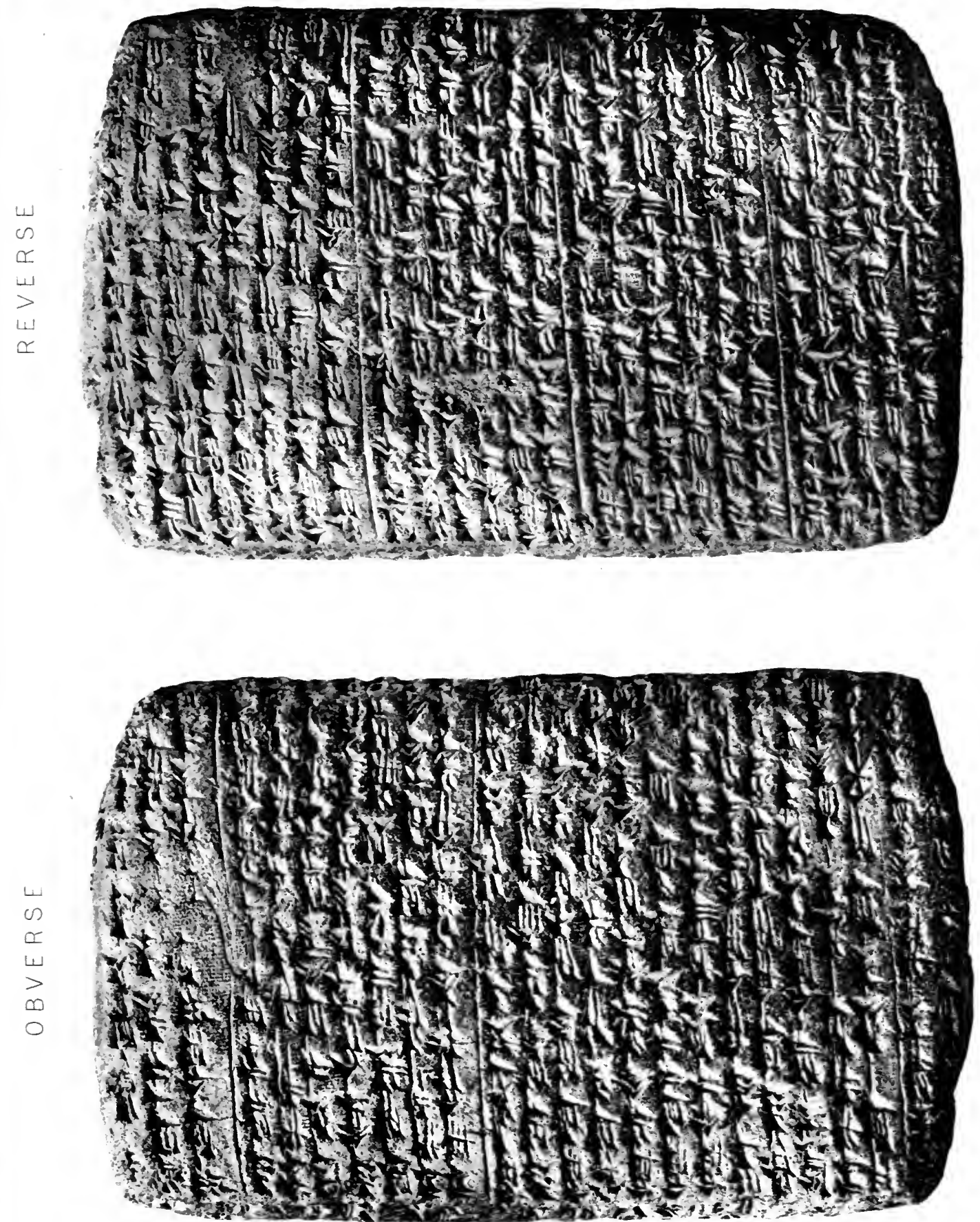



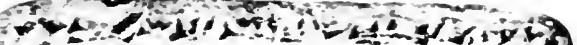

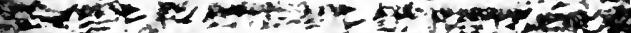
50 50.

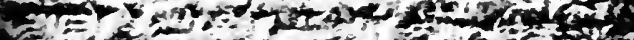

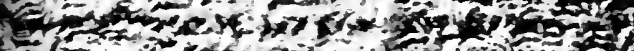

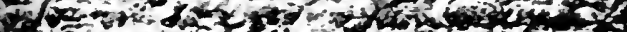

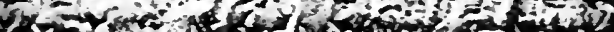

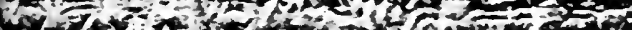

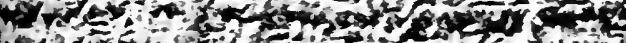

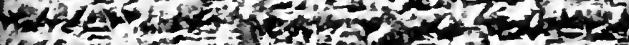

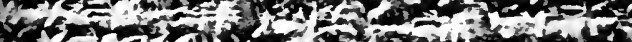

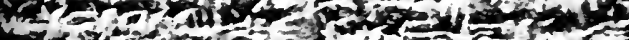

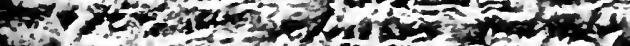

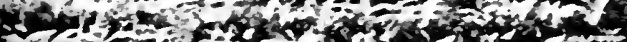
1 - th 5 4

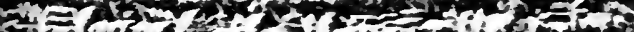

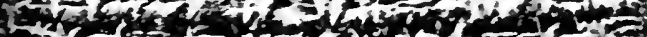

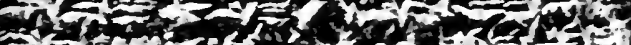

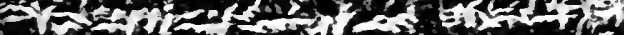
$-10=20$ by

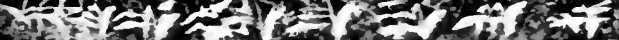
$3 \mathrm{x}$ -

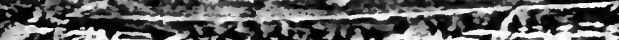

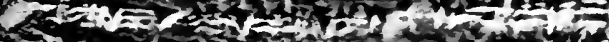

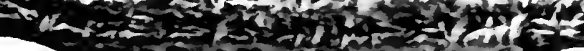

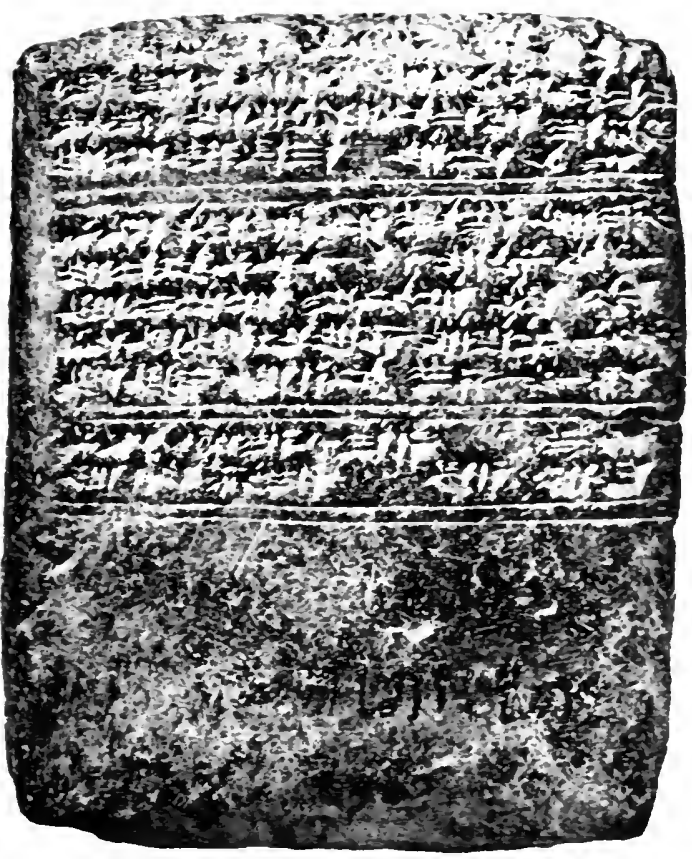

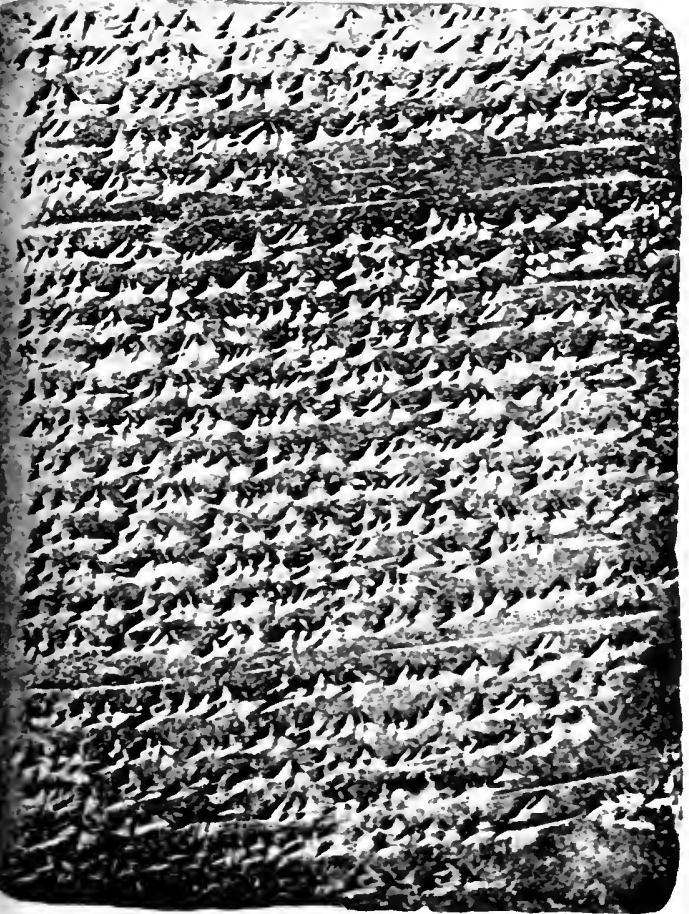

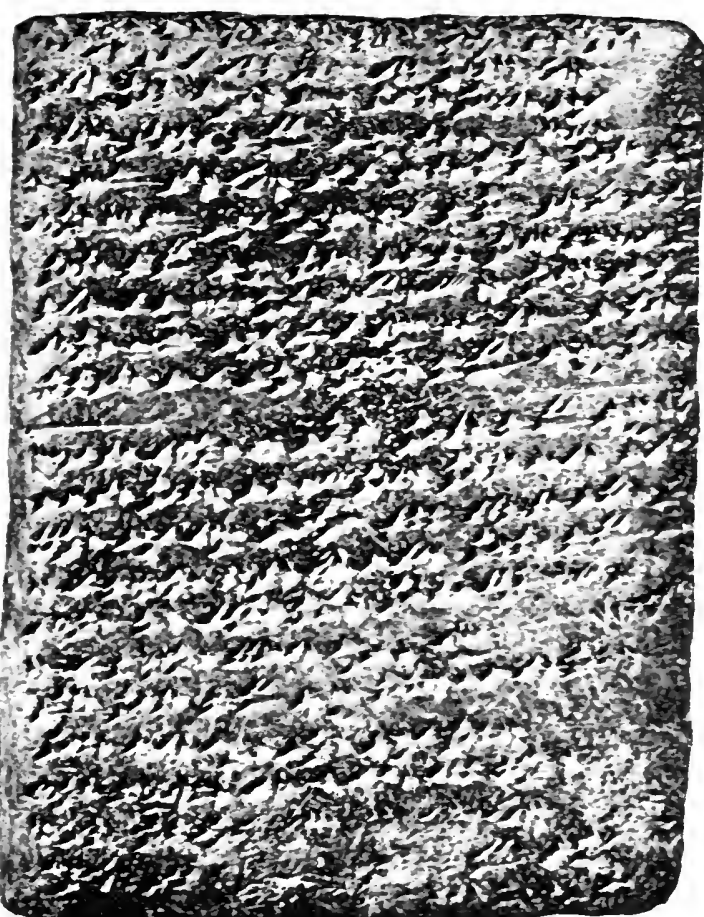




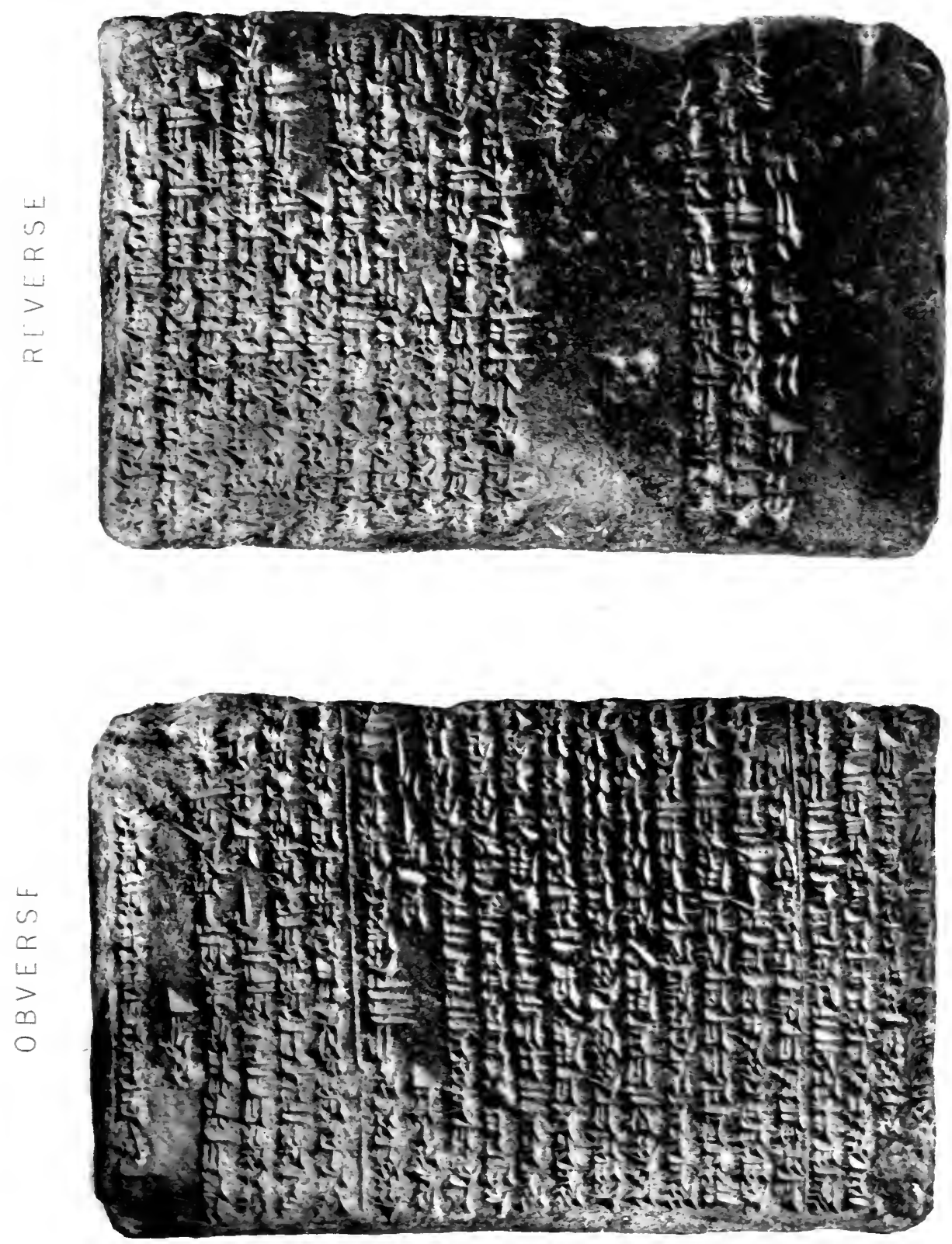



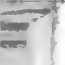



PLEASE DO NOT REMOVE CARDS OR SLIPS FROM THIS POCKET

UNIVERSITY OF TORONTO LIBRARY

LaAsy

British Museum. Dept. of

B862t Egyptian and Assyrian Antiquities

The-Tell El-Amarna Tablets in the British Museum 
